\title{
The Law of Nations and Natural Law 1625-1800
}

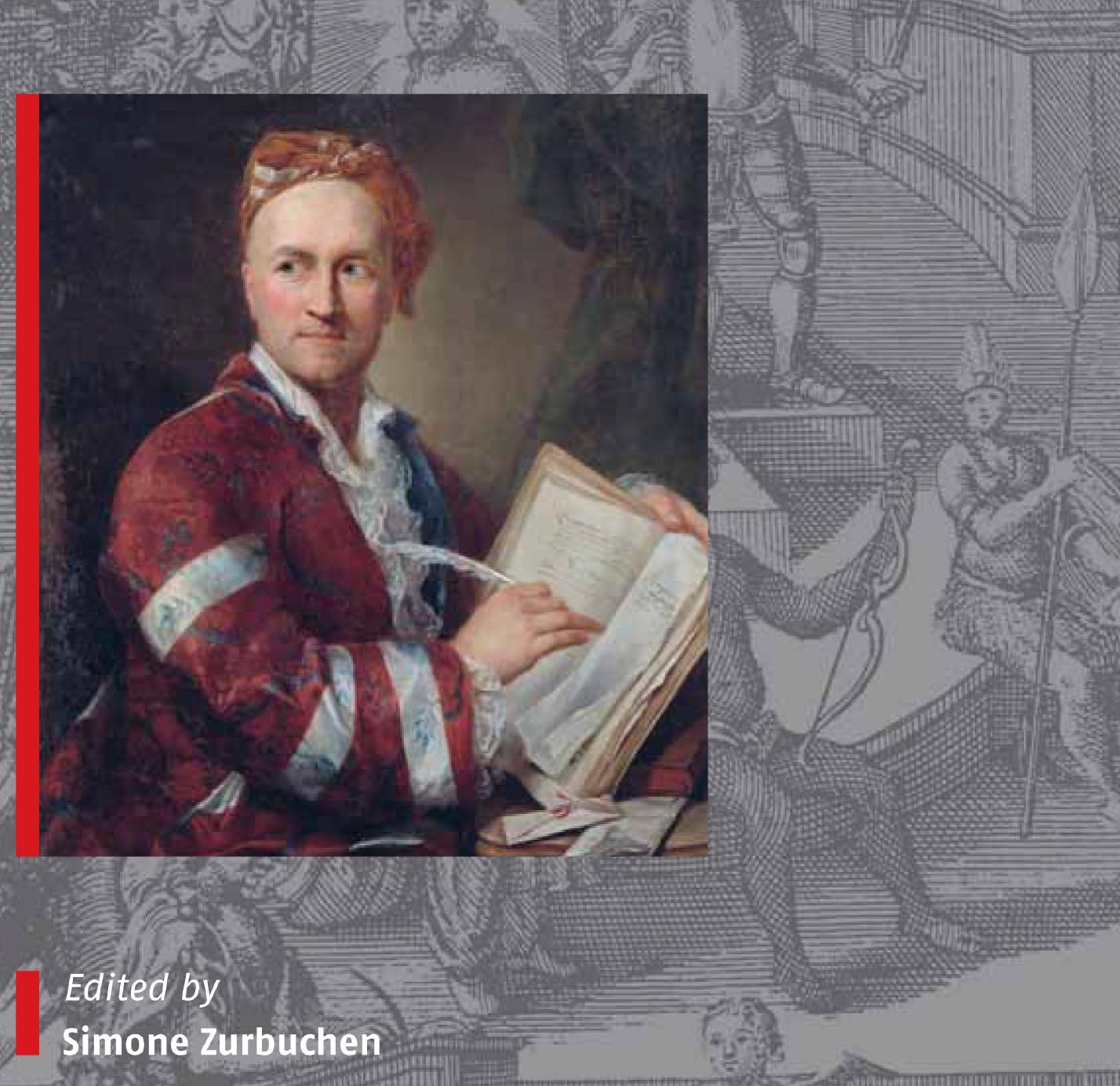

\section{simone Zurbuchen}

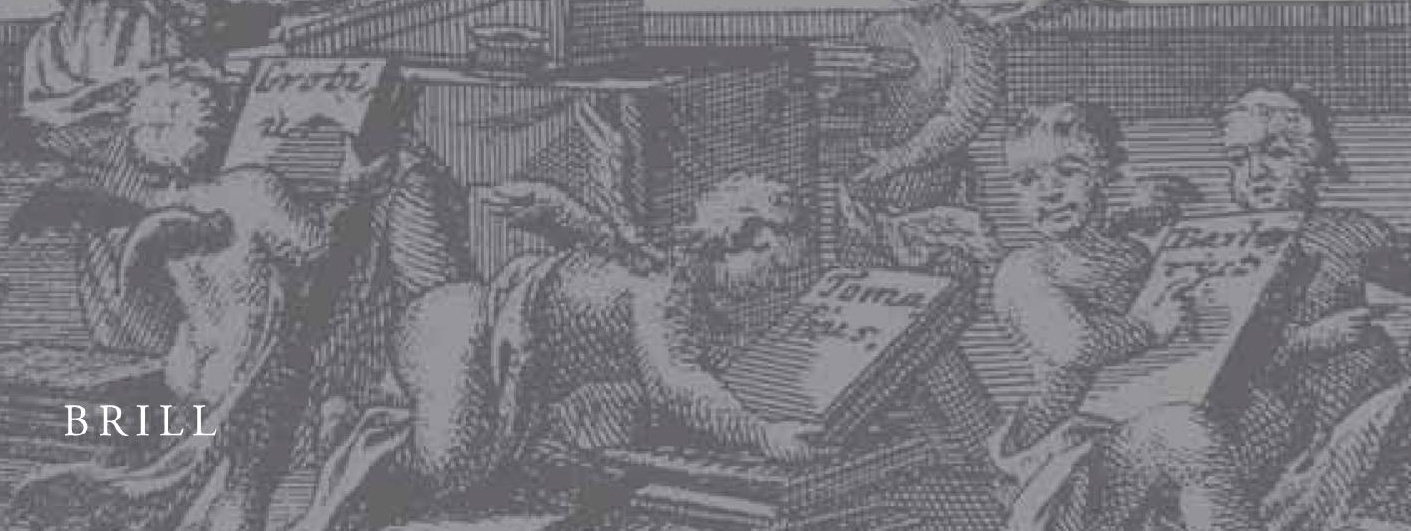


The Law of Nations and Natural Law 1625-180o 


\title{
Early Modern Natural Law
}

\author{
STUDIES \& SOURCES
}

\author{
Series Editors
}

Frank Grunert (Martin-Luther-Universität Halle-Wittenberg) Knud Haakonssen (University of St Andrews and Universität Erfurt) Diethelm Klippel (Universität Bayreuth)

\author{
Board of Advisors \\ Maria Rosa Antognazza (King's College London) \\ John Cairns (University of Edinburgh) \\ Thomas Duve (Max-Planck-Institut für Europäische \\ Rechtsgeschichte, Frankfurt am Main) \\ Ian Hunter (University of Queensland) \\ Martin Mulsow (Universität Erfurt) \\ Barbara Stollberg-Rilinger (Westfälische Wilhelms-Universität \\ Münster and Wissenschaftskolleg zu Berlin) \\ Simone Zurbuchen (Université de Lausanne)
}

VOLUME 1

The titles published in this series are listed at brill.com/emnl 


\title{
The Law of Nations and Natural Law 1625-1800
}

\author{
Edited by
}

Simone Zurbuchen

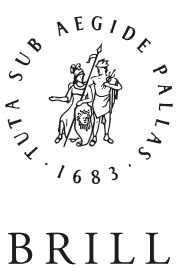


This is an open access title distributed under the terms of the CC-BY-NC-ND 4.O License, which permits any non-commercial use, distribution, and reproduction in any medium, provided no alterations are made and the original author(s) and source are credited.

The publication of this book has been made possible with the support of the Swiss National Science Foundation.

Cover illustration: Portrait of Emer de Vattel. @ C Bibliothèque publique et universitaire de Neuchâtel, Switzerland.

The Library of Congress Cataloging-in-Publication Data is available online at http://catalog.loc.gov LC record available at http://lccn.loc.gov/2019023142

Typeface for the Latin, Greek, and Cyrillic scripts: “Brill”. See and download: brill.com/brill-typeface.

ISSN 2589-5982

ISBN 978-90-04-38419-4 (hardback)

ISBN 978-90-04-38420-0 (e-book)

Copyright 2019 by the Authors. Published by Koninklijke Brill NV, Leiden, The Netherlands. Koninklijke Brill NV incorporates the imprints Brill, Brill Hes \& De Graaf, Brill Nijhoff, Brill Rodopi, Brill Sense, Hotei Publishing, mentis Verlag, Verlag Ferdinand Schöningh and Wilhelm Fink Verlag. Koninklijke Brill NV reserves the right to protect the publication against unauthorized use and to authorize dissemination by means of offprints, legitimate photocopies, microform editions, reprints, translations, and secondary information sources, such as abstracting and indexing services including Authorization to photocopy items for internal or personal use is granted by Koninklijke Brill NV provided databases. Requests for commercial re-use, use of parts of the publication, and/or translations must be addressed to Koninklijke Brill NV.

This book is printed on acid-free paper and produced in a sustainable manner. 


\section{Contents}

Acknowledgements VII

Notes on Contributors VIII

Introduction 1

Simone Zurbuchen

\section{PART 1}

Teaching the Law of Nations

$1 \quad$ Natural Law for the Nobility? The Law of Nature and Nations at the Erlangen Ritterakademie (1701-1741) 11

Katharina Beiergroesslein and Iris von Dorn

2 Serving Danish Foreign Policy: Andreas Hojer's De eo quod iure belli licet in minores (1735) 39

Mads Langballe Jensen

3 The Law of Nations at the Naval Academy in Copenhagen around 1800: the Lectures of Christian Krohg 60

Thor Inge Rørvik

4 The Law of Nations in German historia literaria and Encyclopaedias in the Eighteenth Century 89

Frank Grunert

\section{PART 2}

The Law of Nations from the Peace of Westphalia to the Enlightenment

$5 \quad$ Pufendorf on the Law of Sociality and the Law of Nations 107 Kari Saastamoinen 
6 The International Political Thought of Johann Jacob Schmauss and Johann Gottlieb Heineccius: Natural Law, Interest, History and the Balance of Power 132

Peter Schröder

7 Men, Monsters and the History of Mankind in Vattel's Law of

Nations 159

Pärtel Piirimäe

8 Guarantee and Intervention: the Assessment of the Peace of Westphalia in International Law and Politics by Authors of Natural Law and of Public Law, c. 1650-1806 186

Patrick Milton

\section{PART 3}

The Law of Nations and the 'École romande du droit naturel'

9 Born to Rule: Burlamaqui and Rousseau on the Education of Princes 229

Lisa Broussois

10 Defining the Law of Nations: the École romande du droit naturel and the Lausanne Edition of Grotius' De jure belli ac pacis (1751-1752) 253 Simone Zurbuchen

11 Vattel's Doctrine of the Customary Law of Nations between Sovereign Interests and the Principles of Natural Law 278

Francesca Iurlaro

12 The Circulation of the École romande du droit naturel in EighteenthCentury Italy 304 Elisabetta Fiocchi Malaspina

Persons Index 327

Places Index 331

Subjects Index 333 


\section{Acknowledgements}

The publication of this volume would not have been possible without the support of various institutions and persons. I wish to thank the Swiss National Foundation for financial support of the project 'Natural Law in Switzerland and beyond: sociability, natural equality, social inequalities' conducted at the University of Lausanne. The work on the Swiss-romande school of natural law is an outcome of this research project, which worked up manuscripts and other sources linked to the teaching of natural law at the Academies of Lausanne and Geneva. These are available at http://lumieres.unil.ch/projets/ droit-naturel/ (version du 20.08.2018). The workshop 'The Law of Nations and Natural Law: 1625-1850' (University of Lausanne, $5^{-6}$ November 2015), where first drafts of the chapters in this volume were presented and discussed, was also part of this project. I am very grateful to Lisa Broussois, who helped to organize the workshop, and to the directors of the international network 'Natural Law $1625^{-185^{\prime}}$ for their sustained support. I also wish to thank Ralph Footring for professional linguistic revision of the chapters. 


\section{Notes on Contributors}

\section{Katharina Beiergroesslein}

is historian and archivist. She works as a research fellow at the City Archives of Stuttgart. Her main research interests lie in the field of early modern English and German History, the history of migration as well as natural law as a university subject. She also teaches early modern history at the Ludwig-MaximiliansUniversität in Munich.

\section{Lisa Broussois}

holds a PhD in philosophy from the University of Paris 1 Panthéon-Sorbonne and from the Brazilian Federal University of Minas Gerais. She has published in French, English and Portuguese on Scottish moral and political philosophy, modern philosophy, animal and environmental ethics. She was a postdoctoral researcher at the SNF research project 'Natural law in Switzerland and beyond: sociability, natural equality, social inequality' (University of Lausanne).

\section{Iris von Dorn}

is a historian who has participated in research and exhibition projects at, among others, the Universität Bayreuth, the Ludwig-Maximilians-Universität München, the Max-Planck-Institut für europäische Rechtsgeschichte (Frankfurt am Main). Her main research interests in early modern German history include the history of scholarship, the history of administrative law (15th to 19th century), and princely courts as places of political decision making.

\section{Elisabetta Fiocchi Malaspina}

is Assistant Professor of Legal History at the Law Faculty of the University of Zurich. Her main research fields include history of international law, circulation and dissemination of natural law and law of nations theories from the 18th to the 19th century, history of water resources law, history of land ownership and land registration (19th and 2oth centuries).

\section{Frank Grunert}

is Senior Research Fellow at the Interdisciplinary Centre for European Enlightenment Studies at the Martin-Luther-University Halle-Wittenberg and an associated fellow of the Max Weber Centre at the University of Erfurt. He has published extensively on the German Enlightenment, especially on its early period. He is one of the editors of the series Werkprofile and of the correspondence of Christian Thomasius. 


\section{Francesca Iurlaro}

is a $\mathrm{PhD}$ candidate in international legal thought at the European University Institute (Florence), working on an analysis of the concept of customary international law from Francisco de Vitoria to Emer de Vattel. Her interests include modern jus naturae et gentium and the relationship between law and literary genres. She has published on Alberico Gentili, including a translation of his commentary on Virgil, Lectionis Virgilianae Variae Liber (1603).

\section{Mads Langballe Jensen}

is a postdoctoral researcher at Royal Holloway, University of London. He has published on Protestant political thought and natural law theory from Philipp Melanchthon to the early enlightenment. He is currently working on the role natural law theory played in the ideological legitimisation and politics of the early absolutist monarchy of Denmark-Norway, from domestic to foreign affairs, including the colonization of the Guinea Coast.

\section{Patrick Milton}

is a Research Fellow at Peterhouse and affiliated lecturer at Department of Politics and International Studies, University of Cambridge. He has published numerous articles on the political and constitutional history of the Holy Roman Empire, and the history of early modern European international relations and law. He is currently working on a Cambridge-based project entitled 'A Westphalia for the Middle East'.

\section{Pärtel Piirimäe}

is Professor of Intellectual History at the University of Tartu, Estonia. He has published on early modern international political and legal thought, the history of propaganda, polemics and official historiography, and regionalist concepts and identities. He is also the editor of The Estonian Historical Journal.

\section{Thor Inge Rørvik}

is a Lecturer in History of Ideas at the Faculty of Humanities (IFIKK), University of Oslo. He is the author of several articles on Norwegian and DanishNorwegian intellectual history in the eighteenth and nineteenth century, with a focus on the history of philosophy, university history, and legal history. He recently published 'Samuel Pufendorf - Natural Law, Moral Entities and the Civil Foundation of Morality', in Contemporary Philosophy, vol. 12: Philosophy of Justice, ed. Guttorm Fløistad (2014), 61-73. 


\section{Kari Saastamoinen}

is a Senior Lecturer in History at the University of Helsinki. He has published on early modern natural law, especially on Samuel Pufendorf. He is a member of the directorial team of the Helsinki Centre for Intellectual History. His latest publication is 'Natural Equality and Natural Law in Locke's Two Treatises', in Laws, Rights and Politics, 1579-1832, Studies in Honour of Knud Haakonssen, eds. Ian Hunter and Richard Whatmore (Edinburgh: 2019), 127-146.

\section{Peter Schröder}

is Professor of the History of Political Thought at University College London. His main research interest is early modern and modern history of political thought and he has published widely in this field. His latest monograph Trust in Early Modern International Political Thought, 1598-1713 was published in 2017. He has been visiting professor at universities in Paris, Rome and Seoul, and held numerous visiting research fellowships.

\section{Simone Zurbuchen}

is Professor of Modern and Contemporary Philosophy at the University of Lausanne. She has published widely on the history of early modern moral and political philosophy, with a focus on Samuel Pufendorf and the reception of his work in the eighteenth century. She was the director of the SNF research project 'Natural law in Switzerland and beyond: sociability, natural equality, social inequality' (2014-2018). 


\title{
Introduction
}

\author{
Simone Zurbuchen
}

During the past thirty years, the history of public international law has become an important field of research in various disciplines. New discussions of the origin, growth and evolution of international law from the fifteenth century to the present are at the origin of different proposals for reinterpreting the history of international law and legal discourse, mainly from the perspective of those who were largely excluded from participating in this discourse, such as colonized nations, indigenous peoples and religious or cultural minorities. By questioning the classical narrative of international law as a story of progress, the new de-centred interpretations aim at showing how international law was used by the centre as a means to dominate and exploit the periphery, and how different kinds of moral universalism have accompanied imperial expansion. Much of the recent literature testifies to an overall attempt to reinterpret the history of international law and legal discourse in terms of an ideology legitimizing European colonialism and imperialism.

While revisionist history covers a much longer time-span, references to moral and legal discourse in the seventeenth and eighteenth century form a crucial element of it mainly for two reasons. First, critical accounts of international law require questioning of the narrative inherited from the nineteenth century, which attributed a central role to the Peace of Westphalia or, rather, to what is considered today as the 'myth' of Westphalia. According to this myth, international law proper - that is, law exclusively applicable to states as such and regulating the relationships between them - was first developed in Europe, in the context of a system of sovereign and independent states, which consider each other to be free and equal. According to the formerly dominant story of international law, this system of states was founded in the treaties of Westphalia, and it was concluded, as Jennifer Pitts put it, that 'this essentially European system gradually came to incorporate other states as they reached the appropriate "standard of civilization", or, as more recent language would have it, as they entered the state system or decolonized and became independent.' ${ }^{1}$ A historically more accurate account of the peace settlements of 1648 shows,

1 Jennifer Pitts, 'Empire and Legal Universalisms in the Eighteenth Century', American Historical Review, 117 (2012): 92-121, at 93. I forgo here any attempt to account for the relevant literature. A broad overview is presented in Bodo Fassbender and Anne Peters (eds.), The Oxford Handbook of the History of International Law (Oxford: Oxford University Press, 2012). 
however, that the so-called 'Westphalian system' was, rather, an ideal-type interpretation of the European legal order as it was proposed by Emer de Vattel around the middle of the eighteenth century - an interpretation which did not accurately reflect the positive European law of nations. The development of international law thus needs to be studied against the background of the complex and shifting legal order within and among the European states, including conflicts connected to imperial expansion.

The second reason why the period from 1625 to 1800 plays an important role in deconstructing the 'progress' story of international law has to do with the very concept of international law. The term 'international law' was coined by Jeremy Bentham, to designate the body of legal rules and norms which apply between sovereign states and other entities that are legally recognized as international actors. ${ }^{2}$ The term was eventually to replace the older phrase 'law of nations' (jus gentium, droit des gens, Völkerrecht), ${ }^{3}$ which was still used in the context of modern natural law. For a long time, there was no clear distinction between the jus intra gentes and the jus inter gentes, and the law of nations could not be conceived independently from the law of nature. Hugo Grotius has famously been credited with the foundation of a 'dualist' account of the law of nations - consisting of the 'natural' law on one hand and the 'voluntary' law of nations on the other - and thus with the pulling apart of the formerly tight relationship between the law of nations and natural law. This move is held to mark the birth of international law in its modern sense. This was, however, a complicated story, which needs to be explored on the basis of a wide range of sources and taking into consideration the competing definitions of the law of nations. Grotius' 'dualist' account of the law of nations, which was later taken up by Christian Wolff and Emer de Vattel, was, for instance, challenged by Samuel Pufendorf and his numerous followers, who maintained that there was no such thing as a 'voluntary' law of nations. ${ }^{4}$ These rival accounts of the law of nations were especially important

2 Jeremy Bentham, An Introduction to the Principles of Morals and Legislation, ed. by H.J. Burns and H.L.A. Hart (London: Athlone Press, 1970), 296: 'The word international, it must be acknowledged, is a new one; though, it is hoped, sufficiently analogous and intelligible. It is calculated to express, in a more significant way, the branch of law which goes under the name of the law of nations: an appellation so uncharacteristic that, were it not for the force of custom, it would seem rather to refer to internal jurisprudence'.

3 There is no unified spelling of the word 'ius' in seventeenth- and eighteenth-century editions. Depending on the publisher, the spelling is either 'ius' or 'jus'. In the present volume, 'ius' will appear only where the reference is to a specific edition.

4 Stephen C. Neff, Justice among Nations: A History of International Law (Cambridge, MA: Harvard University Press, 2014), chap. II. 
in relation to the law of war, where the 'dualist' account allowed that questions of intrinsic justice, which referred to 'natural' law, could be relegated to the conscience of sovereigns, whereas the 'voluntary' law, which regulated the formal conduct of war, was a flexible tool for adapting the strict rules of justice to practical necessities. This had important consequences with regard to issues such as the declaration of war, rights in war, peace-making, and neutrality. ${ }^{5}$

One of the questions addressed in this volume is whether and to what extent the law of nations, as it was conceived within the tradition of modern natural law, beginning with Grotius' De jure belli ac pacis (1625), fits into the counter-narrative of the history of international law described above. This question merits attention since specialists in the field have argued that the justification of colonization and imperial expansion was by no means the central aim of the modern law of nature and nations. ${ }^{6}$ Unlike Grotius, the main representatives of this tradition in the seventeenth and eighteenth centuries paid comparatively little attention to the antagonism between 'civilized' Europeans and 'barbarian' others. They were more concerned with the 'barbarians' within Europe and sought to develop a code of conduct suitable to regulate the European nations. The main question after the Peace of Westphalia was how to ensure peaceful coexistence among the European states by means of diplomacy, alliances, arbitration, guarantees and (threat of) intervention, the last being often linked to the idea of the balance of power. Such legal and political devices were theorized within the framework of the law of nature and nations, albeit never from a single, unified perspective. Quite to the contrary, doctrines of the law of nations were forged and developed in various contexts, where questions of power and state interest intermingled with attempts to conform with natural-law rules of justice. ${ }^{7}$

5 Stephen C. Neff, War and the Law of Nations: A General History (Cambridge: Cambridge University Press, 2015), part II.

6 Emmanuelle Jouannet, 'Des origines coloniales du droit international: à propos du droit des gens moderne au $18^{\mathrm{e}}$ siècle', in The Roots of International Law - Les fondements du droit international, ed. by Pierre-Marie Dupuy and Vincent Chetail (Leiden, Boston: Martinus Nijhoff, 2014), 649-671. For a nuanced account of the law of nations see also Georg Cavallar, 'Vitoria, Grotius, Pufendorf, Wolff and Vattel: Accomplices of European Colonialism or True Cosmopolitans?', Journal of the History of International Law 10/2 (2008): 181-209.

7 In his study of the historical evolution of occupation, Andrew Fitzmaurice shows, for example, in an exemplary way, how the intellectual contexts and the contexts of imperial practice shaped different theories of occupation and the uses that were made of these theories: Andrew Fitzmaurice, Sovereignty, Property, and Empire, 1500-2000 (Cambridge: Cambridge University Press, 2014). 
So far, accounts of the history of the modern law of nations have mainly focused on a restricted number of classic treatises, such as the published works of Hugo Grotius, Samuel Pufendorf, Christian Thomasius, Cornelius van Bynkershoek, Christian Wolff or Emer de Vattel. While lesser known figures have occasionally been dealt with in the specialized literature, we still know comparatively little about this very rich tradition of moral and legal thinking and its influence on the law of nations and legal practice in various European countries. In this context, the fact that the law of nature and nations constituted, from the late seventeenth until the middle of the nineteenth century, an academic discipline that was taught at a great number of universities and other institutions of higher education throughout Europe no doubt plays a crucial role.

This volume explores, for the first time, a wide range of formerly obscure literature related to the law of nature and nations. The volume presents studies conducted by participants in the international research network 'Natural Law 1625-1850', many of whom are currently working on archival materials related to the teaching of the law of nature and nations in various European countries. These case studies show how the conception of the law of nations varied in intellectual content and practical function, depending on the contexts in which it was developed and applied. They are supplemented by new interpretations of classic texts in the field and by studies of figures and theories hitherto largely neglected in research.

The volume comprises three sections. In the first, "Teaching the Law of Nations', the studies show by way of examples what can be gained from exploring the law of nature and nations on the basis of specialized academic texts on the subject (dissertations, textbooks, programmatic writings, etc.) and general introductory courses. This literature emerged in several European countries and in a variety of educational institutions, often addressed to specific audiences. One example is that of the Ritterakademie, a particular kind of institution in the Holy Roman Empire aimed at preparing the sons of the nobility for their future functions as civil servants. Several programmatic writings connected with the short-lived Ritterakademie at Erlangen (1701-1741), in the Franconian magravate of Brandenburg-Bayreuth, show the significance of the law of nature and nations not only in the education of this social class but also how it was used to keep ministers and magistrates at German courts informed about developments in international law, such as diplomatic immunity.

Two further chapters deal with the law of nature and nations in the Danish context, which is rarely considered in historical accounts of international law in the eighteenth century. One study focuses on the inaugural dissertation of Andreas Hojer, who was appointed as first ex officio professor of the law of 
nature and nations at Copenhagen University in 1734. By discussing the dissertation against the political and polemical background of Denmark-Norway's participation in the Great Northern War, the author shows how expertise in the law of nature and nations was used to defend the political interests of the Danish monarchy. At the same time, he explains why there had been ongoing concerns with improving the teaching of the law of nature and nations at Copenhagen University for decades before Hojer was appointed: DenmarkNorway needed an academic expertise in the field comparable to that of the university in Kiel, which had been among the first universities to create a chair in natural law and appointed teachers able to defend the interests of the rivals of the Danish kings in the Great Northern War. Yet another chapter explores how Danish interest in the law of nations was reinvigorated by the outbreak of the French Revolutionary Wars and the events leading to the foundation of the Second League of Armed Neutrality in 180o. The chapter shows how teaching at Copenhagen University was adapted in a textbook used to teach the law of nations at the Royal Danish Naval Academy at the very beginning of the nineteenth century. The work included thoroughgoing reflections on the different applications of the universally valid law of nations to morally and culturally 'developed' European nations on the one hand and 'barbarian' and 'savage' nations on the other. Not surprisingly, the textbook also deals extensively with trade and shipping, the laws of war, and the rights and duties of neutral nations - subject matters Danish-Norwegian naval officers had to be familiar with at the time.

The second section of this volume, "The Law of Nations from the Peace of Westphalia to the Enlightenment', presents chapters on continuing disputes about the alleged Hobbesianism of a highly influential classic in the field, namely Pufendorf's The Law of Nature and Nations, and on lesser known successors of Pufendorf and Thomasius such as Johann Jacob Schmauss and Johann Gottlieb Heineccius. The focus is on how these authors judged the problems inherent in the antagonistic European state system, how they reformulated the notion of state interest and to what extent they believed that the latter could be protected by the balance of power. Yet other studies in this section take up some of the key questions raised above in connection with the challenges that the revisionist history of international law faces with regard to the tradition of modern natural law. On the one hand, there is the question of how the distinction between 'civilized' and 'savages' or 'barbarian' nations featured in Vattel's treatise on the law of nations. It is suggested that the Swiss author did not use this distinction to demarcate Europeans from non-European 'others'. He distinguished rather 'men' from 'monsters' on the basis of a specific history of progress, a vision of the advancement of humanity driven by enlightened monarchs, who had a 
correct understanding of enlightened self-interest and true glory, as exemplified by Tsar Peter the Great. On the other hand, this section offers a novel unmasking of the 'myth' of Westphalia by showing how natural lawyers writing on the law of nations dealt with the guarantees and interventions in the domestic affairs of the Holy Roman Empire that had been laid down by the Peace of Westphalia. It turns out that while some natural lawyers did welcome interventions to protect foreign subjects in accordance with the guarantee of the peace treaties, others proved to be highly critical of interventions because of concerns that the guarantee would be instrumentalized by France under Louis XIV.

The chapters in the third section deal with "The Law of Nations and the école romande du droit naturel'. The idea here is to shed new light on the intellectual context in which Emer de Vattel developed his highly influential treatise on the law of nations. The main representatives of the Swiss school of natural law before Vattel, Jean Barbeyrac and Jean-Jacques Burlamaqui, inaugurated natural law as an academic discipline in the French-speaking part of the old Helvetic confederation and their works had a decisive influence all over Europe. This is generally well known, but the academic and historical background to their teaching, the publishing strategies they and their disciples adopted, and the debates their publications triggered in various European countries, especially with regard to the law of nations, have so far not been studied in their own right. Such questions are addressed in a chapter on the definition of the law of nations in the Swiss context, which takes into account the multi-volume Latin edition of Grotius' De jure belli ac pacis, published in Lausanne in $175^{1-175^{2}}$. The novel feature of this edition consists in the integration of the extensive annotations and commentaries to Grotius' work by Heinrich and Samuel Cocceji (father and son), which had previously been published in Breslau as Grotius illustratus. While the reasons Barbeyrac's disciples had for preparing this edition are not wholly clear, there is no doubt that the Coccejis' radical critique of Grotius' 'voluntary' law of nations strengthened the 'naturalist' position of Pufendorf and his successors, which was largely predominant in the Swiss context before Vattel resumed the Grotian 'dualist' account of the law of nations in his Law of Nations. This study is supplemented with a broad overview of the reception and use of Barbeyrac's, Burlamaqui's and Vattel's works on the law of nature and nations in eighteenth-century Italy. Despite - or perhaps because of - its political fragmentation and the influence of the Roman Catholic Church, the Italian peninsula provided the context for enlightened debates on natural law, diplomacy and the law of nations, and the école romande du droit naturel had a major influence on these debates.

Albeit from very different angles, two further chapters in this section deal with the function Swiss natural lawyers ascribed to the enlightened self-interest 
of rulers in making them comply with the natural-law rules of justice. One study takes up Jean-Jacques Rousseau's radical critique of the idea that young people, and princes, should be educated by means of books on law and ethics - which would be filled with prejudices instead of true knowledge of humanity. This is confronted with Jean-Jacques Burlamaqui's actual practice of educating a prince (Frederick II, Landgrave of Hessen-Kassel, was his pupil from 1732 to 1737) and his idea that an enlightened prince could be educated according to the law of nature and nations that he would be subject to as a rul$\mathrm{er}$, in the same way as any other man. Since in Burlamaqui's view the sovereign had to become an interpreter of natural law instead of legislating arbitrarily, the prince needed to be provided with the appropriate tools for this through education. Yet another study in this part of the volume is devoted to Vattel's doctrine of the customary law of nations - a subject that has so far never been studied in the scholarly literature. The focus on custom and practice provides an interesting link between this chapter and the one on Burlamaqui. The author shows that the function Vattel attributed to custom in his account of the law of nations needs to be assessed in light of his critique of Wolff's idea of perfectio as foundation of natural law, which Vattel replaced with a 'noble', anti-Hobbesian, concept of self-interest. Based on this finding it is possible to show how Vattel conceived of custom as a peaceful means for states to pursue their own interest without necessarily conflicting with the law of nations. It is also shown that Vattel installed custom as a tool for mediating between the natural and the voluntary law of nations, by providing states with a flexible and dynamic source of obligation.

While the chapters in this volume take issue with questions linked to the revisionist turn in the history of international law, it does not by any means aim to compete with the specialized literature in the field, which accounts for the history of international law over a much longer period. Neither does it seek to make an overall argument about the role of international law in justifying European exceptionalism. The goal is, rather, to show how specialists in the field of modern natural law, who work on a wide range of formerly unknown sources, can contribute to a better understanding of the law of nations in the period which was decisive for its origin and constitution as a discipline which eventually emancipated itself from natural law. 

PART 1

Teaching the Law of Nations 



\title{
Natural Law for the Nobility? The Law of Nature and Nations at the Erlangen Ritterakademie (1701-1741)
}

\author{
Katharina Beiergroesslein and Iris von Dorn
}

\section{The Matveyev Incident}

By the middle of 1708, Europe's newspapers were full of reports of a diplomatic incident between Great Britain and Czarist Russia. Because of its unpredictable consequences, this so-called Matveyev (also Matveev or Metveyev) incident not only caused a great sensation all over Europe, but also put great diplomatic pressure on the relationship between the British Queen Anne and Czar Peter the Great of Russia. In the end, however, it helped to clarify the issue of diplomatic immunity: how it was to be understood and what practical impact it had on the interaction with envoys sent by foreign princes or states. It thus contributed 'to shape an important component of modern international relations.' Hence the event also reveals that the right of diplomatic immunity understood as inviolability of the ambassador's person, his home and vehicles, his luggage and letters, and including the exemption of the ambassador and his staff 'from both civil and criminal litigation' ${ }^{2}$ - was, by the beginning of the eighteenth century, far from being interpreted in completely the same manner at European courts, even though the principles of extraterritoriality and diplomatic immunity had been discussed at least since the fifteenth century and put in writing by Hugo Grotius during the 1620 s. $^{3}$

On the evening of 21 July 1708, while on his way to a soirée with other foreign diplomats at Somerset House, Andrey Artamonovich Matveyev (1666-1728), ${ }^{4}$ special envoy of Peter the Great to Queen Anne, 'was stopped by three men who

1 James Cracraft, The Revolution of Peter the Great (Cambridge, MA: Harvard Univ. Press, 2003), 73 .

2 De Lamar Jensen, 'Diplomacy,' in Europe 1450 to 1789. Encyclopedia of the Early Modern World, vol. 2, ed. Jonathan Dewald (New York: Thomson-Gale, 2004), 147-152, here 149.

3 Jensen, 'Diplomacy,' 149; Anuschka Tischer, 'Diplomatie,' in Enzyklopädie der Neuzeit Online, ed. Friedrich Jaeger, accessed 15 April 2017. http://dx.doi.org.emedien.ub.uni-muenchen.de/ 10.1163/2352-o248_edn_ao7740oo, first published online: 2014.

4 Vladimir E. Grabar, The history of international law in Russia 1647-1917: a bio-bibliographical study (Oxford: Clarendon Press, 199o), 47. 
dragged his footmen down and beat them, and then pulled him out of the coach, seizing his sword and forcibly taking possession of the vehicle. ${ }^{5}$ Shortly after, Matveyev, who had been injured by the attackers, found himself locked up in prison. Four hours later, and after several foreign diplomats had intervened on his behalf, Matveyev was set free. ${ }^{6}$ But what had caused this embarrassing event? At first, Andrey Matveyev's mission to Great Britain seemed to have been normal diplomatic business. In May 1707, prior to which time he had been delegated to The Hague, he was sent to London. And only ten days after his arrival at Greenwich he had an audience with the Queen. As with a former (unsuccessful) mission to Paris, where he had stayed from September 1705 to October $1706,{ }^{7}$ Matveyev's legation had been designed to try to break the hegemony of Charles XII of Sweden in the Baltic. Its main task was to persuade Anne to mediate in peace negotiations between Sweden and Russia; since 1700, Russia and Sweden had been fighting over outlets to and control over the Baltic Sea region. ${ }^{8}$ Additionally, Matveyev was supposed to express Peter's readiness to join the Grand Alliance (also known as League of Augsburg), which had been founded in 1686 as a counterbalance to France's expansionist policies. ${ }^{9}$ Furthermore, Britain was to be restrained from acknowledging the new Polish king, Stanislaus I Leszcynski, as the appointment of Stanislaus was completely against Peter's interests. First, this was because Stanislaus had become king by the grace of Charles XII and the Polish opposition and was thus regarded as a Swedish puppet monarch. Secondly, Russia had lost an important ally when the former Polish king and elector of Saxony, Augustus II, had lost the Polish throne to Stanislaus with the Peace of Altranstädt in $1706 .^{10}$ Finally, Matveyev was to offer a British-Russian trade agreement concerning British trade via Baltic ports, especially the new Russian city of St Petersburg, instead of Archangel. This was supposed to aim at challenging 'the intermittent Swedish blockade of Russia's new outlets in the Baltic'.11

$5 \quad$ Andrew Rothstein, Peter the Great and Marlborough: Politics and Diplomacy in Converging Wars (New York: St. Martin's Press, 1986), 90.

6 For more details on the Matveyev incident see: Aleksander Wierzbicki, Peter the Great of Russia: an English Historiography of the XVIII and XIX Centuries (London: Athena Press, 2004), 62-66; Rothstein, Peter the Great, 79-94; Cracraft, Peter the Great, 73; Janet M. Hartley, Charles Whitworth: Diplomat in the Age of Peter the Great (Aldershot: Ashgate, 2002), 69-79.

7 Rothstein, Peter the Great, 68.

8 Ibid., 34-37.

9 Ibid., 8o.

10 Heinz Duchardt, Europa am Vorabend der Moderne 1650-180o (Stuttgart: Eugen Ulmer, 2003), 293-294; Rothstein, Peter the Great, 61-63.

11 Rothstein, Peter the Great, 5 o. 
Unfortunately, Matveyev's mission was a complete failure. It was not only because of the British government playing for time and putting the Russian envoy off several times and thus prolonging his stay and testing not only his but also Peter's patience. But Queen Anne let him know that because of her long-standing friendship with Charles XII of Sweden, she would not interfere between the two main opponents of the Great Northern War. However, what she did not mention was that concerning Britain's engagement in the War of the Spanish Succession, it suited Britain that Charles maintained an army in the Holy Roman Empire. ${ }^{12}$ Hence she had no interest in displeasing the Swedish monarch. Consequently, the commercial agreement failed also. On top of that Britain recognized the new Polish king a few months later. As a result, Matveyev's mission ended and he was called back to Moscow. But as already mentioned, matters became even worse, indeed disastrous, for the Russian envoy. The reason for Matveyev's arrest was a debt of $£_{5}$, which he had not been able to settle immediately. Apparently, the creditor had feared the envoy might leave England without paying him, and he had gained an official arrest warrant for Matveyev. But as Matveyev had not had his farewell audience with the Queen yet, the stated reasons for the arrest seem likely to have been fabricated. Matveyev himself, for example, suspected the Swedish envoy at St James's of having plotted against him. The day after the insult, the Russian envoy complained to Queen Anne about the way he had been treated and demanded severe punishment of the offenders as compensation for infringing on his inviolable dignity. Eight days later he left the British Isles. Anne, being afraid that the incident would redound upon the British in Czarist Russia, was in turn very much concerned to straighten the affair out quickly. Therefore the attackers were arrested and the Queen commissioned one of her most experienced diplomats to resolve the dispute amicably. She chose Charles Whitworth (1675-1725), who had already served at Vienna and the Imperial Diet at Ratisbon. Moreover, he was known to the Czar and his ministers through an earlier embassy to Russia. Nevertheless, the mission was a very delicate task. Peter the Great had demanded the death penalty for Matveyev's attackers, a requirement the Queen was not able to meet. First, 'she could not do such a thing by her own authority, less than seventy years after the great Revolution'. Secondly, was there no 'provision in law for the punishment of the offenders by death.13 Therefore Whitworth was to present a ceremonial apology to the Czar and to inform him of the

\footnotetext{
12 Wierzbicki, Peter the Great, 63.

13 Rothstein, Peter the Great, 92.
} 
Diplomatic Privileges Act which had, in consequence of the Matveyev incident, been passed by the British Parliament in 1708. As it 'contributed importantly $[. .$.$] to the final elaboration in Europe of the law on diplomatic$ immunity, ${ }_{14}^{14}$ the Act was probably the most important outcome of the affair. The Act 'for preserving the Privileges of Ambassadors, and other Public Ministers of Foreign Princes and States' not only acquitted Matveyev of all charges but also defined how the term diplomatic immunity henceforth was to be understood in Britain. Namely, 'all Writs and Processes that shall [...] be sued forth or prosecuted, whereby the person of any Ambassador, [etc.] authorised and received as such by Her Majesty [...] may be arrested or imprisoned, or his or their goods or chattels may be distrained, seized, or attached, shall be deemed and adjudged to be utterly null and void, to all intents, constructions, and purposes whatsoever. ${ }^{15}$ In short, accredited and officially received envoys now enjoyed absolute immunity in Britain. Following this, the affair was settled to mutual satisfaction.

Because of its importance for the interpretation of the law of nations, and thus for international relations in general, princely courts - and especially the princes' magistrates dealing with foreign affairs - were very much interested in detailed descriptions of the incident. For example, a 'vornehme[r] Königl. Ministre'16 asked for a close analysis of the affair. Probably shortly after the incident had been resolved in 1709, a minister of King Frederick I of Prussia, who is not mentioned by name, commissioned Dietrich Hermann Kemmerich $\left(1677^{-1745)}\right.$ 'to investigate the whole affair more precisely, because this matter was rather curious and caused a great deal of attention at various European courts; at the same time it would testify to the manner in which the law of nations was treated by the Muscovites. ${ }^{17}$ Kemmerich, who had studied theology, history and law at the universities of Rostock, Leipzig and Halle, was, at that time, teaching natural law, law of nations and constitutional law at the

\footnotetext{
14 Cracraft, Revolution, 73 .

157 Anne Cap. 12, § III.

16 Dietrich Hermann Kemmerich, Grund=Sätze des Völcker=Rechts von der Unverletzlichkeit der Gesandten. Samt einer Relation von dem Affront, welcher dem Moscowitischen Abgesandten in Engelland Anno 1708 erwiesen und der darauf erfolgten Satisfaction, Wie auch einer kurtzen Untersuchung dieser Affaire nach solchen Grund=Sätzen (ChristianErlangen: Johann Andreas Lorber, 1710).

17 Kemmerich, Grundsätze, 1: '[...]weil nun diese Sache ziemlich merckwürdig ist / und an verschiedenen Europaeischen Höfen grosses Aufsehen verursachet hat / auch zugleich ein Zeugniss giebt / wie auch bey den Moscowitern anjetzo das Völcker=Recht excoliert werde $[\ldots]$ die gantze Affaire etwas genauer zu untersuchen'.
} 
newly founded Ritterakademie ${ }^{18}$ at Erlangen. In 1716 he became director of the Ritterakademie at Brandenburg, in 1719 first professor of natural law and law of nations at the University of Wittenberg and finally in 1730 Fürstlich Sächsischer Gemeinschafftlicher Hofrath and professor at the law faculty of the university at Jena. ${ }^{19}$ As asked by the Prussian minister, Kemmerich in 1710 published a 52-page treatise in which he analysed 'die Affaire wegen des dem Moscowitischen Gesandten Mantuesof [sic] in London vor einiger Zeit angethanen Affronts'.20 The introductory part deals with 40 questions concerning the contemporary theory of diplomatic law, focusing on different aspects of diplomatic immunity. In a second step, Kemmerich applies these basic principles to the Matveyev incident. First, he recaps in a descriptive, non-judgemental way the course of events. He complements this with German translations of three relevant documents: the oration of the British ambassador Charles Whitworth ${ }^{21}$ which he gave when being received by Peter the Great in public audience; Anne's letter of apology to the Czar, which Whitworth was to deliver; and Peter's formal answer. Kemmerich is thus giving background information as well as some of the essential primary sources before he starts his analysis of the case.

Although the Grund=Sätze des Völcker=Rechts was not in the first instance meant for teaching purposes at the Ritterakademie, but for keeping the ministers and magistrates at the German courts informed about these new developments in international law, the context of the treatise is nonetheless the teaching of natural law and the law of nations at Erlangen. First, Kemmerich wrote them explicitly in his function as professor of the law of nature and

18 Instead of using alternative, not completely adequate English translations like 'knights' academy' the German term Ritterakademie will be used throughout the text to denote this special type of educational institution.

19 Teichmann, 'Kemmerich, Dietrich Hermann,' in Allgemeine Deutsche Biographie 15 (1882), 599, https://www.deutsche-biographie.de/gnd10017731X.html\#adbcontent [29.05.2017]; Franckesche Stiftungen zu Halle (Saale), Datenbank zu den Einzelhandschriften in den historischen Archivabteilungen: 'Kemmerich, Dietrich Hermann' (Stand 29.03.2016), http://192.124.243.55/cgi-bin/gkdb.pl [31.03.2017]; Johann Jacob Moser, Lexicon derer jetzlebenden Rechts=Gelehrten in und um Teutschland, welche die Rechte öffentlich lehren oder sich sonsten durch Schriften bekannt gemacht haben, so viel ihrer damalen zu erkundigen gewesen seynd (Züllichau: Gottlob Benjamin Frommann, ${ }^{2}$ 1739), $116-122$.

20 Kemmerich, Grundsätze, 1.

21 Hartley, Charles Whitworth, 1-13; Rothstein, Peter the Great, 3-11; D.D. Aldridge, 'Whitworth, Charles, Baron Whitworth (bap. 1675, d. 1725),' Oxford Dictionary of National Biography (Oxford University Press, 2004); online ed., Jan 2008, accessed 15 April 2017 , http://www.oxforddnb.com.odnb.emedia1.bsb-muenchen.de/view/article/29336. 
nations as well as public law at the Erlangen Ritterakademie. ${ }^{22}$ Secondly, the work provides an insight into Kemmerich's methods of teaching. The 40 questions concerning the theory of diplomatic law show his preference for teaching dialogues; the application of the discussed aspects of diplomatic theory and law to the particular case of Andrey Matveyev, as well as the translation of the documents, reveal how much he, most likely influenced by Christian Thomasius, ${ }^{23}$ emphasized a practical approach to teaching. Finally, the outcome of the Matveyev incident, and thus the conclusions he drew from it, affected the relevant chapters of his textbook Neu=eröffnete Academie der Wissenschaften (Newly Opened Academy of Sciences) for the teaching at Ritterakademien, which he published in 1714, and thus also the contents of the lessons in natural law and law of nations at the Erlangen Ritterakademie.

\section{Natural Law and Law of Nations at the Erlangen Ritterakademie}

The Ritterakademie was founded in 1701, at the small, still young, Franconian town of Erlangen (at that time Christian-Erlangen). The purpose of this special type of school was to educate and prepare the sons of the nobility for their future duties and functions at princely courts. Christian-Erlangen had been founded at the end of the seventeenth century by Christian Ernst, Margrave of Brandenburg-Bayreuth, to receive Huguenot refugees from France. Because of its strong French influence in terms of language and lifestyle as well as its growing importance as a secondary residence of Brandenburg-Bayreuth, which offered the opportunity for young nobles to take part in courtly events, the town appeared to be highly appropriate for such an educational institution. Besides the exercitia (subjects like riding, dancing and fencing) and several foreign languages (Latin, French and Italian), the so-called studia (religious education, arithmetic, geometry, techniques of fortification, history, chronology, geography, ethics, politics, logic, physics and jus naturae, civile et publicum) were to be part of the curriculum.

The Ritterakademie was designed for a maximum of $5^{\circ}$ pupils (who were housed and catered for there, as well as educated). It was provisioned with annual funds from Margrave Christian Ernst's coffers. Around half of the students - preferably from families of the Franconian nobility - were to be given

22 Kemmerich, Grundsätze, Titlepage: 'Juris Nat. Politic. \& Juris Publ. Prof. auf der Ritter $=$ Academie $z$ u Christian=Erlang'.

23 Hans-Christof Kraus, Englische Verfassung und politisches Denken im Ancien Régime 1689 bis 1789 (München: R. Oldenbourg, 2006), 374. 
free admission, financed by a donation from Baron Christoph Adam Gross von Trockau (1649-1724), who had, since 1692, been Oberpräsident of the French colony at Erlangen and virtual initiator of the Ritterakademie. Additionally, three or four of the most capable pupils should be enabled to go on a Grand Tour, limited to a maximum duration of four years; the tour should incorporate trips to France, Italy, England and the Netherlands, and the courts of Hannover, Wolfenbüttel, Berlin and Dresden, as well as visits to other universities and internships at the Reichskammergericht (Imperial Chamber Court) or the Reichshofrat (Aulic Council). Being without a male heir, Gross von Trockau had decided to invest his assets in the education of the children of the Reichsadel (nobility of the Holy Roman Empire), as he regarded the lack of an appropriate education as the main cause of the decline of many once distinguished and powerful noble families. ${ }^{24}$

At first, the educational project at Erlangen, originally called Academia Practica, then renamed Academia Equestris, was rather popular. But only a few years later major difficulties occurred, mainly due to underfunding. Although the Ritterakademie formally existed until 1741, not a single student lodged there or attended its public lessons over the course of many years. However, a number of young noblemen on Grand Tour resided at Erlangen and attended private lessons given by the academy's teachers. ${ }^{25}$ In view of this, it is difficult to determine when, how and by whom natural law and the law of nations was actually taught at Erlangen. Nevertheless, it is at least possible to spotlight a few aspects of this teaching. Because of a lecture announcement ${ }^{26}$ of the newly appointed professor of Philosophia Moralis \& Civilis as well as Eloquentiae, Dietrich Hermann Kemmerich, who later became professor of natural law, law

24 Grossische Stifftung. Die unter der Protection dess Durchleuchtigsten Fürsten und Herren, Herrn Christian Ernsten, Marggrafen zu Brandenburg ... zu errichtende Academia Practica in Neu Erlang (Erlangen: [1702]); 'Ansprache an junge Standes-Personen,' in Christoph Adam Gross von Trockau, Recreationes Academicae Grosianae, Oder: Anleitungen Junge Stands=Personen Auf eine leichte und biss dato noch unbekannte Art zu einer Standes=mässigen Erudition nach dermaliger Welt=Art und dann zu Erlernung der vier Occidentalischen Sprachen zugleich und ohne Confusion in der Erlanger Ritterakademie anzuführen.... Meistens in denen vier Occidentalischen Sprachen als Französisch, Italienisch, Spanisch und Lateinisch beschrieben samt einer Teutschen Vorrede von Einrichtung und Endzweck dieses Wercks (Christian-Erlang: Daniel Michael Schmatz, 1713), n.p; Ernst Mengin, Die Ritter-Academie zu Christian-Erlang. Ein Beitrag zur Geschichte der Pädagogik (Erlangen: Palm \& Enke, 1919).

25 Mengin, Ritter-Academie, 34-57.

26 Dietrich Hermann Kemmerich, Praeliminar-Discours von der Weissheit und Beredsamkeit, deren sich ein Jungervon Adel oder auch höhere Standes-Person zu befleissigen ... (Erlangen: Johann Friedrich Regelein, 1706). 
of nations and public law, we know that lessons in natural law were taught at least from 1705. Kemmerich's teaching was based on Johann Franz Buddeus's Elementa Philosophiae Practicae, on which he lectured for several hours a week, in German. Additionally, during another lesson at the end of the week, the subject matter was repeated and the knowledge of it deepened by a Latin exam or an exercitium disputatorium. Furthermore, Kemmerich referred to the topic in his courses on rhetoric, using for instance Cicero's De officiis to illustrate the principles of jus naturae \& gentium. Moreover, it can be noted that in 1741 natural law was still part of the Erlangen curriculum. It was taught as a part of lessons in philosophy and based on Johann Christoph Gottsched's Erste Gründe der gesamten Weltweisheit. ${ }^{27}$

Although the surviving archival material is not sufficient to analyse in detail how education at the Ritterakademie took place, an impression of how natural law and the law of nations fit best into the overall educational pattern of the Ritterakademie can be gained by three programmatic writings, by von Trockau, Johann Christoph Vetter and Kemmerich. The essays show the subject's relation to other disciplines, its significance as part of the education of young nobles, as well as the specific contents thought important by the contemporaries in charge. Certainly, one has to keep in mind that these are normative texts which do not necessarily tell anything about the reality of the teaching at the Erlangen Ritterakademie.

\subsection{Baron Christoph Adam Gross von Trockau}

Christoph Adam Gross von Trockau, spiritual father of the Erlangen Ritterakademie, outlined his ideas concerning the programme, methods and contents of an appropriate noble education in his Recreationes Academicae Grosianae, published in 1713. His intention was to provide the students with a 'standesmässige doch reale Erudition nach jetziger Welt-Art'. ${ }^{28}$ In short, this meant a threefold approach: the teaching of several foreign languages ('der heut im Flor stehenden Sprachen'), of a courteous and general real-life scholarliness - 'eine[r] galante[n], anbey reale[n] und solide[n] Gelehrsamkeit' as he calls it - as well as of well-formed behaviour. ${ }^{29}$ It seems clear that Gross von Trockau devised his teaching system in contrast to the usual higher education

27 Nachricht von der gegenwärtigen Verfassung der Ritter-Academie und des Seminarii zu Christian Erlang ([Christian Erlangen]: 1741), 6-8.

28 'Ansprache an junge Standes-Personen,' in Gross von Trockau, Recreationes Academicae Grosianae, n.p.

29 'Fernere Anmerckungen. Und zwar in specie über das Studiren und Education junger Standes-Personen,' in Gross von Trockau, Recreationes Academicae Grosianae, n.p. 
at grammar schools and universities, where - in his opinion - young people spent too much time on unnecessary and useless matters. ${ }^{30}$ The teaching seems to have been some kind of crash course, with a slimmed version of each subject covered in less time, and only subjects and lessons geared to actual requirements and absolutely necessary for the pupils' future activities and occupation. And the pupils should be tutored in a clear, vivid and practical way. This included - in contrast to lessons at university - the possibility to ask questions. Instead of applying the method of memorizing, teachers were supposed to train their students in rational thinking. The underlying idea was that a young noble, when finished with his education, would not end up merely a learned parrot ('gelehrte[r] Papagay'), ${ }^{31}$ only able to learn things by heart but with no ability to reason.

However, the Recreationes Academicae Grosianae contains much more than Gross von Trockau's ideas for realizing his educational project. The work was intended to serve as the main textbook for the Ritterakademie: approximately 1500 pages long, it collects a variety of texts, written by different authors, which were supposed to form the basis of the teaching at the Ritterakademie. The baron not only edited the texts but also translated some of them. The textbook reflects his intention for all lessons to have at least a dual benefit: in addition to conveying specialized knowledge and skills in a specific subject, they were also supposed to serve as exercises in different languages, and vice versa. The chapters destined for imparting language skills comprised texts in various languages, including French, Italian, Spanish and Latin. Other chapters were, however, also written either in one of these so-called occidental languages ('occidentalischen Sprachen'), or in German. As the acquisition of language skills was not seen as an end in itself but as vehiculum rerum, the choice of language usually depended on the information to be conveyed. The same teaching method was favoured by Kemmerich. ${ }^{32}$ The chapter titled 'Vorgeschmack vom Jure Civili und Jure Feudali' (foretaste of civil and feudal law), ${ }^{33}$ for example, was written in Latin, still the common language of lawyers and law. An attached glossary - Lexicon Juridicum Verbale \& Reale - explained the Latin legal terminology in German; this was likely to make the subject matter more accessible. While

30 'Vorrede,' in Gross von Trockau, Recreationes Academicae Grosianae, n.p.: 'zu viel Zeit mit unnöthigen und zu jetziger Welt=Art undienlichen Sachen zu [bringen]'.

31 Ibid.

32 Gunter E. Grimm, Literatur und Gelehrtentum in Deutschland. Untersuchungen zum Wandel ihres Verhältnisses vom Humanismus bis zur Frühaufklärung (Studien zur deutschen Literatur 75) (Tübingen: Max Niemeyer, 1983), 452. 
Gross von Trockau stuck to Latin for these legal subdisciplines, he chose French when it came to public law ${ }^{34}$ as well as natural law and law of nations. ${ }^{35}$

The baron's educational programme aimed at introducing the young nobles to studies much earlier than usual. This applied especially to the teaching of the languages he saw as indispensable for a nobleman of the day ('eine StandesPerson nach jetziger Weltart'). ${ }^{36}$ Ideally a boy should have acquired the basics of Latin as early as by the age of eight and additionally he should be able to understand a little Italian and Spanish. He was also expected to have already a good command of the French language. According to Gross von Trockau, both the French and their language were exemplary: he saw a strong connection between learning French and acquiring contemporary - that is gallant - norms of communication and interaction. Additionally, he regarded the French language culture as being worthy of imitation because the French would tend to a plain and clear linguistic style. Moreover, all good books would be available in French translation. ${ }^{37}$ One reason for the rapid increase in French translations during the so-called siècle classique was most likely to demonstrate France's cultural superiority by cultivating and enhancing the French language. Yet the aim of making complex matters easily accessible could also be the driving force for translations. This is at least what Jean Barbeyrac points out in the preface to his translation of Pufendorf's De jure naturae et gentium in 1706. ${ }^{38}$ Barbeyrac particularly aimed at reaching young people who were preparing for ecclesiastical or political posts and 'who, due to their poor Latin, are unable to read with pleasure and profit from a work in the style of Pufendorf's. ${ }^{39}$ In the first instance, he was thinking of those whose mother tongue was French, but he might also have had in mind the pupils of the Ritterakademie in Berlin, which had been founded shortly before, in 1705 , and which he praises in his dedication letter to Frederick I of Prussia as an institution 'where the young

34 Ibid., Part 3, 343-411.

35 Ibid., Part 3, 416-448.

36 Ibid., 'Vorrede,' n.p.

37 Ibid., 'Vorrede,' n.p.

38 Samuel Pufendorf, Le Droit de la Nature et des Gens, transl. Jean Barbeyrac, 2 vols. (Amsterdam: Kuyper, 1706). See also: Sieglinde C. Othmer, Berlin und die Verbreitung des Naturrechts in Europa. Kultur- und sozialgeschichtliche Studien zu Jean Barbeyracs Pufendorf-Übersetzungen und eine Analyse seiner Leserschaft (Berlin: Walter de Gruyter \& Co., 1970) and Fiammetta Palladini, Die Berliner Hugenotten und der Fall Barbeyrac. Orthodoxe und 'Sozinianer' im Refuge (1685-1720) (Leiden: Brill, 2011).

39 Pufendorf, Le Droit de la Nature et des Gens, LXXXIV-LXXXv: 'qui, avec le peu de Latin qu'ils savent, ne peuvent pas lire avec plaisir \& avec fruit un Ouvrage du stile de celui de Pufendorf'. 
noblemen [...] come to acquire early on the exercises necessary for the nobility, and all they need to know of useful skills, mainly those serving to regulate their conduct and enabling them to fulfill the offices they may be appointed to one day'. ${ }^{40}$ With his translation of and commentary on Pufendorf's work and his Traité du jeu (1709), ${ }^{41}$ Barbeyrac became the most famous figure of the Berlin Huguenot community dealing with natural law and contributing to its dissemination. However, he was not the only one: since the early 169 os several members of the French Colony, for example Charles Ancillon, Antoine Teissier and Etienne Chauvin, participated in the debate on natural law. The doctrine of natural law according to Grotius and Pufendorf provided them with the tools they needed to defend their political and religious existence as well as to declare the revocation of the Edict of Nantes and its outcomes null and void. ${ }^{42}$

Baron Gross von Trockau's Praegustus Juris Naturae \& Gentium might be related to the writings of the Berlin Huguenots, who virtually initiated the study of natural law in the French language, although that study was pre-dated by a translation of Grotius's work by the French diplomat Antoine de Courtin, first published in $1687 .{ }^{43}$ In any case, Gross von Trockau adds to his general remarks on the law of nature and nations a few annotations - 'tirée d'un Auteur François Refugié 44 - on the ongoing wars of Louis XIV. On the basis of that current example, pupils were supposed to learn about natural law or rather single aspects of the law of nations in a practically oriented way. The author Gross von Trockau refers to is not known by name. But, as exiled French Protestants in particular were taking part in the contemporary discourse, which strongly condemned Louis XIV's warfare, many Huguenots are worth being considered. Indeed, many of them referred, besides the relevant medieval theories on bellum justum, to modern natural law as a practical norm. ${ }^{45}$

'EPITRE A SA MAJESTÉ LE ROI DE PRUSSE', in Pufendorf, Le Droit de la Nature et des Gens, n.p.: 'où les Jeunes Gentilshommes [...] viennent apprendre de bonne heure, \& les exercises nécessaire à la Noblesse, \& tout ce qu'ils doivent savoir des connoissances utiles, sur tout de celles qui servent à regler leur conduite, \& à les rendre capables des Emplois auxquels ils peuvent être élevez un jour'. Jean Barbeyrac, Traité Du Jeu, Où l'on examine les principales Questions De Droit Naturel Et De Morale qui ont du rapport à cette Matiere, 2 vols. (Amsterdam: Humbert, 1709). Othmer, Verbreitung des Naturrechts, 42-53.

43 Hugues Grotius, Le droit de la guerre et de la paix, transl. [Antoine] de Courtin (Paris: Arnould Seneuze, 1687).

44 Gross von Trockau, Recreationes Academicae Grosianae, Part 3, 446-448, here 446.

45 Émilie Dosquet, 'Die Verwüstung der Pfalz als (Medien-)Ereignis: von der rheinländischen Kriegshandlung zum europäischen Skandal,' in Krieg und Kriegserfahrung im Westen des Reiches 1568-1 714, ed. Rutz Andreas (Göttingen: Vandenhoeck \& Ruprecht, 2016), 333369 , here $361-366$, with further reading. 


\section{$2.2 \quad$ Johann Christoph Vetter}

The Unpartheyische Gedanken von der Alt- und Neuen Gelehrsamkeit (Impartial thoughts about ancient and new erudition $)^{46}$ appeared under the pseudonym Orontes in 1712. The author of the treatise was the Protestant clergyman Johann Christoph Vetter (1676-1736), who had presumably been teaching at the Erlangen Ritterakademie since 1708. By the time of his death he had been professor at the institution for 28 years. ${ }^{47}$ It thus seems reasonable to suggest that the book, which had been drafted as Anweisung zu den Nöthigst-und Nützlichsten Wissenschaften vor Junge Edelleute (Instruction to the Sciences Most Necessary and Most Useful for Young Noblemen), was derived from practice and experience in the field. However, Vetter's 264-page work should not be mistaken as a schoolbook for young nobles, nor as a manual for teachers and professors at the Ritterakademie on how to conduct the lessons. Rather, as suggested by the letter of dedication to the Franconian nobles Ernst Friedrich and Johann Wilhelm Gottfried von Seckendorff, it constituted a guide for members of the nobility on how, for their own and their rank's sake, their children should be educated:

By serious studies they make an effort to provide the high nobility with new luster, and thus by their own ability and merits to exalt what they inherited. Already in their youth they recognize which arts, languages and sciences are most useful if one wishes to serve great masters and republics. This is what encourages me to dedicate to your highness this little treatise, aimed at the best for the nobility, who already more or less know and practice what it contains, but are also laudably determined to practice in the future. ${ }^{48}$

Moreover, the text also seems to function as some kind of advertising brochure or 'image booklet' for the Erlangen Ritterakademie.

46 Orontes (= Johann Christoph Vetter), Unpartheyische Gedancken von der Alt- und Neuen Gelehrsamkeit.NebsteinerUnvorgreifflichen Anweisung zu denNöthigsten-undNützlichsten Wissenschaften vor Junge Edelleute ans Licht gegeben (Frankfurt, Leipzig: Johann Andreas Lorber, 1712).

47 UniA Erlangen, D1/1 Nr. 15, Supplik Felicitas Barbara Vetters an Markgraf Friedrich von Brandenburg-Bayreuth, o9.03.1736.

48 Orontes, Unpartheyische Gedanken, 4a-5a: 'Sie bemühen sich durch warhaffte studien Dero hohen Adel einen neuen Glantz zu geben / und das / was Sie ererbt / durch eigene Geschicklichkeit und Verdienste noch mehr zu erheben. Sie erkennnen schon in Dero Jugend/ was nützliche Künste / Sprachen und Wissenschaften / emsten helffen können / wann man grossen Herren und Republiqven dienen will. Und dieses eben ist es / was mich kühn macht / dieses kleine der Noblesse vornehmlich zum Besten abzielende Tractaetgen Dero hohen Nahmen zu dediciren / als die theils schon selbst das / was darinnen enthalten / ziemlich eingesehen und practiciret / theils aber noch zu practiciren rühmlich entschlosse'. 
Consequently, Orontes includes little in the way of concrete contents for teaching and no recommended reading on which the lessons should be based. In fact, he sketches more of a general overview on which subjects and issues should receive priority in educating the sons of the nobility. He suggests that the main purpose of their education should be to prepare and to equip them exclusively with the knowledge and skills they would need for their presumed future duties at court and in the field. ${ }^{49}$ In practice, this results in targeted studies and a reduced range of subjects, strongly utilitarian in their orientation. By this way of teaching and sensible studying ('vernünfftiges studiren'50 as he puts it), Orontes wants to avoid young noblemen's minds being stuffed and cluttered with unnecessary and useless details and knowledge: 'as if he were decorated at the front and back, like brother Jacob is with shells, with unnecessary and useless school disciplines'. ${ }^{51}$ The idea was that a 'Cavalier', in order to exercise his office and attend his duties in a Christian, just and wise manner, has no need for school, but rather for 'state erudition' ('Schul= sondern Staats=Erudition'). ${ }^{52}$ Good knowledge of religion and ethics, of natural law and the law of nations, history and statecraft as well as basic knowledge of different natural sciences like mathematics and physics are seen as prerequisite for this. Additionally, the command of several languages, but especially of French, is regarded as advantageous. ${ }^{53}$ A strong religious focus or rather the text's embedding in a religious context, presumably resulting from Orontes' training as a clergyman, is noticeable. In particular, negligence of the faith, ${ }^{54}$ or, even worse, atheism, ${ }^{55}$ are a thorn in his side.

Natural law and the law of nations are in a prominent position within the drafted curriculum. According to Orontes, following ethics, this is the second most important subject a person of rank should occupy himself with. ${ }^{56}$ Within the framework of the teaching, natural law and the law of nations, the latter again being interpreted as a component of natural law, ${ }^{57}$ are part of the so-called philosophia practica, which Orontes subdivides into three sections, namely: moral theory, or ethics; natural law and the law of

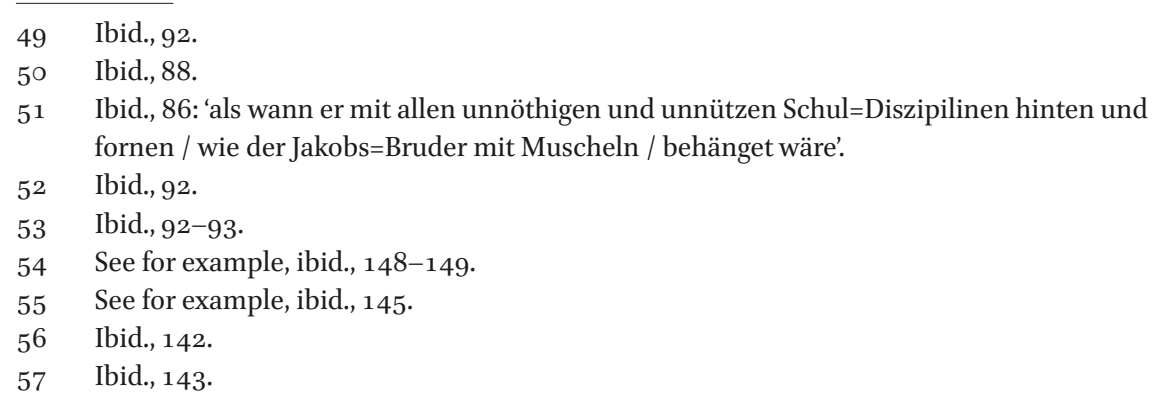


nations; and politics - 'Aus angeführten Stücken bestehet nun die Philosophia Practica, ohne welche der Adel=Stand ein wahrhafftiger Ubel=Stand zu nennen: Es begreifft dieselbe aber vornehmlich drey Theile in sich / die Moral- oder Sitten=Lehre / [...]; Das Natur= und Völcker=Recht / [...]; Und dann die Politic, $[\ldots]^{\prime} .58$

The great significance of natural law, which in Orontes's view originates directly from the nature of God, is to provide man with universal, unalterable guiding principles for his activities. ${ }^{59}$ In contrast, law made by men could be changed or even abolished. ${ }^{60}$ Still, the purpose of all laws should be human salvation. ${ }^{61}$ As a result, Orontes regards scholarly debates on the primary objects of natural law as being fruitless and superfluous. ${ }^{62}$ To him it seems clear that natural law consists of three main rules: 'honour God; preserve yourself; do everything necessary to sustain sociality' ('Ehre GOtt; Erhalte dich selbst; Thue alles / was zu Unterhaltung einer Socialität nöthig ist'). ${ }^{63}$

Finally, as peoples and nations are interconnected by the principle of 'sociality' and thus mutually obliged, Orontes also touches on the law of nations in his remarks on natural law. Here he is concentrating on diplomatic law and especially on the ambassador's inviolability. Although he does not explicitly mention the Matveyev incident, he nevertheless seems to account for it. Thus he points to the sacred character of the person of the ambassador - from which originates the inviolability of the ambassador's person, his staff, home and goods. Moreover, he explicitly mentions the question of how to deal with debts accumulated by foreign envoys, ${ }^{64}$ which, as explained above, had been the stumbling block and cause of the diplomatic crisis between Russia and Great Britain in 1708/1709.

\subsection{Dietrich Hermann Kemmerich}

Shortly after he had been appointed professor of Philosophia Moralis \& Civilis and Eloquentiae, Dietrich Hermann Kemmerich left Erlangen again to obtain a licentiate in law. He matriculated at the University of Halle in March $1705 .{ }^{65}$

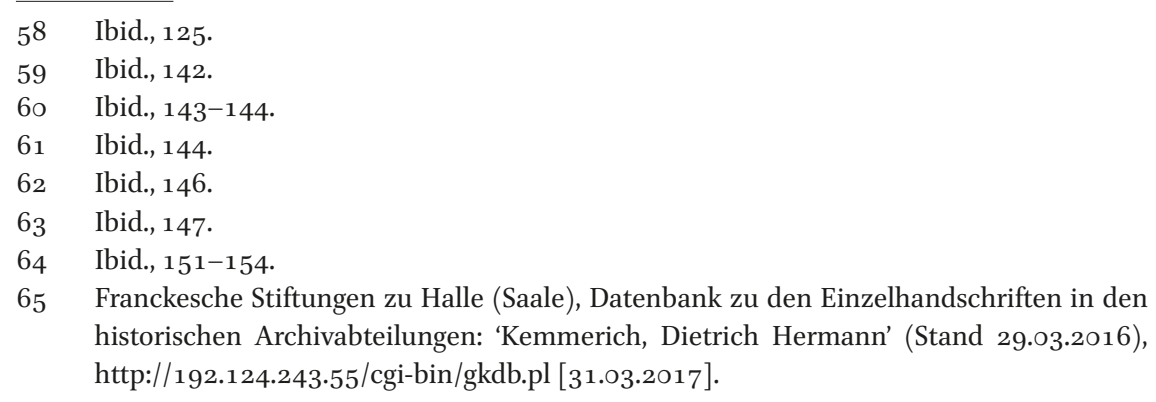


Two years later he asked for reappointment to the Ritterakademie at Erlangen. As his former position had already been taken, he was assigned to the professorship in Jus naturae et gentium and Jus publicum, the first and the last person ever appointed to this chair at the Erlangen Ritterakademie. In his letter of reapplication at Erlangen he mentions for the first time his monumental compendium for the education of noblemen, the Neu=eröffnete Academie der Wissenschaften. ${ }^{66}$ It is most likely that those parts of the work published in 1711 and 1714 had already been written, or at least drafted in 1707 and became the basis of his upcoming further teaching at the Ritterakademie. Initially Kemmerich had intended to publish the compendium in 13 parts. ${ }^{67}$ But in the end only three parts appeared in print, those dealing with the education of noblemen in general, ${ }^{68}$ with logic ${ }^{69}$ and with morals or ethics ('morale oder sitten=lehre') as well as natural law and the law of nations. ${ }^{70}$

The first part of the Neu=eröffnete Academie der Wissenschaften can be regarded as a general introduction to the whole compendium. Kemmerich gives an introductory overview of all the subjects he plans to deal with, virtually the whole compendium in a nutshell, in which he emphasizes the significance and value of each subject or topic for the education and thus the professional advancement of young nobles; he also includes some basic bibliographic references as well as some advice for the tutors concerning elementary teaching in each subject. Additionally, he discusses how young noblemen as well as young ladies should be educated and how they should conduct their studies. In his opinion their education should include travel to foreign countries. Moreover, in his preface to the first part of the Academie der Wissenschaften Kemmerich gives a quick insight into his favourite method of teaching. As in the lecture announcement mentioned above, it is evident that he prefers teaching through dialogue, 'since the best method for informing young people consists in reasoning with them through continuous questioning and answering, thereby loosening their tongue and examining whether the intellect has a proper

66 Mengin, Ritter-Academie, 27.

67 Dietrich Hermann Kemmerich, Neu=eröffnete ACADEMIE Der Wissenschaften, Zu welchen vornemlich Standes=Personen nützlich können angeführet, und zu einer vernünfftigen und wohlanständigen CONDUITE geschickt gemacht werden (Leipzig: Thomas Fritsch, 1711), c4b-c5b.

68 Kemmerich, Neu=eröffnete Academie, vol. 1.

69 Kemmerich, Neu=eröffnete Academie, vol. 2.

70 Dietrich Hermann Kemmerich, Neu=eröffnete ACADEMIE Der Wissenschaften, Zu welchen vornemlich Standes=Personen nützlich können angeführte werden. Dritte Eröffnung Welche die MORALE und das Natur=und Völcker=Recht in sich begreiffet (Leipzig: Thomas Fritsch, 1714). 
concept of the thing. ${ }^{71}$ What is more, Kemmerich favours teaching in German instead of Latin. Albeit he is not objecting to Latin as a common academic language as well as European lingua franca, like some kind of universal language, which enables one to get along almost in the entirety of Europe, though not in the whole world, ${ }^{72}$ he still thinks it more convenient to use the young nobles' mother tongue when explaining complex issues to them. Otherwise they might not only struggle with understanding the language but also with fathoming the teaching contents. Hence, to enhance their command of Latin and thus to kill two birds with one stone, he recommends explaining things in German first. But as soon as the students have understood the subject matter and can cope with it, they are to translate it into Latin. Finally, exams are to be held in Latin, too. We may conclude from this that Kemmerich wrote the compendium in German mainly for didactic reasons. ${ }^{73}$ Lastly, Kemmerich was no doubt motivated to undertake that huge project out of a feeling of necessity. If the sons of the nobility still wanted to obtain positions of responsibility at court and avoid the risk of being beaten to those positions by well-educated commoners, they needed to be properly educated. Consequently, it proved insufficient for them to master the so-called exercitia, namely riding, fencing, dancing and singing; in addition, they also needed to study useful sciences. According to Kemmerich, academic studies were, however, held in low esteem by the nobility of the Holy Roman Empire, particularly because of the 'wrong instruction and pedantic method of teaching, [...] by which people are tortured with grammar and Latin, or with logic and metaphysics, or by pointless longwindedness.' ${ }^{74}$ Actually, Kemmerich makes the same point as Orontes before him: usually, young noblemen are strained with too many details they have no need for and which prolong their studies unnecessarily - 'scholastischen formalitäten und unnützen grillen' (scholastic formalities and unnecessary whimsies). ${ }^{75}$ To avoid this and to make education at a Ritterakademie more attractive to

71 Kemmerich, Neu=eröffnete Academie, vol. 1, c1b: '[...]weil die beste methode junge leute zu informiren ist, durch continuirliches fragen und antworten mit ihnen raisonniren, und dadurch so wohl die zunge lösen, als den verstand prüfen, ob er einen rechten begriff von der sache hat'.

Kemmerich, Neu=eröffnete Academie, vol. 1, b8a.: ‘[...] gleichsam eine universal-sprache [...], damit man, wo nicht durch die gantze welt, doch zum wenigsten fast durch gantz Europa kommen kan'.

73 Kemmerich, Neu=eröffnete Academie, vol. 1, b8b-c1b.

74 Ibid., b4a: '[...] verkehrte anführung und pedantische lehr=art, [.... indem man leute [...] entweder mit der Grammatic u. dem lieben latein oder der Logic und Metaphysic gar zu sehr martert oder durch unnöthige weitläuffigkeit'.

Ibid., b4b. 
them than a university education, Kemmerich drafted his impressive work, providing in his words a 'rigorous, orderly, distinct, concise but nevertheless adequate and complete concept of the most eminent sciences' ('gründliche[r], ordentliche[r], deutliche[r], kurtze[r], aber dennoch zulängliche[r] und vollständige[r] begriff von den vornehmsten wissenschaften'), ${ }^{76}$ which should be sufficient to prepare young members of the nobility for their future life.

Like Orontes, Kemmerich deals with the law of nature and nations as part of philosophia practica. He places strong emphasis on the teaching of this subject, because in his opinion people with no command of it lack 'a great part of human reason' ('ein gross theil der menschlichen vernufft') ${ }^{77}$ and are thus unable to properly distinguish right from wrong, just from unjust. Secondly, natural law is regarded as forming the basis for all other fields of law, especially the jus civilis. Additionally, natural law plays an important role in the interpretation of law; plus, when it comes to international relations, there is no other way to deal with legal matters among sovereigns. Thus it is vital for all who are preparing for a career at court, or who will have to deal with lawyers and lawsuits, to gain a deeper knowledge of the subject.

Although Kemmerich does not think it necessary to refer to authors in the sciences themselves ('in den wissenschaften selbst [Autores] zu allegiren'), he nevertheless recommends, in the general introduction to each subject of study ('General-einleitung bey einem ieden studio'), ${ }^{78}$ what students might best read, depending on their level of knowledge. For beginners he suggests Johann Franz Buddeus's Historia juris naturalis (1704) and Gottlieb Gerhard Titius's Observationes in Pufendorffi libros II de officiis hominis et civis (1703), or the French translation of Pufendorf's book by Jean Barbeyrac. More advanced students should deal with Christian Thomasius's Institutiones jurisprudentiae divinae (1688) and, in addition, as well as for comparative purposes, with his lately published Fundamenta juris naturae et gentium (1705). Next, students could turn to Samuel von Pufendorf's De jure naturae et gentium (1672) and finally to Hugo Grotius's De jure belli ac pacis (1625). Concerning Grotius, Kemmerich also recommends the textbook adaptations by Caspar Ziegler, Johann Georg Kulpis and Philipp Reinhard Vitriarius. To make things as easy as possible for young people ('der jugend die sache so leicht [...], als immer möglich'), ${ }^{79}$ and in view of his preference for German or French as teaching languages, Kemmerich recommends the use of editions or translations of

\begin{tabular}{ll}
\hline 76 & Ibid., b5a. \\
77 & Ibid., 218. \\
78 & Ibid., b6b. \\
79 & Ibid., b8b.
\end{tabular}


the classical texts which include introductions and notes, for example Barbeyrac's French translation of Pufendorf or the German translation of Grotius by Philipp Balthasar Sinold (von Schütz) with an introduction by Thomasius. Additionally, as an exercise, and to get a notion of the practical relevance of the subject, he encourages teachers and students to test their knowledge by studying historical cases. ${ }^{80}$

With the third volume of his Neu=eröffnete Academie der Wissenschaften, published only in 1714, though it had been written for quite a while, Kemmerich finally presented his own compendium on the subject. ${ }^{81}$ In this so-called Dritte Eröffnung Welche die Morale und das Natur= und Völker=Recht in sich begreiffet (Third Introduction Which Comprises Morals as well as the Law of Nature and Nations), the influence of Christian Thomasius is evident. After a general introduction, in which he explains the subject of natural law as well as the origin and history of it, Kemmerich elucidates how the law of nature can best be treated. ${ }^{82} \mathrm{He}$ considers it appropriate to divide jus naturae et gentium into three domains, namely private law (Von dem allgemeinen Recht der Privatpersonen), ${ }^{83}$ public law (Von dem allgemeinen Staatsrecht $)^{84}$ and the law of nations (Von dem allgemeinen Völkerrecht). ${ }^{85}$ All three parts are systematically structured, again in the form of a teaching dialogue, starting with general, universal aspects of the topic and moving down to more specific issues. With regard to the law of nations, one of Kemmerich's main aims seems to be to show - as he already had in his little treatise on the Matveyev incident - that there is no need to follow Grotius in inventing a separate law of nations, distinct from the law of nature ('mit Grotio ein besonderes Völcker-Recht zu erdencken'). ${ }^{86} \mathrm{He}$ argues that this would be superfluous because international relations are regulated either by provisions of natural law in general or by contract law. Everything else in terms of international relations is administered by the principles of courtesy and friendship or by the customs of decorum, and thus does not involve binding rules anyway. On this issue Kemmerich thus seems to follow a very heterogeneous

\footnotetext{
8 o Ibid., 212-223.

81 Initially, Kemmerich had envisaged natural law and the law of nations to form the fourth part of the Neu=eröffnete Academie. For this see 'Verzeichnis der wissenschaften / so in dieser Academie sollen tractiret werden,' Kemmerich, Neu=eröffnete Academie, vol. 1, $\mathrm{c} 4 \mathrm{~b}-\mathrm{c} 5 \mathrm{~b}$.

82 Kemmerich, Neu=eröffnete Academie, vol. 3, 1577-1613.

83 Ibid., $1613-1766$.

84 Ibid., $1766-1854$.

85 Ibid., $1855^{-1906 .}$

86 Kemmerich, Grund=Sätze, 18.
} 
school of thinkers on natural law, which 'denied in principle the existence of a "positive" law of nations'. ${ }^{87}$

\section{Conclusion}

Baron Christoph Adam Gross von Trockau, Johann Christoph Vetter and Dietrich Hermann Kemmerich were not the only ones trying to reform the education of young nobles by introducing new subjects, contents and methods. In fact, they were able to draw on various tracts dealing with reformist educational ideas and concepts which had been published across Europe during the last decades of the seventeenth century. Among the authors they relied on were Bernard Lamy, ${ }^{88}$ John Locke and Christian Thomasius. Also, the establishment of a school focusing on the needs of the nobility was not an isolated occurrence. From the late sixteenth until the end of the eighteenth century several new Ritterakademien were founded all over the Empire as well as in other parts of Europe. These institutions offered an education and teaching programme exclusively aligned to the requirements of the nobility, especially to its need for aristocratic socialization, and functioned as supplements and alternatives to the universities. Influenced by ideas of Renaissance humanism and provoked by the growing competition at court with commoners holding legal degrees, ideals of education and of educating the nobility had changed since the sixteenth century. On the one hand, this new form of aristocratic education had to serve the purpose of professional competence and modernization; on the other hand, it had still to be distinctive and prepare noble offspring for their special social role. Until the sixteenth century it had been quite uncommon for the nobility to attend university. In most cases, the few noblemen who did attend were preparing for an ecclesiastical career. But as requirements in education were also changing for aristocrats, the institutions of higher education became increasingly important for them, too. ${ }^{89}$ The emergence of newly

87 Wilhelm Greve, The Epochs of International Law (Berlin: de Gruyter, 200o), 351.

88 His treatise Entretiens sur les sciences dans lesquels on apprend comment l'on doit étudier les sciences et s'en servir pour se former l'esprit juste et le cour droit, mentioned by Gross von Trockau, was first published in 1683 . During the eighteenth century it became a very popular book of methodology and was held in high esteem, for example by Montesquieu and Rousseau.

89 Norbert Conrads, Ritterakademien der frühen Neuzeit. Bildung als Standesprivileg im 16. und 17. Jahrhundert (Göttingen: Vandenhoeck \& Ruprecht, 1982); Simone Giese, 'Adelsstudium,' in Enzyklopädie der Neuzeit Online, ed. Friedrich Jaeger, accessed 29 May 2017, http://dx.doi.org.emedien.ub.uni-muenchen.de/10.1163/2352-0248_edn_aoo36ooo, 
founded Ritterakademien was paralleled by some universities also trying to adjust to the new requirements. In fact, at the beginning of the seventeenth century there are some examples of universities expanding their teaching programmes to meet the needs of noble students. For instance, the University of Strasbourg offered a range of exercises such as riding, dancing, fencing, modern languages and fortification..$^{90}$ After a period of stagnation and decline during the Thirty Years' War and its aftermath, the idea of academies exclusively for the nobility turned up again and they peaked in the decades between 1680 and ${ }^{1730}{ }^{91}$ It seems that, in this context, the law of nature and nations became an integral part of aristocratic education, indeed an ever-present part of the curriculum. ${ }^{92}$ For example, in Some Thoughts Concerning Education (1693), John Locke's tract on the education of gentlemen, which was much noticed by the European Republic of Letters and quickly translated into several languages, the English philosopher recommends that, after having imparted the principles and precepts of virtue on the young noble on the basis of Cicero's De officiis, the pupil could go on with further reading regarding the 'general Part of Civil-Law'. Further, 'it may be seasonable to set him upon Grotius de Jure Belli \& Pacis, or which I think, is the better of the two, Puffendorf de Jure naturali \& Gentium; wherein he will be instructed in the natural Rights of Men, and the Original and Foundations of Society, and the Duties resulting from thence'. ${ }^{93}$

first published online: 2014; Katrin Keller, 'Standesbildung, in Enzyklopädie der Neuzeit Online, ed. Friedrich Jaeger, accessed online on 29 May 2017, http://dx.doi.org.emedien.ub.uni-muenchen.de/10.1163/2352-0248_edn_a41180oo, first published online: 2014 . Anton Schindling, 'Die Strassburger Hochschule zur Zeit des Späthumanismus um 16oo,' in Universität Würzburg und die Wissenschaft in der Neuzeit, ed. Peter Herde and Anton Schindling (Würzburg: Ferdinand Schöningh, 1998), 95-107, here 105-106; Anton Schindling, Humanistische Hochschule und freie Reichsstadt. Gymnasium und Akademie in Strassburg 1538-1621 (Wiesbaden: Steiner, 1977), 383; Arthur Schulz, Die örtliche und soziale Herkunft der Strassburger Studenten 1621-1793 (Frankfurt: [Selbstverlag], 1926); Gustav C. Knod (ed.), Die alten Matrikel der Universität Strassburg 1621-1793, vol. 1: Die allgemeine Matrikel und die Matrikel der Philosophischen und Theologischen Facultät (Strassburg: Trübner, 1897), XXIV-XXVI.

91 An overview is provided in 'Bibliographie der Ritterakademien' in Conrads, Ritterakademien, 345-400.

92 There is a short reference to this in Michael Stolleis, Geschichte des öffentlichen Rechts in Deutschland, vol. 1:Reichspublizistik und Policeywissenschaft 16oo-180o (München: Beck, 1988), 145. See also Friedrich Debitsch, Die staatsbürgerliche Erziehung an den deutschen Ritterakademien (PhD diss. University of Halle an der Saale, 1927), 19-51. An extensive survey dealing with this issue is not yet available.

93 John Locke, Some Thoughts Concerning Education (London: Churchill, 1693), § 175, 221. Until his death in 1704 John Locke revised the treatise several times. In the last, fourth edition, published in 1699, he also recommends 'Puffendorf de Officio hominis \& civis'; he 
Also in 1693, the Licentiatus Juris and court tutor Anton Wilhelm Schowart ${ }^{94}$ published a treatise in which he emphasized the importance of jus naturae and jus gentium in general and especially of the works of Hugo Grotius and Samuel Pufendorf for the education of young nobles. ${ }^{95}$ August Hermann Francke's 1698 idea of an educational institution especially for the nobility, where the pupils should, among other things, be taught 'in Philosophia moralis, Politica, Jurae Naturae, und in denen ersten fundamentis Juris publici \& Juris Civilis, ${ }^{96}$ was indeed never realized. Still, at the Paedagogium regium, which was part of the Franckeschen Stiftungen (Francke Foundations) at Halle, pupils - mainly sons from wealthy families of the bourgeoisie as well as young nobles ${ }^{97}$ - had lessons in 'Philosophia moralis samt den Fundamentis juris naturae und politicae' as soon as they reached the fourth grade, which was regarded as a preparatory course for university; the lessons were mainly based on the writings of Johann Franz Buddeus, though only in strongly condensed form. ${ }^{98}$ Finally, in 1704 Christian Schröter, deputy headmaster of the Ritterakademie at Liegnitz (Legnica), stated in his Kurtze Anweisung zur Information Der Adlichen Jugend that a young noble should let himself explain at the academy 'Jus Naturae und Gentium, Publicum und Privatum'.99

sees it, however, as basic reading in ethics. See John Locke, Some Thoughts Concerning Education (London: Churchill, 1693), § 186, 330.

94 In 1691 Schowart, Licentiatus juris of the University of Frankfurt an der Oder, applied to the Ritterakademie at Lüneburg. According to himself, he had served as tutor for several noble families. See Klaus Bleeck, Adelserziehung auf deutschen Ritterakademien. Die Lüneburger Adelsschulen 1655-185o (Frankfurt am Main, Bern, Las Vegas: Peter Lang, 1977), 133 .

95 [Anton Wilhelm Schowart], Der Adeliche Hofemeister/ Oder Wahrhafftige und deutliche Vorstellung was ein Adelicher Hofemeister vor Eigenschafften an sich haben: Wie derselbe sich in allen vorfallenden Begebenheiten klüglich verhalten/ seine Untergebene so wohl auff Universitäten als andern Orten treulich anführen und endlich mit ihnen nützliche peregrinationes anstellen solle (Frankfurt: Hartmann, 1693), § 6, 230-234.

96 Projecte, Wie die Anführung Herren-Standes/ Adelicher und anderer fürnehmen Jugend veranstaltet/ Und guten Theils wircklich eingerichtet und angefangen (Halle: Christian Henkel, 1698).

97 Concerning the intensive relationship between Halle pietism and the nobility of the Holy Roman Empire see Andreas Pečar, Holger Zaunstöck and Thomas Müller-Bahlke (eds.), Wie pietistisch kann Adel sein? Hallescher Pietismus und Reichsadel im 18. Jahrhundert (Halle: Mitteldeutscher Verlag, 2016).

98 'Verbesserte Methode des Padagogii Regii zu Glaucha vor Halle 1721,' in August Hermann Francke's Pädagogische Schriften. Nebst der Darstellung seines Lebens und seiner Stiftungen, ed. Gustav Kramer (Langensalza: Hermann Beyer \& Söhne, ${ }^{2} 1885$ ), 287-368, here 338.

99 Christian Schröter, Kurtze Anweisung zur Information Der Adlichen Jugend (Leipzig: Johann Friedrich Gleditsch, 1704), 5. 
During the second wave of Ritterakademien, which the Holy Roman Empire underwent around 1700, the Ritterakademie at Wolfenbüttel, founded in 1687, provided an example for others to follow. ${ }^{100}$ At Wolfenbüttel, natural law was among the most important subjects. ${ }^{101}$ All later projects - either arrangements for or reforms and foundations of Ritterakademien - included dissemination of basic knowledge in natural law and the law of nations; this applies for example to the institutions founded shortly after, at Erlangen, Brandenburg, ${ }^{102}$ Berlin ${ }^{103}$ and Liegnitz (Legnica) $)^{104}$ as well as those founded in Vienna during the late 1740s. ${ }^{105}$

A closer look at the new foundations as well as the reforms undertaken at Ritterakademien makes it clear that many were influenced by existing institutions and vice versa; this mutual intellectual impact usually resulted from personal contacts. Baron Gross von Trockau for example admits that his ideas concerning the concrete planning and arrangements for the Ritterakademie at Erlangen followed the Ritterakademie of the Dukes of BraunschweigWolfenbüttel. ${ }^{106}$ Additionally, the Erlangen project was strongly influenced by Halle and particularly its newly founded university. Gross von Trockau as well as his personal environment had good and long-standing relations with the scholarly world connected to Halle. Over time, these relations were even

100 Conrads, Ritterakademien, 273-322.

101 Friedrich Koldewey (ed.), Braunschweigische Schulordnungen von den ältesten Zeiten bis zum Jahre 1828, vol. 2: Schulordnungen des Herzogtums Braunschweig (mit Ausschluss der Hauptstadt des Landes) (Berlin: Hofmann, 189o), 235, 262-263.

102 Johannes-Matthias Graf von der Schulenburg, 'Die Gründung der Ritterakademie zu Brandenburg im Jahre 1704,' in Berichte und Forschungen aus dem Domstift Brandenburg 4 (2011), 5-99, here 62 and 85 .

103 The first professor in natural law was Johann Heinrich Hertenstein, who also published a little tract on natural law and the law of nations: Kurtzer Vorbericht Das Natürliche Und Völcker-Recht betreffend, Mit welchem Denen Durchlauchtigen, Hoch- und Wohl-Gebohrnen Herren Academicis Seine bey der Von Ihro Königl. Majestät in Preussen etc. Allergnädigst angerichteten Fürsten- und Ritter-Academie, Über gedachte beyde Rechte Dieses Erste halbe Jahr über zu haltende Lectiones anzeiget (Cölln an der Spree: Ulrich Liebpert, [1705]).

104 Ihro Röm. Kayserl. Auch zu Hungarn und Böheimb Königl. Majest. ... Josephi I. Neu aufgerichtete Academie Oder Ritter-Schul Zu Liegnitz in Schlesien. Wie solche von Höchst gedachter Kayserl. und Königl. Maj. mit Privilegiis und Ordnungen in diesem 1708 ten Jahr Allergnädigst approbirt und confirmirt worden ([n.p.], 1708).

105 Ivo Cerman, 'Habsburgischer Adel und Theresanum. Wissenvermittlung, Sozialisierung und Berufswege,' in Adelige Ausbildung. Die Herausforderung der Aufklärung und ihre Folgen, ed. Ivo Cerman and Luboš Velek (München: Martin Meidenbauer, 2006), 143168; Olga Khavanova, 'Official Policies and Parental Strategies of Educating Hungarian Noblemen in the Age of Maria Theresa,' in Adelige Ausbildung, ed. Cerman and Velek, 95-115.

106 Mengin, Ritter-Academie, 105. 
intensified as scholars who had graduated at Halle University were preferred as professors for the Erlangen Ritterakademie. Dietrich Hermann Kemmerich, for example, had been studying law at Halle before he became professor of natural law and the law of nations at Erlangen. The influence of Halle was most likely due to Christian Thomasius's writings, especially his works on the idea of gallantry, which emerged between 1687 and $1694 .{ }^{107}$

The influence of Thomasius is most evident in Gross von Trockau's project of a courteous, real and solid erudition ('galante und reale und solide Gelehrsamkeit'). ${ }^{108}$ Additionally, it is mirrored by the Ritterakademie's self-conception as an Academia Practica, characterized by the abolition of the teaching methods of scholasticism and the introduction of new teaching techniques as well as a teaching programme focusing, unlike at universities, on the practical relevance of the subject matters.

One key issue in such an up-to-date education for young nobles was the knowledge of natural law and the law of nations, as this was crucial for political counselling at court. The conception of the Erlangen Ritterakademie shows clearly the nobility's need to acquire these qualifications. Otherwise, they risked being replaced at court by learned commoners and thus losing their traditional role of counselling elite. As a consequence, they would lose one vital possibility of participating in ruling.

For members of the gentry, the possibilities of education offered by Ritterakademien were of great importance. Many of them had been thrown into financial crisis during the Thirty Years' War. ${ }^{109}$ Subsequently, they could no longer afford an education befitting their social status, including preceptors, tutors and attendance at universities as well as travel to foreign countries. This situation can be seen as a framework, not only for Gross von Trockau's foundation at Erlangen, but also for the other schools for the nobility which were founded around 170o. These aimed to educate young members of the local nobility as quickly as possible, at advantageous prices, which meant the syllabus was focused and condensed. Especially time spent at foreign courts and universities should be shortened. The idea was not only to save money but also to stop - in accordance with mercantilist thinking - the drain of money to

107 See Jörn Steigerwald, Galanterie. Die Fabrikation einer natürlichen Ethik der höfischen Gesellschaft (1650-1710) (Heidelberg: Winter, 2011), 17-46, 220-246.

108 'Ansprache an junge Standes-Personen,' in Gross von Trockau, Recreationes Academicae Grosianae, n.p.

109 Including some Franconian examples: see Andreas Flurschütz da Cruz, Zwischen Füchsen und Wölfen. Konfession, Klientel und Konflikte in der fränkischen Reichsritterschaft nach dem Westfälischen Frieden (Konstanz: UVK, 2014). 
foreign territories or at least to limit it.110 Additionally, the education of young nobles at Ritterakademien was regarded as serving the territory's welfare, as it aimed at the education of those who were supposed later to serve the country, as civil servants, at court or in the military. While at a Ritterakademie, they received the set of necessary tools and knowledge for these future tasks and responsibilities. Also in ideological terms, they were set on the desired track. By offering natural law and the law of nations for the nobility the Ritterakademien made it possible for the nobility to maintain their traditional role as princely courtiers and political advisors. That this was necessary is reflected in the fact that the institutions were soon open also for commoners, indeed, some of them had admitted bourgeois students from the beginning.

\section{Bibliography}

Aldridge, D.D., 'Whitworth, Charles, Baron Whitworth (bap. 1675, d. 1725),' Oxford Dictionary of National Biography (Oxford University Press, 2004); online ed., Jan 2008. http://www.oxforddnb.com.odnb.emediai.bsb-muenchen.de/view/article/29336 [accessed April 15, 2017].

[Anonymous], Ihro Röm. Kayserl. Auch zu Hungarn und Böheimb Königl. Majest. ... Josephi I. Neu aufgerichtete Academie Oder Ritter-Schul Zu Liegnitz in Schlesien. Wie solche von Höchst gedachter Kayserl. und Königl. Maj. mit Privilegïs und Ordnungen in diesem 1708ten Jahr Allergnädigst approbirt und confirmirt worden ([n.p.], 1708).

[Anonymous], Projecte, Wie die Anführung Herren-Standes/Adelicher und anderer fürnehmen Jugend veranstaltet/Und guten Theils wircklich eingerichtet und angefangen (Halle: Christian Henkel, 1698).

[Anonymous], Nachricht von der gegenwärtigen Verfassung der Ritter-Academie und des Seminarii zu Christian Erlang ([Christian Erlangen]: 1741).

Barbeyrac, Jean, Traité Du Jeu, Où l'on examine les principales Questions De Droit Naturel Et De Morale qui ont du rapport à cette Matiere, 2 vols. (Amsterdam: Humbert, 1709).

Bleeck, Klaus, Adelserziehung auf deutschen Ritterakademien. Die Lüneburger Adelsschulen 1655-1850 (Frankfurt/Main, Bern, Las Vegas: Peter Lang, 1977).

Cerman, Ivo, 'Habsburgischer Adel und Theresanum. Wissenvermittlung, Sozialisierung und Berufswege,' in Adelige Ausbildung. Die Herausforderung der Aufklärung und ihre Folgen, ed. Ivo Cerman and Luboš Velek (München: Martin Meidenbauer, 2006), 143-168.

110 Conrads, Ritterakademien, 271-272; Debitsch, Staatsbürgerliche Erziehung, 6. 
Conrads, Norbert, Ritterakademien der frühen Neuzeit. Bildung als Standesprivileg im 16. und 17. Jahrhundert (Göttingen: Vandenhoeck \& Ruprecht, 1982).

Cracraft, James, The Revolution of Peter the Great (Cambridge, MA: Harvard Univ. Press, 2003).

Debitsch, Friedrich, Die staatsbürgerliche Erziehung an den deutschen Ritterakademien ( $\mathrm{PhD}$ diss. University of Halle/Saale, 1927).

Dosquet, Émilie, 'Die Verwüstung der Pfalz als (Medien-)Ereignis: von der rheinländischen Kriegshandlung zum europäischen Skandal,' in Krieg und Kriegserfahrung im Westen des Reiches 1568-1714, ed. Rutz Andreas (Göttingen: Vandenhoeck \& Ruprecht, 2016), 333-369.

Duchardt, Heinz, Europa am Vorabend der Moderne 1650-180o (Stuttgart: Eugen Ulmer, 2003).

Flurschütz da Cruz, Andreas, Zwischen Füchsen und Wölfen. Konfession, Klientel und Konflikte in der fränkischen Reichsritterschaft nach dem Westfälischen Frieden (Konstanz: UVK, 2014).

Franckesche Stiftungen zu Halle (Saale), Datenbank zu den Einzelhandschriften in den historischen Archivabteilungen: 'Kemmerich, Dietrich Hermann' (Stand 29.03.2016), http://192.124.243.55/cgi-bin/gkdb.pl [31.03.2017].

Giese, Simone, 'Adelsstudium,' in Enzyklopädie der Neuzeit Online, ed. Friedrich Jaeger, accessed online on May 29, 2017. http://dx.doi.org.emedien.ub.uni-muenchen.de/ 10.1163/2352-0248_edn_aoo36ooo, first published online: 2014 .

Grabar, Vladimir E., The history of international law in Russia 1647-1917: a biobibliographical study (Oxford: Clarendon Press, 1990).

Greve, Wilhelm, The epochs of international law (Berlin: de Gruyter, 2000).

Grimm, Gunter E., Literatur und Gelehrtentum in Deutschland. Untersuchungen zum Wandel ihres Verhältnisses vom Humanismus bis zur Frühaufklärung (Studien zur deutschen Literatur 75) (Tübingen: Max Niemeyer, 1983).

[Gross von Trockau, Christoph Adam], Grossische Stifftung. Die unter der Protection dess Durchleuchtigsten Fürsten und Herren, Herrn Christian Ernsten, Marggrafen zu Brandenburg ... zu errichtende Academia Practica in Neu Erlang (Erlangen: [1702]).

Gross von Trockau, Christoph Adam, Recreationes Academicae Grosianae, Oder: Anleitungen Junge Stands=Personen Auf eine leichte und biss dato noch unbekannte Art zu einer Standes=mässigen Erudition nach dermaliger Welt=Art und dann zu Erlernung der vier Occidentalischen Sprachen zugleich und ohne Confusion in der Erlanger Ritterakademie anzuführen. ... Meistens in denen vier Occidentalischen Sprachen als Französisch, Italienisch, Spanisch und Lateinisch beschrieben samt einer Teutschen Vorrede von Einrichtung und Endzweck dieses Wercks (Christian-Erlang: Daniel Michael Schmatz, 1713).

Grotius, Hugo, Le droit de la guerre et de la paix: divise en trois livres, ou il explique le droit de nature, le droit des gens, \& les principaux points du droit public, ou qui concerne 
le gouvernement d'un etat ... Traduit du latin en francois par Monsieur de Courtin ... (Paris: Arnould Seneuze, 1687).

Hartley, Janet M., Charles Whitworth: Diplomat in the Age of Peter the Great (Aldershot: Ashgate, 2002).

Hertenstein, Johann Heinrich, Kurtzer Vorbericht Das Natürliche Und Völcker-Recht betreffend, Mit welchem Denen Durchlauchtigen, Hoch- und Wohl-Gebohrnen Herren Academicis Seine bey der Von Ihro Königl. Majestät in Preussen etc. Allergnädigst angerichteten Fürsten- und Ritter-Academie, Über gedachte beyde Rechte Dieses Erste halbe Jahr über zu haltende Lectiones anzeiget (Cölln an der Spree: Ulrich Liebpert, [1705]).

Jensen, De Lamar, 'Diplomacy,' in Europe 1450 to 1789. Encyclopedia of the early modern world, vol. 2, ed. Jonathan Dewald (New York: Thomson - Gale, 2004).

Keller, Katrin, 'Standesbildung,' in Enzyklopädie der Neuzeit Online, ed. Friedrich Jaeger, accessed online on May 29, 2017. http://dx.doi.org.emedien.ub.uni-muenchen .de/10.1163/2352-0248_edn_a4118ooo, first published online: 2014.

Kemmerich, Dietrich Hermann, Praeliminar-Discours von der Weissheit und Beredsamkeit, deren sich ein Junger von Adel oder auch höhere Standes-Person zu befleissigen ... (Erlangen: Johann Friedrich Regelein, 1706).

Kemmerich, Dietrich Hermann, Grund=Sätze des Völcker=Rechts von der Unverletzlichkeit der Gesandten. Samt einer Relation von dem Affront, welcher dem Moscowitischen Abgesandten in Engelland Anno 1708 erwiesen und der darauf erfolgten Satisfaction, Wie auch einer kurtzen Untersuchung dieser Affaire nach solchen Grund=Sätzen (Christian-Erlangen: Johann Andreas Lorber, 1710).

Kemmerich, Dietrich Hermann, Neu=eröffnete ACADEMIE Der Wissenschaften, Zu welchen vornemlich Standes=Personen nützlich können angeführet, und zu einer vernünfftigen und wohlanständigen CONDUITE geschickt gemacht werden. Zweyte Eröffnung (Leipzig: Thomas Fritsch, 1711).

Kemmerich, Dietrich Hermann, Neu=eröffnete ACADEMIE Der Wissenschaften, Zu welchen vornemlich Standes=Personen nützlich können angeführte werden. Dritte Eröffnung Welche die MORALE und das Natur=und Völcker=Recht in sich begreiffet (Leipzig: Thomas Fritsch, 1714).

Khavanova, Olga, 'Official Policies and Parental Strategies of Educating Hungarian Noblemen in the Age of Maria Theresa,' in Adelige Ausbildung, ed. Cerman and Velek, 95-115.

Knod, Gustav C. (ed.), Die alten Matrikel der Universität Strassburg 1621-1793, vol. 1: Die allgemeine Matrikel und die Matrikel der Philosophischen und Theologischen Facultät (Strassburg: Trübner, 1897).

Koldewey, Friedrich (ed.), Braunschweigische Schulordnungen von den ältesten Zeiten bis zum Jahre 1828, vol. 2: Schulordnungen des Herzogtums Braunschweig (mit Ausschluss der Hauptstadt des Landes) (Berlin: Hofmann, 189o). 
Kramer, Gustav (ed.), August Hermann Francke's Pädagogische Schriften. Nebst der Darstellung seines Lebens und seiner Stiftungen (Langensalza: Hermann Beyer \& Söhne, ${ }^{2} 1885$ ).

Kraus, Hans-Christof, Englische Verfassung und politisches Denken im Ancien Régime 1689 bis 1789 (München: R. Oldenbourg, 2006).

Lamy, Bernard, Entretiens sur les sciences dans lesquels on apprend comment l'on doit étudier les sciences et s'en servir pour se former l'esprit juste et le cour droit, ed. Pierre Clair and François Girbal (Paris: Presses universitaires de France, 1966).

Locke, John, Some Thoughts Corncerning Education (London: Churchill, 1693).

Mengin, Ernst, Die Ritter-Academie zu Christian-Erlang. Ein Beitrag zur Geschichte der Pädagogik (Erlangen: Palm \& Enke, 1919).

Moser, Johann Jacob, Lexicon derer jetzlebenden Rechts $=$ Gelehrten in und um Teutschland, welche die Rechte öffentlich lehren oder sich sonsten durch Schriften bekannt gemacht haben, so viel ihrer damalen zu erkundigen gewesen seynd (Züllichau: Gottlob Benjamin Frommann, ${ }^{2}$ 1739).

Orontes (= Johann Christoph Vetter), Unpartheyische Gedancken von der Alt- und Neuen Gelehrsamkeit. Nebst einer Unvorgreifflichen Anweisung zu den Nöthigsten- und Nützlichsten Wissenschaften vor Junge Edelleute ans Licht gegeben (Frankfurt/Leipzig: Johann Andreas Lorber, 1712).

Othmer, Sieglinde C., Berlin und die Verbreitung des Naturrechts in Europa. Kultur- und sozialgeschichtliche Studien zu Jean Barbeyracs Pufendorf-Übersetzungen und eine Analyse seiner Leserschaft (Berlin: Walter de Gruyter \& Co., 1970).

Palladini, Fiammetta, Die Berliner Hugenotten und der Fall Barbeyrac. Orthodoxe und "Sozinianer" im Refuge (1685-1720) (Leiden: Brill, 2011).

Pečar, Andreas, Zaunstöck, Holger and Müller-Bahlke, Thomas (eds.), Wie pietistisch kann Adel sein? Hallescher Pietismus und Reichsadel im 18. Jahrhundert (Halle: Mitteldeutscher Verlag 2016).

Pufendorf, Samuel von, Le Droit de la Nature et des Gens, ou Systeme general Des Principes les plus importans de la Morale, de la Jurisprudence, et de la Politique [...] Avec des Notes du Traducteur [Jean Barbeyrac], ou il supplee, explique, defend et critique les pensées de l'Auteur, et une Preface, qui sert d'introduction a tout l'Ouvrage, 2 vols. (Amsterdam: Kuyper, 1706).

Rothstein, Andrew, Peter the Great and Marlborough. Politics and Diplomacy in Converging Wars (New York: St. Martin's Press, 1986).

Schindling, Anton, Humanistische Hochschule und freie Reichsstadt. Gymnasium und Akademie in Strassburg 1538-1621 (Wiesbaden: Steiner, 1977).

Schindling, Anton, 'Die Strassburger Hochschule zur Zeit des Späthumanismus um 16oo,' in Universität Würzburg und die Wissenschaft in der Neuzeit, ed. Peter Herde and Anton Schindling (Würzburg: Ferdinand Schöningh, 1998), 95-107.

[Schowart, Anton Wilhelm], Der Adeliche Hofemeister/ Oder Wahrhafftige und deutliche Vorstellung was ein Adelicher Hofemeister vor Eigenschafften an sich haben: Wie 
derselbe sich in allen vorfallenden Begebenheiten klüglich verhalten/ seine Untergebene so wohl auff Universitäten als andern Orten treulich anführen und endlich mit ihnen nützliche peregrinationes anstellen solle (Frankfurt: Hartmann, 1693).

Schröter, Christian, Kurtze Anweisung zur Information Der Adlichen Jugend (Leipzig: Johann Friedrich Gleditsch 1704).

Schulenburg, Johannes-Matthias Graf von der, 'Die Gründung der Ritterakademie zu Brandenburg im Jahre 1704,' in Berichte und Forschungen aus dem Domstift Brandenburg 4 (2011), 5-99.

Schulz, Arthur, Die örtliche und soziale Herkunft der Strassburger Studenten 1621-1793 (Frankfurt: [Selbstverlag] 1926).

Steigerwald, Jörn, Galanterie. Die Fabrikation einer natürlichen Ethik der höfischen Gesellschaft (1650-1710) (Heidelberg: Winter, 2011).

Stolleis, Michael, Geschichte des öffentlichen Rechts in Deutschland, vol 1: Reichspublizistik und Policeywissenschaft 16oo-180o (München: Beck, 1988).

Teichmann, 'Kemmerich, Dietrich Hermann,' in Allgemeine Deutsche Biographie 15 (1882), 599 [Online-Version]; https://www.deutsche-biographie.de/gnd1oo17731X. html\#adbcontent [29.05.2017].

Tischer, Anuschka, 'Diplomatie,' in Enzyklopädie der Neuzeit Online, ed. Friedrich Jaeger, accessed April 15, 2017. http://dx.doi.org.emedien.ub.uni-muenchen.de/10.1163/ 2352-0248_edn_ao7740oo, first published online: 2014 .

Wierzbicki, Aleksander, Peter the Great of Russia: an English historiography of the XVIII and XIX centuries (London: Athena Press, 2004).

\section{Archival material}

UniA Erlangen, D1/1 Nr. 15 


\title{
Serving Danish Foreign Policy: Andreas Hojer's De eo quod iure belli licet in minores (1735)
}

\author{
Mads Langballe Jensen
}

Andreas Hojer (1690-1739) is arguably one of the most fascinating but understudied figures in the early enlightenment in Denmark. Hailing from SchleswigHolstein, Hojer studied in Halle under Christian Thomasius $\left(1^{6} 55^{-1728}\right)$, where he became fascinated with the new teachings on natural law and the law of nations. His first published works were an academic exercise on the (non-)prohibition of incestuous marriage by divine law, the De nuptiis propinquorum iure divino non prohibitis [...] diagramma, and a short history of Denmark. ${ }^{1}$ Both works led him into polemics and rivalry with Ludvig Holberg (1684-1754), who is now widely considered the (only) major figure of the early Danish enlightenment. Having successfully weathered a storm over his work on marriage, Hojer was employed in a string of positions, including royal historiographer and Justitsråd, before being appointed the first ex officio professor of the law of nature and nations at Copenhagen University in $1734{ }^{2}$

No substantive account of his natural law theorizing and its political and intellectual significance has thus far been attempted. An informative and detailed biography of Hojer was published in 1961, and Hojer is mentioned in the standard histories of jurisprudence in Denmark. ${ }^{3}$ But in neither case is there any detailed discussion of his teachings on natural law. ${ }^{4}$ This is perhaps

1 Andreas Hojer, Kurtzgefasste Dännemärckische Geschichte vom Anfang dieses mächtigen Reichs bis zum Ausgang des XVII. Seculi (Flensburg: Bosseck, 1719); Andreas Hojer, De nuptiis propinquorum iure divino non prohibitis [...] diagramma (n.p.: n.n., 1718).

2 Troels G. Jørgensen, Andreas Hojer, jurist og historiker (København: Arne Frost-Hansens Forlag, 1961), 134. For the university statutes, see William Norvin, Københavns Universitet i Reformationens og Orthodoxiens Tidsalder, vol. 2 (København: Gyldendal, 1940), 114.

3 Jørgensen, Andreas Hojer, jurist og historiker; Ditlev Tamm, Juraen på Københavns Universitet 1479-2005 (København: Københavns Universitet, 2005), 66, 7off, 92ff.

4 There is, however, a brief but indicative discussion of Hojer's natural law theory in Knud Haakonssen, 'Holberg's Law of Nature and Nations,' in Ludvig Holberg (1684-1754): Learning and Literature in the Nordic Enlightenment, ed. Knud Haakonssen and Sebastian OldenJørgensen (London and New York: Routledge, 2017), 59-79, at 68-70. 
because the sources are rather disappointing. According to a lecture catalogue, Hojer lectured publicly on 'the law of nature as well as the precepts of moral philosophy' in $1736-1740 .{ }^{5}$ But seemingly no notes from Hojer's lectures on natural law survive. Instead, the most important sources for Hojer's teaching on natural law are his programme or manual for Danish students of law from 1736, the Idea iurisconsulti danici (with a Danish translation the following year), and his inaugural dissertation at the occasion of his appointment to the professorship of natural law, De eo quod iure belli licet in minores, published the year before. ${ }^{6}$ Of these two, the latter provides the most substantial view of his mature thoughts on the law of nations and natural law. To this might be added his early Diagramma, which was, however, published eighteen years before he started lecturing.

This chapter offers a characterization of Hojer's theory of natural law and the law of nations on the basis of his inaugural dissertation De eo quod iure belli licet in minores and its intellectual and political significance in earlyeighteenth-century Denmark-Norway. The following section briefly outlines the intellectual context of natural law theorizing in Copenhagen around 1700. The chapter then proceeds to outline the political context of the conflict with the dukes of Holstein-Gottorp over the dominion of Schleswig, followed by a discussion of the polemics on this question during the Great Northern War. This provides the background for a detailed analysis of Hojer's inaugural dissertation, on the basis of which the chapter offers a concluding interpretation of Hojer's natural law profile and its significance.

Although Hojer was the first to hold a professorship in Copenhagen in the law of nature and nations, he was not the first to work on the discipline or teach it. The subject had been taught there since the 169 os, by the Kiel-educated

5 'Jus Naturæ nec non Moralis Philosophiæ Præcepta,' Lectiones publicae Professorum in Universitate Hauniensi (Hafniae: Ex Typographeo Regiae Majest. \& Universit., 1604-1786). See also Holger Rørdam, ed., Historiske Samlinger og Studiervedrørende danske Forhold og Studier iscer i det 17. Aarhundrede (Kjøbenhavn: Gad, 1891-1902), IV: 146.

6 Andreas Hojer, Dissertatio iuris publici universalis de eo quod iure belli licet in minores, Vom Recht des Krieges gegen die Minderjährige (Hafniae: Typis Reg. Majest. \& Universit. Typogr. Joh. G. Höpffneri, 1735); Andreas Hojer, Ideae Icti Danici partem 1. disputatione anniversaria expositam publico eruditorum examini subiciit Andreas Hoier (Hafniae: Typis Reg. Majest. \& Universit. Typogr. Joh. G. Höpffneri, 1736); Andreas Hojer, Forestilling paa en DanskJurist, den 1. Part (Kjøbenhavn: Kongl. Majests. priviligerede Bogtrykkerie, 1737). 
Henrik Weghorst (1653-1722) and by Christian Reitzer (1665-1736), who had conducted much of his studies under Christian Thomasius in Halle before being appointed professor of law at Copenhagen University. Each published several shorter works on natural law. ${ }^{7}$ In addition, in 1716 Ludvig Holberg had published the first compendium on natural law in the Danish language, drawing on Hugo Grotius, Christian Thomasius and especially Samuel Pufendorf. ${ }^{8}$ Finally, the likewise Halle-educated Christoph Heinrich Amthor (1678-1721), professor of natural law, public law and politics at Kiel University, had published works in favour of the Danish monarch Frederick IV during the Great Northern War. For this service he was awarded positions as Justitsråd and royal historiographer. Although he published little on natural law in Copenhagen, where he died in 1721, he published several polemical works on the conflict with Holstein-Gottorp during the war, and his lectures on ethics, natural law and decorum were published posthumously in $1738 .^{9}$

In the years before receiving the professorship in natural law, Andreas Hojer had in more than one way taken up the mantle from Amthor. Apart from continuing Amthor's work on the history and life of Frederick IV, he had also defended Danish interests to the south. When Denmark-Norway came into conflict with the free imperial city of Hamburg, as a consequence of the latter setting up a new exchange bank and refusing to accept Danish currency on equal rates, Hojer advised the Danish government on the best measures to take in accordance with the law of nations, and also published anonymous polemical works on the conflict intended to sway public opinion towards

7 For a discussion of the natural law profiles of these first teachers of the subject in Copenhagen, see Mads Langballe Jensen, 'Contests about Natural Law in Early Enlightenment Copenhagen,' History of European Ideas 42 (2016): 1027-1041.

8 On Holberg's natural law theory, including its different uses, see Knud Haakonssen and Sebastian Olden-Jørgensen, eds., Ludvig Holberg (1684-1754): Learning and Literature in the Nordic Enlightenment (London and New York: Routledge, 2017); Jørgen Sejersted and Eiliv Vinje, eds., Ludvig Holbergs naturret (Oslo: Gyldendal Akademisk, 2012).

9 Christoph Heinrich Amthor, Philosophia moralis seu doctrina de justo, honesto et decoro. Hierbey ist statt einer Vorrede vorangesetzet Authoris unvorgreiffliche Gedancken von der beqvemsten Methode, deren sich ein academischer Lehrer bedienen kan (Hafniae, Lipsiae: Joh. Nicol. Lossius, 1738). For Amthor's biography, see Heiner F. Klemme and Manfred Kuehn, eds., Dictionary of Eighteenth-Century German Philosophers (London: Continuum, 2010), 17f.; Carl Frederik Bricka, ed., Dansk biografisk Lexikon tillige omfattende Norge for Tidsrummet 1537-1814 (Kjøbenhavn: Gyldendalske Boghandels Forlag, 1887), 1: 197f., available online at http://runeberg.org/dbl/. For Amthor's work on decorum, see Kasper Risbjerg Eskildsen, 'Print, Fashion, and the Making of the Enlightenment Philosopher,' in Northern Antiquities and National Identities. Perceptions of Denmark and the North in the Eighteenth Century, ed. Knud Haakonssen and Henrik Horstbøl (København: Det Kongelige Danske Videnskabernes Selskab, 2008), 126-144. 
Denmark-Norway. ${ }^{10}$ It is thus not surprising that when, in a letter of May 1735 , Hojer mentioned a desire to choose a topic for his inaugural dissertation that would please the king, Danish political interests to the south were predominant. The first potential topic concerned what was allowed in war against minors, the second that Denmark had never been a feudal vassal of the German Empire, the third concerned the Emperor's rights to mint coins (against Moser), the fourth the Emperor's rights over the river Elbe, which had been bestowed on Hamburg, and the final one concerned the east Frisians' status by public law. Of these, Hojer eventually chose the first. ${ }^{11}$

To understand why Hojer chose that particular topic, we need to look into the larger intellectual and political context. All of Hojer's suggested topics concerned Denmark-Norway's political interests to the south, and his final choice of subject tapped directly into the political-legal debates of the Great Northern War.

\section{Denmark-Norway in the Great Northern War}

In the Great Northern War of 1700-1721, Denmark-Norway was allied with Saxony-Poland and Russia against Sweden. To the south of Denmark was the ducal house of Schleswig-Holstein-Gottorp. The Gottorp family was a cadet branch of the Oldenburg family in Denmark, which had been vassals of the Danish crown until the mid-seventeenth century, when Sweden had forced the Danish king to accept the sovereignty of Gottorp. ${ }^{12}$ For most of the war, the ruler of Gottorp was the underage duke Charles Frederick (1700-1739), and although Gottorp had adopted a position of neutrality it did not escape being drawn into the war. At the outset of the war, Frederick IV of Denmark-Norway invaded and occupied the ducal lands in Schleswig-Holstein. ${ }^{13}$ Initially, Frederick IV was

\footnotetext{
10 Jørgensen, Andreas Hojer, jurist og historiker, $103 \mathrm{f}$.

11 Andreas Hojer, '[Letter to an unnamed "Monseigneur"]', 28 May 1735, Royal Library, Copenhagen: MS Kall 383, 4to. The letter, as well as (very briefly) the inaugural dissertation, is summarised in Jørgensen, Andreas Hojer, jurist og historiker, 246-248.

For a brief overview of Danish-Gottorp-Swedish relations in the seventeenth and early eighteenth century, see Otto Brandt, Casparvon Saldern und die nordeuropäische Politik im Zeitalter Katharinas II., etc. (Erlangen; Kiel: Palm \& Enke; Walter G. Mühlau, 1932), 3 ff. The most detailed history is still Edvard Holm, Danmark-Norges Historie fra den store nordiske Krigs Slutning til Rigernes Adskillelse, 1720-1814, 7 vols. (Kjøbenhavn: Gad, 1891-1912). I will be drawing on both these works in my discussion of the Great Northern War below.

13 In the following, I am relying on the accounts in Holm, Danmark-Norges Historie; Brandt, Casparvon Saldern.
} 
forced to withdraw and sign the Peace of Travendal in 1700, promising not to engage in further hostilities against Sweden and to respect the sovereignty of Holstein-Gottorp over its lands.

Frederick IV re-entered the war in 1709, however. When Stenbock, the Swedish field marshal, led a Swedish army into northern Germany in 1712, the war took a decisive turn. Hard pressed by united Danish, Saxon and Russian forces, Stenbock retreated northwards into Schleswig-Holstein. At this point, the ministers and 'administrator' (guardian) of the young Charles Frederick decided to offer Stenbock protection in the main Holstein-Gottorp fortification at Tønning at the mouth of the river Eider, in southern Schleswig. This was done in secret, as it was arguably contrary to Holstein-Gottorp neutrality in the war, declarations of which were simultaneously given to King Frederick IV. Danish forces besieged Stenbock's forces at Tønning, forcing them to surrender in 1713. This led to the discovery of documents allegedly proving the duplicity of the Holstein-Gottorp ministers, and subsequently to Danish occupation and sequestration of the Gottorp lands in Schleswig and Holstein.

At the end of the Great Northern War, the peace treaty of Frederiksborg (1720) confirmed Danish dominion over Schleswig, while the German Emperor Charles VI, to whom duke Charles Frederick had appealed as his supreme liege lord, secured the restitution of the Gottorp possessions in Holstein. ${ }^{14}$ This would not be the end of the matter, however, for Charles Frederick would continue campaigning, now from Russia, for the restitution of his lands in Schleswig as well, a question in which most of the major European powers would regularly become involved. ${ }^{15}$

While Denmark concluded a treaty with both Russia and Vienna in 1732 according to which Denmark would pay Charles Frederick two million Rigsdaler (Rdl.) in return for Gottorp renouncing its claims to Schleswig, neither Russia nor the German Emperor had been able to persuade Charles Frederick to give his consent to this. ${ }^{16}$ As such, the question of the legitimacy of the Danish sequestration of the Gottorp lands became a bargaining chip in the negotiations during the Polish War of Succession (1733-1735/1738), and the Danish crown sought assurances for its possessions from all of the powers involved, each giving or questioning such assurances in turn, according to their own interests and expediencies.

14 The circumstances and drafting of the peace treaty of Frederiksborg, as part of his detailed account of the Danish-Norwegian participation in the Great Northern War, can be found in Hojer, König Friederich des Vierten glorwürdigstes Leben, II: 19.

15 Holm, Danmark-Norges Historie, I: 48.

16 Ibid., II: 53 . 
There clearly was a great deal of power politics involved in the question of the recognition of the Danish sequestration of Schleswig, but since any recognition had to take the form of treaties, there was equally a question of legal and moral legitimation. ${ }^{17}$ The first wave of polemics came immediately after the Danish conquest of Tønning and occupation of Schleswig in 1714-1715, while Hojer's intervention came in August 1735, two months before the peace preliminaries of the Polish War of Succession in October 1735 and three years before the final settlement in 1738 .

During the pamphlet war following the fall of Tønning and the Danish sequestration of Gottorp lands, the Danish case was chiefly made (anonymously) by Christoph Heinrich Amthor, the former professor of natural law at Kiel University. In the In iure et facto Gegründeter Beweis der vielfältigen Treulosigkeiten (1715), Amthor answered two Holstein-Gottorp pamphlets: the Succincte Deduction and the In facto gegründete umbständliche Nachricht from $1714 .{ }^{18}$

Central to the Danish case was the argument that Gottorp had broken its treaties and reneged on its promise of neutrality by giving Tønning over to Stenbock and the Swedish army. In so doing, Gottorp revealed itself to be an enemy of Denmark-Norway, a fact further corroborated by the secret treaty and articles that had been concluded between the House of Gottorp and field marshal Stenbock as representative of the Swedish king, and that had duly been published when they fell into Danish hands. ${ }^{19}$ This in turn justified the

17 For another study of the interplay between power politics and moral-legal legitimization, see Pärtel Piirimäe, 'The Capitulations of 1710 in the Context of Peter the Great's Foreign Propaganda,' in Die baltischen Kapitulationen von 1710 : Kontext - Wirkungen Interpretationen, eds. Karsten Brüggemann, Mati Laur, and Pärtel Piirimäe (Köln: Böhlau Verlag, 2014), 65-86.

18 [Christoph Heinrich Amthor], In iure et facto Gegründeter Beweis der vielfältigen Treulosigkeiten, So das Jetzt-regierende Allerdurchlauchtigste Königl. Dähnische Haus von dem Fürstl. Holstein-Gottorfischen bisher erlitten / Worin ... ausführlich gezeiget wird, Daß das Hertzogthum Schleswig durch offenbahre Rebellionen ... von der Krohne Dennemarck zum erstenmahl abgerissen, hernach durch gleich wenig zugelassene Felonien ... zur Souveraineté erhaben ... (Kopenhagen, 1715); [Anonymous], Succincte Deduction daß Seine König Majest von Dennemark des Hoch-Fürst. Hauses Holstein-Gottorp Aggressor seyn, 1714; [Anonymous], In Facto Gegründete umbständliche Nachricht, Wie Der Königl. Dänische Hoff Des Fürstl. Holstein-Gottorpischen Hauses Untergang und Ruin beständig gesuchet, auch aus einer solchen absicht weder Verträge, noch Friedensschlüsse jemahln gehalten ... / Auff Gnädigsten Befehl publiciret Im Jahr 1714, 1714.

19 [Anonymous], Wahrhafter Abdruck Des In Händen habenden Original-Tractats nebst den Separat-Articuln / So Zwischen dem Fürstl. Hauße Gottorff und Dem Königl. Schwedischen Raht und Feld-Marschall Graffen von Steenbock unterm 21 ten Januarii Anno 1713. im 
occupation and eventual sequestration of Gottorp lands by Frederick IV. As Amthor argued, when Gottorp assisted the Swedish army and let it into Tønning, 'His Royal Majesty of Denmark was given most necessary cause, according to all laws of nature and of nations, to seize the Ducal lands, and defend himself as far as possible against this new approaching enemy together with the old'. ${ }^{20}$ As such, Frederick IV was further justified in sequestrating the Gottorp lands not just in Schleswig but also in Holstein, to prevent further Gottorp aggression and ensure the security of his realm. ${ }^{21}$

Faced with the occupation and sequestration of their lands following the defeat of the Swedes and the fall of Tønning, and the uncovering of documents supposedly proving their duplicity, the Gottorp ministers and pamphleteers adopted several arguments. First and foremost, they argued - mainly on the basis of the legal, political and military history of Denmark-Norway and Holstein-Gottorp - that Gottorp had not violated its obligations of neutrality in admitting Stenbock's Swedish army into Tønning. It was in fact Denmark that was the true aggressor, declaring war against Sweden in contradiction of existing treaties with Gottorp. The authority of Hugo Grotius was cited to argue that Gottorp was thereby absolved of obligations towards Denmark. ${ }^{22}$ At the same time, it was also denied that Stenbock had been invited into Tønning and asserted that it had happened without the knowledge and consent of duke Charles Frederick. These assertions were marshalled to argue that the sequestration was illegal and that although Frederick IV might think himself injured by the guardian of Charles Frederick, he, the Danish king, should nevertheless restore the lands to the young duke, 'an entirely innocent young lord'. To achieve this purpose, the Gottorp ministers appealed to the Imperial Diets and the care of the Emperor as the 'supreme guardian' (Ober-Vormündische Fürsorge) of Charles Frederick. ${ }^{23}$ Another pamphlet referred to a treaty concluded

Rahmen Sr. Königl. Mayst. von Schweden getroffen und geschlossen worden, umb Dadurch, ... das Gegen Ihre Königl. Majest. zu Dennemarck, Norwegen [et]c. und Dero Alliirte von Dem Fürstlichen Hauße Gottorff begangenes treuloses und wieder alle Conventiones und Verträge, unverantwortliches und Friedbrüchiges Verfahren der gantzen unpartheischen Welt an den Tag zu legen (Kopenhagen: Königl. Maj. und Univ. privilegirten Buchdr., 1714). 'Hiedurch bekahmen nun Ihro Königl. Majest. von Dännemarck nach allen Natürlichen / und Völcker-Rechten / höchstgemüssigten Anlasz / die Fürstlichen Länder einzuziehen / und so viel möglich sich dieses neuen zudringlichen Feindes mit dem Alten auf eins zuentschütten.' [Amthor], In Iure Et Facto Gegründeter Beweis, 7 o.

21 Ibid., 74.

22 Grotius, De iure belli ac pacis $2.15 . \$ 15$, cited in In Facto Gegründete umbständliche Nachricht, para. 215. 
between Gottorp and Prussia as well as other declarations to show that the 'unbiased powers' (ohnpartheyische Puissancen) guaranteeing the Westphalian, Northern and other recent peace treaties were sympathetic to the plight of a 'still minor prince facing utter ruin' and regarded the Danish occupation as 'unjust and insufferable.'.

In his replies, Amthor constructed a section-by-section rejection of the Gottorp case. This included a detailed legal interpretation of the initial division of Schleswig-Holstein between Denmark and Gottorp as well as subsequent treaties. He also argued in detail that Gottorp's actions in Denmark's war with Sweden were in contradiction of its obligations as a neutral party, according to the laws of nature and nations, drawing on Hugo Grotius's De iure belli ac pacis, as well as more recent discussions by Johann Heinrich Boeckler. ${ }^{25}$ What is particularly interesting for our purposes, however, is Amthor's treatment of the Gottorp pamphleteers' appeal to and use of the minority status of Charles Frederick. As we have seen, Gottorp used the minority of Charles Frederick to argue that he was not party to the administrator's actions, and in particular to appeal to the protection of the Emperor (as supreme guardian) and other major powers within the legal framework of the imperial constitution and European peace treaties. This had the further effect of constituting Frederick IV's status in the conflict as a fellow vassal of the Emperor rather than sovereign king of Denmark-Norway. In contrast, Amthor construed the issue strictly as one pertaining to the law of nature regulating the conduct of war between two independent states.

At first, Amthor argued that while the minority of the Gottorp duke had been used to create sympathy for his case, the Gottorp pamphleteers had avoided the actual status controversiae in an attempt to conceal the injustice (Unfug) of their claim. The real issue or 'status', according to Amthor, was 'whether an underage prince or ruler duly has to answer for what has happened during

24 'Dasz hingegen auch andere ohnpartheyische Puissances des Fürstl. Hauses gegenwertige zerrüttung und Seiner unschuldigen lande verheerung ebenfalls vor ungerecht und unleydlich ansehen / wie ingleichen den für augen liegenden eussersten ruin eines annoch minderjährigen Fürsten höchstrühmlich behertzigen / ist theils aus dem sub lit. D. beygehenden art. 8. des zwischen Jhr. Königl. Majest. in Preussen und des Herrn Administratoris Durchl. errichteten tractat, theils aus einiger hohen Puissancen, welche die Westphälische / Nordische / Fontainebleauische / Altonaische und Travendahlische Friedensschlüsse zu garantiren übernommen haben / desfalls gegebenen Declarationen zu ersehen.' In Facto Gegründete umbständliche Nachricht, para. 220. 
his minority, if he thereby suffers considerable damage.. ${ }^{26}$ In other words, the issue was whether the young Charles Frederick should be obliged to accept the sequestration of his lands by Frederick IV as a consequence of the Gottorp violation of neutrality during his minority. Those who might be inclined to answer in the negative should be considered, asserted Amthor, to be led by their passions or careless ignorance of the common law of nations (allgemeines Völcker-recht). ${ }^{27}$

Amthor argued that the fundamental error of this position was to assume that since there were provisions in civil law (in foro civili) protecting minors against damages resulting from the actions of their guardians, this would apply to an underage prince as well. But this was to mistakenly confuse the civil state of citizens with the state of nature in which rulers exist with regard to one another. ${ }^{28}$ Reason itself showed, he argued, that to accept the non-responsibility of underage princes (exceptio minorennitatis) would be to adopt a principle that was contrary to the entire sociality of states (Völcker-Socialität). It would endanger the security of all states neighbouring a state which had a minor ruler, for the latter would be able to do whatever it wanted without fearing the consequences. ${ }^{29}$ In short, whatever was done by the guardian of a minor ruler would have to be considered done by the ruler himself. Otherwise, Amthor argued, citing Pufendorf and Barbeyrac, 'there would be no true and faithful trust between such a prince and his neighbours, and consequently, as no reasonable moral philosopher can deny, no one would have anything to do with him. ${ }^{30}$ 'These natural reasons of rational morality', would, Amthor trusted, suffice to show that the 'present minority' of Charles Frederick of Gottorp 'can in no way release him from having to give satisfaction' for breaching the peace against Denmark. $^{31}$

26 'Ob ein minderjähriger Printz / oder Potentate / desjenigen / was währender siner Minderjährigkeit geschehen / wann ihm daraus ein empfindlicher Schaden erwächset / billiger Weise zu entgelten habe?' Ibid., para. 63 .

27 'Leuthe / bey denen die Passion, oder eine nachlässige Unwissenheit des allgemeinen Völcker-rechts prævaliret'. Ibid.

28 Ibid.

29 Ibid., para. 64.

30 'Weil sonst bey der-gleichen Fällen / so lange der Fürst die Regierung nicht selber anträte / zwischen ihm und seinen Nachbahren keine Treu und sicherer Glaube mehr vorhanden seyn / einfolglich / wie kein verständiger Moraliste wird läugnen können / niemand mit einem jungen Fürsten würde zu schaffen haben wollen (gg).' Citing Pufendorf, De Iure Naturae et Gentium, III, 10, $\$ \S 2-3$, and Barbeyrac's commentary in his French translation. Ibid.

31 'Diese natürliche Gründe der vernunfftmässigen Morale sind verhoffentlich zwar zulänglich gnug darzuthun / dass Ihrer Durchl. Hertzog Carl Friedrichs bisherige 
Whether Amthor's intervention on Danish side proved significant or not is difficult to say. Regardless, the debate indicates the significance of academic natural law and law of nations in early-eighteenth-century Denmark-Norway, as elsewhere in Europe. Academic expertise in the law of nature and nations was absolutely essential in maintaining Danish political interests against the arch-rival Sweden and its close ally to the south. The peace treaty of Frederiksborg in 1720 confirmed the Danish sequestration of the Gottorp lands in Schleswig. But, typically of such treaties, this was not, as we saw, the final word in the matter, and Hojer would return to the subject fifteen years later, under Christian VI, Frederick IV's son and successor.

\section{5}

Hojer's Choice of Topic

This, then, was the background to Andreas Hojer's choice of the topic for his inaugural dissertation. Appeals to Charles Frederick's minority had been one of several arguments drawn upon by Gottorp pamphleteers in trying to establish the illegitimacy and illegality of the Danish sequestration of Gottorp lands and in seeking to secure international support for their restitution. In this connection, Gottorp had primarily appealed to the imperial constitution and prior treaties; it was Christoph Heinrich Amthor who first established Charles Frederick's minority as an issue specifically of the law of nature and nations, in order to prove - in brief - its irrelevance on those grounds. As such, Hojer's dissertation simply took up in greater detail a topic established by Amthor.

Hojer knew the history of the Great Northern War very well and was most likely conscious that he was taking up a topic first established by Amthor, even if he did not say so explicitly. One of Hojer's first official appointments by the Danish monarch had been as royal historiographer, in 1721, replacing Amthor; this was, on Amthor's request, to continue the latter's history of Frederick IV. ${ }^{32}$ Hojer finally completed a history of King Frederick IV's reign under his son, King Christian vI, around $1734 \cdot{ }^{33}$ Much of the work dealt in detail with Frederick IV's

Minorennitæt das Haus Gottorff auf keinerley Weise von der Satisfaction dispensiren könne / die es Seiner Königl. Majest. von Dännemarck wegen des letzteren zudringlichen Friedens-Bruchs zu leisten schuldig ist.' Ibid., para. 65.

32 Jørgensen, Andreas Hojer, jurist og historiker, 76, 89ff. See also documents in Rørdam, Historiske Samlinger og Studier, I: $375 \mathrm{f}$ and II: $375 \mathrm{ff}$.

33 Jørgensen, Andreas Hojer, jurist og historiker, 1 16; Rørdam, Historiske Samlinger og Studier, III:495. Although it would not be printed until 1829: Hojer, König Friederich des Vierten glorwürdigstes Leben. 
role in the Great Northern War and the conflict with Gottorp. Hojer had conducted extensive archival studies for his work, and described, among much else, Gottorp's duplicity in simultaneously assisting Sweden and giving assurances of neutrality to Frederick IV, the Danish siege of the fortress Tønning and the subsequent conflict over the justification of the Danish occupation, including appeals to the minority of the Gottorp ruler. ${ }^{34} \mathrm{He}$ was clearly familiar with Amthor's role as anonymous polemicist for the Danish side and his writings in this capacity. The causes of the war, Hojer explained, 'can easily be understood from the published declarations and the Amthorian writings', as well as from the Swedish intrusions in recent years. In this connection it was particularly unfortunate that 'it had not been common in Denmark to call upon people knowledgeable of the law of nature and of nations, of public law, as well as of history and good policy, in controversies over matters of state [Staats-Deductionen]', ${ }^{35}$

These were precisely the topics on which Hojer had worked to establish his expertise, from his early work on marriages and the history of Denmark to his later defences of Denmark in the conflict with Hamburg. The passage was a forthright call for the necessity of expertise in natural law and history, and at the same time of Hojer's own usefulness, for pursuing the political aims of the Danish monarchy. The inaugural dissertation thus gave Hojer the opportunity to demonstrate this. That the dissertation demonstrated an expertise in natural law was emphasized explicitly in the preface. The topic, what the right of war allowed against minors, was most appropriate for the discipline but had been discussed inadequately and by few. That it was also a question of the highest political interest (as he had emphasized in a private letter) was only hinted at an 'illustrious' issue 'among others, that are discussed in our time'36 - but was quite obvious to anyone with just a minimum of political awareness.

Hojer on the Right of War against Minors

The dissertation itself can be divided into four parts. Befitting an academic disputation, Hojer began by specifying the questions that must first be

34 Hojer, König Friederich des Vierten glorwürdigstes Leben, I: 249ff., for Hojer's account of Gottorp's appeals to the duke's minority status, see p. 253. For a brief summary of the work, see Jørgensen, Andreas Hojer, jurist og historiker, 117-123.

35 'Allein zum Unglück war man in Dännemark von vielen Jahren her nicht gewohnt zu Staats-Deductionen Leute, die der Natur- Völker- und Staatsrechte, wie auch der Ante actorum und der rechten Politik kundig, aufzusuchen.' Hojer, König Friederich des Vierten glorwürdigstes Leben, I: 182. 
answered in order to determine the rights of war against minors: first, what is the right of war (ius belli); and second, what does it mean to say that someone is a minor? On this basis, Hojer then discussed the rights of war against minor subjects and finally the rights of war against minor princes. Throughout the dissertation, Hojer amply demonstrated his expertise in the 'modern' natural law pioneered by Hugo Grotius and particularly Samuel Pufendorf and Christian Thomasius, making use of the theoretical innovations and distinct methods of the latter two on critical and fundamental points. However, he followed neither of them slavishly, siding with thinkers such as Gottlieb Gerhard Titius and Christian Gottlieb Schwarz against Pufendorf, and betraying influences also of others of his own generation, such as Michael Heinrich Griebner, on the categorization of the parts of natural jurisprudence.

Hojer began by defining the right of war (ius belli) in line with the Pufendorfian conception, according to which it was derived from natural law, or ius universale. "The right of war is that part of universal law which defines the duties of those waging war according to the dictates of right reason' concerning what is necessary for conserving human society. ${ }^{37}$ This was, as Hojer saw it, now the consensus of the learned community. ${ }^{38}$ It was a position that departed from Grotius's conception of the law of nations as distinct from the law of nature and a part of human voluntary ('positive') law. The latter had been the position of Samuel Rachel in Kiel and later his student Henrik Weghorst in Copenhagen, and it was not the only view explicitly singled out for criticism in Hojer's dissertation. ${ }^{39}$ To Hojer it was an equally serious mistake to try to define this law on the basis of Roman law, or indeed that of other people. ${ }^{40}$ This did not mean that the inquiry into the laws of various states did not play a role in Hojer's argumentation, but, as we shall see, this did and could not serve the purpose of determining the laws or rights of war. Hojer then explained that the ius which governs the 'human race' is of a twofold kind: perfect and imperfect, according to which the resulting duties were either commanded or merely permitted. Thus the 'right of war' consisted of the precepts of universal jurisprudence determining the perfect and imperfect

'Ius belli illa pars Iuris universalis, quae officia belligerantium ex dictamine rectae rationis definit.' Ibid., 2.

38 Compare Hojer's comments on ius gentium in Hojer, Ideae Icti Danici partem 1., $27 \mathrm{f}$.

39 For Rachel, see Tetsuya Toyoda, Theory and Politics of the Law of Nations: Political Bias in International Law Discourse of Seven German Court Councilors in the Seventeenth and Eighteenth Centuries (Leiden; Boston, MA: Martinus Nijhoff Publishers, 2011), chap. 3. For Weghorst, see his Compendii juris naturce, Dissertatio prima (Hafniae: Joachim Smetgen, 1696), $22 f$. 
duties of those waging war, that is, what was prescribed or forbidden and what was allowed or licit.41

Hojer went on to discuss the definition of minority. He presented a wideranging survey of the status of minors in various European laws, quoting passages from Greek and Roman law, ancient Germanic law, including Frankish and Anglo-Saxon law, old Danish and Jutish law, as well as the laws of various northern German cities. ${ }^{42}$ All European laws, Hojer observed, agreed in viewing minority as an age between childhood and adulthood (legitima aetas), where a person was in need of a guardian because of a certain defect of reason and inconstancy of will. As such, the minor person could not legally decide his own affairs independently of a guardian. What these laws did not agree on, however, was exactly what age constituted this minority status. ${ }^{43}$ This showed, argued Hojer, that it was impossible to determine minority on the basis of reason alone, that is, by natural law. It was a matter decided solely by the authority of the legislator, that is, positive law. ${ }^{44}$

In other words, for Hojer the historical investigation of (the incongruence of) positive laws served to show that there was no 'innate norm' stipulating minority status, but that it was a status instituted by human law or convention. The most that could be said of the 'intentions' of the lawgivers, argued Hojer, was that they aimed to ensure that no harm was done to the state as a result either of the impunity of minors or of their defencelessness without guardians. While natural law prescribed this end, namely the security of the state and of minors, it left open the means to secure this end. However, in this as in so many other matters, the lawyers had started to confuse positive and natural law. They had thus, erroneously, concluded that the Roman and canon law stipulations were part of natural law, so that minors should receive restitution according to natural law irrespective of how they had been injured. ${ }^{45}$

This all necessitated a more careful examination of the question 'Are there minors according to the discipline of natural law?' This Hojer could confidently deny by summarizing his argument from the preceding pages, and confirming it with references to Grotius, Pufendorf and Thomasius, as well as Ulrik Huber and M.H. Griebner. ${ }^{46}$ Hojer further strengthened his argument

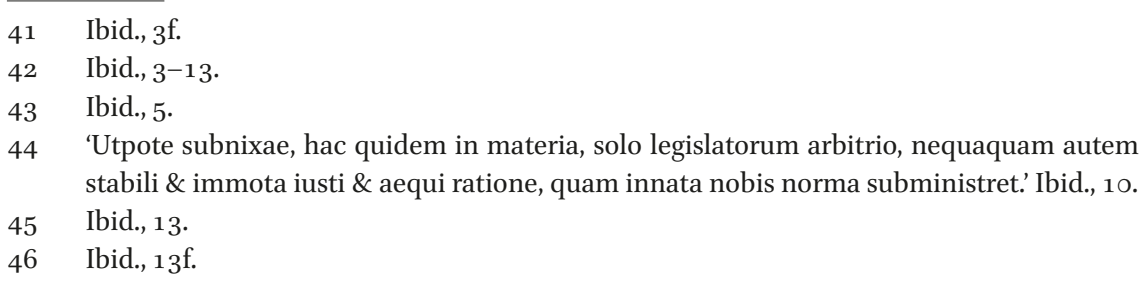


by distinguishing between different parts of natural or universal law. In the part dealing with the internal constitution of states, the ius civitatis universale, there could be said to be a place for minority. But this was precisely in the civil state and determined by positive law, as Hojer had previously explained. ${ }^{47}$ His topic was, however, a different part of the ius universale, that dealing with relations between states and as such the state of nature.

In the remainder of his argument, Hojer drew on the conceptual apparatus pioneered by Pufendorf, with its distinction between physical and moral entities and its discussion of different moral personae and moral states, to develop a consistent and rather radical position on the rights of war against minors. Simply put, Hojer argued that neither the physical constitution nor the civic status as child, minor or adult within a state was relevant when it came to interstate relations and the rights of war. Rather, what was relevant was, in the case of rulers, the moral persona they carried as office-bearers (sovereigns) in their states, and, in the case of private persons, their moral persona as subjects of an enemy state and even their status as full enemies if engaged in hostile acts.

Hojer began by clarifying the characteristics of the natural state as opposed to the civil state. Following again the Pufendorfian position, he defined the natural state as one obtaining between free and equal persons. As such, the rights and duties of persons in a state of nature concerned only the conservation and preservation of themselves and their goods. From this it followed that there could be no minority status in the natural state, for minority entailed a relationship of dependence, and this would mean entering into a 'relationship either familial or civil, which would take the place of the earlier state of liberty'. In their mutual relations, rulers and states were precisely 'moral persons' in the natural state, enjoying the liberty, rights and duties constituting this state. The conclusion was, therefore, that such a moral person could not be considered a minor. 'Again, concerning complete societies and their rulers it is beyond any doubt that, although a king or a prince himself is a minor, considered together with his state and as its head, he cannot be considered by other free states as a minor. ${ }^{4}$

Having recounted a number of historical examples confirming his argument, Hojer went on to argue that the natural state's 'ignorance of minority' was even greater in case of war, so that the rights of war could show no respect for whatever minority status a person might have in their own state. Rather, 'disregarding any difference of age or authority, whoever is an enemy may be

$47 \quad$ Ibid., 15.

48 'De integris Societatibus earumque Rectoribus adhuc magis est indubium, quantumuis Rex aut Princeps ipse sit Minor, eum tamen vt caput suæ reipublicæ vna cum illa spectatum non posse ab aliis liberis statibus pro Minori haberi.' Ibid., 16. 
pursued by right of war. ${ }^{49}$ The rights of war were determined by the justice and intention of the party waging war. Whoever was waging a just war could rightfully do whatever was necessary to obtain the end of the war and the security of their own state. 'In short, whatever our safety or public security demands, or whatever can hasten peace or make it more constant and stable, all that not only may but even should be done by right of war to the enemy, even if a minor. 50

The only exception Hojer was willing to make was that of infants, 'who in no way can inflict harm'. Other than that, the only relevant distinction was according to the 'status' of the enemy, that is, whether he was a subject or a ruler. ${ }^{51}$ Accordingly, Hojer went on to discuss the rights of war against those two different classes of enemies. It is beyond the scope of this chapter to follow Hojer's argumentation in all details in this regard. Suffice it to say that he allowed fairly widespread licence to rob, abduct or kill even unarmed enemy subjects insofar as they could assist the enemy's war effort, or if it was a 'war of extinction', which Hojer held to be a legitimate form of war. ${ }^{52}$ Thus Hojer argued with Caspar Ziegler against Grotius that a 'right of retaliation' was justified not only against the person who had transgressed, but against his whole people or state as members of a 'moral person. ${ }^{53}$ Armed minors were simply to be considered enemies: 'here we should consider arms and the intention to harm us, not age. ${ }^{44}$ In short, 'a person is an enemy when he can rightly be considered to be in the position of an enemy, regardless of age [ ... ]. He who assists the army of the enemy with arms, military works or advice, or who causes us injury, cannot be considered a minor. 55

Turning to the case of a minor prince, Hojer reiterated the fundamentals of the universal right of war. He argued, first, that 'the natural state of equal liberty, the rights of which princes exercise among themselves, does not know minority or its benefits'; second, that, in war, whoever intends and is able to

49 'Adeoque ante omnia notandum est, Ius belli nullum nec habere nec admittere respectum Minorum, sed absque ullo vel aetatis vel auctoritatis discrimine, quotquot inter hostes sunt, iure belli persequi.' Ibid., 17 .

50 'quicquid vel salus nostra vel publica securitas postulat, aut ad pacem vel accelerandam vel eo constantius stabiliendam facere potest, id omne ex belli iure in hostem vtut Minorem recte \& absque iniuria fieri non potest modo, sed debet etiam;' ibid., 18.

51 Ibid., 19.

52 Ibid., 20.

53 Ibid., 21.

54 'Arma hic \& nobis nocendi animus spectandus est, non anni.' Ibid., 22.

55 'Hostis qui est, hostis loco recte habetur, in quacunque sit aetate [...] Minor denique non habetur, qui hostium exercitium vel armis, vel militari opera vel conciliis firmat, aut nobis damna infert.' Ibid., 23. 
harm another should not be considered a minor but 'a perfect enemy'; and finally, that as far as actions are concerned which affect other rulers, 'a ruler, as the head of his state and considered one moral body together with it, should always be considered of age (maior), as acting by his own right and wholly master of his own affairs, even if everything - in domestic and foreign affairs is carried out in his name by guardians or administrators'. ${ }^{56}$

This position, Hojer argued, could not be denied without destroying all the principles of natural jurisprudence, as well as 'its end and foundation, the peace of the human race. ${ }^{57}$ Hojer emphasized that this was evident particularly from the characteristics of the natural state, but he also proceeded to prove his case, as had Amthor, from the necessity of ensuring order and safety in international affairs. If a prince or his successors could not be held responsible for what had happened during his minority, he would be able to act with impunity and no neighbours could be safe. ${ }^{58}$ This would endanger the security not only of neighbouring states but also of the minor prince himself and his state, as the neighbours would seek to remove him from the throne in the interest of their own security. 59

Continuing to discuss the more specific rights of war against a minor prince, Hojer once again emphasized that such rights and obligations pertained not just to the prince but to the whole moral person of the state. ${ }^{60}$ No doubt with a view to the contemporary situation, Hojer argued that one could justifiably take into possession, exact tribute from and otherwise ravage the 'dominions and lands' of a prince who waged war against oneself, insofar as this was demanded by the reasons of war. ${ }^{61}$ Such rights of war also resulted, Hojer argued, from a prince aiding one's enemy even if this fell short of actual outright aggression. This was of course precisely what Charles Frederick had done by giving Stenbock's army shelter in Tønning. In this case, Hojer cited Grotius's quotation from Agathias that 'he is an Enemy who does what pleases an Enemy'.62 Against the objection that it would be more virtuous to conserve a minor prince, and restore his lands after hostilities had ended than to ruin him completely, Hojer answered

56 'Principem ut caput suae reipublicae \& unum cum illa corpus morale spectatum, in actibus, qui alios status aut Principes attingunt, semper haberi pro Maiore; qui sui iuris, suarumque rerum plenus sit arbiter, etiamsi omnia domi forisque ipsius nomine a Tutoribus aut administris gerantur.' Ibid., 24.

57 Ibid.

58 Ibid., 25 .

59 Ibid., 3 of.

$60 \quad$ Ibid., 35 .

61 Ibid., 37.

62 Ibid., 39. I am here citing from the English translation in Hugo Grotius, The Rights of War and Peace, ed. Richard Tuck (Indianapolis, IN: Liberty Fund, 2005), book III, chap. 17, §3. 
that these were considerations of virtue and political prudence, not of justice or natural law. Natural law demanded that a state look to its own security also in the future, and in fact both virtue and prudence dictated that one should deprive an enemy of weapons and lands by which he could do one harm. ${ }^{63}$

Hojer concluded his inaugural dissertation by turning to the question of whether the rights of the victor resulted solely from the consent of the vanquished. This was again implicitly addressing the contemporary situation, for, as we saw, Charles Frederick had refused to consent to both the peace treaty of Frederiksborg and the settlement brokered by Russia and Vienna and thereby Danish dominion over his former possessions in Schleswig. According to Hojer, 'the victor enjoys the rights of victory and retains what he has justly occupied, even if the minor objects'.64 Hojer explicitly disagreed here with Pufendorf and Hobbes, according to whom the rights of the victor resulted only from 'a pact with the defeated' who submitted to the will of the victors. Instead, he argued with Johann Friedrich Horn, G.G. Titius and C.G. Schwarz that by 'the victory itself' and the law of nature 'arise supreme rule' over the vanquished and the occupied things, 'apart from any preceding pact'.65 This is because otherwise there would be no end to war, or war would be renewed on the pretext that consent had not been truly given, which would be contrary to the natural right of war. In fact, Hojer presented Pufendorf as having come to much the same conclusion, quoting a longer passage from $D e$ officio hominis et civis, where it was argued that a party engaging in war was held to have 'tacitly consented' in whatever condition the war resulted in. ${ }^{66}$ All that therefore remained according to the law of nature was that the victor ensured his security and satisfaction, retaining as far as necessary the goods, lands and dominions of the enemy, defending and fortifying them to prevent further hostilities. That is: the Danish king should retain his possessions in Schleswig to pre-empt further danger arising from Charles Frederick allying with Sweden.

\section{$7 \quad$ Conclusion: a Radical Pufendorfian in the Service of Denmark-Norway}

On the basis of the preceding discussion and by way of concluding, we are now in a better position to address two questions. First, why was a professorship in

\footnotetext{
63 Hojer, De eo quod iure belli licet in minores, 41-43.

64 'fruitur tamen victor iure victoriae, \& retinet, quae iuste occupavit, etiam reclamante Minore'. Ibid., 44.

65 Ibid. Reading 'naturae' for 'natura'.

66 Ibid., 45 .
} 
natural law and the law of nations created at Copenhagen University and why was Hojer appointed? Second, why did Hojer choose for his inaugural dissertation the topic he did, and what does that tell us about his natural law profile?

Although the professorship in natural law and the law of nations was created with the new university statutes of 1732 and filled with the appointment of Hojer in 1734, there had been ongoing concerns with improving the teaching of that discipline for decades. There was thus a clear sense of the need to offer this new and popular subject to students in Denmark. What Hojer's career and remarks emphasize is that an expertise in the subject was a political necessity. The Danish monarchs Christian V (grandfather of Christian vI) and Frederick IV needed to draw on experts in the field to justify their political interests domestically and abroad, particularly against Sweden and the dukes of Gottorp, but also vis-à-vis Hamburg and the German Empire more broadly.

Both of these needs could only have been accentuated by the Gottorp university in Kiel. Although the university of a very minor power, it was both geographically and, in many ways, intellectually closer than Copenhagen to the new developments in Germany. It had been one of the first universities to create a chair in natural law, which had been held by Samuel Rachel, who had used this expertise to defend Gottorp interests against the Danish kings in the later seventeenth century. Denmark-Norway simply lacked a comparable academic tradition and expertise, and accordingly had to draw on foreigners to supply this: that both Weghorst and Amthor were called from Kiel should not be explained only by its geographical proximity.

It would seem that both these concerns were present in creating the new chair in natural law. That Hojer was appointed to the position has been credited to his activities and writings on behalf of Danish interests in a conflict with the city of Hamburg over its refusal to accept Danish currency. ${ }^{67}$ Hojer's eagerness to demonstrate the political utility of his expertise in natural law is evident from the topics he suggested for the dissertation. The topic of the rights of war against minors allowed Hojer to address both concerns. First, it held immediate relevance as the Danish dominion over Schleswig became a matter of discussion in the Polish War of Succession. Second, it was also the subject most suited to demonstrate his expertise in the field. It was the only topic that he himself characterized as pertaining to 'the law of nature and nations', the others being topics of 'ius publicum' ${ }^{68}$

67 Rørdam, Historiske Samlinger og Studier, IV: 135f., see also III: 516; Jørgensen, Andreas Hojer, jurist og historiker, 143. 
As we have seen, Hojer drew fully on the Pufendorfian conceptual framework of moral personae, and what has been termed Pufendorf's conventionalist conception of natural law and morality. This indicates his personal interest in taking up the topic, as well as the distinctive characteristics of his natural law profile within the larger context of natural law theorizing and enlightenment thought in early-eighteenth-century Denmark-Norway. Hojer seems to have been particularly interested in the conventionalist theory of morality and politics suggested by Pufendorf's theory of natural law, as well as its potential to fundamentally undermine contemporary 'naturalist' conceptions of morality. ${ }^{69}$ During his studies in Halle, Hojer seems to have adopted Thomasius's interest in criticizing this naturalistic theory of morality, which Thomasius had characterized as the scholastic doctrine of perseitas, as well as an interest in pushing the Pufendorfian conceptual framework to its limits. In his dissertation on the rights of war against minors, and particularly in his work on the non-prohibition of incestuous marriages, Hojer was developing this agenda, reaching conclusions that, while perhaps serviceable to Denmark's absolute monarchs, went far beyond the moral commonplaces of his day, and even ours. ${ }^{70}$ That he could do so and still hold such influential positions in earlyeighteenth-century Denmark is arguably what makes Hojer such an interesting figure and the question of his significance for the early enlightenment in Denmark so pressing.

\section{Bibliography}

Amthor, Christoph Heinrich, In Iure Et Facto Gegründeter Beweis der vielfältigen Treulosigkeiten, So das Jetzt-regierende Allerdurchlauchtigste Königl. Dähnische Haus von dem Fürstl. Holstein-Gottorfischen bisher erlitten / Worin ... ausführlich gezeiget wird, Daß das Hertzogthum Schleswig durch offenbahre Rebellionen ... von der Krohne Dennemarck zum erstenmahl abgerissen, hernach durch gleich wenig zugelassene Felonien ... zur Souveraineté erhaben ... (Kopenhagen: n.n., 1715).

Amthor, Christoph Heinrich, Philosophia moralis seu doctrina de justo, honesto et decoro. Hierbey iststatteiner Vorredevorangesetzet Authoris unvorgreiffliche Gedancken

69 For a characterization of Pufendorf's natural law theory in this regard in the context of discussing Holberg, see Haakonssen, 'Holberg's Law of Nature and Nations,' 68-71.

70 An influential proponent of the scholastic doctrine of 'perseitas' in Denmark around 1700 was Henrik Weghorst, for which see Jensen, 'Contests about Natural Law in Early Enlightenment Copenhagen.' For Holberg's criticism of Hojer's Diagramma on much more conventional grounds, see Haakonssen, 'Holberg's Law of Nature and Nations,' 71. 
von der beqvemsten Methode, deren sich ein academischer Lehrer bedienen kan (Hafniae, Lipsiae: Joh. Nicol. Lossius, 1738).

[Anonymous], Succincte Deduction daß Seine König Majest von Dennemark des HochFürst. Hauses Holstein-Gottorp Aggressor seyn, (N.p.: n.n. 1714).

[Anonymous], In Facto Gegründete umbständliche Nachricht, Wie Der Königl. Dänische Hoff Des Fürstl. Holstein-Gottorpischen Hauses Untergang und Ruin beständig gesuchet, auch aus einer solchen absicht weder Verträge, noch Friedensschlüsse jemahln gehalten ... / Auff Gnädigsten Befehl publiciret Im Jahr 1714, (N.p.: n.n. 1714).

[Anonymous], Wahrhafter Abdruck Des In Händen habenden Original-Tractats nebst den Separat-Articuln / So Zwischen dem Fürstl. Hauße Gottorff und Dem Königl. Schwedischen Raht und Feld-Marschall Graffen von Steenbock unterm 2iten Januarii Anno 1713. im Rahmen Sr. Königl. Mayst. von Schweden getroffen und geschlossen worden, umb Dadurch, ... das Gegen Ihre Königl. Majest. zu Dennemarck, Norwegen [et]c. und Dero Alliirte von Dem Fürstlichen Hauße Gottorff begangenes treuloses und wieder alle Conventiones und Verträge, unverantwortliches und Friedbrüchiges Verfahren der gantzen unpartheischen Welt an den Tag zu legen (Kopenhagen: Königl. Maj. und Univ. privilegirten Buchdr., 1714).

Brandt, Otto, Caspar von Saldern und die nordeuropäische Politik im Zeitalter Katharinas II., etc. (Erlangen; Kiel: Palm \& Enke; Walter G. Mühlau, 1932).

Bricka, Carl Frederik, ed., Dansk biografisk Lexikon tillige omfattende Norge for Tidsrummet 1537-1814 (Kjøbenhavn: Gyldendalske Boghandels Forlag, 1887), available online at http://runeberg.org/dbl/.

Eskildsen, Kasper Risbjerg, 'Print, Fashion, and the Making of the Enlightenment Philosopher,' in Northern Antiquities and National Identities. Perceptions of Denmark and the North in the Eighteenth Century, ed. Knud Haakonssen and Henrik Horstbøl (København: Det Kongelige Danske Videnskabernes Selskab, 2008), 126-144.

Haakonssen, Knud and Olden-Jørgensen, Sebastian, eds., Ludvig Holberg (1684-1754): Learning and Literature in the Nordic Enlightenment (London and New York: Routledge, 2017).

Hojer, Andreas, De nuptiis propinquorum iure divino non prohibitis [ ... ] diagramma (n.p.: n.n., 1718).

Hojer, Andreas, Kurtzgefasste Dännemärckische Geschichte vom Anfang dieses mächtigen Reichs bis zum Ausgang des XVII. Seculi (Flensburg: Bosseck, 1719).

Hojer, Andreas, Dissertatio iuris publici universalis de eo quod iure belli licet in minores, Vom Recht des Krieges gegen die Minderjährige (Hafniae: Typis Reg. Majest. \& Universit. Typogr. Joh. G. Höpffneri, 1735).

Hojer, Andreas, Ideae Icti Danici partem 1. disputatione anniversaria expositam publico eruditorum examini subiciit Andreas Hoier (Hafniae: Typis Reg. Majest. \& Universit. Typogr. Joh. G. Höpffneri, 1736). 
Hojer, Andreas, Forestilling paa en Dansk Jurist, den 1. Part (Kjøbenhavn: Kongl. Majests. priviligerede Bogtrykkerie, 1737).

Hojer, Andreas, König Friederich des Vierten glorwürdigstes Leben, 2 vols. (Tondern: Gedruckt in der Königl. priviligierten Buchdruckerey der Wittwe Forchhammer, 1829).

Holm, Edvard, Danmark-Norges Historie fra den store nordiske Krigs Slutning til Rigernes Adskillelse, 1720-1814, 7 vols. (Kjøbenhavn: Gad, 1891-1912).

Jensen, Mads Langballe, 'Contests about Natural Law in Early Enlightenment Copenhagen,' History of European Ideas 42 (2016): 1027-1041.

Jørgensen, Troels G., Andreas Hojer, jurist og historiker (København: Arne FrostHansens Forlag, 1961).

Klemme, Heiner F. and Kuehn, Manfred, eds., Dictionary of Eighteenth-Century German Philosophers (London: Continuum, 2010).

Lectiones publicae Professorum in Universitate Hauniensi (Hafniae: Ex Typographeo Regiae Majest. \& Universit., 1604-1786).

Lockhart, Paul Douglas, Denmark, 1513-166o: The Rise and Decline of a Renaissance Monarchy (Oxford: Oxford University Press, 2007).

Matzen, Henning, Kjøbenhavns universitets retshistorie 1479-1879 (Kjøbenhavn: H. Schultz, 1879).

Norvin, William, Københavns Universitet $i$ Reformationens og Orthodoxiens Tidsalder, 2 vols. (København: Gyldendal, 1937-1940).

Piirimäe, Pärtel, 'The Capitulations of 1710 in the Context of Peter the Great's Foreign Propaganda,' in Die baltischen Kapitulationen von 1710: Kontext - Wirkungen - Interpretationen, eds. Karsten Brüggemann, Mati Laur, and Pärtel Piirimäe (Köln: Böhlau Verlag, 2014), 65-86.

Rørdam, Hoger, ed., Historiske Samlinger og Studier vedrørende danske Forhold og Studier iscer i det 17. Aarhundrede, 4 vols. (Kjøbenhavn: Gad, 1891-1902).

Sejersted, Jørgen and Vinje, Eiliv, eds., Ludvig Holbergs naturret (Oslo: Gyldendal Akademisk, 2012).

Tamm, Ditlev, Juraen på Københavns Universitet 1479-2005 (København: Københavns Universitet, 2005).

Toyoda, Tetsuya, Theory and Politics of the Law of Nations: Political Bias in International Law Discourse of Seven German Court Councilors in the Seventeenth and Eighteenth Centuries (Leiden, Boston, MA: Martinus Nijhoff Publishers, 2011).

Weghorst, Henrik, Compendii juris naturce, Dissertatio prima (Hafniae: Joachim Smetgen, 1696). 


\title{
The Law of Nations at the Naval Academy in Copenhagen around 180o: the Lectures of Christian Krohg
}

\author{
Thor Inge Rørvik
}

Recent scholarship has no doubt contributed to a better understanding of the law of nature and nations by no longer regarding it exclusively as a topic developed in a limited number of classical works forming a single identifiable tradition, and, further, by identifying it as a subject of academic teaching established in the late seventeenth century and ending well into the nineteenth. As a consequence, the law of nature and nations should not only be measured by its theoretical coherence or originality, but also be understood by the way it was received, appropriated and transmitted in various institutional, legal and political contexts. Moving forward from this angle, it is, however, important to realize that we still know comparatively little about the workings of this tradition of moral and legal thinking and that we - in order to gain a better understanding of the matter - will need a more comprehensive mapping of the territory. The scope of this chapter is to contribute to such a mapping, by introducing a Danish-Norwegian textbook that has remained virtually unknown until today. The book in question is Forsøg til en Ledetraad ved Forelesninger over Folke-Retten (An Attempted Guide to Lectures on the Law of Nations), published in Copenhagen in 1803; its author is Christian Krohg (1777-1828) and the lectures on which the textbook is based were held at the Royal Danish Naval Academy in 1801 and 1802.

To introduce a textbook is, in many ways, a different enterprise from presenting an innovative theoretical work where one can highlight its contribution to an ongoing debate or focus on the way it makes established ways of thinking obsolete. A textbook will always remain anchored in a tradition that must be accounted for in order to understand its content. Before turning its attention to Krohg's lectures, this chapter will therefore begin with an attempt to sketch a contextual background against which they must be understood. Two contexts are particularly important here:1) the way the law of nations was treated as an academic subject at the University of Copenhagen; and 2) the 
emergence of a different understanding of the subject in the 179os that put its mark on a generation of Danish-Norwegian jurists.

Three years after entering the University of Copenhagen as a student, Christian Krohg passed the final degree examination in the faculty of law in 1797 . He belonged to a circle of talented jurists who in the years to come would find themselves in important positions, both within and outside of the academic world. Inspired by their teacher, Professor Johan Friedrich Wilhelm Schlegel (1765-1836), the circle held the Kantian philosophy of law in high esteem, both as a key to the relation between moral philosophy and law and as a foundation upon which a scientific legal edifice should build. But despite his veneration of Kant, Schlegel had in his textbook on natural law refuted the idea of a distinct Weltbürgerrecht (cosmopolitan law), because this topic should be treated as a part of public law or the law of nations. ${ }^{1}$ That Schlegel was too much of a jurist to fall prey to what he believed to be philosophical chimeras is also evident in the way he outlines in his textbook the principles of the natural law of nations before moving on to what he referred to as the positive law of nations. This sub-discipline did not quite fit into his larger system, but he had included it because it was an important issue and no presentation of it was yet available to a Danish-Norwegian audience. Schlegel hoped that this amendment to what had hitherto been considered a sufficient outline of the law of nations would be appreciated, even if it involved a different way of looking at things and put new demands on the way a textbook should be written.

As a historical science the positive law of nations relies on facts. It is therefore necessary to provide the reader with references to where further information can be found concerning the different topics in question, whereas this is not necessary in the other parts of the book which deal with the exposition of truths of reason. ${ }^{2}$

If one looks at his predecessors' lectures, Schlegel was no doubt right to regard the positive law of nations as a neglected topic. And the reason was obvious.

1 J.W.F. Schlegel, Naturrettens eller den almindelige Retslares Grundscetninger (Copenhagen: Johan Frederik Schulz, 1798), I, 20 and II, 321.

2 Ibid., II, preamble (not paginated). Translations from Danish original works here and below are by the present author. 
The university statutes of 1732 and the regulations of the formal examination for a degree in law, introduced in 1736, stated that students aspiring to the higher level of the grading scale (laudabilis or haud illaudabillis) should account for the principles of the law of nature and nations. The textbooks in use were, however, more or less Pufendorfian, and according to Pufendorf the law of nations 'is nothing other than the law of nature, insofar as different nations, not united with another by a supreme sovereignty, observe it, who must render one another the same duties in their fashion, as are prescribed for individuals by the law of nature.' ${ }^{3}$ Regarding the law of nature as the guiding principle also in matters of interstate relations, Pufendorf found it unnecessary to conduct a special treatment of the law of nations, because what he had already said about the law of nature and the duties of individuals could be applied either to whole states or to nations, which he considered to be moral persons. In the textbooks used at the University of Copenhagen until the middle of the eighteenth century, the law of nations was therefore treated only briefly, in connection with war and peace, alliances (treaties), and the holiness of envoys. ${ }^{4}$

The first attempt to give a comprehensive introduction to the law of nations and point out its place in the theoretical edifice of the law of nature came in a Wolffian textbook in 1776. According to its author, Professor Lauritz Nørregaard $\left(1745^{-1804)}\right.$, the law of nations was a part of jus naturae sociale - i.e. the natural law which deduces the rights and duties characterizing different social organizations. Because these organizations are either small (the household) or big (the state), jus naturae sociale must be divided into 1) jus naturae oeconomicum sive familiarum and 2) jus naturae politicum sive jus universale civitatum. The duties and rights imposed upon a state are either such that they concern only the state itself or they signify its rights and duties towards other states. In the first case they are a part of jus naturae politicum sic dictum; in the second they belong to jus gentium. ${ }^{5}$

3 Samuel Pufendorf, Elementorum Iurisprudentiae Universalis Libri Duo (166o), book I, chap. XIII, § 24. Here quoted from the English translation by W.A. Oldfather: Two Books of the Elements of Universal Jurisprudence, ed. Thomas Behme (Indianapolis, IN: Liberty Fund, 2009), 225. See also De jure naturae et gentium (1672), book II, chap. III, § 23.

4 The textbooks were Ludvig Holberg, Introduction til Naturens- og Folke-Rettens Kundskab (Copenhagen: Johan Kruse, 1716) and a Danish translation of De officiis hominis et civis made in 1735. See Knud Haakonssen, 'Holberg's Law of Nature and Nations,' in Ludvig Holberg (1684-1754). Learning and Literature in the Nordic Enlightenment, ed. Knud Haakonssen and Sebastian Olden-Jørgensen (London and New York: Routledge, 2017), 59-79.

5 Lauritz Nørregaard, Natur-Rettens første Grunde, 2nd ed. (Copenhagen: Gyldendals Forlag, 1784), §§ 164-167. 
Presented as a part of the system of natural law, the law of nations continued to be assessed with regard to the system's founding certainties. Throughout the eighteenth century, Danish-Norwegian jurists understood this system as a framework that could not itself be captured in legal terms and as a tacit philosophical foundation of contemporary legislation. In a more practical sense it was also considered to be a supplementary legal system. According to Nørregaard, natural law 'was the only subsidiary law that one can and should follow', and Schegel later stated that 'all positive laws should be founded on natural law, and where these are either silent or ambiguous, the jurists must take recourse to natural law as a jus subsidiarum.6 According to the university statutes of 1732 , the professor responsible for lecturing on Danish-Norwegian law had to demonstrate how this law 'complied with the law of nature and nations'. The purpose of this demonstration was to show that the absolutist state's legislation was in accordance with moral maxims and hence an expression of the dictates of reason. In the absence of an international legal system, the law of nations could not serve as a benchmark in the same sense as other parts of natural law. What it could do was provide general guidelines for wise statecraft and the handling of international relations. But the way the law of nations was taught at the University of Copenhagen until the late 179os simply ruled out the idea that it could be anything more than a part of a larger system. The idea of a discipline that took current international arrangements as its vantage point and also realized that binding agreements could modify the general maxims of natural law was never presented to the students. The professors on their part could hardly have been unfamiliar with this idea, because it was put forth in the works of Hugo Grotius and Emer de Vattel.

In the prolegomena to his great work, Grotius declared that as the laws of each state respected the benefits of the state, 'so amongst all or most States there might be, and in Fact there are, some Laws agreed on by common Consent, which respect the Advantage not of one Body in particular, but of all in general. And this is what is called the Law of Nations. ${ }^{7}$ The difference between natural law and the law of nations amounted to more than the fact that the first was a just inference from the principles of nature whereas the second originated in a universal consent, because 'that which cannot be deduced from certain Principles by just Consequences, and yet appears to be everywhere observed, must owe its rise to a free and arbitrary Will!: ${ }^{8}$ Grotius here identified

6 Ibid., § 158; see also Schlegel, Naturrettens, § 15 .

7 Hugo Grotius, De jure belli ac pacis (1652), Prolegomena, 18, 41. Here quoted after the English translation from the edition of Jean Barbeyrac, ed. by Richard Tuck: The Rights of War and Peace (Indianapolis, IN: Liberty Fund, 2005), 96.

8 Ibid., 112. 
the law of nations as an existing body of law that, on the one hand, differed from jus naturae by being a result of the human will, and, on the other hand, differed from civil law by not being enforceable by a court. By regarding the law of nations as more flexible or adaptable to local conditions than the universal timeless principles of natural right, Grotius had thus admitted state interests into the picture. ${ }^{9}$ Although Vattel wrote his major work under different historical conditions and with other problems in mind, there is a similarity between the Grotian understanding of jus gentium and Vattel's distinction between the necessary law of nations and the positive law of nations, consisting of a voluntary, conventional and customary law. What distinguished the positive law from the necessary was the fact that the three kinds of law of which it consisted 'proceed from the will of nations, - the voluntary from their presumed consent, the conventional from an express consent, and the customary from tacit consent'.10 What characterized the voluntary law was that, despite being a part of the positive law of nations, it was, like the necessary law of nations, established by nature, but in a different manner. The necessary law is 'a sacred law which nations and sovereigns are bound to respect and follow in all their actions', while the voluntary law is 'a rule which the general welfare and safety oblige them to admit in their transactions with each other'11 And whereas the necessary law is based on the natural principle of self-perfection, the voluntary law accounts for what nations need to tolerate by necessity in order to avoid greater evils. In the hands of Vattel, the law of nations became what Grotius had suggested when submitting it to a free and arbitrary will, that is, more an issue of political prudence than a part of the system of natural law..$^{12}$ In interstate relations there

For a more thorough account of this point, see Ian Hunter: 'The Law of Nature and Nations,' in The Routledge Companion to Eighteenth Century Philosophy, ed. Aaron Garrett (London and New York: Routledge, 2014), 578; see also Stephen C. Neff, War and the Law of Nations. A General History (Cambridge: Cambridge University Press, 2005), 96-102.

10 Emer de Vattel, Le droit des gens (1758), preface (not paginated). Here quoted from the anonymous English translation of 1797, ed. Béla Kapossy and Richard Whatmore, The Law of Nations (Indianapolis, IN: Liberty Fund, 2008), 78.

11 Vattel, The Law of Nations, 14, 17. Regarding the voluntary law of nations, see also Simone Zurbuchen: 'Emer de Vattel on the Society of Nations and the Political System of Europe,' in System, Order, and International Law, ed. Stefan Kadelbach, Thomas Kleinlein and David Roth-Isigkeit (Oxford: Oxford University Press, 2017), 263-282.

12 This transition from Grotius to Vattel is outlined in Koen Stapelbroek, 'Universal Society, Commerce and the Rights of Neutral Trade,' in Universalism in International Law and Political Philosophy, ed. Petter Korkman and Virpi Mäkinen (Helsinki: Helsinki Collegium for Advanced Studies, 2008), 63-89, here 77-78. See also Ian Hunter, 'Vattel's Law of Nations: Diplomatic Casuistry for the Protestant Nation,' Grotiana 31 (2010), 108-140, and T.J. Hochstrasser, Natural Law Theories in the Early Enlightenment (Cambridge: Cambridge University Press, 2000), 180-182. 
are no higher principles of justice, only the conscience of a sovereign ruler well aware that in matters concerning the prosperity of the state he is the sole arbitrator.

This can explain the lack of references to Grotius or Vattel in the DanishNorwegian tradition until Schlegel introduced the positive law of nations in the 179os. By turning jus gentium into a matter of political statecraft or diplomatic casuistry, they had made it unfit as a topic for university lectures. But as long as these lectures were based on the conviction that the law of nations was part of natural law, it was possible to maintain a necessary distance to the arcana imperii. It is also worth noticing that until the end of the century lectures on the law of nations did not present it as an independent topic, but always in conjunction with jus publicum. ${ }^{13}$ This was the discipline where different kinds of governmental potestas were treated, including the right and power to engage in matters external to the state, which was part of potestas executoria - as were also jus foederum publicorum and jus belli et pacis. ${ }^{14}$ In its general form, jus publicum was supposed to show how things ought to be, regardless of how they actually were. In an introduction to the study of law, Professor Peder Kofod Ancher (1710-1788) bluntly denied the existence of a jus publicum particulare pertaining to Denmark-Norway, because the limitations that the Royal Law of 1665 put on the sovereign power were not sufficient to form a separate juridical discipline; and the purpose of it all would only be to show the absolutist state's 'proper nature and its correspondence with the principles of general public law'. ${ }^{15}$ However, with the publication of a series of lectures on jus publicum by the late Professor Andreas Hojer (169o-1739), something akin to what Kofod Ancher found unnecessary actually turned up. According to Hojer, an understanding of the Danish-Norwegian constitution required knowledge not only of law, but also of geography, pragmatic history and genealogy as well as knowledge of the alliances that throughout history had been made with other governments. Two topics treated by Hojer were the Sound dues at Øresund and Denmark's jus dominium over the Baltic Sea. The right to the dues rested on '[t]he consent of all sea powers, that is: Holland, France, England, Spain' and 'the Danish King's willingness and ability to defend vessels passing through the

13 The last series of lectures on jus publicum and the law of nations joined together was held at the University of Copenhagen in the winter of 1795-1796 by professor C.U.D. von Eggers (1758-1813). The lectures were published under the title Institutiones juris civitatis publici et gentium universalis (Copenhagen: Proft et Storch, 1796).

14 Ibid., $\$$ 98-111.

15 Peder Kofod Ancher, Anviisning for en Dansk Jurist angaaende Lovkyndigheds adskillige Deele, Nytte og Hielpemidler, 2nd ed. (Copenhagen: Ludolpf Henrich Lille, 1777), 20. 
Sound against pirates'. The jus dominium over the Baltic Sea was likewise due to the successful fight against pirates, which had made other sovereign powers recognize Denmark as the Baltic Sea's 'defender and master.' ${ }^{16}$

What Hojer covered here was not current international law; it was still a part of jus publicum and the practice of wise government. Apart from the king's duty to promote salus populi in accordance with proper rules, there was still no autonomous international legal system in existence and no legal sources independent of what the king himself regarded as a reasonable way to exercise his sovereignty. Nevertheless, it was the results of such exercises - i.e. treaties and interstate agreements, or more precisely, conventional and customary law that eventually became the backbone of the positive law of nations. Whereas the foundation of the discipline was the conviction that the practice of diplomacy was also an important part of the law of nations, as Vattel had suggested, its content was the compilation of the newest European state practice, which, from the 1770 os on, had been a part of German Staatsrecht. ${ }^{17}$ Christian Ulrich Detlev Von Eggers still anchored his lectures on jus publicum and the law of nations in the traditional frame of natural right, but when he explained the different kinds of potestas he pointed to the Allgemeines Gesetzbuch für die Preußischen Staaten (1792). In his presentation of the positive law of nations, Schlegel augmented the German connection by numerous references to Johann Jakob Moser (1701-1787), Karl Gottlob Günther (1752-1832) and Georg Friedrich von Martens (1756-1821). In the textbook he later wrote as a guide to his lectures at the Naval Academy, Christian Krohg took the matter one step further by including excerpts from treaties and agreements in order to explain what the positive law of nations was all about.

\section{Towards a New Understanding of the Law of Nations}

The late 179os witnessed a growing interest in the law of nations at the University of Copenhagen. Whereas the decade had begun with the introduction of Kant's moral and legal philosophy, attention now turned to issues concerning international relations. This change of focus was, no doubt, due to the outbreak

16 Andreas Hojer, Jus Publicum det er Stats-Ret eller Statsforfatning og Rettigheder for Danmark, Norge og Fyrstendommene forklaret ved private Forelcesninger eller Kollegio (Christiania: Jens Ørbek Berg, 1783), 9-12.

17 Martti Koskenniemi, 'Into positivism: Georg Friedrich von Martens (1756-1821) and Modern International Law,' Constellations 15 (2008): 190-191, and 'The Advantage of Treaties: International Law in the Enlightenment,' Edinburgh Law Review 13 (2009):27-67. 
of the French Revolutionary Wars and the events leading to the founding of the Second League of Armed Neutrality in 1800 . The problems now confronting the jurists were a matter of public interest in the same way that the hotly debated Kantian philosophy had been. But whereas this debate had gained momentum because the philosophy in question challenged an established intellectual culture, international matters were strictly legal and political. The most important agent of this change of focus was Professor Schlegel. As editor of the leading legal periodical Astrcea, he filled its pages with issues of legal philosophy until 1799, when an increase in space given over to matters concerning the law of nations became noticeable. ${ }^{18}$ And although his textbook on natural law was at the outset an attempt to found the scientific legal edifice on philosophical principles, he had ended it with an introduction to the positive law of nations - a discipline that was not only unknown to the broader public, but also at odds with the philosophical principles he had introduced at the beginning of the book. But Schlegel was not alone in his quest for a new understanding of the law of nations in Denmark-Norway.

In the summer of 1796 the University's faculty of law announced that it would offer, for the first time, lectures on the law of nations, without mentioning jus publicum. That these lectures were not delivered by any of the faculty's professors, but by the adjunct Frederik Theodor Hurtigkarl (1763-1829), might suggest that the subject was not considered too important. It was not among the main subjects at the students' final exam, and it was, rather, Danish law, Roman law and jus publicum that primarily occupied the professors as part of their official duties in a faculty that remained understaffed. It was therefore decided that the adjunct at the faculty of law should no longer be occupied with only administrative tasks, but also lecture. The position of adjunct thus became a recruitment position at a time when the doctoral degree was still reserved for those who already belonged to the upper echelons of the civil service. Between 1798 and 1800 three new adjuncts were employed; two of them, Christian Krohg and Mathias Hastrup Bornemann (1776-1849), were later appointed as extraordinary professors. All applicants for the position of adjunct had to undergo a series of trial lectures and several of these were later published. In 1798 the applicants had to explain the concepts of right and duty and the means at their disposal was the Kantian philosophy. In 1799 they had to answer the following question: 'What is the holiness of envoys - and what is its extent according to both the natural and the customary law of nations?'

18 Dag Michalsen, 'Legislators, Journals, and the Public Legal Sphere in Scandinavia around 180o,' in Eighteenth-Century Periodicals as Agents of Change, ed. Ellen Krefting, Aina Nøding and Mona Ringvej (Leiden and Boston: Brill Academic Publishers, 2015), 207-208. 
The answer provided by the winner of the competition shows that the problem was approached from two angles. What the natural law of nations said about the matter called for a systematic presentation, with references to Grotius, Pufendorf, Wolff and Vattel. What the customary law of nations said about the matter was shown in a historical account, starting with Livy and ending close to the present. The candidate also presented some reflections on the relation between the two types of law: in comparing the customary law of nations to the natural law one should be cautious, he argued, because even if there are similarities between interstate relations and the state of nature, the former contain at least 'an analogon of juridical security'. The mixture of 'juridical wisdom, politics and coutumes' that is normally referred to as the customary law of nations is a result of sound human reasoning that could be traced back to the ancient conception of jus feciale, 'without which no dealings between nations was possible.19 There had to be a way to approximate the two parts of the law of nations. The same eagerness to dissolve problems or discrepancies through philosophical formalization was also present in Bornemann's later attempt to sketch a set of rules for the visitation of neutral vessels and the rights of convoys in wartime. Although Krohg recommended this work to his students at the Naval Academy, its content was too abstract for the practical needs of future naval officers. ${ }^{20}$

Few details are known about Krohg's appointment to adjunct in 1800; and although trial lectures were once again held, none were published. It is also far from clear why the University sent the new adjunct to lecture at the Naval Academy and not Bornemann, who had already proven himself capable of dealing with issues of the law of nations. The most probable answer is that Krohg possessed comprehensive knowledge of foreign legislation and hence, unlike Bornemann, who was inclined to abstract speculations, was considered better suited to teach at an institution where the students needed to learn how to find their way through repositories of diplomatic and treaty practice. How to provide the cadets at the Academy with the necessary skills was, however, a question that Krohg had to solve on his own, because the

19 Mathias Hastrup Bornemann, 'Prøveforelæsning over det Spørgsmaal: Hvad forståes ved Gesandteres Hellighed, og hvorvidt strækker den sig, saavel efter den naturlige som sædvanemæssige Folkeret?', Minerva (180o): IV, 36, 52, 63.

20 Mathias Hastrup Bornemann, Over den brugelige Visitation af neutrale Skibe og konvojen, og et Middel til at hœeve begge ved en almindelig og garanteret Søhandelsfolkeret (Copenhagen: Thiele, 1801), translated into German as Über die gebräuchliche Visitation der neutralen Schiffe, und über die Convoi, nebst einem Mittel, beyde durch ein allgemeines garantirtes Seehandels-Völkerrecht zu heben (Copenhagen and Leipzig: Schubothe, 1801). 
law of nations had not previously been among the teaching subjects at the institution.

The Royal Danish Naval Academy was established in 1701 and soon became the single avenue to a naval officer position in Denmark-Norway. In order to understand the role of the Academy, one must take into consideration that from the end of the Great Northern War (1721) and until the Battle of Copenhagen (1801) the Danish-Norwegian state had enjoyed a period of relative peace. ${ }^{21}$ And although the decision to introduce the law of nations at the Academy predated the recent hostilities, it was clearly called for by international political events. Thanks to its position as a neutral power, Denmark-Norway had throughout the eighteenth century expanded its commercial interests, and its merchant fleet was about to become a main European carrier. As a result, stronger demands were put on the navy to protect merchant ships from pirates or belligerent nations. This need for protection had to do with the fact that, despite a great number of legal and diplomatic attempts to solve the problem, there was no generally acknowledged practice concerning the rights of neutral vessels. ${ }^{22}$ From a Danish-Norwegian point of view, the core of the problem was the way Britain handled neutral shipping. In the 179 os the British attitude hardened, triggered by the suspicion that neutral vessels were supplying France with much-needed goods. In 1798 two Swedish convoys were arrested by the British Royal Navy in the Channel and in 1800 a Danish convoy and the naval ship guarding it were led to a British port. ${ }^{23}$ In his response to a verdict passed by the High Court of Admiralty in Britain in one of the Swedish convoy cases, Professor Schlegel defended the rights of neutrals according to what he regarded as the established principles of the law of nations. He hoped that his investigation would 'render the rights of neutral commerce more respected by the belligerent Powers, and the voice of justice in the clamour and tumult of war more intelligibly heard in cases where the whole property of industrious and peaceable citizens is

21 For an account of the Naval Academy and a comparative study of naval education in Denmark, Sweden and England, see Evan Wilson, Jacob Seerup and Anna Sara Hammar, 'The education and careers of naval officers in the long eighteenth century: an international perspective,' Journal for Maritime Research 17 (2015): 17-33.

22 Silvia Marzagalli and Leos Müller, 'In apparent disagreement with all law of nations in the world: Negotiating neutrality for shipping and trade during the French Revolution and Napoleonic Wars,' International Journal of Maritime History 28 (2016): 112.

23 Ibid., 116. See also Pierre Pourchasse, 'Danish shipping in the Mediterranean during the Revolutionary wars (1793-1795),' The International Journal of Maritime History 28 (2016): 165-179, and Ole Feldbæk, 'The Anglo-Danish Convoy Conflict of 180o: A study of small power policy and neutrality,' Scandinavian Journal of History 2 (1977): 161-182. 
probably at stake', but he doubted that the counter-party would pay heed to his arguments. ${ }^{24}$

As he did with Bornemann's treatise on visitation, Krohg also recommended Schlegel's work to his students at the Naval Academy. But whereas Bornemann's work was too abstract and philosophical, Schlegel's resembled the work of an expert, treating the relevant parts of the natural law of nations since Grotius and revealing an intimate knowledge of current treaties and agreements. Krohg's objective as teacher at the Academy had to be more modest and take into account the level of instruction already provided in subjects of a nontechnical character. The naval articles for the shore service (1756) stated that scientific knowledge was paramount for being a good officer, and the Academy had to provide the cadets with sufficient knowledge not only of tactics, navigation, gunnery and applied mathematics, but also of (modern) history and geography. According to Carl Frederik Dichmann (1763-1806), teacher of history and geography at the Academy from 1796 to 1806, the purpose of these two subjects, joined together, was to provide knowledge of the contemporary world and its historical prerequisites - geography by describing territories belonging to different states, history by outlining the origins of various territorial rights.

\section{4}

Krohg's Lectures 1: the Founding Principles

Whereas history and geography provided knowledge about the distinctiveness of modern states, Krohg started his lectures from the opposite angle, by explaining what a state or a nation is. A state is an association that individuals had entered into for protection and security and this association was also a legal state, involving enforceable rights and duties. But this legal state is internal to the state and hence not binding on other states or individuals not counted as citizens. To believe otherwise would, according to Krohg, 'in most cases contradict every independent nation's original purpose of founding the state.'25 This is not to say that interstate relations were devoid of legal regulations, only that these were different from those pronounced in a state's positive legislation. In order to understand the nature of these regulations, natural law had come to regard the state as a moral person and the relationship between states as akin to

24 J.W.F. Schlegel, An Examination of the Sentence in the Case of the Sweedish Convoy Pronounced in the High Court of Admiralty of England on the Eleventh of June, 1799 (London: W. Wilson, 1800), 115.

25 Christian Krohg, Forsøg til en Ledetraad ved Forelsninger over Folke-Retten (Copenhagen: Andreas Seidelin, 1803), § 3 . 
the relationship between individuals in the state of nature. But this application of natural law is not sufficient. Rather than being content with the commands of natural law as a guide to interstate relations, one must realize that these relations are of a more complicated character. Hence they need a more thorough treatment than what can be provided by a 'general legal science.' ${ }^{26}$

Even if nations are not living under any human superior and do not acknowledge a common legislator or regent, they are by human reason itself entitled 'by interrelated consent to decide certain rules for their actions, that as laws will bind them either forever or for a certain time and whereby their original legal relationship, established by reason itself, is more exactly determined or even changed insofar as this change does not exceed the limits that the purpose of the state and human dignity have declared to be unchangeable., ${ }^{27}$ These arbitrary provisions are the subject of the positive law of nations; and according to the different means whereby nations announce their consent, this discipline can be divided into a) the law of treaties, i.e. consent founded on real agreements, and b) the law of custom, i.e. consent founded on previously repeated actions. These were also two of the three sub-disciplines that according to Vattel made up the positive law of nations. As for the third one, the voluntary law, Krohg never uses the term nor does he seem to regard the content treated under that term as an issue of its own. It is, however, worth noticing Vattel's remark about how and why the decisions of the necessary law of nations 'must be modified by the voluntary law'28 - and in one of his later lectures Krohg paid due attention to the way treaties and agreements put limitations on the commands of the natural law of nations, as will be seen below.

Concerning the difference between the natural and the positive law of nations, Krohg points to the definitions presented in an encyclopedia of the sciences by the German philosopher Wilhelm Traugott Krug (1770-1842): a science is natural when its content and scope are determined by 'the nature of the objects themselves to which they refer, and by the nature of the human intellectual capacity as such', whereas it is positive when 'in regard of its truth and validity it is conceived as depending on any kind of arbitrariness.'29 Besides this formal difference Krohg also underlines a difference in content:

The natural law of nations takes place as soon as we imagine the founding of states - and must be applied to all, and between all, nations; the

26 Ibid., § 4 .

27 Ibid., $\$ 6$.

28 Vattel, The Law of Nations, 78.

29 Wilhelm Traugott Krug, Versuch einer Systematischen Enzyklopädie der Wissenschaften. Zweiter Theil (Jena: J.G. Voigt, 1797), § 228. 
positive law of nations can only oblige nations that have already entered an association that must be regarded as binding or to the extent that they acknowledge the binding power of customs. The commands of the natural law of nations are, like its very foundation, reason itself, eternal and unchanging.

The commands of the positive law of nations are, on the contrary, changeable, depending on what the will and the needs of nations decide or demand.

The natural law of nations is not dependent on the positive, but the positive on the natural. The natural law of nations is a philosophical science; the positive is a purely historical science. The former decides what ought to happen without regard to what has happened; the latter most often derives the rules for what ought to happen from what has happened (through treaties, customs). ${ }^{30}$

Krohg admits a lack of certainty in the system of the natural law of nations, but this is due to a disagreement between different authors on specific topics and not a flaw of the system itself. Even if the natural law of nations is as old as the nations themselves, its commands have been interpreted in different ways. It would therefore be beneficial for students to get acquainted with various authors' treatment of the matter, because adherents of different philosophical opinions are inclined to understand certain topics in a one-sided manner. Krohg then turns his attention back to the positive law of nations, this time as the result of historical development. Almost all nations we know from history have had some kind of relation with neighbors or strangers, and these relations have been subject to regulations. War and peace, trade and intercourse have made rules of conduct all the more necessary because increased contact between nations also raises the possibility of conflict. The purpose of this historical sketch is twofold: Krohg wants to show that, unlike the natural law of nations, the positive law of nations is the result of a certain cultural and historical development; and even if we find positive regulations between nations far back in history, these are not the subject of the positive law of nations. As an academic discipline the positive law of nations is concerned only with the treaties or associations which are still binding.

What these treaties and associations show us is the European nations' state of law, and in its systematic treatment the positive law of nations 
restricts itself to these states and their connections between themselves as well as their relations to other powers outside of Europe.

But not all of the associations known from history are of interest to us in a legal sense; only those that are still valid - and in a direct or indirect manner concern us. We rarely need to move further back than the seventeenth century when we investigate the still binding power of the treaty-bound law of nations. There are no examples of a common treaty joined by all European powers, but there are some that come close; therefore there is no common treaty-based European law of nations. We can, however, by comparing the principles upon which the main parts of the treaties are based, deduce a certain similarity - and thus presume that certain rules have been followed. Likewise we can to a certain extent deduce some common customs from the different nations' similar behavior under identical circumstances. ${ }^{31}$

The most important contributions to the discipline were not theoretical works but practical introductions, handbooks and collections of treaties running through one augmented edition after another. And when lecturing on the positive law of nations, Krohg's task was not to present theoretical knowledge to his students, but to guide them through reference works and other recommended literature. His own textbook might well be understood as an attempt to enable the students to find their way through more substantial works on the subject. ${ }^{32}$

In the first four chapters of his textbook Krohg deals with 1) some common rules according to which the nations' special legal relations should be determined, 2) the nations' property rights and territorial rights in general, 3) treatises in general and 4) envoys. Although these are classical issues in the law of nations and the two last subjects are treated in a rather traditional manner, the first two deserve closer attention. To clarify the legal relations between the nations was a task for the natural law of nations, for the simple reason that it had nothing to do with current treaties; on the contrary, it was a prerequisite to any binding agreement between nations. And here one had to cope with the same problems that had once occupied Vattel: What is the difference between

31 Ibid., $\S 8$.

32 Among the works recommended by Krohg were two important collections of treaties: Gabriel Bonnot de Mably, Le droit public de l'Europe fondé sur les traités conclus jusqu'en l'année 1740 (The Hague: Jean Van-Duren, 1746), and Georg Friedrich von Martens, Recueil des principaux traités d'alliance, de paix, de trêve, de neutralité, de commerce, de limites, d'échange etc. conclus par les puissances de l'Europe (Göttingen: Dieterich, 1791-1801). 
a sovereign state's obligations towards itself and its obligations towards other states? And to what extent can interstate obligations be regarded as something more solid than the temporary results of diplomatic casuistry or the political prudence expressed in numerous treaties and other formal agreements? While authorities on the positive law of nations tried to move beyond Vattel regarding the second problem, they simply bypassed the first by taking the difference between the two forms of obligations for granted. To regard interstate obligations as equally binding as a state's obligations to itself presupposed a political arrangement different from the existing system of sovereign states. This was a philosophical concern, like the Kantian idea of a perpetual peace or a cosmopolitan law, not a matter for jurists - and certainly not for the positive law of nations. ${ }^{33}$

Although Krohg's references to Vattel are sparse and his textbook does not include the almost mandatory sketch of the history of the law of nations, he would no doubt have accepted the statement that the Swiss had brought the law of nations back on the right track after it had lost itself in philosophical speculations, and that he thus provided the discipline with a foundation upon which to build. ${ }^{34}$ That said, Krohg has no misgivings about quoting from or referring to works of a more philosophical or utopian kind, such as a proposition presented to the French National Convention in April 1795 by Henri JeanBaptiste Grégoire (1750-1831). This proposition was at odds with the idea of a law of nations based on the European system of sovereign states and had been subject to severe criticism in sources also used by Krohg. ${ }^{35}$ Some of Grégoire's principles were abstract moral maxims that could only be implemented under conditions which, if they were present, would make the implementation unnecessary. Other principles were more dangerous, like the prohibition of alliances that violated the interests of a single nation or the suggestion that only constitutions based on the principles of freedom and equality conformed to

33 Georg Friedrich von Martens, Précis du droit des gens moderne de l'Europe (Göttingen: Dieterich, 1801), 14.

34 See Georg Friedrich von Martens, Einleitung in das positive Europäische Völkerrecht (Göttingen: Johann Christian Dieterich, 1796), § 8, and Karl Gottlob Günther, Europäisches Völkerrecht in Friedenszeiten (Altenburg: Richter, 1787), §§ 26, 27.

'Discours de Grégoire, député à la Convention nationale par le département de Loir et Cher, prononcé dans la séance de 4. Floreal an. 3. de la Rép. Francaise (23. Avril. 1795.) sur une déclaration de droit des gens à faire par la Convention nationale,' Recueil des Traités de paix, d'amitié, d'alliance, de neutralité et autres conclus entre la République francaise et les différentes Puissances de l'Europe depuis 1792 jusqu’à la paix générale. Premiere Partie. Septembre 1791 - Aout 1795 (Hamburg: Fréderic Perthes; Paris: Treuttel et Würtz, 1796), 9-25. For the criticism of Grégoire, see Martens, Einleitung, V-XVI. 
the rights of peoples. The constitution of a state was a matter for nobody but the sovereign state itself. Whatever the status of the principles of the natural law of nations, they were not something a state could invoke in order to take action against another state. This is the unequivocal message in Krohg's outline of how the rules regulating legal relations between nations maintain the balance between equality and sovereignty.

The internal organization of every state regarding the legal relations between the ruler and the subject or between subjects is an issue that only concerns the state itself and is dependent upon its will. The laws and the form of government are therefore, according to the advice of policy and wisdom, different in different states. But this difference has no direct influence on the law of nations. The law of nations can therefore not embark on these matters that first and foremost belong to public law and political prudence without transgressing its boundaries. ${ }^{36}$

Being free and independent, the nations do not acknowledge a common superior except God and the law of justice and right. The interpreter of the law is the single nation itself, and in its contentions with other nations it is also entitled to pass its own verdict - and to implement it. But this must be done according to the principles of reason, which, on the one hand, highlight security, peace and perfection as the ultimate purposes of nations, and, on the other hand, maintain that no nation is entitled to pursue these purposes in a way that interferes with the rights of others. Between nations there is legal equality; and according to the natural law of nations, a single nation cannot have other or more extensive rights than another nation would be entitled to under similar circumstances. Supremacy in power, higher culture, enlightenment or refinement does not give a nation any rightful advantages over others. On the contrary, because every nation has a natural inclination to pursue justice and virtue, it can claim respect from others just as well as any citizen can demand to be respected as a human being. Mutual respect is a prerequisite for any kind of cooperation and interstate sociality - and with a reference to Vattel, Krohg declares that the only natural limit to the nations' right to interact with each other is their own security. ${ }^{37}$

Before closing his chapter on legal relations between nations Krohg introduces the following problem: does the fact that the positive law of nations

$36 \quad$ Krohg, Forsøg, § 20.

37 Ibid., § 27; see also Vattel, The Law of Nations, Preliminaries, §§ 11-12. 
presupposes an advanced stage of cultural development also have consequences for relations between more developed and less developed nations? According to Krohg there is no doubt that historical circumstances have created social ties between the European states that are much closer than any ties they might have with other nations. Bypassing the fact that many of the authors he elsewhere refers to insist that whereas Turkey is a European nation it is not on the same cultural level as the rest of Europe, Krohg emphasizes that the cultural ties between European nations do not make them into a society that is so distinct from all other nations that it has had or has its own positive law of nations. ${ }^{38}$ Philosophers and travel authors use culture, enlightenment and justice as a benchmark in order to distinguish between ethical, barbarian and savage nations. Whereas the European nations ascribe the title of moral to themselves,

[t]hose nations, on the other hand, that normally do not pay heed to the commands of the general law of nations, except through specific promises to do so, or that are unwilling to acknowledge the binding power of European customs, are in Europe given the name of barbarians; but this denomination cannot deny them the protection of the general law of nations. ${ }^{39}$

Although Krohg later refers to barbarians and savages, he seems to use the terms interchangeably and does not elaborate the distinction between them in the way that was then prevalent. ${ }^{40}$ According to this distinction the barbarian states might not meet the European moral and cultural standards, but it was still possible to make agreements with them, as a number of current treaties illustrated. Savages, on the other hand, appeared to lack law, liberty and civilization and hence to be devoid of all means for cooperation. It makes perfect sense, therefore, that when Krohg later returns to barbarians and savages, it is in his account of the concept of terra nullius: neither the natural nor the positive law of nations prohibits a nation from taking possession of a territory over which no other nation claims ownership or which has been abandoned by its previous owner. All nations do not enjoy the same level of culture, but a lack of culture is not a crime leading to the loss of property

38 See Jennifer Pitts, 'Empire and Legal Universalisms in the Eighteenth Century,' The American Historical Review 117 (2012): 101-104.

39 Krohg, Forsøg, § 28.

40 For a meticulous examination of these concepts, see J.G.A. Pocock, Barbarism and Religion IV: Barbarians, Savages and Empires (Cambridge: Cambridge University Press, 2005). 
rights. According to the dictates of reason, the use of a possession is entrusted to the owner's discretion insofar as it does not intend to harm others, and no nation is entitled to expropriate an uncultivated territory within the borders of another nation.

The possessions of the so-called savage nations can thus not be subject to the states' right to expropriation. And even less can differences in religion, forms of government etc. give other nations such rights. The injustices that the European nations have made themselves guilty of in this regard are common knowledge, and the guardian angel of humanity seems, in our time, to have prevented such violent deeds from achieving the name of justice. The present treaties and arrangements of the European nations explicitly presuppose that the territory of the barbarian or savage belongs to him in the same sense that it can become European through legal negotiations. ${ }^{41}$

Whereas Krohg here seems to run barbarian and savage nations together, recognizing both as legal persons, they do not fully meet the standards of moral nations. In his chapter on treaties he explains to his students that the united voices of politics and justice tell the moral nations to keep their treaties with barbarian states 'with twice the normal meticulousness.' ${ }^{42}$ Although he does not explain why this is so, any explanation would confirm the indelible difference between moral and barbarian nations. The rights and duties prescribed by the natural law of nations might apply to all nations alike, but the reliability or trustworthiness of barbarians and savages remain an open question. Despite all arguments for the universal validity of the law of nations, the fact that he introduces the difference between types of nations shows the extent to which Krohg adhered to the view that the legal relations between nations is modelled on a European cultural self-understanding. And it is no coincidence that this is the only place in his lectures where he refers to works that are not strictly juridical, but general surveys of the uniqueness of European culture. ${ }^{43}$

41 Krohg, Forsøg, § 35. See also Vattel, The Law of Nations, book II, chap. 7, §§ 86-88. Most of what Krohg has to say about this subject seems to be lifted from Vattel.

42 Krohg, Forsøg, § 62 .

43 The works are Daniel Jenisch, Cultur-Character des achtzehnten Jahrhunderts, nach bürgerlicher Verfassung, Sittlichkeit, Kunstgeschmack und Wissenschaft (Berlin: Verlag de Königl. Preuss. Akad., 180o), and Friedrich Gentz, Von dem politischen Zustand von Europa vor und nach der Französischen Revolution (Berlin: Heinrich Frölich, 1801). 
Little of what Krohg had said so far suggested that his audience was not students of law at the University, but cadets at the Naval Academy. However, this changes in the last three chapters of his textbook, dealing with trade and shipping (chap. 5), the legal relations between belligerent nations (chap. 6) and the duties and rights of neutral nations (chap. 7). These issues were of great relevance to his audience and they are presented in a manner different from the rest of the book. Although Krohg had insisted that the natural and the positive law of nations should be treated together, his last chapters are first and foremost about the latter. The very order of these chapters also illustrates a general trend in the literature on the law of nations in the late eighteenth century: the concept of neutrality is treated not only in the light of warfare but also in the light of trade and shipping, and it is regarded as a topic of its own.

After telling his students that need and industry once gave birth to trade between the nations, Krohg underlines that laws were introduced in order to prevent this enterprise from evolving into fighting or injustice. For a naval officer it is just as important to learn the rules of justice in shipping and trade as it is to know the trajectory of a bullet and the power of stormy waves. ${ }^{44}$ The rules to be obeyed are the law of nations, royal commands, current treaties and custom. Krohg here cites numerous excerpts from treaties and trade agreements, not only between European powers but also between Denmark-Norway and other European states as well as the Barbary states, i.e. the North African nations of Morocco, Algiers, Tunisia and Tripoli. The signing of treaties with these nations in the 1740 os and 175 os was of great significance for the sea trade, because it allowed Danish-Norwegian ships to sail through the Strait of Gibraltar and carry goods across the Mediterranean Sea.

In addition to the rules specified in treaties or agreements there were two sets of regulations that a Danish-Norwegian naval officer had to know about. The first was the unwritten set of rules for ceremonial conduct at sea, including the proper way to salute, the striking of sails, the hoisting and lowering of flags etc. According to Krohg this set of rules was 'in its original form sensible, but had through its many amendments become something of a bone of contention'. The more complex the rules, the more difficult it was to avoid mistakes that could provoke an opponent. ${ }^{45}$ Some of these rules were also specified in

\footnotetext{
44 Krohg, Forsøg, $\$ 83$.

45 Krohg, Forsøg, § 95 .
} 
the Danish-Norwegian naval articles of 1752, which was the second set of regulations here in question.

Moving from the regulations of peacetime to the rules of wartime, Krohg defines war as 'the state in which the nations find themselves after declaring the general state of mutual security to be repealed, and the nations have made manifest their will to inflict damage upon each other by applying coercive power. ${ }^{46}$ Because peace and the enforcement of right are the purpose of war, warfare is a means permitted by reason itself in order to achieve this purpose. It is, however, important to notice that, in the same way as reason, by prescribing a purpose to man, does not endorse whatever means could be considered as convenient in order to achieve this purpose, there are also rules according to which war between nations ought to be waged. But even if the nations, and especially those that wish to deserve the title of moral, acknowledge these rules, they are not to be found in any general treaty of warfare but are the rules of custom and the sacred commands of reason.

According to Krohg, war is the circumstance, or situation, that occurs as a result of a state's will to use extraordinary means to pursue right and peace. Although he does not mention Grotius here, he nevertheless seems to follow a Grotian argument according to which war has little to do with the law of nature, but all the more with the law of nations, regarded as voluntary: 'Custom has so prevailed, that not the Act of Hostility, but the State and Situation of the contending Parties, now goes by that Name; so that War is the State or situation of those [...] who dispute by Force of Arms.47 This means that war does not refer to specific acts: it refers, rather, to the circumstance in which these acts take place. But as Krohg further explained to his students, even if war repeals the mutual security that accompanies peace and overrules a number of the duties imposed upon peaceful nations, this does not mean that it puts an end to all binding relations between nations. There are limits to what you can do in war, and it is 'the sacred commands of custom, reason and humanity' that must guide the warrior. ${ }^{48}$

Therefore, an enemy, as a human being, can still demand a certain amount of respect - despite the unjust cause of his nation. [...] To despise

\footnotetext{
46 Krohg, Forsøg, § 100.

47 Grotius, The Rights of war and peace, book I, chap. 1, § II, 134; see also Vattel's definition: 'War is that state in which we prosecute our right by force'. The Law of Nations, book III, chap. I, § 1, 291. For a thorough treatment of this issue, see Neff, War and the Law of Nations, 138-140. 
individual members of a nation just because the nation is our enemy is a behaviour that cannot be justified in any reasonable manner. The warrior defends his fatherland, but the enemy warrior that attacks him, is not his personal foe. ${ }^{49}$

The secondary rights to exercise violence in wartime are, however, limited in scope - and they should also, ideally, be limited in degree. In the first place, one must notice that the purpose of war is not individual gain; war is waged by the state and is a matter between states. It is the regent who declares war and decides who among his underlings are entitled to perform hostile actions and under what conditions. In the second place, it is not for the natural law to decide which coercive measures a belligerent party should make use of. This question must be handed over to the parties themselves and be answered in light of what the occasion demands. But because the right to use coercive measures is prompted by necessity, reason recommends that neither party resort to harsher measures where more lenient ones are sufficient. And some measures, such as the use of traitors or assassins and the poisoning of wells, are not to be used under any circumstances. Reason cannot endorse, nor can nations regard as legal, actions that will exterminate righteousness and virtue. ${ }^{50}$

Krohg then turns to an issue concerning naval warfare. Having made clear that the natural law of nations does not permit private citizens to exercise hostilities and prohibits assaults, attacks or maltreatment of citizens of a hostile state as long as they remain peaceful, he adds that this rule in general also protects private property. 'The positive law of nations has, however, introduced certain exceptions to this rule by allowing that merchant vessels from hostile states that are encountered at sea by warships or privateers from the counterparty, can be arrested, seized and brought before a prize court.51 When telling his students that only regular armed forces were entitled to attack or open hostilities, Krohg made an exception for those who had received special permission through a letter of marque, i.e. privateers. This kind of engagement in maritime warfare by commission had developed during the Middle Ages, and in the eighteenth century a large part of the total military force at sea were privateers. In a Danish-Norwegian context this system was well known from the Great Northern War (1709-1720), and it would in a few years' time be used again on a greater scale than ever. What made privateering legal in contrast to piracy was the fact that the permission was anchored in a set of generally 
accepted rules. A privateer should not only seize his booty according to the terms stated in his letter of marque but also bring it before a prize court, i.e. a court authorized to decide if the booty had been lawfully captured.

What Krohg had to say about war and belligerent nations is clearly anchored in a Grotian framework. His treatment of neutrality, on the other hand, illustrates how this concept had been transformed during the eighteenth century. According to Grotius, 'it is the Duty of those that are not engaged in the War, to sit still and do nothing, that may strengthen him that prosecutes an ill Cause, or to hinder the Motions of him that hath Justice on his Side., ${ }^{52}$ And even if he did not draw the conclusion of the old doctrine of just war - that because one of the belligerents will have a just cause for war, it is morally reprehensible not to support him - Grotius still understood 'neutrality' from the vantage point of war. ${ }^{53} \mathrm{Krohg}$, on his side, approached neutrality from two different angles: one of them was, of course, the concept of war; the other, and more important, was maritime trade in peacetime. Here he followed what had become the prevalent understanding of neutrality. Whereas the contractual understanding of war acknowledged the right of third parties to remain neutral, it was far from clear whether they also had the right to carry on business as usual. Among the most important contributors to this new understanding of neutrality was the person whom Schlegel had described as 'the great champion of neutral privileges', the Danish-German jurist Martin Hübner (17231795). ${ }^{54}$ Although Krohg only has one single reference to Hübner's De la saisie des bâtimens neutres (1759), his treatment of the issue suggests that Hübner's importance is far greater than the lack of further quotations or references might suggest. After all, Hübner was not only the author of an influential book on neutrality but had also been an advisor to the Danish-Norwegian minister for foreign affairs and the architect of the nation's policy of neutrality, J.H.E. von Bernstorff $(1712-1772) .55$

$5^{2}$ Grotius, The Rights of War and Peace, book III, chap. 17, § III.1, p. 1525; see also Koen Stapelbroek, 'The Rights of Neutral Trade and its Forgotten History', in Trade and War: The Neutrality of Commerce in the Interstate-System, ed. Koen Stapelbroek (Helsinki: Helsinki Collegium for Advanced Studies, 2011), 3-13.

Grotius never uses the term 'neutrality' but talks about 'eorum qui a bello abstinet'. And although the chapter is entitled 'Of Neuters in war', this is a translation of 'De his qui in bello medii sunt'.

54 Schlegel, An Examination, 132.

55 The literature on Hübner is sparse, but a fine introduction to his major work is Nora N. Leerberg, The Legal Politics of Neutrality in the Age of Privateering. Martin Hübner's Law of Neutrality and Prize (Oslo: Dreyer, 2015). See also Stapelbroek, 'Universal Society, Commerce and the Rights of Neutral Trade'. 
Krohg opens his chapter on neutrality with half a dozen pages of references to relevant works on the subject, before telling his students that a neutral nation resides in a state of neutrality and therefore has not only duties towards others but also rights of its own. ${ }^{56}$ Here it is crucial to distinguish between a nation's right to stay neutral and its rights as neutral. It is for a nation itself to decide if a just cause of war is present and if it should help another nation against its enemies, but it is not compelled to do so unless an explicit promise has been given. Peace is the natural state of nations and every nation must be regarded as peaceful and neutral and also be treated as such, unless it has proved otherwise. Against this background it should be rather easy to point out the rights and duties of the neutral nation.

Because the neutral nation lives in peace with the belligerents, it should enjoy all the rights and all security that characterizes a peaceful relationship in general, as it should also fulfill all the duties that the law of nations imposes on a nation that lives in peace with others. The same liberty of trade and commerce, the same security on its own and on foreign territory in regard to persons and goods that behooved it under a common peace, should still be ascribed to it after the outbreak of war between other nations, towards which the neutral should enjoy the safety of a peace that it in no way can be presumed to have broken. ${ }^{57}$

This is the status of a neutral nation according to the natural law of nations. But because treaties and custom have long since put restrictions upon the rights of neutral nations, it is important to determine whether the positive law of nations has overruled these rights or whether these restrictions should be modified according to the general freedom of nations. And even if there is no general agreement concerning neutral nations' legal relations with belligerents and hence no unequivocal specification of the rights and duties in question, neutral nations have no doubt, by consent, renounced the general freedom of trade and thus acknowledged principles apparently alien to the natural law of nations.

Neutral nations agree not to supply belligerent nations with certain goods that were given the name of contraband of war. In treaties it was decided whether the principle: free ship, free goods was valid or not. The investigation or visitation that neutral vessels, under certain conditions, 
should submit to, was given a more determined form, and rules according to which the neutrality of the vessel and the legality of the cargo should be proven, were fixed. ${ }^{58}$

Using this historical fact as a vantage point, Krohg turns to the positive law of nations, leaving the natural law of nations aside because it has no room for concepts like contraband of war or blockade. In general, 'contraband' was goods 'that immediately and in their present form are destined for waging war'; but to qualify as contraband these goods had to be destined for a port belonging to a belligerent power, and no goods 'which are not explicitly regarded as contraband of war in treaties, can be regarded as such.59 Concerning blockades, the natural law of nations acknowledged the right of belligerent nations to deny neutral ships access to a certain port even if they did not carry contraband. But in order for a port to be recognized as blocked, two further criteria had to be met:1) the blockade had to apply to a specific port and 2) there had to be warships present in order to render attempts to access the port a dangerous adventure. ${ }^{60}$ Whereas the concept of contraband put limits on the principle of free ship, free goods, a blocked port limited the freedom of navigation. On the other hand, both restrictions were beneficial to neutral nations in a twofold manner: 1) they introduced specifications that made it easier to understand the rules of play, and 2) they were countermeasures against 'the interventions that belligerent nations had allowed themselves in regard to neutral nations' natural and treaty-bound rights'. Here Krohg refers to the Russian Declaration of 28 February 1780 where Tsarina Catharina II presented 'a draft of a sea-law that included the most important principles concerning neutral nations' rights and duties towards belligerents'. ${ }^{61}$ In the absence of a universal agreement, these principles became the foundation upon which a viable politics of neutrality was conducted.

Almost all the sea-powers that these principles were announced to, gave them their consent; and when some nations united in order to render them valid through armed force, the system of armed neutrality so renowned to the recent naval law of nations was founded - and its main principles have since then been repeated and renewed in numerous treaties. [...] Even those powers between whom no mutual agreements

$5^{8} \quad$ Ibid., $§ 135$.

$59 \quad$ Ibid., § 136, § 138.

$60 \quad$ Ibid., § $138, \S 140$.

$61 \quad$ Ibid., $§ 138$. 
concerning the right of the neutral flag have been concluded are committed to acknowledge the maxim: free ship, free goods; provided those powers, in one way or another, have also acknowledged the validity of the armed neutrality and its compliance with the natural law of nations. ${ }^{62}$

The political context of the Russian Declaration was beyond the scope of Krohg's lectures. Regarded as a contribution to the positive law of nations, it was sufficient to present the principles upon which the League of Armed Neutrality was founded as a reaffirmation of the rights of neutral nations, and support this view with references to recent treaties and agreements. The students were not told that this was an alliance of naval powers (Russia, DenmarkNorway and Sweden), founded in order to protect neutral shipping against the British Royal Navy's wartime policy during the American War of Independence $\left(1775^{-1783}\right)$ and the Anglo-French War (1778-1783) - a policy that included coastal blockades and unlimited search for contraband. In his aforementioned response to the High Court of Admiralty, Schlegel had complained that the British in their maritime wars relied on their superior naval power, and sought 'to extend the contraband articles of war as far as possible, in order thereby to distress their enemies to the utmost of their power' ${ }^{63}$ It was against a conception of contraband that included not only goods that directly and in their actual form served the purpose of war, but also goods that indirectly or occasionally could do so, that treaty-bound specifications were aimed. The restricted concept of a blockade was, likewise, targeted against the British attempt to cut off neutral maritime vessels from entire coastlines.

Although the League was dissolved in 1783 , its principles retained their validity and when the same naval powers founded a second League of Armed Neutrality during the War of the Second Coalition (1798-1802) they reconfirmed the political programme of $178 \mathrm{o}$. But this time the British government regarded the League as an alliance with France and attacked Denmark-Norway, destroying parts of its naval fleet in the first Battle of Copenhagen in April 1801 and forcing it to withdraw from the League. ${ }^{64}$ By then the League itself was about to collapse, and after negotiations between Britain and Russia a convention was signed in June 1801 and later joined by Denmark-Norway. Here two new principles forwarded by the League were confirmed: 1) that seizure of neutral

$62 \quad$ Ibid., § 138, § 139.

63 Schlegel, An account, 94-5.

64 See Ole Feldbæk, Denmark and the Armed Neutrality $1800-1801$ (Copenhagen:Akademisk Forlag, 1980), and The Battle of Copenhagen 1801. Nelson and the Danes (Barnsley: Leo Cooper, 2002). 
ships required a just cause, and 2) that merchant ships under neutral convoy should not be visited by belligerent warships. Krohg's translation of a large part of the convention forms the bulk of his section on visitation of neutral ships. ${ }^{65}$ Although he thereafter adds three short paragraphs on verdicts passed on seized neutral ships, hostilities on neutral territory, and the rights of warships and privateers to enter neutral ports, he clearly regarded this convention as the last contribution to the positive law of nations and hence a natural place for his lectures to end.

Following the path that Professor Schlegel had cleared when he introduced the positive law of nations in a Danish-Norwegian context and showed that this discipline amounted to more than natural right applied to interstate relationships, Krohg in his textbook guided the cadets at the Naval Academy all the way from the principles of the natural law of nations to the most recent statements of the positive law of nations. Both teachers relied, more or less explicitly, on the theories once put forth by Grotius and Vattel and used these as a vantage point from which to approach the works of Martens and other proponents of the law of nations as a historical science. Whereas Schlegel still treated the law of nations as a part of the comprehensive system of natural right, Krohg focused on making the discipline more accessible to an audience with more practical needs. More than half of his textbook's 280 pages were in fact references, quotations or excerpts from treaties, conventions and agreements. Unlike Schlegel, Krohg was not inclined to theoretical or systematic thinking. Soon after his textbook was published he left the academic world, despite his appointment as extraordinary professor of law in 1803. Eager to seek employment in Norway, Krohg was appointed assessor in the regional high court in Trondheim in 1804 and turned his attention to practical legal matters for a while, before he once again got caught up in issues pertaining to the law of nations.

Krohg's textbook addressed future naval officers in a neutral state; after the outbreak of the Napoleonic Wars (1803-1815), however, it became more difficult for the state to maintain its neutrality. When Britain noticed that DenmarkNorway had come under severe pressure from France and Russia to pledge its naval forces to Napoleon, the Royal Navy bombarded Copenhagen in September 1807 and then seized the fleet. After the attack, Denmark-Norway entered 
an alliance with France through the Treaty of Fontainebleau, in October 1807. But as early as September 14, when the ruins of Copenhagen still smoldered, the government issued regulations for privateering - and more than thirty vessels were fitted out for this task in less than a month. According to the positive law of nations, prize courts were established in several towns along the Danish and Norwegian coastlines in order to supervise the privateering. One of the members of the prize court in Trondheim was assessor Krohg; and from 1810 and until it was dissolved in 1814 he served as the court's chief justice. What he had once told his students at the Naval Academy about neutrality probably occurred to him as irrelevant at this time. What he had said about the rules of privateering was more relevant than ever before.

\section{Bibliography}

Ancher, Peter Kofod, Anviisning for en DanskJurist angaaende Lovkyndigheds adskillige Deele, Nytte og Hielpemidler, 2nd. ed. (Copenhagen: Ludolpf Henrich Lille, 1777).

Bornemann, Mathias Hastrup, 'Prøveforelæsning over det Spørgsmaal: Hvad forståes ved Gesandternes Hellighed, og hvorvidt strækker den sig, saavel efter den naturlige som sædvansmæsseige Folkeret?', Minerva (1800) III: 32-72.

Bornemann, Mathias Hastrup, Über die gebräuchliche Visitation der neutralen Schiffe, und über die Convoi, nebst einem Mittel, beyde durch ein allgemeines garantirtes Seehandels-Völkerrecht zu heben (Kopenhagen und Leipzig: Schubothe, 1801).

Eggers, C[hristian] U[lrich] D[etlev] von, Institutiones juris civitatis publici et gentium universalis (Hafniae: Proft et Storch, 1796).

Feldbæk, Ole, 'The Anglo-Danish Convoy Conflict of 180o: A study of small power policy and neutrality,' Scandinavian Journal of History 2 (1977): 161-182.

Feldbæk, Ole, Denmark and the Armed Neutrality 1800-1801 (Copenhagen: Akademisk Forlag, 1980).

Feldbæk, Ole, The Battle of Copenhagen 1801. Nelson and the Danes (Barnsley: Leo Cooper, 2002).

Gentz, Friedrich, Von dem politischen Zustande von Europa vor und nach der Französischen Revolution (Berlin: Heinrich Frölich, 1801).

[Grégoire, Henri Jean-Baptiste], 'Discours de Grégoire, député à la Convention nationale par le département de Loir \& Cher, prononcé dans la séance de 4. Floreal an. 3. de la Rép. Francaise (23. Avril. 1795.) sur une déclaration de droit des gens à faire par la Convention nationale,' in Recueil des Traités de paix, d'amitié, d'alliance, de neutralité et autres conclus entre la République francaise et les différentes Puissances de l'Europe depuis 1792 jusqu'à la paix générale. Premiere Partie. Septembre 1791-Aout 1795 (Hambourg: Fréderic Perthes; Paris: Treuttel et Würtz, 1796), 9-25. 
Grotius, Hugo, The Rights of War and Peace, transl. from the edition by Jean Barbeyrac, ed. Richard Tuck (Indianapolis, IN: Liberty Fund, 2005).

Günther, Karl Gottlob, Europäisches Völkerrecht in Friedenszeiten (Altenburg: Richter, 1787).

Haakonssen, Knud, 'Holberg's Law of Nature and Nations,' in Ludvig Holberg (16841754). Learning and Literature in the Nordic Enlightenment, ed. Knud Haakonssen and Sebastian Olden-Jørgensen (London and New York: Routledge, 2017), 59-79.

Hochstrasser, T.J., Natural Law Theories in the Early Enlightenment (Cambridge: Cambridge University Press, 2000).

Hojer, Andreas, Jus Publicum det er Stats-Ret eller Statsforfatning og Rettigheder for Danmark, Norge og Fyrstendommene forklaret ved private Forelcesninger eller Kollegio (Christiania: Jens Ørbek Berg, 1783).

Holberg, Ludvig, Introduction til Naturens- og Folke-Rettens Kundskab (Copenhagen: Johan Kruse, 1716).

Hunter, Ian, 'Vattel's Law of Nations: Diplomatic Casuistry for the Protestant Nation,' Grotiana 31 (2010): 108-140.

Hunter, Ian, 'The Law of Nature and Nations', in The Routledge Companion to Eighteenth Century Philosophy, ed. Aaron Garrett (New York: Routledge, 2014), 559-592.

Jenisch, Daniel, Cultur-Character des achtzehnten Jahrhunderts, nach bürgerlicher Verfassung, Sittlichkeit, Kunstgeschmack und Wissenschaft (Berlin: Verlag der Königl. Preuss. Akad., 180o).

Koskenniemi, Martti, 'Into positivism: Georg Friedrich von Martens (1756-1821) and Modern International Law,' Constellations 15 (2008): 189-207.

Koskenniemi, Martti, 'The Advantage of Treaties: International Law in the Enlightenment,' Edinburgh Law Review 13 (2009): 27-67.

Krohg, Christian, Forsøg til en Ledetraad ved Forelsninger over Folke-Retten (Copenhagen: Andreas Seidelin, 1803).

Krug, Wilhelm Traugott, Versuch einer Systematischen Enzyklopädie der Wissenschaften. Zweiter Theil (Jena: J.G. Voigt, 1797).

Leerberg, Nora Naguib, The Legal Politics of Neutrality in the Age of Privateering. Martin Hübner's Law of Neutrality and Prize (Oslo: Dreyer, 2015).

Mably, Gabriel Bonnot de, Le droit public de l'Europe fondé sur les traités conclus jusqu'en l'année 1740, 2 vols. (La Haye: Jean Van-Duren, 1746).

Martens, Georg Friedrich von, Einleitung in das positive Europäische Völkerrecht auf Verträge und Herkommen gegründet (Göttingen: Johann Christian Dieterich, 1796).

Martens, Georg Friedrich von, Recueil des principaux traités d'alliance, de paix, de trêve, de neutralité, de commerce, de limites, d'échange etc. conclus par les puissances de l'Europe, 7 vols. (Goettingue: Dieterich, 1791-1801).

Martens, Georg Friedrich von, Précis du droit des gens moderne de l'Europe fondé sur les traités et l'usage, 2nd and revised ed. (Gottingue: Dieterich, 1801). 
Marzagalli, Silvia and Müller, Leos, "In apparent disagreement with all law of nations in the world": Negotiating neutrality for shipping and trade during the French Revolution and Napoleonic Wars,' The International Journal of Maritime History 28 (2016): 108-117.

Michalsen, Dag, 'Legislators, Journals, and the Public Legal Sphere in Scandinavia around 180o,' in Eighteenth-Century Periodicals as Agents of Change, ed. Ellen Krefting, Aina Nøding and Mona Ringvej (Leiden and Boston: Brill Academic Publishers, 2015), 202-214.

Neff, Stephen C., War and the Law of Nations. A General History (Cambridge: Cambridge University Press, 2005).

Nørregaard, Lauritz, Natur-Rettens første Grunde, 2nd ed. (Copenhagen: Gyldendals Forlag, 1784).

Pitts, Jennifer, 'Empire and Legal Universalisms in the Eighteenth Century,' The American Historical Review 117 (2012): 92-121.

Pocock, J.G.A., Barbarism and Religion IV: Barbarians, Savages and Empires (Cambridge: Cambridge University Press, 2005).

Pourchasse, Pierre, 'Danish shipping in the Mediterranean during the Revolutionary wars (1793-1795),' The International Journal of Maritime History 28 (2016): 165-179.

Pufendorf, Samuel, Two Books of the Elements of Universal Jurisprudence, transl. W.A. Oldfather (Indianapolis, IN: Liberty Fund, 20o9).

Schlegel, J.W.F., Naturrettens eller den almindelige Retslceres Grundscetninger (Copenhagen: Johan Frederik Schulz, 1798).

Schlegel, J.W.F., An examination of the sentence in the case of the Sweedish convoy pronounced in the High Court of Admiralty of England on the eleventh of June, 1799 (London: W. Wilson, 180o).

Stapelbroek, Koen, 'Universal Society, Commerce and the Rights of Neutral Trade,' in Universalism in International Law and Political Philosophy, ed. Petter Korkman and Virpi Mäkinen (Helsinki: Helsinki Collegium for Advanced Studies, 20o8), 63-89.

Stapelbroek, Koen, 'The Rights of Neutral Trade and its Forgotten History,' in Trade and War: The Neutrality of Commerce in the Interstate-System, ed. Koen Stapelbroek (Helsinki: Helsinki Collegium for Advanced Studies 2011), 3-13.

Vattel, Emer de, The Law of Nations, ed. Béla Kapossy and Richard Whatmore (Indianapolis, IN: Liberty Fund, 2008).

Wilson, Eva, Seerup, Jacob and Hammar, Anna Sara, 'The education and careers of naval officers in the long eighteenth century: an international perspective,' Journal for Maritime Research 17 (2015): 17-33.

Zurbuchen, Simone, 'Emer de Vattel on the Society of Nations and the Political System of Europe,' in System, Order, and International Law, eds. Stefan Kadelbach, Thomas Kleinlein and David Roth-Isigkeit (Oxford: Oxford University Press, 2017), 263-282. 


\title{
The Law of Nations in German historia literaria and Encyclopaedias in the Eighteenth Century
}

\author{
Frank Grunert
}

1 Introduction: Textbooks for Academic Teaching

If one is interested in the law of nations as an academic subject, one clearly has to focus on lectures and textbooks dedicated to the subject. But from a historical point of view, it is worthwhile also to analyse the more general knowledge of the law of nations - that provided to non-specialists and especially to young academics before they started their specialist training. What did a beginning academic get to know about the law of nations? The propaedeutic lessons available provide interesting information regarding what the general academic public knew about the subject.

In the German context during the eighteenth century, historia literaria ('Geschichte der Gelehrsamkeit', 'history of learning') was the most prominent genre of general instruction in any subject of academic relevance. Its prominence is shown by the large number of textbooks which appeared throughout the whole of the century and the significant number of courses which were offered at all universities, academies and even at high schools. For more than a century, historia literaria was considered extremely successful, keeping the same general aim and changing only in the form of its practical realization. An authoritative definition of the purpose of historia literaria is given in Christoph August Heumann's Conspectus reipublicae literariae sive via ad historiam literariam, which appeared for the first time in 1718 and for the last time in a posthumous eighth edition in the 179os. Heumann provides that definition in the first paragraph: 'The history of learning is the history of letters [i.e. books] and authors, or the narration of the origin and progress of learning from the beginning up to our times.' ${ }^{1}$

1 Christoph August Heumann, Conspectus reipublicae literariae sive via ad historiam literariam iuventuti studiosae aperta, editio tertia (Hannover: apud Io. Jacobum Foersterum, 1733), 1: 'Historia literaria est Historia literarum et literatorum, sive Narratio de ortu et progressu studiorum literariorum ad nostram usque aetatem'. See: Sicco Lehmann-Brauns, 'Neukonturierung und methodologische Reflexion der Wissenschaftsgeschichte. Heumanns 
The original idea of historia literaria goes back to Francis Bacon. In Of the Proficience and Advancement of Learning (1605) Bacon suggested the establishment of a new historical discipline distinct from civil history and ecclesiastical history which had to represent all knowledge of the past - ideally without any limits. Bacon's objective was a sort of enormous repository of all knowledge from every period and every geographical area, with the purpose of giving constructive impulses to both scientific research and political governance. ${ }^{2}$ Since his concept had utopian dimensions, it is not surprising that its realization is also described in his New Atlantis. ${ }^{3}$ Although the German historians of learning and scholarship were fascinated by the idea of collecting every piece of former knowledge, they realized that a complete collection of knowledge was simply impossible. So while they adopted the idea, they reduced its scope and adapted it to propaedeutic purposes. That is, they decided to provide a focused and comprehensive survey of important scholarly information about all disciplines at any given time for the benefit of students in all disciplines. That comprised for example bibliographical and biographical information, outlines

Conspectus reipublicae literariae als Lehrbuch der aufgeklärten Historia literaria,' in Historia literaria. Neuordnung des Wissens im 17. Und 18. Jahrhundert, ed. Frank Grunert and Friedrich Vollhardt (Berlin: Akademie Verlag, 2007), 129-16o; Helmut Zedelmaier, 'Heumanns Conspectus Reipublicae Literariae. Besonderheit, Kontext, Grenzen,' in Christoph August Heumann (1684-1764). Gelehrte Praxis zwischen christlichem Humanismus und Aufklärung, ed. Martin Mulsow, Kasper Risbjerg Eskildsen and Helmut Zedelmaier (Stuttgart: Franz Steiner, 2017), 71-92. For more information on historia literaria in general, see Martin Gierl, 'Bestandsaufnahme im gelehrten Bereich. Zur Entwicklung der "Historia Literaria” im 18. Jahrhundert,' in Denkhorizonte und Handlungsspielräume. Festschrift für Rudolf Vierhaus zum 7o. Geburtstag (Göttingen: Wallstein, 1992), 53-80; Helmut Zedelmaier, “'Historia Literaria”. Über den epistemologischen Ort des gelehrten Wissens in der ersten Hälfte des 18. Jahrhunderts,' Das achtzehnte Jahrhundert, 22, 1 (1998): 11-21. Frank Grunert, Anette Syndikus, 'Historia literaria. Erschließung, Speicherung und Vermittlung von Wissen,' in Wissensspeicher der Frühen Neuzeit. Formen und Funktionen, ed. Frank Grunert and Anette Syndikus (Berlin: de Gruyter, 2015), 243-293; Hanspeter Marti, '§62. Litterärgeschichte (historia literaria),' in Grundriss der Geschichte der Philosophie, begr. von Friedrich Ueberweg. Die Philosophie des 18. Jahrhunderts, ed. Helmut Holzhey and Vilem Mudroch (Basel: Schwabe, 2014), vol. 5, 1425-1429. And last but not least the contributions in Frank Grunert and Friedrich Vollhardt (eds.), Historia literaria. Neuordnung des Wissens im 17. und 18. Jahrhundert (Berlin: Akademie Verlag, 2007).

2 Francis Bacon, Of the Proficience and Advancement of Learning, Divine and Humane (1605), in The Works of Francis Bacon, ed. James Spedding et al., vol. 3 (London: Longman, 1859).

3 Francis Bacon, The New Atlantis (1627), ibid., vol. 3. See Frank Grunert, "Viel Tausend und Millionen Bücher". Zur Bewältigung und zur Hervorbringung von Wissenspluralität in der frühneuzeitlichen "Historia literaria", in Pluralisierungen. Konzepte zur Erfassung der Frühen Neuzeit, ed. Jan-Dirk Müller, Wulff Österreicher and Friedrich Vollhardt (Berlin: de Gruyter, 2010), 192-194; Grunert and Syndikus, 'Historia literaria. Erschließung, Speicherung und Vermittlung von Wissen,' $253-255$. 
of the nature and development of disciplines, and at least some advice for learning and conducting scientific work. So, generally, German historia literaria became an important part of propaedeutic lessons to introduce students to the world of academic erudition. ${ }^{4}$

Despite its prominence historia literaria was - especially in the second half of the century - complemented by another historical genre, which pursued a similar aim. This was the encyclopaedic text, which likewise offered a first orientation in the scientific world, especially for beginning students and the general public. Encyclopaedias focused on each discipline by defining its nature and its function. They also recommended important authors and their books, but, unlike historia literaria, they did not try to present a more or less full history of the disciplines - they did not give a 'narratio de ortu et progressu disciplinarum' (Heumann). Instead they concentrated on a short sketch ('kurzer Begriff') and avoided long and sometimes complicated histories. These texts were organized as a course in all the academic disciplines, and accordingly they were generally called 'encyclopaedias', after the Greek term popularized during the Renaissance 'enkyklios paedeia', meaning the circle of learning about a certain subject with propaedeutic aims. The encyclopaedia as a repository of knowledge has its own rather long history, but the idea became more and more attractive in the second half of the eighteenth century, which may indicate a crisis for historia literaria. ${ }^{5}$ The assimilation of the detailed historical and bibliographical information of the latter seemed no longer feasible, at least not in the eyes of a part of the public. The purpose and the structure of the general historia literaria were nevertheless continued in specialized histories of individual disciplines. So the general knowledge of the law of nations that was provided to non-specialists at the beginning of their academic training during the eighteenth century is to be found in three particular historical genres: the general historia literaria, the specialized history of scholarship focused on one discipline, and the broader encyclopaedia.

In relation to the perception and the presentation of the law of nations, it is necessary to keep the following questions in mind: 1. To which discipline

4 Paul Nelles, 'Historia litteraria at Helmstedt: Books, professors and students in the early Enlightenment university', in Die Praktiken der Gelehrsamkeit in der Frühen Neuzeit, ed. Helmut Zedelmaier and Martin Mulsow (Tübingen: Niemeyer, 2001), 147-176; Anette Syndikus, 'Historia literaria als Propädeutikum an der Königsberger Universität des 18. Jahrhunderts,' in Die Universität Königsberg in der Frühen Neuzeit, ed. Hanspeter Marti and Manfred Komorowski (Köln, Wien, Weimar: Böhlau, 20o8), 379-422.

5 See Grunert, Syndikus, 'Historia literaria. Erschließung, Speicherung und Vermittlung von Wissen,' 289-293. 
was the law of nations said to belong? 2. How was the law of nations defined? 3. How were natural law and the law of nations said to relate to each other? 4. Which authors and which books were principally presented in discussions of the law of nations? It is important to note that the following sketch does not deal with the history of the law of nations itself: the aim is only to set out the ideas of a couple of representative authors who were significant in the history of learning for a certain period. The purpose is to find out what contemporaries learned about the law of nations when they studied the widely used textbooks on the history of learning and encyclopaedias.

2

\section{A Brief Sketch: the Law of Nations, Seventeenth to Eighteenth Century}

Before our questions can be answered, it is necessary to outline the discussion of the law of nations in the seventeenth and eighteenth centuries. If one surveys the whole debate, beginning inevitably with the highly influential categorical distinctions in Grotius's De jure belli ac pacis and ending most plausibly with the Primae lineae juris gentium Europaeum (1785), a general treatise on international law by the Göttingen law professor Georg Friedrich von Martens, one can get the impression that the core of the whole discussion was the relationship between natural law and the law of nations (jus gentium). Grotius made a distinction between the voluntary law of nations and natural law - as Francisco Suárez had done before - but the idea of a voluntary law of nations was rejected by Samuel Pufendorf, who asserted that only natural law can create obligations between states. As a consequence, the discussion went on between two more or less extreme positions: on the one hand, that of 'naturalists', such as Pufendorf and Samuel Cocceji, who relied on natural law and denied that a manmade law of nations can invoke more or less universal obligations; and on the other hand, that of thinkers such as Johann Jakob Moser and Georg Friedrich von Martens, who emphasized the manmade aspect of the law of nations along with an early positivist philosophy of international law, to use anachronistic terms. ${ }^{6}$

6 See Stephen C. Neff, Justice among Nations. A History of International Law (Cambridge, MA: Harvard University Press, 2014), esp. 155-201; Wilhelm Grewe, The Epochs of International Law, transl. and revised by Michael Byers (Berlin: de Gruyter, 2000), esp. 348-360; Oliver Diggelmann, 'The Periodization of the History of International Law,' in The Oxford Handbook of the History of International Law, ed. Bardo Fassbender and Anne Peters (Oxford: Oxford University Press, 2012), 997-1011; Karl-Heinz Ziegler, Völkerrechtsgeschichte, and 
Since Pufendorf had set the tone ${ }^{7}$ it is hardly surprising that his highly influential follower Christian Thomasius had no concern at all with the law of nations. Thomasius of course knew everything that Hugo Grotius had written on this topic, but clearly he had no interest in it. In his eyes, the law of nations is just a part of natural law, which deals with only two issues, namely duties towards legatees - 'De officiis erga legatos' - and duties towards deceased persons - 'De officio erga mortuos': 'There remains the society of nations, in which as we already said above no new purpose or new precepts are to be expected, only the application of the general precepts set out in the second book to two of the more important parts of the law of nations, those concerning legations and the right of burial:.8 But while Thomasius stuck to this as far as the duties to diplomats are concerned and explicitly denied that they formed part of a voluntary law of nations, he went on to argue that the duties towards deceased persons are not a subject of natural law but that they do not contradict it. One may wonder why he discussed them in the context of the law of nations at all, but it confirms the impression of his entire lack of interest in the law of nations in his first book on natural law, an impression that is reinforced in his second major work in the field, the Fundamenta juris naturae et gentium (1705). ${ }^{9}$

However, during the lifetime of Thomasius, Adam Friedrich Glafey returned to Grotius's distinction between natural law and jus gentium voluntarium. He seemed to follow Thomasius and other natural lawyers when he stated that the law of nations is nothing but an 'applicatio regularum Juris naturae ad statum gentium, ${ }^{10}$ Nevertheless, he emphasized the already existing concept of jus gentium voluntarium ('willkührliches Völker-Recht'), which he defined

ed. (München: Beck, 2007); Tilmann Altwicker, Francis Cheneval, Oliver Diggelmann (eds.), Völkerrechtsphilosophie der Frühaufklärung (Tübingen: Mohr Siebeck, 2015).

7 See for a more detailed discussion of Pufendorf's concept of the law of nations: Michael Seidler, 'Der Begriff des Völkerrechts bei Samuel Pufendorf,' in Völkerrechtsphilosophie, ed. Altwicker, Cheneval and Diggelmann, 61-78.

8 Christian Thomasius, Institutes of Divine Jurisprudence with Selections from Foundations of the Law of Nature and Nations, ed., transl. and with an introduction by Thomas Ahnert (Indianapolis, IN: Liberty Fund, 2011), 544. English translation of Institutiones jurisprudentiae divinae (Frankfurt and Leipzig: M.G. Weidmann, 1688).

9 Christian Thomasius, Fundamenta juris naturae et gentium (Halle: Salfeld, 1705). For the English translation see note 8 .

10 Adam Friedrich Glafey, Vernunfft- und Völcker-Recht (Frankfurt and Leipzig: Christoph Riegel, 1723), 231. For Glafey's ideas of the law of nations, see Frank-Steffen Schmidt, Praktisches Naturrecht zwischen Thomasius und Wolff: Der Völkerrechtler Adam Friedrich Glafey (1692-1753) (Baden-Baden: Nomos, 2007), esp. 199ff. 
as 'customs $[\ldots]$, which were transformed into rights through common practice among different nations and admitted to be obligatory law among them.'11 Glafey explicitly contrasted this idea with the position of Christian Thomasius and thus demonstrated a certain interest in the theoretical independence of the law of nations.

A similar interest was shown by Christian Wolff through the publication of his Jus gentium methodo scientifica pertractatum (1749) separately from his eight-volume Jus naturae (1740-1749). Based on the Grotian dualistic conception, Wolff announced a careful distinction of the 'Natural Law of Nations [...] from that which is voluntary, stipulative and customary'.12 He opened his Jus gentium with the following definition: 'By the Law of Nations we understand the science of that law which nations or peoples use in their relations with each other and the obligations corresponding thereto.'.13 Wolff admitted that the Jus gentium necessarium consists in natural law as applied to nations in general, ${ }^{14}$ but he introduced a more comprehensive definition of the law of nations, which encompasses all juridical relations between nations without regard to their sources. The complete emancipation of the law of nations from any kind of natural law was accomplished in the works of Johann Jakob Moser and Georg Friedrich von Martens. They were interested in practical agreements as guidelines for politics and even explicitly denied 'the existence of a general international law'. ${ }^{15}$ It is therefore not surprising that especially von Martens 'was regarded, with at least some reason, as an important progenitor of the positivist philosophy of international law'.16

11 Glafey, Vernunff- und Völcker-Recht, 195: ‘[D]iejenigen Gebräuche [...], welche bey verschiedenen Völkern durch langen Brauch zu Rechte gediehen, und sie unter sich als ein verbindliches Recht gelten lassen'.

12 Christian Wolff, The Law of Nations treated according the Scientific Method, transl. by Joseph H. Drake, ed. and with an introduction by Thomas Ahnert (Carmel, IN: Liberty Fund, 2017), 1.

13 Wolff, The Law of Nations, 12. Christian Wolff, Jus Gentium Methodo Scientifica Pertractatum (Halle: Renger, 1749), in Gesammelte Werke, Abt. 2, vol. 25 (Hildesheim, Zürich, New York: Olms, 1972), 1: 'Per Jus Gentium intelligimus scientiam juris, quo Gentes, sive populi inter se utuntur \& obligationum eidem respondentium'. On Wolff see Knud Haakonssen, 'Christian Wolff (1679-1754),' in The Oxford Handbook of the History of International Law, ed. Fassbender, Peters, 1106-1109.

14 Wolff, The Law of Nations, 14: 'We call that the necessary law of nations which consists in the law of nature applied to nations'.

15 Neff, Justice among Nations, 194, see also 199.

16 Ibid., 200. 


\section{Neglect: the Law of Nations in the Early General} Compendia of historia literaria

Turning to the textbooks in historia literaria, we clearly find all steps in the development sketched above. Especially in the first half of the century, one can get the impression that there is nearly no interest in dealing with the law of nations as a special topic. It is surprising that the historians of learning in the early eighteenth century, despite their programmatic aims and explicit intentions, sometimes completely ignore the law of nations. We find detailed remarks on natural law in volume 3 of the famous Kurtze Anleitung zur Historie der Gelahrheit $(1718)^{17}$ by Gottlieb Stolle, a student of Christian Thomasius, but not a single word on the law of nations. Neither does the later and otherwise detailed Anleitung zur Historie der juristischen Gelahrheit $(1745)^{18}$ by the same author deal with the law of nations. Apparently, Stolle still did not consider it a topic in jurisprudence. The same lack of interest can be observed in Heumann's Conspectus. He there presents a very brief 'historia jurisprudentiae naturalis', but the term 'jus gentium' appears, without any further explanation, only in the context of some remarks about Samuel Pufendorf's natural law. ${ }^{19}$

Nicolaus Hieronymus Gundling - also a former student of Christian Thomasius - treats the history of natural law in his programme announcing a Collegium uber die Historiam litterariam (1713). No more than a list of items to be highlighted in his lecture, number 106 in the programme explicitly asks whether jus gentium should be treated separately from natural law - 'ob das Ius Gentium besonders zu tractiren' - and he adds that in this context he will make some remarks on Johann Wolfgang Textor's Synopsis Juris Gentium. ${ }^{20}$ One may expect that he would present some definition of the law of nations, but the programmatic text does not allow us to tell. In his treatise on natural law Gundling rejects the necessity of treating the law of nations, because he explicitly denies it a separate identity; it is nothing but the application of natural law to nations. ${ }^{21}$ We find the same position in the Versuch zu einer Historie

\footnotetext{
17 Gottlieb Stolle, Kurtze Anleitung zur Historie der Gelahrheit (Halle: Neue Buchhandlung, 1718).

18 Gottlieb Stolle, Anleitung zur Historie der juristischen Gelahrheit (Jena: Johann Meyers seel. Erben, 1745).

19 Heumann, Conspectus, 245.

20 Nicolaus Hieronymus Gundling, Collegium uber die Historiam litterariam (Halle, [1713]), 35. Johann Wolfgang Textor, Synopsis juris gentium (Basel: Rüdinger, 168o).

21 Nicolaus Hieronymus Gundling, Jus naturae ac gentium, 3rd ed. (Halle: Renger 1736), $20-21$.
} 
der Gelehrheit (1728) by Martin Schmeitzel, a historian and a former student of Gundling. He, too, explains that he treats jus naturae and jus gentium together because the latter is only jus naturae applied to the nature and the negotiations of nations. ${ }^{22}$ His further treatment of the law of nations is as meagre as that in the large Abriß einer allgemeinen Historie der Gelehrsamkeit (1752-1754), in whose three volumes Johann Andreas Fabricius found room for only one sentence on the subject: 'when natural law is applied to the state of nations it is called the law of nations which deals with the rights and duties of nations and countries towards each other.23 Fabricius, who was a famous historian of learning, classified natural law and hence the law of nations as part of philosophy. In other words, the works of Glafey and Wolff on the law of nations did not lead Fabricius to include any further details on that law.

\section{Philosophy vs. Law: the Law of Nations in Later Compendia of historia literaria and in Encyclopaedias}

However, as times changed so did theories. In textbooks on the history of learning from the second half of the eighteenth century, the law of nations was dealt with in a far more elaborate way. The change is still more obvious if one includes the already mentioned encyclopaedias and the specialized compendia of historia literaria, texts such as Johann Georg Sulzer's Kurzer Begriff aller Wissenschaften ${ }^{24}$ (1759), Christian Heinrich Schmid's Abriß der Gelehrsamkeit ${ }^{25}$ (1783), Johann Joachim Eschenburg's Lehrbuch der Wissenschaftskunde $^{26}$ (1792), Johann Stephan Pütter's Neuer Versuch einer Juristischen Encyclopädie und Methodologie ${ }^{27}$ (1767) or Dietrich Heinrich Ludwig von

22 Martin Schmeitzel, Versuch zu einer Historie der Gelehrheit (Jena: Fickelscherr, 1728), 552.

23 Johann Andreas Fabricius, Abriß einer allgemeinen Historie der Gelehrsamkeit, vol. 1 (Leipzig: Weidmann, 1752), 402: '[W]enn dieses Recht der Natur auf den Stand der Völker angewendet wird, so heißt es das Völkerrecht und ist sodann die Wissenschaft der Rechte und Pflichten der Völker und Staaten gegeneinander'.

24 Johann Georg Sulzer, Kurzer Begriff aller Wissenschaften und andern Theile der Gelehrsamkeit, worin jeder nach seinem Innhalt, Nuzen und Vollkommenheit kürzlich beschrieben wird, 4th ed. (Frankfurt and Leipzig: [s.n.],1774).

25 Christian Heinrich Schmid, Abriß der Gelehrsamkeit für encyklopädische Vorlesungen (Berlin: Himburg, 1783).

26 Johann Joachim Eschenburg, Lehrbuch der Wissenschaftskunde ein Grundriß encyklopädischer Vorlesungen (Berlin, Stettin: Nicolai, 1792).

27 Johann Stephan Pütter, Neuer Versuch einer Juristischen Encyclopädie und Methodologie nebst etlichen Zugaben (Göttingen: Vandenhoeck, 1767). 
Ompteda's extensive Litteratur des gesammten sowohl natürlichen als positiven Völkerrechts (1785). ${ }^{28}$

There can be no doubt that the Wolffian concept of the law of nations caused this change. Although all these authors acknowledge the close connection between the law of nations and natural law, they treat the law of nations as in some sense a sui generis discipline and deal with it in special chapters or paragraphs, separate from natural law. Beginning with Sulzer, we see that for him the law of nations was still a part of natural law and therefore belonged to philosophy, but he nevertheless treated the law of nations in a special paragraph directly after his remarks on natural law. Sulzer defined jus gentium in the traditional way: 'If one considers different independent civil societies as individual persons and if one applies natural law to these persons, then one gets the law of nations. This law deals with the duties of free states towards each other and analyses their rights concerning peace and war, alliances, pacts and negotiations.29 In his chapter on jurisprudence he mentions natural law again and considers it to be the theoretical basis for law as a whole, but in this explicitly juridical context he does not refer to the law of nations. Since Sulzer was a philosopher and not a lawyer, one should perhaps not expect him to focus on juridical questions, but nevertheless one gets the impression that the law of nations is still not important enough to be treated in a more detailed way, despite the development of the subject into a more and more self-reliant discipline.

This development marks the difference between Sulzer and the later authors. Thus towards the end of our period, Johann Georg Meusel's Leitfaden zur Geschichte der Gelehrsamkeit (180o) emphasizes that 'praktisches Völkerrecht' is a new part of jurisprudence and refers to Vattel, Mably, Martens, Günther and von Römer as eminent authors in this field. ${ }^{30}$ Eschenburg's

28 Dietrich Heinrich Ludwig von Ompteda, Litteratur des gesammten sowohl natürlichen als positiven Völkerrechts. Erster Theil. Nebst vorangestellter Abhandlung von dem Umfange des gesammten sowohl natürlichen als auch positiven Völkerrechts, und Ankündigung eines zu bearbeitenden vollständigen Systems desselben, part 2 (Regenburg: Montag, 1785).

29 Sulzer, Kurzer Begriff aller Wissenschaften, 173-174: 'Wenn man verschiedene unabhängliche bürgerliche Gesellschaften als einzelne Personen betrachtet, und das Recht der Natur auf diese Personen anwendet, so entstehet daher das Völkerrecht. Dieses betrachtet demnach die Pflichten, welche ein freyer Staat gegen andere zu beobachten hat, und untersucht das Recht der freyen Staaten in Ansehung des Krieges und Friedens, der Bündnisse, Verträge und Handlungen'.

30 Johann Georg Meusel, Leitfaden zur Geschichte der Gelehrsamkeit (Leipzig: Fleischer, 1800), 1310: 'Ein neuer Zweig ist das praktische Völkerrecht, in welchem vor dem 18. Jahrhundert noch wenig gearbeitet war'. 
Lehrbuch der Wissenschaftskunde (1792), which was supposed to be a Grundriß encyclopädischer Vorlesungen, is an interesting case insofar as he discusses the law of nations twice: in philosophy and in jurisprudence. As a rather traditional philosopher he suggests that the law of nations is closely connected to natural law and treats the nation as a moral person, but he also distinguishes between the law of nations in general and the positive law of nations: the former 'is based on the general relationships between peoples; [the latter] contains the mutual obligations established between several peoples through custom and contracts.'. ${ }^{31}$ Wolff's Jus gentium and Emer de Vattel's Le droit des gens are recommended for further reading. When Eschenburg treats the law of nations in his chapter on jurisprudence, he simply repeats his remarks from the earlier chapter on philosophy without adding details from the perspective of jurisprudence. The way in which he treats the law of nations twice is indicative of the tendency for the law of nations to make it independent from philosophy.

However, an interesting detail may correct this impression. In the chapter on jurisprudence Eschenburg emphasizes that the natural law of nations ('natürliches Völkerrecht') is the basis of the positive law of nations, 'which fairly deduces its judgements and principles from this source, and which has to be led back to it, in spite of all modifications caused by the requirements of the people. ${ }^{32} \mathrm{He}$ also states in the chapter on philosophy that the obligation of the general law of nations is much stronger than the vis obligandi of the positive law, 'because those are founded on the rights and claims of reason itself, while these in contrast are based on particular temporary agreements and agreed conditions'. ${ }^{33}$ These remarks strengthen the role of philosophy and run counter to the impression mentioned above. Eschenburg seems to try to defend the philosophical status of the law of nations against the already established claim by lawyers that the positive law of nations belongs to juridical practice. In other words, a philosopher is defending his turf against the professional claims by jurists.

31 Eschenburg, Lehrbuch der Wissenschaftskunde, 109: 'Jenes beruht auf den allgemeinen Verhältnissen eines Volks gegen andre; dieses enthält die zwischen mehrern Völkern durch Herkommen und Verträge festgesetzten gegenseitigen Verbindlichkeiten des Verhaltens'.

32 Ibid., 262: '[W]elches seine Entscheidungen und Grundsätze billig aus dieser Quelle herleiten, und, bei aller ihrer nach den Bedürfnissen jedes Volks abgeänderten Anwendung, doch zuletzt auf dieselbe zurückführen muß'.

33 Ibid., 109: '[W] eil jenes die Rechte und Ansprüche der Vernunft, dieses hingegen gewisse vorläufige Einwilligungen und gemachte Bedingungen zum Grunde hat'. 


\section{Effects of Specialization: the Law of Nations in Juridical} Encyclopaedias and the Example of a Specialized historia literaria

The emphasis on the juridical function of the positive law of nations is characteristic of the Göttingen school of law. Johann Stephan Pütter - one of the most famous exponents of this school - wrote his Neuer Versuch einer juristischen Encyclopädie und Methodologie for law students, not for a general academic readership. The law of nations plays a significant role in Pütters's Encyclopädie, insofar as he mentions it at all levels of the work. In his chapter on legal theory he deals with the law of nations together with natural law; in the chapter on positive law, he treats the practical law of nations, especially with respect to the German Empire; and he also speaks about the law of nations in his methodological remarks at the end of the book. In a now familiar way, Pütter distinguishes between the general law of nations ('allgemeines Völkerrecht'), which only applies the principles of natural law to nations, ${ }^{34}$ and the positive law of nations, which is based on contracts on the one hand and customs or tacit consent on the other:

So entire nations do not have other sources of obligation than contracts. Thus there is in fact no other law of nations than the universal one which is a part of the law of nature ( $(19)$. But since obliging customs can be created by tacit consent and since several nations, which are related to each other by sharing the same historical level of civilization, the same soil, the same religion and things like that, agree upon certain principles by contracts and customs, another voluntary (positive) law of nations can be conceived, which undoubtedly exists among the European states today and which already existed in former times. ${ }^{35}$

34 Pütter, Neuer Versuch einer juristischen Encyclopädie und Methodologie, 10-11.

35 Ibid., 13-14: 'Ganze Völker haben daher unter einander keine andere Quelle von dieser Art Verbindlichkeiten, als die sie sich selbst mit Verträgen aufladen. Folglich gibt es eigentlich kein ander Völkerrecht, als das allgemeine, so einen Theil des Rechts der Natur ausmacht (§19). Jedoch sofern auch aus stillschweigender Einwilligung verbindliche Gebräuche entstehen können, und sofern mehrere Völker, die einerlei Welt-Alter, einerley Theil des Erdbodens, einerley Religion und was dergleichen mehr ist, in nähere Verbindung setzt, sich durch Gebräuche und Verträge auf gewisse Grundsätze vereinbaren, und insonderheit manche sonst dem allgemeinen Völkerrechte nach unbestimmte Dinge näher zu bestimmen; so läßt sich noch ein weiteres willkührliches (positives) Völkerrecht denken, dergleichen heutiges Tages unter den Europäischen Staaten unleugbar ist, und in vorigen Zeiten eben so wenig ohne Beyspiel gewesen'. 
This positive law of nations plays multiple roles, especially in Germany. It is applied to the relations between the German Empire as a whole with foreign countries, but it is also applied to the relations of the individual territorial states of the Empire with foreign countries, to the relations of the individual German territorial states with each other, and finally to relations between the individual territorial states and the Empire as a whole. So Pütter is right when he states that a German lawyer has a lot of opportunities to work in the field of the law of nations. For this reason, he recommends his students to study history, especially the modern conflicts between European nations since the Peace of Westphalia, and all parts of the practical law of nations and 'statistics' ('Staatenkunde', theory of the state). ${ }^{36}$ So there is no doubt about the juridical importance of the positive law of nations and, hence, of the necessity to present it extensively in the juridical encyclopaedia. As we have seen, Pütter acknowledges the logical priority of natural law as the basis of all general concepts of law, and he certainly stresses that a lawyer is especially useful ('desto brauchbarer') when he combines a wide range of knowledge of positive law (including the positive law of nations) and case law with the ability to base this knowledge on general terms and concepts. So the study of natural law and the study of positive law (including the positive law of nations) should be linked. To this end, Pütter recommends that natural law should be studied not only at the beginning but also at the end of legal education, 'since especially general constitutional law and the law of nations deserve to be reconsidered in a way that is not possible on the first entry into the study of law'. ${ }^{37}$ In spite of its logical priority, it is clear that aspects of natural law - the general constitutional law and the general law of nations - should be re-interpreted, maybe extended or even modified in the light of positive law in general and of the positive law of nations in particular. So the emancipation of the law of nations has reached a much higher level.

The final step was taken by a student and friend of Pütter, Dietrich Heinrich Ludwig von Ompteda, significantly a lawyer, diplomat, and politician, not an academic. ${ }^{38}$ In his Litteratur des gesammten sowohl natürlichen als positiven Völkerrechts (1785) we find everything we missed in all the other compendia. Ompteda delivered a careful 'historia litteraria seu litteratura juris gentium'39

36 Ibid., 102.

37 Ibid., 67: '[D]a insonderheit auch das allgemeine Staats- und Völker-Recht wohl verdiente, alsdenn noch mit andern Augen angesehen werden, als es beym ersten Eintritt in die Rechtswissenschaft geschehen kann'.

38 The title page of his book mentions Ompteda's functions: 'Königl. Grosbrit. Churfürstl. Braunschw. Lüneb. Comitial-Gesandter bey der Reichsversammlung zu Regensburg und bevollmächtigter Minister am Churpfälz. Hofe zu München'.

Ompteda, Litteratur des gesammten sowohl natürlichen als positiven Völkerrechts, 91. 
of no less than 672 pages, in which topics were extensively differentiated - the detailed table of contents alone takes up 21 pages. The book met a desideratum of his time. When Ompteda began his study of international law, he was amazed by the quantity of bibliographical material and the complete lack of guidance through the wide-ranging scholarship on the law of nations. Other scholars had lamented that there was no compendium to this literature, although the law of nations was already an independent discipline separate from natural law. ${ }^{40}$ Ompteda considered his book to be a counterpart to Pütter's Litteratur des teutschen Staatsrechts. Like Pütter's, it is divided into two parts, 'history of the discipline and bibliographical guidance'41 - and it does in fact provide a highly systematic and annotated bibliography of the whole of the relevant literature on the law of nations. Ompteda's work is not a compendium of historia literaria intending to offer an orientation to the world of academic knowledge to new students. It is, rather, a general reference work, written for experts by an expert who was a lawyer and a politician at the same time.

German histories of learning seem to reflect fairly precisely the development of the general discussion of the law of nations in Germany. Initially, historians of scholarship were not interested in presenting the theoretical aspects of or bibliographical material on the law of nations, thus reflecting the distance of early natural lawyers to the subject - although the historia literaria juris gentium of Ompteda does provide evidence that the earlier discussion of the law of nations was in fact more lively than one might have expected. In all the compendia consulted for the present survey, discussions of natural law dominate. It played a significant role in normative political thought and - perhaps even more - in moral theory, so it is not surprising that those historians of learning and those authors of encyclopaedias who had moral concerns ${ }^{42}$ focused on natural law, especially since this focus was supported by the political circumstances in Germany, with its composite constitutional structure. The situation changed when the works of Glafey, Wolff and Vattel appeared - the discussion of international law became more elaborate and it was given a theoretical and practical basis.

$40 \quad$ Ibid., 'Vorrede,' n.p.

41 Ibid., 93: 'Geschichte der Wissenschaft und Bücherkunde'.

42 See Frank Grunert, "Von "guten" Büchern. Zum moralischen Anspruch der Gelehrsamkeitsgeschichte,' in Historia literaria, ed. Grunert and Vollhardt, 65-88. 
The differentiation and specialization of the law of nations was reflected in historia literaria, which was a medium for scholarly developments, and when the law of nations became more important as a subject in legal studies, specialized propaedeutic compendia began to include more information on this field. The historia literaria juris gentium by Ompteda gives a wide-ranging overview of all aspects of the law of nations, from the earliest times to his own. Even though it was not by any means fully specialized, it did facilitate even more differentiation. This development may be contrasted with the state of the generalist histories of learning, in which the treatment of the law of nations remained quite poor. These historians of scholarship - both before and after Friedrich Schiller's Briefe zur ästhetischen Erziehung des Menschen - pursued a more holistic ideal of explicit philosophical 'Bildung', and that entailed an aversion to specialization and a neglect of, for example, the emergence of the law of nations as a separate discipline, even when they were well aware of this.

\section{Bibliography}

Altwicker, Tilmann, Cheneval, Francis and Diggelmann, Oliver (eds.), Völkerrechtsphilosophie der Frühaufklärung (Tübingen: Mohr Siebeck, 2015).

Bacon, Francis, The Works of Francis Bacon, ed. James Spedding et al., vol. 3 (London: Longman, 1859).

Diggelmann, Oliver, 'The Periodization of the History of International Law, in The Oxford Handbook of the History of International Law, ed. Bardo Fassbender and Anne Peters (Oxford: Oxford University Press, 2012), 997-1011.

Eschenburg, Johann Joachim, Lehrbuch der Wissenschaftskunde. Ein Grundriß encyklopädischer Vorlesungen (Berlin and Stettin: Nicolai, 1792).

Fabricius, Johann Andreas, Abriß einer allgemeinen Historie der Gelehrsamkeit, vol. 1 (Leipzig: Weidmann, 1752).

Gierl, Martin, 'Bestandsaufnahme im gelehrten Bereich. Zur Entwicklung der "Historia Literaria" im 18. Jahrhundert,' in Denkhorizonte und Handlungsspielräume. Festschrift für Rudolf Vierhaus zum 7o. Geburtstag (Göttingen: Wallstein, 1992), 53-80.

Glafey, Adam Friedrich, Vernunfft-und Völcker-Recht (Frankfurt and Leipzig: Christoph Riegel, 1723).

Grewe, Wilhelm, The Epochs of International Law, transl. and revised by Michael Byers (Berlin: de Gruyter, 200o).

Grunert, Frank and Vollhardt, Friedrich (eds.), Historia literaria. Neuordnung des Wissens im 17. und 18. Jahrhundert (Berlin: Akademie Verlag, 2007).

Grunert, Frank, "Viel Tausend und Millionen Bücher". Zur Bewältigung und zur Hervorbringung von Wissenspluralität in der frühneuzeitlichen "Historia literaria", 
in Pluralisierungen. Konzepte zur Erfassung der Frühen Neuzeit, ed. Jan-Dirk Müller, Wulff Österreicher and Friedrich Vollhardt (Berlin: de Gruyter, 2010), 191-2O2.

Grunert, Frank and Syndikus, Anette, 'Historia literaria. Erschließung, Speicherung und Vermittlung von Wissen,' in Wissensspeicher der Frühen Neuzeit. Formen und Funktionen, ed. Frank Grunert and Anette Syndikus (Berlin: de Gruyter, 2015), 243-293.

Gundling, Nicolaus Hieronymus, Collegium uber die Historiam litterariam (Halle, [1713]).

Gundling, Nicolaus Hieronymus, Jus naturae ac gentium, 3rd ed. (Halle: Renger 1736).

Heumann, Christoph August, Conspectus reipublicae literariae sive via ad historiam literariam iuventuti studiosae aperta, editio tertia (Hannover: apud Io. Jacobum Foersterum, 1733).

Lehmann-Brauns, Sicco, 'Neukonturierung und methodologische Reflexion der Wissenschaftsgeschichte. Heumanns Conspectus reipublicae literariae als Lehrbuch der aufgeklärten Historia literaria,' in Historia literaria. Neuordnung des Wissens im 17. und 18. Jahrhundert, ed. Frank Grunert and Friedrich Vollhardt (Berlin: Akademie Verlag, 2007) 129-16o.

Marti, Hanspeter, '§ 62. Litterärgeschichte (historia literaria),' in Helmut Holzhey, Vilem Mudroch (eds.): Grundriss der Geschichte der Philosophie, begr. von Friedrich Ueberweg. Die Philosophie des 18. Jahrhunderts, vol. 5, ed. Helmut Holzhey and Vilem Mudroch (Basel: Schwabe, 2014), 1425-1429.

Meusel, Johann Georg, Leitfaden zur Geschichte der Gelehrsamkeit (Leipzig: Fleischer, 180o).

Neff, Stephen C., Justice among Nations. A History of International Law (Cambridge, MA: Harvard University Press, 2014).

Nelles, Paul, 'Historia litteraria at Helmstedt: Books, professors and students in the early Enlightenment university,' in Die Praktiken der Gelehrsamkeit in der Frühen Neuzeit, ed. Helmut Zedelmaier and Martin Mulsow (Tübingen: Niemeyer, 2001), 147-176.

Ompteda, Dietrich Heinrich Ludwig von, Litteratur des gesammten sowohl natürlichen als positiven Völkerrechts. Erster Theil. Nebst vorangestellter Abhandlung von dem Umfange des gesammten sowohl natürlichen als auch positiven Völkerrechts, und Ankündigung eines zu bearbeitenden vollständigen Systems desselben, part 2 (Regensburg: Montag, 1785).

Pütter, Johann Stephan, Neuer Versuch einer Juristischen Encyclopädie und Methodologie nebst etlichen Zugaben (Göttingen: Vandenhoeck, 1767).

Schmeitzel, Martin, Versuch zu einer Historie der Gelehrheit (Jena: Fickelscherr, 1728).

Schmid, Christian Heinrich, Abriß der Gelehrsamkeit für encyklopädische Vorlesungen (Berlin: Himburg, 1783).

Schmidt, Frank-Steffen, Praktisches Naturrecht zwischen Thomasius und Wolff: Der Völkerrechtler Adam Friedrich Glafey (1692-1753) (Baden-Baden: Nomos, 2007). 
Seidler, Michael, 'Der Begriff des Völkerrechts bei Samuel Pufendorf,' in Völkerrechtsphilosophie der Frühaufklärung, ed. T. Altwicker, F. Cheneval and O. Diggelmann (Tübingen: Mohr Siebeck, 2015), 61-78.

Stolle, Gottlieb, Kurtze Anleitung zur Historie der Gelahrheit (Halle: Neue Buchhandlung, 1718).

Stolle, Gottlieb, Anleitung zur Historie der juristischen Gelahrheit (Jena:Johann Meyers seel. Erben, 1745).

Sulzer, Johann Georg, Kurzer Begriff aller Wissenschaften und andern Theile der Gelehrsamkeit, worin jeder nach seinem Innhalt, Nuzen und Vollkommenheit kürzlich beschrieben wird, 4th ed. (Frankfurt and Leipzig: [s.n.],1774).

Syndikus, Anette, 'Historia literaria als Propädeutikum an der Königsberger Universität des 18. Jahrhunderts', in Die Universität Königsberg in der Frühen Neuzeit, ed. Hanspeter Marti, Manfred Komorowski (Köln, Wien, Weimar: Böhlau, 2008), 379-422.

Textor, Johann Wolfgang, Synopsis juris gentium (Basel: Rüdinger, 168o).

Thomasius, Christian, Institutiones jurisprudentiae divinae (Frankfurt and Leipzig: M.G. Weidmann, 1688).

Thomasius, Christian, Fundamenta juris naturae et gentium (Halle: Salfeld, 1705).

Thomasius, Christian, Institutes of Divine Jurisprudence with Selections from Foundations of the Law of Nature and Nations, ed., transl. and with an Introduction by Thomas Ahnert (Indianapolis, IN: Liberty Fund, 2011).

Wolff, Christian, Jus Gentium Methodo Scientifica Pertractatum (Halle: Renger, 1749), in Gesammelte Werke, Abt. 2, vol. 25 (Hildesheim, Zürich, New York: Olms, 1972).

Wolff, Christian, The Law of Nations treated according the Scientific Method, transl. Joseph H. Drake, ed. and with an Introduction by Thomas Ahnert (Carmel, IN: Liberty Fund, 2017).

Zedelmaier, Helmut, “Historia Literaria”. Über den epistemologischen Ort des gelehrten Wissens in der ersten Hälfte des 18. Jahrhunderts,' Das achtzehnte Jahrhundert 22, 1 (1998): 11-21.

Zedelmaier, Helmut, 'Heumanns Conspectus Reipublicae Literariae. Besonderheit, Kontext, Grenzen,' in Christoph August Heumann (1684-1764). Gelehrte Praxis zwischen christlichem Humanismus und Aufklärung, ed. Martin Mulsow, Kasper Risbjerg Eskildsen and Helmut Zedelmaier (Stuttgart: Franz Steiner, 2017), 71-92.

Ziegler, Karl-Heinz, Völkerrechtsgeschichte, 2nd ed. (München: Beck, 2007). 
PART 2

The Law of Nations from the Peace of Westphalia to the Enlightenment 



\title{
Pufendorf on the Law of Sociality and the Law of Nations
}

\author{
Kari Saastamoinen
}

In his grand exposition of natural law, De jure naturae et gentium (hereafter $J N G),{ }^{1}$ Samuel Pufendorf denied the existence of a separate law of nations as a set of positive legislation agreed by all nations. Following Thomas Hobbes, he maintained that the norms which prevailed between sovereign states were nothing but the application of the law of nature to interstate relations. ${ }^{2}$ The fundamental principle of natural law, in turn, was the duty to cultivate and maintain sociality towards other human beings. ${ }^{3}$ This much about Pufendorf's views can be said without much disagreement among modern commentators. But once we ask what he meant by the endorsement of sociality, among individuals or between states, things become complicated and scholarly opinion diverges. One reason for rival interpretations is that Pufendorf's remarks on the law of nature oscillated between two seemingly incompatible positions. On the one hand, he not only observed that human beings are by nature preoccupied with their personal safety and welfare, but also emphasized that observing natural law serves their long-term interests. With such remarks, he appeared to follow Hobbes in deducing natural law from the requirements of

1 Samuel Pufendorf, De jure naturce et gentium libri octo (Lund: 1672). The modern scholarly edition is De jure naturae et gentium, 2 vols., ed. Frank Böhling, Samuel Pufendorf: Gesammelte Werke, ed. Wilhelm Schmidt-Biggemann, vols. 4.1-2 (Berlin: Akademie Verlag, 1998). This edition identifies the additions Pufendorf made to the expanded edition published in 1684 (JNG 1684). Most of the English translations are from De jure naturae et gentium libri octo, 2 vols., vol. 2: Of the Law of Nature and Nations, transl. C.H. Oldfather and W.A. Oldfather, The Classics of International Law, ed. J.B. Scott, no. 17 (Oxford: Clarendon Press, 1934), hereafter $L N N$. Occasionally, I also use The Political Writings of Samuel Pufendorf, transl. Michael J. Seidler, ed. Craig L. Carr (New York: Oxford University Press, 1994). On Pufendorf, his historical significance and modern Pufendorf scholarship see Michael Seidler, 'Pufendorf's Moral and Political Philosophy,' The Stanford Encyclopedia of Philosophy (Winter 2015 Edition), ed. Edward N. Zalta, https://plato.stanford.edu/archives/win2015/entries/pufendorf-moral/.

$2 J N G$ 1672, book II, chap. 3, § 22 (1684, book II, chap. 3, § 23). $L N N, 226$.

$3 J N G 1672$, book II, chap. 3 , § $15 . L N N, 208$. 
individual self-preservation. On the other hand, Pufendorf explicitly distanced his method of deducing natural law from that of Hobbes, maintaining that natural law imposes on human beings a reciprocal duty of general friendship, which is not dependent on any consequences for their own security or welfare but relies solely on their shared humanity.

It has been suggested that the discrepancy between these two ways of characterizing natural law is resolved once we realize that only the first mentioned expressed Pufendorf's sincere opinion on the issue. Despite ostensible attempts to distance himself from Hobbes, Pufendorf followed the English philosopher in identifying natural law with principles needed for individual security and welfare. His efforts to dissociate himself from Hobbes on this issue were motivated by a need to avoid the reputation of being a follower of Hobbes, who was widely associated with atheism and amorality in seventeenth-century Europe. This aspiration was especially strong in the expanded edition of $J N G$ published in 1684, as the accusation of being a Hobbist had been one of the charges levelled at Pufendorf after the publication of the first edition in $1672 .{ }^{4}$ Recently, the idea of the Hobbesian character of Pufendorf's theory has also been associated with what is called his international theory. ${ }^{5}$ Pufendorf is

4 The idea of the Hobbesian character of Pufendorf's natural law is defended in great detail in Fiammetta Palladini, Samuel Pufendorf dicepolo di Hobbes: Per una reinterpretazione del giusnaturalismo moderno (Bologna: Il Mulino, 199o). See also Palladini, 'Pufendorf Disciple of Hobbes: The Nature of Man and the State of Nature: The Doctrine of socialitas,' History of European Ideas, 34 (2008): 26-6o. On the debate following the publication of JNG 1672, see Palladini, Discussioni seicentesche su Samuel Pufendorf. Scritti Latini: 1663-170o (Bologna: Il Mulino, 1978). The idea that Pufendorf deduced the content of natural law from the requirements of individual self-preservation is also to be found in Istvan Hont, "The Language of Sociability and Commerce: Samuel Pufendorf and the Theoretical Foundations of the "FourStages" Theory, in The Language of Political Theory in Early-Modern Europe, ed. Anthony Pagden (Cambridge: Cambridge University Press, 1987), 253, 267; and in Richard Tuck, 'The "Modern" Theory of Natural Law,' in The Languages of Political Theory in Early-Modern Europe, ed. Anthony Pagden (Cambridge: Cambridge University Press, 1987), 105. Tuck has later modified his position, seeing now a marked difference between Hobbes and Pufendorf on this issue. Richard Tuck, The Rights of War and Peace. Political Thought and the International Order from Grotius to Kant (Oxford: Oxford University Press, 1999), 151-152. See also Ian Hunter, 'Natural Law as Political Philosophy,' in The Oxford Handbook of Philosophy in Early Modern Europe, ed. Desmond Clarke and Catherine Wilson (Oxford: Oxford University Press, 2011), 490.

5 Theodore Christov, Before Anarchy. Hobbes and His Critics in Modern International Thought (New York: Cambridge University Press, 2015). Other recent writings exploring Pufendorf from the perspective of international relations are Peter Schröder, Trust in Early Modern International Political Thought, 1598-1713 (Cambridge: Cambridge University Press, 2017), Ben Holland, The Moral Person of the State. Pufendorf. Sovereignty, and Composite Polities (Cambridge: Cambridge University Press, 2017), and Vanda Fiorillo, 'States, as Ethico-Political 
presented as a closet Hobbesian who used the vocabulary of sociality to camouflage the similarities between his and Hobbes's conclusions. Behind his 'selfprofessed anti-Hobbesian sentiments', Pufendorf implicitly acknowledged the 'authentically Hobbesian foundations in the construction of the international political order' 6

The idea of the close affinity between Hobbes's and Pufendorf's accounts of natural law has obvious merits. Above all, it has made obsolete the previously widely shared view of Pufendorf as Hobbes's adversary, who rejected the latter's gloomy picture of human nature and established natural law on the idea of a natural human inclination to sociability, inspired by Hugo Grotius. While Pufendorf heralded Grotius as his most important predecessor in the study of natural law, it has been shown convincingly that the single most significant intellectual inspiration behind his theory was Hobbes. Pufendorf found no natural inclination to peaceful sociality in human nature, as he saw human behaviour governed mainly by self-love and self-preservation, and often also by an inclination to hurt others. The cultivation of sociality was a norm imposed on such creatures with the purpose of advancing peaceful social life. The Hobbesian inspiration was even more obvious in Pufendorf's theories of the state of nature and civil society. It also seems plausible that Pufendorf wanted to avoid the reputation of being a Hobbesian, and some of the things he wrote to that end may well have been the original source for his fame as an adversary of Hobbes. ${ }^{7}$

Nevertheless, nothing in the above forces us to conclude that Pufendorf followed Hobbes in deducing natural law from the requirements of individual selfpreservation. And in this chapter, I will argue that there are good reasons for holding that he did not. While Pufendorf shared Hobbes's view of the pivotal role self-preservation and self-love play in human behaviour, his idea of natural law differed significantly from that of the English philosopher. This disagreement between Hobbes and Pufendorf was most visible in their rival views on the character and status natural law has outside civil society, and it indicated noteworthy differences in the ways they articulated the moral relations between sovereign states. In the first part of this chapter, I will explore how Pufendorf

Subjects of International Law: The Relationship between Theory and Practice in the International Politics of Samuel Pufendorf,' in System, Order, and International Law: The Early History of International Legal Thought from Machiavelli to Hegel, ed. Stefan Kadelbach, Thomas Kleinlein, and David Roth-Isigkeit (Oxford: Oxford University Press, 2017), 199-215. These works came out too late to be commented on here.

6 Christov, Before Anarchy, 143-157, 176.

7 Palladini, 'Pufendorf Disciple of Hobbes,' 59-6o. 
deduced the cultivation of sociality as the fundamental principle of natural law. In the second part, I will analyse his remarks on Hobbes's theory and show how their different methods of deducing natural law were connected to their dissimilar understanding of interstate relations. In doing this, I will distinguish between what Pufentorf wrote in the first edition of $J N G$ (JNG 1672) and what he added to the edition of 1684 (JNG 1684). While the numerous new references to classic Stoic texts and Richard Cumberland's anti-Hobbesian De legibus naturae (1672) may well have served the purpose of defending the author from the charges of being a Hobbesian, many of the remarks Pufendorf added to JNG 1684 were fully in line with the theory he had put forward in $J N G 1672$.

\section{Sociality as the Fundamental Principle of Natural Law}

The first thing to explore here is the demonstrative science of natural law. For Pufendorf, reflecting on natural law and sociality was not a matter of adopting some true philosophical doctrine. There were many argumentative strategies to convince people of their need to ponder morality and social institutions from the perspective of sociality. ${ }^{9}$ One could try to convince them that it serves their personal interests to do so, or one could use suitable citations from philosophers of different schools to show how wise men have reached similar conclusions despite their dissimilar intellectual starting points. In JNG Pufendorf used both approaches, but he also found it important to argue that there was a demonstrative science of natural law. By 'demonstrative science' he did not refer to a process of inquiry but to a certain type of organized knowledge. The model for such knowledge was not Euclidian geometry, which had inspired his early Elementorum jurisprudentiae universalis (1660), but the Aristotelian demonstrative syllogism. Demonstrative science consists of evident propositions and propositions which can be reduced back to such obvious statements, and it offers knowledge about necessary connections between things. In this way, it is 'certain and clear' as well as valid 'everywhere and at all times.'10

8 In this part I will reformulate and further develop ideas presented in Kari Saastamoinen, The Morality of the Fallen Man. Samuel Pufendorf on Natural Law (Helsinki: Finnish Historical Society, 1995).

9 This much, at least, I agree with Knud Haakonssen, 'Rejoinder to My Commentators,' in 'Pufendorf on Power and Liberty', in the series Liberty Matters: A Forum for the Discussion of Matters pertaining to Liberty (January 2017). http://oll.libertyfund.org/pages/lm-pufendorf. JNG 1672, book I, chap. 2, § 3. LNN, 23-24. On Pufendorf's moral science, see Saastamoinen, The Morality of the Fallen Man, 54-62. 
In Pufendorf's view, it was an error to think, as most scholars had done, that demonstrative certainty is impossible in moral sciences. ${ }^{11}$ This did not mean, however, that the quest for certainty was a central concern of his enterprise. Human beings adopt their moral views unreflectively from education and prevailing social practices, and most of them lack the capacity to understand how natural law follows from first principles. ${ }^{12}$ Their knowledge of natural law is always probable in character, and Pufendorf saw no need for things to be otherwise. His criticism of the view that moral sciences lack demonstrative certainty was not that this had left humankind in a state of moral scepticism. What he complained about was that it 'has worked an immense injury' to moral science, as it has 'caused scholars to investigate but diffidently into that which they believed rested on so slippery a foundation'. To those scholars who have altogether neglected the moral sciences, it has offered 'the plausible excuse, that they were founded on no certain demonstrations, and could be treated merely in a rough and ready fashion.'13

Achieving full certainty was less important than exploring natural law in a thorough manner and having a clear understanding of its character and purpose. Such an intellectual exercise was the job of intelligent and well-educated experts and persons in important governmental positions, and it was these people Pufendorf addressed in JNG. It is important to note that his demonstrative account of natural law did not aim to describe or transform the moral selfunderstanding of the uneducated common people, who observed natural law by following the general example of society, without comprehending how its precepts could be demonstrated. ${ }^{14}$ In the case of the common people, it was the duty of the sovereign to take care that they follow laws not so much due to their fear of punishment than out of habit. ${ }^{15}$ To be sure, even those with mediocre intelligence could understand the demonstration of natural law, if this was presented to them by others. ${ }^{16}$ Yet, Pufendorf made it clear that his compendium of natural law for university students, De officio hominis et civis (hereafter $\mathrm{OHC}$ ), offered only the rudiments of the demonstrative understanding of natural law. ${ }^{17}$ In the preface to this work he explained how it is 'in the public interest to steep

\footnotetext{
$11 J N G$ 1672, book I, chap. 2, § 1. LNN, 22.

$12 J N G$ 1672, book I, chap. 3, § 5; book II, chap. 3, § 13. LNN, 42, 2O2-2O3.

$13 J N G 1672$, book I, chap. 2, § 1. LNN, 22.

$14 J N G$ 1672, book II, chap. 3, § 13. LNN, 2O2-203.

$15 J N G$ 1672, book VII, chap. 9, § 4. $L N N$, 1119. On Pufendorf's views on habitual behaviour, see Heikki Haara, Sociability in Samuel Pufendorf's Natural Law Theory (PhD diss., University of Helsinki, 2017), 27-36.

$16 J N G$ 1672, book II, chap. 3, § 13. LNN, 202.

17 Samuel Pufendorf, De officio hominis et civis juxta legem naturalem libri duo (Lund: 1673). The modern scholarly edition is De Officio, ed. Gerald Hartung, Samuel
} 
in the minds of young men a moral doctrine whose usefulness in civil life is accepted as obvious'. But to achieve this aim one should take care that students are not 'put off at the beginning by a massive accumulation of difficult questions', which would happen if they were 'to set out on the wide expanses of this subject without a knowledge of what one might call the elements.' ${ }^{18}$ Thus, the idea of demonstrative moral science was unmentioned in $O H C$, and the argumentation in this work was often considerably looser than in JNG. This should not, however, be understood to mean that Pufendorf regarded the idea of demonstrative moral science as insignificant. After all, what was equally missing in $O H C$ was one of his main claims to fame: the theory of moral entities. ${ }^{19}$

The important point in this context is that when Pufendorf defended the possibility of demonstrative moral knowledge, he made a distinction between two fields of moral sciences. One of them, associated by Pufendorf with prudence, is concerned with 'the successful management of one's own actions and those of others, with an eye to the security and welfare primarily of the public'. ${ }^{20}$ This kind of reasoning cannot achieve demonstrative certainty, as it is founded on 'axioms drawn by a dexterous observation and collection of the customs of men and the events of human history', and because 'the smallest things can change radically the outcome in human affairs'.21 The other field of moral science deals with norms which determine the rectitude of human actions, and this is by and large identical with the science of natural law. Pufendorf explained that why this kind of moral knowledge can be demonstrative would become fully apparent later in the work, when he explores the origins of natural law. ${ }^{22}$ This indicated that the demonstrative character of such knowledge has to do with premises which are founded on the contemplation of 'man's nature, condition and inclinations'.23 Pufendorf added that while our actions are free, and therefore not necessary, once some principles have been imposed on them, this gives rise to 'affections', which can be demonstrated. ${ }^{24}$ In $J N G 1684$ he clarified this remark by explaining that 'the acts which fall under the conduct of the law of nature have an intrinsic force toward sociality'

Pufendorf: Gesammelte Werke, ed. Wilhelm Schmidt-Biggemann, vol. 2 (Berlin: Akademie Verlag, 1997). OHC, Prefatio. The English translation is from On the Duty of Man Citizen, ed. James Tully, transl. Michael Silverthorne (Cambridge: Cambridge University Press, 1991), 6.

19 On moral entities, see $J N G$ 1672, book I, chap. 1.

$20 \quad J N G$ 1672, book I, chap. 2, § 4. LNN, 24.

$21 J N G$ 1672, book I, chap. 2, § 4. $L N N, 25$.

$22 J N G$ 1672, book I, chap. 2, § 5. LNN, 26.

$23 J N G$ 1672, book II, chap. 3, § 14. LNN, 205.

$24 J N G$ 1672, book I, chap. 2, § 5. LNN, 26. 
(socialitas). ${ }^{25}$ While these acts are contingent in the sense that they follow from our free decisions, the relationship between these acts and their effects on sociality 'is necessary and natural, and therefore capable of demonstration.' ${ }^{26}$ Below we will see how Pufendorf referred, already in JNG 1672, to this idea in his definition of the fundamental principle.

Natural law has to do with acts which have a necessary effect on sociality among human beings. To be sure, Pufendorf made it clear that there is also a strong positive correlation between the observance of natural law and the promotion of one's personal salus, a term which referred to both physical security and welfare. This is a theme Pufendorf emphasized especially in JNG 1684. All in all, actions which are in accordance with the rules of sociality not only 'maintain and increase a man's standing, reputation, and position', but also 'procure some advantage and reward for a man, and contribute to his happiness'. Actions repugnant to these rules, in turn, 'may at times return some utility, and more often some pleasure, which however never endures for long, and is followed by a throng of much greater ills. ${ }^{27}$ However, in the paragraph on the sanctions of natural law added to JNG 1684 Pufendorf gave a more nuanced picture of the issue. There, he admitted that those are not totally mistaken who claim that 'many are returned for their benefactions only hatred, envy, and other ills, while, on the other hand, others enjoy without punishment the fruits of their evil deeds'. Accordingly, Pufendorf qualified his position by pointing out that, while 'it cannot be assumed, without chance of error, that for our good deeds we shall be returned in kind by other men', still 'it is sure that, from good actions, we can reasonably hope for advantages with a degree of certainty that would not be justified if one were to expect to get them from opposed vices'. While the consequences of our morally good deeds are never certain, there 'is still an evident probability that not a few benefits will follow, or at all events more than what can be expected from evil actions.' ${ }^{28}$

In other words, while actions ordered or forbidden by natural law have a necessary effect on sociality, their effects on our personal safety and welfare are never more than highly probable. For example, a person who steals a large sum of money evidently violates natural law. And while the likeliest scenario is that this person will be severely punished, it is not impossible that he or she

$25 J N G$ 1684, book I, chap. 2, § 5: 'Sane enim constat, actus, de quibus naturali lege disponitur, intrinsecam habere vim ad socialitatem'. Translation K.S.

26 Ibid. '[N]exus inter actus nostros \& effectus omnes independentes necessarius est, \& plane naturalis, eoque demostrationis capax'. $L N N, 26$.

27 JNG 1684, book II, chap. 3, § 10. LNN, 196.

$28 J N G$ 1684, book II, chap. 3 , § 21. LNN, 223. 
will not get caught, but end up being a rich and respected member of society. Such uncertainty concerning the effects of our actions does not characterize the consequences stealing money has for sociality. Human beings cannot but be grossly aggravated when someone takes their property without their permission, wherefore theft has always a negative effect on sociality. ${ }^{29}$ This would suggest that, in Pufendorf's theory, the duty to cultivate sociality is not merely a means to promote one's own security and welfare. While human beings have strong innate inclination to preserve their own lives and to promote their personal welfare, their most fundamental moral duty is to behave in a manner which promotes sociality among human beings.

There are several features in $J N G$ which support this interpretation. The first thing to note is the role Pufendorf gave to God in defining the content of the fundamental principle. It is well known that he saw the morally obligating character of natural law as being dependent on the idea that it is imposed by God. ${ }^{30}$ However, the idea of God was explicitly present also throughout his discussion of the content of the fundamental principle. While Pufendorf saw human reason as unable to understand the true character of God, this did not prevent him from holding that reason can make it possible to draw some conclusions about God's intentions in creating the human species. Already in the chapter on the moral entities he declared that the first moral entities were imposed on human beings by God, who did not want human beings to live 'without being accountable to any law, rule, or necessity' but wanted 'men's life and actions to be tempered by certain principles. ${ }^{31}$ More importantly, Pufendorf started the discussion of natural law in JNG Book II by asking how, since God has given human beings a free will, do we know for sure that God had not granted them a full liberty to follow their own will but wants them to observe a law. ${ }^{32}$ His answer was that we know this from the fact that full liberty would be disadvantageous and prejudicial to human nature, and that the salus of human nature requires it to be restricted by law. ${ }^{33}$ While God has given other animal species a sort of liberty to follow their own desires, the fact that they had not been endowed with a soul capable of recognizing a law makes it apparent that God was pleased to manifest his power simply by creating and destroying them. ${ }^{34}$ In the case of human beings, the fact that God has endowed them with

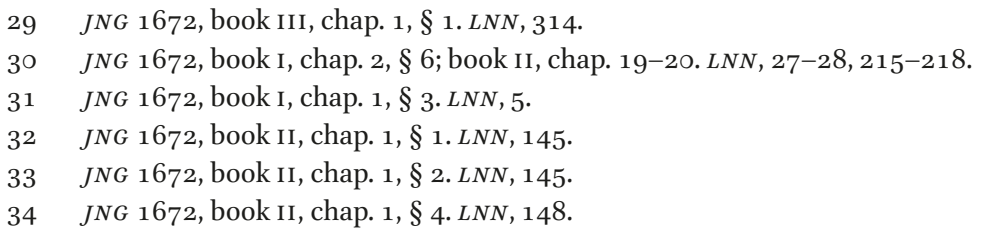


intellectual and moral capabilities indicate that God wanted them to establish an organized way of living, and by doing so increase God's glory and their own happiness. ${ }^{35}$ Moreover, the inability of human individuals to survive without the company and assistance of other members of their species means that a social way of living is necessary for the salus of human beings. Yet, the strong human proclivity to hurt one another and the great variety of their inclinations indicate that social life is impossible without law. Thus, Pufendorf closed the discussion by concluding that the idea of the natural liberty of human beings should always be understood as 'something restrained by sane reason and natural law'. ${ }^{36}$

The above indicates clearly and explicitly that God is concerned with the salus of human beings, and that this is the aim for which he has imposed natural law on them. This was the most elementary assumption in Pufendorf's deduction of the fundamental principle. It was also an idea which, he thought, most of his readers were ready to accept, irrespective of their religious confession and without further evidence or argument. Equally obvious was that God has imposed natural law on the human species collectively. This idea may sometimes be blurred by the fact that Pufendorf used, in the conventional manner, the singular form, homo, as a generic term to indicate both the whole human species and human individuals as representatives of the species. Thus, he spoke interchangeably about the salus of a human being, the salus of human nature and the salus of the human species. ${ }^{37} \mathrm{He}$ also explained how after God had made a human being (homo) an animal who could not be salvum unless he observed natural law, one could not believe that God would annul or change natural law without changing human nature. ${ }^{38}$ In this statement homo did not refer to the members of the human species individually, as Pufendorf knew well that there are people who prosper even though they have violated natural law. It signified the whole human species, which cannot survive unless a significant majority of its members observe natural law at least most of the time. Of course, Pufendorf did not hold that the preservation and welfare of the human species could be separated from the salus of its individual members. But this was something he presented, already in 1672 , as a corollary of the duty to cultivate sociality. The sociality for which God has created human beings 'cannot be exercised and preserved to good advantage unless every man improves and preserves himself to the best of his ability'. Thus, 'when a man

$35 J N G$ 1672, book II, chap. 1, § 5. LNN, 149 .

$36 \quad J N G$ 1672, book II, chap. 1, § 6-8. LNN, 149-153.

37 JNG 1672, book II, chap. 1, § 2; book II, chap. 3, § 11, § 15. LNN, 145, 199, 208.

$38 J N G 1672$, book II, chap. 3 , § 5. LNN, 185 . 
neglects his own care, he works an injury, not, indeed, on himself, but on God, his Creator, and on the human race. ${ }^{39}$ In $J N G ~ 1684$ Pufendorf encapsulated this idea in the remark that 'the safety [salus] of the whole of human society is an unintelligible phrase, if it makes no difference whether individuals are safe [salvum] or not: 40

How, then, do we know that God has imposed the duty to cultivate sociality on the human species? The mere fact that God wants humankind to survive and prosper does not tell us what norms human beings should obey to achieve this end. At the beginning of the chapter 'On the law of nature in general', Pufendorf explained that, after showing how the condition God has imposed on human beings does not permit them to live without law, he would now explore the most general norm human beings are obligated to follow. ${ }^{41}$ After commenting on some previously presented ideas about natural law, he did this in much-cited paragraphs II.3.14-15.

It should be clear by now that, when Pufendorf at the beginning of paragraph II.3.14 declared that 'there is no more direct and appropriate way to investigate natural law than to contemplate carefully man's nature, condition, and inclinations', this did not indicate a fresh start out of nothing. Pufendorf took it for granted that the general end of natural law, the salus of the human species, was clear for every attentive reader. And since these readers understood that human salus consists of both preservation and welfare, he could say, before making a single observation concerning the human condition, that whether this law is imposed by God 'to advance man's happiness or to restrain his evil dispositions, which may be to his own destruction, there is no easier way to learn it than by observing when man needs assistance and when he needs restraint'42 Thus, when Pufendorf started his contemplation on the human condition by referring to the tendency of human beings to love themselves more than others, and to protect their own lives by all possible means, he was not declaring that in these inclinations we have found the true end of natural law: individual preservation and welfare. ${ }^{43}$ Pufendorf's point was that in determining the most general norm needed for the salus of the human

$39 J N G$ 1672, book II, chap. 4, § 1 (1684, book II, chap. 4, § 16). LNN, 256.

$40 \quad J N G$ 1684, book II, chap. 4, § 16. LNN, 256.

$41 J N G 1672$, book II, chap. 3, § 1. LNN, 179.

$42 J N G$ 1672, book II, chap. 3, § 14. LNN, 205.

43 Later in $J N G$ Pufendorf made it clear that the mere fact that the human nature is endowed with an affect or an inclination does not indicate that this is how natural law wants human beings to behave, as most of such natural tendencies are evidently opposed to natural law. JNG 1672, book VI, chap. 1, § 28. LNN, 891 . 
species one could not rely on any human tendency to altruism or self-sacrifice. Instead, one had to take seriously the fact that human beings are usually ready to give assistance to others only if they think that it is in their own interest to do so, and that they are bound to behave aggressively towards anyone they see as a threat to their own security. The other relevant features for identifying the fundamental norm were the inability of human beings to survive without other people's assistance, their extensive ability to help each other, and their strong tendency to inflict harm on one another. ${ }^{44}$

After these observations, Pufendorf was ready to deduce the most general norm for the salus of the human species. His argument had an empirical and a normative component. The empirical component goes as follows.

Man [homo], it is clearly apparent, is an animal most eager to preserve himself, essentially in need, ill-equipped to maintain himself without the aid of those who are like him, and very well suited for the mutual promotion of advantages. All the same, he is often malicious, insolent, easily annoyed, and both ready and able to inflict harm. For this kind of animal to be safe [ut salvum sit], it is necessary that he be sociable. That is, he must will to be so united with those who are similar to himself and conduct himself towards them in such a way that they are provided with no cause to hurt him but instead have a reason to maintain or promote his advantage. ${ }^{45}$

Here, homo is a generic term referring to the human species, and the statement expresses the most general requirement for the preservation and welfare of this species and its individual members: their reciprocal willingness to join together in the purpose of exchanging services, and their need to behave in a manner which mutually motivates such activity. From this observation Pufendorf made the following normative conclusion.

And so the fundamental law of nature will be this: Every man must, inasmuch as he can, cultivate and maintain towards others peaceful sociality. A corollary of this is that, since whoever obligates a man to an end obligates him as well to the means without which the end cannot be obtained. All things which necessarily work to that sociality [ad istam socialitatem

$44 J N G$ 1672, book II, chap. 3 , § 14. LNN, 207.

$45 J N G$ 1672, book II, chap. 3 , § 15. LNN, 207-208. The English translation is from The Political Writings of Samuel Pufendorf, 151-152, excluding a remark Pufendorf added to JNG 1684 . 
necessario faciunt] are understood to be commanded by natural law, and all that disturb or destroy it to be forbidden. ${ }^{46}$

There are two things to note here. First, following the views he had presented in the chapter on the certainty of moral science, Pufendorf maintained that the laws of nature command or forbid acts which have a necessary effect on sociality among human beings. Accordingly, his demonstrations of the most general individual precepts of natural law relied very much on their status as necessary means for preventing violence and discord among human beings. ${ }^{47}$ Second, since the end of natural law is the salus of the whole humankind, it obligates human beings to cultivate sociality also in their relations with individuals who are not able to help or hurt them, including a human foetus, who completely lacks such capabilities. ${ }^{48}$ It should be noted that the above citation is from JNG 1672. In JNG 1684 the argument was interrupted by a long remark on the character of sociality. As a result, the reference to the necessary effects that acts observing or violating natural law have on sociality is often left unmentioned by modern commentators.

It has been argued that Pufendorf's fundamental principle of natural law was actually a reformulation of the first principle of natural law Hobbes had defined in De cive as the duty 'to seek peace when it can be had; when it cannot, to look for aid of war'49 However, Hobbes's first principle relied entirely on his idea of natural law as 'the Dictate of right reason about what should be done or not done for the longest possible preservation of life and limb'.50 Nothing like this was ever suggested or even tacitly assumed by Pufendorf. For him, the principle behind the fundamental principle was the idea of natural law as a norm God had imposed to foster the salus of the human species. Accordingly,

46 Ibid. English translation by K.S., following The Political Writings of Samuel Pufendorf, 152, and $L N N, 208$, and excluding the additions made to $J N G 1684$.

47 For an example of such argumentation, see Kari Saastamoinen, 'Pufendorf on Natural Equality, Human Dignity, and Self-Esteem,' Journal of the History of Ideas 1 (2010): 39-62.

48 Pufendorf held that all human beings share a right of not being hurt by others, and this also applies to an embryo in the womb of her mother. JNG 1672, book I, chap. 1, § 7 . $L N N$, 8. On the natural law and rights in Pufendorf's theory, see Kari Saastamoinen, 'Liberty and Natural Rights in Pufendorf's Natural Law Theory', in Transformations in Medieval and Early-Modern Rights Discourse, ed. Virpi Mäkinen and Petter Korkman (Dordrecht: Springer, 2006), 225-255.

49 Thomas Hobbes, De cive (Amsterdam, 1647, 2nd ed.), chap. II, § 2. The translation is from On the Citizen, ed. Richard Tuck, transl. Michael Silverthorne (Cambridge: Cambridge University Press. 1998), 34. Palladini, 'Pufendorf disciple of Hobbes,' 5o. See also Hunter, 'Natural Law as Political Philosophy', 49o. 
he established the obligation to preserve one's own life and the right to protect it by violent means by arguing that the non-existence of such norms would have negative effects on sociality. The argument for the first mentioned duty was, as we saw above, that sociality cannot be exercised and properly preserved 'unless every man improves and preserves himself to the best of his ability'. ${ }^{51}$ In the case of violent self-defence, Pufendorf found it meaningful to remark that when we kill or injure someone to protect our own lives, we do this to a human being 'with whom we are required to cultivate social life, while by his death apparently as great a loss is entailed upon the human race as would come from our own death'. The reason why this observation should not prevent us from defending ourselves against an unjustified attack is that if natural law denied good people the right to protect themselves against the bad ones, this would not advance the salus of the human species. On the contrary, it would indicate 'the end of mankind'. ${ }^{2}$ It is important to bear in mind that with such arguments Pufendorf was not describing the mental process by which human beings adopt their moral beliefs. Human beings internalize their moral convictions through education and daily social practice, though the above norms happen to find extra motivational strength in self-love and the inclination to self-preservation. What Pufendorf was explaining was how natural law norms follow from the first principles, and he did this for a small minority, whose task it was to understand properly the character and purpose of natural law.

The above method of deducing natural law makes it understandable why Pufendorf felt there was a need to explain how his theory compared with that of Hobbes. As he maintained that self-love and self-preservation have a predominant role in human behaviour, it was inevitable that he was going to be associated with Hobbes by his contemporaries. And his Hobbes-inspired ideas of the state of nature and the origins of civil society were only going to make this connection stronger. Thus, right after deducing the fundamental principle, Pufendorf used three paragraphs to compare his position with the one Hobbes had put forward in De cive. There is no reason to conclude that he did this to camouflage the true Hobbesian character of his natural law. Once we take seriously the idea that the fundamental duty of natural law is to cultivate sociality,

$51 \quad J N G$ 1672, book II, chap. 4, § $1(1684$, II.4.16). LNN, 256.
$5^{2} J N G 1672$, book II, chap. 5, § 1. LNN, 264-265. 
not to preserve one's own life, it becomes apparent that Pufendorf had good reasons to distinguish his own theory from Hobbes's 'cleaver' method of deducing natural law 'solely from the care of one's own safety'.53

Pufendorf admitted that Hobbes's method had the virtue of establishing clearly how important it is for the welfare of human beings that they follow such dictates of reason. After all, Hobbes had not claimed that each person should 'seek his own advantage to the detriment of others', but had, rather, observed how 'care of our own welfare itself orders us to observe the laws of sociality, since our welfare cannot remain secure without this. ${ }^{54}$ This was no small merit, as Pufendorf valued all arguments which could be used to convince people that observing natural law serves their personal interests. Nonetheless, as a demonstration of natural law Hobbes's method was unsatisfactory. The mere fact that some rules are beneficial for one's personal salus fails to indicate 'that a man has right to apply them as means toward his own preservation' and that he is 'bound to observe them as by some law'. To 'receive the force of law', these dictates of reason must be deduced from a different principle. ${ }^{55}$ This could, of course, be understood to mean that in order to be proper laws, these precepts should be seen as God's commands. However, Pufendorf knew well that Hobbes had said the same thing in De cive, so there was no need to criticize Hobbes over this issue. ${ }^{56}$ And when Pufendorf himself made the point about God's role, he wrote that for the rules of sociality to be proper laws, 'a higher principle is needed' (sublimior principio opus est). ${ }^{57}$ In the case of Hobbes's method of deducing natural law, however, a higher principle was not enough. The law of nature had to be deduced from an altogether different principle (omnino ex alio principio deducendum est). ${ }^{58}$

This entirely different principle was the duty to promote sociality, and it relied on the idea of natural law as a norm God has imposed to promote the salus of the human species. This was clearly assumed when Pufendorf commented on Hobbes's infamous remark that if 'man naturally loved his fellow man', it would be difficult to understand 'why everyone would not love everyone equally as equally men, or why every man would rather seek the company of men whose society is more prestigious and useful to him than to others. ${ }^{59}$

$53 J N G$ 1672, book II, chap. 3, § 16. The Political Writings of Samuel Pufendorf, 153.

$54 J N G$ 1672, book II, chap. 3, § 16. LNN, 211.

55 Ibid.

$56 \quad J N G$ 1672, book II, chap. 3, § 20. LNN, 219.

57 Ibid. $L N N, 217$.

$5^{8} J N G$ 1672, book II, chap. 3, § 16. LNN, 211.

59 De cive, chap. I, § 2. On the Citizen, 22. 
In his comment, Pufendorf identified the general love of other human beings with the duty to cultivate sociality, arguing that Hobbes had confused the most general duties of sociality toward all human beings with the motives human beings have when they establish particular societies. For 'reasons cited above', i.e. in the deduction of the fundamental principle, natural law has ordained a duty of general friendship (amicitia) among all human beings, excepting only those whose monstrous deeds had excluded them from the human moral community. This duty of friendship is not dependent on the ability of the other person to help or hurt us, but solely on the fact that he or she is a human being. ${ }^{60}$ It consists of abstaining from violating other people's life and property, holding them as one's moral equals by nature, and observing what Pufendorf called the duties of humanity. Such a friendship is not contradicted by the fact that people seek closer company and make special agreements with those from whom they expect honour or benefits. The end of natural law is the salus of the human species, and it obligates every one of us to take care of ourselves. Therefore, sociality should be cultivated so 'that by mutual exchange among many of assistance and property, we may be enabled to take care of our own concerns to greater advantage. ${ }^{61}$

Hobbes's and Pufendorf's different methods of deducing natural law were connected to a dissimilar understanding of the character this law has outside civil society. In his political theory, Hobbes had maintained that the most elementary requirement for preserving one's own life was peace, and he had identified several laws of nature which human beings needed to observe in order to maintain peace. These laws were, Hobbes declared, 'immutable and eternal' rules of human morality. ${ }^{62}$ However, it was rational to believe that observing these precepts would preserve one's safety only when there were good reasons to assume that others would do the same. Such situations were not impossible outside civil society, but they were limited in scope and usually did not last long. When such circumstances did not prevail, the laws of nature obligated human beings only in 'the internal court' (in Foro interno), meaning that they had a duty to seek a situation in which observing them would become rational. As long as such a situation did not exist, the duty to preserve one's own life ordered them to use all possible means, including war, to protect their own lives. ${ }^{63}$ Since there were no relations of authority among people in the state of nature, it was up to each individual to decide 'whether the means he is to use

6o JNG 1672, book II, chap. 3 , § 16. LNN, 212.

$61 J N G$ 1672, book II, chap. 3, § 18. LNN, 214.

62 De cive, chap. III, § 29. On the Citizen, 54.

63 De cive, chap. III, § 27. On the Citizen, 53-54. 
and the action he intends to take are necessary to the preservation of his life and limbs or not'.64 And Hobbes claimed that in relation to other human beings this meant that 'every man was permitted to do anything to anybody, and to possess, use and enjoy whatever he wanted and could get'. In other words, everyone had 'a right to all things'. ${ }^{65}$

Pufendorf was acutely aware of the above elements in Hobbes's theory, so much so that he seems to have thought they were bound to give a scholar using Hobbes's idea a bad reputation. Thus, when he commented on them in the chapter on the state of nature, he was less interested in criticizing Hobbes than in suggesting that Hobbes had not meant what he had written. While Hobbes's remarks appeared 'paradoxical at the first sight', actually he had not denied that there are objective rules of self-preservation already in the state of nature. After all, the idea that a human being would have a 'licence to do whatever he pleases to anyone he pleases' could not be 'considered by any sane man a sufficient means for his continued preservation'. Thus, it 'must be concluded that nature never has granted it'. The real meaning of Hobbes's remarks must be, first, that natural law has initially given human beings a right to use those material things they need for their preservation, though later these had been divided by agreements, and second, that he who has no superior can use his own will, when guided by right reason, to do 'whatever will work for his continued preservation'.66 Pufendorf returned to Hobbes's views when he discussed the reasons for establishing civil society, offering again a similarly favourable interpretation. Hobbes's idea of 'the right against all men and to all things' should not be extended further 'than sane reason admits'. It indicates merely that a person 'has a right to use all the means, which right reason judges necessary for his preservation, against all by whom the same right reason suggests that he is threatened'. The answer to the question of when a person is so much menaced by someone else that this allows a violent reaction is not a matter of purely subjective reasoning, but something for which there are intersubjective criteria of right reason. ${ }^{67}$

It has been suggested that with the above remarks Pufendorf was correcting Hobbes's theory by using a remark Hobbes himself had made about right reason and natural law in a note he added to the second edition of De cive. ${ }^{68}$ There, Hobbes explained that by 'true reasoning' he meant 'reasoning which

64 De cive, chap. I, § 9. On the Citizen, 27-28.

65 De cive, chap. I, § 10. On the Citizen, 28.

$66 J N G$ 1672, book II, chap. 2, § 3. LNN, 158-159.

$67 J N G$ 1672, book VII, chap. 1, § 7.LNN, 959-962.

68 Palladini, 'Pufendorf Disciple of Hobbes,' 58. 
draws conclusions from true principles correctly stated', and that 'every violation of natural law consists of false reasoning or in stupidity, when men fail to see what duties toward other men are necessary to their own preservation',69 If read in isolation, this remark could be seen as affirming that there is an intersubjective criterion for personal survival already in the state of nature. However, in the note Hobbes continued by pointing out that the 'principles of right reasoning about such duties are those laid out in Chapter I, articles 2-7.70 And the conclusion he presented in these articles was that in the state of nature human beings are able and willing to hurt each other, wherefore 'the first foundation of natural Right is that each man protects his life and limbs as much as he can'.71 In the above note, Hobbes offered a mere reformulation of the subjective character of contemplating the requirements of self-preservation in the state of nature. What right reason teaches human beings in that state is that they have no criterion for what is necessary for their preservation other than their own reasoning. ${ }^{72}$ There was nothing in Hobbes's remarks Pufendorf could have used to transform them into something he would have found more acceptable. And in JNG 1684 he was ready to admit that Hobbes's formulations may not allow the favourable interpretation he had suggested, and that if this was so, it was up to Hobbes himself to see 'how he can avoid a just criticism. ${ }^{73}$

As Noel Malcolm has pointed out, the peculiar feature of Hobbes's natural law was that, in the state of nature, natural law was a purely self-regarding norm of human behaviour. ${ }^{74}$ Human beings have an obligation to do whatever they believe is the best way to preserve their own lives, and even in the state of nature this may sometimes mean acting in a sociable and peaceable manner towards others. However, in this case they do so only for instrumental reasons, as the best way to preserve their own lives. Their relationship with other human beings is not governed by any idea of shared humanity, which would have

69 De cive, chap. II, § 1, n. 1. On the Citizen, 33-34.

70 Ibid.

71 De cive, chap. I, § 7. On the Citizen, 27.

72 De cive, chap. II, § 1, note. On the Citizen, 33: 'By right reason in men's natural state, I mean not, as many do, an infallible Faculty, but the act of reasoning, that is, a man's own true Reasoning about actions of his which may conduce to his advantage or other men's loss. I say his own reasoning, because [...] outside of a Commonwealth, where no one can distinguish right reason from false except by making comparison with his own, each man's own reason must be regarded not only as the measure of his own actions, which are taken at his own risk, but also as the measure by which to judge the reasoning of others in his affairs'.

$73 J N G$ 1684, book II, chap. 2, § 3. LNN, 159.

74 Noel Malcolm, Aspects of Hobbes (Oxford: Oxford University Press, 2002), 32-34, 444-446. 
moral implications. Human beings and sovereigns sin against natural law, for example, by cruelty, which Hobbes defined as 'vengeance without regard to future good. ${ }^{75}$ However, even the duty to abstain from cruelty follows from the system of self-regarding duties and rights related to self-preservation, not from any duty to respect the humanity of the victim. And what counts as cruelty depends solely on one's own evaluation of what is and what is not necessary for one's preservation. Thus, Hobbes remarked that what is done 'of necessity, or in pursuit of peace, or for self-preservation is done rightly'. All other harm inflicted 'on men is a violation against natural Law and wrong against God.' 76 What he did not say was that such behaviour would be wrong against other people. While the law of nature is a universal moral norm of human behaviour, in the state of nature it is universal only in the sense that it is 'duplicated in every individual'. It does not require 'a person to respect the good of any other human being, still less of humanity in general as a primary good. ${ }^{77}$

The above applied also to interstate relations, in which sovereigns were obligated by natural law to advance the preservation and welfare of their subjects. To be sure, Hobbes made it clear that the state of nature which prevailed between sovereign states differed from the one among independent individuals. Above all, as people living in civil societies were quite well protected, the sovereign had most often no reason for unprovoked aggression towards other states. In fact, Hobbes was mostly critical of wars of aggression and expansion, holding that these have, with great likelihood, negative consequences for the long-term security and prosperity of one's country. ${ }^{78}$ For most of the time, natural law ordered sovereigns to advance peaceful relations and commerce with neighbouring countries. Yet, this was a purely self-regarding code of conduct which did not establish any coherent system of rights and duties among sovereign states. This Hobbes expressed clearly in Dialogue between a Philosopher and a Student of the Common laws of England, written in the 166os but published posthumously in 1681 . There, the philosopher, who represented Hobbes, remarked that the king is entitled to defend militarily a neighbouring country which is under attack if he believes that the invader has plans to assault his own country too. When the lawyer replied that surely the king is entitled to do so only if the attack against the neighbour is unjustified, the philosopher disregarded such questions as irrelevant. The only thing which justifies avoiding interference is that the invader 'will, and can put me in security, that neither

75 De cive, chap. III, § 27, note. On the Citizen, 54.

76 Ibid.

77 Malcolm, Aspects of Hobbes, 444.

78 Malcolm, Aspects of Hobbes, 441. 
he, nor his Successors shall make any Advantage of the Conquest of my Neighbour, to do the same to me in time to come.79 In Dialogue the philosopher also identified 'the necessity of subsisting' as a just reason for occupying new territories. If the subjects of the sovereign are facing starvation, he is entitled to invade a neighbouring country with more fertile land, irrespective of the consequences this may have for its inhabitants. ${ }^{80}$ In Leviathan Hobbes stated that if the number of poor people exceeds what the country can sustain, some of them should be 'transplanted into Countries not sufficiently inhabited'. And even though the people moving to colonies should not 'exterminate those they find there', but only 'constrain them to inhabit closer together', there was no reason to consider what the original inhabitants might think about the matter. ${ }^{81}$

Pufendorf addressed the self-regarding element in Hobbes's natural law when he criticized the latter's infamous claim that the natural state of human beings is war. On this issue, Pufendorf was not so much concerned about the universal condition of war Hobbes had attributed to the fictive condition of independent individuals. ${ }^{82}$ What he found truly objectionable was Hobbes's claim that the condition between commonwealths is a 'state of hostility', so that even 'when the fighting between them stops, it should not be called Peace, but an intermission during which each watches the motion and aspect of its enemy and gauges its security not on the basis of agreements but by the strength and designs of the adversary'. ${ }^{83}$ Pufendorf's reason for rejecting such a statement was not an assumption that in reality relations between human beings or states would be overwhelmingly peaceful in character. He held it evident that the condition which once prevailed between independent male householders had been saturated by fear of aggression, and that this had been the main reason for the establishment of civil societies. ${ }^{84}$ War was constantly present also in interstate relations, and there was no reason to assume that things would be different one day.

For Pufendorf, the main question regarding the state of nature was not the amount of warfare that takes place among sovereign states. The crucial

79 Thomas Hobbes, Writings on the Common Law and Hereditary Right, ed. Alan Cromartie and Quentin Skinner (Oxford: Oxford University Press, 2005), 23. Malcolm, Aspects of Hobbes, 455-456.

8o Hobbes, Writings on the Common Law, 135 .

81 Thomas Hobbes, Leviathan, ed. Richard Tuck (Cambridge: Cambridge University Press, 1991), 239 .

$82 J N G$ 1672, book II, chap. 2, § 7. LNN, 168-169.

83 De cive, chap. XIII, § 7. On the Citizen, 144-145.JNG 1672, book II, chap. 2, § 5. LNN, 165 .

84 JNG 1672, book VII, chap. 1, § 7.LNN, 961 . 
question was, rather, the moral relation which prevails between them. Hobbes had written that when human beings 'are not subject one to the other or to any common ruler', they are 'enemies [hostes] to each other'. ${ }^{85}$ Pufendorf saw this as a statement concerning the moral relations between states. In the chapter on the laws of war, he explained that when someone is my enemy, this means that I am morally allowed 'to use force against him to any degree, or so far as I may think desirable' (in infinitum, aut quantum mihivideatur). ${ }^{86}$ In the case of an enemy, one is always entitled to execute a pre-emptive strike. Of course, the logic of Pufendorf's argument allowed the sovereign sometimes to decide that it would be wiser to abstain from such attacks, and to uphold the condition of ceasefire with the enemy. However, he should do so only for instrumental reasons, which have to do with the preservation and welfare of his own people. If he chooses to do otherwise, he does nothing wrong to his enemy.

In other words, if we assume that the natural condition of human beings is war, we are forced to conclude that relations between states are governed by self-regarding principles of self-interest and security. Therefore, Pufendorf held that it is a matter of the utmost importance to know whether those who have no common master, and neither obey nor command one another, should be considered as mutual enemies, or as peaceable people and friends. ${ }^{87}$ And he strongly argued that even though war is, due to human nature, an inescapable element of the human condition, it should always be seen as an aberration from the natural human condition, which is that of peace. In saying this, Pufendorf was not using the term 'peace' in the same way he did in the chapter on moral entities, where he defined peace as a 'state in which men dwell together in quiet and without violent injuries, and render their mutual dues, as of obligation and desire. 88 The peace which prevails in the state of nature does not refer to a total absence of aggression and warfare, but to the moral duty to uphold peace as much as one can. Peace is the state 'the creation and preservation of which constitutes one of the chief reasons for the law of nature being placed in the hearts of men'.89 The reciprocal duty to cultivate peaceful sociality prevails not only within civil society but also in the state of nature, imposing duties to abstain from harming those who do not harm me, to allow everyone to enjoy their own possessions, and to fulfil the agreements they have made

\footnotetext{
85 De cive, chap. XIV, § 19. On the Citizen, 164.

$86 J N G$ 1672, book VIII, chap. 6, § 7. LNN, 1298.

$87 J N G$ 1672, book II, chap. 2, § 5. LNN, 165 .

$88 J N G$ 1672, book I chap. 1, § 8. LNN, 9 .

89 JNG 1672, book VIII, chap. 6, § 2. LNN, 1292.
} 
with one another..$^{90} \mathrm{Of}$ course, there is no reason to assume that people or sovereigns always obey these obligations. Nevertheless, the 'maintenance of peace toward all men as such is a natural state of man' in the sense that it rests 'upon that obligation of natural law, by which all men are bound, in so far as they are endowed with reason, and which does not owe its original introduction to any convention of men.' ${ }^{91}$ All this was not contradicted when Pufendorf remarked that the peace which prevails in the state of nature is but a weak and untrustworthy thing. ${ }^{92}$ This merely indicated that it is the duty of the sovereign not only to cultivate peace and friendship with neighbouring countries, but also to take 'care that everything required to repel invasion stands in readiness, such as forts, arms, and troops. ${ }^{93}$

Pufendorf referred to the self-regarding element in Hobbes's theory also when in $J N G 1684$ he defended the general duty of friendship against Hobbes. While God has so adapted natural law with human nature that its observance is always 'connected with profit and advantage of men', in justifying the duty of friendship as a command of natural law one should not refer to these advantages but to the common nature of human beings. If, for example, one gives a reason for not injuring another person, one does not point out that such behaviour is advantageous for oneself, though it evidently is. What one says is that the other person is 'an animal related by nature, whom it is a crime to injure. ${ }^{94}$ Behind such reasoning one can detect the idea that if the justification for natural law is that obeying it is useful for myself, then if I fail to observe it, the only person to whom I do something wrong is myself. For Pufendorf, the idea of natural law as a norm God has imposed to advance the salus of the whole humankind enabled one to escape such a counterintuitive conclusion.

Pufendorf's non-Hobbesian understanding of the state of nature was reflected in his account of interstate relations. As mentioned above, in Hobbes's view, a sovereign contemplating the need to assist a neighbouring country against an invading third party had no reason to assess the moral character of the war. Pufendorf agreed that wars may sometimes be fought on behalf

$90 \quad J N G$ 1672, book II, chap. 2, § 9. $L N N, 118$. In JNG 1684 Pufendorf added the duty to advance the interests of others, in so far as one is not bound by more pressing obligations.

$91 J N G$ 1672, book II, chap. 2, § 11. LNN, 175 .

$92 J N G$ 1672, book II, chap. 2, § 12. LNN, 176.

$93 J N G 1672$, book VII, chap. 9, § 13. $L N N, 1126$. The general duty to cultivate peace does not forbid civil sovereigns to establish various 'systems of states' with those with whom they have common interests. See Michael Seidler, "Monstrous" Pufendorf: Sovereignty and System in the Dissertations,' in Monarchism and Absolutism in Early Modern Europe, ed. Cesare Cuttica and Glen Burgess (London: Pickering \& Chatto, 2011), 170-174. 
of a neighbouring country. Yet, while the issue was complicated, and there were several things the sovereign had to consider carefully, what was clear was that the war must be morally justified. ${ }^{95}$ Pufendorf also departed from the Hobbesian view that to prevent his citizens from starving, the sovereign was entitled to disregard the loss of lives conquering new territories would cause to their original population. Of course, he admitted that there is a right of necessity which entitles people facing starvation through no fault of their own to disregard conventional property rights, if no other way of being nourished is available to them. And in the state of natural liberty, food can be taken from its owners even by means of war. However, such a right applies only when the owners have more than they need for themselves. It never justifies taking food when the result is that the owners become unable to survive. ${ }^{96}$ Pufendorf did not present necessity as a legitimate reason for conquering territories belonging to other nations. Nor did he find acceptable the idea of transplanting the surplus population to colonies without asking the opinion of those who already lived there. His argument against Vitoria's and Grotius's justifications for colonialism relied on the idea that Europeans and the inhabitants of colonialized countries share reciprocal duties and rights. When he added that the native people were entitled to possess unoccupied land in the form of collective ownership, it followed that the duties of hospitality did not dismantle their right to decide on the use of their own territories any more than it did in the case of Europeans. When Europeans failed to acknowledge these rights, they violated what Pufendorf described as the most universal and necessary of all the duties of natural law: the duty not to hurt other human beings. ${ }^{97}$

To cite Noel Malcom one more time, with his account of natural law Hobbes departed radically from the Stoic and scholastic versions of natural law by taking 'no cognizance of the good of mankind as such'. While individuals and sovereigns had rights and duties in the state of nature, due to the self-regarding character of natural law these were not 'fixed by nature in any pattern of mutual

$95 J N G 1672$, book VIII, chap. 6, § 14. LNN, 1305 .

96 JNG 1672, book II, chap. 6, § 5. LNN, 301-302.

$97 J N G$ 1672, book III, chap. 1, § 1; book III, chap. 3, §§ 7-10; book IV, chap. 6, § 4. LNN, 313-314, 359-368, 571. On Pufendorf's critique of colonialism, see Barbara Arneil, John Locke and America. The Defence of English Colonialism (Oxford: Clarendon Press, 1996), 54-6o; See also Christov, Before Anarchy, 200-297. This analysis does not, in my view, confirm the author's claim about the Hobbesian character of Pufendorf's international theory. For the claim that, in Pufendorf's view, Spanish colonialism took place 'in the a-licit state of nature', see Ian Hunter, 'The Figure of Man and the Territorialisation of Justice,' Intellectual History Review 23 (2013): 296-297. 
harmony or reciprocity'. Outside civil society, natural rights and natural duties were often in direct conflict. It was only inside the commonwealth that they could 'be presumed to be in harmony' ${ }^{98}$ Pufendorf followed Hobbes in rejecting the metaphysical assumptions and teleological conceptions of the Stoic and scholastic doctrines, and by adopting an Epicurean-style anthropology. ${ }^{99}$ One thing Pufendorf was not ready to share with Hobbes, however, was the idea of natural law as a self-regarding rule concerning the preservation of one's own life. Instead, he established natural law on a highly constricted notion of God's intentions, which, he thought, should be acceptable to all human beings, irrespective of their religious confession. This enabled Pufendorf to hold that humankind was one moral community, whose members had duties to one another simply due to their shared humanity. The duties and rights which prevailed in the state of nature were perhaps not always as neatly organized as those in civil society, but Pufendorf held it evident that while the main duty of civil sovereigns was to advance the safety and welfare of their country, natural law imposed on them genuine moral duties to other states and their inhabitants. When sovereigns violated these precepts, they did not merely jeopardize the long-term security and welfare of their country. They also did something morally wrong to their fellow human beings. ${ }^{100}$

\section{Bibliography}

Arneil, Barbara, John Locke and America. The Defence of English Colonialism (Oxford: Clarendon Press, 1996).

Christov, Theodore, Before Anarchy. Hobbes and His Critics in Modern International Thought (Cambridge: Cambridge University Press, 2015).

Fiorillo, Vanda, 'States, as Ethico-Political Subjects of International Law: The Relationship between Theory and Practice in the International Politics of Samuel Pufendorf,' in System, Order, and International Law: The Early History of International Legal Thought from Machiavelli to Hegel, ed. Stefan Kadelbach, Thomas Kleinlein, and David Roth-Isigkeit (Oxford: Oxford University Press, 2017), 199-215.

Haara, Heikki, Sociability in Samuel Pufendorf's Natural Law Theory (PhD diss., University of Helsinki, 2017).

98 Malcolm, Aspects of Hobbes, 455-456.

99 For a celebration of these aspects in Pufendorf's theory, see Ian Hunter, Rival Enlightenments: Civil and Metaphysical Philosophy in Early Modern Germany (Cambridge: Cambridge University Press, 2001).

100 I am grateful to Heikki Haara for commenting on an earlier version of this chapter. 
Hobbes, Thomas, Leviathan, ed. Richard Tuck (Cambridge: Cambridge University Press, 1991).

Hobbes, Thomas, On the Citizen, ed. Richard Tuck, transl. Michael Silverthorne (Cambridge: Cambridge University Press. 1998).

Hobbes, Thomas, Writings on the Common Law and Hereditary Right, ed. Alan Cromartie and Quentin Skinner (Oxford: Oxford University Press, 2005).

Holland, Ben, The Moral Person of the State. Pufendorf. Sovereignty, and Composite Polities (Cambridge: Cambridge University Press, 2017).

Hont, Istvan, 'The Language of Sociability and Commerce: Samuel Pufendorf and the Theoretical Foundations of the "Four-Stages" Theory,' in The Language of Political Theory in Early-Modern Europe, ed. Anthony Pagden (Cambridge: Cambridge University Press, 1987), 253-276.

Hunter, Ian, Rival Enlightenments: Civil and Metaphysical Philosophy in Early Modern Germany (Cambridge: Cambridge University Press, 2001).

Hunter, Ian, 'Natural Law as Political Philosophy,' in The Oxford Handbook of Philosophy in Early Modern Europe, ed. Desmond Clarke and Catherine Wilson (Oxford: Oxford University Press, 2011), 475-499.

Hunter, Ian, 'The Figure of Man and the Territorialisation of Justice,' Intellectual History Review, 23 (2013): 289-307.

Malcolm, Noel, Aspects of Hobbes (Oxford: Oxford University Press, 2002).

Palladini, Fiammetta, Samuel Pufendorf dicepolo di Hobbes: Per una reinterpretazione del giusnaturalismo moderno (Bologna: Il Mulino, 199o).

Palladini, Fiammetta, Discussioni seicentesche su Samuel Pufendorf. Scritti Latini: 16631700 (Bologna: Il Mulino, 1978).

Palladini, Fiammetta, 'Pufendorf Disciple of Hobbes: The Nature of Man and the State of Nature: The Doctrine of socialitas,' History of European Ideas, 34 (2008): 26-6o.

Pufendorf, Samuel, Gesammelte Werke, ed. Wilhelm Schmidt-Biggemann, 9 vols. (Berlin: Akademie Verlag / De Gruyter, 1996-2004).

Pufendorf, Samuel, De jure naturae et gentium libri octo, 2 vols., vol. 2: Of the Law of Nature and Nations, transl. C.H. Oldfather and W.A. Oldfather, The Classics of International Law, ed. J.B. Scott, no. 17 (Oxford: Clarendon Press, 1934).

Pufendorf, Samuel, On the Duty of Man Citizen, ed. James Tully, transl. Michael Silverthorne (Cambridge: Cambridge University Press, 1991).

Pufendorf, Samuel, The Political Writings of Samuel Pufendorf, transl. Michael J. Seidler, ed. Craig L. Carr (New York: Oxford University Press, 1994).

Saastamoinen, Kari, The Morality of the Fallen Man. Samuel Pufendorf on Natural Law (Helsinki: Finnish Historical Society, 1995).

Saastamoinen, Kari, 'Liberty and Natural Rights in Pufendorf's Natural Law Theory,' in Transformations in Medieval and Early-Modern Rights Discourse, ed. Virpi Mäkinen and Petter Korkman (Dordrecht: Springer, 2006), 225-255. 
Saastamoinen, Kari, 'Pufendorf on Natural Equality, Human Dignity, and Self-Esteem,' Journal of the History of Ideas 1 (2010): 39-62.

Seidler, Michael, '“Monstrous" Pufendorf: Sovereignty and System in the Dissertations,' in Monarchism and Absolutism in Early Modern Europe, eds. Cesare Cuttica and Glen Burgess (London: Pickering \& Chatto, 2011), 159-175.

Seidler, Michael, 'Pufendorf's Moral and Political Philosophy,' The Stanford Encyclopedia of Philosophy (Winter 2015 Edition), ed. Edward N. Zalta, https://plato.stanford .edu/archives/win2015/entries/pufendorf-moral/.

Schröder, Peter, Trust in Early Modern International Political Thought, 1598-1713 (Cambridge: Cambridge University Press, 2017).

Tuck, Richard, 'The “Modern” Theory of Natural Law,' in The Languages of Political Theory in Early-Modern Europe, ed. Anthony Pagden (Cambridge: Cambridge University Press, 1987), 99-119.

Tuck, Richard, The Rights of War and Peace. Political Thought and the International Order from Grotius to Kant (Oxford: Oxford University Press, 1999). 


\title{
The International Political Thought of Johann Jacob Schmauss and Johann Gottlieb Heineccius: Natural Law, Interest, History and the Balance of Power
}

\author{
Peter Schröder
}

Hugo Grotius had been fairly optimistic that his natural law doctrine would be able to regulate the antagonistic relations between sovereign states. By looking at the arguments of Johann Jacob Schmauss (169o-1757) and Johann Gottlieb Heineccius (1681-1741), this chapter scrutinizes the limits of natural law regarding interstate relations. They used classical political or juridical concepts of international political thought - such as interest, balance of power, natural law and history - in their political and philosophical writings. Schmauss and Heineccius were both taught by Christian Thomasius ${ }^{1}$ and were part of the circle of Thomasius's disciples at the newly founded University of Halle who shaped and continued the early Enlightenment and natural law project. But they pursued their writings and teaching in different directions.

Schmauss belonged to the great eighteenth-century jurists. And yet he is almost entirely forgotten, despite the fact that some specialists have emphasized his importance. ${ }^{2}$ Schmauss provides one of the crucial links between the University of Halle and the natural law tradition which is so closely associated with Thomasius, and the up and coming University of Göttingen, where he

1 In contrast to Schmauss and Heineccius, Thomasius has been well researched. See in particular the English contributions by Ian Hunter, The Secularisation of the Confessional State: The Political Thought of Christian Thomasius (Cambridge: Cambridge University Press, 2007); Thomas Ahnert, Religion and the Origins of the German Enlightenment: Faith and the Reform of Learning in the Thought of Christian Thomasius (Rochester, NY: University of Rochester Press, 2006); and Timothy Hochstrasser, Natural Law Theories in the Early Enlightenment (Cambridge: Cambridge University Press, 2000).

2 For instance, Schmauss has been described by Notker Hammerstein as 'the last in the great tradition of Halle [...] and the first great publicist in Göttingen'. Notker Hammerstein, Jus und Historie. Ein Beitrag zur Geschichte des historischen Denkens an deutschen Universitäten im späten 17. und frühen 18. Jahrhundert (Göttingen: Vandenhoek und Ruprecht, 1972), 343: 'Man kann ihn [i.e. Schmauss] getrost als letzten der grossen Hallischen Tradition [...] bezeichnen und zugleich als den ersten grossen Publicisten Göttingens'. 
accepted the chair of natural law and ius gentium in $1721 .{ }^{3}$ Heineccius is equally forgotten today, but during the eighteenth century he found fame and recognition, albeit foremost outside Germany. ${ }^{4}$ This was mostly due to his writings on Roman law. ${ }^{5}$ In contrast to Heineccius, Schmauss enjoyed a greater reputation in the Holy Roman Empire during his lifetime. He was also influenced by Nicolaus Hieronymus Gundling (1671-1729), ${ }^{6}$ the favourite disciple and friend of Thomasius, who became himself a leading philosopher at the University of Halle. Whereas Heineccius was competing with Gundling for the chair of history and eloquence at Halle, Schmauss was full of praise for the latter. ${ }^{7}$ This is all the more remarkable because Gundling defended even the indefensible state of nature of Hobbes and went as far as to write an essay claiming that

3 For biographical details, see Wolfgang Sellert, 'Johann Jacob Schmauss - Ein Göttinger Jurist,' in JuS Juristische Schulung 11 (1985): 843-847.

4 For biographical details, see Christoph Bergfeld, 'Johann Gottlieb Heineccius und die Grundlagen seines Natur- und Völkerrechts,' in J.G. Heineccius, Grundlagen des Natur- und Völkerrechts, transl. Peter Mortzfeld, ed. Christoph Bergfeld (Frankfurt/Main: Insel, 1994), 507-534; Patricia Wardemann, Johann Gottlieb Heineccius (1681-1741). Leben und Werk (Frankfurt/ Main: Lang, 2007), 1-20; Martin Kühnel, 'Halle - Franeker - Frankfurt/Oder - Halle: Heineccius' Laufbahn als Hochschullehrer', in Love as the Principle of Natural Law. The Natural Law Theory of Johann Gottlieb Heineccius and its Contexts, ed. Frank Grunert and Knud Haakonssen (Leiden: Brill, forthcoming).

5 See Fernando Perez Godoy, 'La Teoria del Derecho natural y de gentes de Johannes Heineccius en la Cultura juridical iberoamericana,' Revista de Estudios Histórico-Juridicos XXXVII (2015): 453-474, and the forthcoming articles by Laura Beck Varela, 'Heineccius and his Catholic Readers'; Elisabetta Fiocchi Malaspina, 'Heineccius' Role in Italian Legal Education in the 18th and 19th Centuries' and Alexei Krouglov, 'Die Rezeption Heineccius in Russland'. On Heineccius's influence in the Netherlands during his lifetime, see Klaus Luig, 'Heineccius - ein deutscher Jurist in Franeker,' Tijdschrift voor Rechtsgeschiedenis 79 (2011): 219-227.

6 Gundling, in comparison to Thomasius, is much less studied. See notably Martin Mulsow, 'Gundling vs. Buddeus. Competing Models of the History of Philosophy', in History and the Disciplines. The Reclassification of Knowledge in Early Modern Europe, ed. Donald R. Kelley (Rochester, NY: University of Rochester Press, 1997), 103-125; Hammerstein, Jus und Historie, 205-265; Heinrich Rüping, Die Naturrechtslehre des Christian Thomasius und ihre Fortbildung in der Thomasius-Schule (Bonn: Ludwig Röhrscheid, 1968), 104-108 and passim; Peter Schröder, Naturrecht und absolutistisches Staatsrecht. Eine vergleichende Studie zu Thomas Hobbes und Christian Thomasius (Berlin: Duncker \& Humblot, 2001), 57-61, and less pertinent for our subject, Hermann Klenner, 'Eine fast vergessene Quelle deutscher Menschenrechtsund Rechtsideen: Nicolaus Hieronymus Gundling,' Dialektik (1994): 123-130.

7 In 1707, Heineccius unsuccessfully applied for a professorship at Halle. Instead, Gundling was appointed to the chair of history and eloquence (Professor für Geschichte und Beredsamkeit). It is not known how Heineccius took this decision and whether it influenced his relationship with Gundling. Therefore, not too much should be read into this competition and Heineccius's failure to be appointed as professor in Halle when he was still in his late twenties. In 1708 , the faculty of philosophy appointed him as adjunct, a junior academic position, and Heineccius began teaching at Halle. 
Hobbes was not an atheist. ${ }^{8}$ This shows that Gundling was daring enough to explore intellectual and theological issues bordering what was acceptable at a relatively free place such as Halle, but he soon had to face harsh criticism from the orthodox Lutheran establishment. Gundling fell within the grey area that formed between the clandestine radical and the moderate Enlightenment. ${ }^{9}$

Interestingly, Heineccius, too, seemed to follow Hobbes's argument when he described the state of nature:

For here the doctors justly distinguish between those living in a state of nature, and subject to no magistrate, by whom they may be defended and protected, and those who live in a civil state, and under magistracy. For since, in a state of natural liberty, there is no one to protect us against injuries, our right of self-defence cannot but begin the moment our danger commences, and cannot but continue while it lasts, or till we are absolutely secure. But our danger begins the moment one shews a hostile disposition against us, and while that continues, our right of self-defence lasts. ${ }^{10}$

However, although Heineccius followed Hobbes's argument concerning the precarious and threatening state of nature, which had been explicitly defended by Gundling, he was keen to distance himself from Hobbes in quite polemical terms.

What shall we then say of the whole philosophy of Hobbes in his books de Cive, or his Leviathan? When he asserts the right of every man in a state of nature to all things, he affirms a proposition which is neither true, nor evident, nor adequate, since the duties of men to God and themselves cannot be deduced from that principle; yea, while he goes about it in that manner, pretending to establish the law of nature, he really subverts it. $[\ldots]$ Hence it is plain what we are to think of this other principle, viz. "that external peace is to be sought and studied if it can be obtained, and if not,

8 Nicolaus Hieronymus Gundling, Status Naturalis Hobbesii in corpore iur civ. (Halle: Zeitlerus, 1706); N.H. Gundling, 'Hobbes ab Atheismo liberatus,' in Observationes selectae (Halle: Renger, 1737), vol. 1, 37-77, and N.H. Gundling, 'Von Th. Hobbesii Atheisterey', in Gundlingiana darinnen allerhand zur Jurisprudentz, Philosophie, Historie, Critic, Litteratur und übrigen Gelehrsamkeit gehörige Sachen abgehandelt werden (Halle: Renger, 1717), 303-339.

9 See Martin Mulsow, Enlightenment Underground Radical Germany 1680-1720, transl. H.C. Erik Midelfort (Charlottesville, VA \& London: University of Virginia Press, 2015), 206: 'the radical and the moderate Enlightenments were not two incommensurable movements because they were mutually dependent on each other, woven together in many ways'.

10 Johann Gottlieb Heineccius, A Methodical System of Universal Law: or the Laws of Nature and Nations, transl. G. Turnbull [1741], ed. Thomas Ahnert and Peter Schröder (Indianapolis, IN: Liberty Fund, 2008), 136. 
force and war must be called to our aid." [cf. Hobbes, Leviathan, 92] For here likewise Hobbes lurks behind the curtain."1

Instead, Heineccius argued 'that love is the principle of natural law'.12 Although Heineccius perceived the state of nature and interstate relations, like Hobbes and Pufendorf, as conflictual, he believed that his principle of love provided an adequate answer to the question of how the state of nature could be regulated by natural law. Heineccius held with Hobbes and Pufendorf that all states have, like all individuals in the state of nature, a fundamental right to self-preservation. The decision as to what constitutes the appropriate employment of any means deemed necessary for self-preservation is at the discretion of each state. Hobbes pointed to an inherent structural and juridical problem in the right to everything which becomes manifest where everyone remains judge of their own case. Despite the fact that Heineccius shared common ground with Hobbes and his belief that the very nature of sovereignty fixes states within an unstable and hostile framework, he strongly attacked the notorious Englishman.

\section{Heineccius, the Natural Law Tradition and Systems of States}

Both Schmauss and Heineccius reworked the natural law doctrine as it had been developed by Grotius, Pufendorf and Thomasius. Thomasius claimed that Grotius was part of a modern natural law tradition which, for him, marked a divergence from scholasticism. In particular, Thomasius proposed a history of natural law which was rife with invectives against the scholastics, a history culminating in the alternative of an alleged coherent development from 'the incomparable Hugo Grotius who can never be praised too much' to 'the blessed Baron Pufendorf and his opponents, when he attacked the irrational opinions of the scholastics.' ${ }^{13}$ Most natural law thinkers during the seventeenth and eighteenth centuries followed in one way or another Pufendorf's natural law doctrine and implicitly his interpretation of Grotius.

\footnotetext{
11 Ibid., 59 .

12 Ibid., 63. Note the important parallel to Hutcheson's argument regarding natural law and benevolence.

13 Christian Thomasius, 'On the History of Natural Law until Grotius,' in Ch. Thomasius, Essays on Church, State and Politics, ed. Ian Hunter et al. (Indianapolis, IN: Liberty Fund, 2007), 44 and $46 f$. This essay was the foreword by Thomasius to the first German translation of Grotius's De jure belli ac pacis. Adam Friedrich Glafey made a very similar point when he claimed: 'Eben also fieng mit Grotio ein neuer Periodus an, in welchem die Gelehrten im Studio Juris Nat. weiter nichts thaten, als dass sie über dessen Jus $B \& P$ [i.e. the Latin
} 
Heineccius was perhaps more distanced from Thomasius and his circle than Schmauss. In his A Methodical System of Universal Law: or the Laws of Nature and Nations, first published in Latin as Elementa juris naturae et gentium in 1738 and a result of his teaching at the University of Halle, ${ }^{14}$ he reworked the established natural law tradition. ${ }^{15}$ Heineccius often closely engaged with the arguments he found in Grotius, Pufendorf and Thomasius. ${ }^{16}$ Although the title suggests otherwise, there is not that much one can take from Heineccius regarding the law of nations or the question of interstate relations more generally. Nevertheless, it is illustrative to see to what extent former pupils of Thomasius followed different directions and pursued what they believed to be not just the advancement of the juridical discipline, but a way forward to organize and stabilize the conflict-rife European state system.

In fact, Heineccius followed Pufendorf's use of the state system and helped to give it further prominence within the discussion of early modern interstate relations. ${ }^{17}$ Pufendorf analysed how states related to new ideas which he had

abbreviation of Grotius's On the Law of War and Peace] disputirten, commentirten selbige in Compendia und Tabellen brachten, und endlich gar in andere Sprachen übersetzten. Dieses dauerte so lange, bis Pufendorff auftrat'. Adam Friedrich Glafey, Vollständige Geschichte des Rechts der Vernunfft, worinnen in dieser Wissenschaft ans Licht getretenen Schriften nach ihrem Inhalt und wahren Werth beurtheilet (Leipzig: Christoph Rigel, 1739), 111. See also the discussion by Frank Grunert, 'The Reception of Hugo Grotius's De jure belli ac pacis in the Early German Enlightenment,' in Early Modern Natural Law Theories: Contexts and Strategies in the Early Enlightenment, ed. T.J. Hochstrasser and Peter Schröder (Dordrecht: Kluwer, 2003), 89-105 and J.B. Schneewind, The Invention of Autonomy. A History of Modern Moral Philosophy (Cambridge: Cambridge University Press, 1998), 66-70.

14 Heineccius emphasized in the preface to his Elementa the crucial connection between teaching and a textbook written by the teacher himself, rather than having to rely on other works. Johann Gottlieb Heineccius, Elementa iuris naturae et gentium (Halle: Orphanotrophei, 1738), xI: 'Et sane qui in academiis erudiendae iuventuti operam nauant, ii reipsa quotidie experiuntur, quanto cum taedio coniuncta sit servitus, cui obnoxii sunt omnes qui aliorum libellos enarrare coguntur'.

15 Since 1727 , Heineccius had been professor of law at the University of Frankfurt an der Oder, but against his will he had to leave Frankfurt, because the Prussian king, Frederick William I, appointed him to a chair at the University of Halle in 1733. The appointment of such a prestigious scholar was intended to boost the reputation of Halle, but Heineccius had to accept conditions that did not reflect his international reputation.

16 A little too superficial and certainly too dismissive is the judgement of Wieacker, who described Heineccius's natural law doctrine as hardly original, mainly revealing his indebtedness to Thomasius. Franz Wieacker, Privatrechtsgeschichte der Neuzeit unter besonderer Berücksichtigung der deutschen Entwicklung (Göttingen: Vandenhoeck \& Ruprecht, 1967), 223.

17 See also the general remarks on Pufendorf's influence on Heineccius in Christoph Bergfeld, 'Pufendorf und Heineccius,' in Samuel von Pufendorf und die europäische Frühaufklärung, ed. Fiammetta Palladini and Gerald Hartung (Berlin: Akademie Verlag, 1996), 225-235. 
developed under the influence of Hobbes. ${ }^{18}$ For Pufendorf, natural law can be most meaningful for regulating interstate relations in the specific context of a system of states. ${ }^{19}$ When writing about the constitution of the Holy Roman Empire, Pufendorf developed the Hobbesian categories into his theory on the irregularity of the Empire. He had shown that Bodin's definition of sovereignty was not a sufficient category to characterize the constitution of the Empire. However, as far as Pufendorf was concerned, the concept of sovereignty was not to be abandoned. On the contrary, while building on Bodin and Hobbes, Pufendorf recognized that the strict notion of absolute sovereignty was applicable neither to the Holy Roman Empire nor to interstate relations. On the former, he famously concluded that 'the best account we can possibly give of the Present State of Germany, is to say, That it comes very near a System of States, in which one Prince or General of the League excells the rest of the Confederation'.20 What he effectively argued for was a system-based concept of sovereignty which would allow states to enter into agreements without giving up their sovereignty entirely. A 'system results when several neighbouring states are so connected by perpetual alliance that they renounce the intention of exercising some portions of their sovereign power, above all those which concern

18 Hobbes had already elaborated on the concept of a system - which was to become one of the key terms for theorizing interstate relations in outlining a theory of regular and irregular political bodies: 'Having spoken of the Generation, Forme, and Power of a Commonwealth, I am in order to speak next of the parts thereof. And first of Systems [...], by [which] I understand any numbers of men joyned in one Interest, or one Businesse. Of which some are Regular, and some are Irregular. Regular are those, where one Man, or Assembly of men, is constituted Representative of the whole number. All other are Irregular.' Thomas Hobbes, Leviathan, ed. Richard Tuck (Cambridge: Cambridge University Press, 1992), 155. See the instructive discussion by David Boucher, 'Resurrecting Pufendorf and capturing the Westphalian moment,' Review of International Studies 27 (2001): 57of., and Martin Wight, Systems of States (London: Leicester University Press, 1977), 21-45.

19 Because natural law thereby acquires a new place within interstate relations, it would be wrong to privilege the concept of 'interest' as foundational for Pufendorf's international political thought. This is the argument made by Meinecke and Dufour. See Friedrich Meinecke, Die Idee der Staatsräson (Munich: R. Oldenbourg, 1960), 264-286, and Alfred Dufour, 'Pufendorfs föderalistisches Denken und die Staatsräsonlehre,' in Samuel von Pufendorf und die europäische Frühaufklärung, ed. Fiammetta Palladini and Gerald Hartung (Berlin: Akademie Verlag, 1996), 122. More nuanced is the argument by David Boucher, Political Theories of International Relations (Oxford: Oxford University Press, 1998), 246: 'It is certainly the case that in trying to accommodate self-interest with the universal standards of conduct expressed in the Natural Law, the ethical constraint often appears to be extremely weak, and even subordinate to the Reason of State'.

20 Samuel Pufendorf, The Present State of Germany, ed. Michael J. Seidler (Indianapolis, IN: Liberty Fund, 2007), 178, see also 161 and 217. 
external defence, except with the consent of all, but apart from this the liberty and independence of the individual states remain intact. ${ }^{21}$

Heineccius seemed to have taken Pufendorf's concept of a state system on board when he wrote that 'many republics may, each preserving its form of government and its independency intire [sic], make a confederacy for acting with common consent for their common preservation and safety. Such confederated republics [...] are called systems of republics'.22 However, in an annotation to this page he criticized Pufendorf's use of 'system' and maintained that neither subjection nor a situation where different states retain their independent political constitution should be considered a state system. As far as Heineccius was concerned, only on the basis of mutual consent was it appropriate to talk of a state system: only in the case 'in which two kingdoms, or two bodies of people uniting their will and strength for common defence, constitute one larger society, and therefore are a system of republics, according to our definition.23

Schmauss, the Natural Law Tradition and Interstate Relations

Schmauss was more critical of Pufendorf than Heineccius in his writings on natural law theory. Perhaps a little surprisingly, given the close intellectual relationship between Pufendorf and Thomasius, Schmauss appears closer to Thomasius than to Pufendorf. ${ }^{24} \mathrm{He}$ is best known for his history of the jus publicum

21 Samuel Pufendorf, On the Duty of Man and Citizen, ed.James Tully (Cambridge: Cambridge University Press, 1991), part II, chap. 8, § 15, 145. On the innovative and modern character of Pufendorf's position, even in relation to discussions about the European Union, see Boucher, 'Resurrecting Pufendorf and capturing the Westphalian moment,' $572-577$, and more generally Werner Maihofer, 'Schlusswort: Was uns Pufendorf noch heute zu sagen hat,' in Samuel Pufendorf und seine Wirkungen bis auf die heutige Zeit, ed. Bodo Geyer and Helmut Goerlich (Baden-Baden: Nomos, 1996), 223-282. See also Andreas Osiander, 'Sovereignty, International Relations, and the Westphalian Myth,' International Organization 55 (2001), 279: 'If the European system as a whole can be called a loose, informal regime with few institutions [...], the empire was essentially a more developed regime with more elaborate institutions, providing a system of governance for matters of common interest while leaving internal government to each of the participating actors individually'.

22 Heineccius, A Methodical System of Universal Law, 419.

23 Ibid.

24 The relationship between Thomasius and Pufendorf, and how the former developed the thought of the latter, deserves further research. See, however, Simone Zurbuchen, 'Gewissensfreiheit und Toleranz: Zur Pufendorf-Rezeption bei Christian Thomasius,' in Samuel von Pufendorf und die europäische Frühaufklärung, ed. Fiammetta Palladini and Gerald Hartung (Berlin: Akademie Verlag, 1996), 169-180, and Schröder, Naturrecht, 137 f. 
of the Holy Roman Empire, ${ }^{25}$ but he also presented his own fairly original account of natural law. ${ }^{26}$ One of the key texts for understanding Schmauss's contribution to a theory of interstate relations is his influential Einleitung zu der Staats-Wissenschafft, which was first published in 1741. This work is influenced by Gundling, whose earlier account had used a strikingly original approach to advance arguments similar to those later taken up by Schmauss. The latter was open in acknowledging his debt to Gundling, as in the preface to his Corpus Juris Gentium Academicum, published 1730 in Leipzig, in which he recognized Gundling's ground-breaking work on international political thought:

This Juris publici Europaei course of study is seldom taught at academies now; and yet after [...] the famous Friedrich University in Halle was fortunate enough that, with all of his learning and chiefly his political studies, the greatly meritorious Royal Prussian Privy Councillor and Professor Nicol. Hieron. GUNDLING first initiated this course of study and gave it the correct form, and led the young people to such matters that would otherwise only have been obtainable through royal prerogative and secrets of major state ministries, others are now beginning, hither and thither, to follow his example, and as the gains can even be distinctly felt and every day more and more subsidies through the publication of very large volumes of state negotiations are contributed to this, there is the hope that these sciences will henceforth be properly treated, in forma artis, especially at Protestant universities and in particular by Professoribus historiarum, as has already happened in some places. ${ }^{27}$

25 Johann Jacob Schmauss, Historisches Ius Publicum des Teutschen Reichs, oder Auszug der vornehmsten Materien des Reichs-Historie (Göttingen: Abraham Vandenhoecks Witwe, 1754). On Schmauss's importance for developing a political science (Staatslehre) on the basis of a new understanding and interpretation of imperial history, see Sellert, 'Johann Jacob Schmauss,' 846, and Hochstrasser, Natural Law Theories, $147 \mathrm{f}$.

26 Johann Jacob Schmauss, Neues Systema des Rechts der Natur (Göttingen: Abraham Vandenhoecks Witwe, 1754). Frank Grunert, 'Das Recht der Natur als Recht des Gefühls. Zur Naturrechtslehre von Johann Jacob Schmauss,' Jahrbuch für Recht und Ethik/Annual Review of Law and Ethics 12 (2004), 153: 'Schmauss presented a theory of natural law that lay beyond the mainstream of the German natural law discussion of the eighteenth century [...] with an emphasized anti-Wolffian accent and a critique of Samuel Pufendorf's theory of natural law'.

27 Johann Jacob Schmauss, Corpus Juris Gentium Academicum, enthaltend die vornehmsten Grund-Gestetze, Friedens- und Commercien-Tractate, Bündnüsse und andere Pacta der Königreiche, Republiquen und Staaten von Europa (Leipzig: Joh. Friedrich Gleditschens Sohn, 1730), if. The cumbersome German baroque reads: 'Nun wird zwar dieses Studium Juris publici Europaei auf Academien noch gar selten getrieben; Nachdem jedoch [...] 
Before discussing how Schmauss conceptualized interstate relations, it will, therefore, be useful to have a closer look at the nature of Gundling's influence. What exactly is the 'correct form' Gundling - according to Schmauss - had provided for the jus publicum Europaeum and the political thought on interstate relations more generally? Gundling's main works on this subject, and those which Schmauss presumably had in mind, are Jus Naturae et Gentium, Ausführlicher Discours über den ietzigen Zustand der europäischen Staaten and Ausführlicher Discours über das Natur- und Völcker-Recht, as well as his writings on the Peace of Westphalia and on the Spanish Succession. ${ }^{28}$ It is beyond the scope of this chapter to discuss systematically Gundling's impressive body of writings. It is enough for the purpose of my argument to show briefly that Schmauss took up Gundling's argument that a proper knowledge and understanding of the history of the European state system was the indispensable basis for conceptualizing international political thought. ${ }^{29}$ This seems to be a banal statement, but as we know from the ground-breaking studies by, for instance, Notker Hammerstein or Tim Hochstrasser, the introduction of a new understanding and use of history was a crucial part of the development of the early modern natural law theory and political thought alike. ${ }^{30}$

die berühmte Friedrichs-Universität zu Halle das Glück gehabt, dass der um die ganze Gelehrsamkeit, und vornehmlich um die politische Studia so hoch verdiente Königl. Preusische Geheimde Rath und Professor Hr. Nicol. Hieron. GUNDLING dasselbe zuerst in den Gang und in eine rechte Form gebracht, und die Jugend auf solche Sachen geführet hat, die man sonst nur von Reservata und Geheimnüsse grosser Staats-Ministres gehalten; so fangen nun auch hier und dar andere an, seinem Exempel nachzufolgen, und da man den Nutzen davon gar mercklich spühret, und täglich mehr und mehr Subsidia durch an Taggebung gantzer grossen Voluminum von Staats-Negociationen hierzu beygetragen werden, so ist Hoffnung, dass absonderlich auf Protestantischen Universitäten diese Wissenschafften hinfüro ordentlich in forma artis, zumahlen von Professoribus historiarum, wie bereits einiger Orten geschieht, werden abgehandelt werden.'

28 There are also some less prominent writings by Gundling of which Schmauss presumably was also aware, such as Nicolaus Hieronymus Gundling, 'Ob wegen der anwachsenden Macht der Nachbarn man den Degen entblössen könne,' in Gundlingiana, Darinnen allerhand zur Jurisprudenz, Philosophie, Historie, Critic, Litteratur und übrigen Gelehrsamkeit gehörige Sachen abgehandelt werden (Halle: Renger, 1716), 379-416.

29 See Sellert, 'Johann Jacob Schmauss,' 846. On the more general argument, see Richard Devetak, 'Historiographical Foundations of Modern International Thought: Histories of the European States-System from Florence to Göttingen,' History of European Ideas 41 (2015): 62-77.

30 See Hammerstein, Jus und Historie, 17-42, and Hochstrasser, Natural Law Theories, 1-23. Also very important is Reinhart Koselleck, Vergangene Zukunft - Zur Semantik geschichtlicher Zeiten (Frankfurt/Main: Suhrkamp, 1989). 
Gundling was among the first in the Holy Roman Empire to apply this approach to the international sphere. In his preface to Ausführlicher Discours über den ietzigen Zustand der europäischen Staaten, he addressed the reader by wondering why it is that knowledge of the various states or political science (Staatslehre $)^{31}$ was hardly taught at the universities. This political science, Gundling asserted, is 'perceived like a strange Indian animal. ${ }^{32} \mathrm{He}$ claimed that only a profound knowledge of history would enable a proper understanding of political science, which is, in turn, necessary for an adequate handling of state affairs. ${ }^{33}$

This move was taken up and amplified by Schmauss. ${ }^{34}$ In his Corpus Juris Gentium he explains that just as he had treated the history of the Holy Roman Empire, he now wants to extend this historical approach to other European states. His aim was not only to provide an academic compendium for students; he also hoped that his work would be useful for statesmen. Such a claim to practical usefulness is much more than simply promotional rhetoric, given that Gundling and Schmauss both believed that relations between states were organized by the positive treaties concluded between them. They were 'the reason that Europe was at peace. ${ }^{35}$ However, at the same time, the very reason why conflict and even war might ensue among the European states lay in the possibility of conflicting interpretations of these treaties.

\section{Heineccius and Schmauss on Trust and} Mistrust in Interstate Relations

For Heineccius, the natural law principle of love informed the dealings between states and prevented misuse of pacts. Trust between states was based on this underlying principle, because

31 'Political science' does not fully translate the meaning of the German term Staatslehre, which was used by Gundling and his contemporaries. For want of a better term, I have used the usual translation.

32 Nicolaus Hieronymus Gundling, Ausführlicher Discours über den ietzigen Zustand der europäischen Staaten (Frankfurt and Leipzig, 1733), I: 'die Staaten-Lehren, als ein Indianisches unbekandtes Thier ansehen wollen'.

33 Gundling, Ausführlicher Discours über den ietzigen Zustand der europäischen Staaten, Ix: 'weil doch derjenige Weg, welchen man sich aus denen vormahligen Geschichten zu der Staats-Lehre bahnet, als die sicherste Vorbereitung anzusehen, dadurch man zu einer künfftigen Bedienung by Staats-Affairen könne geschickt werden'.

34 Rüping, Die Naturrechtslehre, 100, also very briefly discusses Schmauss. But he hardly does justice to Schmauss's natural law theory and his overall political theory when he claims that Schmauss maintains 'an extreme voluntarism and a right of nature which is based only on passions and dispenses of human reason and the concept of norms'. 
the love of justice is the source of all the duties we owe to one another, and this love commands us not to do to others what we would not have done by them to ourselves. But surely none would desire to be deluded by the promises and pacts of another. It is therefore our duty not to deceive anyone by our pacts and promises; not to defraud one, by making him trust to our fidelity, but faithfully and conscientiously to perform what we engage to do. ${ }^{36}$

Heineccius's appeal to natural law based on the principle of love and his reference to and application of the 'golden rule' fell short of providing any mechanism of deciding conflicting interpretations. ${ }^{37} \mathrm{He}$ simply demanded that states act faithfully and that, therefore, trust between states ought to be possible. However, the problem of trust in interstate relations had long since been forcefully expressed by Machiavelli. By asking 'how trust may be preserved among princes', the title of chapter XVIII of the Principe called into question the idea that trust should be maintained under all circumstances. ${ }^{38}$ Although Machiavelli was by no means the first to point to this issue, ever since he had posed his poisonous and notorious question, it continued to trouble political thinkers. And it was more often than not felt that an appeal to moral norms as reiterated by Heineccius would not be sufficient. ${ }^{39}$

Schmauss was prepared to engage with this thorny issue. For him, any political theory which claimed to be relevant to the organization of the European state system not only would have to take the problem of the misuse and pretence of legal titles into account, but, more importantly, would have to offer a reliable means of eradicating such abuse. Providing a consistent and uncontested interpretation of these international agreements which would encompass their historical development was thus of the highest relevance for the

36 Heineccius, A Methodical System of Universal Law, 298.

37 It is noteworthy that in his natural law doctrine, the Neues Systema des Rechts der Natur, Schmauss also relied upon the golden rule. But in contrast to Heineccius, the 'binding effect of the Golden Rule [...] is not based on moral understanding, but rather on the individual's own feeling of fear of the injured person's unavoidable revenge'. Grunert, 'Das Recht der Natur als Recht des Gefühls', 153. See Turnbull's summary discussion of the golden rule in his annotations to Heineccius's Methodical System. George Turnbull, 'Remarks,' in Heineccius, A Methodical System of Universal Law, 170. See Joachim Hruschka, 'Die Goldene Regel in der Aufklärung - die Geschichte einer Idee,' Jahrbuch für Recht und Ethik/Annual Review of Law and Ethics 12 (2004): 157-172.

38 Machiavelli, The Prince, ed. Quentin Skinner and Russell Price (Cambridge: Cambridge University Press, 2008), 61 [translation altered]. See, for example, Heineccius, A Methodical System of Universal Law, 329 and 508. 
conduct of international politics. Demonstrating that one had right on one's side was a crucial element in the practice of international politics. ${ }^{40}$ Louis XIV was the most notorious example in recent European history of a ruler who had justified his various wars with highly contested claims. Among the many writers and philosophers who reacted against the aggressive policies of Louis XIV were Pufendorf and Gottfried Wilhelm Leibniz (1646-1716). Despite their obvious animosity, Pufendorf and Leibniz shared concerns about the defence of the Holy Roman Empire and Protestantism from the French quest for religious and political hegemony in Europe. When Strasbourg was taken by the French, against the stipulations of the Peace of Münster, Leibniz was alarmed. In his polemic Mars Christianissimus, he argued against this blatant violation of the peace. This is one of the few polemics Leibniz published during his lifetime, and was presumably known by Schmauss and Heineccius. ${ }^{41}$ Leibniz saw that the main political and juridical problem - as already formulated by Machiavelli - posed by such an ambitious ruler was the destruction of trust in an existing legal and diplomatic framework: 'But France [...] forces the others to desperate resolutions and acts in such a way that it will be henceforth an impardonable folly to trust her word and to hope for a good peace.42 Leibniz probed whether the existing political system could reasonably allow the actors to have good faith in their counterparts:

Certainly, if there is a way to trust in assurances in human negotiations, if the public pledge of kings has some effect, if religion and conscience are not simply names invented to fool the simple-minded, this peace ought to have been solid and sure; but since it has been broken and trampled underfoot on the first favourable occasion, one must grant (they say) that he who would henceforth trust the word of France is in fact simple-minded, and worthy of being deceived; this is why the Dutch, the Spanish, the Emperor, and the rest of the allies who treated peace at Nimwegen are being at present, or will soon be, punished for their credulity. ${ }^{43}$

40 Schmauss, Corpus Juris Gentium Academicum, III: 'mit einem Schein des Rechtens'.

41 On Leibniz's international political thought, see Peter Schröder, '“Un Politique peut dire ce qu'un Prince devroit faire" - les concepts de paix et d'équilibre dans la pensée politique de Leibniz,' in La Paix des Pyrénées (1659) ou le triomphe de la raison politique, ed. Lucien Bély, Bertrand Haan and Stéphane Jettot (Paris: Classiques Garnier, 2015), 109132, and Peter Schröder, Trust in Early Modern International Political Thought, 1598-1713 (Cambridge: Cambridge University Press, 2017), 141-154.

42 Gottfried Wilhelm Leibniz, 'Mars Christianissimus,' in G. W. Leibniz' Political Writings, ed. Patrick Riley (Cambridge: Cambridge University Press, 1972), 143. 
The taking of Strasbourg during peacetime without any legal title and in obvious breach of the existing law as stipulated in the Peace of Münster provoked strong reactions against the French king, and other princes were increasingly unwilling to trust his word.

Writing after the death of Louis XIV, Schmauss can be seen in this tradition of thinkers who were very suspicious of French foreign policy. He, too, insinuated that he had the aggressive attitude of Louis XIV in mind when writing his treaties. ${ }^{44}$ However, he hoped that his work would contribute to a better understanding of the sources of conflict and thus the ways in which these conflicts could be solved or even avoided. In this context, he also discussed the extent to which the various pacts, alliances, peace treaties and existing international laws had legal or obliging force. 45

To what extent was Heineccius concerned with this question? In his preface to the Elementa, the issue of the validity and binding force of international law was flagged up quite prominently. He argued against using holy scripture or Roman law to resolve interstate conflicts, because such a source would not be accepted by non-European peoples such as the Turks, Japanese or Chinese. Heineccius ironically stressed that Europeans would hardly be prepared to accept references to Mohamed by the Turks or Confucius by the Chinese to resolve a dispute with European powers. If one did not want to give up entirely on resolving interstate disputes, a different source was necessary. According to Heineccius, the law of nature and nations (jus naturae et gentium) provided these rules. God, silently accepted by Heineccius as an 'acceptable source' for all peoples, had given it to the whole of humanity, regardless how different in language and geographically remote the various peoples might be. This law had to be used to regulate relations and affairs among independent states. ${ }^{46}$ The preface was, therefore, quite promising in suggesting a concrete application of natural law regarding interstate relations. His natural law doctrine is treated in book II of the Elementa, entitled Of the Law of Nations, and so it might be expected that he would offer his thoughts on interstate relations there. But despite the auspicious claims in the preface, the treatment of the jus gentium is rather disappointing. Heineccius mostly seems keen instead to deal with questions regarding the internal organization of civil societies.

44 He criticized, for instance, those states that were ruled by the arbitrary power of a single ruler and not by positive constitutional law. Schmauss, CorpusJuris Gentium Academicum, IV: 'Staaten, welche nicht nach der blossen Willkühr eines einigen Haupts, sondern nach Positiven Grund Gesetzten regiert werden'.

45 Schmauss, Corpus Juris Gentium Academicum, Iv: 'vim legis oder obligandi'.

46 Heineccius, Elementa, Ixf. 
Heineccius discusses only selected aspects of interstate relations. He employs the well-trodden argument that 'the law of nations is the law of nature' 47 at the very beginning of book II, and only towards the end of it does he turn to some concrete aspects of interstate relations and international law. Heineccius engaged with Grotius and Pufendorf and his arguments tend to be closer to those of Pufendorf than to those of Grotius. ${ }^{48}$ For instance, Heineccius sided with Pufendorf against Grotius when he maintained that 'the punishment of crimes is not to be admitted as a just cause of war; rather, that it is certain an equal cannot be punished by an equal; and therefore one nation cannot be punished by another'. 49

Regarding the right to punish in interstate relations, Pufendorf had followed Hobbes's understanding that punishment can be inflicted only if there is a superior authority endowed with this right. ${ }^{50}$ Although Pufendorf subscribed to

47 Heineccius, $A$ Methodical System of Universal Law, 323. See, for instance, the same argument by Hobbes, Pufendorf and later also Vattel. In Leviathan, 244, Hobbes famously made the point that 'concerning the Offices of one Souveraign to another, which are comprehended in that Law, which is commonly called the Law of Nations, I need not say any thing in this place; because the Law of Nations, and the Law of Nature, is the same thing'. Pufendorf followed Hobbes's argument and claimed almost verbatim that 'the Law of Nations, [...] is nothing other than the law of nature'. Samuel Pufendorf, Two Books of the Elements of Universal Jurisprudence, ed. Thomas Behme (Indianapolis, IN: Liberty Fund, 2009), 225. Vattel drew attention to this development and summarized it at the beginning of his influential Le droit des gens, ou Principes de la loi naturelle appliqués à la conduite \& aux affaires des Nations \& des Souverains: 'Hobbes was [...] the first who gave a distinct though imperfect idea of the law of nations. He divides the law of nature into that of man, and that of states: and the latter is, according to him, what we usually call the law of nations. [...] This author has well observed, that the law of nations is the law of nature applied to states or nations. But we shall see in the course of this work, that he was mistaken in the idea that the law of nature does not suffer any necessary change in that application [...]. Pufendorf declares he unreservedly subscribes to this opinion espoused by Hobbes. He has not therefore separately treated of the law of nations but has everywhere blended it with the law of nature properly so called.' Emer de Vattel, The Law of Nations, ed. Béla Kapossy and Richard Whatmore (Indianapolis, IN: Liberty Fund, 2008), 8f.

48 Even in the preface to the Elementa, viII, Grotius was substantially criticized. See as well Heineccius's repeated criticism of Grotius when, for instance, he argued that 'Grotius's distinction between private and public war hath no foundation'. Heineccius, A Methodical System of Universal Law, 501 f. Or with further criticism ibid., 313 or 459. See also Ernst Reibstein, 'Johann Gottlieb Heineccius als Kritiker des grotianischen Systems,' Zeitschrift für öffentliches Recht und Völkerrecht 24 (1964): 236-264.

49 Heineccius, A Methodical System of Universal Law, $502 \mathrm{f}$.

$50 \quad$ See Gerald Hartung, 'Von Grotius zu Pufendorf. Die Herkunft des säkularisierten Strafrechts aus dem Kriegsrecht der Frühen Neuzeit,' in Samuel Pufendorf und die europäische 
Grotius's definition of punishment as an evil inflicted for an evil which had been done ${ }^{51}$ he insisted against the Dutchman that neither in the state of nature nor in a war between states would it make sense to speak of punishment. Pufendorf argued against the position Grotius had advanced in his Dejure belli ac pacis ${ }^{52}$ and maintained that it is an improper Expression to say, a Man is obliged to be punished, or that such a one owes a Punishment; because Punishment signifies Harm inflicted against a Man's Consent, and implies Aversion of the Will to it'. ${ }^{3}$ Pufendorf profoundly contradicted Grotius's notion of punishment regarding the state of nature and interstate relations. As far as natural law is concerned, he was adamant that in the state of nature 'violations of natural law $[\ldots]$ have no penal sanctions attached'.54 But on what basis could the binding force of the natural law be founded? This question had already been of concern to Grotius and Pufendorf, and they had offered different solutions. However, it remained a contested issue, one which Heineccius did not want to take up again. Nor did Schmauss want to rely solely on natural law; he was

Frühaufklärung, ed. Fiammetta Palladini and Gerald Hartung (Berlin: Akademie Verlag, 1996), 123-136.

Pufendorf, On the Duty of Man and Citizen, part II, chap. 13, §4, 158: 'A punishment is an evil one suffers, inflicted in turn for an evil one has done; in other words, some painful evil imposed by authority as a means of coercion in view of a past offence'.

$5^{2}$ Grotius offered a book-length discussion of punishment in the international sphere in book II, chap. xx of his De iure belli ac pacis. Hugo Grotius, The Rights of War and Peace, ed. Richard Tuck (Indianapolis, IN: Liberty Fund, 2005), vol. 2, 949-1052. He argued that the right to punish originally belonged to everyone and that it was derived from the law of nature (972). See also Hugo Grotius, Commentary on the Law of Prize and Booty, ed. M.J. v. Ittersum (Indianapolis, IN: Liberty Fund, 2006), 136. However, he also maintained that sovereigns 'have a Right to exact Punishment, not only for Injuries committed against themselves, or their Subjects, but likewise, for those which do not peculiarly concern them, but which are, in any Person whatsoever, grievous Violations of the Law of Nature or Nations. For the Liberty of consulting the Benefit of human Society, by Punishments, which at first $[. .$.$] was in every particular Person, does now, since Civil Societies, and$ Courts of Justice, have been instituted, reside in those who are possessed of the supreme Power, and that properly, not as they have an Authority over others, but as they are in Subjection to none' (Grotius, The Rights of War and Peace, vol. 2, 1021). In his translation of the works of Grotius and Pufendorf, Jean Barbeyrac pointed out that 'almost this Whole Chapter [chapter xx of Grotius's De Iure Belliac Pacis] should be compared with the third [chapter] of the eighth Book of Pufendorf, where the same Matter is treated of, and our Author's Thoughts frequently explained or corrected; tho' sometimes defended in the Notes'. Annotation by Barbeyrac in Grotius, The Rights of War and Peace, book II, 949.

53 Pufendorf, Of the Law of Nature and Nations, book VIII, chap. III, § 4, 766.

54 Pufendorf, On the Duty of Man and Citizen, book II, chap. 12, § 4, 155f. On punishment between states in Grotius, Hobbes and Pufendorf, see my discussion in Schröder, Trust, 89-136. 
trying to pursue an alternative route. The problem that states could too easily pervert existing moral and legal norms in their self-interest within the European state system was still depressingly present and unsolved for Schmauss. In many ways he followed a twofold strategy to address this fundamental issue. On the one hand, his historical account and natural law doctrine attempted to provide a set of norms and rules which - although not new - aimed to help create a universally accepted system which could claim to possess legitimate and enforceable authority. At the same time, he realized, following Pufendorf, that this claim to internationally binding obligations remained deficient. This is why he endeavoured on the other hand to incorporate the idea of a balance of power in his international political thought. ${ }^{55}$

\section{Interest and the Balance of Power}

Pufendorf's contribution is crucial for understanding the options available to Heineccius and Schmauss. Writing after the Peace of Westphalia, Pufendorf reflected on the theoretical tools of international political thought. For him, interstate relations were not determined by natural law alone. ${ }^{56}$ In his Introduction to the History of the Principal Kingdoms and States of Europe, he discussed interstate relations within an empirical historical account of the European political scene. Pufendorf wanted to ensure that his theory as presented in his natural law doctrine was related to these concrete political issues. Following the reason of state doctrine, he recognized 'interest' as the guiding principle

55 Schmauss was not alone in developing the idea of a balance of power. For further discussion see Bruno Arcidiacono, Cinq types de paix. Une histoire des plans de pacification perpétuelle (Paris: PUF, 2011). Of particular interest in this context is Ludwig Martin Kahle, who was vice provost of the University of Göttingen from 1749 to $175^{\circ}$ and supported George II's pro-Hanoverian policies in his La balance de l'Europe. Kahle was also influenced by Gundling, but he went even further than Gundling and Schmauss when he claimed that justice between states rested on the balance of power. Louis Martin Kahle, La balance de l'Europe considerée comme la regle de la paix et de la guerre, transl. from Latin (Berlin and Göttingen: Les frères Schmid, 1744), $118 \mathrm{f}$.

56 Dufour even claims that interest and not natural law is the foundation of Pufendorf's international law. Dufour, 'Pufendorfs föderalistisches Denken und die Staatsräsonlehre,' 122: 'die Staatsräson, wie sie in seiner Staatsinteressenlehre formuliert ist, [bildet] den fundamentalen Grundsatz des Völkerrechts'. An excellent overview of the place of historiography within Pufendorf's political thought is given by Michael Seidler, 'Natural Law and History, Pufendorf's Philosophical Historiography,' in History and the Disciplines. The Reclassification of Knowledge in Early Modern Europe, ed. Donald R. Kelley (Rochester, NY: University of Rochester Press, 1997), 203-222. 
for state actions: 'the Interest of each State $[. .$.$] is to be esteemed the Principle,$ from whence must be concluded, whether State-Affairs are either well or ill managed. ${ }^{57}$ Interest can be misunderstood and thus state affairs misguided. The study of contemporary history can help to identify the real interest of a state and to avoid policies whereby 'great Errors are committed [...] against the Interest of the State. ${ }^{58}$ Thus, the interest of one state can be opposed to the interest of another, and it can change with time. Pufendorf's theory of interstate relations thus takes two distinct aspects into account. One has to consider historical experience and analyse the conflicting interests of the various states. ${ }^{59}$ One aggravating factor in an already volatile situation is that rulers often pursue 'an Imaginary Interest', for instance 'when a Prince judges the welfare of his State to consist in such things as cannot be perform'd without disquieting and being injurious to a great many other States, and which these are oblig'd to oppose with all their Power. ${ }^{60}$ Above all else, the pursuit of universal monarchy is 'the Fuel with which the whole World may be put into a Flame'.61 Because rulers do not only pursue the 'real interest' 62 of their state, it is much more difficult to calculate the behaviour of the various actors. In the end, there may be no alternative to 'everyone decides for himself whether the measures are apt to conduce to self-preservation or not. ${ }^{63}$

Heineccius engaged less emphatically with the troublesome question of the extent to which international treaties would be binding and could, therefore, reliably regulate interstate relations even if interest seemed to point towards breaking them. Without mentioning 'interest' expressis verbis, he reached a pragmatic conclusion by emphasizing that interest would overrule any agreement a state had previously entered into: 'nothing ought to be held more sacred than treaties, nor nothing more detestable than the perfidiousness of treaty-breakers. Yet because no society is obliged to prefer another's interest

57 Samuel Pufendorf, An Introduction to the History of the Principal Kingdoms and States of Europe, ed. Michael J. Seidler (Indianapolis, IN: Liberty Fund, 2013), 7.

58 Pufendorf, An Introduction to the History of the Principal Kingdoms and States of Europe, 8.

59 There is a strong indication that Pufendorf's understanding of 'interest' led him to argue in his natural law doctrine, too, that 'the relation of states to each other is a somewhat precarious peace. It is therefore a duty of sovereigns to take measures to develop military virtue and skill with weapons in the citizens $[\ldots]$. But one should not take the initiative in aggression even with a just cause for war, unless a perfectly safe opportunity occurs and the country's condition can easily bear it.' Pufendorf, On the Duty of Man and Citizen, book II, chap. 11, § 13, 154 .

6o Pufendorf, An Introduction to the History of the Principal Kingdoms and States of Europe, 7 .

61 Ibid., 8.

62 Ibid.

63 Pufendorf, On the Duty of Man and Citizen, book II, chap. 1, § 8, 117. 
to its own, a republic cannot be obliged by an alliance or treaty to assist another, if its own condition doth not permit' ${ }^{\prime}{ }^{4}$ Contrary to Pufendorf, Heineccius did not endeavour to determine how interest should be assessed. Given that Pufendorf had already shown that interest could be defined differently, depending on different viewpoints, Heineccius's discussion fell behind the level Pufendorf had already reached in his analysis. As with Heineccius's treatment of Hobbes's arguments, Heineccius drew upon some of Pufendorf's key arguments without adding anything substantially new. Instead, he reiterated the familiar argument that sovereignty entailed 'the right of making alliances and treaties, sending ambassadors, and making war and peace; since without these rights the state could not be preserved safe and secure' ${ }^{65}$ But Heineccius did not endeavour to show how natural law could be conceived to regulate this volatile situation.

The idea of a balance of power was at the time of his writings a wellestablished concept in political thinking and provided the crucial alternative to the natural law doctrine. Pufendorf had attempted to reconcile these two concepts by discussing natural law in view of state interest. However, despite its widely recognized significance for the organization of the European state system, the concept of balance of power was also contested in many ways. ${ }^{66}$ The criticism by the Abbé Saint Pierre is perhaps the most pertinent critique of the shortcomings of this system at the beginning of the eighteenth century. ${ }^{67}$ Furthermore, the concept of the balance of power was also employed in the polemics of the period. In the English context, Charles D'Avenant is presumably

64 Heineccius, A Methodical System of Universal Law, $5^{17}$.

65 Ibid., $45^{2}$.

66 The best study on the history of political thought on the balance of power is still Ernst Kaeber, Die Idee des europäischen Gleichgewichts in der publizistischen Literatur vom 16. bis zur Mitte des 1 8. Jahrhunderts (Berlin: A. Duncker, 1907), but see also Arno Strohmeyer, Theorie der Interaktion. Das europäische Gleichgewicht der Kräfte in der frühen Neuzeit (Wien: Böhlau, 1994); Heinz Duchhardt, Balance of Power und Pentarchie: Internationale Beziehungen 1700-1785 (Paderborn: F. Schöningh, 1996); Hans Fenske, 'Gleichgewicht, Balance,' in Geschichtliche Grundbegriffe. Historisches Lexikon zur politisch-sozialen Sprache in Deutschland, vol. 2, ed. Otto Brunner et al. (Stuttgart: Klett-Cotta, 1975), 959-996; Evan Luard, The Balance of Power. The System of International Relations 1648-1815 (London: Palgrave MacMillan, 1992); Richard Little, The Balance of Power in International Relations: Metaphors, Myths and Models (Cambridge: Cambridge University Press, 2007); and Michael J. Sheehan, The Balance of Power. History \& Theory (London, New York: Routledge, 1996).

67 Unparalleled on the Abbé Saint Pierre is Olaf Asbach, Die Zähmung der Leviathane. Die Idee einer Rechtsordnung zwischen Staaten bei Abbé de Saint-Pierre und Jean-Jacques Rousseau (Berlin: de Gruyter, 2002). 
the best-known example. He used the concept of the balance of power quite forcefully against Louis XIV in his Essay upon the Balance of Power.

Despite this multi-faceted use of the balance of power, Schmauss was among those who were confident that it would actually achieve its purpose of stabilizing the European state system. Interestingly, in contrast to Schmauss, Heineccius seemed not at all interested in discussing the balance of power. What is perhaps most remarkable about Schmauss's contribution to this debate is the fact that he combined it with, and embedded it in, his historical approach and his resultant account. This approach aimed to unearth the validity of the balance of power as a political general maxim which operated beyond specific individual state interest. The first part of his Einleitung zu der Staats-Wissenschaft deals, as its title indicates, with the history of the balance of power in Europe.' The structure of this account is quite telling, with the first part concerned with the period before the Peace of Westphalia and the Peace of the Pyrenees. The latter effectively added the missing piece to the construction of $1648 .{ }^{68}$ The second part is concerned with the period from 1659 to the beginning of the War of the Spanish Succession, and the third part considers the current situation up to 1740.

This presentation of European history was aimed at influencing the current affairs of the European state system, which Schmauss perceived to be under substantial threat. As D'Avenant and many others had done, Schmauss insisted that Europe's liberty was closely related to the balance of power: 'For more than two hundred years the whole of Europe has turned to Great Britain as the only power capable of providing protection when its liberty was under threat'. ${ }^{\prime} 9$ Schmauss's argument is familiar, not only in the way he employs the balance of power doctrine, but also in the way he juxtaposes this doctrine as providing the structural guarantee of Europe's freedom against claims to universal monarchy and their inherent threat to the independence and liberty of the European states. ${ }^{70}$

68 Michael Rohrschneider, Der gescheiterte Frieden von Münster. Spaniens Ringen mit Frankreich auf dem Westfälischen Friedenskongress 1643-1649 (Münster: Aschendorff Verlag, 2006); Heinz Duchhardt (ed.), Der Pyrenäenfriede 1659: Vorgeschichte, Widerhall, Rezeptionsgeschichte (Göttingen: Vandenhoeck \& Ruprecht, 2010); and Lucien Bély, Bertrand Haan and Stéphane Jettot (eds.), La Paix des Pyrénées (1659) ou le triomphe de la raison politique (Paris: Classiques Garnier, 2015).

69 Johann Jacob Schmauss, Einleitung zu der Staats-Wissenschafft und Erläuterung des von ihm heruasgegebenen Corpus Juris Gentium Academici und aller andern seit mehr als zweyen Seculis her geschlossenen Bündnisse, Friedens- und Commercien- Tractaten (Leipzig: J.F. Gleditsch, 1741), If. Translations here and below are by the present author.

70 See, for instance, Schmauss, Einleitung zu der Staats-Wissenschafft, 106. The modern authoritative account on universal monarchy is Franz Bosbach, Monarchia Universalis. Ein politischer Leitbegriff der Frühen Neuzeit (Göttingen: Vandenhoeck \& Ruprecht, 1988). 
What is substantially different in his argument from the others I have cited, however, is that he did not attempt to contribute to contemporary polemical arguments, but rather tried to systematize the various stages of the European conflicts. In this respect the struggle for universal monarchy was seen by him as yet another variant of the contest between the powerful houses of Austria and France, ${ }^{71}$ a contest which he believed was at the heart of most European wars of the period. The stalemate between these crowns was always precarious and almost all other European states were drawn into the conflict. According to his own assertion, Schmauss intended to provide a better understanding of 'the principles, maxims and rules after which the European states and their governments conduct their affairs, ${ }^{72}$ the current situation being, to his mind, unsustainable.

Although Schmauss had followed Gundling and had taken up the natural law tradition in his conception of international thought, he maintained that he did not believe that these principles and rules could be found in 'natural or international law or a jus publicum universale, but only in view of the interest. ${ }^{73}$ This seems a surprising assertion, but throughout his historical analysis Schmauss tried hard to demonstrate how interstate relations through history develop into a system in the form of the expanding repertoire of current treatises, which are at the same time a manifestation of the state. What he attempted to achieve seems thus to reformulate the notion of interest in view of the European state system, which in his view found its clearest expression in the balance of power. He thus tried to demonstrate that the real interest of each European state was enshrined in and protected by the balance of power. By undertaking this huge task in his historical approach, Schmauss contributed substantially to the international political thought of the first half of the eighteenth century.

71 Schmauss, Einleitung zu der Staats-Wissenschafft, viII.

72 Ibid., XI.

73 Ibid. Incidentally, Merio Scattola showed that the process of disintegration of natural law actually began with Schmauss, and in particular with his theory of the passions. See Merio Scattola, 'Das Naturrecht der Triebe, oder das Ende des Naturrechts: Johann Jacob Schmauss und Johann Christoph Claproth', in Das Naturrecht der Geselligkeit. Anthropologie, Recht und Politik im 18 . Jahrhundert, ed. Vanda Fiorillo and Frank Grunert (Berlin: Duncker \& Humblot, 2009), 25o. With a similar judgement, see Sellert, 'Johann Jacob Schmauss', 846. 
One year after the death of Schmauss, in 1758, Emer de Vattel (1714-1767) summarized the European situation that Schmauss, Heineccius and their generation had tried to come to grips with:

Europe forms a political system, [...] closely connected by the interests of the nations inhabiting this part of the world. [...] The continual attention of sovereigns to every occurrence, the constant residence of ministers, and the perpetual negotiations, make of modern Europe a kind of republic, of which the members - each independent, but all linked together by the ties of common interest - unite for the maintenance of order and liberty. Hence arose that famous scheme of the political balance, or the equilibrium of power; by which is understood such a disposition of things, as that no one potentate be able absolutely to predominate, and prescribe laws to others. ${ }^{74}$

Perhaps it is fair to say that Heineccius was much more pessimistic about the regulation and pacification of the European state system. Towards the end of his text on natural law doctrine he summarized his views on interstate relations. For him, the sovereignty of the state meant that states would remain in a volatile situation, rife with conflict, as each state had to decide for itself how best to protect its security. Indeed, it seems that Heineccius had, for very similar reasons to Hobbes, as little hope as Hobbes of overcoming the antagonistic state system:

Because all empire is supreme and absolute, it follows, that different empires or civil states are independent, and subject to no common authority on earth. But such states are in the state of nature, and therefore in a state of natural equality and liberty. And because in such a state the injured have no defence or protection but in themselves, and therefore in it everyone has a right to repel violence and injury, and to extort by force what is due to him by perfect right, it is abundantly evident, that every civil state or republic has the right of making war. ${ }^{75}$

74 Vattel, The Law of Nations, 496. On Vattel's use of the balance of power, see the discussions in Richard Devetak, 'Law of Nations as reason of State: Diplomacy and the Balance of Power in Vattel's Law of Nations,' Parergon 28 (2011): 105-128; and Isaak Nakhimovsky, 'Vattel's Theory of the International Order: Commerce and the Balance of Power in the Law of Nations,' History of European Ideas 33 (2007): 157-173.

75 Heineccius, A Methodical System of Universal Law, 498. I have argued elsewhere that Hobbes actually was seriously concerned with overcoming the state of nature between sovereign states. See Schröder, Trust, 104-119. 
Without mentioning it here, Heineccius underpins his theory of sovereignty with the self-interest of each individual state. This can lead only to the aggressive conduct of interstate relations, and Heineccius provided no indication of whether he thought that natural law was able to mediate and better this antagonistic constellation.

In contrast to Heineccius, Schmauss - like Vattel - belongs to those natural law theorists whose historical philosophizing about European order and liberty was not merely taught as an academic subject, but pursued in the hope of influencing the ways politics were conducted. Schmauss's and Heineccius's emphasis on the importance and applicability of natural law to interstate relations differs considerably. Whereas Schmauss employed the concepts of interest and balance of power in a constructive and innovative way which was informed by his historical analysis and increasingly led him away from seeing natural law as crucial for regulating the state system, Heineccius reworked the existing natural law traditions without showing serious concern for offering new solutions to antagonistic interstate relations. This is mainly due to the underlying principle of his natural law doctrine, which baulked at the use and application of natural law in the interstate sphere. With the natural law doctrines as developed by Schmauss and Heineccius, we reach the limits of natural law as far as effective regulation of interstate relations are concerned. ${ }^{76}$

\section{Bibliography}

Ahnert, Thomas, Religion and the Origins of the German Enlightenment: Faith and the Reform of Learning in the Thought of Christian Thomasius (Rochester, NY: University of Rochester Press, 2006).

Arcidiacono, Bruno, Cinq types de paix. Une histoire des plans de pacification perpétuelle (Paris: PUF, 2011).

Asbach, Olaf, Die Zähmung der Leviathane. Die Idee einer Rechtsordnung zwischen Staaten bei Abbé de Saint-Pierre und Jean-Jacques Rousseau (Berlin: de Gruyter, 2002).

Beck Varela, Laura, 'Heineccius and his Catholic Readers' (forthcoming).

Bély, Lucien, Bertrand Haan and Stéphane Jettot (eds.), La Paix des Pyrénées (1659) ou le triomphe de la raison politique (Paris: Classiques Garnier, 2015).

76 I am grateful to the Max-Weber-Kolleg at the University of Erfurt for awarding me one of their COFUND fellowships. This chapter is part of a larger project that has received funding from the European Union's Horizon 2020 research and innovation programme under the Marie Sklodowska-Curie grant agreement, no. 665958. 
Bergfeld, Christoph, 'Johann Gottlieb Heineccius und die Grundlagen seines Naturund Völkerrechts,' in J.G. Heineccius, Grundlagen des Natur- und Völkerrechts, transl. Peter Mortzfeld, ed. Christoph Bergfeld (Frankfurt am Main: Insel, 1994), 507-34.

Bergfeld, Christoph, 'Pufendorf und Heineccius,' in Samuel von Pufendorf und die europäische Frühaufklärung, ed. Fiammetta Palladini and Gerald Hartung (Berlin: Akademie Verlag, 1996), 225-235.

Bosbach, Franz, Monarchia Universalis. Ein politischer Leitbegriff der Frühen Neuzeit (Göttingen: Vandenhoeck \& Ruprecht, 1988).

Boucher, David, 'Resurrecting Pufendorf and capturing the Westphalian moment,' Review of International Studies 27 (2001): 557-577.

Boucher, David, Political Theories of International Relations (Oxford: Oxford University Press, 1998).

Devetak, Richard, 'Law of Nations as reason of State: Diplomacy and the Balance of Power in Vattel's Law of Nations,' Parergon 28 (2011): 105-128.

Devetak, Richard, 'Historiographical Foundations of Modern International Thought: Histories of the European States-System from Florence to Göttingen,' History of European Ideas 41 (2015): 62-77.

Duchhardt, Heinz, Balance of Power und Pentarchie: Internationale Beziehungen 17001785 (Paderborn: F. Schöningh, 1996).

Duchhardt, Heinz (ed.), Der Pyrenäenfriede 1659: Vorgeschichte, Widerhall, Rezeptionsgeschichte (Göttingen: Vandenhoeck \& Ruprecht, 2010).

Dufour, Alfred, 'Pufendorfs föderalistisches Denken und die Staatsräsonlehre,' in Samuel von Pufendorf und die europäische Frühaufklärung, ed. Fiammetta Palladini and Gerald Hartung (Berlin: Akademie Verlag, 1996), 105-122.

Fenske, Hans, 'Gleichgewicht, Balance,' in Geschichtliche Grundbegriffe. Historisches Lexikon zur politisch-sozialen Sprache in Deutschland, vol. 2, ed. Otto Brunner et al. (Stuttgart: Klett-Cotta, 1975), 959-996.

Fiocchi Malaspina, Elisabetta, 'Heineccius' Role in Italian Legal Education in the 18th and 19th Centuries' (forthcoming).

Glafey, Adam Friedrich, Vollständige Geschichte des Rechts der Vernunff, worinnen in dieser Wissenschaft ans Licht getretenen Schriften nach ihrem Inhalt und wahren Werth beurtheilet (Leipzig: Christoph Rigel, 1739).

Grotius, Hugo, The Rights of War and Peace, ed. Richard Tuck (Indianapolis, IN: Liberty Fund, 2005).

Grotius, Hugo, Commentary on the Law of Prize and Booty, ed. M.J. v. Ittersum (Indianapolis, IN: Liberty Fund, 2006).

Grunert, Frank, 'The Reception of Hugo Grotius's De jure belli ac pacis in the Early German Enlightenment,' in Early Modern Natural Law Theories: Contexts and Strategies in the Early Enlightenment, ed. T.J. Hochstrasser and Peter Schröder (Dordrecht: Kluwer, 2003), 89-105. 
Grunert, Frank, 'Das Recht der Natur als Recht des Gefühls. Zur Naturrechtslehre von Johann Jacob Schmauss,' Jahrbuch für Recht und Ethik/Annual Review of Law and Ethics 12 (2004), 137-153.

Gundling, Nicolaus Hieronymus, Status Naturalis Hobbesii in corpore iur civ. (Halle: Zeitlerus, 1706).

Gundling, Nicolaus Hieronymus, 'Hobbes ab Atheismo liberatus,' in Observationes selectae (Halle: Renger, 1737), vol. 1, 37-77.

Gundling, Nicolaus Hieronymus, 'Von Th. Hobbesii Atheisterey,' in Gundlingiana darinnen allerhand zur Jurisprudentz, Philosophie, Historie, Critic, Litteratur und übrigen Gelehrsamkeit gehörige Sachen abgehandelt werden (Halle: Renger, 1717), 303-339.

Gundling, Nicolaus Hieronymus, Ausführlicher Discours über den ietzigen Zustand der europäischen Staaten (Frankfurt and Leipzig, 1733).

Gundling, Nicolaus Hieronymus, 'Ob wegen der anwachsenden Macht der Nachbarn man den Degen entblössen könne,' in Gundlingiana, Darinnen allerhand zur Jurisprudenz, Philosophie, Historie, Critic, Litteratur und übrigen Gelehrsamkeit gehörige Sachen abgehandelt werden (Halle: Renger, 1716), 379-416.

Hammerstein, Notker, Jus und Historie. Ein Beitrag zur Geschichte des historischen Denkens an deutschen Universitäten im späten 17. und frühen 18. Jahrhundert (Göttingen: Vandenhoek und Ruprecht, 1972).

Hartung, Gerald, 'Von Grotius zu Pufendorf. Die Herkunft des säkularisierten Strafrechts aus dem Kriegsrecht der Frühen Neuzeit,' in Samuel Pufendorf und die europäische Frühaufklärung, ed. Fiammetta Palladini and Gerald Hartung (Berlin: Akademie Verlag, 1996), 123-136.

Heineccius, Johann Gottlieb, Elementa juris naturae et gentium (Halle: Orphanotrophei, 1738).

Heineccius, Johann Gottlieb, A Methodical System of Universal Law: or the Laws of Nature and Nations, transl. George Turnbull [1741], ed. Thomas Ahnert and Peter Schröder (Indianapolis, IN: Liberty Fund, 2008).

Hobbes, Thomas, Leviathan, ed. Richard Tuck (Cambridge: Cambridge University Press, 1992).

Hochstrasser, Timothy, Natural Law Theories in the Early Enlightenment (Cambridge: Cambridge University Press, 200o).

Hruschka, Joachim, 'Die Goldene Regel in der Aufklärung - die Geschichte einer Idee,' Jahrbuch für Recht und Ethik/Annual Review of Law and Ethics 12 (2004): 157-172.

Hunter, Ian, The Secularisation of the Confessional State. The Political Thought of Christian Thomasius (Cambridge: Cambridge University Press, 2007).

Kaeber, Ernst, Die Idee des europäischen Gleichgewichts in der publizistischen Literatur vom 16. bis zur Mitte des 18. Jahrhunderts (Berlin: A. Duncker, 1907). 
Kahle, Martin, La balance de l'Europe considerée comme la regle de la paix et de la guerre, transl. from Latin (Berlin and Göttingen: Les frères Schmid, 1744).

Klenner, Hermann, 'Eine fast vergessene Quelle deutscher Menschenrechts- und Rechtsideen: Nicolaus Hieronymus Gundling,' Dialektik (1994): 123-130.

Koselleck, Reinhart, Vergangene Zukunft - Zur Semantik geschichtlicher Zeiten (Frankfurt am Main: Suhrkamp, 1989).

Krouglov, Alexei, 'Die Rezeption Heineccius in Russland' (forthcoming).

Kühnel, Martin, 'Halle - Franeker - Frankfurt/Oder - Halle: Heineccius' Laufbahn als Hochschullehrer' (forthcoming).

Leibniz, Gottfried Wilhelm, 'Mars Christianissimus,' in G. W. Leibniz' Political Writings, ed. Patrick Riley (Cambridge: Cambridge University Press, 1972), 121-145.

Little, Richard, The Balance of Power in International Relations: Metaphors, Myths and Models (Cambridge: Cambridge University Press, 2007).

Luard, Evan, The Balance of Power. The System of International Relations 1648-1815 (London: Palgrave MacMillan, 1992).

Machiavelli, Niccolò, The Prince, ed. Quentin Skinner and Russell Price (Cambridge: Cambridge University Press, 2008).

Maihofer, Werner, 'Schlusswort: Was uns Pufendorf noch heute zu sagen hat,' in $\mathrm{Sa}$ muel Pufendorf und seine Wirkungen bis auf die heutige Zeit, ed. by Bodo Geyer and Helmut Goerlich (Baden-Baden: Nomos, 1996), 223-282.

Meinecke, Friedrich, Die Idee der Staatsräson (Munich: R. Oldenbourg, 196o).

Mulsow, Martin, 'Gundling vs. Buddeus. Competing Models of the History of Philosophy', in History and the Disciplines. The Reclassification of Knowledge in Early Modern Europe, ed. Donald R. Kelley (Rochester, NY: University of Rochester Press, 1997), $103^{-125}$.

Mulsow, Martin, Enlightenment Underground Radical Germany 1680-1720, translated by H.C. Erik Midelfort (Charlottesville, VA \& London: University of Virginia Press, 2015).

Nakhimovsky, Isaak, 'Vattel's Theory of the International Order: Commerce and the Balance of Power in the Law of Nations,' History of European Ideas 33 (2007): 157-173.

Perez Godoy, Fernando, 'La Teoria del Derecho natural y de gentes de Johannes Heineccius en la Cultura juridical iberoamericana,' Revista de Estudios Histórico-Juridicos XXXVII (2015): 453-474.

Osiander, Andreas, 'Sovereignty, International Relations, and the Westphalian Myth,' International Organization 55 (2001): 251-288.

Pufendorf, Samuel, On the Duty of Man and Citizen, ed. James Tully (Cambridge: Cambridge University Press, 1991).

Pufendorf, Samuel, The Present State of Germany, ed. Michael J. Seidler (Indianapolis, IN: Liberty Fund, 2007).

Pufendorf, Samuel, Two Books of the Elements of Universal Jurisprudence, ed. Thomas Behme (Indianapolis, IN: Liberty Fund, 2009). 
Pufendorf, Samuel, An Introduction to the History of the Principal Kingdoms and States of Europe, ed. by Michael J. Seidler (Indianapolis, IN: Liberty Fund, 2013).

Reibstein, Ernst, 'Johann Gottlieb Heineccius als Kritiker des grotianischen Systems,' Zeitschrift für öffentliches Recht und Völkerrecht 24 (1964): 236-64.

Rohrschneider, Michael, Der gescheiterte Frieden von Münster. Spaniens Ringen mit Frankreich auf dem Westfälischen Friedenskongress 1643-1649 (Münster: Aschendorff Verlag, 2006).

Rüping, Heinrich, Die Naturrechtslehre des Christian Thomasius und ihre Fortbildung in der Thomasius-Schule (Bonn: Ludwig Röhrscheid, 1968).

Scattola, Merio, 'Das Naturrecht der Triebe, oder das Ende des Naturrechts: Johann Jacob Schmauss und Johann Christoph Claproth,' in Das Naturrecht der Geselligkeit. Anthropologie, Recht und Politik im 18.Jahrhundert, ed. Vanda Fiorillo and Frank Grunert (Berlin: Duncker \& Humblot, 2009), 231-250.

Schmauss, Johann Jacob, Corpus Juris Gentium Academicum, enthaltend die vornehmsten Grund-Gestetze, Friedens- und Commercien-Tractate, Bündnüsse und andere Pacta der Königreiche, Republiquen und Staaten von Europa (Leipzig: Joh. Friedrich Gleditschens Sohn, 1730).

Schmauss, Johann Jacob, Neues Systema des Rechts der Natur (Göttingen: Abraham Vandenhoecks Witwe, 1754).

Schmauss, Johann Jacob, Historisches Ius Publicum des Teutschen Reichs, oder Auszug der vornehmsten Materien des Reichs-Historie (Göttingen: Abraham Vandenhoecks Witwe, 1754).

Schmauss, Johann Jacob, Einleitung zu der Staats-Wissenschafft und Erläuterung des von ihm heruasgegebenen Corpus Juris Gentium Academici und aller andern seit mehr als zweyen Seculis her geschlossenen Bündnisse, Friedens- und CommercienTractaten (Leipzig: J.F. Gleditsch, 1741).

Schneewind, J.B., The Invention of Autonomy. A History of Modern Moral Philosophy (Cambridge: Cambridge University Press, 1998).

Schröder, Peter, Naturrecht und absolutistisches Staatsrecht. Eine vergleichende Studie zu Thomas Hobbes und Christian Thomasius (Berlin: Duncker \& Humblot, 2001).

Schröder, Peter, “Un Politique peut dire ce qu'un Prince devroit faire” - les concepts de paix et d'équilibre dans la pensée politique de Leibniz,' in La Paix des Pyrénées (1659) ou le triomphe de la raison politique, ed. Lucien Bély, Bertrand Haan and Stéphane Jettot (Paris: Classiques Garnier, 2015), 109-132.

Schröder, Peter, Trust in Early Modern International Political Thought, 1598-1713 (Cambridge: Cambridge University Press, 2017).

Sheehan, Michael J., The Balance of Power. History \& Theory (London, New York: Routledge, 1996).

Seidler, Michael, 'Natural Law and History, Pufendorf's Philosophical Historiography,' in History and the Disciplines. The Reclassification of Knowledge in Early Modern 
Europe, ed. by Donald R. Kelley (Rochester, NY: University of Rochester Press, 1997), 203-222.

Sellert, Wolfgang, 'Johann Jacob Schmauss - Ein Göttinger Jurist,' in JuS Juristische Schulung 11 (1985): 843-847.

Strohmeyer, Arno, Theorie der Interaktion. Das europäische Gleichgewicht der Kräfte in der frühen Neuzeit (Wien: Böhlau, 1994).

Thomasius, Christian, 'On the History of Natural Law until Grotius,' in Ch. Thomasius, Essays on Church, State and Politics, ed. Ian Hunter et al. (Indianapolis, IN: Liberty Fund, 2007), 1-48.

Vattel, Emer de, The Law of Nations, ed. Béla Kapossy and Richard Whatmore (Indianapolis, IN: Liberty Fund, 2008).

Turnbull, George, 'Remarks,' in J.G. Heineccius, A Methodical System of Universal Law: or the Laws of Nature and Nations, transl. George Turnbull [1741], ed. Thomas Ahnert and Peter Schröder (Indianapolis, IN: Liberty Fund, 2008).

Wardemann, Patricia, Johann Gottlieb Heineccius (1681-1741). Leben und Werk (Frankfurt/Main: Lang, 2007).

Wieacker, Franz, Privatrechtsgeschichte der Neuzeit unter besonderer Berücksichtigung der deutschen Entwicklung (Göttingen: Vandenhoeck \& Ruprecht, 1967).

Wight, Martin, Systems of States (London: Leicester University Press, 1977).

Zurbuchen, Simone, 'Gewissensfreiheit und Toleranz: Zur Pufendorf-Rezeption bei Christian Thomasius,' in Samuel von Pufendorf und die europäische Frühaufklärung, ed. Fiammetta Palladini and Gerald Hartung (Berlin: Akademie Verlag, 1996), 169-18o. 


\title{
Men, Monsters and the History of Mankind in Vattel's Law of Nations
}

\author{
Pärtel Piirimäe
}

\section{Introduction}

Emer de Vattel has been widely considered a seminal figure in the European tradition of the law of nations. While attaching himself to the earlier tradition of natural jurisprudence, he offered a normative system of the law of nations that was more firmly and explicitly anchored to the political practice of his contemporary Europe than were the doctrines of his predecessors. Vattel promoted the practical applicability of his Droit des gens (1758), stressing that it was not so much written for interested 'private individuals', i.e. other scholars or the general public, but it was a 'law of sovereigns' that was primarily intended for 'them and their ministers'. It would not help much, he explained, if his maxims were studied only by those who had no influence over public affairs; the 'conductors of states', on the other hand, if they chose to learn this science and adopt its maxims as the 'compass' for their policies, could produce many 'happy results.' ${ }^{1}$ Vattel emphasized the easy comprehension and applicability of his book, contrasting his approach with that of Christian Wolff, whose treatise on the law of nations could be understood only if one 'previously studied sixteen or seventeen quarto volumes which precede it'. ${ }^{2}$ As Vattel famously declared, his original intention was to introduce Wolff's system to a wider readership, by rendering his rigid and formal work more 'agreeable and better calculated to ensure it a reception in the polite world'. ${ }^{3}$

While it is clear that Vattel's work amounted to much more than a systematic account of Wolff's principles, ${ }^{4}$ it is in the manner of presentation that the differences between the two scholars are the most striking. Already the choice of French over Latin, the language of diplomats over that of the republic of

1 Emer de Vattel, The Law of Nations, ed. Béla Kapossy and Richard Whatmore (Indianapolis, IN: Liberty Fund 2008), Preface, 18.

2 Ibid., 12.

3 Ibid., 10-12.

4 Vattel himself outlines some differences in ibid., 13-16. 
letters, is a sign of an appeal to political and diplomatic rather than scholarly circles. But an even more important difference appears from Vattel's choice of examples. The Swiss scholar illustrated his maxims with numerous historical cases, with a clear purpose in mind. He explains that if the aim of a book is not just to inform readers of the right principles of action but also to motivate those who are in charge to follow these principles, it is not sufficient to lay out a systematic account of the law: one also needs to cite examples, 'to render the doctrine more impressive. ${ }^{5}$ For this reason, 'whenever I found a convenient opportunity, I have, above all things, endeavoured to inspire a love of virtue, by shewing, from some striking passage of history, how amiable it is, how worthy of our homage in some truly great men, and even productive of solid advantage.' 6 Teaching through exempla is, of course, an essential feature of humanist rhetorical strategy that most seventeenth-century natural jurists had also followed, with a few notable exceptions such as Thomas Hobbes and the early Samuel Pufendorf, who set out to construct a more rigid geometrical system. ${ }^{7}$ But it is important to note here that Vattel contrasts his choice of examples with that of his predecessors: 'I have quoted the chief part of my examples from modern history, as well because these are more interesting as to avoid a repetition of those which have been already accumulated by Grotius, Puffendorf, and their commentators' 8

The broader aim of this chapter is to discuss the relationship between Vattel's normative system and his usages of history. I will argue that Vattel's resort to examples from modern history had a greater significance for his overall theory than he modestly indicates in the passage quoted above, and also a far greater importance than earlier historiography has attached to it. In previous research, Vattel's uses of history have not been addressed in any systematic manner, creating an impression that Vattel was not interested in history as such, and that his examples, therefore, serve indeed only as illustrations. Some scholars have suggested more explicitly that Vattel's approach is ahistorical, in the sense that he provides a normative account that is not anchored in any systematic understanding of European or civilizational history. Walter Rech, for

5 Ibid., 18.

6 Ibid., 19 .

7 Thomas Hobbes, On the Citizen (1642), ed. Richard Tuck and Michael Silverthorne (Cambridge: Cambridge University Press, 1998); Thomas Hobbes, Leviathan (1651), ed. Richard Tuck (Cambridge: Cambridge University Press, 1991); Samuel Pufendorf, Two Books of the Elements of Universal Jurisprudence (1660), ed. Thomas Behme (Indianapolis, IN: Liberty Fund, 2009); see Fiammetta Palladini, Samuel Pufendorf discepolo di Hobbes: Per una reinterpretazione del giusnaturalismo moderno (Bologna: Il Mulino, 199o).

8 Vattel, The Law of Nations, Preface, 20. 
example, has stated that Vattel 'moved away from history', replacing the 'historicism' or 'cultural relativism' of his predecessors (Bodin, Grotius and Bynkershoek) with a 'faith in universal Reason'. Vattel's ahistorical approach was, in Rech's view, purely rationalist, and the 'inherent rationality and conformity with the principles of the natural law of nations' of his 'Europe's international law' enabled him to justify 'the hegemony of the civilized.' ${ }^{9}$

Another example is Ian Hunter's interpretation of Vattel, which in its central contentions is almost an exact opposite to those of Rech. In a number of essays Hunter presents a convincing refutation of the post-colonialist critique of Vattel, arguing that Vattel's concerns were primarily intra-European. Rather than constructing a universalist theory aimed at justifying European colonization or dispossessing the barbarian, Vattel's central objective was 'to consolidate the civilizing effect of the intra-European regulation of warfare. ${ }^{10}$ For this purpose Vattel worked with a 'double register' of norms. In their conscience, sovereigns were bound by the natural law principles of universal justice based on a Wolffian natural law metaphysics of self-perfecting corporate persons. ${ }^{11}$ In the actual practice of international relations, where there was no universal authority to form judgements on the conduct of free, independent and equal nations, these universal principles were suspended and replaced with a body of rules that Vattel calls 'voluntary law'.12 These were prudential rules drawn from European state practice, the essence of which was to treat both parties in war as legally equal, no matter how their behaviour seemed from the point of view of universal justice. Voluntary law was derived from natural law, as it was natural law itself that commanded sovereigns to suspend its rigorous principles in favour of these prudential rules in order to reduce the violence of inter-state warfare. ${ }^{13}$ Hunter portrays Vattel's theory as 'diplomatic casuistry' that operates in the space between these distinct normative registers, providing the diplomats who were serving the interests of a European territorial state with the tools of adjusting universal justice to the conditions of national self-interest. The suspension of natural law in the interests of one's own nation simultaneously served the interests of the society of nations as a whole,

Walter Rech, Enemies of Mankind: Vattel's Theory of Collective Security (Leiden, Boston: Martinus Nijhoff Publishers, 2013), 118.

10 Ian Hunter, 'Global Justice and Regional Metaphysics: On the Critical History of the Law of Nature and Nations', in Law and Politics in British Colonial Thought: Transpositions of Empire, ed. Shaunnagh Dorsett and Ian Hunter (Basingstoke: Palgrave Macmillan, 2010), $11-29$, at 19 .

11 Hunter, 'Global Justice and Regional Metaphysics', 17.

12 Vattel, The Law of Nations, Preliminaries, § 21.

13 Vattel, The Law of Nations, Preface, 17. 
supporting the principles of non-discriminatory war and peace settlement through compromise. ${ }^{14}$

Among the variety of intellectual sources that inform Vattel's vision of international order, Hunter attributes a distinct role to European public law, collections of treaties, and diplomatic history, from which the prudential voluntary law rules were inferred. ${ }^{15}$ But with regard to his usage of the conjectural histories of the Enlightenment, Hunter appears in line with Rech, although on opposite grounds. For Rech, Vattel's supposed lack of interest in the histories of mankind and the denial of any collective advancement of humanity ${ }^{16}$ is a sign of his disregard of cultural-historical diversity for the sake of justifying the forced export of Europe's international law. Hunter also denies that Vattel 'based his construction of the law of nature and nations on a universal philosophy of justice or a universalising philosophical history' but this was not because of a Eurocentric prejudice but because his thought was wholly internal to 'a specifically European political history'. ${ }^{17}$

One can only agree with Hunter that a universalizing philosophical history was not the main pillar on which Vattel constructed his normative theory. Indeed, Vattel writes hardly anything explicit about the history of mankind or the logic of collective advancement of humanity. Nevertheless, the lack of a systematic account of philosophical history does not mean that we should reduce his theory to a mere European peace project. This chapter is an attempt to show that his concern with European nations and European international relations had a universalist framework, as he projected his pragmatic diplomatichistorical account onto a specific version of Enlightenment philosophical history. It was not a stadial conjectural history of humanity that was sketched by

14 Ian Hunter, 'Vattel's Law of Nations: Diplomatic Casuistry for the Protestant Nation', Grotiana 31 (2010), passim. For a similar interpretation, see Martti Koskenniemi, From Apology to Utopia: The Structure of International Legal Argument (Cambridge: Cambridge University Press, 2005), 108-122.

15 Ian Hunter, "The Figure of Man and the Territorialisation of Justice in "Enlightenment" Natural Law: Pufendorf and Vattel', Intellectual History Review 23:3 (2013): 289-307, at 291. This does not mean that Vattel replaced universalist rules with a mere conventional law of treaties or European customary laws. He explicitly distinguished between the universalist realms of natural law and voluntary law on the one hand, and conventional or particular law on the other hand, arguing that the latter realm does not belong to a treatise on the law of nations, but to 'the province of history'. Vattel, The Law of Nations, Preliminaries, $\$ 24$.

16 Rech, Enemies of Mankind, 119. Rech also denies that Vattel does not use the concept of 'progress', which is not correct. See the mentions of national 'progrès' in Vattel, The Law of Nations, book I, § 22, § 25; book II, § 18 . Hunter, 'The Figure of Man', 291, has both Pufendorf and Vattel in mind. 
Pufendorf and developed more fully by Scottish authors only after Vattel's work was published, ${ }^{18}$ nor a Rousseauian sceptical vision of the corrupting force of civilization. Instead, he drew on Voltaire's optimistic account of general human progress that was driven by enlightened monarchs who exercised a specific kind of political virtue. Vattel's debt to Voltaire's thèse royale is particularly visible in his account of the Russian tsar Peter the Great that drew directly on Voltaire's historical works. I will argue that through his portrayal of Peter the Great, Vattel intended to demonstrate the potential of global human progress, which did not rely on the implementation of natural law by force, nor on virtuous self-denial, but on the proper, enlightened understanding of self-interest.

\section{$2 \quad$ Men and Monsters in Vattel's Law of Nations}

In order to understand Peter the Great's role in Vattel's theory we first need to take a look at Vattel's portrayal of human cultural and moral diversity. Despite the fact that Vattel's Law of Nations does not offer a systematic classification of humanity, the large number of examples scattered throughout the book allow us to reconstruct a moral hierarchy of nations that characterizes the world in which his normative theory obtains. What emerges from the treatise is a picture of the globe that has been and still is inhabited by a variety of peoples whose customs, manners and civilizational achievements exhibit different stages of cultural and moral development. Accordingly, nations are labelled pejoratively as 'savage' or 'barbarous', or positively as 'civilized' or 'polished'. Vattel employs these widely used labels to indicate that nations have realized their duty of self-perfection to different degrees. But he introduces an additional category, namely that of 'monsters', which cuts through all these distinctions. The concept of monsters does not refer to fabulous creatures known from early modern travel writings ${ }^{19}$ nor to a specific level of cultural development existing in some part of the globe, but it is a theoretical concept to signify individuals or nations who lack the minimum of morality that is necessary for social life, and who are, therefore, morally speaking, more similar to brutes than to men. As this concept is an important tool for Vattel to determine the applicability and

18 See Istvan Hont, "The language of sociability and commerce: Samuel Pufendorf and the theoretical foundations of the "Four-Stages Theory"', in The Languages of Political Theory in Early-Modern Europe, ed. Anthony Pagden (Cambridge: Cambridge University Press, 1987), 253-276.

19 See Jonathan P.A. Sell, Rhetoric and Wonder in English Travel Writing, 1560-1613 (Aldershot: Ashgate, 2006). 
scope of the voluntary law of nations, the distinction between monsters and men deserves a closer scrutiny.

The first instance where we encounter 'monsters' occurs in the first book where Vattel discusses various obligations that nations owe to themselves by the laws of nature. It is important to note that these obligations are not derived from the Hobbesian-Pufendorfian minimal concept of natural law that restricts its purview to mere self-preservation and societal peace. Instead, the duties to oneself originate from the Wolffian-Leibnizian metaphysics of perfectibility, with a view to achieving perfection and happiness, both as an individual and as a nation. ${ }^{20} \mathrm{~A}$ sovereign is thus not a mere peacekeeper but is ultimately responsible for creating the conditions where all citizens are capable and motivated to strive towards perfection, which is the road to happiness. ${ }^{21}$ The sovereign should, first of all, enable and promote economic activities that produce 'a happy plenty of all the necessaries of life, with its conveniences, and innocent and laudable enjoyments'.22 Yet not all economic activities that might be able to provide for human necessities are morally equal for Vattel. There are some ways of life that are natural to men and thus conducive to achieving perfection; there are others that tend to corrupt the character and thus impede happiness; and finally, there are some that are thoroughly corrupt. Thus there is a gradation of employments, according to their effects on the human soul, ${ }^{23}$ but also according to the effects that they have on other nations.

This gradation is articulated in the chapter 'Of the Cultivation of the Soil', where Vattel lifts agriculture above all other economic activities. Agriculture is not only the most stable foundation of national wealth and an infinite source of growth, ${ }^{24}$ but it is also the 'natural employment of man', which a sovereign should promote by any available means. Vattel does not place European

20 Emmanuelle Jouannet calls this perfectionist-eudamonist aspect of Vattel's theory 'le droitprovidence', or 'welfarist' purpose of the law, which complements the 'liberal' purpose, which is concerned with liberty and preservation of states: Emmanuelle Jouannet, The Liberal-Welfarist Law of Nations: A History of International Law (Cambridge: Cambridge University Press, 2012), 64, 105-106.

21 'The society is established with the view of procuring, to those who are its members, the necessaries, conveniences, and even pleasures of life, and, in general, every thing [sic] necessary to their happiness', Vattel, The Law of Nations, book I, $§ 72$.

22 Ibid.

23 See Vattel's critique of luxury in the essay 'Dialogue Between the Prince of **** and His Confidant, on Certain Essential Elements of Public Administration', in Vattel, The Law of Nations, 783-796; on Vattel in the context of the eighteenth-century debates on luxury, see Isaac Nakhimovsky, 'Vattel's theory of the international order: Commerce and the balance of power in the Law of Nations', History of European Ideas 33:2 (2007): 157-173. 
nations above the rest of the world in this respect. Quite the opposite is the case, because in many European countries, especially in Spain, where the Church owns too much land, the Roman heritage has been forgotten and the 'beloved employment of the first consuls and dictators of Rome' is disdained by 'a little insignificant haberdasher, a tailor' and 'even the most servile mechanics'. A positive modern example is provided by the Chinese, who hold agriculture in honour, with the result that China is the 'best cultivated country in the world. ${ }^{25}$

Now Vattel moves on to those who fully neglect the obligation to cultivate the soil. Here he makes an important theoretical addition: this duty is not only derived from the obligation to pursue individual or national self-perfection but it is an 'obligation imposed by nature on mankind' as a whole, because the earth is given to all its inhabitants to nourish themselves, not to each nation separately. This perspective enables him to censure those who, 'to avoid labour, chuse to live only by hunting, and their flocks.'. ${ }^{26}$ It is clear that Vattel morally condemns such 'idle' and wasteful modes of life but it also has important legal implications, because other, 'more industrious' nations that are 'too closely confined' are entitled to take possession of the vast tracts that are 'rather ranged through than inhabited. ${ }^{27}$ In another chapter, Vattel outlines a more systematic account of the acquisition of property. He argues that uncultivated lands should be considered 'vacant', that is, without ownership in the legal sense, and therefore the colonization and appropriation by the 'people of Europe' of the lands of which the 'savages' did not make 'actual and constant use' was wholly legitimate. ${ }^{28}$ Vattel contrasts the legitimate colonization of North America with the conquest of the 'civilized empires of Peru and Mexico', which in his view was a 'notorious usurpation'. ${ }^{29}$ In another famous passage Vattel rejects Grotius's doctrine of universal punishment, which enabled the European nations to argue that they were entitled to subject these nations on the grounds of the civilizing and Christianizing mission. ${ }^{30}$ According to Vattel, sovereigns can rightfully punish only those transgressions that affect their own

\footnotetext{
25 Ibd., § 80.

26 Ibid., $\$ 81$.

27 Ibid.

28 Ibid., $\$ 209$.

29 Ibid., § 81.

30 These passages have been in the focus of researchers who are interested in Vattel's 'colonial' legacy, such as: Richard Tuck, The Rights of War and Peace: Political Thought and the International Order from Grotius to Kant (Oxford: Oxford University Press, 1999), 194-196; Antony Anghie, Imperialism, Sovereignty and the Making of International Law (Cambridge: Cambridge University Press, 2005), 269-27o.
} 
rights and safety. ${ }^{31}$ With regard to the question of cultivation, it is clear that an injury occurs only when the 'savages' do not allow the legitimate appropriation of their lands by colonists. But Vattel also mentions another class of non-agricultural savages who can be rightfully punished by everyone: 'those nations (such as the ancient Germans, and some modern Tartars) who inhabit fertile countries, but disdain to cultivate their lands, and chuse rather to live by plunder, are wanting to themselves, are injurious to all their neighbours, and deserve to be extirpated as savage and pernicious beasts.' ${ }^{32}$ A much stronger language is warranted here because these nations violate not just the duty of self-perfection but infringe the natural rights of others. Those savages who do not harm others, however, should be treated humanely and moderately, as was done by the English settlers who even purchased the land from the North American Indians, although this was clearly not needed for the acquisition of a legal title..$^{33}$

The second cluster of beastly or monstrous nations appears in various chapters of the second book, where Vattel examines the obligations that a nation owes to other nations. First, there is a general stipulation that when a sovereign condones the atrocities committed by the state's citizens, the entire nation can be punished as a common enemy: 'when by its manners and by the maxims of its government it accustoms and authorizes its citizens indiscriminately to plunder and maltreat foreigners, to make inroads into the neighbouring countries, \&cc. [...] all nations have a right to enter into a league against such a people, to repress them and to treat them as the common enemies of the human race'. Vattel presents two examples, the Usbecks and the Barbary states, 'with whom the love of plunder, or the fear of just punishment, is the only rule of peace and war'. ${ }^{34}$ He provides more cases of the maltreatment of foreigners in his discussion of the duty of hospitability, condemning those 'savage nations who treated strangers ill, that Scythian tribe who sacrificed them to Diana', and agrees with Grotius that 'their extreme ferocity excluded them from the great society of mankind' ${ }^{35}$ It also appears that it is not necessarily an entire nation that can act monstrously but a sovereign can alone become an enemy of mankind and can therefore be subjected to a collective punishment: 'As to those monsters who, under the title of sovereigns, render themselves the scourges

31 Vattel, The Law of Nations, book II, § 7; book I, § 169; see Simone Zurbuchen, 'Vattel's law of nations and just war theory', History of European Ideas 35 (2009): 408-417, at 412.

32 Vattel, The Law of Nations, book I, § 81.

33 Ibid.

34 Ibid., book II, $§ 78$.

35 Ibid., § 104. 
and horror of the human race, they are savage beasts, who every brave man may justly exterminate from the face of the earth'. ${ }^{36}$ Vattel does not present any contemporary examples here, but mentions only three mythical tyrants: 'all antiquity has praised Hercules for delivering the world from an Antaeus, a Busiris, a Diomede. ${ }^{37}$ Yet the context for this statement is the question of the rights of sovereigns to interfere in the quarrel of another sovereign with his subjects where those subjects have risen in self-defence against an 'insupportable' tyranny. A single example of such a justified intervention is taken from modern history, namely the deposition of James II by William of Orange. ${ }^{38}$ This suggests that monstrous tyrants can also rise among the civilized peoples of Europe.

The third book, which is devoted to moral and legal issues related to war, offers yet another significant passage on 'monsters' that is crucial for an understanding of the function of these quasi-humans in Vattel's system. It also helps to clarify some common misconceptions relating to the position of the traditional just war doctrine in his theory. In a paragraph about nations who 'make war without reason or apparent motives' Vattel writes as follows:

Nations that are always ready to take up arms on any prospect of advantage, are lawless robbers: but those who seem to delight in the ravages of war, who spread it on all sides, without reasons or pretexts, and even without any other motive than their own ferocity, are monsters, unworthy the name of men. They should be considered as enemies to the human race $[\ldots]$. All nations have a right to join in a confederacy for the purpose of punishing and even exterminating those savage nations. ${ }^{39}$

Vattel makes here a distinction between two kinds of immoral nations: those who wage war without a just cause, only for the motive of advantage, and those

$36 \quad$ Ibid., $§ 56$. Vattel's own terminology is: 'Pour ce qui est de ces Monstres, qui sous le titre de Souverain, se rendent les fléaux \& l'horreur de l'humanité; ce sont des bêtes féroces'. Vattel, Le Droit des Gens, ou Principes de la Loi Naturelle, appliqués à la Conduite \& aux Affaires des Nations \& des Souverains (Londres, 1758), book II, § 56 .

Vattel, The Law of Nations, book II, $\S 56$. The quote is taken from Grotius: 'And upon this Account it is, that Hercules is so highly extolled by the Antients, for having freed the Earth of Antaeus, Busiris, Diomedes, and such like Tyrants'. Hugo Grotius, The Rights of War and Peace, ed. Richard Tuck (Indianapolis, IN: Liberty Fund, 2005), book II, chap. xx, § 40.2.

38 Vattel, The Law of Nations, book II, §56; see book I, § 121: 'The monster who does not love his people is no better than an odious usurper, and deserves, no doubt, to be hurled from the throne'. 
who do not have any reasons, pretexts or apparent motives but enjoy warfare as such. This distinction is not a novelty proposed by Vattel. His direct source of inspiration was Christian Wolff, who, in turn, drew on a long discussion of monstrously bellicose nations that was introduced by Hugo Grotius. But Vattel added an important further construction onto these foundations: a focus on pretexts as the criterion for distinguishing between monsters and men. Let us have a brief look at the foundations so as to gain an understanding of the role of monsters and the function of pretexts in Vattel's theory.

Vattel starts his account of the causes of war with a distinction between 'justificatory reasons', which refer to legal grounds of war, and 'motives', which refer to expediency. ${ }^{40}$ This distinction, too, is an inheritance from Grotius, who discussed a number of cases from antiquity when rulers had publicly presented a justifying reason (causa justifica) but the actual motive (causa suasoria) was 'a strong desire of glory, empire and riches'. ${ }^{41}$ Wolff utilized exactly the same terminology for a distinction between justifying (justifica) and persuasive (suasoria) reasons. ${ }^{42}$ All authors in the early modern tradition of natural jurisprudence argued that if a war was waged without legitimate justifying reasons (i.e. an injury done or threatened), it was unjust, as it violated the (perfect) rights of the other nation. But even worse were those who lacked even the expedient motives: these nations were described as ferocious, savage, beast-like enemies of mankind. Grotius writes that to covet dangers for danger's sake is a 'vice that so far passes the bounds of humanity, that by Aristotle it is styled brutishness.' ${ }^{43}$ As Grotius further elaborates in the chapter about punishments, such men are not completely human because, normally, people commit crimes for some wicked, selforiented motives. Sinful desires are part and parcel of humanity whereas pure wickedness without any benefit to oneself is not: "There is hardly any man wicked for nothing, and if there be any one who loves wickedness for its own sake, he is a sort of monster'44 This is something so unnatural that Jean Barbeyrac in his commentaries on Pufendorf, referring to Grotius's

$40 \quad$ Ibid., $§ 25$.

41 Grotius, The Rights of War and Peace, book II, chap. 22, § 1.2. For a systematic distinction between 'justifying reasons' and 'motives of advantage', see also book II, chap. 1, § 1.1.

42 Christian Wolff, The Law of Nations Treated According to the Scientific Method (1749), transl. Joseph H. Drake, rev. and ed. Thomas Ahnert (Indianapolis, IN: Liberty Fund, 2017), §621.

43 Other words used by Grotius include feritas, saevitia, mera insania: Grotius, The Rights of War and Peace, book II, chap. 22, § 2. 
discussion of different kinds of unjust wars, doubts that such nations actually exist. ${ }^{45}$

Wolff also presents a Grotian typology of unjust wars that is based on the existence and relative force of 'justifying' and 'persuasive' reasons: first, wars undertaken solely for utility; second, wars waged for utility but with the existence of a just cause; and third, wars waged for utility but under the appearance of quasi-justifying reasons (i.e. pretexts). The strongest moral condemnation belongs, again, to the fourth type: 'The war of those who, influenced neither by justifying nor by persuasive reasons, are carried into wars, is not only unjust but also transgresses the law of humanity'46 Like Grotius and Barbeyrac, Wolff is puzzled why anyone would go to war without any apparent benefit to oneself. Therefore, those who, 'influenced neither by justifying nor by persuasive reasons, are carried into war, must represent to themselves as a benefit the war considered as such, consequently, filled with a mistaken notion of good, they must gain pleasure from it, and consequently the slaughter and mangling of men and the destruction of property belonging to innocent men delights them, ${ }^{47}$

Wolff's recipe for dealing with such monsters is also influenced by Grotius, who famously argued that every sovereign had the right to exact punishments not only for injuries done to the nation itself but for 'any grievous violations of the law of nature or nations.' ${ }^{48}$ Thus war can be waged against those who 'offend against nature'. The list of such offenders includes those who practise tyranny, those who are inhuman to their parents, those who eat human flesh and those who practise piracy. The last group are described as semi-human monsters whose 'depravity of mind' has cut them off from human society. Against 'such barbarians, and rather beasts than men', a war is just and even 'natural'.49 Wolff, however, takes the side with those critics of Grotius who argued that such an indeterminate account of universal punishment is an anathema to international

45 'Thus a war may be vicious, or unjust, with regard to the causes, for several ways: First, when we undertake it either without any justifying cause, or any motive of profit, tho' never so little, but only out of a fierce and brutal fury, that makes us delight in blood and slaughter purely for the sake of killing. But there is reason to doubt, whether we can find any example of so barbarous a war'. Samuel Pufendorf, Of the Law of Nature and Nations, transl. Basil Kennett, 4th ed. (London: J. Walthoe et al., 1729), book VIII, chap. VI, § 4, 835 , note 2. Pufendorf does not mention such nations, so Barbeyrac complements his analysis with additions from Grotius.

46 Wolff, Law of Nations, § 626 .

47 Ibid.

48 Grotius, The Rights of War and Peace, book II, chap. 20 , $\$ 40.1$.

49 Ibid., $§ 40.2-4$. 
order. Nevertheless, he did not go so far as to agree with Pufendorf's wholesale rejection of the possibility of applying the concept of punishment to international relations. ${ }^{50}$ Wolff restricted the right of punitive war only to injuries done to oneself: 'For no one has a right of a war except one to whom a wrong has been done. ${ }^{51}$ But in Wolff's view this restriction is not applicable to those who delight in war as such. Since these people 'do not hesitate to injure any nations simply for selfgratification [...] a right of war belongs to all nations in general' against them. ${ }^{52}$

As we can see from the above, Vattel's account of the 'enemies of the human race' who can be punished and even exterminated by all nations drew directly on that of Wolff. But Vattel added a very important twist to Wolff's argument that enabled him to determine with greater precision whether we are dealing with men or with monsters. This, in turn, was vital for him in order to determine whether or not natural law stipulations were to be suspended and a voluntary law regime applied in a particular case. In Vattel's view, this cannot be decided on the basis of an analysis of the content of justifiable reasons presented by a party in war, because, as discussed above, nobody can claim to be able to judge the rightfulness of a sovereign's cause. It may indeed often be the case that someone goes to war merely from motives of advantage; his conduct in that case is 'reprehensible, and sullied by the badness of his motives'. War is so dreadful that only 'manifest justice, joined to a kind of necessity' renders it exempt from reproach. ${ }^{53}$ Nevertheless, as Vattel emphasizes, he cannot 'be charged with injustice', because 'in every case susceptible of doubt, the arms of the two parties at war are to be accounted equally lawful, at least as to external effects. $^{54}$

Thus, in Vattel's (and Wolff's) theory of just war there emerges an extensive space between the two extremes of manifest justice and manifest injustice. It is a sphere of epistemic moral uncertainty where we cannot be sure of the

$5^{\circ}$ On Grotius's idea of natural right of punishment and Pufendorf's critique, see Gerald Hartung, 'Von Grotius zu Pufendorf. Die Herkunft des säkularisierten Strafrechts aus dem Kriegsrecht der Frühen Neuzeit', in Samuel Pufendorf und die europäische Frühaufklärung, ed. Fiammetta Palladini and Gerald Hartung (Berlin: Akademie-Verlag, 1996), 123136, and more recent discussion by Peter Schröder, Trust in Early Modern International Political Thought, 1598-1713 (Cambridge: Cambridge University Press, 2017), 101-103, 133-134.

$5^{1} \quad$ Wolff, Law of Nations, $§ 636$.

52 Ibid., §627. It should be noted that Pufendorf also allows war against those who 'kill and eat' innocent travellers, but this can be waged only by the sovereign whose subjects have been attacked. Pufendorf, Of the Law of Nature and Nations, book VIII, chap. 6, §5. 
substantive justice of the parties at war, and therefore we should give them the benefit of doubt, allowing the suspension of the rigorous regime of natural law and the application of voluntary law with regard to the external effects of war. ${ }^{55}$ Since the first boundary between manifestly just and doubtful war affects only the moral appraisal of a belligerent, Vattel is more concerned with establishing with greater certainty the boundary between morally doubtful and manifestly unjust wars. Wolff did not offer a definitive solution to this problem but Vattel was able to construct his own solution on Wolff's explanation as to when the voluntary law applies. Presenting the already familiar doctrine of the liberty and independence of states, Wolff writes:

Therefore, since no nation can assume for itself the functions of a judge, and consequently cannot pronounce upon the justice of the war, although by natural law a war cannot be just on both sides, since nevertheless each of the belligerents claims that it has just cause of war, each must be allowed to follow its own opinion; consequently by the voluntary law of nations the war must be considered as just on either side, not indeed in itself $[\ldots]$ but as regards the results of war. ${ }^{56}$

Vattel focuses on Wolff's implied criterion, that a belligerent power must indeed claim that he has a just cause in order to qualify as a legitimate belligerent. ${ }^{57}$ Therefore, the public presentation of justifying reasons is not only a necessary but, as Vattel further elaborates, also a sufficient condition for a legitimate war under the regime of voluntary law. It does not matter whether the reasons announced are 'real justificatory reasons' or mere pretexts, which might be 'even absolutely destitute of all foundation'.58 This is because:

Pretexts are at least a homage which unjust men pay to justice. He who screens himself with them shews that he still retains some sense of shame. He does not openly trample on what is most sacred in human

55 Wolff, Law of Nations, $\S 887-888$.

56 Ibid., $§ 888$.

57 In fact, Grotius had already suggested that the modern laws of nations that restrict violence in a formal war between legitimate enemies may not be followed in case 'we should have to do with a state so barbarous, as to think it lawful without any manner or reason, or denunciation of war, to treat in a hostile manner the persons and goods of all strangers'. Grotius, The Rights of War and Peace, book III, chap. 9, § 19.2, 85 . 
society: he tacitly acknowledges that a flagrant injustice merits the indignation of all mankind. ${ }^{59}$

It should be noted that the shift of focus from substantive justice to pretexts does not mean a decriminalization of all enemies in warfare, nor an abandonment of the just war theory as such, as claimed by Carl Schmitt and his followers. The Schmittian interpretation has posited that Vattel, following the lead of Grotius, abandoned the 'medieval doctrine of just war' and stipulated the legal equality of both sides in war, as long as the war was waged by a sovereign authority. ${ }^{60}$

Thus, according to this interpretation, the formal concept of justice replaced the substantive one, and the 'non-discriminatory' treatment of belligerents was established as a legal principle, with no reference to the existence or nonexistence of a just material cause for war. Schmitt argued that Vattel reached 'the classical transparency of the enlightened 18th century' and displaced the whole problem of a substantive, normative justice 'openly and clearly in the mere "form", i.e. in the purely state structure of war.' 61

It is, however, impossible to reconcile this argument with Vattel's account of monsters and the declaration of war. As we saw, a declaration was required not for the sake of proving that a war was waged by sovereign authority but for the sake of publicly announcing the reasons for war. Vattel never argued that the exercise of sovereign authority was sufficient to qualify as a legitimate belligerent who should enjoy non-discriminatory treatment under the regime of voluntary law. On the contrary, his distinction between men and monsters retained the traditional separation between just and unjust enemies in a particularly strong form, and this distinction was not tied to the concept of sovereignty. This position is clearly evident in Vattel's treatment of the Barbary corsairs, who admittedly exercised sovereignty over their own territories but who nevertheless were to be punished as the enemies of humankind by other nations. This is also recognized by Walter Rech, who struggles to reconcile his firm support for Schmitt's thesis with Vattel's account of the Barbary states.

59 Ibid., $\S 32$. In his discussion of the faith of treaties, Vattel specifies that a pretext should not be 'evidently frivolous'. Ibid., book II, $§ 222,388$.

6o Carl Schmitt, The Nomos of the Earth in the International Law of the Jus Publicum Europaeum, transl. G.L. Ulmen (New York: Telos, 2006), 165-166; Rech, Enemies of Mankind, 3, 111. For an excellent discussion of the Schmittian argument, see Gabriella Silvestrini, 'Justice, War and Inequality. The Unjust Aggressor and the Enemy of the Human Race in Vattel's Theory of the Law of Nations', Grotiana 31:1 (2010): 41-68. 
Rather than using the latter as evidence to question Schmitt's interpretation of Vattel's normative system, Rech concludes that Vattel is inconsistent and betrays his own principles. He first attributes to Vattel the aim of 'moving away from the traditional just war doctrine by focusing on the modality as opposed to the morality of warfare'. But Vattel failed to reach this supposed goal, because in order to 'make a case against Barbary warfare [he] had to depart from the idea that sovereignty as such elicited the right to wage war'. Therefore, in Rech's view, Vattel 'problematically resorted to the just cause argument, which he put aside when describing the "war in due form" between European sovereigns.' ${ }^{62}$

I do not see the need to accuse Vattel of inconsistency or hypocrisy in this respect, because the figure of monsters and the argument of pretexts were introduced by him precisely to maintain the principles of natural justice as the overarching framework within which voluntary law could operate. It was not the case that 'strict natural law re-enters into force' in the face of 'grave and systematic violations of the "voluntary law of nations", as Rech has argued. ${ }^{63}$ On the contrary, strict natural law was always binding in conscience, and the voluntary law regime would not be applicable to nations or sovereigns who clearly and evidently violated the principles of natural justice, which is why they would be punished with its full force. Therefore, the requirement of a declaration of reasons was not mere 'form' but it enabled men to be distinguished from monsters, buttressing the validity of natural justice. Vattel thus retained the distinction between justus hostis and an unjust enemy who should be treated as a common criminal, even though he lowered the bar for the qualification as justus hostis so as to render the potential criminalization less arbitrary and subjective.

Moreover, the presentation of a pretext was not a purely formal criterion because it functioned as an indication that a nation or a sovereign possessed a minimum of natural morality. This minimum was established not with regard to how a nation treated others but with regard to how it behaved towards itself, that is, whether or not it had a basic understanding of its own proper good and the desire to advance it. A sovereign who presented a pretext was at least willing to appear that he was playing by the rules. This purely expedient or self-interested action indicated the presence of two basic components of moral behaviour upon which one could hope to build more advanced levels of morality: first, that sovereign (or nation) was not led purely by desires but demonstrated the presence of a certain level of instrumental rationality; and secondly,

62 Rech, Enemies of Mankind, 108. Rech (58) also accuses Gentili of similar inconsistency.

63 Ibid., 3 . 
that it had a 'sense of shame', that is, an awareness of the existence of the moral rules of human society. The thrust of Vattel's theory is that peaceful international relations could not be realistically built on altruistic considerations of other nations' good but upon enlightened self-interest. ${ }^{64}$ In the course of history, nations would gradually realize that the best way to advance their own interests was to pursue 'mutual affection' by honouring other nations' rights and performing the offices of humanity: 'Wise and prudent nations often pursue this line of conduct from views of direct and present interest: a more noble, more general, and less direct interest, is too rarely the motive of politicians.' ${ }^{65}$ Therefore, one could achieve peaceful and cooperative relationships that enabled mutual self-perfection even with selfish nations but not with monsters, who were guided by brutish desires rather than by motives of advantage.

\section{Peter the Great and the Moral Development of Nations}

As suggested in the introduction to this chapter, Vattel's portrayal of men and monsters was not an abstract normative system but it was projected onto European history in a manner that reveals an underlying but not fully articulated civilizational history of mankind. Unlike the works of his predecessors Grotius, Pufendorf, Burlamaqui, Wolff and others, Vattel's treatise reveals a belief in recent momentous historical change and the corresponding understanding that his own age was qualitatively different from preceding ones. Law of $\mathrm{Na}$ tions is peppered with references to 'the present age'66 and the 'enlightened century, ${ }^{67}$ which has higher moral standards than the earlier times. ${ }^{68}$ Vattel's

64 See Kapossy and Whatmore, 'Introduction' to Vattel, The Law of Nations, xvii.

65 Vattel, The Law of Nations, book II, § 12.

66 Vattel writes of the distinctiveness of the 'present age' in relation to, for example, the arts and sciences (The Law of Nations, book I, § 113), treaties with non-believers (book II, § 162), the treatment of hostages (book II, § 246), and assassination and poisoning (book III, § 155). Vattel also refers to 'those unhappy times' when the Popes intervened in the actions of sovereigns (book I, § 146, § 154).

67 '[...] dans un siécle éclairé': Vattel, Le Droit des Gens, book I, § 61, book II, § 275. Elsewhere he says 'Why does there still remain any vestige of so barbarous a law in Europe, which is now so enlightened and so full of humanity', The Law of Nations, book II, § 112. The term 'enlightened' is also frequently used in book I, chap. 11-13, which discuss the duties of sovereigns to perfect the nation.

68 A typical example: 'How could it be conceived in an enlightened age, that it is lawful to punish with death a governor who has defended his town to the last extremity, or who, in a weak place, has had the courage to hold out against a royal army? In the last century, this notion still prevailed'. Vattel, The Law of Nations, book III, § 143 . 
account implies that the last 100 years had been a particularly productive period in the long-term moral history of mankind. The 'sacred precepts of nature' that obliged nations to cultivate friendship with others for their own long-term interest were not an inborn knowledge of moral psychology but were 'for a long time unknown to nations' ${ }^{69}$ The ancients had no notion of the duty they owed to other nations by virtue of common humanity but 'at length the voice of nature came to be heard among civilized nations; they perceived that all men are brethren.70 But as we saw above, not all nations had heard this voice of nature or acted upon it, which explains the moral diversity of mankind, with a fundamental fault-line between monsters and men.

Emer de Vattel's fascination with Peter the Great can be explained in the context of his account of the moral development of nations. Peter the Great's Russia served for him as an example that pointed to the possibility of accelerating the historical process which in general seemed to be slow and gradual. Rather than reflecting a genuine and critical interest in what had actually happened in Russia during and after Peter the Great's reign, the figure of the tsar was used by Vattel as a vehicle to emphasize the transformative capacity of a single monarch who had a proper understanding of enlightened self-interest. Therefore, Peter had a different and more ambiguous role than was typical of progressive sovereigns of Europe, such as Louis XIV, who could draw on the long-term development of polite customs and manners of their cultured nations. The ambiguity of Peter's role expressed Vattel's dual concerns. On the one hand, his figure pointed to the need to adhere to the minimum standards of morality necessary for peaceful international coexistence. On the other hand, Peter's rational and self-interested striving towards perfecting his nation was simultaneously a call to European sovereigns to act as agents of improvement rather than falling back to former, false concepts of military honour and vainglory that could put national welfare and international order in danger.

In Vattel's Law of Nations, Peter the Great is mentioned on ten occasions. We encounter the tsar who not only strives towards perfecting his nation but also appears to have achieved his goal of transforming Russia into a civilized country: 'things have been greatly changed in Russia; a single reign - that of Peter the Great - has placed that vast empire in the rank of civilized nations. ${ }^{71}$ What Vattel means by 'civilized nations' is not, however, immediately clear, as he does not offer any definitions in his treatise. By contrast, Wolff had discussed at some length the differences between nations at various levels of moral

\footnotetext{
69 Ibid., book II, § 20.

70 Ibid.

71 ' [...] a mis ce vaste Empire au rang des Etats civilisés'. Vattel, Le Droit des Gens, book II, § 108.
} 
and civilizational development. Wolff distinguishes barbarous nations from 'cultured and civilized' ones: cultured nations (gentes doctae) are those who cultivate intellectual virtues, whereas civilized nations (gentes cultae) have 'civilized manners which conform to the standard of reason and politeness' (quae cultis utitur moribus, seu ad normam rationis et suavitatem compositis). ${ }^{72}$ The distinction was purely theoretical, though, because in actual practice the care for intellectual virtues tended to lead to the adoption of civilized customs and manners and, vice versa, a neglect of the development of the mind led to the domination of natural inclinations that was typical of barbarians: 'If a cultured nation is assumed to cultivate the intellectual virtues without restriction, it will scarcely happen that it will not at the same time become civilized, since civilized customs develop from intellectual virtues, just as the uncivilized from the natural inclinations, unrestricted by reason. ${ }^{73}$

Although Vattel is not interested in these specific definitions, a Wolffian eudaimonist doctrine of happiness provides the background against which he develops his portrayal of Peter the Great. As Wolff had argued, the cultivation of intellectual virtues is not morally indifferent but nations 'ought' to become civilized and therefore 'develop the mind by that training which destroys barbarism. ${ }^{74}$ In practice it was the ruler of the state who was responsible for 'perfecting and preserving his nation'. ${ }^{75}$ In contrast to the Hobbesian-Pufendorfian model of a relatively limited state where the sovereign functions primarily as a peacekeeper, Vattel follows Wolff in attributing a key role to the sovereign in 'procuring the true Happiness of the Nation. ${ }^{76}$ This meant that the sovereign was responsible not only for providing material conditions for a happy life but also for directing the life projects of citizens beyond 'earthly enjoyments' towards achieving 'their own perfection'. An important means for doing so was the advancement of arts and sciences, which 'enlighten the mind and soften the manners'.77 Vattel uses the opportunity to attack Rousseau's sceptical theory of civilization, without mentioning the name of his opponent: 'Let the friends of barbarism declaim against the sciences and polite arts; - let us, without deigning to answer their vain reasonings, content ourselves with appealing

72 Wolff, Law of Nations, § 53 .

73 'Quoniam vero Gentes barbarae moribus incultis utuntur, ideo Genti barbarae opponitur Gens docta \& culta'. Ibid.

74 Ibid., $§ 55$.

75 Ibid., $§ 38$.

76 The chapter title of Vattel, Le Droit des Gens, book I, chap. xi: 'Second objet d'un bon Gouvernement, procurer la vraie félicité de la Nation'. 
to experience' ${ }^{78}$ The empirical proof is found when we compare 'England, France, Holland, and several towns of Switzerland and Germany, to the many regions that lie buried in ignorance, and see where we can find the greater number of honest men and good citizens.' ${ }^{79}$ Peter the Great functions here as a prime example of the present, more enlightened age, when the utility and necessity of 'literature and the polite arts' are generally acknowledged: 'The immortal Peter I thought that without their assistance he could not entirely civilize Russia, and render it flourishing'. ${ }^{80}$

This grand design of perfecting through civilizing is also the leitmotiv in other instances where Peter is mentioned in the first book. For example, Vattel disapproves of the general idea that a sovereign can freely appoint his successor, which for him is associated with a 'shocking, improper and dangerous' notion of a patrimonial state. ${ }^{81}$ But Peter's example shows that there are exceptions to this rule because he nominated his wife to succeed him, not for his own private advantage but for the welfare of his empire: 'He knew that heroine to be the most capable person to follow his views, and perfect the great things he had begun'. From this example Vattel derives a more general, albeit a rather vaguely formulated rule in the spirit of enlightened despotism: 'If we often found on the throne such elevated minds as Peter's, a nation could not adopt a wiser plan in order to ensure to itself a good government, than to intrust the prince, by a fundamental law, with the power of appointing his successor.82

We see from these examples that Peter the Great was a rare, extraordinary figure whose grand design was to 'entirely civilize Russia' but it is not apparent yet, in the first book, whether and to what extent, in Vattel's opinion, he had actually reached his goal. In the second and third book, which deal with nations' duties towards others and with the issue of war, it appears that his concept of 'civilized' did not imply an advanced level of 'politeness' which would make Russia comparable with England, France or Switzerland, but rather the minimum level of morality to enable it to interact on an equal footing with

78 On Vattel's criticism of Rousseau, see Béla Kapossy and Richard Whatmore, 'Emer de Vattel's Mélanges de littérature, de morale et de politique (176o)', History of European Ideas 34:1 (2008), 77-103; Béla Kapossy and Richard Whatmore, 'Introduction', in Vattel, The Law of Nations, ix-xx; Theodore Christov, Before Anarchy: Hobbes and His Critics in Modern International Thought (Cambridge: Cambridge University Press, 2015), 238-244.

79 Vattel, The Law of Nations, book I, § 113.

8 o Ibid.

$81 \quad$ Ibid., Preface, 13; book I, $§ 61,68$.

82 Ibid., book I, § 70. Vattel adds here the example of the Roman emperors, whose right to appoint a successor by adoption produced 'a series of sovereigns unequalled in history Nerva, Trajan, Adrian, Antonius, Marcus Aurelius'. 
those states. Vattel frequently refers to 'polite' or 'polished' nations whose behaviour towards others expresses the 'superior gentleness' of his age. ${ }^{83}$ This is particularly visible in war, where the 'polished nations of Europe' 84 have adopted much higher moral standards than required by the stipulations of the necessary or voluntary law of nations. In the third book of the treatise, Vattel keeps heaping praise on European sovereigns for their customs of warfare, presenting thus a standard of humanity that all nations should aspire to: 'At present the European nations generally carry on their wars with great moderation and generosity. These dispositions have given rise to several customs which are highly commendable, and frequently carried to the extreme of politeness'. 85

The standard of civilization that Russia had achieved was on a completely different level. In fact, the congratulatory remark that praised Russia for reaching the rank of civilized nations occurs in the context of the discussion of the duties towards foreigners. Vattel mentions here a particularly grievous violation of the rights of individuals, namely the imprisonment of shipwrecked foreigners. This had also been practised in Muscovy but, as we saw above, things had 'greatly changed' in Russia during Peter's reign, which had placed the state 'in the rank of civilized nations'. 86

All the other instances where Peter is discussed in the second and third books convey the same message: Russia should not be considered a 'monstrous' nation because, thanks to Peter's efforts, it fulfils the minimum standard of morality that allows other countries to apply the regime of voluntary law in their mutual relations. The fact that Peter just barely cleared the bar is most evident in Vattel's discussion of the reasons for his war against Sweden and the manner in which he waged it. Peter had justified his war against Sweden with an offence against his dignity:

The czar Peter the First, in his manifesto against Sweden, complained that the cannon had not been fired on his passing at Riga. He might think it strange that they did not pay him this mark of respect, and he might complain of it; but to have made this the subject of a war, must have indicated a preposterous prodigality of human blood. ${ }^{87}$

83 See for ibid., book II, § 139, § 169, book III, § 65, § 148 .

84 Ibid., book III, § 148; see also § 147, § 158 .

85 Ibid., $§ 158$.

86 Ibid., book II, § 108.

87 Ibid., $§ 48$. 
The same manifesto illustrates for Vattel the distinction between real justificatory reasons and mere pretexts:

The name of pretexts may likewise be applied to reasons which are, in themselves, true and well-founded, but, not being of sufficient importance for undertaking a war, are made use of only to cover ambitious views, or some other vicious motive. Such was the complaint of the czar Peter I that sufficient honours had not been paid him on his passage through Riga. ${ }^{88}$

But, as indicated above, the mere fact that Peter presented such a manifesto is a sufficient sign that he is not a monstrous enemy of mankind. ${ }^{89}$

Peter the Great is contrasted simultaneously with polite nations and with monsters also in Vattel's analysis of 'the rights of nations in war', which later became known as the 'ius in bello' doctrine. Charles XII, the king of Sweden, listened to the 'voice of humanity' when he released all Russian prisoners after the Battle of Narva of 1700. Peter, on the contrary, 'still impressed with the apprehensions which his warlike and formidable opponents had excited in his mind, sent into Siberia all the prisoners he took at Pultowa'. ${ }^{90}$ Later the course of the war showed, however, that Peter's action was more commendable: 'the Swedish hero confided too much in his own generosity: the sagacious monarch of Russia united perhaps too great a degree of severity with his prudence: but necessity furnishes an apology for severity, or rather throws a veil over it altogether. ${ }^{91}$ Similarly, in the discussion of ravaging and burning in warfare, Vattel condemns 'savage and monstrous excesses, when committed without necessity', but Peter the Great is excused for similar behaviour because he was motivated by legitimate concerns of self-preservation: 'The czar Peter the Great, in his flight before the formidable Charles the Twelfth, ravaged an extent of above fourscore leagues of his own empire, in order to check the impetuosity of a torrent which he was unable to withstand. ${ }^{92}$ Vattel emphasizes that one should not too eagerly follow the example of the tsar, because these kinds of actions are only excusable in case of extreme necessity. A counter-example is provided

88 Ibid., book III, $§ 32$.

89 For the historical context of the Russian manifesto, see Pärtel Piirimäe, 'Russia, the Turks and Europe: Legitimations of War and the Formation of European Identity in the Early Modern Period', Journal of Early Modern History 11:1/2 (2007), 63-86.

$90 \quad$ Vattel, The Law of Nations, book III, $\S 32$.

91 Ibid.

92 Ibid., $§ 167$. 
by the French, who, 'in the last century [...] ravaged and burnt the Palatinate' without necessity, which is why 'all Europe resounded with invectives against such mode of waging war. ${ }^{93}$ Like the case with tyrants who, as we saw, can appear anywhere in Europe, the apparently civilized states are not immune from monstrous war-mongers raising their heads either. Vattel stresses this possibility also in his discussion of monsters, who wage wars without reason or pretext. Historical 'barbarians' such as Tamerlane, Attila and Genghis-Khan, ${ }^{94}$ 'who make war only for the pleasure of making it', serve here as warning examples to the bellicose rulers of Europe: 'Such are, in polished ages and among the most civilized nations, those supposed heroes, whose supreme delight is a battle, and who make war from inclination purely, and not from love to their country. 95

Peter the Great is thus a liminal figure whose barbarous origins are unmistakable (a person tolerant of a 'prodigality of human blood') but who has passed the threshold of humanity, showing in the process what the essence of civility is all about. True civility consists in actions that are based on the proper understanding of national interest and motivated by a love of country, not by a false concept of glory attainable by military conquests, which is the main threat to European peace. These views of Vattel reflect a vision of history that draws heavily on the philosophical histories of Voltaire. In his histories of Charles XII (Histoire de Charles XII, 1731) and Louis XIV (Siècle de Louis $X I V, 1751)$, and especially in Essai sur les moeurs (1756) - a summary of world history and the narrative of the rise of Europe - Voltaire envisions a march of humankind towards a better and more 'polished' world, under the leadership of great legislating monarchs. ${ }^{96}$ Although Vattel never directly refers to Voltaire, his portrayal of Peter the Great is unmistakably Voltairean. Voltaire's Histoire de l'Empire de Russie (176o-1762), which recounts in great detail the progress achieved by Peter the Great, was published only after Vattel's treatise, but Voltaire's fascination with the tsar is evident already in the history of Charles XII, where Peter emerges as the other main protagonist. As J.G.A. Pocock has shown, Voltaire wrote his histories as an exponent of a thèse royale,

93 Ibid.

94 'Such were several German tribes mentioned by Tacitus [...]. Such have been the Turks and other Tartars, - Genghis-khan, Timur-Bec or Tamerlane, who, like Attila, were scourges employed by the wrath of heaven'. Ibid., § 34 .

95 Ibid.

96 See Siofra Pierse, 'Voltaire: Polemical Possibilities of History', in A Companion to Enlightenment Historiography, ed. Sophie Bourgault and Robert Sparling (Leiden: Brill, 2013), 153-188; Karen O'Brien, Narratives of Enlightenment: Cosmopolitan History from Voltaire to Gibbon (Cambridge: Cambridge University Press, 1997), 21-55. 
as an admirer of enlightened absolutism who rejected the equation of absolute monarchy with despotism. ${ }^{97}$ Voltaire contrasted Louis XIV and Peter the Great, who were both legislators, with Charles XII, who was not: 'The Swedish king is presented as a hero and nothing else, a conqueror whose conquests have no meaning, a figure contrasted with that of his adversary Tsar Peter, who is both a conqueror and a legislator. ${ }^{98}$

The contrast can also be expressed in terms of different understandings of glory: the Swedish king seeks it in personal heroism, while for Peter glory is intimately connected with the good of the nation. Vattel's account of true glory draws on Wolff's understanding of the 'true and enduring fame of a nation,' ${ }^{99}$ which depends on its perfection: 'True glory consists in the favourable opinion of men of wisdom and discernment: it is acquired by the virtues or good qualities of the head and the heart, and by great actions which are the fruits of those virtues'. ${ }^{100}$ But Vattel's attribution of these qualities and actions uncritically to Peter is almost certainly influenced by his reading of Voltaire, who was chiefly responsible for the construction of a mythological image of the tsar, who 'resolved to be a man, to command men, and to create a new nation.'101

The fact that Voltaire's juxtaposition of Peter, 'who consulted only his interest', with Charles, who 'had never given way to anything but his idea of revenge and glory', ${ }^{\prime 02}$ stimulated Vattel's ideas is further attested by a dialogue that Vattel published in 176o. Its title indicates both the main protagonists and the topic to be discussed: 'Dialogue between Peter the Great and Charles XII of Sweden on the Glory of Conquerors. ${ }^{103}$ Charles acts here as the spokesperson for military glory, which is acquired by great commanders in war. There is no doubt, however, that Vattel's own views are represented by Peter, who contrasts

J.G.A. Pocock, Barbarism and Religion, Vol. 2: Narratives of Civil Government (Cambridge: Cambridge University Press, 1999), 75 .

$98 \quad$ Ibid., 76 .

99 Wolff, Law of Nations, § 49 .

100 Vattel, The Law of Nations, book I, § 187.

101 Voltaire, The History of Charles the XIIth, King of Sweden, transl. W.S. Kenrick, to which is added, The Life of Peter the Great, transl. J. Johnson (London, 1780), 18. Voltaire also describes Peter's civilizing projects - for example, 'Sciences, which in other countries have been the slow product of so many ages, were, by his care and industry, imported into Russia, in full perfection' (24). For Voltaire's image of Peter, and the subsequent Enlightenment debates, see also Reto Peter Speck, The History and Politics of Civilisation: The Debate about Russia in French and German Historical Scholarship from Voltaire to Herder (PhD dissertation, Queen Mary University of London, 2010).

102 Voltaire, The History of Charles the XIIth, King of Sweden, 147.

103 Published originally in Mélanges de littérature, de morale et de politique, transl. and published in English by B. Kapossy and R. Whatmore in Vattel, The Law of Nations, 8o-85. 
military feats with other human achievements: 'There are other things which demand perhaps still greater ability, more sublime talents. Such are the enquiries of true philosophers, the deep designs of a legislator, the art of ruling'. Peter does not despise military glory, conceding that 'the warrior whose bravery and abilities have preserved the State, should be foremost in the esteem of men, but always behind wise and enlightened Princes who are in essence the Fathers of their Peoples and the benefactors of the human race'. This is how Vattel's Peter sees his own historical role: 'I civilized a vast empire that I received from my Forefathers in a semi-barbarous state. [...] While famous Warriors have often been the cause of the destruction of their native lands, I have been the creator of mine'. ${ }^{104}$

\section{4}

\section{Conclusions}

The philosophical histories of the Enlightenment investigated the driving forces and obstacles on the road towards human progress, with a view to providing instruction and guiding political reform in the present. ${ }^{105}$ Voltaire offered a specific view of the progress of mankind that was driven by enlightened monarchs with a proper understanding of national interest and true glory. The aim of this chapter was to show that Vattel's normative account of the duties of nations to themselves and to other nations cannot be fully understood if we disregard the philosophical history-writing of the era. Vattel expressed the Voltairean thése royale most forcefully in his portrayal of Peter the Great. Peter appears as a demiurge who 'created' his native country by civilizing it, but also as a liminal figure who passed the boundary between monsters and men, delineating more precisely where this boundary was situated. The figure of Peter the Great underlines Vattel's minimalist definition of the notion 'civilized', and at the same time demonstrates that a minimum level of morality is the proper foundation for further development towards enlightened forms of self-interest, which gives hope for the moral advancement of humankind and for a reduction in violence in inter-state relations. By tracing the changes in European customs of warfare in the present 'enlightened age', Vattel posited a dynamic account of international law, the development of which did not necessarily depend on constant positive international legislation by treatymaking but which could, at least partly, rely on voluntary adherence to the

\footnotetext{
104 Ibid., 83-85.

105 Speck, The History and Politics of Civilisation, 12.
} 
laws of humanity that many European sovereigns were already undertaking. This progress was threatened not so much by non-European barbarians or savages as by the monsters from within Europe who were led astray by a false concept of glory. Vattel's unrealistically optimistic portrayal of Peter as a singularly virtuous ruler who leapfrogged the otherwise slow and cumbersome process of civilization, served as a moralistic reminder to other European sovereigns to seek glory not from military achievements but from leading the nation towards perfection and happiness. ${ }^{106}$

\section{Bibliography}

Anghie, Antony, Imperialism, Sovereignty and the Making of International Law (Cambridge: Cambridge University Press, 2005).

Beaulac, Stéphane, 'Emer de Vattel and the Externalization of Sovereignty', Journal of the History of International Law 5 (2003): 237-292.

Christov, Theodore, Before Anarchy. Hobbes and His Critics in Modern International Thought (Cambridge: Cambridge University Press, 2015).

Grotius, Hugo, The Rights of War and Peace, ed. Richard Tuck (Indianapolis, IN : Liberty Fund, 2005).

Hartung, Gerald, 'Von Grotius zu Pufendorf. Die Herkunft des säkularisierten Strafrechts aus dem Kriegsrecht der Frühen Neuzeit', in Samuel Pufendorf und die europäische Frühaufklärung, ed. Fiammetta Palladini and Gerald Hartung (Berlin: Akademie-Verlag, 1996), 123-136.

Hobbes, Thomas, Leviathan [1651], ed. Richard Tuck (Cambridge: Cambridge University Press, 1991).

Hobbes, Thomas, On the Citizen [1642], ed. Richard Tuck (Cambridge: Cambridge University Press, 1998).

Hont, Istvan, "The language of sociability and commerce: Samuel Pufendorf and the theoretical foundations of the "Four-Stages Theory"', in The Languages of Political Theory in Early-Modern Europe, ed. Anthony Pagden (Cambridge: Cambridge University Press, 1987), 253-276.

Hunter, Ian, 'Global Justice and Regional Metaphysics: On the Critical History of the Law of Nature and Nations', in Law and Politics in British Colonial Thought: Transpositions of Empire, ed. Shaunnagh Dorsett and Ian Hunter (Basingstoke: Palgrave Macmillan, 2010), 11-29.

106 Research for this chapter was kindly supported by the Pro Futura Scientia Fellowship of the Swedish Collegium for Advanced Study. 
Hunter, Ian, "The Figure of Man and the Territorialisation of Justice in "Enlightenment" Natural Law: Pufendorf and Vattel', Intellectual History Review 23:3 (2013): 289-307.

Hunter, Ian, 'Vattel's Law of Nations: Diplomatic Casuistry for the Protestant Nation', Grotiana 31 (2010): 108-140.

Jouannet, Emmanuelle, The Liberal-Welfarist Law of Nations: A History of International Law (Cambridge: Cambridge University Press, 2012).

Kapossy, Béla and Richard Whatmore, 'Emer de Vattel's Mélanges de littérature, de morale et de politique (1760)', History of European Ideas 34:1 (2008): 77-103.

Kapossy, Béla and Richard Whatmore, 'Introduction', in Emer de Vattel, The Law of Nations (Indianapolis, IN: Liberty Fund, 2008), ix-xx.

Koskenniemi, Martti, From Apology to Utopia. The Structure of International Legal Argument (Cambridge: Cambridge University Press, 2005).

Nakhimovsky, Isaac, 'Vattel's theory of the international order: Commerce and the balance of power in the Law of Nations', History of European Ideas 33:2 (2007): 157-173.

O'Brien, Karen, Narratives of Enlightenment: Cosmopolitan History from Voltaire to Gibbon (Cambridge: Cambridge University Press, 1997).

Palladini, Fiammetta, Samuel Pufendorf discepolo di Hobbes: Per una reinterpretazione del giusnaturalismo moderno (Bologna: Il Mulino, 199o).

Pierse, Siofra, 'Voltaire: Polemical Possibilities of History', in A Companion to Enlightenment Historiography, ed. Sophie Bourgault and Robert Sparling (Leiden: Brill, 2013), 153-188.

Piirimäe, Pärtel, 'Russia, the Turks and Europe: Legitimations of War and the Formation of European Identity in the Early Modern Period', Journal of Early Modern History, 11:1/2 (2007), 63-86.

Pocock, J.G.A., Barbarism and Religion, vol. 2: Narratives of Civil Government (Cambridge: Cambridge University Press, 1999).

Pufendorf, Samuel, Of the Law of Nature and Nations, transl. Basil Kennett, 4th ed. (London: J. Walthoe et al., 1729).

Pufendorf, Samuel, Two Books of the Elements of Universal Jurisprudence [166o], ed. Thomas Behme (Indianapolis, IN: Liberty Fund, 2009).

Rech, Walter, Enemies of Mankind. Vattel's Theory of Collective Security (Leiden, Boston: Martinus Nijhoff Publishers, 2013).

Schröder, Peter, Trust in Early Modern International Political Thought, 1598-1713 (Cambridge: Cambridge University Press, 2017).

Sell, Jonathan P.A., Rhetoric and Wonder in English Travel Writing, 1560-1613 (Aldershot: Ashgate, 2006).

Silvestrini, Gabriella, 'Justice, War and Inequality. The Unjust Aggressor and the Enemy of the Human Race in Vattel's Theory of the Law of Nations', Grotiana 31:1 (2010): 41-68. 
Speck, Reto Peter, The History and Politics of Civilisation: the Debate about Russia in French and German Historical Scholarship from Voltaire to Herder (PhD dissertation, Queen Mary University of London, 2010). https://qmro.qmul.ac.uk/jspui/handle/ $123456789 / 423$.

Tuck, Richard, The Rights of War and Peace. Political Thought and the International Order from Grotius to Kant (Oxford: Oxford University Press, 1999).

Vattel, Emer de, Le Droit des Gens, ou Principes de la Loi Naturelle, appliqués à la Conduite \& aux Affaires des Nations \& des Souverains (Londres, 1758).

Vattel, Emer de, The Law of Nations, ed. Béla Kapossy and Richard Whatmore (Indianapolis, IN: Liberty Fund, 2008).

Voltaire, The history of Charles the XIIth, King of Sweden, transl. W.S. Kenrick, to which is added, the life of Peter the Great, transl. J. Johnson (London, 1780).

Wolff, Christian, The Law of Nations Treated According to the Scientific Method (1749), transl. Joseph H. Drake, rev. and ed. Thomas Ahnert (Indianapolis, IN: Liberty Fund, 2017).

Zurbuchen, Simone, 'Vattel's law of nations and just war theory', History of European Ideas 35 (2009): 408-417. 


\title{
Guarantee and Intervention: the Assessment of the Peace of Westphalia in International Law and Politics by Authors of Natural Law and of Public Law, c. 1650-1806
}

\author{
Patrick Milton
}

\section{1 \\ Introduction}

The Peace of Westphalia is simultaneously one of the most thoroughly researched, and one of the most misunderstood peace settlements of early modern history, albeit not by the same people. The fact that this paradox has persisted in the last two decades, when detailed historical research into the treaties of Münster (Instrumentum Pacis Monasteriensis, IPM) and Osnabrück (Instrumentum Pacis Osnabrugensis, IPO $)^{1}$ and their implications has been booming, is indicative of the tenacity of the myth surrounding Westphalia. ${ }^{2}$ Broadly, the misperception of Westphalia has two dimensions, the international - according to which the Peace inaugurated a new international 'Westphalian system' of equal, sovereign states which do not intervene in each other's domestic affairs ${ }^{3}$ - and the internal-constitutional, which alleges that the treaties granted the princely territories (Imperial Estates) of the Holy Roman Empire

1 Both treaties together constituted the peace settlement that ended the Thirty Years' War and were both signed at Münster on 24 October 1648. See 'Internet-Portal "Westfälische Geschichte”, last modified 1 November 2004, http://www.lwl.org/westfaelische-geschichte/portal/Internet/finde/langDatensatz.php?urlID=740\&url_tabelle=tab_quelle (IPO), and http://www.lwl .org/westfaelische-geschichte/portal/Internet/finde/langDatensatz.php?urlID=741\&url_tabelle=tab_quelle (IPM).

2 For the latest research on Westphalia, see the literature cited in Niels F. May, Zwischen fürstlicher Repräsentation und adliger Statuspolitik: Das Kongresszeremoniell bei den westfälischen Friedensverhandlungen (Ostfildern: Jan Thorbecke, 2016).

3 E.g.: Arnaud Blin, 1648, la paix de Westphalie ou la naissance de l'Europe politique moderne (Bruxelles: Editions Complexe, 2006); Daniel Philpott, Revolutions in Sovereignty: How Ideas Shaped Modern International Relations (Princeton, NJ: Princeton University Press, 2001), 4 , 30,85 . 
sovereignty. ${ }^{4}$ To a greater or lesser degree, some or all of these ascriptions have been repeated by political scientists, historians, scholars of international law, and legal historians. ${ }^{5} \mathrm{~A}$ rich body of research into the treaties and the Westphalian order, including several pieces which explicitly provide correctives to the misperceptions, have only partially dented the Westphalian myth. ${ }^{6}$

Many scholars have viewed natural law as an ideological tool used by early modern rulers in the pursuit of princely absolutism, which helped the territorial state to overcome corporate rights and customary practice, ${ }^{7}$ in order to realize the potential of sovereignty and absolute authority supposedly inherent in the Westphalian settlement. In the eighteenth-century Holy Roman Empire, natural law was used by the princes to legitimate the streamlining and centralizing of administration and law in the territories, which often included attempts to sweep away the customary privileges of the territorial estates, and to inhibit the possibilities of appeals to the higher

4 E.g.: Derek Beales, Joseph II, vol 2: Against the World, 1780-1790 (Cambridge: Cambridge University Press, 1987), 410-411; Michael Hughes, Law and Politics in Eighteenth Century Germany: The Imperial Aulic Council in the Reign of Charles VI (Woodbridge: Boydell Press, 1988), 16-17; James Sheehan, German History, 1770-1866 (Oxford: Clarendon Press, 1989), 16; Albrecht Randelzhofer, Völkerrechtliche Aspekte des Heiligen Römischen Reiches nach 1648 (Berlin: Duncker \& Humblot, 1967), passim.

5 E.g.: Gene Martin Lyons and Michael Mastanduno, Beyond Westphalia? State sovereignty and international intervention (Baltimore, MD: Johns Hopkins University Press, 1995); Sasson Sofer, 'The Prominence of Historical Demarcations: Westphalia and the New World Order,' Diplomacy and Statecraft 20, no. 1 (2009): 1-19.

6 Derek Croxton, The Last Christian Peace: The Congress of Westphalia as A Baroque Event (Basingstoke: Palgrave Macmillan, 2013), 351-362; Heinz Duchhardt, 'Das "Westfälische System": Realität und Mythos,' in Akteure der Außenbeziehungen. Netzwerke und Interkulturalität im Historischen Wandel, ed. Hillard von Thiessen and Christian Windler (Cologne: Böhlau, 2010), 393-402; Georg Schmidt, 'Der Westfälische Frieden - eine neue Ordnung für das alte Reich?', in Wendemarken in der Deutschen Verfassungsgeschichte: Tagung der Vereinigung für Verfassungsgeschichte, ed. Reinhard Mußgnug (Berlin: Duncker \& Humblot, 1993), 45-84; Johannes Burkhardt, 'Der Westfälische Friede und die Legende von der landesherrlichen Souveränität,' in Landes- und Reichsgeschichte: Festschrift für Hansgeorg Molitor zum 65. Geburtstag, ed. Jörg Engelbrecht and Stephan Laux (Bielefeld: Verlag für Regionalgeschichte, 2004), 199-220; Peter H. Wilson, Europe's Tragedy: A New History of the Thirty Years War (London: Penguin Books, 2010), 776-778; Derek Croxton, "The peace of Westphalia of 1648 and the origins of sovereignty', International History Review 21, no. 3 (1999): 569-591; Andreas Osiander, 'Sovereignty, international relations, and the Westphalian myth,' International Organization 55, no. 2 (2001): 251-287; Stephane Beaulac, 'The Westphalian legal orthodoxy myth or reality?', Journal of the History of International Law 2 (2000): 148-177.

7 E.g.: Michael Stolleis, Geschichte des öffentlichen Rechts in Deutschland, vol. 1 (Munich: C.H. Beck, 1988), 276-277; Notker Hammerstein, 'Christian Thomasius,' in Politische Theorien des 17. und 18. Jahrhunderts: Staat und Politik in Deutschland, ed. Bernd Heidenreich and Gerhard Göhler (Darmstadt: Philipp von Zabern, 2011), 123-124, 131. 
(extra-territorial) judicial tribunals of the Empire. ${ }^{8}$ While such arguments are illuminating with regard to strategies of princely rule and consolidation, they also sometimes perpetuate the misperceptions about the treaties of Westphalia. ${ }^{9}$ This is not surprising, however, in light of the interpretations of Westphalia by several early modern theorists of natural law themselves, such as Gottfried Wilhelm Leibniz, Emer de Vattel and Gottfried Achenwall, who varyingly viewed Westphalia as a charter for absolutism within the framework of the Empire, or the final stage in the evolution of the Empire into an overarching system of sovereign states. ${ }^{10}$ Thus, the mythologizing of

8 Knud Haakonssen, 'German natural law,' in The Cambridge History of Eighteenth-Century Political Thought ed. Mark Goldie and Robert Wokler (Cambridge: Cambridge University Press, 2006), 257. It is worth pointing out that discourses grounded in natural law were also cited by these very same Imperial authorities (chiefly the Reichshofrat - Imperial Aulic Council) when justifying punitive actions and interventions against princes for the protection of the traditional customary rights of their suppressed territorial estates and other subjects, as well as confessional and other rights confirmed at Westphalia, a fact which is insufficiently appreciated in the existing literature. In suspending the Duke of MecklenburgSchwerin from power, for example, the Reichshofrat argued that the duke's disregarding of the obligations detailed in treaties concluded by his predecessors with their subjects was contrary to natural law. See report by the Reichshofrat, 3 Nov. 1722: Haus- Hof- und Staatsarchiv, Vienna, RHR, Vota 34. See also Patrick Milton, 'Intervening against tyrannical rule in the Holy Roman Empire during the seventeenth and eighteenth centuries,' German History 33, no. 1 (2015): 1-29, and Robert von Friedeburg, 'Natural Jurisprudence, Argument from History and Constitutional Struggle in the Early Enlightenment: The Case of Gottlieb Samuel Treuer's Polemic Against Absolutism in 1719,' in Early Modern Natural Law Theories: Contexts and Strategies in the Early Enlightenment, ed. T.J. Hochstrasser and Peter Schröder (Dordrecht: Kluwer Academic Publisher, 2003), 141-168. Early modern practitioners and lawyers used an eclectic range of sometimes contradictory, sometimes reinforcing legal traditions in their argumentation: Haakonssen, 'German natural law', 259.

9 E.g.: Detlef Döring, 'Der Westfälische Frieden in der Sicht Samuel Pufendorfs,' Zeitschrift Für Historische Forschung 26, no. 3 (1999): 353, 358.

10 Gottfried Wilhelm Leibniz, Sämtliche Schriften und Briefe (Berlin: Akademie der Wissenschaften der DDR, 1983), series IV, vol. 2, 21; Emer de Vattel, The Law of Nations, Or, Principles of the Law of Nature, Applied to the Conduct and Affairs of Nations and Sovereigns, with Three Early Essays on the Origin and Nature of Natural Law and on Luxury, ed. Béa Kapossy and Richard Whatmore (Indianapolis, IN: Liberty Fund, 2008), 683-684; Gottfried Achenwall, Geschichte der allgemeineren Europäischen Staatshändel des vorigen und ietzigen Jahrhunderts im Grundriss der europäischen Geschichte (Göttingen: Verlag der Witwe Vandenhoeck, 1761), 84. Another aspect of the Westphalian myth that was already argued by some natural law writers is the notion that the treaties of 1648 granted Switzerland and the Dutch republic full independence from the Holy Roman Empire: e.g. Vattel, The Law of Nations, 212, 696. For a refutation thereof, see Siegrid Westphal, Der Westfälische Frieden (Munich: C.H. Beck, 2015), 105, and Croxton, Last Christian Peace, $354-35^{6 .}$ 
Westphalia began much earlier than is often assumed, beginning soon after the conclusion of the Peace itself. ${ }^{11}$

This leads to the broader question of how Westphalia in all its aspects and implications was perceived and assessed by writers in the tradition of the law of nature and nations, and how this differed from the reception of Westphalia in other traditions of seventeenth- and eighteenth-century legal and political thought. The literature on the Peace of Westphalia, both before and after the end of the Empire and therefore the Westphalian treaties' legal validity in 1806, is immense, and several modern scholars have addressed the question of the reception of the Peace among early modern jurists and philosophers. ${ }^{12}$ This literature mainly dealt with the confessional and constitutional stipulations of the IPO as applied within the Holy Roman Empire, and their implications in the subsequent 15 o years. ${ }^{13}$ Therefore, and in light of the theme of this volume, this chapter will address the assessment of those parts of the treaties which related to the law of nations, along with their subsequent impact and relevance. The most salient among these, because of its innovative nature, is the institution of the mutual guarantee (IPO art. 17, § 4-5; IPM § 115-116), and the impact this had on external interventionism. The focus will be on the assessment of Westphalia by natural law theorists while writing in different capacities, as authors of works of constitutional law, history and political tracts, for example. After all, these different roles were not as separate as modern scholarship might suggest, and such capacities often overlapped and intersected..$^{14}$ Furthermore, such texts were written through the lens of the authors' respective

11 While Leibniz and Christian Thomasius had ascribed extensive authority approximating sovereignty to the Imperial Estates, most authors in the later eighteenth century, such as Johann Jacob Moser and Johann Stephan Pütter, no longer shared these interpretations: Bernd Mathias Kremer, 'Die Interpretationen des Westfälischen Friedens durch die "Schulen" des Jus Publicum,' in Der Westfälische Friede: Diplomatie, politische Zäsur, kulturelles Umfeld, Rezeptionsgeschichte, ed. Heinz Duchhardt (Munich: Oldenbourg Verlag, 1998), 766-769.

12 For works published between 1648 and 1996, see Heinz Duchhardt, Eva Ortlieb, and Matthias Schnettger, ed., Bibliographie zum Westfälischen Frieden (Münster: Aschendorff Verlag, 1996). For works published after 1996, see the literature cited in Westphal, Der Westfälische Frieden.

13 Bernd Mathias Kremer, Der Westfälische Friede in der Deutung der Aufklärung. Zur Entwicklung des Verfassungsverständnisses im Hl. Röm. Reich Deutscher Nation vom Konfessionellen Zeitalter bis ins späte 18. Jahrhundert (Tübingen: Mohr, 1989); Döring, 'Der Westfälische Frieden in der Sicht Samuel Pufendorfs'.

14 Michael J. Seidler, 'Introduction,' in Samuel Pufendorf, An Introduction to the History of the Principal Kingdoms and States of Europe, ed. Michael J. Seidler, transl. Jodocus Crull (Indianapolis, IN: Liberty Fund, 2013), ix. 
understandings of natural law. This will be accompanied by the assessment of Westphalia by those writing on matters of international law who hailed from different intellectual traditions, primarily jus publicum. After briefly outlining the influence of Westphalia on the development of positive treaty law in the European legal order, the chapter will proceed by analysing how Westphalia and its impact were assessed by scholars of natural law, the law of nations, and public law, in terms of a general appraisal of the Peace, and the mutual guarantee along with foreign interventionism, both in theory and in practice.

\section{The Impact of the Treaties of Westphalia on the droit public de l'Europe}

While the Peace of Westphalia in many ways simply reaffirmed and enshrined existing constitutional conditions domestically within the Holy Roman Empire - albeit in an optimized and recalibrated set-up - internationally, it was one of the most innovative features in the law of nations. This is because the Westphalian treaties were simultaneously a fundamental constitutional law for the Empire, and an international peace treaty. As part of the measures designed to secure the longevity of the peace in IPO art. 17, the various contracting parties, including both sovereign European powers and the non-sovereign German Imperial Estates, mutually and reciprocally guaranteed the entire settlement, which was also recognized as a basic law of the Empire. This tied German public law to the law of nations, by creating an international responsibility to uphold the Imperial constitution, thereby arguably establishing a system of collective security for central Europe, which built on the 'Eternal Territorial Peace' that had been declared for the Empire in $1495 \cdot{ }^{15}$ The guarantee therefore anchored German constitutional law to a collective enforcement and compliance mechanism under international law. Westphalia thus added a further level to the legal hierarchy of Imperial Estates subordinated to the Emperor and Empire, by bestowing the 'external' guarantors, France and Sweden, ${ }^{16}$

15 SiegridWestphal, 'Reichskammergericht, Reichshofrat und Landfrieden als Schutzinstitute der Reichsverfassung,' in Schutz der Verfassung: Normen, Institutionen, Höchst- und Verfassungsgerichte, ed. Thomas Simon and Johanne Kalwoda (Berlin: Duncker \& Humblot, 2014), 13-37.

16 They were not technically external guarantors, as this would imply that a non-signatory third party such as a mediator had taken responsibility for the guarantee, which was not the case at Westphalia, where France, Sweden, the Emperor and the princes were all signatories and guarantors. For simplicity's sake, though, France and Sweden may be 
with a duty and a right to uphold the Imperial constitution by intervening under certain circumstances and after a specified sequence of steps. Other notable innovations which proved to be seminal in the law of nations include the instrument of the multilateral peace congress and the neutralization of religious canon law through the assertion of the primacy of secular law. ${ }^{17}$

Heinhard Steiger has demonstrated that the Peace of Westphalia cannot strictly be viewed as a fundamental basic law of Europe, contrary to the Westphalian myth. However, it left a clear imprint on subsequent treaty law, as a basic instance that was continuously mentioned in subsequent treaty texts, as a 'reference peace', and as a basic order that subsequent treaties sought to reaffirm and re-establish. It was specifically the guarantee which largely ensured that the treaties' immediate legal effects had a broader European scope than the internal constitutional matters of the Empire with which the settlement primarily dealt. For it was precisely in their capacity as guarantors of the peace that the signatories referred back to Westphalia and its guarantee when they concluded subsequent peace treaties, especially those involving the Empire. This was the case, for example, in the treaties of Nijmegen in 1679, Ryswick in 1697, Rastatt/Baden in 1714, and Teschen in 1779. Through these references, the basic order of Westphalia was reaffirmed by its guarantors as the 'foundation', 'fundamental norm' or 'unchangeable basis' of relations among them and within the Empire, following a temporary suspension during the preceding wars. ${ }^{18}$

Taking a longer-term perspective, it can plausibly be argued that by placing the confessional rights of religious groups under international guarantee, the Peace of Westphalia and its guarantee clauses helped to establish the principle of internationally guaranteed minority rights as a part of the positive law of nations. ${ }^{19}$ This, together with the experience over many years of peaceful, legally regulated confessional co-existence within the Empire, arguably contributed to the gradual emergence of the philosophical conviction of confessional toleration as a desirable principle within states, ${ }^{20}$ as well as minority rights

referred to as external guarantors, as the confessional-constitutional clauses of the treaties (which made up most of the treaty stipulations) applied only to the Holy Roman Empire.

17 Heinhard Steiger, 'Konkreter Friede und allgemeine Ordnung - zur rechtlichen Bedeutung der Verträge vom 24. Oktober 1648,' in 1648: Krieg und Frieden in Europa ed. Klaus Bußmann and Heinz Schilling (Munich: Bruckmann, 1998), 137-146.

18 Heinhard Steiger, 'Der Westfälische Frieden - Grundgesetz für Europa?' in Der Westfälische Friede, ed. Duchhardt, 33-8o. See also Croxton, Last Christian Peace, 363.

19 Steiger, 'Grundgesetz', 78.

20 This has recently been argued by Christoph Kampmann: 'Der Festgeschnürte Frieden: Prof. Christoph Kampmann erklärt ein Meisterwerk der Diplomatie,' P.M. History, May 2017. 
protection as a principle in the natural law-based jus gentium, beyond merely being partially stipulated by the Westphalian guarantee in the positive jus inter gentes.

The Peace of Westphalia seems to experience somewhat cyclical fortunes in its general appraisal by scholars and commentators over the years, which is remarkably reflective of the political context. While it was enthusiastically hailed as a milestone in early modern progressivism, and as a possible model for European unity around the turn of the millennium and specifically its 35oth anniversary, ${ }^{21}$ more measured evaluations have been proposed in recent years, although the appraisal is still very positive. Going back a step in history, verdicts in the nineteenth and the first two-thirds of the twentieth century were drastically different. Under the influence of the collapse of the Empire in 1806 and the subsequent Prussian drive for a new kleindeutsch empire which would be capable of power accretion and power projection, Westphalia was seen to mark the death knell of the old Reich as a political entity, the only advantage of which was that its impotence allowed Brandenburg-Prussia to rise and fulfil the mission of true national unification..$^{22}$ This negative view of Westphalia persisted remarkably long; as late as the 1950s and 196os the standard monograph on the Peace described it as a 'national misfortune' for the Germans. ${ }^{23}$

Going back further yet, jurists and writers of the seventeenth and eighteenth century again viewed the treaties in a completely different, largely positive, light, although assessments naturally differed and changed over the course of those 150 years or so. The almost uniformly negative perceptions which began to set in very soon after 1806 are in striking contrast to the favourable assessments of the Peace during the preceding period when the Empire still existed. However, it should be noted that, contrary to many accounts, the Peace was not unanimously eulogized over this period, even among Protestants. Bernd

21 E.g.Johannes Burkhardt, 'Das größte Friedenswerk der Neuzeit,' Geschichte in Wissenschaft und Unterricht 49 (1998): 592-612.

22 Johann Gustav Droysen, Geschichte der preußischen Politik, Dritter Teil, Der Staat des großen Kurfürsten, Erste Abteilung (Leipzig: Verlag von Veit und Comp., 1861), 61, 75; Heinrich von Treitschke, Deutsche Geschichte im 19. Jahrhundert (Leipzig: Verlag von S. Hirzel, 1879), vol. 1: 11-12; Leopold von Ranke, Französische Geschichte, vornehmlich des 16. und 17. Jahrhunderts, vol. 2 (Stuttgart: Koehler, 1954), 359-36o. 
Mathias Kremer has shown how shifting intellectual and normative currents affected scholars' evaluations of Westphalia, often leading to negative evaluations. ${ }^{24} \mathrm{~A}$ dissonance between the principles underpinning the treaty terms on the one hand, and subsequent prevailing mindsets and conceptions of constitutional and religious issues on the other hand, inevitably resulted in academic and intellectual debate on the merits or demerits of the continued validity of the terms of the Peace.

As a peace treaty and a constitutional law, the Peace of Westphalia ostensibly seems more relevant to public law than to natural law. Indeed, it immediately assumed a high priority in the curricula of teaching and training in public constitutional law, ${ }^{25}$ and according to the jurist Carl Friedrich Gerstlacher it virtually spawned a whole new jus publicum. ${ }^{26}$ Most of the writing on public law after 1648 dealt with questions which were all affected by a particular interpretation of IPO. $^{27}$ But the intellectual and philosophical shifts mentioned above were especially discernible among writers of natural law, as they were less concerned with compiling applicable positive law than with deriving underlying principles from it, and vice versa. ${ }^{28}$ Earlier theorists felt the need to defend the legitimacy of a legal-political inter-confessional peace, which failed to achieve a theological union, and Hermann Conring went to lengths to refute the legitimacy of the Papal protest against the Peace, something which would have seemed superfluous to later eighteenth-century natural law theorists. ${ }^{29}$ Westphalia's granting of limited, graded toleration, while ostensibly retaining

24 Kremer, Westfälischer Friede.

25 Konrad Repgen, 'Der Westfälische Friede: Ereignis und Erinnerung,' Historische Zeitschrift 267 (1998): 615-647.

26 Carl Friedrich Gerstlacher, Corpus Juris germanici publici et privati: das ist der möglichst ächte Text der teutschen Reichsgeseze, Reichsordnungen und andrer Reichsnormalien; in sistematischer Ordnung mit Anmerkungen (Karlsruhe: Schmieder, 1784), 310. Indeed, questions pertaining to the treaties gave rise to hundreds of mainly legal dissertations from the mid-seventeenth century: see Heinz Duchhardt, 'Münster und der Westfälische Friede - Kollektives Gedächtnis und Erinnerungskultur im Wandel der Zeit,' in Der Westfälische Friede, ed. Duchhardt, 856-857.

27 Joachim Whaley, Germany and the Holy Roman Empire (Oxford: Oxford University Press, 2012), vol. 2, 17 .

28 The foremost jurist of German public law, Johann Jacob Moser, criticized the tendency, as he viewed it, of natural law scholars to interpret Westphalia as they would like to see it, and also rejected their generalizing statements on the Imperial constitution: Johann Jacob Moser, Neues deutsches Staatsrecht (Stuttgart: Mezler, 1766), vol. 1, 527.

29 Kremer, Westfälischer Friede, 25-27. However, in $175^{8}$ Vattel still described the Pope's invalidation and statements of protest against Westphalia as 'violations of the law of nations', which 'directly tended to destroy all the bands that could unite mankind, and to sap the foundations of their tranquillity': Vattel, Law of Nations, 390. 
the Right of Reformation (jus reformandi), chimed with the conceptions of toleration, and of church-state relations of natural law writers such as Samuel Pufendorf and Christian Thomasius, whose conceptions thereof were likely affected by the experience of Westphalia and the modes of peaceful confessional co-existence introduced by the peace settlement. ${ }^{30}$

Most natural law theorists favoured the secularization of law and the desacralization of politics. ${ }^{31}$ However, the confessional terms of IPO were soon regarded, under the influence of the early Enlightenment, as resulting in an inadequate separation of church and state, and an excessively limited and circumscribed tolerance, by such writers as the Halle natural law professor Nicolaus Hieronymus Gundling, as well as by writers in the later Enlightenment such as Renatus Karl von Senkenberg, in even more vociferous terms. ${ }^{32}$ This applied in particular to the rigid freezing of confessional conditions and possessions according to the 'normative year', with the concomitant ability of princes to expel subjects whose religion had not been practised in the relevant territory on 1 January $1624,{ }^{33}$ and the continued ban on sects and religions other than Catholicism, Lutheranism and Calvinism. Senkenberg asked himself 'whether these stipulations are still valid' and answered: 'let all these provisions of the Peace of Westphalia which run contrary to natural law be considered invalid! They have not yet been explicitly abrogated, but since the

30 Samuel Pufendorf, Of the Nature and Qualification of Religion in Reference to Civil Society, ed. Simone Zurbuchen, transl. Jodocus Crull (Indianapolis, IN: Liberty Fund, 2002); Christian Thomasius, Essays on Church, State, and Politics, ed. Ian Hunter, Thomas Ahnert, and Frank Grunert (Indianapolis, IN: Liberty Fund, 2007). See also Döring, 'Der Westfälische Frieden', $361-364$.

31 Stolleis, Geschichte des öffentlichen Rechts, vol. 1, 273-275; T.J. Hochstrasser, Natural Law Theories in the Early Enlightenment (Cambridge: Cambridge University Press, 2000), 108. This applies less to the 'Christian natural lawyers': see Hans-Peter Schneider, Justitia universalis. Quellenstudien zur Geschichte des 'Christlichen Naturrechts' bei Gottfried Wilhelm Leibniz (Frankfurt a. M.: Vittorio Klostermann, 1967).

32 Renatus Karl von Senkenberg, Darstellung des Osnabrück- und Münsterischen oder sogenannten Westfälischen Friedens, nach der Ordnung der Artikel (Frankfurt am Main: Gebhard und Körber, 1804); Gérard Laudin, 'Le Gründlicher Discours über den Westfälischen Frieden de Nicolaus Hieronymus Gundling,' in De la guerre juste à la paix juste: Aspects confessionnels de la construction de la paix dans l'espace franco-allemand (XVIe-XXe siècle), ed. Jean-Paul Cahn, Françoise Knopper, and Anne-Marie Saint-Gille (Villeneuve d'Ascq: Presses Univ. du Septentrion, 2008), 136-137. I am grateful to Prof. Anuschka Tischer for pointing out this article to me.

33 By the early eighteenth century, examples of such expulsions, while legal according to IPO, nevertheless caused public outrage across the Empire and Europe. For the example of the expulsion of the Salzburg Protestants, see Andrew C. Thompson, Britain, Hanover and the Protestant Interest, 1688-1756 (Woodbridge: Boydell Press, 2006), 152-167. 
Peace of Westphalia the Empire has not had the audacity to attempt to prevent individual Imperial Estates from tolerating other religions and sects. ${ }^{34}$

Apart from the implications of the external guarantee (see below), there was also some criticism among writers, of various legal and intellectual traditions, of the supposed opacity of many aspects of the treaties, although some believed that was deliberate, in order to facilitate adaptations to conditions in later periods, given that the Peace was proclaimed to be valid in perpetuity. ${ }^{35}$ Indeed, some authors explicitly declared that it was necessary to continually re-interpret the Peace in line with shifting circumstances, and that the ambiguities of the treaties permitted this. ${ }^{36}$ An area of disagreement surrounding the Peace related to differing interpretations of its specific role in the mutual protection of individual and corporate rights, which, along with common defence, was arguably the raison dêtre of the Empire. ${ }^{37}$ According to many writers of natural law, Westphalia chiefly enshrined the corporate rights of the Imperial Estates, whereas writers of the jus publicum generally emphasized the importance of upholding the corporate rights of mediate subjects, i.e. territorial estates and other subjects. They therefore placed greater emphasis on Westphalia's role in safeguarding individual rights of subjects, as well as its role in regulating and strengthening the broader Imperial structure as a restraint against princely absolutism in defence of mediate subjects. ${ }^{38}$

34 Senkenberg, Darstellung, 146.: 'ob diese Verordnung noch gelte? Ich antworte: möchten doch alle, die viele dem Naturrecht so sehr zuwider lauffende Verordnungen des W. Fr. so wenig gelten wie diese! Sie zwar noch nirgends ausdrücklich abgeschafft, aber man hat doch seit dem W. Fr. von Seite des ganzen Reichs einzelnen Reichsständen, nichts in den Weg zu legen sich unterstanden, wann Sie in ihren Landen andere Religionen und Sekten [...] zu toleriren, für gut befunden'. This is not entirely correct though. For an example of an Imperial prince being fined by the judicial tribunals of the Empire for tolerating sects, see Heinhard Steiger, 'Die Gewährung der Gewissensfreiheit durch Ernst Casimir von Ysenburg-Büdingen im Jahre 1712,' in Festschrift für Walter Mallmann, ed. Otto Triffterer and Friedrich von Zezschwitz (Baden-Baden: Nomos, 1978), 293-318. See also Kremer, Westfälischer Friede, 132-152.

35 Kremer, Westfälischer Friede, 3.

36 Johann Friedrich Vetter, Rechtliches Bedenken über drey wichtige, die Religions-Freyheit in dem Heiligen Römisch-Teutschen Reiche betreffende, Fragen; Aus dem Instrumento Pacis Westphalicae, und zwar dessen V. und VII. Articul, erwiesen u. abgefasset (Wetzlar: Nikolaus Ludwig Winkler, 1752), prologue.

37 PeterH.Wilson, War, State and Society in Württemberg, 1677-1 793 (Cambridge:Cambridge University Press, 1995), 19; idem., The Holy Roman Empire. A Thousand Years of Europe's History (London: Penguin Books, 2016), passim.

38 Johann Jacob Moser, Neues Deutsches Staatsrecht, 14: 257-258, 263-264; Johann Stephan Pütter, Historische Entwicklung der heutigen Staatsverfassung des teutschen Reiches, vol. 3 (Göttingen: Vandenhoeck, 1788), 234-239; Karl Friedrich Häberlin, Handbuch des Teutschen Staatsrechts, vol. 3 (Berlin: Vieweg, 1797), 423-425. 
For the natural law writers who advocated a maximum degree of state authority on the level of the territories, a perspective also shared by writers in the tradition of jus publicum universale, such as Justus Henning Böhmer, ${ }^{39}$ the Peace was advantageous and progressive for precisely the same - albeit largely mythical - reasons that the kleindeutsch nationalist historians of the nineteenth century reprobated it: the supposed sovereignty (or, approximate sovereignty) of the German princes. Paradoxically, this was also at the heart of an unwelcome effect of the Peace, which was sometimes commented upon, namely the effects it had on the disunity of the Empire. ${ }^{40}$ It was the same argument of princely quasi-sovereignty supposedly derived from Westphalia which led Friedrich Karl von Moser, rather exceptionally among constitutional jurists of the later Empire, to provide a markedly negative interpretation of the effects of the Peace of Westphalia. As a champion of subjects' rights against princely despotism, the younger Moser was well known for his crusades against the tyrannical tendencies of some of the German princes. In an example of the early mythologizing of Westphalia mentioned above, Moser argued that the effects of Westphalia were regrettable because they greatly empowered the princes and thereby weakened the subjects, by extending the former's authority and prerogatives. ${ }^{41}$ Commenting on 'the increasingly arbitrary power of the princes and lords over their largely very pathetic subjects', he wrote in 1761 that 'the Peace of Westphalia and the Imperial capitulations of election are [...] the foundation of the greatness of the princes, but simultaneously also of the misfortune of their subjects. ${ }^{2}$

39 Justus Henning Böhmer, Introductio in jus publicum universale, ex genuinis juris naturae principiis deductum (Halae Magdeburgicae: Orphanotropheum, 1710).

$40 \quad$ Hermann Conring, De pace perpetua inter Imperii Germanici Ordines religione dissidentes servanda Libelli Duo (Helmstedt: Mullerus, 1657), prologue; Samuel Pufendorf, The Present State of Germany, ed. Michael J. Seidler, transl. Edmund Bohun (Indianapolis, IN: Liberty Fund, 2007), 205-206; Johann Jacob Schmauss, Kurtzer Begriff der ReichsHistorie, in diner accuraten chronologischen Ordnung (Leipzig: Verlag Johann Ludwig Gleditsch, 1720), 689-721.

41 Such arguments made their way into twentieth-century historians' assessments of the state-focussed and authoritarian nature of conceptions of 'German Liberties': Leonard Krieger, The German Idea of Freedom: History of a Political Tradition (Chicago, IL: University of Chicago Press, 1957), 5-7. More recently, Georg Schmidt has provided a corrective to this portrayal: Georg Schmidt, 'Die Idee “deutsche Freiheit”: Eine Leitvorstellung der politischen Kultur des Alten Reiches,' in Kollektive Freiheitsvorstellungen im frühneuzeitlichen Europa (1400-1850), ed. Georg Schmidt, Martin v. Gelderen, and Christopher Smigula (Frankfurt am Main: Peter Lang, 2006), 159-189.

42 Friedrich Karl von Moser, Beherzigungen (Frankfurt am Main: Verlag der Knoch- und Esslingerschen Buchhandlung, 1762), 586: ‘[...] der zunehmenden willkührlichen Gewalt der Fürsten und Herren über ihre größten Theils sehr bedauerns-würdige 
But such debates and criticisms should not detract from the fact that there was general agreement in this period that the treaties were a boon overall, in that they had successfully settled, in a more or less satisfactory manner, all of the main areas of conflict contributing to the Thirty Years' War. ${ }^{43}$ Apart from some Catholic commentators, ${ }^{44}$ there was no principled rejection of the overall legitimacy of Westphalia, a view that predominated in the nineteenth century. Particularly among Protestants, it was viewed as a laudable milestone which secured the rights of their confession and safeguarded peaceful co-existence, while also confirming princely prerogatives and therefore 'German liberties'. It was seen by jurists of public law, such as Johann Jacob Moser and Johann Stephan Pütter, as the most important constitutional law of a praiseworthy legal-political structure of the Empire. ${ }^{45}$ Johann Jacob Schmauss, a professor of history and the law of nature and nations at Göttingen, wrote in 1766 that 'the Peace of Westphalia is the bond which upholds the calm of the German Empire and the friendship between Catholics and Protestants.46 The historian and jurist Johann Ehrenfried Zschackwitz described the Peace as 'the fundamental pillar of the well-being of the German state', although he recognized that it did not succeed in overcoming confessional tensions, which were again increasing at the time he was writing. ${ }^{47}$ He later referred to Westphalia not only as the most important fundamental law of the Empire, but also as the 'guiding star' of its governance. ${ }^{48}$ Several commentators, such as Gundling, routinely described Westphalia as the 'palladium' of the Empire. ${ }^{49} \mathrm{He}$ was not alone in believing that Westphalia formed the basis

Unterthanen [...] Der Westphälische Frieden und die Kaiserliche Wahl-Capitulationen seynd der Grund [...] zu der Größe der Fürsten, zugleich aber auch der Grund von dem Unglück ihrer Unterthanen'.

43 The highly positive assessment of the Peace in Zedler's encyclopaedia entry of 1748 exemplifies this attitude at the time of Westphalia's 1ooth anniversary: Johann Heinrich Zedler, Grosses vollständiges Universal-Lexicon aller Wissenschafften und Künste, vol. 55 (Halle and Leipzig: J.H. Zedler, 1748), 932-936.

44 Kremer, Westfälischer Friede, 1.

45 Pütter, Historische Entwicklung der heutigen Staatsverfassung des Teutschen Reiches, 3: passim; Johann Moser, Neues teutsches Staatsrecht, 1: passim.

46 Johann Jacob Schmauss, Academische Reden und Vorlesungen über das teutsche Staatsrecht (Lemgo: Meyersche Buchhandlung, 1766), 24: 'Der Westphälische Friede ist das Band, wodurch die Ruhe des teutschen Reichs und die Freundschaft zwischen Catholischen und Protestanten aufrecht erhalten wird'.

47 Johann Ehrenfried Zschackwitz, Einleitung zu dem Teutschen Jure Publico, oder StaatsRechte (Leipzig: J.F. Braun, 1710), 96-98.

48 Johann Ehrenfried Zschackwitz, Geschichtsmäßige und in der Reichspraxi gegründete Erläuterung des westfälsichen Friedens (Halle, 1741), 2.

49 Nicolaus Hieronymus Gundling, Gründlicher Discours über den Westphälischen Frieden (Frankfurt and Leipzig: W.L. Spring, 1736), 6. 
not only of a German Imperial order, but also of a European international order. Similar views were held by Heinrich von Cocceji, a professor of the law of nature and nations at Heidelberg, as well as writers who expounded the positive European law of nations based on treaties, such as the Abbé de Mably, although not everyone agreed with this. ${ }^{50}$ Jean-Jacques Rousseau famously regarded the treaties of Westphalia as the basis of the European political system and argued that preservation of the order it had created for the Empire was crucial for the maintenance of the wider balance of power in Europe. ${ }^{51}$

Whether or not Westphalia was seen as the foundation of a broader European order, many writers did grasp the crucial significance of the treaties for the development of international law. The inclusion of the IPO and IPM in published collections of treaties and the popularity of compendia of original sources related to the congress of Westphalia in the early eighteenth century to some extent reflects this. ${ }^{52}$ Zschackwitz considered the securing of the peace through a mutual guarantee of contracting parties particularly noteworthy, while others commented that the multilateral congress at Westphalia was an influential model for subsequent peace-making. ${ }^{53}$ Gerstlacher argued that it was the combination of constitutional law and the law of nations that made Westphalia unique and so important. ${ }^{54}$

In light of this immense significance accorded to Westphalia by all writers, it is unsurprising that many natural law authors viewed it as a constitutional order that needed to be defended, and several writers, such as Pufendorf and Leibniz, placed it at the heart of their reform plans for the Holy Roman

50 Heinrich von Cocceji, Juris Publici Prudentia Compendio exhibita (Frankfurt am Main: J. Schrey \& Heredum H.J. Meyeri, 1695), 8-6o.

$5^{1}$ Jean-Jacques Rousseau, The Political Writings, ed. Charles E. Vaughan (Cambridge: Cambridge University Press, 1915), vol. 2, 372: 'Malgré les défauts de cette constitution de l'Empire, il est certain que, tant qu'elle subsistera, jamais l'équilibre de l'Europe ne sera rompu, qu'aucun potentate n'aura à craindre d'être détrôné par un autre, et que le traité de Westphalie sera peut-être à jamais parmi nous la base du système politique. Ainsi le droit public, que les Allemands étudient avec tant de soin, est encore plus important qu'ils ne pensent, et n'est pas seulement le droit public germanique, mais, à certains égards, celui de toute l'Europe'.

52 Benjamin Durst, Archive des Völkerrechts: Gedruckte Sammlungen europäischer Mächteverträge in der frühen Neuzeit (Berlin: De Gruyter Oldenbourg, 2016); Antje Ochsmann, 'Johann Gottfried von Meiern und die "Acta pacis Westphalicae publica", in Der Westfälische Friede, ed. Duchhardt, 779-803.

53 Zschackwitz, Einleitung zu dem Teutschen Jure Publico, 99; Gottfried Ferdinand von Buckisch und Loewenfels, Observationes Historico-Politicae in Instrumentum Pacis Osnabrugo-Westphalicum (Frankfurt am Main, Leipzig: J.N. Andreae, 1722).

54 Carl Friedrich Gerstlacher, Corpus Juris Germanici Publici et Privati (Karlsruhe: Schmieder, 1784), 310. 
Empire. ${ }^{55}$ The Abbé de Saint-Pierre went further in the early eighteenth century and saw in the post-Westphalian Holy Roman Empire a model for a perpetual peace in Europe, arguing that European states ought to surrender their sovereignty to an international organization in a fashion somewhat analogous to the Imperial Estates' lack of sovereignty and dependence on the Empire. ${ }^{56}$

\section{$4 \quad$ Interventions and Guarantees in the Law of Nature}

By including the 'foreign crowns' France and Sweden in the mutual guarantee of Westphalia, a right to intervene for the protection of constitutional and religious rights within another state was enshrined in positive treaty law, which was unprecedented in the law of nations. ${ }^{57}$ As Westphalia was a fundamental constitutional law, the guarantee theoretically applied to all manner of legal rights, arrangements and privileges within the rather protean Imperial constitution. Because this extended to a variety of mainly confessional rights enjoyed by subjects, the guarantee of the actual Peace of Westphalia, as opposed to the 'Westphalia' of myth, therefore legalized interventions for the protection of the legal rights of subjects in a foreign state. ${ }^{58}$

55 Michael J. Seidler, 'Introduction,' in Pufendorf, Present State of Germany, xvi, xix. Leibniz supported the elevation of Hanover to the gth electorate on the basis that it would strengthen the Westphalian order by adding a militarily powerful and Protestant prince to the select group of electors. He believed this would improve the political and confessional balance at the heart of Westphalia. He repeated this argument following the conversion of the Saxon elector in 1697: Leibniz, Sämtliche Schriften und Briefe, series Iv, vol. 5, xxvii; vol. 5, no. 22; vol. 6, no. 11. For his reform plans see ibid., vol. 1, no.7.

56 Peter Schröder, 'The Holy Roman Empire as a model for Saint-Pierre's Projet pour rendre la paix perpétuelle en Europe,' in The Holy Roman Empire, 1495-1806: A European Perspective, ed. Peter H. Wilson and R.J.W. Evans (Leiden: Brill, 2012), 35-5o.

57 For the use of legal and other argumentation in governments' justifications of interventions in other states' domestic affairs, see Anuschka Tischer, 'Grenzen der Souveränität: Beispiele zur Begründung gewaltsamer Einmischung in "innere Angelegenheiten" in der Frühen Neuzeit,' Historisches Jahrbuch 131 (2011): 41-64.

$5^{8}$ See the following works on the guarantee: Hans Wehberg, 'Die Schieds- und Garantieklausel der Friedensverträge von Münster und Osnabrück,' Die Friedens-Warte 48, no. 6 (1948): 281-289; Heinz Duchhardt, 'Friedenssicherung im Jahrhundert nach dem Westfälischen Frieden,' in Friedenssicherung. Bd. 3: Historische, politikwissenschaftliche und militärische Perspektiven, ed. Manfred Spieker, vol. 3 (Münster: Regensberg, 1989), 11-18; Maria-Elisabeth Brunert, 'Friedenssicherung als Beratungsthema der protestantischen Reichsstände in der Anfangsphase des westfälischen Friedenskongresses,' in Frieden und Friedenssicherung in der Frühen Neuzeit: Das Heilige Römische Reich und Europa ed. Guido Braun and Arno Strohmeyer (Münster: Aschendorff 
The two relevant theoretical components of the Westphalian guarantee were intervention for the protection of another prince's subjects, and safeguards of treaties of peace and alliance. Both topics received attention from natural law theorists. There was a contextual shift in the writings on intervention over the course of the early modern period. Sixteenth-century writers such as Francisco de Vitoria and the Spanish Scholastics discussed the legitimacy of intervention in the context of the European colonization of the New World..$^{59}$ This colonial element was still present in the theories of some seventeenth-century writers, such as Hugo Grotius, and to a lesser extent Pufendorf, but the focus now shifted towards a consideration of interventions within Europe, reflecting a greater concern with the European context by natural law theorists. 60

While Thomas Hobbes argued that such interventions for the protection of another prince's subjects were impermissible, ${ }^{61}$ Grotius was much more accommodating to the notion. Building on previous arguments by Jean Bodin and Alberico Gentili, he argued that sovereign rulers could intervene for the protection of foreign subjects in order to punish egregious violations of the law of nature. Subjects themselves had no right of resistance against their own rulers, and therefore foreign sovereigns were entitled to act defensively on their behalf. Subjects' lack of a right of resistance, sovereignty, and protective intervention therefore reinforced one another. ${ }^{62}$ According to Pufendorf's

Verlag, 2013), 229-258; Guido Braun, 'Die französische Diplomatie und das Problem der Friedenssicherung auf dem Westfälischen Friedenskongress,' in Assecuratio Pacis: Französische Konzeptionen von Friedenssicherung und Friedensgarantie 1648-1815, ed. Guido Braun (Münster: Aschendorff Verlag, 2011), 67-130.

59 William Bain, 'Vitoria: the laws of war, saving the innocent, and the image of God', in Just and Unjust Military Intervention. European Thinkers from Vitoria to Mill, ed. Stefano Recchia and Jennifer M. Welsh (Cambridge: Cambridge University Press, 2013), 70-95; Simone Zurbuchen, 'Eigenes und Fremdes im Völkerrecht der Frühen Neuzeit: Rechtfertigung und Kritik der Unterwerfung der Völker der Neuen Welt', in Völkerrechtsphilosophie der Frühaufklärung, ed. Tilmann Altwickler, Francis Cheneval and Oliver Diggelmann (Tübingen: Mohr Siebeck, 2015), 177-197.

6o Emmanuelle Jouannet, 'Des origines coloniales du droit international: à propos du droit des gens moderne au $18^{\text {ème }}$ siècle', in The Roots of International Law - Les fondements du droit international, ed. Pierre-Marie Dupuy and Vincent Chetail (Leiden: Brill, 2014), 649-671.

61 See Jonathan Havercroft, "Was Westphalia "all that"? Hobbes, Bellarmine, and the norm of non-intervention,' Global Constitutionalism 1, no. 1 (2012): 120-140; Richard Tuck, 'Grotius, Hobbes, and Pufendorf on humanitarian intervention', in Just and Unjust Military Intervention, ed. Recchia and Welsh, 107-110.

62 Christoph Kampmann, 'Das "Westfälische System", die Glorreiche Revolution und die Interventionsproblematik', Historisches Jahrbuch 131 (2011): 65-92, at 69 n. 1 1; G.P. van Nifterik, 'Religious and humanitarian intervention in sixteenth and early seventeenth century legal thought,' in Sovereignty and the Law of Nations (16th-18th Centuries), ed. 
conception of natural law, the right to intervene was more restricted. It could take place only if specifically requested by the oppressed subjects, and only if they had a legal right of resistance according to the constitutional set-up of the target state. ${ }^{63}$ Christian Wolff's conception of natural law was similarly disinclined towards intervention: 'to interfere in the government of another [...] is opposed to the natural liberty of nations'.64 However, Wolff's theory did hypothetically permit collective intervention if it was carried out by a so-called civitas maxima. He conceived of this fictitious body as a commonwealth, or republic, encompassing a series of smaller associations and political units. On contractarian grounds, collective intervention by this overarching body could be legitimate, since the member states were joined to this larger unit and committed themselves to its laws. ${ }^{65}$ It is possible that Wolff was influenced by the Holy Roman Empire in devising this theory, as internal interventions within the Empire, mandated by the supreme judicial tribunals on the Emperor's authority against the component territories (Imperial Estates), was legally possible and occurred frequently. Far from curtailing such internal interventions, Westphalia strengthened them by increasing the scope of the basis upon which interventions could take place (chiefly by adding a catalogue of enshrined confessional rights), and by enhancing the legitimacy of the intervening supreme courts through the imposition of confessional parity onto their personnel composition. ${ }^{66}$ Vattel's conception of intervention was even more restrictive. ${ }^{67}$ According to his theory, the international system should consist of legally equal and politically independent sovereign states, which adhere to

Randall Lesaffer and Georges Macours (Brussels: Peeters Publishers, 2006), 35-6o; Tuck, 'Grotius, Hobbes, and Pufendorf on humanitarian intervention'.

63 Tuck, 'Grotius, Hobbes, and Pufendorf on humanitarian intervention', 110-112.

64 Quoted in Jennifer Pitts, 'Intervention and sovereign equality: legacies of Vattel', in Just and Unjust Military Intervention, ed. Recchia and Welsh, 143. See also Richard Tuck, The Rights of War and Peace: Political Theory and the International Order from Grotius to Kant (Oxford: Oxford University Press, 1999), 189-19o.

65 Pitts, 'Intervention and sovereign equality: legacies of Vattel', 142, 144-145.

66 Brendan Simms, 'A false principle in the Law of Nations': Burke, state sovereignty, [German] liberty, and intervention in the age of Westphalia,' in Humanitarian Intervention: A History, ed. Brendan Simms and D.J.B. Trim (Cambridge: Cambridge University Press, 2011), 92; Michael Geyer, 'Humanitarianism and human rights: A troubled rapport,' in The Emergence of Humanitarian Intervention: Ideas and Practice from the Nineteenth Century to the Present, ed. Fabian Klose (Cambridge: Cambridge University Press, 2016), 31-55; Milton, 'Intervening against tyrannical rule'.

67 Simone Zurbuchen, 'Vattel's "Law of Nations" and the Principle of Non-Intervention', Grotiania 31 (2010): 69-84; idem., 'Emer de Vattel on the Society of Nations and the Political System of Europe', in System, Order, and International Law. The Early History of International Legal Thought from Machiavelli to Hegel, ed. Stefan Kadelbach, Thomas 
the attendant rule of non-intervention in each other's domestic affairs. Intervention was allowed only under extraordinary conditions, such as to aid tyrannized subjects who appeal for help and who are actually already in a state of revolt, or in the context of a civil war when the state has collapsed into warring factions, in which case the factions have in effect become distinct polities and it is therefore not truly an intervention within a state. ${ }^{68}$

These exceptions on the part of Vattel and Wolff notwithstanding, the fact that theories of natural law and the law of nations appear to become increasingly anti-interventionist after 1648 seems to lend credence to a key aspect of the 'Westphalian system'. However, as Jennifer Pitts and Brendan Simms have pointed out, these theories were an ideal-type normative narrative, rather than an accurate depiction of post-Westphalian state practice. Nor did they accurately reflect the positive European law of nations, at least with regard to the possibility of French and Swedish intervention in the Empire. Pitts has therefore astutely remarked that the 'Westphalian' model of equal, independent sovereign states should more accurately be termed a 'Vatellian' model. ${ }^{69}$

According to Richard Tuck, Pufendorf's restrictive approach to intervention was influenced by his personal experiences of the Thirty Years' War, with its destabilizing foreign interventions, and he was loath to see the carefully constructed arrangements of Westphalia upset by a new round of interventionism. However, Louis XIV's revocation of the edict of Nantes in 1685 led Pufendorf to reconsider his views and he began to argue for a more expansive possibility to intervene in defence of subjects' rights. ${ }^{70}$ Here one can discern a likely influence of Westphalia, and in particular its juridification of intervention and of toleration, on Pufendorf's theory of the law of nations with regard to intervention. According to his theory, intervention was permissible only if the legal basis for it existed, which is exactly what Westphalia furnished for the first time. However, it provided for the possibility only of a one-sided intervention, by the external guarantors France and Sweden into Germany. Faced with the crisis of the expulsion of the French Protestants, Pufendorf expanded his conception of intervention, on the basis of the principles underpinning Westphalian guarantor intervention, by arguing that the Huguenots legally possessed the liberty of religion 'in their own Right', on the basis of the edict of Nantes, just as the three recognized

Kleinlein, and David Roth-Isigkeit (Oxford: Oxford University Press, 2017), 263-281, at $266-267$.

68 Pitts, 'Intervention and sovereign equality: legacies of Vattel,' 146-148; Tuck, The Rights of War and Peace, 193-194.

69 Pitts, 'Intervention and sovereign equality: legacies of Vattel', 134-135; Simms, 'A false principle in the Law of Nations,' 91. 
confessions possessed it on the basis of IPO. ${ }^{71}$ If the adherents of the three recognized confessions in the Empire were denied this right, then the guarantee of Westphalia could be activated, leading eventually to an intervention. Pufendorf was now arguing that an intervention against France was also permissible, on the similar basis of legal rights of toleration being denied in a tyrannical fashion:

A Prince, who troubles his faithful Subjects merely upon the score of Religion, commits a gross Error [...] as for such Princes and States, as have shaken off the Yoke of Popish Slavery, if they seriously reflect, how their fellow-Protestants are persecuted, and in what barbarous manner they are treated, will, questionless [...] take such measures, as may be most convenient for to secure themselves from so imminent a Danger. ${ }^{72}$

Discussions of guarantees of treaties also appeared in the sections of their works which natural law scholars devoted to the law of nations. Here the influence of Westphalia seems not to have been particularly great, as the innovative character of the guarantees of 1648 - the fact that they were mutually guaranteed by the contracting parties themselves and included lower-ranking guarantors, i.e. Imperial Estates - usually did not make its way into the theoretical works. Pufendorf and Wolff both described the older types of guarantees, whereby third parties, usually mediators, or higher-ranking persons such as the Pope, assume the responsibility of a guarantee. Pufendorf wrote 'when a Peace is mutually ratified by each Sovereign Governour [...] it is usual [...] for some others oftentimes, especially amongst the Assistants at the Treaty, to undertake the Guaranty of the same, with Promises of Aid to him who ever is injured by the other'. ${ }^{73}$ Wolff similarly described the guarantee as commonly being taken over by 'a third party'. ${ }^{74}$ Vattel, however, did refer to the possibility of the contracting parties of a peace treaty guaranteeing their own peace reciprocally, in a manner that first occurred at Münster, without however mentioning Westphalia. Possibly influenced by the policies of Louis XIV towards the Empire in the later seventeenth century, Vattel warned that external guarantors cannot execute treaty

71 Simone Zurbuchen, 'Introduction,' in Samuel Pufendorf, The Divine Feudal Law: Or, Covenants with Mankind, Represented, ed. Simone Zurbuchen, transl. Theophilus Dorrington (Indianapolis, IN: Liberty Fund, 2002), xi.

72 Pufendorf, Of the Nature and Qualification of Religion, 120-121.

73 Samuel Pufendorf, The Whole Duty of Man According to the Law of Nature, ed. Ian Hunter and David Saunders, transl. Andrew Tooke (Indianapolis, IN: Liberty Fund, 2003), 244.

74 Christian Wolff, Grundsätze des Natur- und Völckerrechts, worinn alle Verbindlichkeiten und alle Rechte aus der Natur des Menschen in einem beständigen Zusammenhange hergeleitet werden (Halle: Renger, 1754), 837-838. 
terms on their own accord without being called upon by the signatories, 'lest, under colour of being a guarantee, a powerful sovereign should render himself the arbiter of the affairs of his neighbours, and pretend to give them laws.' ${ }^{75}$

\section{The Mutual Guarantee of Westphalia in the Law of Nations and International Politics: Perceptions by}

\section{Natural Law and Public Law Writers}

How did natural law and public law writers assess the guarantee as specifically adopted at the Peace of Westphalia, and as applied in the post-1648 period? It is important to note that the geopolitical context of the time of writing was central, as were the personal circumstances of the author. It is also important to recall that the guarantee applied not only to the religious and constitutional stipulations for the Empire and its inhabitants, but also to the various terms that formed the international dimension of the peace treaty between great powers. Indeed, these terms were prominent in discussions of the guarantee during the first few decades after the conclusion of the Peace, a time when German commentators were highly concerned with preventing the Empire being drawn back into ongoing wars.

A key stipulation in this regard was IPM §3, the so-called Assistenzverbot, which prohibited the Austrian Habsburgs from providing any assistance to their Spanish Habsburg cousins in the ongoing Franco-Spanish war (lasting until 1659), and which also exempted the Burgundian circle of the Empire (consisting largely of the Spanish territory of the Southern Netherlands) from the Imperial defensive framework and from the guarantee. Under Cardinal Richelieu's original plan, the French had approached the peace congress with a view towards achieving a 'universal' peace, in other words, a peace treaty that would simultaneously settle all constituent and related conflicts of the Thirty Years' War. When it became clear that the Franco-Spanish war could not be settled at Westphalia, the congress reached a point of crisis and risked dissolving. At this crucial moment, the congress was arguably saved by the efforts of a cross-confessional 'third party' of smaller princes who were willing to compromise, and who propelled the negotiations forward in its final phase, forcing the Emperor to agree to the guarantee and the non-assistance clause. ${ }^{76}$ This provided France with the assurance that it could continue fighting Spain without

75 Vattel, Law of Nations, 396.

76 Christoph Kampmann, Europa und das Reich im Dreißigjährigen Krieg (Stuttgart: W. Kohlhammer, 2013), 128-170. 
having to face the Emperor as well, and also assured the Protestant princes that France would come to their aid if the Catholics and the Emperor reneged on their religious concessions and resumed confessional depredations.

It was therefore an important instrument both to propel the peace settlement to its conclusion, and to instil a degree of trust in a mutual and reciprocal enforcement mechanism at a time when trust between the contracting parties was lacking. Pufendorf captured this mutual distrust which necessitated a mutual guarantee when he wrote "The Roman Catholicks charge the Protestants, That they have deprived them of a great part of their Wealth and Riches, and they are night and day contriving how they shall recover what they have thus lost, and the other Party are as well resolved to keep what they have got. ${ }^{77}$ Although it is unknown whether he had the Westphalian congress in mind, Gundling grasped the importance of guarantees in his work on the law of nature and nations, by arguing that the existence of a guarantee could instil trust and increase the willingness of warring parties to conclude a peace treaty, noting that it is 'highly necessary to conclude such guarantees, otherwise the stronger will devour the weaker. ${ }^{78} \mathrm{He}$ recognized that the treaty and its guarantee created a pacified security zone for central Europe, and expressed the hope this zone could eventually be expanded to cover all of Christian Europe. ${ }^{79}$

In the post-war years, the above-mentioned 'third party' of smaller princes continued to actively work towards the preservation of the peace on the basis of upholding the guarantee. In forming the cross-confessional 'Rhenish alliance' (1658-1668) together with both France and Sweden but not the Emperor, the message was clear that they considered the latter the biggest threat to their liberties and to peace. Indeed, he resented being prohibited by treaty law from allying with his relatives in Spain, while his own immediate subjects, the Imperial Estates, allied with France and Sweden. The princes' perspectives soon changed with Louis XIV's assumption of personal rule and the advent of his policy of aggressive expansionism towards the Rhine from the late 166os, after which they viewed Emperor Leopold I as a more effective protector. ${ }^{80}$ This context is important in understanding the assessments of the guarantee in this period by commentators such as Pufendorf and Leibniz. Pufendorf's

77 Pufendorf, Present State of Germany, 204.

78 Nicolaus Hieronymus Gundling, Ausführlicher Discours über das Natur-und Völcker-Recht (Frankfurt am Main and Leipzig: Spring, 1747), 333.

79 Laudin, 'Le Gründlicher Discours', 133.

8o Roman Schnur, Der Rheinbund von 1658 in der deutschen Verfassungsgeschichte (Bonn: Röhrscheid, 1955). 
Monzambano first appeared just as this shift was beginning and later editions were published at the height of the Empire's enmity to France.

Leibniz extensively discussed these geopolitical challenges facing Germany in his oeuvre, although his frame of reference was not so much theoretical and philosophical as grounded in historical empirical analysis. ${ }^{81}$ It is therefore hard to determine how or whether his assessments of Westphalia influenced his conceptions of natural law. In the late 166os, Leibniz discusses the question of the duration of the exemption of the Burgundian circle from the Westphalian guarantee as part of the non-assistance clause. This was highly disputed and the text was ambiguous, but it had clear geopolitical implications as it largely covered the Spanish Netherlands, against which Louis XIv had aggressive designs. France argued that the exemption was perpetual, whereas Spain argued that it was exempt only during the Franco-Spanish war that was ongoing at the time of the conclusion of the treaties of Westphalia, and that had ended in 1659. Spain therefore demanded collective Imperial assistance on the basis of the guarantee were it to be attacked in that circle, and indicated that it would not offer financial contributions to the Empire if it was denied this assurance. The issue became salient in 1667 with the French attack on the Spanish Netherlands. Leibniz argued strongly in favour of the duty and the right of the Empire to defend the Spanish Netherlands, and that the guarantee remained exempt only for the duration of the war that was ongoing between France and Spain at the time of the signing of the treaty of Münster. He argued that failing to provide the requested assistance would amount to an abdication of the responsibilities of the guarantee of Westphalia. ${ }^{82}$

Leibniz followed this up with a political tract in 1670 in which he discussed the best means for the Empire to achieve security in light of France's hegemonic designs. ${ }^{83}$ Its primary addressee was the archbishop-elector of Mainz, who had been the chief architect of the Rhenish alliance of 1658. Leibniz considered means to strengthen the defence of the Empire in the face of the

\footnotetext{
81 Wilhelm Schmidt-Biggemann, 'Leibniz,' in Politische Theorien des 1 7. und 1 8.Jahrhunderts: Staat und Politik in Deutschland ed. Bernd Heidenreich and Gerhard Göhler (Darmstadt: Philipp von Zabern, 2011), 149-151.

82 Leibniz, Sämtliche Schriften und Briefe, series IV, vol. 1: 115-130, 141.

83 Bedencken welchergestalt Securitas publica interna et externa und Status praesens im Reich, jitzigen Umständen auf festen Fuss zu stellen (1670), in ibid, pp. 133-214. See also Christoph Kampmann, Arbiter und Friedensstiftung. Die Auseinandersetzung um den politischen Schiedsrichter im Europa der Frühen Neuzeit (Paderborn: Ferdinand Schoeningh, 2011), 220-226, and Wolfgang Burgdorf, Reichskonstitution und Nation. Verfassungsreformprojekte für das Heilige Römische Reich Deutscher Nation im Politischen Schrifttum von 1648 Bis 1806 (Mainz: Philipp von Zabern, 1998), 88-95.
} 
French threat. He believed that Louis XIV did not want to directly conquer the German lands but rather, as had already occurred via the Rhenish alliance, place himself in the position to be the arbiter of conflicts within the Empire and therefore indirectly dominate Germany. However, the solution was not for Mainz or the Emperor to join the triple alliance of England, Sweden and Netherlands. Leibniz considered it 'a particularly dangerous alliance, which France would interpret as a hostile declaration'. Instead, the princes should seek to form a broad-based alliance that was not necessarily reliant on the Emperor, modelled on the Rhenish alliance and designed to secure the Westphalian order, in order to harness the defensive capacity of the Empire: 'the purpose of this alliance should be nothing other than to provide each other the guarantee of the Peace of Westphalia, which all Imperial Estates are bound into anyway'. A broad-based alliance of princes would do little to draw the Empire into foreign wars that did not directly affect its interests, nor would it cause offence or provoke aggression among other powers, primarily France, 'especially because such an alliance amounts to nothing less than the Rhenish alliance which is in accordance with the Peace of Westphalia and the guarantee incorporated therein'.

According to Leibniz, the Westphalian order was very much at the heart of what needed defending and strengthening: 'everyone has an interest in ensuring that the Peace of Westphalia remains active, and all should act together so as to ensure that it is better implemented. ${ }^{84}$ Leibniz argued that France was very adept at using the guarantee as an occasion or pretext to strengthen its position in the Empire and achieve the position of an influential arbiter, or arbitrium rerum, which allowed it to build a strong patronage network and essentially usurp the position of the Emperor as a mediator and adjudicator in inter-territorial disputes. Depending on its own interest, France would take sides against the party that was unwilling to ally with it or to become its client. ${ }^{85}$

Thus, although Leibniz saw the mutual guarantee as a helpful institution that ought to be strengthened, he was acutely cognisant of the dangers

84 Leibniz, Sämtliche Schriften und Briefe vi, 1: 141:: 'ein absonderlich gefährlich Bündnüß, so Franckreich pro declaratione hostilitatis aufnehmen wird'; ibid., 1: 158: 'Der Zweck solcher Allianz soll nichts anders seyn, als blatt und bloß Garantiam Instrumenti Pacis, darinnen ohne das alle stände begriffen, einander zu leisten'; ibid., 1: 140: 'Sind iede insonderheit verbunden daran zu seyn damit das Instrumentum pacis in vigore bleibe, so können sie sich ja dazu mit einander zu beßerer Execution noch mehr verbinden'.

85 Ibid., 1: 193-5. For an analysis of French protection and patronage policy towards the Rhenish ecclesiastical electors, see Tilman Haug, Ungleiche Außenbeziehungen und grenzüberschreitende Patronage. Die französische Krone und die geistlichen Kurfürsten (16481679) (Cologne: Böhlau, 2015). 
emanating from France's instrumentalization of it for Louis XIV's own interests. In the 1680s he accused France of having violated the IPM as the rightful foundation of relations between France and the Empire, and abused its guarantor position with the Reunions policy. ${ }^{86}$ At the time of the Peace of Ryswick, the fourth article of which altered the confessional balance in the Palatinate, Leibniz described the clause in question as a violation and a great blow to the religious terms of Westphalia, 'which are one of the best foundations of peace and calm', but regretted its 'lack of guarantees'. ${ }^{87}$ Westphalia was not seen as ideal by Leibniz, but it was nevertheless to be the basis for an improved system. The above quote shows that he saw the treaty structure as a good internal organizing system as well as the basis of a defensive barrier against France.

Pufendorf's Monzambano appeared in the context of one of the interterritorial disputes mentioned by Leibniz, the Wildfangstreit between the elector-Palatine and a number of its neighbours, in which the former sought assistance from the external guarantors, Sweden and France. ${ }^{88}$ Pufendorf was employed at the elector-Palatine's university of Heidelberg at the time, which might explain why the Swedish intervention in the Thirty Years' War was portrayed in a fairly positive light as having ensured the protection of Protestants from Austrian persecution. ${ }^{89}$ The guarantee itself is not portrayed negatively, although Pufendorf did criticize the princes' right to form alliances (jus foederum), an old customary practice that was enshrined at Westphalia. In combination, the two weakened the unity of the Empire and exposed it to deleterious foreign machinations. Pufendorf considered it a 'pernicious Disorder [...] That the Princes of Germany enter into Leagues, not only one with another, but with Foreign Princes too, and the more securely, because they have reserved to themselves a Liberty to do so in the Treaty of Westphalia'. He believed the jus foederum was dangerous because it 'not only divides the Princes of Germany into Factions', but also because it provides the guarantors, France and Sweden, with an ability to 'mould Germany to their own particular Interest and Wills, and ultimately, when given an appropriate opportunity, by the assistance of their German Allies, to insult on all the rest of the Princes, especially when the

86 Leibniz, Sämtliche Schriften und Briefe, series vi, vol. 2: 471-502.

87 Leibniz, Sämtliche Schriften und Briefe, series I, vol. 14: no. 56: 'welche eine der besten Fundamente des Friedens und der Ruhe sind [...] Mangel an Garantien'; Leibniz, Sämtliche Schriften, series vi, vol. 6: no. 42, 6: 289-297.

88 Roman Schnur, Der Rheinbund von 1658 in der deutschen Verfassungsgeschichte (Bonn: Röhrscheid, 1955), 8o-83.

89 Pufendorf, Present State of Germany, 191. The intervention is portrayed even more positively in his later publications when he was a royal court historian of Sweden: Pufendorf, An Introduction, 519 . 
Design of those Leagues is not levell'd against other Foreign Princes [...] but against the Members of the Empire itself'. Pufendorf therefore suggested that, while retaining Westphalia as a foundation, the members of the Empire must make provision to prevent foreign interference in its affairs and to harness common defence efforts to prevent a loss of territory to foreign conquerors. Amending the jus foederum to prevent princes allying against each other was one such option. ${ }^{90}$ In later editions of the piece, the earlier anti-Habsburg tone was replaced by a strong anti-French sentiment, reflecting the shifting mood outlined above. ${ }^{91}$ Towards the end of his career, Pufendorf accused France of pretending 'to play the Master over Princes' through designs 'which overturn the Westphalian Treaty, or are intended against the Protestants in Germany and Holland'.92

The basic premise of Pufendorf's view of the well-being of Europe was that universal monarchy must be prevented. Westphalia was valuable and laudable in that it represented the culmination of the successful struggle against such attempts by the Habsburgs and, moreover, the achieved balance was mutually guaranteed and therefore secured for the future. Preventing the Holy Roman Empire from being dominated by a single power was vital to undercutting the emergence of universal monarchy. This risk existed both from within the Empire, chiefly through the Habsburgs, and from without, by being subjected to a foreign power's control. Therefore, the mutual guarantee clauses were highly important and effective, as none of the guarantors would permit the other to establish such a domination over Germany. While retaining this basic premise, Pufendorf's assessment of various individual stipulations and the state of the Westphalian order shifted in response to the changing geopolitical context, as well as the interests of his employer. Nevertheless, his writings were always guided by a belief in the necessity of upholding the basic German and international order as established at Westphalia; however, the treaties also contained provisions which themselves threatened to undermine that very order..$^{93}$

In the early 1740 , during a renewed period of French activism and military operations in the Empire (following a period of relative withdrawal in 17141733), Schmauss sought to analyse individual states' self-interests and he argued that France assigned great value to its guarantor status. He wrote that France

90 Pufendorf, Present State of Germany, 205-206, 219-220. See also Peter Schröder, 'The constitution of the Holy Roman Empire after 1648: Samuel Pufendorf's assessment in his Monzambano,' The Historical Journal 42, no. 4 (1999): 970.

91 Pufendorf, Present State of Germany, 193.

92 Pufendorf, An Introduction, 6o2. See also Döring, 'Der Westfälische Frieden', 359-36o.

93 Döring, 'Der Westfälische Frieden', 353-355. 
uses guarantees to enhance its influence without expensive wars of conquest and direct rule. The guarantees allow France to achieve an 'ascendancy and a higher degree of a general direction of Europe [...] The guarantee of the peace of Westphalia gives her a pretext to interfere in German affairs'. The French security apparatus combined this with numerous other guarantees, such as that of Polish liberties and its 'leapfrog diplomacy ${ }^{\prime 94}$ with the Swedes and the Turks. In general, France's use of its guarantor status shows 'that France knows well how to cunningly make use of the guarantee, in order to acquire direction over everything that occurs in Europe'. ${ }^{95}$ Guarantees of peace treaties and other international arrangements were an effective instrument of French hegemony, because 'a guarantee is nothing other than a right to involve oneself in other affairs, by citing one's obligation as a guarantor, if this is deemed to further one's interests. ${ }^{96}$

Other assessments by German jurists and other scholars in the early to mideighteenth century were similarly critical of France's use of its guarantee, without necessarily denying the theoretical value of the institution as a method to secure the peace. Like Pufendorf, Johann David Köhler and Franz Dominicus Häberlin viewed the jus foederum as dangerous, especially in combination with the French guarantee. They believed that the liberties granted to the princes were excessive, weakened the Empire as a whole, and helped France gain ascendancy over Germany, primarily through the guarantee. France's previous intervention in the Thirty Years' War was argued to have been designed purely to serve its own geopolitical interests, with Teutsche Freiheit employed as a blind to cover its own naked ambitions. ${ }^{97}$ In determining the reception of the

94 Brendan Simms, 'Europe's shifting balance of power,' in The Oxford Handbook of Early Modern European History, 1350-1750, Vol 2: Culture and Power, ed. Hamish Scott (Oxford: Oxford University Press, 2015), 649-65o.

95 Johann Jacob Schmauss, Einleitung zu der Staats-Wissenschafft, und Erleuterung Des von ihm herausgegebenen Corporis Juris Gentium Academici und aller andern seit mehr als zweyen Seculis her geschlossenen Bündnisse, Friedens- und Commercien-Tractaten, vol. 1 (Leipzig, 1741), 63o.: 'Ascendant, und höhern Grad einer allgemeinen Direction in Europa [...] Die Garantie des Westphaelischen Friedens giebt ihm Vorwand, sich in Teutsche Sachen zu Mengen ... daß sich Frankckreich der Garantie gar listig zu bedienen weiß, um sich [...] über alles und iedes was nur in Europa vorgehet eine Direction zu erwerben'.

96 Ibid., 631: 'Eine Garantie ist nichts anders, als ein Recht, sich unter Anführung der Obliegenheit eines Garant in andere Händel zu mischen, wann man es seinem Interesse gemäß erachtet'.

97 Johann David Köhler, Kurtzgefaste und gründliche teutsche Reichs-Historie (Frankfurt and Leipzig: Riegel, 1736), 564-566; Franz Dominicus Häberlin, Anmerkungen über die in Johann Carl Königs Selectorum juris publ. P. VIII. c. 1 6. befindliche Erörterung der Frage: Ob die Crone Frankreich vor einen Erbfeind des H. R. Reichs zu achten seye? (n.p., 1745), passim. 
guarantee among legal and political writers of the period, one ought to be clear about the purpose of the author. One must distinguish between assessments of the guarantee as it operated in geopolitical and diplomatic practice on the one hand, in other words its role in Franco-German and Swedish-German relations, and how it was evaluated as an instrument under the law of nations on the other hand. This distinction is more significant than locating the author in a particular tradition such as natural law or public law, although individual writers often addressed both aspects in the same publications. The commentaries in the works examined so far have mainly been of the former category, namely assessments of the role and effects of the guarantee in practice. When assessed in principle, the guarantee was viewed much more positively, especially in the later eighteenth century, during a period of French decline far removed from the hegemonic wars of Louis XIV. Johann Stephan Pütter, for example, lauded the guarantee as 'highly praiseworthy' ${ }^{98}$ The Halle professor Johann Christian Krause viewed the guarantee as beneficial in theory and in practice, as it promoted the unity of Europe by tying numerous powers into a reciprocal system of securing the peace..$^{99}$ Mably argued that the mutual guarantee elevated Westphalia above other peace treaties because it encompassed carefully devised mechanisms to provide long-term safeguards of the peace. ${ }^{100}$

The prolific scholar of public law Johann Jacob Moser was one of the few jurists to write a monograph specifically on the guarantee of Westphalia. ${ }^{101}$ It was primarily a legal exposition of the guarantee in theory, although it also served a contemporary political purpose, namely to define a set of parameters in order to limit the ways in which the guarantee could be applied in practice, otherwise the external guarantors could plausibly assert a right to intervene in any matter affecting the Imperial constitution. ${ }^{102}$ Moser's aim was undoubtedly influenced by more than a century of French instrumentalization of the guarantee for power-political ends. ${ }^{103} \mathrm{He}$ did this by insisting that the guarantee could be activated and implemented by armed force only if it was requested by the injured party, and only if all other internal Imperial judicial channels

98 Johann Stephan Pütter, Der Geist des Westfälischen Friedens; nach dem Buchstaben und Sinn desselbigen (Göttingen: Vandenhoeck und Ruprecht, 1795), 543.

99 Johann Christoph Krause, Lehrbuch der Geschichte des Dreyßigjährigen teutschen Krieges und Westphälischen Friedens (Halle: Johann Christian Hedel, 1782), 130.

100 Gabriel Bonnot de Mably, Le droit public de l'Europe, fondé sur les traités (Amsterdam: Arkstee \& Merkus, 1761), 8-10.

101 Johann Jacob Moser, Von der Garantie des Westphaelischen Friedens; nach dem Buchstaben und Sinn desselbigen ([Stuttgart], 1767). See also Kremer, Westfälischer Friede, 44-46.

102 Moser, Von der Garantie, 44.

103 Moser, Neues teutsches Staatsrecht, 1: 450. 
had been exhausted without procuring redress. In exercising the guarantee, the guarantors must comply with natural law and the law of nations. Although the Emperor was himself a guarantor as well, Moser argued that the exercise of his guarantee must not allow him to arrogate to himself rights as a guarantor derived from the law of nations which were denied him as head of the Empire on the basis of Imperial constitutional law. Therefore, jus publicum set limits to his freedom of action as derived from jus gentium. Moser also emphasized that the guarantee was designed to uphold not only princely rights, but also those of the 'mediate members of the Empire, territorial estates and subjects'. ${ }^{104}$ This was the case because 'In so far as much of the Peace of Westphalia is provided for their benefit, it applies to them as interested parties of the Peace; and just as the Peace itself, this is also the case with its guarantee, according to which one can and must take up their cause, if they are affronted in violation of the Peace.'105

Moser was thus one of the few scholars who discussed the guarantee in terms of its potential role as a legalized form of intervention for the protection of foreign subjects. ${ }^{106}$ When addressing the question of who could be targeted in an intervention according to the guarantee, Moser wrote that anyone violating the terms of the Peace was a legitimate target, including the Emperor, an external power and the territorial princes. ${ }^{107}$ Moser stressed that the guarantee did not render the Imperial judiciary obsolete in the securing and executing of the Peace. Instead, he viewed the guarantee as its substitute, to be resorted to only if the regular channels failed to enforce Westphalian rights:

This armed guarantee should be a surrogate for the judicial office, and the guarantors should be authorized to take those measures which the judge, under whose jurisdiction the complainant is, should have taken, but did not take, either because he was not appealed to, or because he hesitated

\footnotetext{
104 Moser, Von der Garantie, 46: 'mittelbare Glieder des Reichs, Land=Stände und Unterthanen'.

105 Ibid.: 'In so ferne aber viles in dem Westphälischen Friden zu ihrem Besten verordnet ist, seynd sie Fridens=Intereßenten, und wie des Fridens selbst, also auch dessen Garantie, in so fern fähig, daß man sich ihrer annehmen kan und muß, wann sie gegen den Fridens=Schluß beleidiget werden'.

106 An actual example of the implementation of the guarantee for the protection of foreign subjects (albeit not strictly following the prescribed steps) was Sweden's intervention for the benefit of the Protestants of Austrian Silesia in 1707. See Norbert Conrads, Die Durchführung der Altranstädter Konvention in Schlesien 1707-1709 (Cologne: Böhlau, 1971).

107 Moser, Von der Garantie, 47.
} 
for too long. Hence the external guarantors, who otherwise have no jurisdiction in this state, may nevertheless intervene in such cases. ${ }^{108}$

While Moser generally sought to restrict the practical application of the guarantee by the foreign powers (instead pointing to the internal guarantors as being more promising), he did seek to make it more impactful in one important respect. He argued that the three-year waiting period stipulated by the treaty before a guarantor intervention could take place was excessive and should therefore be ignored, because in urgent cases the injured party might incur unacceptable losses if rapid redress were not forthcoming. ${ }^{109}$ He was making the case for adhering to the spirit rather than the letter of the law, as the title of his monograph indicated.

Another author who devoted a work to the guarantee was the professor of public law Johann Christoph Steck, who penned his essay on instructions from Brandenburg-Prussia in $1757 .{ }^{110}$ The geopolitical context was the recent activation of the guarantee by all guarantors, France, Sweden, the Emperor and the Empire, against Prussia for having invaded and laid waste to Saxony at the outset of the Seven Years' War (1756-1763). It is notable that despite the wartime interests of his employer of having this example portrayed as an abuse of the guarantee, given that it was directed against Berlin, the author nevertheless highlights the benefits of the mutual guarantee in theory and when properly applied. In general, he held the Peace of Westphalia in very high regard, as it safeguarded and enshrined Protestant and princely rights, and he portrayed the mutual guarantee as a necessary, effective, and appropriate new instrument in international law to secure the longevity of the peace terms: 'no more effective means to eternalize this Peace and to secure its holiness could have been devised than the guarantee and warranty, which all contracting powers have reciprocally assumed over it'.111 Older means of securing the peace, such

108 Ibid., 64: 'Dise gewaffnete Garantie solle ein Surrogatum des richterlichen Amtes seyn, und die Garants sollen befugt seyn, das zu thun, was der Richter, unter dem der Beleidigte stehet, hätte thun sollen, aber nicht gethan hat, weil er entweder nicht angeruffen worden ist, oder zu lang gezaudert hat, dahero die auswärtige Garants, denen sonsten in solchem Staat keine Gerichtbarkeit zustehet, in solchem Fall dennoch zugreiffen dörffen'.

109 Ibid., 49, 57.

110 Johann Christoph Wilhelm Steck, 'Abhandlung von den Rechten und Pflichten der hohen Garans des Westphälischen Friedens,' in Abhandlungen aus dem deutschen Staats- und Lehnrecht zur Erläuterung einiger neuen Reichsangelegenheiten (Halle: Johann Justinus Gebauer, 1757), 99-132.

111 Ibid., 103.: 'Kein wirksameres Mittel aber konte ausgesonnen werden, diesen Frieden zu verewigen, und seine Heiligkeit zu versichern, als die Garantie und Gewährleistung welche alle schließende Mächte wechselweise darüber übernommen haben'. 
as the exchange of oaths and hostages, 'had long ago ceased to be adequate in instilling loyalty and faith in treaties between nations.'12 ${ }^{112}$ The guarantee was effective precisely because self-interest and suspicion about the other side's future adherence to the agreement prevailed. Not all parties were believed to have had an equal desire to see Westphalian terms upheld, particularly the Emperor, who lost entire provinces and saw his plans for an 'unlimited power over Germany' scuppered, while also being highly suspicious of Sweden's new role as an Imperial Estate with considerable territories in north Germany. It was therefore 'highly necessary to employ great care and guidance, to make this peace perpetual and binding'. In pursuit of this goal, 'all diligence would have been futile, if all contracting powers had not committed themselves to reciprocally safeguard the holiness and compliance with this Peace, and to offer each other powerful assistance against any violator.'13

Steck argued that one needed to distinguish between the internal and the external guarantors, because 'our Peace is a treaty between European powers, and simultaneously a fundamental constitutional law of the German Empire.'114 The external guarantors did have certain rights and duties which Steck saw as grounded in natural law. Citing Wolff's and Cocceji's work on jus gentium et naturae, ${ }^{115}$ Steck argued that guarantors were obliged to ensure that treaty terms are upheld and to remonstrate, and if need be act against violators of the guaranteed treaty, if called upon to do so by the injured party. Steck then applied this to the Westphalian guarantors and stated that Sweden and France were empowered to ensure the maintenance and upkeep of the terms of Westphalia and the Imperial constitution in general. They were authorized to defend the constitutional and fundamental laws of the Empire, to intervene on behalf of and for the protection of those whose Westphalian rights had been violated, 'to guard the freedom of the Imperial Estates', to interfere in Imperial business as long as called upon by the injured party, and to defend

112 Ibid.: 'längstens nicht mehr hinreichend Treue und Glauben in den Bündnissen der Völcker zu befestigen'.

113 Ibid., 104-105: 'unumschränkten Gewalt über Teutschland [...] höchstnöthig, alle Maasregeln der Vorsichtigkeit zu ergreifen, und diesen Frieden dauerhaft und seine Verbindlichkeit unauflöslich zu machen [...] Alle Behutsamkeit aber würde vergeblich gewesen sein, wenn sich nicht alle schließenden Mächte wechselsweise verpflichtet hätten, über der Heiligkeit und Beobachtung dieses Friedens zu wachen, und sich wider alle Übertreter desselben kräftigen Beistand zu leisten'.

114 Ibid., 107:'unser Friede ein Bündnis Europäischer Mächten, und zugleich ein Grundgesetz des deutschen Reiches ist'.

115 The works cited are Christian Wolff, Jus gentium methodo scientifica pertractatum (Halle: Renger, 1749), chap. IV, $\S \S 443-445,363-364$; Heinrich v. Cocceji, Disputatio juris gentium publici de guarantia pacis (np, 1702), vol. 1, diss. 4 . 
the confessional rights of the three recognized confessions. This broad scope made the dangers of potential abuse and exploitation particularly large, although Steck did not deny that the external guarantors had a right and duty to intervene in the internal affairs of the Empire only if Westphalian terms were actually violated, and only if they were called upon by the injured party beforehand. ${ }^{116}$ Given the political aims he pursued, Steck argued that France had indeed abused the guarantee for its own self-interest, as was the case in 1756/ 1757. Steck submitted that Prussia was in fact defending Westphalian rights by acting defensively against a planned dismemberment through pre-emption in order to defend the principle of Imperial Estates being allowed to retain the territories whose possession had been confirmed at Westphalia. He suggested that more emphasis needed to be placed on the internal guarantors to defend the terms of Westphalia that dealt with arrangements within the Empire and the Imperial constitution in general. ${ }^{117}$

The exercise of the guarantee by the internal guarantors, which Steck and Moser both viewed as more beneficial to the Empire's interests than the external guarantee, was not uncontroversial either. It had been at the heart of a constitutional crisis that emerged in the early eighteenth century at a time of renewed confessional strife occasioned by several restrictions imposed on Protestant subjects by the electors of the Palatinate and Mainz, and several smaller Catholic princes along the Rhine. The umbrella organization of Reichstag envoys representing all Protestant Imperial Estates, the Corpus Evangelicorum, used this crisis and the publicity campaign surrounding it to assert a new interpretation of the guarantee of Westphalia. In the 1710 and 1720 s the Corpus developed a constitutional vision which asserted that, as contracting parties of the treaties of Westphalia, the Protestant princes were entitled on the basis of the guarantee to execute the treaty terms by force if necessary, if Westphalian terms were violated and if the Emperor refused to immediately dispatch execution commissions. The Corpus was therefore asserting a right to intervene in the domestic territorial affairs of Catholic princes for the protection of the latter's Protestant subjects. It claimed to derive this right not only from the positive law of the Westphalian guarantee, but also from the right, based in natural law, of corporate groups proffering assistance to fellow members. ${ }^{118}$

116 Ibid., 114-115: 'Vor die Freyheit der Reichsstande zu wachen'.

117 Ibid., 118-119, 122-124.

118 See Patrick Milton, 'The early eighteenth-century German confessional crisis: the juridification of religious conflict in the re-confessionalised politics of the Holy Roman Empire,' Central European History 49 (2016): 39-68. 
The Protestant diplomats at Regensburg received ample intellectual support in this endeavour from several of their co-religionists in the field of public law and natural law. While the Emperor and the Catholics rejected this expanded scope of legally buttressed interventions for the protection of other princes' subjects, Protestant jurists largely espoused the Corpus's pluralistic interpretation of protective intervention, based on Westphalia and general invocations of natural law. ${ }^{119}$ Moser, the most vociferous advocate of this expanded authority of intervention conceived as self-help, answered the question of 'Whether [...] Imperial Estates of either religion are permitted to step in and support fellow estates of their own religion, as well as co-religionists who are subject to the territorial rule of other Imperial Estates', with an emphatic yes. ${ }^{120} \mathrm{He}$ was also of the opinion that individual princes or corporate unions such as the Corpus Evangelicorum had the right 'to resort to more forceful and finally violent measures, when amicable means have been fruitless, and when the confessional grievances have multiplied.121 Furthermore, Moser commented 'that in the entire text of the Treaties of Westphalia there is not a single passage which states that Protestants should necessarily be obliged to refer only their confessional grievances to the Emperor, and to await only his verdict and assistance in such matters'. The only exception to this right had been made for the Austrian hereditary lands. ${ }^{122} \mathrm{He}$ stressed that 'there can be no doubt that customary protective justice [...] and art. 17 Pac. Westph. § 5, 6 \&c grants all contracting parties an undeniable right to uphold all and every stipulation of the said Peace, and to protect everyone for whose benefit the terms were stipulated [...] those terms of the 5 th article which stipulate subjects' religious and

119 Steck supported this interpretation of the guarantee: Steck, 'Abhandlung von den Rechten', 132. See also Nicolaus Hieronymus Gundling, Ausführlicher Discours über das Natur- und Völcker-Recht, 332, and the references cited in the published appeal by the Corpus Evangelicorum to the Emperor's representative (Prinzipalkommissar) at the Imperial Diet, Regensburg, 28 Dec. 1719, in Europäische Staats-Cantzley, ed. Anton Faber (Frankfurt a. M. and Leipzig, 1697-1760), vol. 35 (1720), 381-439.

120 Moser, Neues teutsches Staatsrecht, vol. 7: 208: 'Ob [...] der einen oder anderen Religion zugethanen Reichs=Ständen erlaubt seye, sich ihrer Religionsverwandten Mitstände, wir auch ihrer unter anderer Reichsstände Landeshoheit stehenden Glaubensgenossen, anzunehmen?'.

121 Ibid. 254: 'wann die gütliche Mittel nichts haben verfangen wollen, und die Religions=Beschwerden [...] gehäuffet worden seynd, nachdrücklichere und endlich gewaltsame Wege zu ergreiffen'.

122 Ibid. 426-427: 'Es ist aber höchst=merckwürdig, daß in dem ganzen Instrumento Pacis kein Wort zu befinden ist, daß die Evangelischen schuldig seyn sollten, ihre Religionsbeschwerden nothwendig bey dem Kayser anzubringen, und alleine Dessen Auspruch und Hülffe darüber zu erwarten'. 
church rights are by no means excluded therefrom.123 It was in this context of the internal exercise of the guarantee for the protection of Protestant subjects' Westphalian confessional rights that Moser called for the disregarding of the three-year waiting period. Gundling also supported the Corpus's interpretation of its right to intervene on the basis of his natural law conception of guarantees in the international sphere, although not on the basis of a right to intervene for the protection of a foreign ruler's subjects whose rights are being violated.124

\section{Conclusion}

This chapter has attempted to demonstrate that assessments of Westphalia among jurists varied considerably depending on the particular aspect of the settlement that was being written about, as well as the context and period in which its later impact was being evaluated. Contrary to the claims of the Westphalian myth, the Peace increased the legal scope of external involvement in the Empire and its individual territories, by providing for (and in the case of internal Imperial interventions, strengthening) a juridification of intervention. This new development in international and constitutional law furnished legal thinkers with much food for thought. Among writers of the natural law tradition, there was a distinct ambivalence towards the guarantee and foreign intervention in the Empire in general, especially on the part of seventeenthcentury and early-eighteenth-century scholars. The experience of the Thirty Years' War had undoubtedly been traumatic and the foreign interventions had greatly exacerbated the suffering and prolonged the war. However, such writers portrayed the risk of Habsburg monarchical hegemony over the Empire as a threat, and the confessional and princely liberties which were threatened by it could be defended only through foreign assistance. The resulting guarantee legalized this external protection of confessional and political rights, and thereby 'codified' foreign involvement in the Imperial constitution. Yet this state of affairs was largely seen as deleterious in practice, due to French abuse,

123 Ibid., 7:202-203: 'Es lässet sich unter keinem Schein zweifeln, ob nicht [...] von Alters hergebrachten Schuz= und Schirms=Gerechtigkeiten [...] Art 17 Pac Westph $\S 5,6$ \&c den sämtlichen Pacis Consortibus ein unwidersprechliches Recht beygelegt seye, alle und jede Verordnungen selbigen Fridens zu handhaben, und diejenige, denen zu gute sie gemacht sind, dabey zu schützen [...] wovon diejenige hauptsächliche Verordnungen des 5 ten Art welche von der Unterthanen Religions= und Kirchen=Gerechtsamen disponiren, keineswegs auszuschliessen sind'.

124 Nicolaus Hieronymus Gundling, Ausführlicher Discours über das Natur-und Völcker-Recht, 332 . 
and some theorists also saw it as damaging in theory because it arguably weakened the unity of the Empire.

The paradox can be illustrated by Pufendorf's writing on the topic. In his theory of the law of nature and nations, he argued that states are a necessary form of human organization, which allow people to escape from their natural state of insecurity, and therefore to achieve common peace. Yet in order to fulfil these tasks, such states must be of a 'regular' form, with clearly unified sovereignty. ${ }^{125} \mathrm{He}$ famously viewed the Empire as lacking such regularity, ${ }^{126}$ and he regarded the jus foederum and the external guarantee as among the chief reasons for the disunity of the Empire. Yet his modest reform plans for the Empire were firmly grounded in a continuation of the Westphalian order, and he often argued that the liberties of Europe and the Protestant interest required that Germany not be dominated by a single power. In any case, he argued that to re-impose a centralized Imperial monarchy in Germany would exact too high a price in terms of conflict and disorder. ${ }^{127} \mathrm{He}$ also expressed contradictory attitudes towards the foreign interventions in the Empire. On the one hand he viewed the ability of foreign powers to interfere in the Empire as highly deleterious in his Monzambano, yet on the other hand he later portrayed the Swedish intervention of 1632 in particular as having been advantageous and the foreign crowns as having secured German liberties when writing his Introduction to the History of the Principal Kingdoms, which was clearly a reflection of the influence of his personal circumstances.

The influence of the experience of the war and the peace settlement on the conceptions of natural law can be inferred at times, yet more detailed research would be necessary on this topic to achieve a clearer picture. When comparing the writing on the law of nations in the context of the guarantee of Westphalia by authors from the public law tradition and by authors from the natural law tradition, some differences emerge. Several natural law writers argued that interventions for the protection of foreign subjects were permissible in the law of nature and nations, a right which the public law scholars who focussed more on positive treaty law, such as Moser, denied. According to him, such interventions were possible only if explicitly provided for in positive treaty law, as opposed to being permissible in the underlying normative framework of natural law, and it was precisely the guarantee of Westphalia which provided the only permissible form of foreign intervention. It is clear, though,

125 Vattel, Law of Nations, vir.2.13, 8.1-4. Michael Seidler, 'Introduction,' in Pufendorf, Introduction, xxii-xxiii.

126 Pufendorf, Present State of Germany, 159.

127 Ibid., 216. 
that scholars from both a natural law and a public law perspective agreed on the significance of the seminal nature of the peace settlement for the development of the law of nations. ${ }^{128}$

\section{Bibliography}

'Der Festgeschnürte Frieden: Prof. Christoph Kampmann erklärt ein Meisterwerk der Diplomatie,' P.M. History, May 2017.

Achenwall, Gottfried, Geschichte der allgemeineren Europäischen Staatshändel des vorigen und ietzigen Jahrhunderts im Grundriss der europäischen Geschichte (Göttingen: Verlag der Witwe Vandenhoeck, 1761).

Beales, Derek, Joseph II, vol 2: Against the World, 1780-179o (Cambridge: Cambridge University Press, 1987).

Beaulac, Stephane, 'The Westphalian legal orthodoxy - myth or reality?', Journal of the History of International Law 2, no. 2 (2000): 148-177.

Blin, Arnaud, 1648, la paix de Westphalie ou la naissance de l'Europe politique moderne (Bruxelles: Editions Complexe, 2006).

Böhmer, Justus Henning, Introductio in Jus Publicum Universale, Ex Genuinis Juris Naturae Principiis Deductum (Halae Magdeburgicae: Orphanotropheum, 1710).

Braun, Guido, 'Die französische Diplomatie und das Problem der Friedenssicherung auf dem Westfälischen Friedenskongress', in Assecuratio Pacis: Französische Konzeptionen von Friedenssicherung und Friedensgarantie 1648-1815, ed. Guido Braun (Münster: Aschendorff Verlag, 2011), 67-130.

Brunert, Maria-Elisabeth, 'Friedenssicherung als Beratungsthema der protestantischen Reichsstände in der Anfangsphase des westfälischen Friedenskongresses,' In Frieden und Friedenssicherung in der Frühen Neuzeit:Das Heilige Römische Reich und Europa, ed. Guido Braun and Arno Strohmeyer (Münster: Aschendorff Verlag, 2013), 229-258.

Buckisch und Loewenfels, Gottfried Ferdinand von, Observationes Historico-Politicae in Instrumentum Pacis Osnabrugo-Westphalicum (Frankfurt am Main, 1722).

Burgdorf, Wolfgang, Reichsskonstitution und Nation: Verfassungsreformprojekte für das Heilige Römische Reich deutscher Nation im politischen Schriftum von 1648 bis 1806 (Mainz: Philipp von Zabern, 1998).

Burkhardt, Johannes, 'Das größte Friedenswerk der Neuzeit,' Geschichte in Wissenschaft und Unterricht 49, no. 10 (1998): 592-612.

128 I would like to thank Simone Zurbuchen Pittlik and Knud Haakonssen for their useful comments, and Maximilian Fenner for his help in preparing bibliographical material. 
Burkhardt, Johannes, 'Der Westfälische Friede und die Legende von der landesherrlichen Souveränität,' In Landes- und Reichsgeschichte: Festschrift für Hansgeorg Molitor zum 65. Geburtstag, ed. Jörg Engelbrecht and Stephan Laux (Bielefeld: Verlag für Regionalgeschichte, 2004), 199-220.

Cocceji, Heinrich von, Juris Publici Prudentia Compendio exhibita (Frankfurt am Main, 1695).

Conrads, Norbert, Die Durchführung der Altranstädter Konvention in Schlesien 17071709 (Cologne: Böhlau, 1971).

Conring, Hermann, De pace perpetua inter Imperii Germanici Ordines religione dissidentes servanda libelli duo, (Helmstedt: Mullerus, 1657).

Croxton, Derek, The Last Christian Peace: The Congress of Westphalia as A Baroque Event (Basingstoke: Palgrave Macmillan, 2013).

Croxton, Derek, 'The peace of Westphalia of 1648 and the origins of sovereignty,' International History Review 21, no. 3 (1999): 569-591.

Dickmann, Fritz, Der Westfälische Frieden (Münster: Aschendorff Verlag, 1959).

Döring, Detlef, 'Der Westfälische Frieden in der Sicht Samuel Pufendorfs,' Zeitschrift für Historische Forschung 26, no. 3 (1999): 349-364.

Dorpalen, Andreas, German History in Marxist perspective: the East German approach (London: Tauris, 1985).

Droysen, Johann Gustav, Geschichte der preußischen Politik, Dritter Teil, Der Staat des großen Kurfürsten, Erste Abteilung (Leipzig: Verlag von Veit und Comp., 1861).

Duchhardt, Heinz, 'Das "Westfälische System": Realität und Mythos,' in Akteure der Außenbeziehungen. Netzwerke und Interkulturalität im historischen Wandel, ed. Hillard Thiessen and Christian Windler (Cologne: Böhlau, 2010), 393-402.

Duchhardt, Heinz, 'Friedenssicherung im Jahrhundert nach dem Westfälischen Frieden,' in Friedenssicherung. Bd. 3: Historische, politikwissenschaftliche und militärische Perspektiven, ed. Manfred Spieker (Münster: Regensberg, 1989), 11-18.

Duchhardt, Heinz, (ed.), Der Westfälische Friede. Diplomatie, politische Zäsur, kulturelles Umfeld, Rezeptionsgeschichte (Munich: Oldenbourg Verlag, 1998).

Duchhardt, Heinz, Eva Ortlieb, and Matthias Schnettger (eds.), Bibliographie zum Westfälischen Frieden (Münster: Aschendorff Verlag, 1996).

Durst, Benjamin, Archive des Völkerrechts: Gedruckte Sammlungen europäischer Mächteverträge in der frühen Neuzeit (Berlin: De Gruyter Oldenbourg, 2016).

Friedeburg, Robert von, 'Natural Jurisprudence, Argument from History and Constitutional Struggle in the Early Enlightenment: The Case of Gottlieb Samuel Treuer's Polemic Against Absolutism in 1719', in Early Modern Natural Law Theories: Contexts and Strategies in the Early Enlightenment, ed. T.J. Hochstrasser and Peter Schröder (Dordrecht: Kluwer Academic Publisher, 2003), 141-168.

Gerstlacher, Carl Friedrich, Corpus Juris germanici publici et privati: das ist der möglichst ächte Text der teutschen Reichsgeseze, Reichsordnungen und 
andrer Reichsnormalien ; in sistematischer Ordnung mit Anmerkungen (Karlsruhe: Schmieder, 1784).

Geyer, Michael, 'Humanitarianism and human rights: A troubled rapport,' in The Emergence of Humanitarian Intervention: Ideas and Practice from the Nineteenth Century to the Present, ed. Fabian Klose (Cambridge: Cambridge University Press, 2016), 31-55.

Gundling, Nicolaus Hieronymus, Ausführlicher Discours über das Natur- und VölckerRecht (Frankfurt am Main, 1747).

Gundling, Nicolaus Hieronymus, Vollständiger Discours über des Westphaelischen Frieden (Frankfurt am Main, 1739).

Haakonssen, Knud, 'German natural law,' in The Cambridge History of EighteenthCentury Political Thought, ed. Mark Goldie and Robert Wokler (Cambridge: Cambridge University Press, 2006), 249-29o.

Häberlin, Franz Dominicus, Anmerkungen über die in Johann Carl Königs Selectorum juris publ. P. VIII. c. 16. befindliche Erörterung der Frage: Ob die Crone Frankreich vor einen Erbfeind des H. R. Reichs zu achten seye? (n.p., 1745).

Häberlin, Karl Friedrich, Handbuch des deutschen Staatsrechtes, vol. 3 (Berlin: Vieweg, 1797).

Hammerstein, Notker, 'Christian Thomasius,' in Politische Theorien des 17. und 18. Jahrhunderts: Staat und Politik in Deutschland, ed. Bernd Heidenreich and Gerhard Göhler (Darmstadt: Philipp von Zabern, 2011), 117-140.

Haug, Tilman, Ungleiche Außenbeziehungen und grenzüberschreitende Patronage. Die französische Krone und die geistlichen Kurfürsten (1648-1679) (Cologne: Böhlau, 2015).

Havercroft, Jonathan, 'Was Westphalia "all that"? Hobbes, Bellarmine, and the norm of non-intervention,' Global Constitutionalism 1, no. 1 (2012): 120-140.

Hochstrasser, T.J., Natural Law Theories in the Early Enlightenment (Cambridge: Cambridge University Press, 2000).

Hughes, Michael, Law and Politics in Eighteenth Century Germany: The Imperial Aulic Council in the Reign of Charles VI (Woodbridge: Boydell Press, 1988).

Jouannet, Emmanuelle, 'Des origines coloniales du droit international: à propos du droit des gens moderne au $18^{\text {ème }}$ siècle', in The Roots of International Law - Les fondements du droit international, ed. Pierre-Marie Dupuy and Vincent Chetail (Leiden: Brill, 2014), 649-671.

Kampmann, Christoph, Arbiter und Friedensstiftung: Die Auseinandersetzung um den politischen Schiedsrichter im Europa der Frühen Neuzeit (Paderborn: Ferdinand Schoeningh, 2011).

Kampmann, Christoph, Europa und das Reich im Dreißigjährigen Krieg (Stuttgart: W. Kohlhammer, 2013).

Kampmann, Christoph, 'Das "Westfälische System”, die Glorreiche Revolution und die Interventionsproblematik', Historisches Jahrbuch 131 (2011): 65-92. 
Köhler, Johann David, Kurtzgefaste und gründliche teutsche Reichs-Historie (Frankfurt and Leipzig: Riegel, 1736).

Krause, Johann Christoph, Lehrbuch der Geschichte des Dreyßigjährigen teutschen Krieges und Westphälischen Friedens (Halle, 1782).

Kremer, Bernd Mathias, Der Westfälische Friede in der Deutung der Aufklärung. Zur Entwicklung des Verfassungsverständnisses im Hl. Röm. Reich Deutscher Nation vom Konfessionellen Zeitalter bis ins späte 18. Jahrhundert (Tübingen: Mohr, 1989).

Krieger, Leonhard, The German Idea of Freedom: History of a Political Tradition (Chicago, IL: University of Chicago Press, 1957).

Laudin, Gérard, 'Le Gründlicher Discours über den Westfälischen Frieden de Nicolaus Hieronymus Gundling,' In De la guerre juste à la paix juste: Aspects confessionnels de la construction de la paix dans l'espace franco-allemand (XVIe-XXe siècle), ed. Jean-Paul Cahn, Françoise Knopper, and Anne-Marie Saint-Gille (Villeneuve d'Ascq: Presses Univ. Septentrion, 2008), 125-142.

Leibniz, Gottfried Wilhelm, 'Bedenken welcher Gestalt Securitas publica interna et externa und Status praesens im Reich auf festen Fuß zu stellen,' in G.W. Leibniz Politische Schriften (Darmstadt: Preussische Akademie der Wissenschaften, 1931), vol. 1: 133-214.

Leibniz, Gottfried Wilhelm, Sämtliche Schriften und Briefe, Erste Reihe: Allgemeiner, politischer und historischer Briefwechsel, 25 vols. (Berlin: Akademie der Wissenschaften der DDR, 1983).

Leibniz, Gottfried Wilhelm, Sämtliche Schriften und Briefe, Vierte Reihe: Politische Schriften, 8 vols. (Berlin: Akademie der Wissenschaften der DDR, 1983).

Lyons, Gene Martin, and Michael Mastanduno, Beyond Westphalia?: State sovereignty and international intervention (Baltimore, MD: Johns Hopkins University Press, 1995).

Mably, Gabriel Bonnot de, Le droit public de l'Europe, fondé sur les traités (Amsterdam, 1761).

May, Niels F., Zwischen fürstlicher Repräsentation und adliger Statuspolitik: Das Kongresszeremoniell bei den westfälischen Friedensverhandlungen (Ostfildern: Jan Thorbecke, 2016).

Milton, Patrick, 'Intervening against tyrannical rule in the Holy Roman Empire during the seventeenth and eighteenth centuries,' German History 33, no. 1 (2015): 1-29.

Milton, Patrick, 'The early eighteenth-century German confessional crisis: the juridification of religious conflict in the re-confessionalised politics of the Holy Roman Empire,' Central European History 49, no. 1 (2016): 39-68.

Moser, Friedrich Karl von, Beherzigungen (Frankfurt am Main, 1762).

Moser, Johann Jacob Neues teutsches Staatsrecht (Stuttgart: Mezler, [1967]), vols. 1, 7 .

Moser, Johann Jacob, Von der Garantie des Westphaelischen Fridens; nach dem Buchstaben und Sinn desselbigen (Stuttgart, 1767). 
Nifterik, G.P. van, 'Religious and humanitarian intervention in sixteenth and early seventeenth century legal thought,' in Sovereignty and the Law of Nations (16th-18th Centuries), ed. Randall Lesaffer and Georges Macours (Brussels: Peeters Publishers, 2006), 35-6o.

Osiander, Andreas, 'Sovereignty, international relations, and the Westphalian myth,' International Organization 55, no. 2 (2001): 251-287.

Philpott, Daniel, Revolutions in Sovereignty: How Ideas Shaped Modern International Relations (Princeton, NJ: Princeton University Press, 2001).

Pufendorf, Samuel, An Introduction to the History of the Principal Kingdoms and States of Europe ed. Michael J. Seidler, transl. Jodocus Crull (Indianapolis, IN: Liberty Fund, 2013).

Pufendorf, Samuel, Of the Nature and Qualification of Religion, in Reference to Civil Society, ed. Simone Zurbuchen, transl. Jodocus Crull (Indianapolis, IN: Liberty Fund, 2002).

Pufendorf, Samuel, The Divine Feudal Law: Or, Covenants with Mankind, Represented, ed. Simone Zurbuchen, transl. Theophilus Dorrington (Indianapolis, IN: Liberty Fund, 2002).

Pufendorf, Samuel, The Present State of Germany, ed. Michael J. Seidler, transl. Edmund Bohun (Indianapolis, IN: Liberty Fund, 2007).

Pufendorf, Samuel, The Whole Duty of Man According to the Law of Nature, ed. Ian Hunter and David Saunders, transl. Andrew Tooke (Indianapolis, IN: Liberty Fund, 2003). Pütter, Johann Stephan, Der Geist des Westfälischen Friedens; nach dem Buchstaben und Sinn desselbigen (Göttingen: Vandenhoeck und Ruprecht, 1795).

Pütter, Johann Stephan, Historische Entwicklung der heutigen Staatsverfassung des teutschen Reiches Vol. 3 (Göttingen: Vandenhoeck, 1788).

Raeff, Marc, The Well-Ordered Police State: Social and Institutional Change through Law in the Germanies and Russia, 1600-180o (New Haven, CT: Yale University Press, 1983).

Randelzhofer, Albrecht, Völkerrechtliche Aspekte des Heiligen Römischen Reiches nach 1648 (Berlin: Duncker \& Humblot, 1967).

Ranke, Leopold von, Französische Geschichte, vornehmlich des 16. und 17. Jahrhunderts, vol. 2 (Stuttgart: Koehler, 1954).

Recchia, Stefano and Jennifer M. Welsh (eds.), Just and Unjust Military Intervention. European Thinkers from Vitoria to Mill (Cambridge: Cambridge University Press, 2013).

Repgen, Konrad, 'Der Westfälische Friede: Ereignis und Erinnerung,' Historische Zeitschrift 267, no. 1 (1998): 615-647.

Rousseau, Jean-Jacques, The Political Writings, ed. Charles E. Vaughan, 2 vols. (Cambridge: Cambridge University Press, 1915).

Schmauss, Johann Jacob, Academische Reden und Vorlesungen über das teutsche Staatsrecht (Lemgo, 1766). 
Schmauss, Johann Jacob, Einleitung zu der Staats-Wissenschafft, und Erleuterung des von ihm herausgegebenen Corporis Juris Gentium Academici und aller andern seit mehr als zweyen Seculis her geschlossenen Bündnisse, Friedens- und CommercienTractaten, vol. 1 (Leipzig: J.F. Gleditsch, 1741).

Schmauss, Johann Jacob, Kurtzer Begriff der Reichs-Historie, in einer accuraten chronologischen Ordnung (Leipzig: im Verlag Johann Ludwig Gleditschs, 1720).

Schmidt-Biggemann, Wilhelm, 'Leibniz,' in Politische Theorien des 17. und 18. Jahrhunderts: Staat und Politik in Deutschland, ed. Bernd Heidenreich and Gerhard Göhler (Darmstadt: Philipp von Zabern, 2011), 149-151.

Schmidt, Georg, 'Der Westfälische Frieden - eine neue Ordnung für das alte Reich?', in Wendemarken in der deutschen Verfassungsgeschichte: Tagung der Vereinigung für Verfassungsgeschichte, ed. Reinhard Mußgnug (Berlin: Duncker \& Humblot, 1993), 45-84.

Schmidt, Georg, 'Die Idee "deutsche Freiheit”: Eine Leitvorstellung der politischen Kultur des Alten Reiches,' in Kollektive Freiheitsvorstellungen im frühneuzeitlichen Europa (1400-1850), ed. Georg Schmidt, Martin van Gelderen, and Christopher Smigula (Frankfurt am Main: Peter Lang, 2006), 159-189.

Schnur, Roman, Der Rheinbund von 1658 in der deutschen Verfassungsgeschichte (Bonn: Röhrscheid, 1955).

Schröder, Peter, 'The constitution of the Holy Roman Empire after 1648: Samuel Pufendorf's assessment in his Monzambano,' The Historical Journal 42, no. 4 (1999): 961-83.

Schröder, Peter, 'The Holy Roman Empire as a model for Saint-Pierre's projet pour rendre la paix perpétuelle en Europe,' in The Holy Roman Empire, 1495-1806: A European Perspective, ed. Peter H. Wilson and R.J.W. Evans (Leiden: Brill, 2012), 35-50.

Senkenberg, Renatus Karl von, Darstellung des Osnabrück- und Münsterischen oder sogenannten Westfälischen Friedens, nach der Ordnung der Artikel (Frankfurt am Main: Gebhard und Körber, 1804).

Sheehan, James, German History, 1770-1866 (Oxford: Clarendon Press, 1989).

Simms, Brendan, "A false principle in the Law of Nations": Burke, state sovereignty, [German] liberty, and intervention in the age of Westphalia,' in Humanitarian Intervention: A History, ed. Brendan Simms and D.J.B. Trim (Cambridge: Cambridge University Press, 2011), 89-110.

Simms, Brendan, 'Europe's shifting balance of power,' in The Oxford Handbook of Early Modern European History, 1350-1750, vol. 2: Culture and Power, ed. Hamish Scott (Oxford: Oxford University Press, 2015), 649-650.

Sofer, Sasson, 'The Prominence of Historical Demarcations: Westphalia and the New World Order,' Diplomacy and Statecraft 20, no. 1 (2009): 1-19.

Steck, Johann Christoph Wilhelm, 'Abhandlung von den Rechten und Pflichten der hohen Garans des Westphälischen Friedens,' in Abhandlungen aus dem deutschen 
Staats- und Lehnrecht zur Erläuterung einiger neuen Reichsangelegenheiten (Halle: Johann Justinus Gebauer, 1757), 99-132.

Steiger, Heinhard, 'Die Gewährung der Gewissensfreiheit durch Ernst Casimir von Ysenburg-Büdingen im Jahre 1712,' in Festschrift für Walter Mallmann, ed. Otto Triffterer and Friedrich von Zezschwitz (Baden-Baden: Nomos, 1978), 293-318.

Steiger, Heinhard, 'Konkreter Friede und allgemeine Ordnung - zur rechtlichen Bedeutung der Verträge vom 24. Oktober 1648,' in 1648: Krieg und Frieden in Europa, ed. Klaus Bußmann and Heinz Schilling (Münster: Bruckmann, 1998), 137-146.

Stolleis, Michael, Geschichte des öffentlichen Rechts in Deutschland, vol. 1: Reichspublizistik und Policeywissenschaft 16oo-180o (Munich: C.H. Beck, 1988).

Thomasius, Christian, Essays on Church, State, and Politics ed. Ian Hunter, Thomas Ahnert, and Frank Grunert (Indianapolis, IN: Liberty Fund, 2007).

Thompson, Andrew C., Britain, Hanover and the Protestant Interest, 1688-1756 (Woodbridge: Boydell Press, 2006).

Tischer, Anuschka, 'Grenzen der Souveränität: Beispiele zur Begründung gewaltsamer Einmischung in "innere Angelegenheiten” in der Frühen Neuzeit,' Historisches Jahrbuch 131 (2011): 41-64.

Treitschke, Heinrich von, Deutsche Geschichte im 19. Jahrhundert (Leipzig: Verlag von S. Hirzel, 1879).

Tuck, Richard, The Rights of War and Peace: Political Theory and the International Order from Grotius to Kant (Oxford: Oxford University Press, 1999).

Vattel, Emer de, The Law of Nations, Or, Principles of the Law of Nature, Applied to the Conduct and Affairs of Nations and Sovereigns, with Three Early Essays on the Origin and Nature of Natural Law and on Luxury ed. Béla Kapossy and Richard Whatmore (Indianapolis, IN: Liberty Fund, 2008).

Vetter, Johann Friedrich, Rechtliches Bedenken über drey wichtige, die Religions-Freyheit in dem Heiligen Römisch-Teutschen Reiche betreffende, Fragen; Aus dem Instrumento Pacis Westphalicae, und zwar dessen V. und VII. Articul, erwiesen u. abgefasset (Wetzlar: Nikolaus Ludwig Winkler, 1752).

Wehberg, Hans, 'Die Schieds- und Garantieklausel der Friedensverträge von Münster und Osnabrück,' Die Friedens-Warte 48, no. 6 (1948): 281-289.

Westphal, Siegrid, Der Westfälische Frieden (Munich: C.H. Beck, 2015).

Westphal, Siegrid, 'Reichskammergericht, Reichshofrat und Landfrieden als Schutzinstitute der Reichsverfassung,' in Schutz der Verfassung: Normen, Institutionen, Höchst- und Verfassungsgerichte, ed. Thomas Simon and Johannes Kalwoda (Berlin: Duncker \& Humblot, 2014), 13-50.

Whaley, Joachim, Germany and the Holy Roman Empire: Volume II: The Peace of Westphalia to the Dissolution of the Reich, 1648-1806 (Oxford: Oxford University Press, 2012). 
Wilson, Peter H, Europe's Tragedy: A New History of the Thirty Years War (London: Penguin Books, 2010).

Wilson, Peter H, The Holy Roman Empire. A Thousand Years of Europe's History (London: Penguin Books, 2016).

Wilson, Peter H, War, State and Society in Württemberg, 1677-1793 (Cambridge: Cambridge University Press, 1995).

Wolff, Christian, Grundsätze des Natur- und Völckerrechts, worinn alle Verbindlichkeiten und alle Rehte aus der Natur des Menschen in einem beständigen Zusammenhange hergeleitet werden (Halle, 1754).

Zedler, Johann Heinrich, Grosses vollständiges Universal-Lexicon aller Wissenschafften und Künste, vol. 55 (Leipzig, 1748).

Zschackwitz, Johann Ehrenfried, Einleitung zu dem Teutschen Jure publico, oder StaatsRechte (Leipzig, 1710).

Zschackwitz, Johann Ehrenfried, Geschichtsmäßige Erläuterung des westfälischen Friedens (Halle, 1741).

Zurbuchen, Simone, 'Vattel's "Law of Nations" and the Principle of Non-Intervention,' Grotiania 31 (2010): 69-84.

Zurbuchen, Simone, 'Emer de Vattel on the Society of Nations and the Political System of Europe,' in System, Order, and International Law. The Early History of International Legal Thought from Machiavelli to Hegel, ed. Stefan Kadelbach, Thomas Kleinlein, and David Roth-Isigkeit (Oxford: Oxford University Press, 2017), 263-281. 
PART 3

The Law of Nations and the 'École romande du droit naturel' 



\title{
Born to Rule: Burlamaqui and Rousseau on the Education of Princes
}

\author{
Lisa Broussois \\ 1 The Barbarous Philosopher: Rousseau's \\ Critique of the Education of Princes
}

The opening lines of Rousseau's Principles of the Right of War, probably mainly written in $1755^{-1756}$, $^{1}$ gave a radical critique of the literary world of the time. Rousseau denounced the gap he noticed between what was generally taught in books on law and ethics and the reality people had to face in their everyday lives. He began:

I open the books on right and on ethics; I listen to the scholars and jurisconsults and, moved by their ingratiating discourses, I deplore the miseries of nature, I admire the peace and justice established by the civil order, I bless the wisdom of public institutions, and console myself for being a man by seeing that I am a citizen. Fully instructed about my duties and happiness, I close the book, leave the class-room, and look around me $[\ldots]^{2}$

What did Rousseau see around him? The answer was clear: the huge gap between the scholars and jurisconsults' books and the real world. Nothing he had read in books could prepare him for facing the reality of his time. Rousseau used harsh words to describe it: misery, chaos, the more powerful with the laws on their side and the weakest being the unfortunate victims of an unjust system. The worst of all our destructive creations that he mentioned was war. War

1 See Blaise Bachofen and Céline Spector, 'Introduction: Jean-Jacques Rousseau, la guerre et la paix,' in Principes du droit de la guerre, Écrits sur la paix perpétuelle, ed. B. Bachofen and C. Spector (Paris: Vrin, 2008), 10.

2 Jean-Jacques Rousseau, 'The State of War,' in Rousseau, The Social Contract and other later political writings, ed. Victor Gourevitch (Cambridge: Cambridge University Press, 1997), 162. French edition: Jean-Jacques Rousseau, 'Principes du droit de la guerre,' in Principes du droit de la guerre, Écrits sur la paix perpétuelle, ed. Bachofen and Spector, 69 . 
everywhere - war, which was the product of public institutions, the product of existing policies. He expressed his indignation: 'So this is the fruit of these peaceful institutions! Pity, indignation swell up in the depths of my heart. Ah barbarous philosopher! Read us your book on a battlefield!3

Indignation and pity were the only possible emotional reactions for a man who had decided to face the truth that public institutions and civil order were far from guaranteeing peace and justice and there was no wisdom to be found in them at all. Rousseau believed that experience was a better means of education than books because books brought with them all the prejudices and the lies of their authors. Experience, at least, gave an opportunity to judge for oneself. Rousseau's idea of education was, firstly, to preserve and protect children from a culture that was harmful in order to have future individuals who were capable of judging for themselves. In Emile, his book on education, he insisted on this point: 'I do not tire of repeating it: put all the lessons of young people in actions rather than in speeches. Let them learn nothing in books which experience can teach them'. ${ }^{4}$ He believed that reading books led to a habit of taking for granted what other people believed or wanted their readers to believe. Instead of developing their own thinking, young people were, little by little, deprived of their natural sense of judgment and were not able to think autonomously anymore. He explained:

We are bent over books from our childhood and accustomed to read without thinking; what we read is all the less striking to us since we already contain within ourselves the passions and the prejudices which fill history and the lives of men, and therefore all [that] men do appears natural to us because we are outside of nature and judge others by ourselves. ${ }^{5}$

Teachers misled their pupils insofar as they filled the heads of young people with prejudices and made them become exactly like their educators. Rousseau pointed out that the teachers were, in general, not the best people to be taken as examples. Indeed, Rousseau believed that, unfortunately, philosophers writing on law and ethics not only created a gap between reality and their books, which were filled with prejudices, but also were ignorant of the very matter they were supposed to teach: 'It is not philosophers who know men best. They

3 Rousseau, 'The State of War,' 162. Rousseau, 'Principes du droit de la guerre,' 69.

4 Jean-Jacques Rousseau, Emile, or On Education (Hanover and London: University Press of New England, 2010), 408. French edition: Jean-Jacques Rousseau, Émile ou De l'éducation (Paris: Gallimard, 1969), 382.

5 Rousseau, Emile or on Education, 396. Rousseau, Émile ou De l'éducation, 368. 
see them only through the prejudices of philosophy, and I know of no station where one has so many' 6

His critique of those philosophers, writers of books on law and ethics, professors and jurists, went further. It was not just the gap between those books and reality that worried Rousseau, nor was it the ignorance of philosophers about what human beings were; it was also the support those philosophers gave to the political system, to the figure of the prince in monarchies who oppressed his subjects. Rousseau strongly condemned what he called the interested author, the one who wrote books only for her/his career and the advantage it could create for her/him, without caring about truth or authentic good and real justice. He observed:

The People grants neither pensions, nor positions, nor [University] chairs, nor memberships in Academies; why should it be protected? Magnanimous princes, I speak in the name of the literary establishment; oppress the people with a clear conscience; we expect everything from you alone; the people is no good to us. ${ }^{7}$

In Emile, he noticed how self-interested preceptors were and how bad was the result for the education of young people: 'A preceptor thinks of his own interest more than of his disciple's. He is devoted to proving that he is not wasting his time and that he is earning the money he is paid. He provides the child with some easily displayed attainments that can be showed off when wanted'. 8

The figure of the 'barbarous philosopher', eminent member of the literary establishment', was the exact opposite of what Rousseau aspired to be - to such an extent that he defined his own philosophical project in reaction to what these self-interested authors were doing. Rousseau's aim was to study human institutions and call them into question through study of their first principles and, above all, he wanted to correct the 'false ideas' that these self-interested authors supported. ${ }^{9}$ In the books of self-interested authors could be found, for example, the idea that the aim of the government was public felicity and that the administration was acting in the public interest. But in book III, chapter 6 of the Social Contract, 'Monarchy', Rousseau wrote the following: 'everything proceeds toward the same goal, it is true, but that goal is not public felicity, and the very force of the administration constantly works to the prejudice of

6 Rousseau, Emile, or On Education, 399. Rousseau, Émile ou De l'éducation, 371.

7 Rousseau, 'The State of War,' 162. Rousseau, 'Principes du droit de la guerre,' 69-70.

8 Rousseau, Emile, or On Education, 306-307. Rousseau, Émile ou De l'éducation, 260.

9 Rousseau, 'The State of War,' 163. Rousseau, 'Principes du droit de la guerre,' 70. 
the State'. Did it serve to try to make people believe in lies? The truth was that princes acted in their own personal interest and did the contrary of what they should do in the public interest. ${ }^{10}$ Rousseau continued:

A political sermonizer may well tell them that since the people's force is their force, their greatest interest is to have the people flourishing, numerous, formidable; they know perfectly well that this is not true. [...] I admit that, assuming always perfectly submissive subjects, it would be in the Prince's interest that the people be powerful, so that this power, being his, might render him formidable to his neighbors $[\ldots] .^{11}$

Without doubt, a flourishing, numerous, and formidable people would be a great advantage for a prince, so that the state might be respected and feared, and might discourage attacks on its frontiers, but this would be the case only if the prince had 'perfectly submissive subjects'. Princes were well aware that it was never in their private interest to have powerful subjects. It was thus useless to continue telling a prince that he should act in the interest of his people. The prince's interest and the people's interest differed too much.

Let us take for example the book of reference in Europe at the time for the education of princes, François Fénelon's The Adventures of Telemachus. Fénelon's Mentor was among those who defended this pattern. He taught Telemachus that the wise king saw to it that his subjects should live in abundance and acted in the interest of their happiness. ${ }^{12}$ It is clear that Rousseau also had Hobbes in mind, as the Leviathan was presented as a manuscript to the future King Charles II when they were both in exile in Paris. Hobbes hoped that the Leviathan would instruct the prince in the best methods of ruling. He explained: 'Now in Monarchy, the private interest is the same with the publique. The riches, power, and honour of a Monarch arise onely from the riches, strength, and reputation of his Subjects. For no King can be rich, nor glorious,

10 The same severe statement can be found in Rousseau's Jugement sur la paix perpétuelle, in Principes du droit de la guerre, Écrits sur la paix perpétuelle, ed. Bachofen and Spector, 118. Rousseau explained that kings' actions pursued two goals: to spread their dominion beyond their country and to make their dominion more absolute within. Public felicity was a mere pretext.

11 Rousseau, Of the Social Contract, in The Social Contract and other later political writings, ed. Gourevitch, 95. French edition: Jean-Jacques Rousseau, Du contrat social (Paris: Flammarion, 2001), 106-107.

12 Fénelon, Telemachus, son of Ulysses, ed. and transl. Patrick Riley (Cambridge: Cambridge University Press, 1994), 16. Fénelon, Les aventures de Télémaque (Paris: Garnier, 1987), 137 . 
nor secure; whose Subjects are either poore, or contemptible, or too weak through want, or dissention, to maintain a war against their enemies.' ${ }^{13}$ But the truth for Rousseau was the opposite: private and public interests were never the same, at least in a monarchy. Princes knew it and so did their instructors.

If princes read books on law and ethics, as Rousseau did, they would also recognize quickly enough that these books described a different world from the one they lived in. These books told people what they were supposed to be and what they should do. However, the truth was, firstly, that princes considered themselves different from other people and, secondly, that they had never been used to listening and obeying. The reality of the army and the court invited them instead to behave quite differently from the way philosophers claimed they should. Instead of learning about their duties as princes and about their responsibilities, princes were encouraged to act as they wished, without any care for the consequences and, worst of all, self-interested authors defended them and pretended to be unaware of the reality that was right in front of their eyes.

Fénelon's Telemachus complained about the duplicity of a king's entourage and thought a monarch was lost if she/he could not resist flattery. ${ }^{14}$ But what happened in the real world? Princes were not morally good and not politically responsible. These latter remarks also showed why the figure of the prince was important and, at the same time, why the situation seemed so desperate to Rousseau, because the solution to human misery might lie in the prince's hands, but he was never up to the task. Rousseau was very pessimistic about the education of princes; indeed, in his view it was a complete failure. The problem was that the monarchic system was entirely corrupt. Even if the prince and the instructor had good intentions and wanted to make things right, there would still be the flattery of the court and the corruption of the army to spoil everything: "Everything conspires to deprive of justice and reason a man brought up to command others. Great pains are taken, so they say, to teach young Princes the art of ruling; it does not appear that this education profits them. It would be better to begin by teaching them the art of obeying'. ${ }^{15}$ Even if a prince was, in the future, destined to rule, a young prince was not yet a ruler. He was a child, not a monarch. Children were not just future adults; they were already people with their own needs and their own identities. Raising a child as a prince meant that there was confusion between what the child was

13 Thomas Hobbes, Leviathan, ed. Richard Tuck (Cambridge: Cambridge University Press, 1996), 131.

14 Fénelon, Telemachus, 20. Fénelon, Les aventures de Télémaque, 141.

15 Rousseau, Of the Social Contract, 97. Rousseau, Du contrat social, 110. 
and what he was supposed to become one day. Young princes were raised as if they were different from ordinary mortals: inevitably, the result was that they believed it and acted accordingly.

How could a prince be a good ruler if he was not able to put himself in the place of the people he commanded? Rousseau concluded by asking: 'and if a royal education necessarily corrupts those who receive it, what can be expected of a succession of men brought up to rule?'16 For Rousseau, selfinterested authors pretended to be unaware of how royal education corrupted young princes. They taught them only how to make speeches using virtuous and noble vocabulary, but this fooled no one: 'Our Authors have noticed these difficulties, but they have not been disturbed by them.. ${ }^{17}$

Unlike the 'literary establishment', Rousseau wanted to denounce these difficulties. This is probably one of the main reasons why Rousseau refused to advise the Swiss Reverdil to help the preceptor Reventlow in educating the future king Christian viI of Denmark. ${ }^{18}$ Rousseau's rejection of the education of princes may appear surprising at first sight, knowing that his major work, Emile, focused on education. However, in Emile, Rousseau expressed his views even more clearly, recounting, for example, the following anecdote:

Someone of whom I know only the rank had the proposal to raise his son conveyed to me. He doubtless did me a great deal of honor; but far from complaining about my refusal, he ought to congratulate himself on my discretion. If I had accepted his offer and my method were mistaken, the education would have been a failure. If I had succeeded, it would have been far worse. His son would have repudiated his title; he would no longer have wished to be a prince. I am too impressed by the greatness of a preceptor's duties, I feel my incapacity too much ever

16 Rousseau, Of the Social Contract, 98. Rousseau, Du contrat social, 110-111.

17 Rousseau, Of the Social Contract, 99. Rousseau, Du contrat social, 111.

18 See Michel Termolle, 'Rousseau, conseiller pédagogique par correspondance,' in Lire la correspondance de Rousseau, ed. Jacques Berchtold and Yannick Séité (Genève: Droz, 2007), Annales de la Société Jean-Jacques Rousseau 47, 309-326. See also John Christian Laursen, 'Télémaque manqué: Reverdil at Court in Copenhagen,' in Reconceptualizing Nature, Science, and Aesthetics: Contribution à une nouvelle approche des Lumières helvétiques, ed. Patrick Coleman, Anne Hofmann, and Simone Zurbuchen (Genève: Slatkine, 1998), 147-156. More generally about Denmark-Norway, see Henrik Horstboll, 'Defending Monarchism in Denmark-Norway in the Eighteenth Century', in Monarchisms in the Age of Enlightenment: Liberty, Patriotism, and the Common Good, ed. Hans Blom, John Christian Laursen, and Luisa Simonutti (Toronto, Buffalo, London: University of Toronto Press, 2007), 175-193. 
to accept such employment from whatever quarter it might be offered to me. $^{19}$

If Rousseau felt incapable of becoming a preceptor, it was because this function required him to comply with the established education practice and system of his time. Yet, Rousseau showed, in Emile, that the most important thing to learn could not be found in books on law or ethics, nor in a lecture room with a preceptor. Concerning Emile's education, he said, 'Living is the job I want to teach him. On leaving my hands, he will, I admit, be neither magistrate nor soldier nor priest. He will, in the first place, be a man'. ${ }^{20}$

If there was one thing that the education of princes did not provide, clearly it was the way to become a 'man'. Emile was raised in the countryside, not in a palace surrounded by the court and the army. If Rousseau felt incapable of accepting such employment, it was because he did not want to become a selfinterested author and he knew all too well that princes grew in an environment that would never allow them to become what they were supposed to be. He described the prince as a 'factitious being', corrupted by the court and the army as well as by the preceptor:

[A]fter having stifled his nature by passions that one has caused to be born in him - this factitious being is put in the hands of a preceptor who completes the development of the artificial seeds that he finds already all formed and teaches him everything, except to know himself, except to take advantage of himself, except to know how to live and to make himself happy. ${ }^{21}$

The result of such an education of princes was not long in coming and was the opposite of the result that should have been arrived at: 'The rich, the nobles, the kings are all children who, seeing that men are eager to relieve their misery, derive a puerile vanity from that very fact and are very proud of care that one would not give to them if they were grown men.22 For Rousseau, learning to be a citizen was not the principal task of education; first, children needed to learn how to become 'men'. On the one hand, they needed to be preserved and protected from a culture that corrupted them and, on the other, they needed to learn how to become free individuals. Authority was nothing without

\footnotetext{
19 Rousseau, Emile, or On Education, 176. Rousseau, Émile ou De l'éducation, 100.

$20 \quad$ Rousseau, Emile, or On Education, 166. Rousseau, Émile ou De l'éducation, 88.

21 Rousseau, Emile, or On Education, 174. Rousseau, Émile ou De l'éducation, 97.

22 Rousseau, Emile, or On Education, 216. Rousseau, Émile ou De l'éducation, 146-147.
} 
freedom and freedom was not the fate of the princes of this world because they would always need other people for everything. Princes were incapable of doing anything by themselves. The truth was that men brought up to rule were men brought up to be slaves; they always depended on others and because of this they were miserable. What could an education do to free a human being from such a deplorable condition? Even worse: what could an education do for the sake of a nation ruled by such a miserable being?

\section{2 \\ Teaching the Laws of Justice and Humanity: Burlamaqui's Royal Education}

In order to seek answers to these questions, we must leave Rousseau to one side and join the opposite camp. To Rousseau's question 'what can be expected of a succession of men brought up to rule?', Burlamaqui's response was that there was much that might be expected (or so at least he claimed to believe).

The portrait Rousseau painted of the philosophers and the literary establishment' he criticized could, in many respects, call to mind Burlamaqui's actions and works. Jean-Jacques Burlamaqui, born in Geneva just like Rousseau, was indeed a celebrated philosopher and jurist, who was professor of natural law and civil law at the Academy of Geneva (1723-1739), and achieved the greatest political honours as a member of the councils of his native republic. ${ }^{23}$ Frederick II, Landgrave of Hessen-Kassel (son of William VIII, nephew of the king of Sweden), came to Geneva in November 1732 and became Burlamaqui's pupil in his classes on the law of nature. In 1734, when the prince left the city, Burlamaqui accompanied him and followed him to his court in Kassel. ${ }^{24}$ The prince later came back to Geneva and stayed until 1737. During all this time, Burlamaqui was in charge of educating the young prince about the law of nature and the law of nations. When the two were not together, they continued their lessons by letter, with Burlamaqui sending exercises to the prince.

23 In a funeral oration given in the Sovereign Council of Geneva, the general prosecutor Leonard Buisson said, about Burlamaqui: 'Combien de lumières, en effet, combien de vertus n'avons-nous point vu briller dans Monsieur le Conseiller Burlamaqui! En lui se sont trouvés réunis l'homme de lettre, le philosophe, l'orateur, le jurisconsulte, l'homme d'État'. [What lights, indeed, what virtues have we not seen shine in Councillor Burlamaqui! In him were united the man of letters, the philosopher, the orator, the jurisconsult, the statesman]. Cited after Bernard Gagnebin, Burlamaqui et le droit naturel (Geneva: éditions de la Frégate, 1944), 78.

24 For an account of the particular circumstances in which the prince and Burlamaqui left Geneva, see Gagnebin, Burlamaqui et le droit naturel, 51-68. 
Without asserting that Burlamaqui was necessarily one of Rousseau's targets in the texts referred to above - even if Rousseau did mention Burlamaqui in his Second Discourse and otherwise critically engaged with his writings ${ }^{25}$ - it is difficult to avoid the impression that Burlamaqui matches Rousseau's description of the self-interested author in many respects. However, despite this resemblance, it is important to ask what exactly Burlamaqui's royal education consisted of and whether Rousseau's critique of the 'barbarous philosopher' could really apply to Burlamaqui's attempt to educate a young prince. ${ }^{26}$ I will also add that Rousseau's judgment was not entirely negative concerning all the professors in Geneva and Paris. He often pointed out that the main problem was the entire educational system rather than the educators. Maybe Burlamaqui was among those Rousseau had in mind when he said, "There are in the academy of Geneva and the University of Paris Professors whom I like, whom I esteem very much and believe to be very capable of instructing the Young well, if they were not forced to follow the established practice.'. ${ }^{27}$

What was the established practice in the case of Burlamaqui? Before answering this question, let us first explain how Burlamaqui defended the legitimacy of his royal education. To understand this, we need to focus on the role of the law of nature. Far from agreeing with the idea that royal education corrupted princes, Burlamaqui argued that this kind of education was absolutely necessary to the process of founding a good government, which would respect the law of nature and nations. In other words, Burlamaqui believed, or at least seemed to believe, that it was possible to raise an enlightened prince if the prince was educated according to the law of nature. This idea was directly linked to his definition of the law of nature and the law of nations as being fundamentally one and the same thing. Burlamaqui sided with Pufendorf and Barbeyrac by maintaining, in his Principles of Politic Law, that the law of nations

25 See for example Robert Derathé,Jean-Jacques Rousseau et la science politique de son temps (Paris: Vrin, 1971), and Gabriella Silvestrini, Diritto naturale e volontà generale. Il contrattualismo repubblicano di Jean-Jacques Rousseau (Torino: Claudiana, 2010), chap. 3.

26 Jean-Jacques Rousseau, 'Preface to the Discourse on the Origin and the Foundations of Inequality among Men,' in Rousseau, The Discourses and other early political writings, ed. Victor Gourevitch (Cambridge: Cambridge University Press, 1997), 125-26. French edition: Rousseau, Discours sur l'origine et les fondements de l'inégalité parmi les hommes (Paris: Gallimard, 1969), 54. Rousseau said: 'It is this ignorance of the nature of man that casts such uncertainty and obscurity on the genuine definition of natural right: for the idea of right, says M. Burlamaqui, and still more that of natural right, are manifestly ideas relative to the nature of man. Hence, he goes on, it is from this very nature of man, from his constitution and his state, that the principles of this science have to be deduced'. Rousseau, Emile, or On Education, 165, note. Rousseau, Émile ou De l'éducation, 86, note. 
was 'no more than the laws of nature, which men, considered as members of society, in general, ought to practise towards each other.' ${ }^{28} \mathrm{He}$ said, in his Principles of Natural Law, that the law of nations was necessary 'to serve as a rule for mutual commerce' and that 'this law [could] be nothing else but the law of nature itself'. ${ }^{29}$

More precisely, Burlamaqui theorized the law of nations by dividing it into two types: first, the law of nations itself as universal, which was not different from the law of nature; second, the law of nations derived from conventions (between two or more states), which was obligatory only for the contracting states. However, the obligation linked to the second type of law of nations was the obligation of the law of nature itself (through the duty to respect our commitments). In other words, the law of nations could not be understood as a separate entity from the law of nature. One problem for Burlamaqui was that distinguishing the law of nations from the law of nature had very dangerous consequences, in particular in relation to princes:

It is owing perhaps to our distinguishing the law of nations from the law of nature, that we have insensibly accustomed ourselves to form quite a different judgment between the actions of sovereigns and those of private people. Nothing is more usual than to see men condemned in common, for things which we praise, or at least excuse in the persons of princes. ${ }^{30}$

The most fundamental point for Burlamaqui was to show that princes were not different from the common people in relation to the law of nature and that they were subject to the same obligations. If princes needed to learn one thing in their classroom, it was that 'there is only one sole and the same rule of justice for all mankind'. He carried on in the same passage: 'Princes who infringe the law of nations, commit as great a crime as private people, who violate the law of nature: and if there be any difference in the two cases, it must be charged to the prince's account, whose unjust actions are always attended with more dreadful consequences than those of private people'.

28 Jean-Jacques Burlamaqui, The Principles of Natural and Politic Law, ed. Petter Korkman (Indianapolis, IN: Liberty Fund, 2006), 288. French edition: Jean-Jacques Burlamaqui, Principes du droit politique (Amsterdam: Zacarie Chatelain, 1751), 2-3.

29 Burlamaqui, The Principles of Natural and Politic Law, 116. French edition: Burlamaqui, Principes du droit naturel (Genève: Barrillot \& Fils, 1747), 221.

30 Burlamaqui, The Principles of Natural and Politic Law, 118. Burlamaqui, Principes du droit naturel, 226-227. 
This refusal to distinguish between the law of nature and the law of nations grounded his definition of politics:

These remarks may serve to give us a just idea of that art, so necessary to the directors of states, and distinguished commonly by the name of Polity [Politics]. Polity [Politics] considered with regard to foreign states, is that ability and address by which a sovereign provides for the preservation, safety, prosperity and glory of the nation he governs, by respecting the laws of justice and humanity. ${ }^{31}$

The rules of the law of nature consisted of what reason approved and prescribed as the best means for attaining happiness. ${ }^{32}$ Nevertheless, reason had to be exercised and this is why education was so important. It was not a question of preserving and protecting children so they would learn to judge for themselves. It was a question of exercising and developing a faculty that would allow them to judge rightly or correctly. In brief, princes could only succeed in realizing good policies and could only understand what politics was if, and only if, they learned to respect 'the laws of justice and humanity'. What were these laws? They were nothing more than the laws of nature. The laws of nature were key to ensuring that the private interest of the prince and the public interest of his people were convergent. The role of the professor was clear: make sure that princes learned to govern on the basis of the law of nature. For Burlamaqui, the need for safety and security was not sufficient to ground the right of sovereignty. The right of sovereignty was justified insofar as it pursued public happiness. The role of the sovereign was to know the law of nature so she/he could promulgate positive laws on this basis. The sovereign was never 'the' law but only an interpreter of the law of nature and because she/he was an interpreter, it was better to be sure that her/his education gave her/him the necessary tools to interpret rightly. ${ }^{33}$

31 Burlamaqui, The Principles of Natural and Politic Law, 117. Burlamaqui, Principes du droit naturel, 222.

32 Burlamaqui, The Principles of Natural and Politic Law, 69. Burlamaqui, Principes du droit naturel, 58 .

33 See, for example, Jérémy Simonin, 'L'homme et le citoyen dans la science du droit naturel de J.-J. Burlamaqui,' in Genève et la Suisse dans la pensée politique, Actes du colloque de Genève (sept. 2006), ed. Michel Ganzin (Aix-en-Provence: Presses Universitaires d'Aix-Marseille, 2007), 89-101. For more on Burlamaqui's concept of sovereignty, see, for example, Gagnebin, Burlamaqui et le droit naturel, 183-189, 234-235, and Helena Rosenblatt, Rousseau and Geneva, From the First Discourse to the Social Contract, 17491762 (Cambridge: Cambridge University Press, 1997), 100-101. 
For Rousseau, the problem was always that the prince never became the virtuous person he was supposed to be and that royal education did not help him to improve. For Burlamaqui though, correct study of the law of nature had the capacity to turn the prince into a good and virtuous person and to achieve some results. In truth, man's nature consisted in exercising reason until he was able to know what the law of nature was. While Rousseau argued that learning too much about the science of reigning made princes ignorant of it, the point for Burlamaqui was to show that princes needed to stay in the classroom as long as necessary for them to learn the law of nature, because all their actions depended on their knowledge of the law of nature, on the battlefield as well as everywhere else.

In Burlamaqui's teaching on the law of nature, there was, for example, the idea that the strength of a state, with regard to war, was its people and that the prince had 'to neglect nothing that [could] either support or augment the number of them. ${ }^{34}$ It was one of the main teachings of the law of nature to show the prince the importance of his people. Another important lesson was related to the prince's training in relation to obedience. The written correspondence between Prince Frederick of Hessen-Kassel and Burlamaqui provides a better understanding of Burlamaqui's method for teaching the law of nature to the prince correctly. ${ }^{35}$ One of the letters explained, for example, how the prince should study the law of nature when the professor was not with him (29 May 1734, Burlamaqui to Frederick):

Have Mr. Schmerfeld come to your study at 9 o'clock. Settle him in the armchair beside your desk, then take your second ledger and continue to peruse from the place where you left off the day before yesterday. After that, give your paper to Mr. Schmerfeld who will question you. Repeat this little exercise until 10 o'clock strikes and I will vouch for the success of my method.

Burlamaqui concluded in this letter: 'Sir, I give you frankly the whole secret of my art and should you make sustained use of it, you will soon be in a position to oust me'. At first, the study of the law of nature, at least when Burlamaqui was not with the prince, did not seem to be too demanding and to take too

34 Burlamaqui, The Principles of Natural and Politic Law, 291. Burlamaqui, Principes du droit politique, 10.

35 Correspondence between Burlamaqui and Frederick of Hessen-Kassel, archival material from Staatsarchiv Marburg, replica accessed in Geneva Library, Facs 37, f. 90-142 (my translation). 
much of the prince's time. However, as the prince grew up, it appears that he had to spend more and more time in the study room so he could understand all the implications of the law of nature for his future career.

A letter dated 19th December 1735, from Burlamaqui to Frederick, was an exercise to test the prince's ability to respond to the question of the usefulness of his education. In this letter, Burlamaqui asked the prince if those who were destined to rule should receive the same education as those destined to obey. Burlamaqui began by explaining the interest of such exercises to the prince:

That is to say, Sir, that all one may have learnt in the study room and beneath the eyes and the direction of a master is nothing if one does not then try to make use of it one's self [...]; your mind will work, you will set in motion your energy and your talents, you will train yourself in consistent and sustained attention, which is more necessary to people of your standing than any other.

Burlamaqui then asked the prince:

In a word, I ask whether it is just and fitting to subject those who are born to rule to the same schooling as those who are destined to obey and whether a little common sense and some slight knowledge of the sciences does not suffice a prince for his glory and his happiness, provided that he learns early to know the world and, above all, that he is trained in the great art of war.

As we can guess, the answer was 'no'. A little common sense and some slight knowledge of the sciences were not sufficient for princes. Princes needed to study the law of nature if they wanted to reign justly and rightly. Experience was not enough. Knowledge, exercise and attention were the key to success.

It was part of the prince's training to be able to explain clearly the reasons why the law of nature was so important. Thus, Frederick accomplished the exercise and answered Burlamaqui's question by repeating Burlamaqui's lessons. Frederick began by pointing out that public happiness was the aim of politics and that it was by studying the law of nature that princes had the opportunity of realizing this aim. The prince ended with a reminder of the importance of leaving future governors in the study room, cut off from the world, until they learned what they needed to know ('Answer to the First Letter' by Frederick):

A prince, for example, who must one day be called to govern peoples, is naturally obliged to have as his principal object the happiness of his 
people and from this it follows that the means apt to lead him to this end must be his principal occupation: enlightening his mind through knowledge and shaping his heart through sustained attention; these are certainly the only means that might lead him there.

The prince carried on:

It is certain that neither the world nor the court nor the army can be the primary educator of a young prince. The flattery of one side and the dissipation and frequent opportunities to succumb to his passions of the other are too dangerous for a young man to be exposed to them. Still less would he be able to draw from them the knowledge that is necessary and suitable for the position he must occupy. Therefore, a young prince should be left in the study room until he is instructed in all that he must know.

Rousseau and Burlamaqui might agree on the idea that the court and the army were dangerous for a prince. The only difference was that Burlamaqui thought books could preserve and protect his student from bad influence whereas Rousseau thought that books were themselves part of the bad influence the prince needed to be preserved from.

Following Burlamaqui's teaching, Frederick explained why he could not learn what he needed to know in the court or in the army and why he should be 'left in the study room' to be instructed by books instead of being instructed by the real world outside the classroom. He pointed out something important that he had been taught, namely that the virtues of war were not different from the virtues of justice and humanity. This confirms the connection Burlamaqui made between the law of nature and the law of nations. Prince Frederick had learned to condemn the consequences of war and knew the importance of learning to obey before learning to command. He concluded:

The virtues of war cannot dispense with justice, moderation, and humanity, which differs only by its application. Nonetheless, one cannot deny that peace is more advantageous a situation than war, whose unfortunate consequences are only too well known. In answer to your final question, I end by saying that he who cannot obey will never be able to rule well.

Even if Rousseau was sceptical about the benefit of a prince being left in the study room', he seemed to agree with Burlamaqui on the idea that learning obedience was one of the keys to a good royal education and that the consequences of war were a disaster that needed to be avoided as far as possible. In 
truth, there is apparent agreement between them on many points concerning the definition of what made a good basis for a successful royal education, but the major difference was that Rousseau thought it was not possible to succeed in this task, while Burlamaqui thought it was.

It might be thought that Rousseau's pessimism and Burlamaqui's optimism concerning royal education also depended on their personal situations. Burlamaqui clearly belonged to the 'literary establishment' of his time, with all the honours that came with that position. He was a politician and committed professor who was concerned about what could be done here and now, in the nonideal situation of Europe at that time; he certainly had a pragmatic sensibility, which made him act in favour of princes, monarchs, and governments in power because it seemed to him that this was likely to give better results. ${ }^{36}$ Yet it is also true that Burlamaqui, just like Barbeyrac, was not particularly in favour of absolute monarchy. He clearly preferred a 'tempered government' with a mix of democratic and aristocratic elements. ${ }^{37}$ Burlamaqui was more optimistic than Rousseau, because he had better opportunities, giving him more reason to believe that his actions could have an impact in politics. He was, after all, directly in charge of a prince's education and this function offered the prospect of great influence. But was it truly the case? Did the Burlamaquian education eventually bear fruit?

It seems that only history can have the final word and be the judge of who was right, Rousseau or Burlamaqui, about the education of princes. Of course, most historical examples show that it is difficult to prove Rousseau wrong in his radical critique of royal education. At the same time, it may well be argued that princes could have been far worse without professors like Burlamaqui who tried to teach them the law of nature. We can at least credit Burlamaqui with the merit of having tried and we can analyse the results of his teachings to see if we can find a specimen of what we could call a Burlamaquian enlightened prince.

$3^{6}$ For an account of Burlamaqui's role in politics, especially in relation to the troubles of 1734 in Geneva, see Gagnebin, Burlamaqui et le droit naturel, 51-69. It appears that Burlamaqui preferred giving more support to the aristocracy in power than to the bourgeoisie.

37 Rosenblatt, Rousseau and Geneva, From the First Discourse to the Social Contract, 1749-1762, 100. 
I will let the reader judge for her/himself and I will give only two potential candidates for the title of Burlamaquian enlightened prince, two examples that may provide an illustration of a prince educated on the law of nature. I am aware that the question 'what is enlightened absolutism?' is far from being resolved today and it is not my aim to try to answer it. ${ }^{38} \mathrm{I}$ agree with Charles W. Ingrao when he explains, 'it is difficult to avoid the conclusion that the task of reaching a consensus had been complicated by an underlying clash of national cultural and historical perspectives. ${ }^{39}$ I only propose here to look at two figures that might help us to determine how to consider the efficiency of Burlamaqui's royal education on the law of nature when it comes to practice.

For the first example, I return to Prince Frederick of Hessen-Kassel, since we know that he directly benefited from Burlamaqui's teaching. Even if Frederick seemed to learn Burlamaqui's lessons on the law of nature correctly, it is not certain that he could avoid Rousseau's criticisms concerning the efficiency of his royal education. It is certainly one thing to learn correctly, but quite another to apply what was taught. My second example is Gustav III of Sweden because, even if Burlamaqui was not directly his professor, Gustav was educated using Burlamaqui's writings and he is certainly often acknowledged today for being one of the figures of the eighteenth-century monarchic enlightenment.

First, Frederick of Hessen-Kassel. Of course, it is important to mention that Burlamaqui was not the only one in charge of the prince's education. There were others: for example, Jean-Pierre de Crousaz, former professor of philosophy at the Academy of Lausanne, also had this task for a while. In any case, Prince Frederick grew up with the teachings of Burlamaqui's law of nature and he was indeed known for being an enlightened monarch with respect to arts and letters. He admired the philosophers, for example Voltaire, and enjoyed writing some philosophical thoughts himself. The prince was well known for having enhanced the city of Kassel and its residential properties and he contributed to the development of Marburg University. However, his reputation in other areas was more debatable. He was also very famous for his mercenaries and he raised money by renting his soldiers out many times to those engaged in conflicts, including the American War of Independence, where he

38 As Tore Frängsmyr noted concerning the term 'Enlightenment', 'Originally, the designation was used mainly for the French Enlightenment but it has since come to be used for rationalist currents of ideas of all possible types or as a purely chronological label'. 'Defining the Enlightenment: The Swedish Case,' in Centre(s) and Margins, Enlightenment from Belfast to Beijing, ed. Marie-Christine Skuncke (Paris: Honoré Champion, 2003), 196. 
sent troops to support Great Britain. If Frederick was a Burlamaquian enlightened prince, he was one of a warlike kind. Ingrao commented: 'Notwithstanding everything that he imbibed from the Enlightenment's teaching of natural law, it was inevitable that Frederick would derive a more sanguine attitude toward the military and warfare. [...] Like all Hessian princes he was trained to be a soldier. ${ }^{40}$ Because of this mixture of Enlightenment with military temper, it is not certain that Frederick would have fulfilled Rousseau's criteria or would have gained his approval.

Second, let us consider Gustav III of Sweden as another example of an eighteenth-century prince educated with Burlamaqui's books on law and ethics. Gustav was born in 1746 and ruled between 1771 and 1792. In 1756, Count Carl Fredrik Scheffer, well known in the philosophical circles of Paris, became the prince's new governor and educated him in contemporary political theory, with an emphasis on the works of Locke, Wolff, and Burlamaqui. ${ }^{41}$ In his instructions to the prince's preceptor in 1757 , Scheffer explained that once the prince had gained clear and accurate notions of his duties as a 'man', he needed to learn in an orderly and systematic way what were his duties as a member of civil society. Scheffer thought that Burlamaqui's work was appropriate as Gustav's manual because it was a short but solid system of the law of nature and nations. He thought it was also the most convincing work in terms of proving that unlimited despotism was as dangerous for the prince as it was for the prince's subjects and that the best government for all was grounded on political freedom and demarcated by fundamental laws. ${ }^{42}$ As Marie-Christine

\footnotetext{
40 Ingrao, The Hessian Mercenary State, 15.

41 Pièces concernant l'éducation du prince royal, à présent roi de Suède par son excellence $\mathrm{Mr}$ le Comte Charles de Scheffer, sénateur du royaume et commandeur des ordres du roi, \&c., traduites du suédois (Stockholm: H. Fougt, 1773), 5-6: 'pour parvenir à donner à S.A.R des idées claires et évidentes des vertus et des vices, il est important qu'on lui fasse connaître quelque ouvrage qui traite la morale systématiquement. À cet effet je recommande à Mr le Conseiller de faire étudier à S.A.R l'extrait que j'ai tiré des ouvrages de Wolff, de Locke, de Burlamaqui et d'autres'. [In order to succeed in giving HRH clear and evident ideas on virtues and vices, it is important that he is given to study some work that treats of morality systematically. With this in mind, I recommend that the Councillor has HRH study the extract I have taken from the works of Wolff, Locke, Burlamaqui and others], my translation.

42 Pièces concernant l'éducation du prince royal, 6-7: 'Un système court mais solide du droit de la nature et des gens, qui depuis quelques années a été publié à Genève, peut servir à Mr le conseiller pour ce genre d'instruction, et je recommande d'autant plus volontiers ce petit ouvrage, qu'il est de tous ceux que je connais sur ce sujet, celui qui prouve d'une manière plus convaincante, que le despotisme illimité est aussi dangereux pour le prince, que pour les sujets ; qu'au contraire la liberté politique, et une puissance royale bornée par des lois fondamentales, étant plus conformes à la loi naturelle, constituent aussi le
} 
Skuncke explains, limited monarchy appeared to be the best form of government in accordance with the law of nature. ${ }^{43}$ Just like Frederick, Gustav had to spend most of his days in the lecture room and Scheffer prescribed that the prince had first to study the law of nature and nations before he could study Swedish public law. ${ }^{44}$

Hildor Arnold Barton underlines the fact that catalogues in the Royal Library in Stockholm showed that Gustav's personal library was voluminous and that he quickly acquired the latest works of the Enlightenment. ${ }^{45}$ Gustav was fond of theatre and wrote some pieces himself. He met various philosophers in Paris, including Helvetius, Marmontel, Grimm, Quesnay, d'Alembert, and the elder Mirabeau. He also visited Rousseau and, even if Gustav seemed to prefer Voltaire's ideas to Rousseau's critique of sciences and arts and to the Social Contract, ${ }^{46}$ Barton also evokes Gustav's 'undeniable fascination' with Rousseau. ${ }^{47}$ Burlamaqui's work also seemed to have a place of honour in the prince's Order of the Arc. ${ }^{48}$

gouvernement le plus glorieux pour les rois, et le plus avantageux pour les hommes en général'. [A short but solid system on the law of nature and nations, published some years ago in Geneva, might serve the Councillor for this type of instruction and I recommend wholeheartedly this short work which is, of all those I know on this subject, that which proves most convincingly that unlimited despotism is as dangerous for the prince as for his subjects, that, on the contrary, political liberty and a royal power limited by fundamental laws, conforming more closely to the law of nature, constitute the most glorious form of government for kings and the most advantageous for men in general].

43 Marie-Christine Skuncke, 'Un prince suédois auteur français: l'éducation de Gustave III, 1756-1762,' Studies on Voltaire \& the Eighteenth Century 296 (1992), 127.

44 Pièces concernant l'éducation du prince royal, 12: 'chaque jour de la semaine, excepté le dimanche, depuis dix heures du matin jusqu'à une heure après midi, et depuis trois heures du soir jusqu'à six' and 'lorsque S.A.R aura fait assez de progrès dans le droit public universel et le droit des gens pour qu'on puisse commencer son instruction dans le droit public de la patrie, c'est-à-dire, dans les lois fondamentales de la Suède, on communiquera à Mr le conseiller une instruction particulière sur ce sujet délicat'. [Every day of the week, Sunday excepted, from ten in the morning until one in the afternoon and from three in the afternoon until six] and [when HRH has made sufficient progress in universal public law and the law of the people for his instruction to be begun in the country's public law, that is, the fundamental laws of Sweden, particular instruction on this delicate subject will be sent to the Councillor].

45 Hildor Arnold Barton, Essays on Scandinavian History (Carbondale: Southern Illinois University Press, 2008), 17.

46 Barton, Essays on Scandinavian History, 19.

47 Ibid., 37.

48 Skuncke, 'Un prince suédois auteur français: l'éducation de Gustave III, 1756-1762,' 148-153. 
That said, the question 'Was Gustav a tyrant or an enlightened prince?' is still subject to debate. During Gustav's life, his contemporaries' opinions were already divergent on this question. Skuncke points out that Gustav was one of the most controversial kings of Sweden. She also describes the tensions around Gustav's education, between his mother, partisan of absolutism, and his educators, assigned with the charge of teaching him that the present system of government in Sweden was the best possible. ${ }^{49}$ Even though Claude Nordmann underlines the ambiguity of Gustav and the complexity of judging of his actions during his reign, he mentions at the same time that he was unquestionably 'one of the most brilliant personalities of the rich eighteenth century'.50 Gustav was, according to him, 'a model of the enlightened absolutist', 'idealist', 'liberal by inclination,' 'a Caesarean democrat who conducted a domestic policy of orders', 'levelling, seeking equality for everyone, but following tortuous paths. ${ }^{51} \mathrm{He}$ was also a patron of the arts and letters and allowed his country to fully participate in the Enlightenment. The published correspondence between Scheffer and Gustav helped to spread the image of an enlightened monarch across Europe. ${ }^{52}$

The assessment of his reign is, however, complex and I will not try to provide an overview here. I will simply go on with another of Nordmann's observations, that Gustav was a committed person, engaged in the intellectual movement of his time, open-minded, but that he was also the victim of a real 'disequilibrium between his ambitions and his possibilities..$^{53}$ Gustav was the one responsible for a law that progressively restricted the freedom of the press (1774) but he was also the one who engaged in social egalitarian reforms (1789) and he was finally murdered.

Two important limitations that bring into question the unmitigated success of Burlamaqui's education can be inspired respectively by Ingrao's work on Frederick and the Pieces Concerning the Education of the Royal Prince with Scheffer's instructions for educating Gustav. These limitations may justify a belief that Rousseau could have been wrong when he stated that 'a royal education necessarily corrupts those who receive it' because neither Frederick nor Gustav

49 Skuncke, 'Un prince suédois auteur français: l'éducation de Gustave III, 1756-1762,' $125^{-137 .}$

$50 \quad$ Claude Nordmann, Gustave III Un démocrate couronné (Lille: Presses Universitaires du Septentrion, 1986), 1, my translation.

$5^{1} \quad$ Nordmann, Gustave III Un démocrate couronné, 265.

52 Skuncke, 'Un prince suédois auteur français: l'éducation de Gustave III, 1756-1762,' 157-158.

53 Nordmann, Gustave III Un démocrate couronné, 1. 
seemed to have been corrupted by their Burlamaquian education. At the same time, Burlamaqui could have been wrong for having been too confident in the possibilities of an education based on the law of nature, which was surely not enough to produce either a good prince or a good government. So Burlamaquian education may have been partly successful but some other elements may have prevented it really bearing fruit. Ingrao points out, for example:

$[\mathrm{T}]$ he Frederician regime was obliged to contend with preexisting structures that were essentially inimical to the thrust of its programs: unfavorable demographic and economic circumstances, entrenched institutions that enjoyed lives and constituencies of their own, and existing philosophies of government not wholly compatible with the new ideas of government reformers. ${ }^{54}$

In truth, this difficulty had already been pointed out by Rousseau, who had noticed that the system and the established practice were the core of the problem, even when the preceptor was not corrupt (or at least when he was not entirely corrupt). The prince was not the sole element in need of education the role of bureaucracy was important and the government always functioned by consensus.

So, if we allow that Burlamaqui was successful in his attempt to educate Prince Frederick using the law of nature, that was still no guarantee of successful reforms for the government because the prince, even the absolutist prince, was just an element of the system - the other parts had not all been educated using the law of nature. However, this fact did not prevent Ingrao from gathering sufficient quantitative evidence to support the idea that 'despite its limits, failures, and costs, the Frederician regime succeeded in improving the quality of life of most Hessians.' 55 This means that some seeds of Burlamaquian Enlightenment may have given good results in this case.

The Pieces underlined another difficulty that could hinder a prince's education. Scheffer emphasized the importance of the condition of the prince himself, because reforms could not be undertaken if the prince was not heard, nor loved, nor respected by his subjects. He explained:

If Mgr the prince royal, as there is every reason to presume, makes great progress in all the areas of science just mentioned, he will certainly be a

54 Ingrao, The Hessian Mercenary State, 11.
55 Ibid., 209. 
very enlightened and highly educated prince, but that is not what makes the king's happiness, nor what makes him worthy of his people's love. That requires more feeling than reason; it requires a high and noble soul, a gentle character, a heart filled with benevolence and love for men. To provide the young prince these great benefits, we must, while cultivating his reason, pay constant attention to his heart and his personality and conduct, as far as possible, all his studies in such a way that his heart might be touched, purified, imbued with desire for the love, esteem, and attachment of men. ${ }^{56}$

Reason without feeling or more reason than feeling - perhaps in this lay one major difficulty that could not be solved by a Burlamaquian education based on the law of nature alone. In Emile, Rousseau pointed out what appeared to him as a weakness of the law of nature, at least the law of nature as it was taught in his time. He said that 'the entire right of Nature is only a chimera if it is not founded on a natural need in the human heart'. As for the law of nature, it had to be based on feeling: 'From this I conclude that it is not true that the precepts of natural law are founded on reason alone. They have a base more solid and sure. Love of men derived from love of self is the principle of human justice. ${ }^{57}$ However, this principle of human justice was not to be found directly in books. Even less was it to be found in philosophers' books, because they judged others by themselves and gave a wrong description of humanity. Reading books was not the best way to feel love for men and benevolence. Only a natural feeling such as love of self could lead the way, if it was not too far perverted by education.

This difficulty was clearly linked to the point made by Rousseau above, namely that princes needed to learn how to become 'men'. This was even more important if it was connected to the importance of deserving the love

$5^{6} \quad$ Pièces concernant l'éducation du prince royal, 13-14: 'Si Mgr le prince royal, comme on a tout lieu de le présumer, fait de grands progrès dans toutes les parties des sciences qu'on vient d'énoncer, il sera certainement un prince très éclairé et très instruit ; mais ce n'est pas là ce qui fait le bonheur d'un roi, ni ce qui le rend digne de l'amour de son peuple. Il faut pour cela plus de sentiment que d'esprit ; il faut une âme noble et élevée, un caractère doux, un cœur rempli de bienfaisance et d'amour pour les hommes. Pour procurer au jeune prince ces grands avantages, on doit, en cultivant son esprit, porter une attention continuelle sur son cœur et sur son caractère et diriger autant qu'il est possible toutes ses études de manière que le cœur puisse être touché, épuré, pénétré du désir d'obtenir l'amour, l'estime et l'attachement des hommes'.

57 Rousseau, Emile or on Education, 389, text and note. Rousseau, Émile ou De l'éducation, 359 , text and note. 
of the people. A prince could not be followed if his people did not love him and the prince could not deserve the love of his people if he was incapable of benevolence and love of men. The process of the prince's identification with the rest of humanity was only possible if the prince did not stay cut off from the rest of the world. Too many books, too many hours spent in the classroom, and eventually no one on the battlefield to look around and to repeat after Rousseau, 'Pity, indignation swell up in the depths of my heart!' And what was more natural than pity and indignation in the face of the reality of the world? It seemed that experience could teach what scholars and jurisconsults could never demonstrate in a lecture room. But people living in the real world had no choice but to face reality and, surely, a prince who could not face reality with his people could never be loved and respected. Princes incapable of feeling pity and indignation, incapable of benevolence and love of men were neither lovable nor respectable. People needed to love and to respect a 'man' before they could love and respect a prince.

Burlamaqui did not make the distinction between educating someone to become a 'man' and educating someone to become a citizen. Maybe it was because Burlamaqui did not believe that it was part of his role to do so or, more likely, he did not agree with Rousseau's idea that the major role of education was to make a child become a 'man'. Childhood for Rousseau was the moment of life to open up to the world and to others. If this opportunity was missed, it could be lost forever. Clearly, there is a deeper disagreement here between the two philosophers about what was human nature and what was its perfectibility. In any case, it appears that Scheffer tried to combine a Burlamaquian education and a Rousseauist one when he wrote his instructions to the prince's preceptor - he wanted to educate Gustav to become both a 'man' and a prince, assuming that was compatible. Maybe it was, despite what Rousseau claimed. But then it was entirely in the hands of the preceptor to succeed in this task certainly a heavy burden for a person.

\section{Bibliography}

Barton, Arnold H., Essays on Scandinavian History (Carbondale: Southern Illinois University Press, 2008).

Burlamaqui, Jean-Jacques, Principes du droit naturel (Genève: Barrillot \& Fils, 1747).

Burlamaqui, Jean-Jacques, Principes du droit politique (Amsterdam: Zacarie Chatelain, 1751).

Burlamaqui, Jean-Jacques, The Principles of Natural and Politic Law, transl. Thomas Nugent, ed. Petter Korkman (Indianapolis, IN: Liberty fund, 20o6). 
Correspondence between Burlamaqui and Frederick of Hessen-Kassel, archival material from Staatsarchiv Marburg, replica accessible in Geneva Library, Facs 37, f. 90-142.

Derathé, Robert, Jean-Jacques Rousseau et la science politique de son temps (Paris: Vrin, 1971).

Fénelon, Les aventures de Télémaque (Paris: Garnier, 1987).

Fénelon, Telemachus, son of Ulysses, ed. and transl. Patrick Riley (Cambridge: Cambridge University Press, 1994).

Frängsmyr, Tore, 'Defining the Enlightenment: The Swedish Case,' in Centre(s) and Margins. Enlightenment from Belfast to Beijing, ed. Marie-Christine Skuncke (Paris: Honoré Champion, 2003), 195-212.

Gagnebin, Bernard, Burlamaqui et le droit naturel (Genève: éditions de la Frégate, 1944). Hobbes, Thomas, Leviathan, ed. Richard Tuck (Cambridge: Cambridge University Press, 1996).

Horstboll, Henrik, 'Defending Monarchism in Denmark-Norway in the Eighteenth Century,' in Monarchisms in the Age of Enlightenment: Liberty, Patriotism, and the Common Good, ed. Hans Blom, John Christian Laursen, and Luisa Simonutti (Toronto, Buffalo, London: University of Toronto Press, 2007), 175-193.

Ingrao, Charles W., The Hessian Mercenary State: Ideas, Institutions, and Reform under Frederick II, 1760-1785 (Cambridge: Cambridge University Press, 1987).

Laursen, John C., 'Télémaque manqué: Reverdil at Court in Copenhagen,' in Reconceptualizing Nature, Science, and Aesthetics: Contribution à une nouvelle approche des Lumières helvétiques, ed. Patrick Coleman, Anne Hofmann, and Simone Zurbuchen (Genève: Slatkine, 1998), 147-156.

Nordmann, Claude, Gustave III, un démocrate couronné (Lille: Presses Universitaires du Septentrion, 1986).

Pièces concernant l'éducation du prince royal, à présent roi de Suède par son excellence Mr le Comte Charles de Scheffer, sénateur du royaume et commandeur des ordres du roi, \&c., traduites du suédois (Stockholm: H. Fougt, 1773).

Rosenblatt, Helena, Rousseau and Geneva. From the First Discourse to the Social Contract, 1749-1762 (Cambridge: Cambridge University Press, 1997).

Rousseau, Jean-Jacques, Émile ou De l'éducation (Paris: Gallimard, 1969).

Rousseau, Jean-Jacques, Discours sur l'origine et les fondements de l'inégalité parmi les hommes (Paris: Gallimard, 1969).

Rousseau, Jean-Jacques, The Social Contract and other later political writings, transl. and ed. Victor Gourevitch (Cambridge: Cambridge University Press, 1997).

Rousseau, Jean-Jacques. The Discourses and other early political writings, transl. and ed. Victor Gourevitch (Cambridge: Cambridge University Press, 1997).

Rousseau, Jean-Jacques, Du contrat social (Paris: Flammarion, 2001).

Rousseau, Jean-Jacques, Principes du droit de la guerre. Écrits sur la paix perpétuelle, ed. Blaise Bachofen and Céline Spector (Paris: Vrin, 2008). 
Rousseau, Jean-Jacques, Emile or on Education, transl. and ed. Christopher Kelly and Allan Bloom (Hanover and London: University Press of New England, 2010).

Silvestrini, Gabriella, Diritto naturale e volontà generale. Il contrattualismo repubblicano diJean-Jacques Rousseau (Torino: Claudiana, 2010).

Simonin, Jérémy, 'L'homme et le citoyen dans la science du droit naturel de J.-J. Burlamaqui,' in Genève et la Suisse dans la pensée politique, Actes du colloque de Genève (sept. 2006), ed. Michel Ganzin (Aix-en-Provence: Presses Universitaires d'AixMarseille, 2007), 89-101.

Skuncke, Marie-Christine, 'Un prince suédois auteur français: l'éducation de Gustave III, 1756-1762,' Studies on Voltaire \& the Eighteenth Century 296 (1992), 123-163.

Termolle, Michel, 'Rousseau, conseiller pédagogique par correspondance,' in Lire la correspondance de Rousseau, ed. Jacques Berchtold and Yannick Séité (Genève: Droz, 2007), Annales de la Société Jean-Jacques Rousseau 47, 309-326. 


\title{
Defining the Law of Nations: the École romande du droit naturel and the Lausanne Edition of Grotius' De jure belli ac pacis (1751-1752)
}

\author{
Simone Zurbuchen
}

The single most important Swiss contribution to the law of nations in the eighteenth century is Emer de Vattel's treatise Le Droit des Gens, ou Principes de la Loi Naturelle, appliqués à la Conduite \& aux Affaires des Nations \& des Souverains (1758). ${ }^{1}$ Unlike Jean Barbeyrac and Jean-Jacques Burlamaqui, whose reputation as outstanding natural law scholars is to a lesser or greater extent linked with their being teachers of natural law at the Protestant academies of Lausanne and Geneva, Vattel remained for most of his life an independent scholar and towards the end of his life became the chief advisor to the government of Saxony on foreign affairs. Had Frederick II of Prussia been willing to keep his father's promise to found an academy in Neuchâtel, Vattel might well have become a teacher of the law of nature and nations in his native principality, and thereby resumed the project of lecturing on natural law conceived by Louis Bourguet, who from 1731 to 1742 held the chair of philosophy and mathematics sponsored by the town of Neuchâtel and the guilds, and who also lectured on natural law. ${ }^{2}$

As a classic in the field, Vattel's treatise is well known, and scholars are aware that his main reference was Christian Wolff, whose theory of the law of

1 Emer de Vattel, Le Droit des Gens, ou Principes de la Loi Naturelle, appliqués à la Conduite \& aux Affaires des Nations \& des Souverains (Londres, 1758). The book was actually printed in Neuchâtel in 1757 .

2 On Bourguet see Sophie Bisset, 'Exploring the parameters of the école romande du droit naturel in the Journal helvétique: the case of Louis Bourguet's "Four letters on Leibniz"' in Lectures du 'Journal helvétique, 1732-1782, ed. Séverine Huguenin and Timothée Léchot (Geneva: Slatkine, 2016), 315-328; Sophie Bisset, 'The reception of Pufendorf and Leibniz in the early école romande du droit naturel: Jean Barbeyrac and Louis Bourguet,' Etudes Lumièrs. Lausanne, no. 7, février 2019, http://lumieres.unil.ch/fiches/biblio/9475/; Simone Zurbuchen, 'Bourguet, Louis (1678-1742),' in The Dictionary of Eighteenth-Century German Philosophers, ed. Heiner F. Klemme and Manfred Kuehn, vol. 1 (London: Continuum, 2010), 135-137. 
nations he wanted to ensure a reception in the polite world. To achieve this, he renounced his original idea to simply translate Wolff's Jus gentium methodo scientifica pertractatum (1749) into French. In order to get rid of the mathematical method the German philosopher applied, he eventually decided to write a work of his own. The extent to which Vattel was indebted to Wolff is further documented by his critical observations on Wolff's work on the law of nature. ${ }^{3}$ While it is most likely that Vattel studied natural law with Burlamaqui in Geneva, he never attested any close affiliation with Samuel Pufendorf's theory of the law of nature and nations, which was mainly taught in the Suisse romande as well as in other parts of the Helvetic Confederation. Quite to the contrary, Vattel showed a great deal of interest in Leibniz' philosophy, which he vindicated in his Défense du système Leibnizien contre les objections et les imputations de Mr. de Crousaz (1741), and he attempted to defend a middle position in the famous controversy on the principle of obligation between Barbeyrac and Leibniz in his Essai sur le fondement du droit naturel (1747). ${ }^{4}$ It may well be that his endeavour to secure Leibniz from Barbeyrac's vigorous critique was influenced by Bourguet, who was also a great admirer of Leibniz, but eventually nuanced his position for prudential reasons, when he considered applying for Barbeyrac's position at the Academy of Lausanne upon the latter's departure in 1718.5

So far, much of the research devoted to the Swiss school (or école romande) of natural law has focused on natural and politic law. Almost nothing is known about the teaching and publishing activities related to the law of nations prior to the publication of Vattel's treatise. ${ }^{6}$ Curiously, the new edition of Hugo Grotius' De jure belli ac pacis, which appeared in five volumes in Lausanne in 1751$175^{2}$, has never been commented upon, although it was later praised as one of the best editions of this work. ${ }^{7}$ In what follows, I will first provide information

3 Vattel drafted his Questions de droit naturel, et observations sur le Traité du droit de la nature de M. le baron de Wolf in 1753 . The book was published in 1762.

4 On Vattel's career see Simone Zurbuchen, 'Emer de Vattel on the Society of Nations and the Political System of Europe,' in System, Order, and International Law, ed. Stefan Kadelbach, Thomas Kleinlein and David Roth-Isigkeit (Oxford: Oxford University Press, 2017), 263-282, and further references there.

5 Bisset, 'The reception of Pufendorf and Leibniz,' p. 5.

6 For a brief overview, see Peter Haggenmacher, 'Völkerrecht,' in Historisches Lexikon der Schweiz, accessed 2 January 2018, http://www.hls-dhs-dss.ch/textes/d/D9619.php.

7 In his German translation of Grotius' work, published in 1869, J.H. von Kirchmann stresses the originality of the Lausanne edition: 'Das Werk, das hier zunächst interessiert, "Ueber das Recht des Krieges und des Friedens", ist bisher noch nicht in das Deutsche übersetzt worden. Die besten Ausgaben des Originaltextes sind die von Gronow, mit schätzbaren Anmerkungen, von Barbeyrac und von Samuel Cocceji. Letztere ist in Lausanne in 4 Quartbänden 
about the teaching and the literary production related to the law of nations in the Suisse romande and hence the context of the Lausanne edition of Grotius. We will see that the distinguishing feature of this edition is the incorporation of the extended commentaries on Grotius' theory of the law of nature and nations by Heinrich and Samuel Cocceji (father and son), which had first been published in Breslau (Wratislavia) as Grotius illustratus (1744-1752). ${ }^{8}$ Taking account of the Coccejis' vigorous critique of Grotius' dualist account of the law of nations, I will proceed, secondly, to a comparative account of the definition of the law of nations from Grotius via Pufendorf, Barbeyrac and Burlamaqui to Vattel. This conceptual analysis will lead to the conclusion that while the Lausanne edition of Grotius was most likely undertaken for commercial reasons, it also strengthened the position of the adherents to Samuel Pufendorf's naturalist theory of the law of nations, who were predominant in the école romande, until Vattel resumed the Grotian tradition in his highly influential Law of Nations.

\section{The Lausanne Edition of Grotius in Context}

It is useful to recall that, in contradistinction to the Academy of Lausanne, which created its first law chair in 1711, when Barbeyrac was appointed, its Genevan counterpart had established its law school during the Reformation. This helps to explain why the law of nature and nations was taught in Geneva even before Barbeyrac's French translations of Pufendorf's works became the main reference for teaching the subject. ${ }^{9}$ Indeed, two of the Geneva law professors probably began teaching the law of nations on the basis of Grotius' $D e$ jure belli ac pacis in the last quarter of the seventeenth century. One of them was Philipp Reinhard Vitriarius (1647-1720), who had studied law with Johann Heinrich Boecler at the University of Strasbourg and was professor of civil law

erschienen. Schon Gr. hatte seinem Werke bei einer späteren Auflage im Jahre 1632 Noten beigesetzt. Diese und die von Gronow sind in der Ausgabe von Cocceji mit abgedruckt und ihnen sind weitläufige Excurse über naturrechtliche Fragen beigegeben'. See Hugo Grotius, Recht des Krieges und des Friedens, transl. J.H. von Kirchmann, vol. 1 (Berlin: L. Heimann, 1869), 14 .

8 Henrici de Cocceji, Grotius illustratus seu commentarii ad Hugonis Grotii de juri belli ac pacis libros III, ed. Samuel de Cocceji, 4 vols. (Wratislaviae: Johann Jacob Korn, 1744-1752).

9 In what follows, I will focus on the law of nations only. For a general account of the teaching of the law of nature and nations in the Swiss context see Simone Zurbuchen, "Teaching the Law of Nature and Nations in the Swiss Context,' Etudes Lumières.Lausanne, no. 6, novembre 2018, http://lumieres.unil.ch/fiches/biblio/9472/. 
at the Academy of Geneva from 1677 to 1682 , before he moved to the University of Leiden. In Geneva, Vitriarius taught three courses on the Institutes, i.e. Roman law, and one course on questions of law. The latter was dedicated to the public law of the German Empire, but perhaps also to the law of nature and nations according to Grotius. ${ }^{10}$ I am inclined to think so because he published in 1692 the Institutiones juris naturae et gentium. This book was re-edited several times; in 1745 by Marc-Michel Bousquet in Lausanne, ${ }^{11}$ who also brought out the annotated edition of Grotius. In his Histoire de l'Université de Genève, Charles Borgeaud indicates that Bénigne Mussard (1657-1722), honorary professor of civil law from 1682 to 1685 , was asked to produce the commentary on Grotius' De jure belli ac pacis. ${ }^{12}$ The teaching of the law of nations was later resumed by Burlamaqui, who lectured on the law of nature and nations on the basis of Barbeyrac's translations of Pufendorf's works. ${ }^{13}$

Turning to the Academy of Lausanne, the first text we need to consider is the amply annotated French translation of Grotius' major work on which Barbeyrac was working in Lausanne, Du droit de la guerre et de la paix, first published in Amsterdam in $1724 \cdot{ }^{14}$ It was, however, not Barbeyrac himself, but his successor to the chair of natural law and history, Charles-Guillaume Loys de Bochat (1695-1754), who rendered prominent the law of nations in the Swiss context. Since he is a virtually unknown figure, I will present him here in some detail..$^{15}$

10 Charles Borgeaud, Histoire de l'Université de Genève. L'Académie de Calvin, 1559-1798 (Geneva: Georg \& Cie., 1900), 386-389.

11 Philipp Reinhard Vitriarius, Institutiones juris naturae et gentium [...] ad methodum Hugonis Grotii (Lausanne: Antoine Chapuis, 1745). The publisher, Bousquet, closely collaborated with the printer, Chapuis.

12 Borgeaud, Histoire de l'Université de Genève, 507.

13 In addition to the Principes du droit naturel (1747) and the Principes du droit politique (1751), first translated into English by Thomas Nugent in 1748 and $175^{2}$, and published together in 1763 as Principles of Natural and Politic Law, ed. and with an introduction by Petter Korkman (Indianapolis, IN: Liberty Fund, 20o6), I will also refer below to the Principes du droit de la nature et de gens, ed. by Fortuné-Barthélemy de Félice, 8 vols. (Yverdon: [de Félice], 1766-1768), who referred to Burlamaqui's lecture notes that survived in the library.

14 Hugues Grotius, Le droit de la guerre et de la paix, transl. Jean Barbeyrac (Amsterdam: Pierre de Coup, 1724). See Philippe Meylan, Jean Barbeyrac (1674-1744) et les débuts de l'enseignement du droit dans l'ancienne Académie de Lausanne (Lausanne: F. Rouge \& Cie., 1937), 84-86.

15 On Loys de Bochat, see Jean-François Poudret et al., L'enseignement du droit à l'Académie de Lausanne aux XVIII et XIXe siècles (Université de Lausanne, 1987), 29-38; Meylan, Jean Barbeyrac, 159-171, 208-209; Henry Perrochon, 'Un savant d'autrefois: G.-Ch. Loys de Bochat (1695-1754), Revue historique vaudoise 49 (1941): 29-33; [J.A.D. 
Loys de Bochat first studied philosophy with Jean-Pierre de Crousaz in Lausanne, then theology at the University of Basel. Due to ill health, he needed to return home, and he studied law under Barbeyrac. In 1716, he continued his study of law at the University of Basel, and in 1717 he defended his dissertation there, De optimo principe. ${ }^{16}$ In the same year, the chair of natural law and history at the Academy of Lausanne became vacant, and both Barbeyrac and de Crousaz petitioned the authorities of Berne on behalf of Louis Bourguet's candidacy for the chair. Given that Barbeyrac's main argument against the appointment of his former student was that the latter had 'studied law for two years at most' with 'no hint of erudition,', ${ }^{17}$ it is not surprising that the Bernese authorities encouraged Loys de Bochat to complete his education abroad, by granting him a stipend. Before he began teaching in Lausanne, he studied at different universities, notably at Halle and at Leiden.

As professor in Lausanne (1721-1740), Loys de Bochat became well known for the new method he introduced in his public courses on history, whereby historical events were considered to be 'secondary sources of instruction' and there was discussion of 'how the principles of natural law, of the law of nations, of public law, of politics and morality' were to be applied and developed in various contexts. ${ }^{18}$ The branch of history he was most interested in and which had so far not been taught at Lausanne was ecclesiastical history. In 1733, the public course on natural law was replaced by the course on ecclesiastical history. In his private courses, which took up several hours a day, Loys de Bochat dealt with natural and civil law. From 1725 onwards, he functioned as assessor of the local law court; when he was appointed lieutenant baillival (that is, local substitute of the reeve), he renounced the chair at the Academy. In 1750, he was eventually appointed contrôleur général. In addition to his public positions, Loys de Bochat founded, together with his friend Gabriel Seigneux de Correvon, the journal Bibliothèque italique ou Histoire littéraire de l'Italie (1728-1734), published by Marc-Michel Bousquet in Geneva. ${ }^{19} \mathrm{He}$ also initiated the foundation

Clavel de Brenles], Eloge historique de Monsieur Charles Guillaume Loys de Bochat (Lausanne: Antoine Chapuis, 1755).

16 Charles-Guillaume Loys de Bochat, Dissertatio inauguralis juridica de optimo principe (Basileae: typis Friderici Lüdij, 1717).

17 Barbeyrac in a letter to Bourguet, 28 th May 1717 , quoted by S. Bisset, "The reception of Pufendorf and Leibniz,' p. 3. On Loys de Bochat's nomination see also Meylan, Jean Barbeyrac, 159-166.

18 Clavel de Brenles, Eloge historique, 9-10.

19 On this journal see Francesca Bianca Crucitti-Ullrich, 'Bibliothèque italique (1728-1734),' in Dictionnaire des Journaux 160o-1789, accessed 2 February 2018, http://dictionnairejournaux.gazettes18e.fr/journal/o165-bibliotheque-italique. 
of the book store of the publishing company Marc-Michel Bousquet \& Cie. at Place St.-François in Lausanne in 1736, and he became an influential member of the Société du comte de la Lippe, a local society founded in 1742 in Lausanne that took care of the education of the young earl Simon August von LippeDetmold. ${ }^{20}$

It seems that Loys de Bochat got involved with the law of nations when he adopted the task of defending the Swiss practice of mercenary service abroad against an anonymous critique, first published as a short letter in the Journal littéraire de la Haye (1724) and addressed to Jean-Pierre de Crousaz. This critique was at the origin of a lengthy debate that Loys de Bochat made public in a volume entitled Ouvrages pour et contre les services militaires étrangers, considérés du côté du droit et de la morale $(1738) .{ }^{21}$ His vindication of Swiss mercenary service is interesting: while clearly motivated by the intention to save the reputation of the Swiss abroad as reliable and faithful partners, ${ }^{22}$ in the bulk of his lengthy reply Loys de Bochat deals with those general principles of natural law suitable for justifying the Swiss practice and attempts to demonstrate that these principles are very solid indeed. Once he had published a first dissertation in response to the anonymous letter, where he already relied extensively on the natural law literature available on the subject - notably on Gentili, Grotius, Pufendorf and their commentators - he went on reading all of the systems of law of nature and of public law subsequently available, as well as commentaries on earlier works on that matter, in order to check whether any of them questioned the main arguments he defended. ${ }^{23}$ Hence his first dissertation, as well as the subsequent pieces on more specific issues raised by a critique (again anonymous) of that work, constitute a kind of bibliography of textbooks and dissertationes to which Loys de Bochat referred in order to prove his case, that is, to demonstrate that allowing mercenaries to enrol in foreign armies as well as serving in mercenary troops as a soldier was legitimate both on juridical and on moral grounds. One gets the impression that he

20 Transcriptions of the minutes of this society are available on the website 'Lumières. Lausanne', accessed 2 February 2018, http://lumieres.unil.ch/projets/lippe/.

21 Charles-Guillaume Loys de Bochat, Ouvrages pour et contre les services militaires étrangers, 3 vols. (Lausanne, Genevae: Marc-Michel Bousquet \& Cie., 1738).

22 See Meylan, Jean Barbeyrac, 207-210.

23 Loys de Bochat, Ouvrages pour et contre les services militaires étrangers, vol. 1, 'Préface', XIV: 'Depuis l'impression de ma Dissertation, il s'est publique quelques Systèmes de Droit Naturel \& Public, \& quantité de Notes sur des Ouvrages qui en ont traité. Je crois d'avoir vû tous ces Livres. Aucun n'a touché à la Thèse que je soutiens. N'est-ce point là encore une présomption en sa faveur?'. 
had Barbeyrac's verdict on his poor erudition constantly before his eyes when replying to his critics.

Loys de Bochat also adopted a leading role in a discussion launched by the Société du comte de la Lippe on the balance of power in Europe and the question of whether a preventive war against a neighbouring state which augments its power and threatens weaker states by oppression is legitimate according to the law of nations. ${ }^{24}$ His introductory statement to the debate testifies again to his profound knowledge of the literature on the law of nations. Hence, he first deals with Pufendorf and Grotius, 'the two restorers of natural law', and their commentators, who would have argued that if a state increases its power and is hence in a position to harm its neighbours, this fact alone does not provide the latter with a just cause of war. He then considers the seemingly opposite position defended by Alberico Gentili, Thomas Hobbes and Nicolaus Hieronymus Gundling, with the intention to demonstrate that, all things considered, the latter were of the same opinion as the former.

Loys de Bochat's repeated engagement with questions related to the law of nations and just war, which is further attested by a former student's doctoral dissertation on ambassadors, ${ }^{25}$ help to explain his active participation in the new edition of Grotius' De jure belli ac pacis, published by Marc-Michel Bousquet in Lausanne in $175^{-1}-175^{2}$. The latter was a very able bookseller, who created his first publishing house in Geneva in 1724 with two business associates. As we have seen, he published the journal Bibliothèque italique. After a breakup with his associates, Bousquet settled in Lausanne upon an invitation from Loys de Bochat, where he closely collaborated with the printer Antoine Chapuis. ${ }^{26}$ Bousquet's business was largely based on the practice of exchange with other publishers and on creating networks with reliable customers abroad. This is why he travelled all over Europe. In 1750, he went on a tour of Italy with the intention of obtaining subscriptions for his publication of a Latin edition of Grotius. In the first volume of the edition, we find a salutation, signed by Bousquet, in which the publisher thanks the Italian subscribers for their prepayments and announces that their names will be published at the

24 See Simone Zurbuchen, 'Théorie de la guerre juste et balance du pouvoir en Europe', in L'Europe en province: la Société du comte de la Lippe (1742-1747). Actes du colloque organisé à l'Université de Lausanne du 25 au 26 juin 2009, ed. Béla Kapossy et al. (Lausanne: Lumières. Lausanne, 2013), http://lumieres.unil.ch/fiches/biblio/5687/.

25 Abraham Daniel Clavel de Brenles, De exemptione legatorum, a foro criminali ejus ad quem missi sunt (Marburg: Phil. Casim. Muller, 1740).

26 On Bousquet's publishing companies see Silvio Corsini, 'Vint-cinq ans d'édition et d'imprimerie à Lausanne au siècle des Lumières: le libraire Marc-Michel Bousquet, 17361761, Revue historique vaudoise 120 (2012), 23-53. 
end of the fourth volume. ${ }^{27} \mathrm{He}$ kept his promise and one finds the list of Italian pre-payers there.

What makes the Lausanne edition of Grotius highly original is the incorporation of numerous annotations and commentaries, which had been published before but which were now assembled in the five-volume edition: volumes 1-4 comprise the text of Grotius' work, and on the bottom of each page annotations by Gronovius and by Barbeyrac appear. Heinrich Cocceji's commentaries and his son's additional remarks follow at the end of each chapter. To this, the editors joined, in volume 4, Grotius' dissertations Mare liberum and De aequitate, indulgentia, et facilitate. Volume 5 contains 12 dissertations of Samuel Cocceji, entitled Introductio. In his note of thanks, Bousquet stresses that he had to correct thousands of errors contained in the earlier, Breslau edition, ${ }^{28}$ and from the address to the reader we can gather that Loys de Bochat reorganized Samuel Cocceji's commentaries in order to avoid repetitions. ${ }^{29} \mathrm{~A}$ glimpse at the dissertations suffices to show that Samuel Cocceji availed himself of his father's comments on Grotius to present his own theory of the law of nature and nations, which he had already developed in his earlier writings, and which also attest to some disagreement with his father. In the next section, I will proceed to a selective reading of the Coccejis' theories of the law of nature and focus exclusively on their account of the law of nations. As we will see, they unanimously and vigorously rejected Grotius' account of the law of nations.

To properly assess the Coccejis' critique of Grotius, let us first recall that a major innovation associated with the law of nations in the seventeenth century consisted in 'a rethinking of the relationship between natural law and its less regarded junior partner, the jus gentium'. ${ }^{30}$ As Stephen C. Neff has shown, the pulling apart of the formerly tight bonds between these two kinds of law marked 'the birth of international law in its modern sense.. ${ }^{31}$ In general terms, the distinction between natural law and jus gentium can be described

27 Hugo Grotius, De jure belli ac pacis libri tres, vol. 1 (Lausanne: Marc-Michel Bousquet \& Cie., 1751), 'Epistola dedicatoria'.

28 Ibid.

29 Ibid., LXII.

30 Stephen C. Neff, Justice among Nations. A History of International Law (Cambridge, MA: Harvard University Press, 2014), 151.

31 Ibid. 
as resting on three assumptions: first, jus gentium is not derivable from natural law, but rests on human experience and free will; secondly, in contradistinction to the law of nature, jus gentium is exclusively applicable to states as such and not to individual persons, or private parties; and thirdly, jus gentium cannot be conceived independently from natural law, but rather works in a kind of partnership with the latter and supplements it in certain respects. The emergence of such a dualist conception of the law of nations was a complicated matter. It was accompanied by the use of sometimes confusing terminology, not least because many of the natural lawyers referred back to Roman law in order to show that what they had in mind differed from the Roman-law notion of jus gentium..$^{32}$ Francisco Suárez was the first author to introduce a clearcut distinction between the law of nature and jus gentium along the lines just described. While Suárez named the positive law between states jus gentium proper', Grotius designated it by the expression 'voluntary (or volitional) law of nations' (jus gentium voluntarium). ${ }^{33}$ Although in De jure belli ac pacis the distinction between Roman-law jus gentium and the voluntary law of nations is not spelled out without ambiguities, Grotius clearly followed Suárez in developing a dualist conception of the law of nations, comprising those parts of natural law which are relevant for relations between states on the one hand, and the manmade law of nations, which arises out of agreement between states, on the other. This dualist conception, which exerted a major influence on later writers, is known today as the 'Grotian' approach to international law. ${ }^{34}$

Grotius deals with the law of nations in the Prolegomena, assigning it a role similar to that of municipal or civil law. ${ }^{35}$ He first explains that the bodies of municipal law arose from the promise explicitly or implicitly made by men, who assembled themselves within a group, to conform to the determination of that group or those men to whom the authority had been transferred. This obligation of men to one another rested on the natural law rule 'to abide by

\footnotetext{
32 See Neff, Justice among Nations, $15^{1-153 .}$

33 Ibid., 156.

34 Ibid., 159-16o, 163.

35 Grotius' concept of the law of nations is a complex matter. The goal of the following paragraphs consists exclusively in presenting some of the key elements later scholars commented upon in some detail. For a recent account of Grotius' law of nature, which also accounts for Grotius' earlier writings, see Stafan Kadelbach, 'Hugo Grotius: On the Conquest of Utopia by Systematic Reasoning,' in System, Order, and International Law. The Early History of International Legal Thought from Machiavelli to Hegel, ed. Stefan Kadelbach, Thomas Kleinlein and David Roth-Isigkeit (Oxford: Oxford University Press, 2017), 134-159.
} 
pacts.' ${ }^{36}$ For that reason, nature would have to be considered 'the great-grandmother of municipal law'. Grotius describes the function of municipal law in terms of a reinforcement of natural law when he asserts that the association of men and the subjection to authority 'have their roots in expediency'. For this reason, those who prescribe laws 'have, or ought to have, some advantage in view'. ${ }^{37}$ Grotius then introduces the 'law of nations' or 'the body of law which is maintained between states':

But just as the laws of each state have in view the advantage of the state, so by mutual consent it has become possible that certain laws should originate as between all states, or a great many states; and it is apparent that the laws thus originating had in view the advantage, not of particular states, but of the great society of states. And this is what is called the law of nations, whenever we distinguish that term from the law of nature. ${ }^{38}$

Grotius further explains the analogy between municipal law and the law of nations in the first book of his treatise, where he introduces the expression 'voluntary (or volitional) law' (jus gentium voluntarium) for designating a kind of law which has its origin in the human will. ${ }^{39}$ Beginning again with municipal law, which he explains in the same way as in the Prolegomena, he then introduces two other bodies of human voluntary law, which are respectively narrower or broader in scope than municipal law. The former 'comprises the commands of a father, of a master and all commands of a similar character', and the latter is the 'law of nations', i.e. 'the law which has received its obligatory force from the will of nations, or of many nations'. Grotius explains the qualification 'of many nations' by observing that, with the exception of the law of nature, 'which is also frequently called the law of nations', hardly any law would be common to all nations, and he acknowledges that the voluntary law of nations is not necessarily the same in all parts of the world. ${ }^{40}$ This latter remark is in tension with the paragraph in the Prolegomena where Grotius alludes to the advantage of the 'great society of states', which seems to suggest a universally applicable law of nations, that is, one which is binding on all states.

36 Hugo Grotius, De jure belli ac pacis libri tres, transl. of the ed. of 1646 by Francis W. Kelsey (The Classics of International Law, Oxford: Clarendon Press, 1925), vol. 2, 'Prolegomena', § 15, 14-15.

37 Ibid., § 16, 15 .

$38 \quad$ Ibid., § 17, 15 .

39 Grotius, De jure belli ac pacis, book I, chap. I, § XIII, 44.

$40 \quad$ Ibid., § XIV, 44. 
Grotius makes it very clear that the voluntary law originates directly in the will of nations, and indirectly in the natural law rule to abide by pacts, and he also admits that the mutual consent between nations can only be inferred from practice. Hence, he likens the law of nations to 'unwritten municipal law' and describes it - referring to the Church father Chrysostom - as 'the creation of time and custom.41 This body of law would be found in custom and in the testimony of those who are skilled in law. While this reference to custom is coherent with the assumption of an implicit or tacit consent among a great many nations, it also contributes to rendering ambiguous his concept of the law of nations. For Grotius also uses the notion jus gentium to designate the body of law the Romans called the law of nations, that is, the law the Romans applied not just to their own people but to many surrounding nations as well. ${ }^{42}$ Although at some places Grotius explains very clearly that this Roman jus gentium 'is not international law, strictly speaking, for it does not affect the mutual society of nations in relation to one another' and is therefore 'improperly' called 'law of nations', ${ }^{33}$ he also renders ambiguous his own notion of the law of nations. This is mainly so because he refers as well to 'common custom' when explaining the Roman-law use of the term. ${ }^{44}$ As Neff has aptly explained, the Roman-law notion of jus gentium does, however, not arise out of agreement between states and therefore does not rest on the will of nations. It rather 'arises out of separate unilateral enactments by states - with the contents of those unilateral enactments "matching up" with one another. 45

In view of the development of the law of nations from the eighteenth to the nineteenth century and the constitution of the law of nations as a discipline increasingly distinct from the law of nature, Grotius' dualist conception of the law of nations, comprising both the law of nature applied to states and the voluntary law governing exclusively the relationship between states, is clearly a major innovation. It was, however, challenged by a large group of authors who, following Thomas Hobbes' stripped-down view of natural law and natural right, contested the very existence of a voluntary law of nations. The leading figure of this rival school of international thought was Samuel Pufendorf, who maintained that natural law was the only law of universal application between states. In The Law of Nature and Nations, he introduces the discussion of

\footnotetext{
41 Ibid.

42 On this ambiguity see Neff in his introduction to Hugo Grotius, On the Law of War and Peace, ed. Stephen C. Neff (Cambridge: Cambridge University Press, 2012), XXXII-XXXIII.

43 Grotius, De jure belli, vol. 2, book II, chap. viII, § I, 295.

44 Ibid.

45 Neff, introduction to Grotius, On the Law of War and Peace, XXXII.
} 
Grotius' voluntary law of nations with the following question: 'Whether or no there be any such thing as a particular and positive Law of Nations, contradistinct to the Law of Nature. ${ }^{46}$ He first refers to Hobbes' distinction between the natural law of men, and the natural law of states (commonly called the law of nations), the precepts of which are the same because, once instituted, states assume the proprieties of men. He then fully subscribes to this doctrine and denies the existence 'of any other voluntary or positive Law of Nations, properly invested with a true and legal Force, and obliging as the Ordinance of a superior Power'. ${ }^{47}$ In Pufendorf's view, matters such as the way in which things are acquired or contracts, which are commonly referred to the law of nations, belong either to natural law or to the civil laws of the countries where they are observed. He thus does not deny that there may be agreements among many states on such matters, but he contests that 'it is not proper or fair to constitute these as a peculiar and distinct Species of Law', for ordinances common to many nations would not arise 'in mutual Covenant or Obligation'48 They rather depend on accidental agreement among legislators, who can alter them without advising with their neighbours. In the same context, Pufendorf also recalls the Roman-law concept of jus gentium, which included all foreigners, while the civil law was proper only to Roman citizens. This kind of law, he insists, had, however, nothing to do with what Grotius called the voluntary or positive law of nations. ${ }^{49}$

Concerning the latter, Pufendorf uses several examples to show that matters Grotius dealt with under the heading of the voluntary law of nations in fact concern the law of nature. Thus, he argues that the persons of ambassadors 'are sacred and inviolable [...] by the meer Law of Nature, ${ }^{50}$ because they are necessary for the procuring and preserving of peace by leagues and covenants, which are themselves enjoined on men by the law of nations. Further, he argues that the right of burial, which Grotius also considers to belong to the voluntary law of nations, could very well be referred to the duties of kindness and humanity, which are part of the law of nature. ${ }^{51}$ Pufendorf proves to be highly critical of the many authors who would rank under the title of the

46 Samuel Pufendorf, Of the Law of Nature and Nations, transl. Basil Kennett, 4th ed. (London: J. Walthoe, R. Wilkin, J. and J. Bonwicke, S. Birt, T. Ward and T. Osborne, 1729), book II, chap. III, § XXIII, 149.

47 Ibid., 15 o.

48 Ibid.

49 Ibid., 150-151.

$50 \quad$ Ibid., 151.

$51 \quad$ Ibid., $15^{2}$. 
law of nations the customs mutually observed by tacit consent among 'People pretending to Civility'. Alluding to examples of rules observed in the conduct of war, which Machiavelli described in The Prince, he mocks clement practices such as exempting certain things or persons from martial violence, or the taking of prisoners (who are afterwards released without ransom) instead of killing enemy soldiers, as mere niceties allowing those who fight an unjust war 'to appear wicked with some kind of Temper and Moderation.' ${ }^{52}$ In Pufendorf's view, rules customarily observed in war cannot constitute any law or universal obligation, since any party has the right to absolve themselves from restraints which rest on tacit agreement. This would explain why one finds such practices worn out by time and replaced by contrary practices.

Pufendorf's 'naturalist' account of the law of nations, according to which jus gentium is nothing other than the law of nature applied to states, had a strong influence in Brandenburg-Prussia, notably on Christian Thomasius and his followers Johann Franz Budde and Nicolaus Hieronymus Gundling, who taught natural law at the University of Halle, and on Johann Gottlieb Heineccius at the Universities of Frankfurt an der Oder and Halle. ${ }^{53}$ His rejection of the voluntary law of nations was further strengthened by his French translator, Barbeyrac, who explicitly secured Pufendorf's position in a note to The Law of Nature and Nations and also inserted a lengthy comment on the same issue in his translation of Grotius' work. Hence, we read in a note to the paragraph in the first book of Dejure belli we have been considering above: 'The Positive Law of Nations, distinct from the Law of Nature, is a mere chimera. ${ }^{54}$ Barbeyrac goes on to explain that he does not wish to deny that all nations have to observe certain principles and rules in regard to one another, and that this may well be called the law of nations. He insists, however, that these rules are the same as those of the law of nature properly so called and that the obligation to respect them does not arise, as Grotius held, from the consent of nations. Regarding the customs respected by the generality of nations, which are not enjoined on them by the law of nature, Barbeyrac does not deny that any given nation may be obliged to submit to them as long as it does not give any proof to the

52 Ibid., 151.

53 See Tetsuya Toyoda, Theory and Politics of the Law of Nations. Political Bias in International Law Discourse of Seven Court Councilors in the Seventeenth and Eighteenth Centuries (Leiden, Boston: Martinus Nijhoff, 2011), 140-1. Johann Peter von Ludewig, who also taught law at the University of Halle, defended however the voluntary law of nations (ibid., 140-141).

54 Grotius, Le droit de la guerre et de la paix, livre I, chap. I, § XIV, note 3, 56: 'Le Droit des Gens, Positif, \& distinct du Droit Naturel, est une pure chimére'. 
contrary. In this case the obligation would, however, arise 'from this tacit and private agreement, without which the Customs in question have no force. ${ }^{55}$ The meaning of this 'tacit and private agreement' can be further elucidated by what Barbeyrac says in the corresponding note to Pufendorf's treatise, to which he explicitly directs the reader in his Grotius edition. Here Barbeyrac insists on the difference between an agreement and a law: while an obligation can arise from (private) agreement, this cannot produce 'a particular Law distinct from the natural'. Like any other contractual agreement, an agreement to submit to a custom 'must be referred to that general Law of Nature which obliges us to keep all Covenants.' ${ }^{56}$ In other words, as long as all peoples are naturally equal, there is neither a superior nor an inferior, and consequently no people can impose law upon another. It is also impossible that all peoples, taken together, impose laws on themselves.

Seen against this background of debates on Grotius' voluntary law of nations, the position defended by the Coccejis amounts to a strengthening of the 'naturalist' school. In a note to the same paragraph in De jure belli ac pacis, which provoked Barbeyrac's denial of the voluntary law of nations, Heinrich Cocceji observed that this whole inquiry was superfluous, because a human law that obliges all nations did not exist. There could be no question of the civil law in this place. ${ }^{57}$ And Samuel added in his additional note that he would deal at length with Grotius' system of the voluntary law in the narrower and in the broader sense of the term in his fourth dissertation. Commenting on paragraph 17 of the Prolegomena, he would demonstrate that there does not exist any such jus gentium, that this was an invention of Tribonian, and that therefore all disputes about this law are superfluous. ${ }^{58}$

Only a few scholars have dealt with the Coccejis' theory of law of nature and nations. ${ }^{59}$ Samuel Cocceji is well known for his politico-juridical career in the

55 'Ainsi toute obligation vient de cette convention tacite \& particulière, sans laquelle les Coûtumes, dont il s'agit, n'ont aucune force'. (Ibid.)

56 Pufendorf, Of the Law of Nature and Nations, book II, chap. III, § XXIII, note 2, $15^{\circ}$.

57 Grotius, De jure belli ac pacis libri tres, vol. 1, 58: 'Tota haec tractatio supervacua est, quia jus humanum, quod omnes gentes obliget, non datur : Jus civile autem hujus loci non est'.

$5^{8}$ Ibid., 59: 'Systema Grotii de jure gentium voluntario, eoque tum latius patente, tum arctiori, late exposuimus in Dissertatione Prooemiali IV. ejusque compendium exhibuimus in not. ad. Proleg. $\$ 17$. Simulque demonstravimus, tale jus gentium non dari [...] illudque inventum esse Triboniani. [...] Adeoque omnia, quae hic de tali jure disputantur, supervacua sunt'.

59 For an overview on their career and writings see Oliver Peglow: 'Cocceji, Henrich von,' in The Dictionary of Eighteenth-Century German Philosophers (Oxford: Continuum, 2011), accessed 3 February 2018: http://www.oxfordreference.com/view/10.1093/acref/ 9780199797097.001.0001/acref-9780199797097-e-o1oo, and Oliver Peglow: 'Cocceji, 
service of Frederick Wilhem I and of Frederick II, as well as for his work devoted to the reorganization of the juridical system in Prussia. Before embarking on this career, Samuel was, however, like his father Heinrich before him, a professor of law at the University of Frankfurt an der Oder, where he had studied law and obtained his doctoral degree with a dissertation entitled Tractatus Juris Gentium, de principio juris naturalis unico, vero et adaequato, which was published in two parts in $1702 .{ }^{60}$ In the first part of the dissertation, he deals with fundamental questions such as the very existence of the law of nature and the principle on which it rests. Some disagreements with his father notwithstanding, he subscribes to the latter's critique of the idea to found the law of nature on socialitas and defends God's will as sole principle of natural law. In the second part of the dissertation, he defends his account of the law of nature against an anonymous author (who in fact was Leibniz), against Johann Peter von Ludewig and against Johann Nicolaus Hertius. ${ }^{61}$ In 1713 , Samuel Cocceji published a commentary on Justinian's Institutes, entitled Jus civile controversum, and in 1740 the Elementa jurisprudentiae naturalis et Romanae, which he later included, under the title 'Novum Systema Justitiae Naturalis \& Romanae', in the dissertations appended to the Grotius edition. ${ }^{62}$

The Coccejis' pronounced and radical critique of Grotius' voluntary law of nations has only recently aroused scholarly attention. Tetsuya Toyoda attempted to show that Samuel Cocceji rejected the voluntary law with the intention to please Frederick II, who 'disturbed the then fragile balance of power in Europe' when he started the First Silesian War (1740-1741). ${ }^{63}$ While Toyoda

Samuel von,' accessed 3 February 2018, ibid.: http://www.oxfordreference.com/view/ 10.1093/acref/9780199797097.001.0001/acref-9780199797097-e-0101. In the Englishlanguage literature, Samuel Cocceji's natural law theory has mainly been studied with an interest in the use Adam Smith made of it in his Lectures on jurisprudence. See Knud Haakonssen, Natural Law and Moral Philosophy. From Grotius to the Scottish Enlightenment (Cambridge: Cambridge University Press, 1997), 129-148; Ernest Metzger, 'Adam Smith's historical jurisprudence and the "method of the civilians", in Smith in Glasgow 'og, 31 March-2 April 2009, Glasgow, UK, accessed 3 February 2018, http://eprints.gla.ac.uk/ $25492 /$.

6o Samuel Cocceji, TractatusJuris Gentium, de principiojuris naturalis unico, vero, et adaequato (Frankfurt an der Oder: Jeremiae Schreyi Haered. \& Joh. Christoph. Hartmann, 1702).

61 On the controversy between Leibniz and the Coccejis see Hans-Peter Schneider, 'Die wissenschaftlichen Beziehungen zwischen Leibniz und den beiden Cocceji (Heinrich und Samuel), in Humanismus und Naturrecht in Berlin-Brandenburg-Preussen, ed. Hans Thieme (Berlin, New York: de Gruyter, 1979), 90-102.

62 This was the twelfth dissertation, much longer than the other dissertations.

63 Toyoda, Theory and Politics of the Law of Nations, 137. Toyoda mentions in the same context (ibid., 139) that Samuel Cocceji published pamphlets legitimizing the Prussain seizure of Silesia in order to obtain the Frederick II's patronage. 
seems to acknowledge that Samuel had already mentioned the voluntary law of nations in his dissertation of 1702 and again in the Jus civile controversum of $1713,{ }^{64}$ he downplays the continuity between these latter works and the Introductio, i.e. the 12 dissertations he appended to his father's commentary on Grotius' work, where the rejection of the voluntary law of nations became much more important. What is more, he erroneously assumes that Samuel would have published the dissertation on the voluntary law already in the Elementa, which he published in 1740. This seems, however, not to be the case, for the latter comprised only the 'Novum Systema', which was to become the twelfth dissertation. ${ }^{65}$ Toyoda has, however, a good point when he claims that Samuel Cocceji's critique of Grotius' concept of solemn war, which rested on the voluntary law of nations, proved to be useful for justifying Frederick II's conquests in Silesia. In the ninth dissertation Cocceji argued, indeed, that a war cannot be considered just on both sides and that the justness of the cause of war remains suspended until God determines who has won the war by giving him the ultimate victory. ${ }^{66}$

Let us now have a closer look at Samuel Cocceji's fourth dissertation, which consists of two chapters. Before he gets to a detailed analysis of Grotius' account of the voluntary law of nations in the first chapter, ${ }^{67}$ he introduces the jus humanum voluntarium or jus gentium secundarium, which - as the doctores would hold - the human nations constituted between them 'as occasion and the necessities of human life required'.68 He goes on to observe that since the nations never got together and constituted such a law by common consent, it would be difficult to know what this law is and how it can be proved. He then recalls how his father proposed to deduce this law (by referring to the state of corruption) and how he conceived it himself in his earlier writings, where he likened the secondary law of nations to the law the Romans applied not just to their own people but to foreigners (extraneos) as well, which they admitted to this law 'out of necessity, and common utility'. ${ }^{69}$ This explanation of the jus gentium implied that there did not arise any obligation between the

\footnotetext{
64 Ibid., $142-143$.

65 See Metzger, 'Adam Smith's historical jurisprudence,' 11-12.

66 Toyoda, Theory and Politics of the Law of Nations, 145-148. S. Cocceji, 'Dissertatio prooemialis IX,' § CLXVIII, 242-243.

67 On various aspects of this chapter see Toyoda (note 66 above), and Walter Rech, Enemies of Mandkind. Vattel's Theory of Collective Security (Leiden/Boston: Martinus Nijhoff, 2013), 83-95.

68 S. Cocceji, 'Dissertatio prooemialis IV,' § I, 78: 'quod usu exigente, \& necessitatibus humanis'; this expression refers to the Institutes, book I, title II, 2.

69 Ibid., § IV, 79.
} 
nations and that the Roman people could therefore abrogate that law ad libitum and exclude the foreigners from it with the same right as they admitted them. Samuel Cocceji eventually adds that this interpretation contradicts the definition of the law of nations proposed by Tribonian, who maintained that the human nations established this law between them. ${ }^{70}$ This is in fact the main thesis the younger Cocceji defends in the second chapter of the dissertation. It rests on an argument about the proper interpretation of the jus gentium in the Corpus juris civilis. He attributes the erroneous definition either to Justinian or to Tribonian - who was named by the emperor Justinian as one of the commissioners charged with preparing the new imperial legal code and compares it to various other definitions of the law of nations in the Digest (or Pandects), which he attributes to Gaius and Hermogenian. Through these comparisons, he aims to demonstrate that, according to the Roman jurists, jus gentium, properly understood, is the same as jus naturae, which is accessible by human reason and does not rest on the nations' will. ${ }^{71}$ The secondary law of nations, which Grotius called jus gentium voluntarium, was a 'monster' which originated in an error of Tribonian. ${ }^{72}$

While we do not know why the Lausanne jurist Loys de Bochat took a specific interest in the Coccejis' comments on De jure belli ac pacis, there is no doubt that the latter strengthened the 'naturalist' account of the law of nations, which remained predominant in the context of the école romande until the publication of Vattel's Law of Nations. As we have seen above, Samuel Cocceji's rejection of the voluntary law of nations confirmed Barbeyrac's own defence of Pufendorf's position against Grotius. Given that Burlamaqui taught the law of nature and nations on the basis of Barbeyrac's French translations of Pufendorf's works, it comes as no surprise that he also identified the law of nations with the law of nature. It is, however, interesting to observe that in contradistinction to Pufendorf, who attached only marginal significance to treaties and to customary practices of states as possible source of law, ${ }^{73}$ Burlamaqui explicitly acknowledges treaty law and customary law as parts of the law of nations. We can summarize his teaching in the following way: ${ }^{74}$ the same law that

70 Ibid. The proposition he attributes to Tribonian refers again to the Institutes, book I, Title II, 2.

71 Ibid., §XXXIII-VI, 91-92.

72 Ibid., §XXXI, 91; §XLVI, 100.

73 Neff, Justice among Nations, 176.

74 I refer here to Jean-Jacques Burlamaqui, Principes du droit de la nature et des gens. Avec la suite du 'Droit de la nature' qui n'avait point encore paru, ed. Fortuné-Barthélemy de Félice, vol. vi (Yverdon: [F.-B. de Félice], 1768), 'Principes du droit des gens,' part I, chap. I, 1-14. Regarding the dissemination of Burlamaqui's thought, one needs of course to refer to 
is called natural law when applied to individuals is called the law of nations when applied to states. The principle of the law of nations is the general law of sociability (sociabilité), which imposes on peoples or on their sovereigns the same duties to which individuals are subject. ${ }^{75}$ Burlamaqui holds that Grotius' view of the positive law of nations - as a kind of human law, which acquired its obligatory force as an effect of the will of nations - is in fact 'a supposition destitute of foundation. ${ }^{76} \mathrm{He}$ develops three arguments against the voluntary law of nations: first, since nations are equal and independent from each other, only God, their common superior, can impose a law binding them all; secondly, if nations establish customs by express or tacit agreements, these practices are not obligatory by themselves, neither universally nor forever, since customs do not impose on nations any necessity to act always in the same way, and neither are other nations obliged to respect them; and thirdly, customs cannot constitute any obligatory rule, since they might be bad or unjust. Burlamaqui mentions as examples the profession of corsair or pirate, which was for a long time considered legitimate on the grounds of a tacit agreement between nations, and the use of poisoned arms in war. As he sees it, these are barbarous practices, which cannot be part of the law of nations. Customs have to be judged on the basis of the law of nature, and nations may be held responsible for respecting them only as long as they do not explicitly renounce them. ${ }^{77}$

Burlamaqui concludes his critique of Grotius with a proposal to reconcile the previous reasoning by distinguishing two kinds of law of nations: first, a law of nations that is universal, necessary and obligatory by itself, and that is the same as the law of nature; and second, another kind of law of nations, which one might call arbitrary and of liberty, founded on an express or tacit convention. This second kind of law is not universal and obliges only those who subject themselves voluntarily to it and only as long as they wish to do so, insofar as the law of nature requires compliance with contracts. ${ }^{78}$

If we consider Burlamaqui's conclusion together with his critique of the voluntary law of nations, it presents itself like a blueprint of Vattel's concept of the law of nations. In contradistinction to the former, however, Vattel defends the voluntary law of nations instead of rejecting it. Indeed, he acknowledges three kinds of law of nations. First is the natural or necessary law of nations

previous editions, above all to Thomas Nugent's English translations. See note 12 above, and Neff, Justice among Nations, 177.

75 Ibid., part I, chap. I, § IV, p. 5 .

76 Ibid., § VII, 8.

77 Ibid., § VII, 8-9.

78 Ibid., § VIII, 9-11. 
which results from the application of the law of nature to states or nations. Like Barbeyrac in the note on Grotius we have been looking at above, Vattel confirms that the law of nations would slightly change when one applies it to states instead of individuals. ${ }^{79}$ The second kind of law of nations is the voluntary law; this is the jus gentium voluntarium which Grotius defended and which the Pufendorfians and the Coccejis deemed to be a 'chimera'. The third kind of law of nations Vattel acknowledges corresponds to Burlamaqui's arbitrary law of nations, which is founded on an express or tacit convention; this is the customary and treaty law. ${ }^{80}$ The fact that Vattel numbers the voluntary law of nations, together with customary and treaty law, among the positive law of nations is at the foundation of much dispute about the proper interpretation of his concept of the law of nations. While many scholars consider his treatise to inaugurate a positivist account of the law of nations, the present reconstruction of the debates surrounding the voluntary law of nations rather suggests that Vattel resumed the dualist conception Grotius had founded by introducing the jus gentium voluntarium. In fact, Vattel conceived of the law of nations as 'double law' by distinguishing the natural or necessary law of nations from the law of nations properly so called, which originates in the common consent of mankind. ${ }^{81}$ While these two kinds of law are universal, customary and treaty law, which also rest on the agreement of nations, are binding only on parties to the agreement in question.

This account of the law of nations corresponds exactly to the division Wolff indicated already on the title page of his Jus gentium (1749), ${ }^{82}$ and this work was indeed Vattel's main reference for developing the law of nations. As I mentioned in the first part of this chapter, Vattel repudiated, however, the mathematical method as well as Wolff's top-down strategy for founding the law of nations. ${ }^{83}$ Hence, he rejected Wolff's proposal to derive the voluntary law of nations from the idea of a civitas maxima, or 'great republic'. In his view, this fiction was neither admissible in itself nor would it ever receive the 'obedient acquiescence of sovereign states', which claimed and actually possessed absolute independence from each other. Instead of deducing the voluntary law of

79 Emer de Vattel, The Law of Nations, ed. and with an introduction by Béla Kapossy and Richard Whatmore (Indianapolis, IN: Liberty Fund, 2008), 'Preface,' 9-10.

8 o Ibid., $15^{-17}$.

81 Ibid., 17. I have dealt with these matters more extensively in Zurbuchen, 'Emer de Vattel on the Society of Nations and the Political System of Europe'.

82 Christian Wolff, Jus gentium methodo scientifica pertractatum, in quo jus gentium naturale ab eo, quod voluntarii, pactitii et consuetudinarii est, accurate distinguitur (Halle: Renger, 1749).

83 I borrow the expression 'top-down strategy' from Neff, Justice among Nations, 181. 
nations from the fiction of a great republic, Vattel develops this law on the basis of the distinction of internal and external right, which he also borrowed from Wolff. This allowed him to explain how the voluntary law of nations works in partnership with the natural or necessary law of nations and supplements it in various respects: what nations may do by internal right is stated in the natural or necessary law; the voluntary law regulates the domain of external right. Whereas the necessary law corresponds to the immutable laws of justice', which enjoin an obligation on the conscience of nations, the voluntary law indicates what needs to be tolerated in a society of free and independent nations. ${ }^{84}$ Vattel makes it very clear that the voluntary law of nations does not rest on the actual consent of nations. The latter are rather presumed to consent to it by the law of nature, which obliges them not to infringe on their common rights, and especially on the right to decide freely about what justice requires them to do or to omit to do when it comes to a dispute between nations. As Neff has rightly observed, Vattel has sometimes been 'misunderstood as a radical champion of state sovereignty'. ${ }^{85}$ While it is true that he insisted on the legal equality of sovereign nations, he did not, however, renounce the idea that the latter remained subject to the natural or necessary law of nations - a law he claimed rested on general principles and demonstration. Given that he relied on examples in modern history to illustrate his doctrine and that he used the notion of the voluntary law of nations as a flexible tool for showing what nations need to tolerate 'through necessity' in order to respect each other as equal and independent, it seems wholly accurate to place Vattel at the midpoint between rationalist top-down deduction and a pragmatist bottom-up approach to international relations. ${ }^{86}$

\section{Conclusion}

As we have seen in section 2 of this chapter, it is not wholly clear for what reasons the Swiss undertook a multi-volume edition of Grotius' De jure belli ac pacis around the middle of the eighteenth century. After all, they must have been aware that this work had already been published many times in Latin, translated into modern languages and explained in a great number of handbooks and

\footnotetext{
84 Vattel, The Law of Nations, 'Preface,' 14-16.

85 Neff, Justice among Nations, 197.

86 Ibid., 182.
} 
commentaries. ${ }^{87}$ Although Loys de Bochat, who participated in the preparation of the edition, certainly had his own good reasons for studying the law of nations when he attempted to defend the Swiss practice of mercenary service abroad, it remains unclear why he had a special interest in the Coccejis' highly critical commentary of Grotius' dualist account of the law of nations. Given his involvement in the foundation of the publishing company Bousquet \& Cie. in Lausanne and in light of Bousquet's subscription campaign in Italy, I am tempted to conclude that this Grotius edition was above all undertaken for commercial reasons. Samuel Cocceji's pronounced and radical critique of the voluntary law of nations certainly strengthened the naturalist account of the law of nations of Pufendorf and his adherents, who were indeed predominant in the Swiss school of natural law. It seems, however, that the Coccejis' theories of the law of nature and nations did not have any further influence in the Swiss context. This is certainly due to the immediate success of Vattel's Law of Nations, which appeared only a few years after the Grotius edition was published. Vattel never refers to the Grotius edition in his treatise. So far, almost nothing is known about reception of the Coccejis' theory of the law of nature and nations in the wider European context. As Christoph Link observed, Heinrich Cocceji was a well-known expert on public law in his own time. His fame faded rapidly, however, because of his son Samuel, who published the commentary on Grotius after his death and thus made the father speak through the son. What is more, Heinrich's historical foundation of the jus publicum RomanoGermanicum, which was innovative in his own time, was criticized in the nineteenth century by representatives of the historical law school and thus fell into near complete oblivion. 88

In contradistinction, Samuel Cocceji's theory of the law of nature and nations stimulated a number of controversies in the early eighteenth century. He was notably criticized by Leibniz, as well as by von Ludewig and Hertius, to whom he replied in the second dissertation of his Tractatus iuris gentium (1702). Because Samuel became famous as chief architect of Frederick II's law reforms, the theory of the law of nature and nations he had developed before he embarked on his political career has rarely been studied by contemporary

87 See Frank Grunert, 'The Reception of Hugo Grotius's De jure belli ac pacis in the early German enlightenment,' in Early Modern Natural Law Theories. Contexts and Strategies in the Early Enlightenment, ed. T.J. Hochstrasser and P. Schröder (Dordrecht, Boston, London: Kluwer, 2003), 92 and note 24.

88 Christoph Link, 'Menschenwürde und Gerechtigkeit als Staatszweck. Zum Werk Heinrich von Coccejis (1644-1719), in Die Ordnung der Freiheit. Festschrift für Christian Starck zum siebzigsten Geburtstag, ed. Rainer Grote et al. (Tübingen: Mohr Siebeck, 2007), 87-98. 
scholars. The only notable natural law scholar who showed real interest in the Coccejis' commentaries on Grotius was Adam Smith, and most of the research on the Coccejis' works on natural law has been undertaken to explain this. ${ }^{89}$ Regarding the law of nations, I attempted to show in section 3 of this chapter that Samuel's radical critique of the voluntary law of nations, which was first introduced by Grotius and marked a decisive turn in the history of the law of nations, further strengthened the 'naturalist' position of Pufendorf and his followers. The originality of Cocceji's fourth dissertation, which takes issue with the definition of the law of nations, rests on his hypothesis concerning the origin of the voluntary law of nations. As we have seen, he makes use of his expertise in Roman civil law in order to demonstrate that jus gentium proper does not rest on the nations' will. It was beyond the scope of this chapter to examine further aspects of the Coccejis' critique of De jure belli ac pacis. In the Swiss and indeed in the broader European context, it was the dualist account of the law of nations and the concept of the voluntary law in particular which became predominant in the second half of the eighteenth century, mainly through the influence of Emer de Vattel's Law of Nations.

\section{Bibliography}

Bisset, Sophie, 'Exploring the parameters of the école romande du droit naturel in the Journal helvétique: the case of Louis Bourguet's "Four letters on Leibniz", in Lectures du 'Journal helvétique', 1732-1782, ed. Séverine Huguenin and Timothée Léchot (Geneva: Slatkine, 2016), 315-328.

Bisset, Sophie, 'The reception of Pufendorf and Leibniz in the early école romande du droit naturel: Jean Barbeyrac and Louis Bourguet', Etudes Lumières.Lausanne, no. 7, février 2019, http://lumieres.unil.ch/fiches/biblio/9475/.

Borgeaud, Charles, Histoire de l'Université de Genève. L'Académie de Calvin, 1559-1798 (Geneva: Georg \& Cie., 1900).

Burlamaqui, Jean-Jacques, Principes du droit de la nature et de gens, ed. FortunéBarthélemy de Félice, 8 vols. (Yverdon: [de Félice], 1766-1768).

Burlamaqui, Jean-Jacques, Principles of Natural and Politic Law, transl. Thomas Nugent, ed. and with an introduction by Petter Korkman (Indianapolis, IN: Liberty Fund, 2006).

89 See Haakonssen, Natural Law and Moral Philosophy, 135-153; Metzger, 'Adam Smith's historical jurisprudence'. 
Clavel de Brenles, Abraham Daniel, De exemptione legatorum, a foro criminali ejus ad quem missi sunt (Marburg: Phil. Casim. Muller, 1740).

[Clavel de Brenles, A.D.], Eloge historique de Monsieur Charles Guillaume Loys de Bochat (Lausanne: Antoine Chapuis, 1755).

Cocceji, Henrici de, Grotius illustratus seu commentarii ad Hugonis Grotii de juri belli ac pacis libros III, ed. Samuel de Cocceji, 4 vols. (Wratislaviae: Johann Jacob Korn, $\left.1744-5^{2}\right)$.

Cocceji, Samuel, Tractatus Juris Gentium, de principio juris naturalis unico, vero, et adaequato (Frankfurrt an der Oder: Jeremiae Schreyi Haered. \& Joh. Christoph. Hartmann, 1702).

Corsini, Silvio, 'Vint-cinq ans d'édition et d'imprimerie à Lausanne au siècle des Lumières: le libraire Marc-Michel Bousquet, 1736-1761,' Revue historique vaudoise 120 (2012), 23-53.

Crucitti-Ullrich, Francesca Bianca, 'Bibliothèque italique (1728-1734),' in Dictionnaire des Journaux 160o-1789, accessed 2 February 2018, http://dictionnaire-journaux.gazettes18e.fr/journal/o165-bibliotheque-italique.

Grotius, Hugo, Le droit de la guerre et de la paix, transl. Jean Barbeyrac (Amsterdam: Pierre de Coup, 1724).

Grotius, Hugo, De jure belli ac pacis libri tres, 5 vols. (Lausanne: Marc-Michel Bousquet \& Cie., 1751-1752).

Grotius, Hugo, Recht des Krieges und des Friedens, transl. J.H. von Kirchmann (Berlin: L. Heimann, 1869).

Grotius, Hugo, De jure belli ac pacis libri tres, transl. of the ed. of 1646 by Francis W. Kelsey (The Classics of International Law, Oxford: Clarendon Press, 1925).

Grotius, Hugo, On the Law of War and Peace, ed. Stephen C. Neff (Cambridge: Cambridge University Press, 2012).

Grunert, Frank, 'The Reception of Hugo Grotius's De jure belli ac pacis in the early German enlightenment,' in Early Modern Natural Law Theories. Contexts and Strategies in the Early Enlightenment, ed. T.J. Hochstrasser and P. Schröder (Dordrecht, Boston, London: Kluwer, 2003).

Haakonssen, Knud, Natural Law and Moral Philosophy. From Grotius to the Scottish Enlightenment (Cambridge: Cambridge University Press, 1997).

Haggenmacher, Peter, 'Völkerrecht,' in Historisches Lexikon der Schweiz, accessed 2 January 2018, http://www.hls-dhs-dss.ch/textes/d/D9619.php.

Kadelbach, Stefan, 'Hugo Grotius: On the Conquest of Utopia by Systematic Reasoning', in System, Order, and International Law. The Early History of International Legal Thought from Machiavelli to Hegel, ed. Stefan Kadelbach, Thomas Kleinlein and David Roth-Isigkeit (Oxford: Oxford University Press, 2017), 134-159.

Link, Christoph, 'Menschenwürde und Gerechtigkeit als Staatszweck. Zum Werk Heinrich von Coccejis (1644-1719),' in Die Ordnung der Freiheit. Festschrift für Christian 
Starck zum siebzigsten Geburtstag, ed. Rainer Grote et al. (Tübingen: Mohr Siebeck, 2007), 87-98.

Loys de Bochat, Charles-Guillaume, Dissertatio inauguralis juridica de optimo principe (Basileae: typis Friderici Lüdij, 1717).

Loys de Bochat, Charles-Guillaume, Ouvrages pour et contre les services militaires étrangers, 3 vols. (Lausanne \& Genevae: Marc-Michel Bousquet \& Cie., 1738).

Metzger, Ernest, 'Adam Smith's historical jurisprudence and the "method of the civilians", in Smith in Glasgow 'og, 31 March-2 April 2009, Glasgow, UK, accessed 3 February 2018, http://eprints.gla.ac.uk/25492/.

Neff, Stephen C., Justice among Nations. A History of International Law (Cambridge, MA: Harvard University Press, 2014).

Peglow, Oliver, 'Cocceji, Heinrich von (1644-1719),' in The Dictionary of EighteenthCentury German Philosophers, ed. Heiner F. Klemme and Manfred Kuehn, vol. 1 (London: Continuum, 2010).

Peglow, Oliver, 'Cocceji, Samuel von (1679-1755),' in The Dictionary of EighteenthCentury German Philosophers, ed. Heiner F. Klemme and Manfred Kuehn, vol. 1 (London: Continuum, 2010).

Perrochon, Henry, 'Un savant d'autrefois: G.-Ch. Loys de Bochat (1695-1754),' Revue historique vaudoise 49 (1941): 29-33.

Philippe Meylan, Jean Barbeyrac (1674-1744) et les débuts de l'enseignement du droit dans l'ancienne Académie de Lausanne (Lausanne: F. Rouge \& Cie., 1937).

Poudret, Jean-François et al., L'enseignement du droit à l'Académie de Lausanne aux XVIII et XIXe siècles (Université de Lausanne, 1987).

Pufendorf, Samuel, Of the Law of Nature and Nations, transl. Basil Kennett, 4 th ed. (London: J. Walthoe, R. Wilkin, J. and J. Bonwicke, S. Birt, T. Ward and T. Osborne, 1729).

Rech, Walter, Enemies of Mankind. Vattel's Theory of Collective Security (Leiden, Boston: Martinus Nijhoff, 2013).

Schneider, Hans-Peter, 'Die wissenschaftlichen Beziehungen zwischen Leibniz und den beiden Cocceji (Heinrich und Samuel),' in Humanismus und Naturrecht in Berlin-Brandenburg-Preussen, ed. Hans Thieme (Berlin, New York: de Gruyter, 1979), 90-102.

Toyoda, Tetsuya, Theory and Politics of the Law of Nations. Political Bias in International Law Discourse of Seven Court Councilors in the Seventeenth and Eighteenth Centuries (Leiden, Boston: Martinus Nijhoff, 2011).

Vattel, Emer de, Le Droit des Gens, ou Principes de la Loi Naturelle, appliqués à la Conduite \& aux Affaires des Nations \& des Souverains (Londres, 1758).

Vattel, Emer de, The Law of Nations, ed. and with an Introduction by Béla Kapossy and Richard Whatmore (Indianapolis, IN: Liberty Fund, 2008).

Vitriarius, Philipp Reinhard, Institutiones juris naturae et gentium [...] ad methodum Hugonis Grotii (Lausanne: Antoine Chapuis, 1745). 
Wolff, Christian, Jus gentium methodo scientifica pertractatum, in quo jus gentium naturale ab eo, quod voluntarii, pactitii et consuetudinarii est, accurate distinguitur (Halle: Renger, 1749).

Zurbuchen, Simone, 'Bourguet, Louis (1678-1742),' in The Dictionary of EighteenthCentury German Philosophers, ed. Heiner F. Klemme and Manfred Kuehn, vol. 1 (London: Continuum, 2010), 135-137.

Zurbuchen, Simone, 'Théorie de la guerre juste et balance du pouvoir en Europe', in L'Europe en province: la Société du comte de la Lippe (1742-1747). Actes du colloque organisé à l'Université de Lausanne du 25 au 26 juin 2009, ed. Béla Kapossy et al. (Lausanne: Lumières.Lausanne, 2013): http://lumieres.unil.ch/fiches/biblio/5687/.

Zurbuchen, Simone, 'Emer de Vattel on the Society of Nations and the Political System of Europe,' in System, Order, and International Law, ed. Stefan Kadelbach, Thomas Kleinlein and David Roth-Isigkeit (Oxford: Oxford University Press, 2017), 263-282.

Zurbuchen, Simone, 'Teaching the Law of Nature and Nations in the Swiss Context', Etudes Lumières.Lausanne, no. 6, novembre 2018, http://lumieres.unil.ch/fiches/ biblio/9472/. 


\title{
Vattel's Doctrine of the Customary Law of Nations between Sovereign Interests and the Principles of Natural Law
}

\author{
Francesca Iurlaro
}

\section{Introduction}

At the beginning of book II of his Law of Nations, Emer de Vattel expresses his fear that

the following maxims will appear very strange to cabinet politicians: and such is the misfortune of mankind, that, to many of those refined conductors of nations, the doctrine of this chapter will be a subject of ridicule. Be it so! - but we will nevertheless boldly lay down what the law of nature prescribes to nations. Shall we be intimidated by ridicule, when we speak after Cicero? [...] The punctual observance of the law of nature he considered as the most salutary policy to the state. ${ }^{1}$

Vattel's concerns might appear ironic to the contemporary reader, considering the immediate success of his book as the standard source for the positive law of nations. ${ }^{2}$

As a matter of fact, scholars have long insisted on the fundamental role Vattel's treatise played in the emergence ${ }^{3}$ of international law. However, more recent contributions have also emphasized the inherently normative character

1 References throughout the chapter are to the English translation of Vattel's Droit des Gens (1758) edited and with an Introduction by Béla Kapossy and Richard Whatmore: Emer de Vattel, The Law of Nations, or Principles of the Law of Nature, Applied to the Conduct and Affairs of Nations and Sovereigns, with Three Early Essays on the Origin and Nature of Natural Law and on Luxury (Indianapolis, IN: Liberty Fund, 2008).

2 On the pervasive reception of Vattel's Droit des Gens see Elisabetta Fiocchi Malaspina's chapter in this book, and her L'eterno ritorno del Droit des Gens di Emer de Vattel (secc. XVIIIXIX): L'impatto sulla cultura giuridica in prospettiva globale (Frankfurt: Max Planck Institute for European Legal History, 2017).

3 Emmanuelle Jouannet, Emer de Vattel et l'émergence doctrinal du droit international classique (Paris: Pedone, 1998). 
of Vattel's doctrine of the law of nations, by insisting on its relationship with the modern natural law tradition, embodied in the works of authors like Grotius, Pufendorf and Wolff, whose accounts Vattel challenged and discussed in the context of his own doctrinal analysis.

From this latter perspective, the present contribution seeks to address the question of the role of custom within Vattel's doctrine of the law of nations by establishing its close interconnection with natural law. In the modern age, custom became a powerful conceptual device natural law authors made use of in order to demonstrate the existence of norms which spontaneously originated from the will of European sovereigns, as a dynamic source of law situated between the demands of universality of natural law and the effectiveness required by positive law. Such an important role of custom, as both a pragmatic reality as well as a fundamental category of international relations, is one crucial, although neglected, ${ }^{4}$ feature of Vattel's legal doctrine. While seeking to fill this gap in the literature, the main claim of the present chapter is that Vattel's conceptualization of self-interest helps us to explain the role of natural law in the legitimization of the formation of custom ${ }^{5}$ according to a criterion of compliance. Notably, as Vattel claims, the foundation and compelling principle of natural law lies in the concept of self-interest, which is, in his account, the best and the safest means for securing the collective interests of nations. From this perspective, providing a close analysis of selfinterest as a basis for Vattel's theory of custom serves a double purpose. On the one hand, it helps us to understand why custom is such a powerful means to reconcile the interests of sovereign nations with collective justice. Indeed, according to Vattel, despite being based on tacit consent, the customary law of nations allows states to facilitate mutual cooperation by being clearer and more explicit about what kind of rules they want to be bound by. Promoting such a state of affairs is, in other words, one of the possible legal options states have at their disposal to pursue their own self-interest, only to find out

4 Some reference to the importance played by custom in Vattel's doctrine of the law of nations is made by Peter Haggenmacher, 'Introduction: Le modèle de Vattel et la discipline du droit international,' in Vattel's International Law from a XXIst Century Perspective / Le Droit international de Vattel vu du XXIe siècle, ed. Vincent Chetail and Peter Haggenmacher (Leiden: Brill, 2011), 1-48.

5 The distinction between the formation and the identification of the customary law of nations in Vattel is discussed below. The terms 'formation' and 'identification', commonly used in international legal scholarship, refer to the doctrinal distinction between the process leading to the formation of customary international law and its subsequent identification by the jurist. On this aspect, see M. Wood, First Report on the Formation and Evidence of Customary International Law, International Law Commission 65th Session, A/CN.4/663. 
that such interest (as well as that of other states) is best guaranteed by compliance with natural law.

On the other hand, this analysis sheds further light on the debate concerning the allegedly 'Hobbesian' foundation of Vattel's law of nations. It aims to show that, by reconceptualizing Christian Wolff's notion of perfectio in terms of self-interest, Vattel is actually making an anti-Hobbesian claim about the natural state of liberty in which all nations live. Indeed, he argues that even if such a fictional natural state of liberty did exist, nations would not mutually destroy each other, because of the likely terminal consequences of their reciprocal aspirations. They would rather be able to govern themselves exclusively through natural law precisely because custom provides states with a valid legal means to secure their individual and collective interests at one and the same time.

Although Vattel repudiates Wolff's concept of the civitas maxima, the ideal of a general society of nations nonetheless plays an important regulatory role in his doctrine of custom. He replaces Wolff's teleology of perfectio with a more pragmatic approach, which takes into account the liberty and independence of sovereign states as its fundamental, non-derogable principle.

In order to prove this, I will articulate the analysis in three sections. First of all, I will address the question of the relationship between Vattel and Wolff, to whose doctrine he explicitly refers, by pointing out both continuity and ruptures within Vattel's reception of Wolff. Secondly, I will take into account the distinction made by Vattel between the natural, the voluntary and the conventional law of nations. Custom belongs to the last legal regime, although it is closely related to natural law, as I have already pointed out. Finally, I will provide a sketch of Vattel's concept of the customary law of nations, by describing its general rules and providing examples of different cases and circumstances to which they apply.

Vattel vs. Wolff: Self-Interest as the Foundational Principle of Natural Law

As is commonly known, Vattel declaredly engages in a vulgarization of Wolff's doctrine but with some significant differences. The most relevant of them regards the question of the application of the law of nature to states. Indeed, according to Vattel, Wolff has the merit of having realized that 'the law of nature could not, with such modifications as the nature of the subjects required, and with sufficient precision, clearness, and solidity, be applied to incorporated nations or states, without the assistance of those general principles and leading 
ideas by which the application is to be directed. 6 But what exactly are 'those general principles' that should lead the application of natural law to the conduct of states? Vattel excludes the possibility of relying on a civitas maxima both as a political and as a conceptual framework through which such law can be applied. Wolff conceived of the civitas maxima as a quasi-political community of nations aimed at perfecting each other. ${ }^{7}$ Quite on the contrary, for Vattel, the fact that the principles of natural law have to be applied to states does not mean that it is necessary to coerce them into a political community, since by their natural liberty they are already gathered together to live in a natural society. ${ }^{8}$ Furthermore, Vattel argues that natural law is designed for governing human individuals, who essentially differ from nations. That is why Vattel insists on the essential feature of states, namely sovereignty, and conceives of the application of natural law to them accordingly. ${ }^{9}$

As a matter of fact, Vattel replaces Wolffian perfectio (i.e. the teleological orientation of human reason as the foundation of obligation) with self-interest. From this perspective, it has generally been argued in the literature that, by making this choice, Vattel is actually endorsing a Hobbesian view of the law of nature and, consequently, of the law of nations. ${ }^{10}$ However, on closer analysis,

6 Vattel, The Law of Nations, 10. According to Hunter, there are two senses in which the word 'application' as used by Vattel in this particular context has been interpreted by scholars. The first one is that employed by Jouannet, who implies that 'application' refers to the 'practical' application of principles. Such interpretation relies on the view that there is a presumption of general acceptance behind and justifying such application (Ian Hunter, 'Law, War and Casuistry in Vattel's Jus Gentium,' Parergon, 28/2 (2011): 92, quoting Emmanuelle Jouannet, Emer de Vattel et l'émergence doctrinale, 403-417). Another interpretation is that provided by Hunter himself; see below.

7 Christian Wolff, Jus gentium methodo scientifica pertractatum (Halle: Renger, 1749), § 10; on the concept of civitas maxima, see also Nicholas G. Onuf, 'Civitas Maxima: Wolff, Vattel and the Fate of Republicanism,' American Journal of International Law 88/2 (1994): 280303; Georg Cavallar, 'Vitoria, Grotius, Pufendorf, Wolff and Vattel: Accomplices of European Colonialism and Exploitation or True Cosmopolitans?' Journal of the History of International Law, 10/2 (2008): 181-209. Thomas Kleinlein, 'Christian Wolff: System as an Episode?' in System, Order and International Law: the Early History of International Thought from Machiavelli to Hegel, ed. Stephan Kadelbach, Thomas Kleinlein and David Roth-Isigkeit (Oxford: Oxford University Press, 2017), 216-239.

8 Vattel, The Law of Nations, 14.

9 Stéphane Beaulac, 'Emer de Vattel and The Externalization of Sovereignty,' Journal of the History of International Law, 5 (2003): 247.

10 As argued by Quentin Skinner, From Humanism to Hobbes: Studies in Rhetoric and Politics (Cambridge: Cambridge University Press, 2018); Andrew Hurrell, 'Vattel: Pluralism and its Limits,' in Classical Theories of International Relations, ed. Ian Clark and Iver B. Neumann (London: Macmillan Press 1996), 236. 
the way Vattel conceptualizes self-interest shows discontinuity rather than coherence with the Hobbesian model, in which self-interest undermines the collective goal of security and justice and only the public person of the sovereign can abstract from private self-interest to promote the common good. ${ }^{11}$

Vattel makes use of the concept of self-interest to provide natural law with a solid foundation, and jurists with a useful criterion to identify customary norms. In his words, the coercive power of natural law resides in the basic motive behind our actions, creating a situation where motives and actions coincide (which is a requirement for the fulfilment of an obligation): 'each individual has as a general and overriding motive his own self-interest, and this motive creates the obligation to which he is liable.' ${ }^{12}$ The link Vattel establishes here between self-interest and obligation contradicts the Hobbesian assumption that self-interest does not provide us with an appropriate reason to comply with the law - unless one conceives of the law, as Pufendorf did, as the command of a superior. ${ }^{13}$ Vattel refutes this objection by replying 'that when we say that self-interest provides the foundation or the principle of obligation, we are speaking of a noble and agreed expediency, which is located mainly in the observance and practice of virtue - because this observance and practice brings us closer to perfection' and 'reconciles us with the good will of the Creator. ${ }^{14}$ What Vattel means to say here is that this principle of 'noble [...] expediency' brings us closer to true perfection, insofar as it imitates the justice of God. ${ }^{15}$ This imitation produces, according to Vattel, pleasure in our action itself ${ }^{16}$ and, most notably, justice - an outcome that would not be conceivable within a Hobbesian framework.

This fundamental change of perspective on self-interest and obligation also allows Vattel to conceive of the relationship between states in a different way from Wolff: the interest of nations is to pursue their own good in a society to

11 Thomas Hobbes, Leviathan, ed. Edwin Curley (Indianapolis, IN: Hackett, 1994), 61. On the role of self-interest see Pierre Force, Self-Interest before Adam Smith: a Genealogy of Economic Science (New York: Cambridge University Press, 2003); Christopher Brooke, Philosophical Pride: Stoicism and Political Thought from Lipsius to Rousseau (Princeton: Princeton University Press, 2012), 69-75.

12 Emer de Vattel, Essay on the Foundation of Natural Law and on the First Principle of the Obligation Men find Themselves Under to Observe Laws, in The Law of Nations, 754. This essay was originally published by Vattel in his Le loisir philosophique ou pieces diverses de philosophie, de morale et d'amusement (Dresde: George Conrad Walther, 1747).

13 Samuel Pufendorf, De iure naturae et gentium libri octo (Lund: Junghans, 1672), book I, chap. I, § 3 .

14 Vattel, Essay on the Foundation of Natural Law, 762.

15 Ibid., 771.

16 Ibid. 
which they naturally belong, with no need to rely on the idea of civitas maxi$m a$. From this perspective, self-interest seems to be the most honest of collective interests: it allows a non-judgemental space in which no nation can intrude into the internal sphere of judgment of the other and, by doing so, it allows them to pursue their own national and international perfection. The perfection of self-interest ideally consists in compliance with natural law; however, it might be the case that nations do not understand this clearly, resulting in a potential conflict of sovereign interests with collective ones. Ideally, Vattel argues, self-interest, rightly understood, would not imply this kind of conflict; he admits, however, that, in reality, states often pursue what Pufendorf called 'imaginary' interests and thus seek to realize their pretensions to supremacy. ${ }^{17}$ On a more theoretical level, Vattel has faith that the interests of sovereign states should not collide with the desire to achieve justice. This claim rests on a specific view of the natural state of liberty that will be addressed in the next section. Vattel is convinced of the fact that individuals and states, if left in a state of nature, are the best version of themselves that they can be. To remember what their original condition is, one must engage in a fictional reasoning, namely to think of states as if they behaved how they are naturally supposed to do. The ultimate aim of such faith in the potentialities of sovereign states results, at the international level, in the construction of a space of peace and security.

To conclude this section, let us come back to the comparison between Vattel and Wolff: as a consequence of the way in which he proposes to apply natural law to sovereign states, Vattel's understanding of law as a perfecting device is less 'totalizing' than that of Wolff. Nonetheless, he maintains in his legal doctrine a tendency towards a higher degree of perfection, which cannot always be realized by the actual course of events but that nonetheless provides natural law with a solid principle.

Distinguished, Yet Not Treated Separately: Natural and Positive Law of Nations

Having made these clarifications, let us now move to the analysis of the impact of Vattel's reading of Wolff on his doctrine of the law of nations. Vattel divides the latter into natural (or necessary), voluntary and conventional law

\footnotetext{
17 An issue brought up by Pufendorf, who referred to this phenomenon as the 'imaginary interests of state' (Pufendorf, De jure naturae et gentium, book VIII, chap. VI, § 2).
} 
of nations (i.e. treaties and customs). In order to understand the place and importance of the customary law of nations within Vattel's doctrine, it is important to highlight the main characteristics of the law of nations as a whole. As with the 'droit des gens naturel', Vattel claims it is necessary, immutable and consists in the application of the principles of natural law to the conduct of states. ${ }^{18}$ As we have said, according to Vattel the application of natural law to nations is mediated by the concept of sovereignty and, therefore, produces two important effects. On the one hand, natural law promotes general perfection of the society of nations; on the other hand, it also has to preserve each nation's independence, equality and freedom of judgement.

The question of how Vattel seeks to reconcile these two fundamental obligations is one of the most controversial concerning his thought. ${ }^{19}$ The coexistence of these two elements - the independence of sovereign judgement and a striving for justice (an outcome of Vattel's doctrine of self-interest) generates, according to Hunter, a 'double law'.20 This double law, on the one hand, consists in the natural law of nations binding the conscience of states; on the other, it consists in the voluntary law of nations, the rules of which are deduced from natural law: 'since nations are free, independent, and equal, - and since each possesses the right of judging, according to the dictates of her conscience, what conduct she is to pursue in order to fulfil her duties, - the effect of the whole is, to produce, at least externally and in the eyes of mankind [my emphasis], a perfect equality of rights between nations, in the administration of their affairs and the pursuit of their pretensions, without regard to the intrinsic justice of their conduct, of which others have no right to form a definitive judgment; so that whatever may be done by any one nation, may be done by any other; and they ought, in human society, to be considered as possessing equal rights. ${ }^{21}$ However, as we have described, the foundation of such a voluntary law of nations is conceived of by Vattel in opposition to that of Wolff (namely, based on a principle of selfinterest rather than on mere perfectio). ${ }^{22}$ Indeed, what is relevant here is that both the natural and the voluntary law of nations are derived by Vattel from

\footnotetext{
18 Vattel, The Law of Nations, 70.

19 For a famous positivist interpretation of the Vattelian law of nations see Peter Pavel Remec, The Position of the Individual in International Law according to Grotius and Vattel (The Hague: Martinus Nijhoff, 196o).

20 Hunter, 'Law, War and Casuistry,' 92.

21 Vattel, The Law of Nations, 75.

22 Zurbuchen, 'Emer de Vattel on the Society of Nations and the Political System of Europe,' 268.
} 
nature; ${ }^{23}$ perhaps for this reason, Vattel's account of the voluntary law of nations is particularly confusing.

Instead of presenting here the various proposals for dealing with the relationship between the natural and the voluntary law of nations, ${ }^{24} \mathrm{I}$ expose what I consider to be at the origin of the difficulty in properly understanding how Vattel connected these two kinds of law of nations. This is the (unresolved Wolffian) relationship between natural law and perfectio. How should we conceive of an international society based on the dichotomy between the independence of sovereign nations and the obligation to achieve perfectio? This question is further addressed by Vattel in his Dissertation on this question: Can Natural Law Bring Society to Perfection Without the Assistance of Political Laws?25 Vattel says that 'if men were as they ought to be', natural law itself would be sufficient to bring society to perfection. ${ }^{26}$ To prove this point, he provides an interesting thought experiment:

Let us imagine one thousand people of both sexes, chosen from the most rational and virtuous in Europe, and that together they form a kind of small republic. Who can doubt that this society would not be better regulated by natural law alone, than has been any other state with the support of political laws? These one thousand people will be enlightened enough to get to know natural law, and to be convinced that their best interest requires that they conform to it exactly. As a result, their society will be as perfect a human society as any such can. They will have a body of law, just, wise, and complete, which is known to all the members and accompanied by sufficient incentives to shape their will. Without the need for subordination to the authority of a government, they will acknowledge themselves under the obligation of this law that they derive from nature to provide for the common good. They will focus their talents and labor on this goal; everyone will compete to preserve order and peace.

\footnotetext{
23 Ibid.

24 On the debate concerning Vattel's natural and voluntary law of nations, see Haggenmacher, 'Introduction: Le modèle de Vattel et la discipline du droit international'; Remec, The Position of the Individual; Gabriella Silvestrini, 'Justice, War and Inequality. The Unjust Aggressor and the Enemy of the Human Race in Vattel's Theory of the Law of Nations,' Grotiana, 31 (2010): 44-68; Charles Covell, The Law of Nations in Political Thought: A Critical Survey from Vitoria to Hegel (New York: Palgrave Macmillian, 2009), 95-106.

25 A translation of this essay, originally published by Vattel in his Le loisir philosophique ou pieces diverses de philosophie, de morale et d'amusement (Dresde: George Conrad Walther, 1747), can be found in Vattel, The Law of Nations, 773-781. Ibid., 776 .
} 
If differences arise, they will choose arbitrators to resolve them. And if it should happen that one individual, possessed by the force of a violent passion, departs from his duty, then the others, whose reason would not be obscured by the same clouds, would they not readily and with one will restrain him without provoking the least social dislocation? Some might vainly object that regulations would be required for trade, for example, or for crucial periods of war and epidemic disease, and a sovereign authority to ensure that they are observed. But reason will promote wise measures in these instances to the people as we have imagined them, and natural law will oblige them to preserve those rules devotedly, as they will tend to social benefit. But men are very different from what they ought to be and from these one thousand people of whom we have just spoken. ${ }^{27}$

People do not always know the real content of natural law and are not that well informed of the fact that their interests are better pursued by compliance with natural law. Thus, according to Vattel, the answer to this problem is to 'extend the knowledge of natural law by making its application easy, and as a result reducing it to clearly publicized general rules' and to establish 'public authority, and adding a positive obligation to natural obligation, through the means of punishment. ${ }^{28}$ This passage recalls the paragraph in the Law of Nations in which Vattel says that we ought 'to produce, at least externally and in the eyes of mankind [my emphasis], a perfect equality of rights between nations'. Publicity is what helps us achieve this goal. Therefore, Vattel says, 'in the current condition of the human race, natural law cannot bring society to perfection without the assistance of political laws'.29 This statement seems to imply for Vattel that, whereas the possibility of an international legal order governed by a self-legislating natural law sounds unfeasible in his particular historical moment, this does not prevent us from knowing that we are in principle capable of that. To understand this, we must engage in some fictional reasoning, by thinking of human beings as if they were in their natural state of liberty; additionally, we should promote the signing of agreements among nations to secure their reciprocal rights.

As we briefly mentioned above, besides the natural and the voluntary law of nations, Vattel introduces yet another kind of law of nations, that is, conventional law, to which treaties and custom belong. Interestingly, for Vattel, custom plays a fundamental connecting role between the voluntary law of nations

\footnotetext{
27 Vattel, Dissertation, in The Law of Nations, 777.

28 Ibid., 779 .

29 Ibid.
} 
(which comprises the rules indicating what nations need to tolerate between them in order to respect each other's sovereignty and independence) and treaties (as proactive means to secure the interests of states and the scope of what they can demand from others).

Whereas treaties rely on express consent, custom is based on tacit consent. However, Vattel conceives of tacit consent in an innovative way. The fact that it is tacit refers to its formation, but not to its identification: in other words, nations are invited to publicly express with political statements whether they wish to be bound or not by a given custom and to turn them into treaties (see above: according to publicity and promotion). Additionally, Vattel says he will lay down only some 'general rules' that nations are bound to respect with regard to conventions (treaties and customs), ${ }^{30}$ as I will show in the next section.

To conclude, Vattel adds that the voluntary and the conventional law of nations, taken together, can be called the positive law of nations. Positive law must be distinguished, but not treated separately from, natural law: the two often overlap, but sometimes they do not. While positive law should not be confused with natural law, the latter has nevertheless to remain the guiding principle. By so doing, it assures the normative character of the law of nations as a whole. However, the following question arises: how is it then possible to judge the rightness of a conventional law (a treaty or a custom) if no nation is allowed to judge the other? First of all, it is precisely the content of natural law (the general rules of promoting perfection and, yet, respecting sovereign independence of judgement) that provides us with a valid criterion by which to understand whether customary rules are compliant with natural law. Secondly, Vattel solves this problem by conceding a fundamental importance to public statements: through them, nations 'activate' their rights - as is particularly evident in the customs of war, especially those concerning the declaration of war. ${ }^{31}$ Vattel's customary law of nations consists precisely in a series of unilateral acts producing effects on others: nations, by stating, refusing or applying certain rules without necessarily demanding their respect from others, guarantee themselves freedom and independence, since this secures them from being attacked (and from being the object of intrusive judgement of other nations). Vice versa, as we will see, there are customs originating from perfect rights which are binding on the parties involved - unless they opt out in due time.

$30 \quad$ Vattel, The Law of Nations, 77.

31 Silvestrini, 'Justice, War and Inequality,' 59; on regular war in Wolff and Vattel, see also Pablo Kalmanovitz, 'Sovereignty, Pluralism, and Regular War: Wolff and Vattel's Enlightenment Critique of Just War,' Political Theory 45 (2017): 1-24. 
Although the question of Vattel's method is particularly problematic, ${ }^{32}$ I think that it provides us with some useful insights into the question of custom in Vattel. Also, as we have seen, it is difficult to imagine a completely positive Vattelian law of nations, and we have emphasized its core normative elements. However, my claim is that in Vattel a normative claim about the law of nations coexists with a pragmatic method to assess its content, as he says that natural and positive law must be distinguished but not separated. This is particularly relevant for Vattel's doctrine of custom, which contains a coexistence of normative judgements and practical considerations. Vattel investigates the tension between practice and principles mostly by looking at the historical record. He makes massive use of the works of national historiographers and memorialists to support his arguments and, quite differently from his predecessors, he expresses here and there his scepticism towards classical history, which is no longer conceived of as the repository of perfect and generally accepted behaviours, as it was in Gentili or Grotius before him. ${ }^{33}$ Vattel contrasts the errors of a past, which is now perceived as far away, with the vivid descriptions of contemporary historians and memorialists. ${ }^{34}$ This is an interesting aspect, reflecting the changes in the historical discipline, from an erudite source of knowledge to a first-person description of events, where accuracy is less important than direct witness of and involvement in the facts narrated (Vattel himself is author of several Mémoires). ${ }^{35}$ However, it is worth pointing

32 Vattel's method has been described as the application of general normative principles to the study of singular cases of the law of nations. The relationship between the normativity of the principles of natural law and their pragmatic application to concrete situations is what makes the Vattelian method problematic, to the point that Ian Hunter has even spoken of a 'casuistic method'. See Ian Hunter, 'Vattel's Law of Nations: Diplomatic Casuistry for the Protestant Nation,' Grotiana 31 (2010): 108-109; see also Luke Glanville, 'Responsibility to Perfect,' 389; Stefan Oeter, 'Neutrality and Alliances,' in Vattel's International Law, 336-337.

33 On the role of historical examples in Alberico Gentili's doctrine of ius gentium, see Francesca Iurlaro, 'The burden of reason. Ratio probabilis, consensio omnium and the impact of humanitas on Alberico Gentili's theory of customary international law, History of Political Thought 38 (2017): 409-438; on the same topic in Grotius, see Benjamin Straumann, Roman law in the state of nature: The Classical Foundations of Hugo Grotius' Natural Law (Cambridge: Cambridge University Press, 2015).

34 On the importance of official historiography for modern political discourse, starting from Samuel Pufendorf, see Pärtel Piirimäe, 'Official Historiography and the State in Early Modern Europe,' Storia della storiografia 71/1 (2017): 47-75.

35 See for example Mémoires pour server à l'histoire de notre tems, par l'Observateur hollandois [Jacob-Nicolas Moreau], rédigez et augmentez par M. D. V [Emer de Vattel] (Frankfurt 
out an evolution in Vattel's own thought: whereas he makes moderate use of examples in the 1758 edition, he provides more examples in the revisions he drafted and these were included in the posthumous editions of his work. This might suggest an increasing need, perceived by the author, to provide the reader with examples: although they are not substantial to the argument, as he points out many times, they nonetheless provide for us a precious source of information on historical customary behaviours which he conceived of as established practice.

Three main claims are made in this section. First of all, whenever possible, Vattel seeks to provide a conciliation of principles of natural law and state practice. Historical analysis is particularly helpful in this respect. This coincidence between facts and principles shows Vattel's normative commitment (subordinated to the structure and divisio iuris we described above) as well as his need to give instructions to 'cabinet politicians' about customs. This scenario perfectly fits the 'ideal' situation described above, in which states are pursuing their own self-interest by complying with natural law. Secondly, by doing so, Vattel implicitly distinguishes between the process of formation of custom and that of identification: whereas the fact that a custom has received acceptance depends on its compliance with natural law, its identification is a distinct, pragmatic activity in which the jurist or the politician is engaged in his daily life. Therefore, and thirdly, whenever facts and principles do not coincide, Vattel provides us with a useful set of tools in order to identify and detect customs. He calls them 'general rules of custom' and he refers to historical analysis for particular occurrences of custom. From the reading of Vattel's text it is possible to extract three general rules to identify international customs: for each of them I will provide an example, which will also help us to understand the nature and functioning of Vattel's pragmatic-historical method.

Already in the Preface to his Law of Nations, Vattel anticipates the importance of custom, ${ }^{36}$ but it is in his Preliminaries that he gives us a full account of what he means by 'customary law of nations', i.e. a 'law founded on a tacit consent, or, if you please, on a tacit convention of the nations that observe it towards each other' ${ }^{37}$ As Wolff did, Vattel also emphasizes the importance of custom as a particular source of law (as opposed to the universality of

and Lepizig: aux dépens de la compagnie, 1757); Mémoires pour servir à l'histoire de notre tems, par rapport à la guerre anglo-gallicane, par l'Observateur hollandois [JacobNicolas Moreau], rédigez et augmentez par M. D. V. [Emer de Vattel], 2 vols. (Frankfurt and Leipzig: aux dépens de la compagnie, 1757-1758).

36 Vattel, The Law of Nations, 'Preface,' 17.

37 Ibid., 77. 
voluntary and natural law of nations). The regionalism of custom ${ }^{38}$ seems to restrict the application of customs to the European civilized nations, by constructing a unitary source of obligation that automatically excludes nonEuropean customs. ${ }^{39}$ However, together with the customs adopted by certain specific nations (like those concerning the formalities of the declaration of war), Vattel also mentions 'universal customs' with reference to a specific aspect of the laws of embassy, as we will see. It seems, therefore, that there are different degrees of application of custom, of course depending on whether they coincide with principles and on whether they seek to regulate fundamental values of the international order, like the independence of sovereign states. Also, regional customs seem to be for Vattel particular applications of general principles which are now settled as practice; universal customs are, rather, the customary expression of the principles of natural law (like that of sovereign authority, as we will see).

Consistent with these questions, the analysis in this section seeks to extract from Vattel's Law of Nations some general rules concerning the formation and identification of custom which he presents in his examples. These rules concern, as he writes in the above-mentioned passage, both the general functioning of custom and the way to assess its legality and compliance with natural law. It is possible to identify three situations. The first one, in which Vattel claims that there is a convergence of facts and principles, corresponds to the ideal situation, in which nations behave how they should do. In this case, customs are inherently compliant with natural law. However, there might be cases of non-compliance and, in order to avoid such episodes, he suggests that such customs are turned into treaties, in order to make them perfectly enforceable.

Vattel introduces a second category of customs, those which are by their nature 'indifferent' as far as their content is concerned, since they originated from the liberty and will of nations. In this second case, the question of compliance with natural law is not of primary importance, unless customs are manifestly against the law of nature, but in that case they would no longer be indifferent. In this case, Vattel provides us with three methods of identification of customs, consistent with the structure of his legal doctrine: a criterion

38 Haggenmacher, 'Introduction,' has emphasized the 'regional' character of custom in Vattel.

39 On Rech's pluralist reading of the pre-Vattelian tradition of custom, see Rech, Enemies of Mankind, 124; also, on 'intra-European' custom see Ian Hunter, 'The Figure of Man and the Territorialisation of Justice in Enlightenment Natural Law: Pufendorf and Vattel,' Intellectual History Review 23/3 (2013): 289-307; Hurrell, 'Vattel: Pluralism and its Limits,' 235 . 
of non-indifference (similar to but not to be confused with the contemporary doctrine of opinio iuris), acknowledgement by public statement and by violation.

In addition to this, he addresses a fundamental problem: is the violation of custom punishable? The answer to this question will call into question once again the distinction between internal and external obligations and perfect and imperfect rights.

\section{Facts with Meaning: Customs Originating in an} Overlapping of Practice and Principles

The overlapping of facts and principles is a characteristic of most of the customary norms mentioned by Vattel. Such an account of custom, normative and pragmatic at the same time, might have been influenced by Cornelius Bynkershoek, who is frequently quoted in the Law of Nations. He claimed, in his De foro legatorum (1721), that custom is made of ratio and usus. Reason is what gives meaning to mere usus, namely practice based on repetition. ${ }^{40}$ I will here provide two examples of overlapping of facts and principles, one concerning the custom of declaring war and the other concerning the neutrality of commerce.

Declaration of war is an essential moment of Vattel's doctrine of war in due form. ${ }^{41}$ In this respect, "it is necessary that the declaration of war be known to the state against whom it is made. This is all which the natural law of nations requires. Nevertheless, if custom has introduced certain formalities in the business, those nations, who, by adopting the custom, have given their tacit consent to such formalities, are under an obligation of observing them, as long as they have not set them aside by a public renunciation. ${ }^{42}$ Here Vattel precisely hints at the 'regionalism' of customary formalities concerning declaration of war, and he also introduces a fundamental characteristic of custom. Vattel thinks that declaration of war is required by the natural law of nations (as a way of making the intentions of sovereigns explicit and, therefore,

40 As claimed by Kinji Akashi, Cornelius van Bynkershoek: His Role in the History of International Law (The Hague: Kluwer Law International, 1998), 37. The reference to Bynkershoek is explicit in book IV of The Law of Nations, 736, where Vattel discusses the laws of embassy regarding the liability of the ambassador in cases of lawsuits.

41 As it marks the exit from the natural law of nations and the entry into a consensual regime of the voluntary law of nations, as argued by Silvestrini, 'Justice, War and Inequality,' 6o. 
accountable), whereas formalities are the object of custom. In order to activate such customs, nations can respect them, or opt out from them with a public statement, or even violate them, as we will see. What is more important is that an internal obligation is turned into a perfect one by statement or action (not necessarily by turning it into a treaty). Nations shall manifest their intentions, based on their unquestionable judgement, so that other nations know how to behave and, most importantly, how the natural law of nations applies to their conduct. A similar example concerns the meaning of the declaration:

When the sovereign or ruler of the state declares war against another sovereign, it is understood that the whole nation declares war against another nation: for the sovereign represents the nation, and acts in the name of the whole society [...]; and it is only in a body, and in her national character, that one nation has to do with another. Hence, these two nations are enemies, and all the subjects of the one are enemies to all the subjects of the other. In this particular, custom and principles are in accord. ${ }^{43}$

Another example is that of the relationship between war and commerce. During the Seven Years' War the question of neutrality of commerce was particularly urgent because the idea started to emerge that if the trade of an allegedly neutral nation was supporting one of the nations at war, then this would be contrary to the law of nations. ${ }^{44}$ Vattel asserts that the issue needs to be addressed by distinguishing between neutral goods and military goods: whereas it would be a violation of the law of nations to forbid the first, innocent kind of commerce, it would be legitimate to forbid the second one, which constitutes a breach of neutrality. However, Vattel says that the prevailing custom in his own time is to avoid whenever possible the intrusion of neutral nations into the commercial affairs of an enemy nation. ${ }^{45}$ However, how should we treat those who help our enemies? They are in principle enemies as well, and therefore we can ask them to account for their conduct. However, Vattel suggests that this right is exercised with prudence, as it might cause more problems than it might solve. ${ }^{46}$ Additionally, 'if prudence dissuades us from making use of

43 Ibid., 509 .

44 For example, see contributions in War, Trade and Neutrality. Europe in the Mediterranean in the seventeenth and eighteenth centuries, ed. Antonella Alimento (Milano: Franco Angeli, 2011); Oeter, 'Neutrality and Alliance'; Tara Helfman, 'Neutrality, the Law of Nations and the Natural Law Tradition: A Study of the Seven Years' War,' Yale Journal of International Law 30/2 (2005): 549-584.

45 Vattel, The Law of Nations, 511.

46 Ibid., 518-519. 
all our right, it does not thereby destroy that right. A cautious nation chooses rather to overlook certain points than unnecessarily to increase the number of her enemies.' ${ }^{47}$ This hints at the fictional character of custom, as a 'virtual' set of rules that needs to be activated (but the existence of which is not dependent on such activation). On the contrary, if nations made use of such right too often, 'the contrary principles would tend to multiply wars, and spread them beyond all bounds, to the common ruin of nations. It is happy for Europe, that, in this instance, the established custom is in accord with the true principles'.48

Another circumstance arises when a supposedly neutral nation engages in illicit trade with another nation's enemy: if the situation occurs, do nations have a right to confiscate such contraband goods? Vattel contends that 'barely to stop those goods would in general prove an ineffectual mode'; therefore, nations should 'prevent, as far as possible, the enemy's being supplied with such articles as will add to his strength and render him more dangerous, that necessity and the care for her own welfare and safety authorize her to take effectual methods to that purpose, and to declare that all commodities of that nature, destined for the enemy, shall be considered as lawful prize. ${ }^{49}$ The better method to achieve this purpose is for a nation to notify the neutral states of its declaration of war, 'whereupon, the latter usually give order to their subjects to refrain from all contraband commerce with the nations at war, declaring that if they are captured in carrying on such trade, the sovereign will not protect them'. Vattel claims that this rule seems 'at present' to have crystallized as 'the general custom of Europe, 50 and quotes as authoritative sources in support both Grotius ${ }^{51}$ as well as two ordinances of the kings of France, issued in 1543 and $1584^{52}$

Vattel's passage is quite explicit about what happens before a custom becomes a generally established practice: there might be a number of variations, eventually resulting in the current state of events, where a particular custom is introduced (which historical analysis might even help us to date: as with the example of France quoted above). Vattel further says that the custom in question is most 'suitable and compliant with principles of natural law'.53 At the same time, he specifies that this current state of affairs is the result not only of

$47 \quad$ Ibid.

48 Ibid., 521.

49 Ibid., $53^{0}-531$.

50 Ibid., 531 .

51 Grotius, De jure belli ac pacis (Paris, 1625), book III, chap. I, $§ 5$.

52 Vattel, The Law of Nations, 531.

53 Ibid. 
past modifications but also of possible future ones ('this rule is the point where the general custom of Europe seems at present fixed'). However, following his argument, it is hard to imagine that a custom so coincident with both 'mutual duties of nations' and their respective rights could change in time without causing a violation of the principles of natural law it is so agreeable to. This tension might be interpreted, on the one hand, as an instance of regionalism, i.e. a particular external expression, in a given context and time, of a normative principle, which crystallizes over time with no further need of modifications once it is fixed. Such an 'evolutionary' interpretation might pose the problem of considering custom as natural law, and by so doing confusing the two legal regimes (an option which Vattel warns us not to choose). On the other hand, it is possible to argue that the 'present custom' is the best possible option that, in the current state of events, nations can strive for, but that it does not exclude even better applications of the same principles it expresses. This interpretation seems in line with Vattel's thought experiment of the wise 1,00o Europeans governing themselves by only applying natural law: that situation is not a cosmopolitan ${ }^{54}$ society to strive for, but the natural state of affairs of men, if only they were as they are supposed to be. If the custom at stake is agreeable to that natural state of affairs, then it might be interpreted as the best 'external' approximation of the natural law of nations.

To conclude this section, it is also worth mentioning that Vattel suggests that instances of violations are nothing but confirmations of customs. ${ }^{55}$ For example, the person of ambassadors is inviolable by the universal custom and consent of nations', and although Vattel acknowledges that there have occurred some instances to the contrary, 'a few facts do not establish a custom: on the

54 According to Hunter, "The actual practice of abstraction through which Vattel "applies" the natural law to the conduct of nations is thus not one in which he makes the maxims of the latter conform to the principle of the former, or else fails to. Rather it is one in which he deploys both principles in order to structure a specialized practice of judgment. Here it is the difficulty of applying the cosmopolitan principle of natural law to the self-interested conduct of nations that is used to admit a whole series of accommodationist maxims and conventions - the voluntary law of nations - that are to be regarded nonetheless as if they were imperfect approximations of natural law cosmopolitanism' (Hunter, 'Law, War and Casuistry,' 94). In my view, according to what I called Vattel's fictional reasoning of considering men perfect, as they would be if they were following natural principles, they should be, rather, looked at as perfect (although maybe temporary) rather than imperfect approximations of natural law cosmopolitanism.

55 Interestingly, a doctrine also acknowledged by contemporary international law, as famously expressed by the International Court of Justice in 1986 (Military and Paramilitary Activities in and against Nicaragua, Nicaragua v. United States of America, Merits, Judgment, I.C.J. Reports 1986, para. 186). 
contrary, those to which I allude, only contribute, by the censure passed on them, to prove the custom such as I have asserted it to be. ${ }^{56}$

Finally, acknowledgement by violation is nothing but a reinstatement of the doctrine of the overlapping of facts and principles. To support his claim, Vattel here refers to Bynkershoek: 'it may be seen, in monsieur de Bynkershoek's treatise, that custom coincides with the principles laid down in this and the preceding section. In suing an embassador [...] the embassador is to be summoned in the same manner as an absent person, since he is reputed to be out of the country, and his independency does not permit any immediate address to his person in an authoritative manner, such as sending an officer of a court of justice to him.57

This is the first rule established by Vattel:

When a custom or usage is generally established, either between all the civilized nations in the world, or only between those of a certain continent, as of Europe, for example, or between those who have a more frequent intercourse with each other, - if that custom is in its own nature indifferent, and much more, if it be useful and reasonable, it becomes obligatory on all the nations in question, who are considered as having given their consent to it, and are bound to observe it towards each other, as long as they have not expressly declared their resolution of not observing it in future. But if that custom contains anything unjust or unlawful it is not obligatory: on the contrary, every nation is bound to relinquish it, since nothing can oblige or authorize her to violate the law of nature. ${ }^{58}$

An interesting parallel is offered by Vattel when he writes, in his Essay on the Foundation of Natural Law, that natural law cannot be indifferent: 'from there it follows that natural law is universal. Since it requires us to do all that is most suited to our nature, there is no situation in which it can let us down; for in every situation in which there is a better option to take, we are ordered to take it; and if it were possible to find a case of perfect indifference, no law would be of any use in resolving the matter.59 If natural law provided us with a case

56 Vattel, The Law of Nations, 73 .

57 Ibid., 736 .

$58 \quad$ Ibid., 78 .

59 Vattel, 'Dissertation,' in The Law of Nations, 775. 
of perfect indifference, no law would serve as a criterion, since it is only natural law to prescribe for us what is more suitable to our nature (through selfinterest as the principle of obligation).

Vattel provides an application of what we will call a 'fictional criterion of non-indifference' in his book IV, on the law of embassy:

and it must be observed here, with regard to things of institution and custom, that, when a practice is so established, as to impart, according to the usages and manners of the age, a real value and a settled signification to things which are in their own nature indifferent, the natural and necessary law of nations requires that we should pay deference to such institution, and act, with respect to such things in the same manner as if [my emphasis] they really possessed all that value which the opinion of mankind has annexed to them. ${ }^{60}$

In other words, Vattel suggests that a counterfactual reasoning be applied in cases of normative indifference of a given custom. From this mental experiment, we are able to assess that the normative value of a customary rule is not directly derived from the principles of natural law but rests on a generally accepted opinion of mankind which makes such custom meaningful. Of course, this does not mean that 'indifferent customs' can be inconsistent with natural law: rather, Vattel just suggests that the interpreter distinguishes among different sources of obligation.

Another question addressed by Vattel is the issue of the abrogation of custom. He admits that it is possible for a nation to opt out from a custom before the moment of its application. In his words, 'if, in process of time, any nation perceives that such custom is attended with inconveniences, she is at liberty to declare that she no longer chooses to conform to it: and when once she has made this explicit declaration, no cause of complaint lies against her for refusing thenceforward to observe the custom in question. But such a declaration should be made beforehand, and at a time when it does not affect any particular nation' ${ }^{61}$

In this example, the difference between formation and identification is more evident. The fact that custom is a tacit and 'virtual' legal regime does not mean that nations are a society of mute legal subjects: quite on the contrary, since it is unfeasible that they are governed by natural law alone, they have to publicly state their position and promote the signing of positive agreements (through

6o Vattel, The Law of Nations, 695 .

61 Ibid., 724. 
which they can reciprocally demand rights of one another). Also, the fact that the content of custom is normatively indifferent allows us to change it over time.

However, the question once again arises of whether it is possible for sovereigns to opt out from all kinds of customs. Universal customs, like those concerning the inviolability of ambassadors, seem to be more cogent than 'particular ones'. Vattel provides an example of such universal customs, directly deriving from the natural law of nations: to prove his point, he quotes a number of instances of non-European nations respecting them (Chinese, Mexicans, North-American tribes, etc.). ${ }^{62}$ By so doing, he seeks to prove the general acceptance of this customary rule by insisting on the cultural value that various and diverse nations have annexed to it.

Interestingly enough, the following passage concerning the inviolability of the ambassador is supplied with historical examples, although Vattel declares that they do not add any content to the rule, but that he uses them just for the sake of explanation. However, historical examples are more abundant each time that Vattel is not explicitly making the claim that facts coincide with principles. This might suggest that history is essential in ascertaining the value and opinion that 'mankind has annexed' to a given custom, whereas in cases of factual overlapping of custom with principles it aims at helping the jurist to deduce law from facts, by tracing back their first occurrence in time. The choice of historical sources is particularly innovative, if compared with those of Vattel's predecessors: French historians like François-Eudes Mezeray and Abbé de Choisy ${ }^{63}$ are quoted, as well as Simon Ockley's History of the Saracens. ${ }^{64}$ All these historiographic references show that the rationale behind the privileges to be granted to ambassadors is that it is better to leave an ambassador unpunished than to violate his immunity: therefore, it is better to overlook such instances of violation than to put at risk the necessity of nations to communicate and to carry on negotiations.

\section{Is the Violation of Custom Punishable?}

The possibility of punishing the violation of a customary rule depends on different factors. Most importantly, as a general rule and consistently with his

62 Ibid., 721.

63 Vattel, The Law of Nations, 722.

64 On the eighteenth-century development of the historical disciplines, as well on memorialists, see Chantal Grell, Pratiques et Concepts de l'Histoire en Europe XVIème-XVIIIème siècles (Paris: Presses de l'Université de Paris-Sorbonne, 1990). 
theoretical assumptions, Vattel seems to suggest that such decision calls into question the requirement of compliance with natural law: will such punishment impair the sovereign's search for perfection and independence of judgement? In principle, therefore, violation of custom is not punishable for Vattel. This is particularly evident the case of moderation to be applied in the treatment of hostages, which is, according to Vattel, a custom of nations, settled in practice. Its violation, although repugnant to the law of nature, cannot always be punished: indeed, 'all that [the violation of] such a custom can produce, is impunity among the nations who practise it. Whoever is guilty of it cannot complain that another is so too: but every nation may and ought to declare, that she considers the action as a barbarity injurious to human nature. ${ }^{65}$ As we have stated before, nations can publicly state their position on a given issue, by respecting, violating or expressing their support for a given custom. As a general rule, therefore, only violations of the voluntary law of nations (which rests on the presumed consent of nations) are collectively enforceable, subject to certain conditions and moderation. However, as discussed by Toyoda, Vattel writes, in a letter to Brühl, that there is a passage in his Law of Nations justifying a collective intervention by European nations to punish Frederick of Prussia for having introduced those 'sinister customs of war' (i.e. the invasion of Saxony with no declaration of war) ${ }^{66}$ In this case, we can argue that we are dealing with different customs: the one concerning the declaration of war directly stems from natural law and calls into question the justice of the cause, which substantiates itself in the conduct of a regular war. The Prussian invasion of Saxony does not seem to meet these requirements, as the purpose of declaring war is to inform neighbouring states about one's own intentions, once all the peaceful methods of dispute settlement have been exhausted. Furthermore, Frederick's act may introduce, if imitated by other countries, a sinister custom of war and therefore it might be right to intervene against him. In other words, this example shows a conflict between custom and sovereign judgement. How do we respond to a violation of custom when, in order to do so, we have to massively intrude into another sovereign's judgement? This aspect is controversial because it implies, on the one hand, the relationship between states vis-à-vis states and, on the other, it calls into question the problem of Vattel's account as politically loaded. ${ }^{67}$

\footnotetext{
65 Ibid., 115 .

66 Tetsuya Toyoda, Theory and Politics of the Law of Nations: Political Bias in International Law Discourse of Seven German Court Councilors in the Seventeenth and Eighteenth Centuries (Leiden: Martinus Nijhoff Publishers, 2011), 170. Ibid.
} 
Quite on the contrary, the custom of moderation in war does not concern the relationship between states and other states but between states and individuals: it does not imply judgement about the justice of the war (duties of justice), but rather a general duty of moderation that sovereigns have to follow (duties of humanity). In Vattel's words, compassion towards a prisoner is a custom, but if a sovereign cannot comply with it for reasons of force majeure, he may not be charged with violating the laws of war. ${ }^{68}$ Again, Vattel provides historical examples of moderation, taken from contemporary history rather than from Roman history. This is quite original, because for early modern jurists Roman leaders were examples of pietas and clementia - a myth that Vattel seems not to be fascinated by. Indeed, ancient customs about the treatment of prisoners were wrong because they permitted their death: Vattel suggests that contemporary customs, instead, especially those of civilized countries like England or France, are far better than those of the ancients. ${ }^{69}$

Unlike universal customs, regional customs can be enforced, because they are more formalities than customary rules (they are similar to our contemporary 'acts of courtesy'). As an instance of this, Vattel quotes the example of the honours due to ambassadors: the usage of receiving an ambassador wearing a hat, for instance, is a sign of deference due to his persona as a representative of the sovereign. To make this point, Vattel mentions that in 1663 ambassadors from Switzerland 'suffered the king of France, and the nobles of his court, to refuse them those honours which custom has rendered essential to the embassadors of sovereigns, and particularly that of being covered before the king at their audience. ${ }^{70}$ Later on, when Louis XV visited Alsace in 1755 , the Swiss sent no ambassadors precisely because their 'just demand' had been rejected. Again, the partiality of Vattel's example is itself insufficient to claim that there was a general acceptance of such custom; however, it makes the position of Switzerland clear on this issue.

To conclude, and to avoid problems related to punishment, Vattel suggests that on many occasions that it is wiser for nations to turn customs into treaties. For example, a nation which by long custom trades with another one (such as Portugal selling wine to England) and 'desires any right of commerce which shall no longer depend on the will of another, she must acquire it by treaty'71 Also, usucapion and prescription are examples of customs which Vattel suggests should be turned into treaties, but, 'if, in default of treaties, custom has

68 Vattel, The Law of Nations, $55^{1 .}$

69 Ibid., 553.

70 Ibid., 695 .

71 Ibid., 137 . 
determined anything in this matter, the nations between whom this custom is in force, ought to conform to it. ${ }^{72}$ This passage shows that Vattel does not think of custom as an insufficient source of obligation; he just argues that for vital matters - those relating to the life of a state - sovereign interests are better secured by the signing of a treaty.

\section{Conclusion}

To conclude this contribution, it is worth further emphasizing that Vattel's doctrine of the law of nations is a constant restatement of the fact that relying on self-love is the best means for realizing collective interests. The fairer, more public and explicit are the rules of the international 'game', the better will be the outcome. In this perspective, custom plays a crucial role, in at least three respects. First of all, it clarifies the relationship between natural law and positive law, by insisting on the fact that, as a source of law, custom is both compliant with natural law and effective as positive law. Secondly, another important element is Vattel's insistence on the added value that nations annex to custom, which would otherwise be nothing but a mere usus, carrying no legal meaning or obliging force whatsoever. Quite on the contrary, Vattel manages to bind the persuasive force of custom into compliance with natural law and, ultimately, with the pursuit of self-interest. Thirdly, and finally, Vattel's concept of custom calls into question the idea of an international legal order where normative principles coexist with practical considerations of expediency, an aspect which makes such theorization particularly illuminating even for contemporary debates concerning customary international law. ${ }^{73}$

\section{Bibliography}

Akashi, Kinji, Cornelius van Bynkershoek: His Role in the History of International Law (The Hague: Kluwer Law International, 1998).

Alimento, Antonella (ed.), War, Trade and Neutrality. Europe in the Mediterranean in the seventeenth and eighteenth centuries (Milano: Franco Angeli, 2011).

Beaulac, Stéphane, 'Emer de Vattel and The Externalization of Sovereignty,' Journal of the History of International Law 5 (2003): 237-292.

72 Ibid., 337-338.

73 I would like to acknowledge and thank Simone Zurbuchen and Gabriella Silvestrini for providing insightful and stimulating comments on an early draft of this chapter. 
Brooke, Christopher, Philosophical Pride: Stoicism and Political Thought from Lipsius to Rousseau (Princeton: Princeton University Press, 2012).

Cavallar, Georg, 'Vitoria, Grotius, Pufendorf, Wolff and Vattel: Accomplices of European Colonialism and Exploitation or True Cosmopolitans?' Journal of the History of International Law 10/2 (2008): 181-209.

Covell, Charles, The Law of Nations in Political Thought: A Critical Survey from Vitoria to Hegel (New York: Palgrave Macmillian, 2009).

Fiocchi Malaspina, Elisabetta, L'eterno ritorno del Droit des Gens di Emer de Vattel (secc. XVIII-XIX): L'impatto sulla cultura giuridica in prospettiva globale (Frankfurt: Max Planck Institute for European Legal History, 2017).

Force, Pierre, Self-Interest before Adam Smith: a Genealogy of Economic Science (New York: Cambridge University Press, 2003).

Glanville, Luke, 'Responsibility to Perfect: Vattel's Conception of Duties Beyond Borders,' International Studies Quarterly 61 (2017): 385-395.

Grell, Chantal, Pratiques et Concepts de l'Histoire en Europe XVIème-XVIIIème siècles (Paris: Presses de l'Université de Paris-Sorbonne, 1990).

Haggenmacher, Peter, 'Introduction: Le modèle de Vattel et la discipline du droit international,' in Vattel's International Law from a XXIst Century Perspective / Le Droit international de Vattel vu du XXIe siècle, ed. Vincent Chetail, Peter Haggenmacher (Leiden: Brill, 2011), 1-48.

Helfman, Tara, 'Neutrality, the Law of Nations and the Natural Law Tradition: A Study of the Seven Years' War,' Yale Journal of International Law 30/2 (2005): 549-584.

Hobbes, Thomas, Leviathan, ed. Edwin Curley (Indianapolis, IN: Hackett, 1994).

Hunter, Ian, 'Law, War and Casuistry in Vattel's Jus Gentium,' Parergon 28/2 (2011): 87-104.

Hunter, Ian, 'The Figure of Man and the Territorialisation of Justice in Enlightenment Natural Law: Pufendorf and Vattel, Intellectual History Review 23/3 (2013): 289-307.

Hunter, Ian, 'Vattel's Law of Nations: Diplomatic Casuistry for the Protestant Nation,' Grotiana 31 (2010): 108-140.

Hurrell, Andrew, 'Vattel: Pluralism and its Limits,' in Classical Theories of International Relations, ed. Ian Clark and Iver B. Neumann (London: Macmillan Press 1996), 233255.

Iurlaro, Francesca, 'The burden of reason. Ratio probabilis, consensio omnium and the impact of humanitas on Alberico Gentili's theory of customary international law,' History of Political Thought 38 (2017): 409-438.

Jouannet, Emmanuelle, Emer de Vattel et l'émergence doctrinal du droit international classique (Paris: Pedone, 1998).

Kalmanovitz, Pablo, 'Sovereignty, Pluralism, and Regular War: Wolff and Vattel's Enlightenment Critique of Just War', Political Theory 45 (2017): 1-24.

Kleinlein, Thomas, 'Christian Wolff: System as an Episode?' in System, Order and International Law: the Early History of International Thought from Machiavelli to Hegel, 
ed. Stephan Kadelbach, Thomas Kleinlein and David Roth-Isigkeit (Oxford: Oxford University Press, 2017), 216-239.

Military and Paramilitary Activities in and against Nicaragua, Nicaragua v. United States of America, Merits, Judgment, I.C.J. Reports 1986.

Oeter, Stefan, 'Neutrality and Alliances,' in Vattel's International Law from a XXIst Century Perspective / Le Droit international de Vattel vu du XXIe siècle, ed. Vincent Chetail and Peter Haggenmacher (Leiden: Brill, 2011), 335-352.

Onuf Nicholas, 'Civitas Maxima: Wolff, Vattel and the Fate of Republicanism,' American Journal of International Law 88/2 (1994): 280-303.

Piirimäe, Pärtel, 'Official Historiography and the State in Early Modern Europe,' Storia della storiografia 71/1 (2017): 47-75.

Pufendorf, Samuel, De iure naturae ac gentium libri octo (Lund: Junghans, 1672).

Rech, Walter, Enemies of Mankind: Vattel's Theory of Collective Security (Leiden: Brill, 2013).

Remec, Peter Pavel, The Position of the Individual in International Law according to Grotius and Vattel (The Hague: Martinus Nijhoff, 196o).

Silvestrini, Gabriella, 'Justice, War and Inequality. The Unjust Aggressor and the Enemy of the Human Race in Vattel's Theory of the Law of Nations,' Grotiana 31 (2010):44-68.

Skinner, Quentin, From Humanism to Hobbes: Studies in Rhetoric and Politics (Cambridge: Cambridge University Press, 2018).

Straumann, Benjamin, Roman law in the state of nature: The Classical Foundations of Hugo Grotius' Natural Law (Cambridge: Cambridge University Press, 2015).

Toyoda, Tetsuya, Theory and Politics of the Law of Nations: Political Bias in International Law Discourse of seven German Court Councilors in the Seventeenth and Eighteenth Centuries (Leiden: Martinus Nijhoff Publishers, 2011).

Vattel, Emer de, Le loisir philosophique ou pieces diverses de philosophie, de morale et d'amusement (Dresde: George Conrad Walther, 1747).

Vattel, Emer de, Mémoires pour server à l'histoire de notre tems, par l'Observateur hollandois [Jacob-Nicolas Moreau], rédigez et augmentez par M. D. V. [Emer de Vattel] (Frankfort and Leipzig: Aux Dépens de la Compagnie, 1757).

Vattel, Emer de, Mémoires pour servir à l'histoire de notre tems, par rapport à la guerre anglo-gallicane, par l'Observateur hollandois [Jacob-Nicolas Moreau], rédigez et augmentez par M. D. V. [Emer de Vattel], 2 vols. (Frankfurt and Leipzig: aux dépens de la compagnie, $1757-1758$ ).

Vattel, Emer de, The Law of Nations, or Principles of the Law of Nature, Applied to the Conduct and Affairs of Nations and Sovereigns, with Three Early Essays on the Origin and Nature of Natural Law and on Luxury (Indianapolis, IN: Liberty Fund, 2008).

Wolff, Christian, Jus gentium methodo scientifica pertractata (Halle: Renger, 1749).

Wood, Michael, First Report on the Formation and of Customary International Law, International Law Commission 65th Session, A/CN.4/663. 
Zurbuchen, Simone, 'Emer de Vattel on the Society of Nations and the Political System of Europe,' in System, Order and International Law: the Early History of International Thought from Machiavelli to Hegel, ed. Stephan Kadelbach, Thomas Kleinlein and David Roth-Isigkeit (Oxford: Oxford University Press, 2017), 263-382.

Zurbuchen, Simone, 'Vattel's Law of Nations and the Principle of Non-Intervention,' Grotiana 31 (2010): 69-84. 


\title{
The Circulation of the École romande du droit naturel in Eighteenth-Century Italy
}

\author{
Elisabetta Fiocchi Malaspina
}

This chapter investigates how some of the key texts of the so called école romande du droit naturel were translated, received and used in the Italian context during the long eighteenth century. ${ }^{1}$ The circulation of Emer de Vattel's treatise on the law of nations, Le droit des gens (1758), will be considered together with Jean Barbeyrac's translations of Pufendorf's writings and with the various editions of Jean-Jacques Burlamaqui's works. ${ }^{2}$ The école romande had a great influence on the propagation of theories of natural law and law of

1 Alfred Dufour termed the natural law teaching and literary production in the French-speaking part of Switzerland école romande du droit naturel. Although identifying a 'school' within the natural law movement may appear problematic, Dufour held this term to be appropriate, in the sense of 'an intellectual movement committed to defend, in connection with one or several teachers, a certain number of principles, and to propagate them through speech or writing'. According to Dufour, the school was a kind of mediation between the German natural law theories (represented, among others, by Pufendorf, Thomasius and Wolff) and the French ones symbolised, for example, by the works of Montesquieu, Rousseau and Voltaire. See Alfred Dufour, Le mariage dans l'école allemande du droit naturel moderne au XVIIIe siècle (Paris: Libraire générale de droit et de jurisprudence, 1976), 12 (author's translation), and Alfred Dufour, 'Die Ecole romande du droit naturel - ihre deutschen Wurzeln,' in Humanismus und Naturrecht in Brandenburg-Preussen, ed. Hans Thieme (Berlin: W. de Gruyter, 1979), 133143. See also: Simone Zurbuchen, 'Das Prinzip des Naturrechts in der école romande du droit naturel,' Jahrbuch für Recht und Ethik 12 (2004): 189-211, and Simone Zurbuchen, 'Teaching the Law of Nature and Nations in the Swiss Context,' Etudes Lumières.Lausanne, 6 (novembre 2018), 1, accessed 15 February 2019, http://lumieres.unil.ch/fiches/biblio/9472/.

2 Besides the Principes du droit naturel (1747) and the Principes du droit politique (1751) I will also account for the new and annotated edition of Fortunato Bartolomeo de Felice, Principes du droit de la nature et des gens, 8 vols., Yverdon: [de Félice], 1766-1768. On de Felice see Stefano Ferrari, Fortunato Bartolomeo De Felice. Un intellettuale cosmopolita nell'Europa dei Lumi (Milano: Franco Angeli, 2017). On Barbeyrac as translator see: Giulia Maria Labriola, Barbeyrac interprete di Pufendorf e Grozio. Dalla costruzione della sovranità alla teoria della resistenza (Napoli: Editoriale Scientifica, 2003); Meri Päivärinne, 'Translating Grotius's De jure belli ac pacis: Courtin vs Barbeyrac,' Translation Studies 5, 1 (2012): 33-47. 
nations on the Italian peninsula, in a context that was marked by the presence of very different political regimes.

As is well known, the Peace of Utrecht in 1713, the Treaty of Rastatt in 1714 and the Hague Treaty of 1720 marked the end of Spanish rule in Italy. As a result of the Aachen Peace of 1748, the Italian peninsula was fragmented. In the north, Piedmont was ruled by the Savoy dynasty, Lombardy was under Austrian rule, the Duchy of Parma, Piacenza and Guastalla were under the control of the Bourbon family, while Venice remained independent and Florence governed by Francis II of Lorraine. In the south the Bourbons were on the throne in Naples with which Sicily was united in 1815 .

This peculiar situation constituted the context for enlightened debates on natural law, diplomacy and the law of nations. Discussions were often stimulated by texts that came from outside of Italy, and translations, in many cases supplemented with annotations, played an important role in arousing interest in topics such as social contract, sovereignty, constitutions, or the relationship between state and religion. The école romande du droit naturel had a major impact on these debates, as shown by Italian historians and legal historians who have investigated the significance of the Italian translations of Barbeyrac, Burlamaqui and Vattel. Antonio Trampus has pointed out, for example, that the Italian version of Vattel's Le droit des gens was considered a benchmark for a new political science. ${ }^{3}$ Indeed, Vattel's doctrines were discussed and variously adapted to different Italian contexts. ${ }^{4}$

3 Antonio Trampus, 'Il ruolo del traduttore nel tardo illuminismo: Lodovico Antonio Loschi e la versione italiana del Droit des gens di Emer de Vattel,' in Il linguaggio del tardo illuminismo. Politica, diritto e società civile, ed. Antonio Trampus (Roma: Edizioni di storia e letteratura, 2011), 81-108; A. Trampus, 'The circulation of Vattel's Droit des gens in Italy: the doctrinal and practical model of government,' in War, Trade and Neutrality. Europe and the Mediterranean in seventeenth and eighteenth centuries, ed. Antonella Alimento (Milano: FrancoAngeli 2011), 217-232; A. Trampus, 'La traduzione toscana del Droit des gens di Emer de Vattel (circa 1780): contesti politici, transferts culturali e scelte traduttive,' in Traduzione e Transferts nel XVIII secolo tra Francia, Italia e Germania, ed. Giulia Cantarutti, Stefano Ferrari (Milano: Franco Angeli, 2013), 153-174; A. Trampus, 'Le costituzioni italiane prime di Cadice: Vattel e le radici democratiche italiane,' in Cadice e oltre: costituzione, nazione e libertà. La carta gaditana nel bicentenario, ed. García Sanz et al. (Roma: Istituto per la Storia del Risorgimento italiano, 2015), 161-172; A. Trampus, 'Dalla libertà religiosa allo Stato nazione: Utrecht e le origini del sistema internazionale di Emer de Vattel,' in I trattati di Utrecht: una pace di dimensione europea, ed. Frédéric Ieva (Roma: Viella, 2016), 93-106.

4 See Elisabetta Fiocchi Malaspina, L'eterno ritorno del Droit des gens di Emer de Vattel (secc. XVIII-XIX). L'impatto sulla cultura giuridica in prospettiva globale (Frankfurt am Main: Global Perspectives on Legal History, Max Planck Institute for European Legal History Open Access Publication, 2017), http://dx.doi.org/10.12946/gplh8. 
In focusing on translation, transfer and reception, this chapter draws on recent methodological reflections in legal history which suggest that a purely sectoral approach to legal phenomena should be replaced by an interdisciplinary approach, the latter allowing an assessment of law as a dynamic phenomenon that needs to be put into context in terms of space and time. ${ }^{5}$ This manner of proceeding will reveal the political nature of translation, with its frequent conscious manipulations of text. Processes of translation will be presented in three areas of research, or scenarios, related to the propagation of natural law and the law of nations. The first scenario deals with the Italian translation of Barbeyrac's works, intended as a tool for mediating Protestant ideas in a Catholic context. The second focuses on the political contexts of the reception and translation of Burlamaqui's and Vattel's writings. In the third scenario, it will be examined how various works of the école romande were used in teaching the law of nature and nations in different academic contexts in Italy.

The first translation to be considered in this section is Giovambattista Almici's Il diritto della natura e delle genti o sia sistema generale de' principii li più importanti di morale, giurisprudenza, e politica (4 vols, 1757-1759), published in Venice by Pietro Valvasense. Almici was born in Brescia in 1717. He received his doctorate utroque jure in Padua in 1751, became assistant to the chief magistrate of Crema, then of Val Camonica. The cultural and social context in which he lived was that of Brescia Jansenism. ${ }^{6}$ His younger brother, Pietro Camillo, biblical scholar and theologian, entered the Congregation of the Oratory, and was one of the most important Italian critics of the Italian and foreign Enlightenment. ${ }^{7}$

5 See Thomas Duve, 'European Legal History - Global Perspectives Working Paper for the Colloquium European Normativity - Global Historical Perspectives' (Max Planck-Institute for European Legal History, September 2-4 2013), in Max Planck Institute for European Legal History Research Paper Series 6 (2013): 18, accessed 28 January 2017, http:// ssrn.com/ abstract $=2292666$.

6 Stefania Stoffella, 'Almici Giovambattista,' in Dizionario Biografico Giuristi Italiani (XII-XX secolo), ed. Italo Birocchi et al. (Bologna: Il Mulino, 2013), vol. I, 45.

7 Gianni Sofri, 'Pietro Camillo,' in Dizionario Biografico degli Italiani 2 (1960), 512. He wrote Osservazioni critiche sul libro intitolato Dei delitti e delle pene, under the pseudonym of Callimaco Mili, in which he strongly criticized the famous work of Cesare Beccaria, rejecting its contractualist premises and supporting the divine origin of sovereignty. See Callimaco Mili, 'Osservazioni critiche sul libro intitolato Dei delitti e delle pene,' Nuova raccolta d'opuscoli scientifici e filologici 13 (1765): II-XLVII. 
Almici's translation of Pufendorf's main work (De jure naturae et gentium) has been the subject of relevant Italian studies. ${ }^{8}$ Maurizio Bazzoli suggested that Almici might be seen as a sort of Italian Catholic Barbeyrac, because, after translating Pufendorf, he wanted to publish, in 1771, his richly annotated translation of Grotius's De jure belli ac pacis, but this never happened and it remained in manuscript form. ${ }^{9}$ Almici worked on the French translation of Pufendorf's text, obviously with the intention to revisit Barbeyrac's notes. In his view, a rectified and illustrated translation was necessary in order to disseminate in Italy, too, a work presenting natural law in a modern, scientific way, but without questioning the dictates of Catholicism. In fact, he wished to introduce his own version of Pufendorf in order to prevent any dissent from the Roman Church. He justified this manner of proceeding in the preface to the translation, where he also announced his intention to defend the positions of the Catholic Church on, for instance, lying, usury, matrimony, polygamy, pacts and duels. ${ }^{10}$ Despite this, Bazzoli concludes that Almici followed Barbeyrac 'more than it would appear, or, than he out of caution would admit."

Almici added a great number of notes to the translation. Interestingly, in volume IV, published in 1759, there are countless references to Vattel's Droit des gens, which had been published the previous year. In these notes Almici shows great appreciation for the thinking of the jurist from Neuchâtel, and on more than one occasion he does not hesitate to support him energetically, particularly on the issue of diplomacy. For example, in his commentary to Pufendorf's chapter on ambassadors, he refers to Vattel's now famous definition of the

8 Diego Panizza, 'La traduzione italiana del "De iure naturae" di Pufendorf: giusnaturalismo moderno e cultura cattolica nel Settecento,' Studi Veneziani 11 (1969): 483-528; Maurizio Bazzoli, 'Almici e la diffusione di Pufendorf nel Settecento Italiano,' Critica Storica 16 (1979): 3-10o; M. Bazzoli, 'Aspetti della recezione di Pufendorf nel Settecento italiano,' in Dal "De Jure Naturae et gentium" di Samuel Pufendorf alla codificazione prussiana del 1794. Atti del convegno internazionale, Padova, 25-26 ottobre 20o1, ed. Marta Ferronato (Padova: Cedam, 2005), 41-6o; Diego Quaglioni, 'Pufendorf in Italia. Appunti e notizie della prima diffusione della traduzione italiana del De iure naturae et gentium,' Il Pensiero Politico 32 (1999): 23-25o; Stefania Stoffella, 'Assolutismo e diritto naturale in Italia nel Settecento,' Annali dell'Istituto storico italo-germanico, 26 (2000): 137-175; S. Stoffella, 'Il diritto di resistenza nel Settecento Italiano. Documenti per la storia della traduzione del De iure naturae et gentium di Pufendorf,' Magistrature et politique 2 (2001): 173-199, accessed 28 January 2017, http://laboratoireitalien.revues.org/261.

9 Bazzoli, Giambattista Almici e la diffusione di Pufendorf, 6.

$10 \quad$ Ibid., 18. See Giovambattista Almici, 'Prefazione,' in Pufendorf, Samuel, Il diritto della natura e delle genti o sia sistema generale de' principii li più importanti di morale, giurisprudenza e politica, rettificato, accresciuto e illustrato (Venezia: Pietro Valvasense, 1757), t. I, I.

11 Bazzoli, Giambattista Almici e la diffusione di Pufendorf, 22: 'le segue più di quanto non appaia, o per prudenza, non ammetta' (author's translation). 
'representative character' of ambassadors and the ensuing ranking of different kinds of ministers. ${ }^{12}$ Vattel's proposed division of roles was accepted in its entirety by Almici, who observes:

Nowadays various names and titles are given to these government Ministers, that I call Envoys, Residents, Ambassadors. The first two have not the character of personally representing their Prince, but they represent him only for such matters as they are sent to treat. By contrast, the Ambassadors have the character of representing their own Prince par excellence, personally, consequently they have greater dignity. ${ }^{13}$

This example illustrates how Almici proceeded in order to present to his Italian readers an up-to-date version of the law of nature and nations: the wide use of notes allowed him to account for the most recent publications on various subjects.

Pufendorf's manual De officio hominis et civis, also translated into French by Barbeyrac (1707), had a unique history on the Italian peninsula. Two Italian translations were made of this work, one in Venice by Michele Grandi and one by Domenico Amati, published by Raymondi in Naples in 1780 and reissued in 1785. In the Neapolitan context, De officio was practically mandatory reading for generations of students during the age of reform. The same is true of Grotius's De jure belli ac pacis, which was translated into Italian by Antonio Porpora and published in Naples by De Dominicis in $1777 .{ }^{14}$

12 Emer de Vattel, The Law of Nations, Or, Principles of the Law of Nature, Applied to the Conduct and Affairs of Nations and Sovereigns, ed. Béla Kapossy, Richard Whatmore (Indianapolis, IN: Liberty Fund, 20o8), book IV, chap. VI, §§ 70-74, 691-692.

13 'Al giorno d'oggi si danno vari nomi, e titoli a questi pubblici Ministri, cioè Inviati, Residenti, Ambasciatori. Li primi due non hanno il carattere di rappresentazione personale propriamente del Principe loro; ma lo presentano solo per quei tai affari, che trattare inviati sono; al contrario che gli Ambasciatori hanno il carattere rappresentativo del Proprio Principe per eccellenza, personale, onde di maggior dignità sono' (author's translation). Almici in Samuel Pufendorf, Il diritto della natura e delle genti o sia sistema generale de' principii li più importanti di morale, giurisprudenza e politica, rettificato, accresciuto e illustrato (Venezia: Pietro Valvasense 1759), vol. IV, book VIII, chap. X, § 1, 469, note 1 , also 472, 474, 479, in which Almici develops the character of the representativeness of ambassadors with reference to Vattel. For a full discussion on the ambassadors within the theories of the law of nations see Miloš Vec, 'L'ambassade dans la science du droit des gens,' in Les écrits relatifs à l'ambassadeur et à l'art de négocier du Moyen Âge au début du XIX ${ }^{e}$ siècle, ed. Stefano Andretta, Stéphane Péquignot and Jean-Claude Waquet (Rome: École française de Rome, 2015), 487-522.

14 See: Vittorio Conti (ed.), La recezione di Grozio a Napoli nel Settecento (Firenze: Centro Editoriale Toscano, 2002). 
Grandi's translation comprised three quarto volumes, of which the first two were published in 1761 and the third in 1767 , all by Francesco Pitteri..$^{15}$ Grandi was spurred to attempt his translation 'having seen published in Italian the [...] Great Work of Pufendorf by Mr Giovanni Battista Almici'. Grandi publicly questioned Almici's method of directly modifying the text by making insertions and changes to it. He wished instead to recognize the right, or 'common desire', of readers to 'be able to read the opinions of these famous Authors expounded in the manner in which they were published.' ${ }^{16}$

Grandi's translation strategy was completely different from that of Almici. His intellectual bent, however, was very clear: although concerned about religious orthodoxy, he contributed to the circulation of Enlightenment ideas. As Bazzoli argues, Grandi made use of Pufendorf's fame to consciously diffuse among Italian readers Barbeyrac's interpretation of the law of nature and nations. He stoutly defended Barbeyrac against Almici's criticisms and, perhaps with the intention to further support the former's opinions, he followed Barbeyrac's own practice by adding two of the latter's essays in an appendix, which he also translated into Italian: the Discours sur la permission des loix (1715), and the Discours sur le bénéfice des loix (1716). ${ }^{17}$

\section{Second Scenario: Translation and Use of Burlamaqui's and Vattel's Works}

In the Grand Duchy of Tuscany, Burlamaqui's natural law theory was translated on the basis of de Felice's richly annotated edition Principes du droit de la nature et des gens (1766-1768). As Sandro Landi has shown, the translation was begun in Siena in 1772 for the publisher Bindi, but was swiftly halted by Stefano Bertolini, an official overseeing printing in Siena. ${ }^{18}$ Bertolini was convinced that Burlamaqui's text and de Felice's notes were potentially dangerous, mainly for their original theory about the foundation and the limits of royal power, and about the prerogatives of princes concerning religion. Indeed, Bertolini

15 For further references: Bazzoli, Giambattista Almici e la diffusione di Pufendorf, 46.

16 Michele Grandi, 'Avvertimento sopra questa traduzione italiana,' in Samuel Pufendorf, I doveri dell'uomo e del cittadino: tali che a lui dalla legge naturale sono prescritti, dalla versione francese di Giovanni Barbeyrac tradotti, e con molte aggiunte corretti ed illustrati da Michele Grandi accademico di Udine (Venezia: Francesco Pitteri, 1761), vol. I, XI-XII (author's translation).

17 Bazzoli, Giambattista Almici e la diffusione di Pufendorf, 46.

18 Sandro Landi, Il governo delle opinioni. Censura e formazione del consenso nella Toscana del Settecento (Bologna: Il Mulino, 2000), 254; Trampus, La traduzione toscana del Droit des gens di Emer de Vattel, 172. 
justified his decision to stop the printing by saying there were 'points too closely concerning royal rights.'19 There were two particularly delicate issues. The first was the contractualist theory of the state, the second the theory of 'limited' monarchy, which Burlamaqui and de Felice elaborated with reference to the model of the British 'constitutional monarchy' ${ }^{20}$ At all events, the censorship was temporary, and Bindi published the translation in 1780-1782. This sudden change of heart was very probably dictated by the broader view on the freedom of the press taken by the government. ${ }^{21}$

In Venice, Giovanni Gatti published in 1780 a translation of Burlamaqui's Principes du droit naturel. The translator was Count Benedetto Crispi, who signed the work with his initials, B.C. He wrote in his introduction that it was 'well known how passionately the more cultivated Nations of Europe have turned to the study of Natural Law, since Grotius systematized it', and that 'among these Italy has distinguished itself not a little, not only with new editions, translations, confutations of Grotius, of Hobbes, of Pufendorf and of Wolff, but also with original works by its expert and most profound authors.22 After listing the various European translations of Burlamaqui's treatise in England, Holland and Denmark, he pointed out that he had decided to translate the first edition of Burlamaqui's work (1747) instead of the later version annotated by de Felice because the latter obscured Burlamaqui's thinking.

Crispi also translated Burlamaqui's Principes du droit politique (1751). The work was published in the same year (1780), again by Gatti. Crispi was an aristocrat, famous for his excellent translations from German, English and, above all, French. Apart from Burlamaqui's works, he also translated Gabriel Bonnot de Mably's treatise on the public law of Europe, Il diritto pubblico dell'Europa, which was also published by Gatti, in 1784 . The Count was a friend and protector of a group of Jesuits who, having been expelled from Spain in 1767 , had taken refuge in northern Italy. Crispi had no hesitation in involving them in his cultural and

\footnotetext{
19 Landi, Il governo delle opinioni, 255.

20 Ibid.

21 Ibid.

22 'abbastanza noto, con quanto ardore fiensi rivolte le più colte Nazioni d'Europa allo studio della giurisprudenza Naturale, da che Grozio lo ridusse a sistema [...] Tra queste si è pure distinta non poco l'Italia, non solo colle ristampe, traduzioni, confutazioni [del] Grozio, dell'Obbes, del Pufendorf e del Wolff, ma eziandio colle opere originali dei suoi più dotti, e più profondi scrittori' (author's translation). Conte Benedetto Crispi, 'Il traduttore a chi legge', in Jean-Jacques Burlamaqui, Principii del diritto naturale di G.G. Burlamachi consigliere di Stato, già professore di diritto naturale e civile in Ginevra (Venezia: Giovanni Gatti, 1780), vol. I, III-IV.
} 
editorial exploits. ${ }^{23}$ Indeed, to the translations of Burlamaqui's treatises were added notes by a former Jesuit, the Catalan Luciano Galissà y Costa, a specialist in oriental languages and, from 1782, prefect of the library of Ferrara. It has rightly been noted that the aim of Gallissà and Crispi was not merely to present these Protestant texts without offence to the Catholic Church, but actively to contribute to the circulation and diffusion of Burlamaqui's theories. ${ }^{24}$

In his Avvertimento of the translation of Burlamaqui's Principes du droit naturel, the publisher, Gatti, announced an Italian translation of Vattel's treatise on the law of nations. This translation had been done by Lodovico Antonio Loschi, ${ }^{25}$ under the title Il diritto delle genti, ovvero principii del diritto naturale applicati alla condotta e agli affari delle nazioni e de' sovrani, in three octavo volumes, republished in $1804-1805 .{ }^{26}$ It was based on the edition published in Neuchâtel in 1773 and edited by Frédéric Samuel Ostervald.

The Italian edition of Vattel's treatise, as Antonio Trampus points out, had two distinguishing features: respect for the author's intentions and enhancement by the translator's notes. ${ }^{27}$ Indeed, Loschi did not merely translate the text, but inserted some explanatory notes, particularly in the first volume.

23 Niccolò Guasti, L'esilio italiano dei gesuiti spagnoli. Identità, controllo sociale e pratiche culturali (1767-1798) (Roma: Edizioni di storia e letteratura, 2006), 282 and note 75 . Guasti underlines that for Crispi there is extensive archival documentation and correspondence. The Count was an interesting figure who shared ideas and cultural interests with the Jesuit emigrants who brought the ideas of the Spanish ilustración with them to Italy. See also Trampus, Il ruolo del traduttore nel tardo illuminismo, 95. For the Italian translation of Mably's work see Giuseppe Roggerone, L'abbé de Mably: politico della teologia illuminata (Firenze: Centro Editoriale Toscano, 1991), 179.

24 Francesco Berti, 'Illuminismo, rivoluzione, modernità: lo spirito del secolo in alcuni significativi scritti dei gesuiti espulsi,' in La presenza in Italia dei gesuiti iberici espulsi. Aspetti religiosi, politici, culturali, ed. Ugo Baldini and Gian Paolo Brizzi (Bologna: CLUEB, 2010), 330.

25 Lodovico Antonio Loschi (1744-1811) was a scholar and translator who lectured on ethics at the University of Modena; he had a minor role in the political life of Napoleon's 'Three-Year Republic' in northern Italy and in Napoleon's Kingdom of Italy: Trampus, Il ruolo del traduttore nel tardo illuminismo, 81-108.

26 Trampus illustrates the stages of publication of the work, noting in particular that the licences obtained for printing seem to have been acquired in a short time, that is, between 1780 and 1781 . The manuscript of the first volume was given permission to be printed on 22 March 1781, falsely indicating Lyon as the base for the typographer Giovanni Gatti, according to the judgement of the reviewer, Gasparo Gozzi; the second volume, later subdivided into two books, was granted permission on 22 September 1781 , on the basis of the favourable judgement of the reviewer, Cosimo Mei; see Il ruolo del traduttore nel tardo illuminismo, 92. The 1804-1805 edition appeared in three volumes, without any additions or modifications to the previous one.

On Loschi's notes see Trampus, Il ruolo del traduttore nel tardo illuminismo, 89. 
Loschi's notes, Trampus highlights, essentially concern comments or criticisms of the most obviously anti-clerical positions Vattel defended, for example by advocating freedom of religion and freedom of conscience as inviolable human rights. The translator also made various notes about personal liberties. For example, when Vattel describes the duties of the nation regarding its obligation to construct and maintain public works, as commanded by the sovereign, Loschi pointed out in his notes that these works must be proportionate to the interest and profit of the nation. ${ }^{28}$ It should be noted that the notes made by Loschi are, in any case, identifiable and do not distort the original text. In the Avvertimento, the translator specifically states: 'a translation can only be as beautiful and elegant as its original. It is quite sufficient that the work is recognized as excellent for its method and substance.'29

In the appendix to Il diritto delle genti Loschi included a translation of the entry 'Droit de la Nature, ou Droit naturel' written by Antoine-Gaspard Boucher d'Argis for the Encyclopédie of Diderot and d'Alembert. This seemed important to him as it showed 'in what condition this very noble and very useful science was found, when our author began to study it'. ${ }^{30}$ Boucher d'Argis explained that natural law was the 'science of morals' (science des moeurs, qu'on appelle 'morale'), which comprises certain rules of justice and equity, established by human reason among all men. He also stressed that the law of nature should not be confounded with the law of nations, for the latter comprises, in addition to the rules established by right reason, customs that may conflict with the natural order. Boucher d'Argis then provided a short historical overview in which, starting from Roman times, he mentions the works of the most famous jusnaturalists, first and foremost Grotius's De jure belli ac pacis, and then those of Pufendorf and Burlamaqui, but without entering into philosophical, let alone juridical, considerations. The content and structure of this encyclopaedia entry provoked a great deal of criticism, and the debate as to why Diderot wrote another entry, 'Droit naturel (Morale)', for insertion in his Encyclopédie immediately following that of Boucher d'Argis, is still going on. ${ }^{31}$

28 See Trampus, Il ruolo del traduttore nel tardo illuminismo, 100-101.

29 'una traduzione esser non può bella ed elegante che a misura del suo originale. Basta bene che l'opera sia riconosciuta eccellente per metodo e per la sostanza delle cose' (author's translation). Lodovico Antonio Loschi, 'Avvertimento del volgarizzatore,' in Emer de Vattel, Il diritto delle genti, ovvero principii del diritto naturale applicati alla condotta e agli affari delle nazioni e de' sovrani (Lyon: 1781), vol. I, vi.

30 Ibid.: 'in quale stato [si] ritrovasse questa nobilissima ed utilissima scienza, quando prese a trattarla il nostro autore' (author's translation).

31 Luigi Luporini, 'Per una lettura della voce "Droit naturel" nell'Encyclopédie,' Studi Storici, 28, 3 (1987): 679-697; Peter Schröder, 'Natural Law and Enlightenment in France and 
This brief review of Boucher d'Argis's entry on natural law is essential for understanding the climate in which the Italian translation of Vattel's treatise was published. Loschi felt compelled to distance himself from what might be dubbed an 'incomplete' encyclopaedia entry on natural law, and in response to offer the broad, well-conceived treatise of Vattel, which was considered by the translator the most accurate work on the law of nature and nations available at the time.

Loschi's translation had an adverse fate in the Kingdom of Naples during the French Revolution, being placed on the list of prohibited books. At the time, the revision of publications was carried out by Francesco Conforti, professor of the history of Catholic Councils at Naples University and theologian at the Neapolitan court, responsible for controlling the influx of foreign books. ${ }^{32}$ Conforti judged Vattel's Le droit des gens to be 'seditious, because it recognizes the right of the People to reform the constitution and change the government', but he especially railed against Loschi, because in his translation the kept the same maxims as were given in the original., ${ }^{33}$

Loschi's was the only Italian translation of Vattel's work printed in the eighteenth century, but the treatise had been circulating since the time of its first edition in 1758 and, thanks to later editions, certainly aroused great interest in many parts of the Italian peninsula because of its contributions to a wide range of subjects, from academic jurisprudence through applied legal doctrine to diplomacy. There are frequent references, for example, in Cesare Beccaria's Dei delitti e delle pene to Vattel's work, which 'together with that of Burlamaqui seems to constitute one of the main sources for the elaboration of the essay'. ${ }^{34}$ Significantly, Alessandro Verri, in 'Di alcuni sistemi di diritto pubblico' published in the journal Il Caffè (vol. I, 1764-65), states that Vattel was the only

Scotland - A Comparative Perspective,' in Early Modern Natural Law Theories: Contexts and Strategies in the Early Enlightenment, ed. T.J. Hochstrasser and Peter Schröder (Dordrecht: Kluwer, 2003), 297-317.

32 See Pasquale Villani, Mezzogiorno tra riforme e rivoluzione (Bari: Laterza, 1962), and Anna Maria Rao, 'La stampa francese a Napoli negli anni della Rivoluzione,' Mélanges de l'École française de Rome. Italie et Méditerranée, 102, 2 (1990): 478.

'sediziosa, perchè riconosce nel Popolo il diritto di riformare la costituzione e di cambiare il governo [...] si sono conservate le stesse massime, che si dettano nell'originale' (author's translation). Villani, Contributo alla storia dell'anticurialismo napoletano, 249.

34 'assieme a quella di Burlamaqui sembra costituire una delle fonti principali per l'elaborazione del saggio' (author's translation). Gianni Francioni, 'Nota al testo,' Cesare Beccaria, Dei delitti e delle pene, edizioni italiane del "Dei delitti e delle pene", ed. Luigi Firpo (Milano: Einaudi, 1984), 334. See also: Trampus, Il ruolo del traduttore nel tardo illuminismo, 83 . 
person 'who had grasped the truth [of public law] and was the one to peel away the illusions and misunderstandings from this science, reducing it to a system of ideas, not of words.'.35

The illustrious jurist Alberto de Simoni, too, fascinated by the theories of the école romande, attempted to translate Burlamaqui and considered Vattel to be 'l'umanissimo'. He made frequent reference to Vattel's theories in his Del furto e sua pena of 1776 and on more than one occasion had no hesitation in calling them 'absolutely right', ${ }^{36}$ an opinion shared by the jurist Paolo Risi. $^{37}$

In a totally different geographical, political and social context, the Droit des gens was widely consulted for the defence of the Bishop of Mileto, Giuseppe Maria Carafa. In Difesa del vescovo di Mileto e del Collegio dei Greci in Roma (1769), the bishop defended the Church's ownership and rights over the Abbey of Trinità of Mileto, which was being claimed by the court of Naples. The question was very complicated and of long standing, but the crux of his main thesis, overruled by the Court, was the correct interpretation of the Concordat of 2 June 1741 between the King of Naples, Charles of Bourbon, and Pope Benedict IV. Carafa argued that the Concordat ought to be interpreted according to Vattel's rules, which were called upon in their entirety by the bishop in defence of the Church's ownership of the Abbey. ${ }^{38}$

35 'abbia colta la verità [del diritto pubblico] e sia quello che abbia spogliata questa scienza dalle chimere e dagli equivoci riducendola a sistema di idee, non di parole' (author's translation). 'Discorso IX: Di alcuni sistemi del diritto pubblico' appeared, together with other writings of Alessandro Verri, in the journal Il Caffè and also published in Alessandro Verri, Discorsi vari del conte Alessandro Verri pubblicati nel giornale letterario intitolato Il Caffè (Milano: Silvestri, 1818), 349-375, here particularly 370.

36 Alberto De Simoni, Del furto e sua pena (Lugano: Agnelli, 1776), 13. De Simoni referred to book 1, chap. 13, § 171 of Le droit des gens, where Vattel deals with the degree of punishment and criticized the practice of punishing simple robbery with death. See Renato Pasta, 'Dei delitti e delle pene et sa fortune italienne: milieux juridiques et lecture "philosophique"', in Beccaria et la culture juridique des Lumières, (Actes du colloque européenne de Genève 25-26 Novembre 1995), ed. Michel Porret (Genève: Droz, 1997), 132; Italo Birocchi, 'De Simoni Alberto,' in Dizionario biografico dei giuristi italiani (XII-XX secolo), ed. Italo Birocchi et al. (Bologna: Il Mulino, 2013), vol. I, 718-720.

37 See Stefano Solimano, 'Paolo Risi e il processo penale (1766),' in Studi di storia del diritto (Milano: Giuffrè, 2001), vol. III, 440, note 59. About Risi: Stefano Solimano, 'Risi Paolo,' Dizionario Biografico Giuristi Italiani (XII-XX secolo), ed. Italo Birocchi, et al. (Bologna: Il Mulino, 2013), vol. II, 1694-1696.

38 Giuseppe Maria Carafa, Difesa del vescovo di Mileto e del Collegio dei Greci in Roma contro un'istanza fiscale ed una scrittura stampata col titolo di Dimostrazione del padronato della Real Corona, sulla chiesa e badia della Trinità di Mileto (Napoli: 1769), Xxxv-XL. 
From the very beginning, the reception of Vattel's work in Italy was probably linked to the great ability of the author to summarize and systematize natural law theory in a way which could prove particularly useful to Italian political culture, once it was detached from Vattel's critical approach to the Catholic Church. The specific features of Vattel's text, and its considerable conceptual and lexical modernization in particular, effectively led to new interpretations in the light of the political changes that had been triggered by the crisis of the ancien régime and by the Seven Years' War. Le droit des gens portrayed natural law as a 'science', capable of conceptualizing the shift from the analysis of mankind in the state of nature to the study of individuals as members of a political society. 39

In any case, the act of translating became a specific choice, deliberately aimed at meeting the need to 'recreate' Vattel's doctrine in the context of eighteenth-century Italy. Indeed, Vattel's work was not classified merely as a text on the law of nations. On the contrary, it was a sort of political guide to foreign affairs for the small states that at the time made up the Italian peninsula. ${ }^{40}$ Legal transfer, understood as a process of cultural translation, could be achieved if the very contents and aims of a work were able to adapt and mould themselves or - even better - to be re-read according to different historical and geographical requirements. ${ }^{41}$ As will be shown below, it was, for example, of particular interest in the Italian context that Vattel held the creation of a constitution, seen as a fundamental regulation, to be legitimate within a state, on condition that it pursued the common good of the citizens and was not imposed by outside interference. Having dealt with the essential features of the nation-state, he broadens his investigation to the state as an entity able to communicate on an international level. ${ }^{42}$ As Trampus observes, Vattel's treatise 'represents [...] a typical example of reproducing a cultural model outside of its original historical and geographical context, and adapted again and again, with interference from another culture, in new political and social areas.' ${ }^{43}$

39 Trampus, La traduzione toscana del Droit des gens di Emer de Vattel, 153-154.

40 Ibid.

41 See: Lena Foljanty, 'Legal Transfers as Processes of Cultural Translation: on the Consequences of a Metaphor,' Max Planck Institute for European Research Paper series 9 (2015): 7, accessed 28 January 2017 , http://ssrn.com/abstract $=2682465$.

42 Trampus, La traduzione toscana del Droit des gens di Emer de Vattel, 153-154.

43 Ibid.: 'rappresenta [...] un caso tipico di riproduzione di un modello culturale al di fuori dell'originario contesto storico e geografico e adattato sempre più spesso, subendo l'interferenza di cultura terza, in nuovi ambiti politici e sociali' (author's translation). 


\section{Third Scenario: Translating Barbeyrac's, Burlamaqui's and Vattel's Ideas for Academic and Practical Purposes}

The Italian peninsula was of prime geostrategic importance during the eighteenth century, and this promoted the adoption and circulation of modern doctrines on the law of nations. Italy's universities continued the tradition of the jus commune and harboured a distinct style of Enlightenment thought, and the new law of nations was received in this general context. Only in the second half of the eighteenth century were chairs of natural law and law of nations established in various Italian states, almost always in those which were politically or culturally dependent on Austria. In many cases the teaching of natural law was linked to courses in public law, public universal law and the law of nations. ${ }^{44}$

It is interesting to note that works pertaining to the école romande, in particular Vattel's treatise on the law of nations, influenced academic teaching when chairs of natural law were established as a result of university reforms carried out at different periods. At the University of Pavia the works of Burlamaqui, Barbeyrac and Vattel on natural law were particularly valued. This can be seen from indirect references to their works in Institutiones juris naturalis and Institutiones juris publici universalis ${ }^{45}$ by Jean Baptiste Noël de Saint Clair, professor of natural and universal public law, as well as from other references in the teaching and writings of Abbot Pietro Tamburini. ${ }^{46}$

44 Among many see Giorgio Zordan, 'L'insegnamento del diritto naturale nell'Ateneo Patavino e i suoi titolari (1764-1855), Rivista di Storia del Diritto Italiano 72 (1999): 5-76. Gigliola di Renzo Villata, 'Le droit public en Lombardie au XVIIIe siècle et l'Europe,' in Science politique et droit public dans les facultés de droit européennes (XIIIe-XVIIIe siècle), ed. Jacques Krynen and Michael Stolleis (Frankfurt am Main: Klostermann, 20o8), 583-612. For the references to Vattel within the Allegationes see Gigliola di Renzo Villata, 'Introduzione. La formazione del giurista in Italia e l'influenza culturale europea tra Sette e Ottocento: il caso della Lombardia,' in Formare il giurista. Esperienze nell'area lombarda tra Sette e Ottocento, ed. Gigliola di Renzo Villata (Milano: Giuffrè, 2004), 64 .

46 Pietro Stella, 'Pietro Tamburini nel quadro del giansenismo italiano,' in Atti del Convegno internazionale in occasione del $25^{\circ}$ della nascita (Brescia, 25-26 maggio 1989), ed. Paolo Corsini and Daniele Montanari (Brescia: Morcelliana, 1993), 193. About Tamburini see also: Paola Vismara, 'Pietro Tamburini e il "dispotismo pontificio", in Il giansenismo e l'Università diPavia. Studi in ricordo diPietro Stella, ed. Simona Negruzzo (Milano: Giuffrè, 2012), 95-114; Dale K. Van Kley, 'From the Catholic Enlightenment to the Risorgimento: the Exchange Between Nicola Spedalieri and Pietro Tamburini, 1791-1797,' Past \& Present 224, 1 (2014): 109-162; Alberto Carrera, Pietro Tamburini 'Giurista'. Per una storia della cultura giuridica giansenista italiana (PhD diss., University of Milan, 2015). 
Vattel particularly attracted scholars because he relied on Christian Wolff, whose thinking was often praised in academic circles. In Padua, for example, Abbot Matteo Franzoja was teaching natural law in 1773 using Wolff's Institutiones juris naturae et gentium as his textbook. In Pisa, Giovanni Maria Lampredi heavily relied on Vattel. ${ }^{47}$ Indeed, in his Iuris publici universalis, sive Iuris naturae et gentium theoremata, begun in 1767 , there are countless direct and indirect references to Vattel's theories. ${ }^{48}$ In the third part of that work, entirely devoted to jus gentium, Lampredi addresses the complex relationship between natural law and the law of nations, with reference to the most important exponents of natural jurisprudence. He rejects Wolff's proposal to found the law of nations on the idea of a civitas maxima, and accepts the positions defended, for example, by Barbeyrac and Heineccius. ${ }^{49}$ It seems however that Vattel's Le droit des gens were 'one of the works most used by the Tuscan jurist in the field of law of nations.' ${ }^{50}$

In 1788, Lampredi published his Del commercio dei popoli neutrali in tempo di guerra ${ }^{51}$ in which he fervently supported freedom of trade between neutral states - based on the law of nations and of treaty law - in response to the theses advanced by Ferdinando Galiani. ${ }^{52}$ This example provides insight into the way in which Vattel's theory of the law of nations was used in a debate regarding the practical diplomatic issue of neutrality. In 1782, Galiani had published his De' doveri e de' principi neutrali verso i guerreggianti e di questi verso i principi neutrali, a work that was well received throughout Europe and which 'might well be the crowning of his career as political author'.53 He was

47 Maria Rosa Di Simone, 'Linfluenza di Christian Wolff sul giusnaturalismo dell'area asburgica e italiana,' in Dal "De Jure Naturae et gentium" di Samuel Pufendorf alla codifcazione prussiana del 1794. Atti del convegno internazionale, Padova, 25-26 ottobre 2001, ed. Marta Ferronato (Padova: Cedam, 2005), 221-268, particularly 254; Maria Rosa Di Simone, 'Stato e diritto nel pensiero di Gian Rinaldo Carli,' in Percorsi del diritto tra Austria e Italia (secoli XVII-XX) (Milano: Giuffrè, 20o6), 139.

48 Paolo Comanducci,IlSettecento conservatore:Lampredieil dirittonaturale (Milano:Giuffrè, $1981), 267$.

49 Ibid., $262-264$.

50 Ibid., 269: 'è una delle opere più utilizzate dal giurista toscano in tema di diritto delle genti' (author's translation).

51 Concerning Lampredi for a reconstruction of the thought, the context and the doctrinal influences: Comanducci, Il Settecento conservatore; Fabrizio Vannini, 'Lampredi Giovanni Maria,' in Dizionario Biografico degli Italiani 63 (2004): 259-262. Concerning Lampredi, as professor of public law in Pisa, see Giuliano Marini, 'Dal diritto naturale alla filosofia del diritto', in Storia dell'Università di Pisa (Pisa: Pacini, 200o), vol. II, 635-661.

52 Paolo Comanducci, 'Lampredi Maria Giovanni,' Dizionario Biografico Giuristi Italiani (XIIXX secolo), ed. Italo Birocchi et al. (Bologna: Il Mulino, 2013), vol. I, 1138-1141.

53 'ben potrebbe essere il coronamento della sua carriera di scrittore politico' (author's translation). Koen Stapelbroek, 'I significati della neutralità: la storia del commercio 
very critical of the position taken by Vattel regarding the neutral states and particularly challenged the neutral party's freedom of trade that preceded the distinction between active and passive trade. He rails against the lack of explanations given by Vattel: 'Arguments or reasons in support of his sentiment he gives none, and perhaps he had none in his head. The example of the Swiss nation and of others in Europe were all his proof. ${ }^{54}$ Galiani describes Vattel's doctrine of neutrality as 'bizarre', because 'he - [Vattel] - himself applauds it as a more humane teaching, and capable of diminishing the calamities of Europe, by extinguishing the sparks of new wars'. He also observes ironically that Vattel 'in his preface announced a book on the Law of Nations and not a work of Political Dissimulation, or Christian Patience.'.55

Lampredi, in turn, uses Le droit des gens as his main source for contesting Galiani's position. The introduction to Del commercio dei popoli neutrali in tempo di guerra comprises a detailed examination of the principles regulating trade between neutral states and of the most significant doctrinal positions throughout history. Lampredi has no doubt that the most important was that of Alberico Gentili, who endeavoured to create 'a system of justice even amidst the clamour of war, 56 and whose ideas had 'to some extent paved the way for

mediterraneo in Dei Doveri dei Principi Neutrali,' in Il linguaggio del tardo illuminismo. Politica, diritto e società civile, ed. Antonio Trampus (Roma: Edizioni di storia e letteratura, 2011), 77. See also Koen Stapelbroek, Love, Self-deceit and Money: Commerce and Morality in the Early Neapolitan Enlightenment (Toronto: University of Toronto Press, 2008).

54 'Argomenti o ragioni da stabilire il suo sentimento non ne dà, e forse non ne aveva nel suo capo. L'esempio della nazione Svizzera e di altre in Europa formano tutta la sua prova' (author's translation). Ferdinando Galiani, De' doveri e de' principi neutrali verso i guerreggianti e di questi verso i principi neutrali (Napoli: 1782), 120. Galiani intensifies his critique ibid., 120-121, note 2 , where he stresses that giving reasons is all the more important when writing about the law of nations, for states cannot refer to any other laws than the treaties voluntarily stipulated by them.

55 Ibid., 123: 'se n'applaudisce egli stesso come d'un insegnamento più umano, e capace di diminuire le calamità dell'Europa, coll'estinguere le scintille di nuove guerre [...]' (author's translation). Ibid., 124: 'Egli aveva nel suo frontespizio annunziato un libro del Diritto delle genti e non una opera della Dissimulazione Politica, o della Pazienza Cristiana' (author's translation). In endeavouring to find an explanation for Vattel's theory, Galiani declares ibid., 124, note 2, that he wrote his Droit des gens with the intention to please the generous court of Saxony and the Swiss cantons, but, living there, it 'is less excusable that he did not realize that their ancient usage of giving troops to the Sovereigns of Europe has nothing to do with his question' (author's translation).

$5^{6}$ 'un sistema di giustizia anche tra lo strepito dell'armi' (author's translation). Maria Giovanni Lampredi, Del commercio dei popoli neutrali in tempo di guerra (Firenze: 1788), 4. See Enrico Spagnesi, 'The trade of "neutral nations" as viewed by the publicist Lampredi,' in War, Trade and Neutrality. Europe and the Mediterranean in seventeenth and eighteenth centuries, ed. Antonella Alimento (Milano: FrancoAngeli 2011), 233-246. 
the famous Hugo Grotius who, writing with greater elegance, and adorning his Treatise with polished [...] erudition, practically banished his Master from memory, though he almost entirely followed his own design'. ${ }^{57}$ As Lampredi sees it, Gentili focuses on the problem of trade for neutral nations 'as an aside, and says just enough to conclude that $[. .$.$] it is difficult to disentangle as it$ seems [...] that the arguments of the warmonger, who blocks and forbids the trade of the neutrals, and the arguments of the neutrals, who say they are offended by this embargo, are both founded in reason. ${ }^{\prime 8}$ The question was, as he wrote, still pending and unresolved, despite the fact that almost two hundred years had passed since the publication of Gentili's De jure belli libritres. For this reason he intended to address the question, while giving great consideration to the context in which he lived, the customs of the nations and the reasons that were the cause of confusion in the treatment of trade. Attention to practice and to the historical and political situation was also a characteristic of Vattel's work, to which Lampredi referred. He cites Vattel, as an author better able to give prominence to the law of nations than Wolff. Somewhat confusing Vattel's role, Lampredi maintained that he spoke more clearly than Wolff when he translated the latter into French and thereby 'removed his abominably scholastic air and adorned him with much less heavy robes' 59

Finally, as far as Giovanni Gatti's translation of Burlamaqui's Principes du droit naturel is concerned, it was especially well received in Italy, particularly in academic circles. In 1812, Pietro Antonio Magalotti, professor of natural law in Perugia, was still making great use of Burlamaqui. According to Vittor Ivo Comparato, it was 'a model of synthesis that did not separate the natural law of Grotius from the utilitarianism of Pufendorf and allowed Magalotti to take that middle way which time suggested. ${ }^{60}$ In the first part of his lectures, Magalotti actually

57 Lampredi, Del commercio dei popoli neutrali in tempo diguerra, 6: 'in certo modo la strada al celebre Hugo Grotius, il quale scrivendo con maggiore eleganza, ed ornando il suo Trattato di forbita [...] erudizione fece quasi scordare il suo Maestro, di cui però seguitò quasi totalmente il disegno' (author's translation).

$5^{8}$ Ibid., 5: 'per incidenza, e dice quanto basta per concludere che [...] è difficile da sciogliersi sembrando, dic'egli, che tanto il Belligerante, che impedisce e vieta il commercio dei Neutrali, quanto ai Neutrali, che si chiamano offesi da questo impedimento siano fondati in ragione' (author's translation).

59 Ibid., 65: 'ma più chiaramente di lui ha parlato il suo redattore, che traducendolo in lingua francese gli ha tolto la disgustevole aria scolastica, e l'ha ornato di vesti assai più leggiadre' (author's translation).

6o 'un modello di sintesi che non separava il giusnaturalismo groziano dall'utilitarismo pufendorfiano e consentiva al Magalotti di percorrere quella via di mezzo che i tempi 
follows the order and titles of Burlamaqui's chapters and paragraphs, copying them word for word, almost as if he had adopted the work as a textbook. He then broadens his sources in the second part, and distances himself from Burlamaqui, disputing with him, for example, the delicate question of whether reason was sufficient as a foundation for moral obligation, independent of the will of God. ${ }^{61}$

\section{$5 \quad$ Conclusion}

This chapter has presented an overview of the research on the reception of Barbeyrac's, Burlamaqui's and Vattel's works in the Italian context, with a focus on translation. Translation, of course, is not a passive phenomenon, and the end product can reshape the text itself. It is impossible to talk about simple copies or works that have very little originality, because in the context in which they are used, as in the case of translations of Barbeyrac, Vattel or Burlamaqui, they are creative in their own right and, at the same time, they generate cultural and political identity.

In the first scenario, the Italian translation of Barbeyrac's French version of Pufendorf's work highlights the role of the translator as a legal, cultural and social mediator. Almici translates and, at the same time, reflects on the positions of Barbeyrac and Pufendorf, also making use of newly published contemporary works, such as Vattel's Le droit des gens. In the second scenario, it is shown how, in other Italian contexts, translations of Burlamaqui and Vattel were vehicles for political reflection and influenced legal practice. In the third scenario, translation is discussed in its broadest sense as an instrument for doctrinal and academic assimilation of the theories of natural law and law of nations, contributing to the creation of a separate subject that would become international law over the nineteenth century.

It has thus been shown that in addition to the famous works on natural law and the law of nations in the tradition of scholastic philosophy and moral theology, there was in eighteenth-century Italy a growing interest in books that aimed to spread the ideas of the école romande du droit naturel. This trend aided the advent of newer and more open-minded theories on natural law and the law of nations, which was integral to the Enlightenment understood as a continuous process of change. ${ }^{62}$ There was, therefore, a clear 'common desire'

suggerivano' (author's translation). Vittor Ivo Comparato, 'Il diritto di natura a Perugia tra la Repubblica romana e l'Unità,' Annali di storia delle università italiane 18 (2014): 221-242. 61 Ibid.

62 Bazzoli, Giambattista Almici e la diffusione di Pufendorf, 100. 
across eighteenth-century Italy to make use of Le droit des gens and texts of the école romande in adapting natural law and the law of nations at a variety of legislative, political and academic levels.

\section{Bibliography}

Bandelier, André, Emer de Vattel à Jean Henry Samuel Formey. Correspondance autour $d u$ Droit des gens (Paris: Editions Honoré Champion, 2012), 103-105.

Bazzoli, Maurizio, 'Aspetti della recezione di Pufendorf nel Settecento italiano,' in Dal 'De Jure Naturae et gentium' di Samuel Pufendorf alla codificazione prussiana del 1794. Atti del convegno internazionale, Padova, 25-26 ottobre 20o1, ed. Marta Ferronato (Padova: Cedam, 2005), 41-6o.

Bazzoli, Maurizio, 'Giambattista Almici e la diffusione di Pufendorf nel Settecento Italiano,' Critica Storica 16 (1979): 3-10o.

Beccaria, Cesare, Dei delitti e delle pene, Le edizioni italiane del "Dei delitti e delle pene", ed. Luigi Firpo (Milano: Einaudi, 1984).

Berti, Francesco Illuminismo, rivoluzione, modernità: lo spirito del secolo in alcuni significativi scritti dei gesuiti espulsi, in La presenza in Italia dei gesuiti iberici espulsi. Aspetti religiosi, politici, culturali, ed. Ugo Baldini, Gian Paolo Brizzi (Bologna: CLUEB, 2010), 321-336.

Birocchi, Italo et al. (ed.), Dizionario Biografico Giuristi Italiani (XII-XX secolo) (Bologna: Il Mulino, 2013).

Buonafede, Appiano, Della restaurazione di ogni filosofia pe' secoli XVI, XVII, XVIII (Milano, Venezia: Pasquali, 1792).

Burlamaqui, Jean Jacques, Principii del diritto naturale di G.G. Burlamachi consigliere di Stato, già professore di diritto naturale e civile in Ginevra (Venezia: Giovanni Gatti, $1780)$.

Carafa, Giuseppe Maria, Difesa del vescovo di Mileto e del Collegio dei Greci in Roma contro un'istanza fiscale ed una scrittura stampata col titolo di Dimostrazione del padronato della Real Corona, sulla chiesa e badia della Trinità di Mileto (Napoli: 1769).

Carrera, Alberto, Pietro Tamburini "Giurista". Per una storia della cultura giuridica giansenista italiana (PhD diss., University of Milan, 2015).

Comanducci, Paolo, Il Settecento conservatore: Lampredi e il diritto naturale (Milano: Giuffrè, 1981).

Comparato, Vittor Ivo, 'Il diritto di natura a Perugia tra la Repubblica romana e l'Unità,' Annali di storia delle università italiane, 18 (2014): 221-242.

Conti, Vittorio (ed.), La recezione di Grozio a Napoli nel Settecento (Firenze: Centro Editoriale Toscano, 2002).

De Simoni, Alberto, Del furto e sua pena (Lugano: Agnelli, 1776). 
Di Renzo Villata, Gigliola, 'Introduzione. La formazione del giurista in Italia e l'influenza culturale europea tra Sette e Ottocento: il caso della Lombardia,' in Formare il giurista. Esperienze nell'area lombarda tra Sette e Ottocento, ed. Gigliola di Renzo Villata (Milano: Giuffrè, 2004), 1-106.

Di Renzo Villata, Gigliola, 'Le droit public en Lombardie au XVIIIe siècle et l'Europe,' in Science politique et droit public dans les facultés de droit européennes (XIIIe-XVIIIe siècle), ed. Jacques Krynen, Michael Stolleis (Frankfurt am Main: Klostermann, 2008), 583-612.

Di Simone, Maria Rosa, 'L'influenza di Christian Wolff sul giusnaturalismo dell'area asburgica e italiana,' in Dal 'De Jure Naturae et gentium' di Samuel Pufendorf alla codificazione prussiana del 1794. Atti del convegno internazionale, Padova, 25-26 ottobre 2001, ed. Marta Ferronato (Padova: Cedam, 2005), 221-268.

Di Simone, Maria Rosa, 'Stato e diritto nel pensiero di Gian Rinaldo Carli,' in Percorsi del diritto tra Austria e Italia (secoli XVII-XX) (Milano: Giuffrè, 2006), 135-158.

Dufour, Alfred, 'Die Ecole romande du droit naturel - ihre deutschen Wurzeln,' in $\mathrm{Hu}$ manismus und Naturrecht in Brandenburg-Preußen, ed. Hans Thieme (Berlin: W. de Gruyter, 1979), 133-143.

Dufour, Alfred, Le mariage dans l'école allemande du droit naturel moderne au XVIIIe siècle (Paris: Libraire générale de droit et de jurisprudence, 1976).

Duve, Thomas, 'European Legal History - Global Perspectives Working Paper for the Colloquium European Normativity - Global Historical Perspectives (Max Planck Institute for European Legal History, September, 2nd-4th 2013),' Max Planck Institute for European Legal History Research Paper Series 6 (2013), accessed 28 January 2017, https://papers.ssrn.com/sol3/papers.cfm?abstract_id=2292666.

Ferrari, Stefano (ed.), Fortunato Bartolomeo De Felice. Un intellettuale cosmopolita nell'Europa dei Lumi (Milano: FrancoAngeli, 2017).

Fiocchi, Malaspina Elisabetta, L'eterno ritorno del Droit des gens di Emer de Vattel (secc. XVIII-XIX). L'impatto sulla cultura giuridica in prospettiva globale (Frankfurt am Main: Global Perspectives on Legal History, Max Planck Institute for European Legal History Open Access Publication, 2017), http://dx.doi.org/ $10.12946 /$ gplh8.

Foljanty, Lena, 'Legal Transfer as Processes of Cultural Translation: on the Consequences of a Metaphor,' Max Planck Institute for European Research Paper series 9 (2015), accessed 28 January 2017, http://ssrn.com/abstract $=2682465$.

Galiani, Ferdinando, De' doveri e de' principi neutrali verso i guerreggianti e di questi verso i principi neutrali (Napoli: 1782).

Guasti, Niccolò, L'esilio italiano dei gesuiti spagnoli. Identità, controllo sociale e pratiche culturali (1767-1798) (Roma: Edizioni di storia e letteratura, 2006).

Labriola, Giulia Maria, Barbeyrac interprete di Pufendorfe Grozio. Dalla costruzione della sovranità alla teoria della resistenza, (Napoli: Editoriale Scientifica, 2003). 
Lampredi, Maria Giovanni, Del commercio dei popoli neutrali in tempo di guerra (Firenze: 1788).

Landi, Sandro, Il governo delle opinioni. Censura e formazione del consenso nella Toscana del Settecento (Bologna: Il Mulino, 200o).

Luporini, Luigi, 'Per una lettura della voce "Droit naturel" nell'Encyclopédie,' Studi Storici 28/3 (1987): 679-697.

Marini, Giuliano, 'Dal diritto naturale alla filosofia del diritto,' in Storia dell'Università di Pisa (Pisa: Pacini, 200o), vol. II, 635-661.

Mili, Callimaco, 'Osservazioni critiche sul libro intitolato Dei delitti e delle pene,' Nuova raccolta d'opuscoli scientifici e filologici 13 (1765): II-XLVII.

Padoa, Schioppa Antonio, Storia del diritto in Europa. Dal medioevo all'età contemporanea (Bologna: Il Mulino, 2007).

Päivärinne, Meri, 'Translating Grotius's De jure belli ac pacis: Courtin vs Barbeyrac,' Translation Studies 5/1 (2012): 33-47.

Panizza, Diego, 'La traduzione italiana del "De iure naturae" di Pufendorf: giusnaturalismo moderno e cultura cattolica nel Settecento,' Studi Veneziani 11 (1969): 483-528.

Pasta, Renato, 'Dei delitti e delle pene et sa fortune italienne : milieux juridiques et lecture "philosophique"' in Beccaria et la culture juridique des Lumières, (Actes du colloque européen de Genève 25-26 Novembre 1995), ed. Michel Porret (Genève: Droz, 1997), 119-148.

Petronio, Giuseppe, L'autore e il pubblico (Pordenone: Studio Tesi, 1981).

Pufendorf, Samuel, Il diritto della natura e delle genti o sia sistema generale de' principii li più importanti di morale, giurisprudenza e politica, rettificato, accresciuto e illustrato (Venezia: Pietro Valvasense, 1757).

Pufendorf, Samuel, Il diritto della natura e delle genti o sia sistema generale de' principii li più importanti di morale, giurisprudenza e politica, rettificato, accresciuto e illustrato (Venezia: Pietro Valvasense, 1759).

Pufendorf, Samuel, I doveri dell'uomo e del cittadino: tali che a lui dalla legge naturale sono prescritti, dalla versione francese di Giovanni Barbeyrac tradotti, e con molte aggiunte corretti ed illustrati da Michele Grandi accademico di Udine (Venezia: Francesco Pitteri, 1761).

Quaglioni, Diego, 'Pufendorf in Italia. Appunti e notizie della prima diffusione della traduzione italiana del De iure naturae et gentium,' Il Pensiero Politico 32 (1999): 23-25o.

Rao, Anna Maria, 'La stampa francese a Napoli negli anni della Rivoluzione,' Mélanges de l'École française de Rome. Italie et Méditerranée, 102/2 (1990): 469-520.

Roggerone, Giuseppe, L'abbé de Mably: politico della teologia illuminata (Firenze: Centro Editoriale Toscano, 1991).

Sofri, Gianni, 'Almici Pietro Camillo,' in Dizionario Biografico degli Italiani 2 (1960), 512. Solimano, Stefano, 'Paolo Risi e il processo penale (1766),' in Studi di storia del diritto (Milano: Giuffrè, 2001), vol. III, 419-519. 
Spagnesi, Enrico, "The trade of "neutral nations" as viewed by the publicist Lampredi,' in War, Trade and Neutrality. Europe and the Mediterranean in seventeenth and eighteenth centuries, ed. Antonella Alimento (Milano: Franco Angeli, 2011), 233-246.

Stapelbroek, Koen, 'I significati della neutralità: la storia del commercio mediterraneo in Dei Doveri dei Principi Neutrali,' in Il linguaggio del tardo illuminismo. Politica, diritto e società civile, ed. Antonio Trampus (Roma: Edizioni di storia e letteratura, 2011), 53-79.

Stapelbroek, Koen, Love, Self-deceit and Money: Commerce and Morality in the Early Neapolitan Enlightenment (Toronto: University of Toronto Press, 2008).

Stella, Pietro, 'Pietro Tamburini nel quadro del giansenismo italiano,' in Atti del Convegno internazionale in occasione del $250^{\circ}$ della nascita (Brescia, 25-26 maggio 1989), ed. Paolo Corsini, Daniele Montanari (Brescia: Morcelliana, 1993).

Stoffella, Stefania, 'Assolutismo e diritto naturale in Italia nel Settecento', Annali dell'Istituto storico italo-germanico 26 (2000): 137-175.

Stoffella, Stefania, 'Il diritto di resistenza nel Settecento Italiano. Documenti per la storia della traduzione del De iure naturae et gentium di Pufendorf,' Magistrature et politique 2 (2001): 173-199, accessed 28 January 2017, http://laboratoireitalien .revues.org/261.

Trampus, Antonio, 'Il ruolo del traduttore nel tardo illuminismo: Lodovico Antonio Loschi e la versione italiana del Droit de gens di Emer de Vattel,' in Il linguaggio del tardo illuminismo. Politica, diritto e società civile, ed. Antonio Trampus (Roma: Edizioni di storia e letteratura, 2011), 81-108.

Trampus, Antonio, 'Dalla libertà religiosa allo Stato nazione: Utrecht e le origini del sistema internazionale di Emer de Vattel,' in I trattati di Utrecht: una pace di dimensione europea, ed. Frédéric Ieva (Roma: Viella, 2016), 93-106.

Trampus, Antonio, 'La traduzione toscana del Droit des gens di Emer de Vattel (circa 1780): contesti politici, transferts culturali e scelte traduttive,' in Traduzione e Transferts nel XVIII secolo tra Francia, Italia e Germania, ed. Giulia Cantarutti, Stefano Ferrari (Milano: FrancoAngeli, 2013), 153-174.

Trampus, Antonio, 'Le costituzioni italiane prime di Cadice: Vattel e le radici democratiche italiane,' in Cadice e oltre: costituzione, nazione e libertà. La carta gaditana nel bicentenario, ed. Fernando García Sanz et al. (Roma: Istituto per la Storia del Risorgimento italiano, 2015), 161-172.

Trampus, Antonio, 'The circulation of Vattel's Droit des gens in Italy: the doctrinal and practical model of government,' in War, Trade and Neutrality. Europe and the Mediterranean in seventeenth and eighteenth centuries, ed. Antonella Alimento (Milano: FrancoAngeli, 2011), 217-232.

Van Kley, Dale K., 'From the Catholic Enlightenment to the Risorgimento: the Exchange Between Nicola Spedalieri and Pietro Tamburini, 1791-1797,' Past \& Present 224/1 (2014): 109-162. 
Vannini, Fabrizio, 'Lampredi Giovanni Maria,' in Dizionario Biografico degli Italiani 63 (2004), 259-262.

Vattel, Emer de, The Law of Nations, Or, Principles of the Law of Nature, Applied to the Conduct and Affairs of Nations and Sovereigns, with Three Early Essays on the Origin and Nature of Natural Law and on Luxury, ed. Béla Kapossy, Richard Whatmore (Indianapolis, IN: Liberty Found, 2008).

Vattel, Emer de, Il diritto delle genti, ovvero principii del diritto naturale applicati alla condotta e agli affari delle nazioni e de' sovrani (Lyon: 1781).

Vec, Miloš, 'L'ambassade dans la science du droit des gens,' in Les écrits relatifs à l'ambassadeur et à l'art de négocier du Moyen Âge au début du XIX $X^{e}$ siècle, ed. Stefano Andretta, Stéphane Péquignot and Jean-Claude Waquet (Rome: École française de Rome, 2015), 487-522.

Verri, Alessandro, Discorsi vari del conte Alessandro Verripubblicati nel giornale letterario intitolato Il Caffè (Milano: Silvestri, 1818).

Villani, Pasquale, Mezzogiorno tra riforme e rivoluzione (Bari: Laterza, 1962).

Vismara, Paola, 'Pietro Tamburini e il "dispotismo pontificio", in Il giansenismo e l'Università di Pavia. Studi in ricordo di Pietro Stella, ed. Simona Negruzzo (Milano: Giuffrè, 2012), 95-114.

Zordan, Giorgio, 'L'insegnamento del diritto naturale nell'Ateneo Patavino e i suoi titolari (1764-1855),' Rivista di Storia del Diritto Italiano 72 (1999): 5-76.

Zurbuchen, Simone, Das Prinzip des Naturrechts in der école romande du droit naturel,' in Jahrbuch für Recht und Ethik 12 (2004): 189-211.

Zurbuchen, Simone, 'Teaching the Law of Nature and Nations in the Swiss Context,' Etudes Lumières.Lausanne, 6 (novembre 2018): 1-19, accessed 15 February 2019, http://lumieres.unil.ch/fiches/biblio/9472/. 



\section{Persons Index}

Achenwall, Gottfried 188

Adrian, Roman Emperor 177

Agathias 54

Alembert, Jean-Baptiste Le

Rond de 246, 312

Almici, Giovambattista $\quad 306-309,320$

Amati, Domenico 308

Amthor, Christoph Heinrich 41, 44-49, 54, 56

Ancher, Peder Kofod 65

Ancillon, Charles 21

Anne, Queen of Great Britain 11-13, 15

Antonius, Roman Emperor 177

Aristotle 168

Attila 180

Augustus II, Elector of Saxony and King of Poland 12

Bacon, Francis 90

Barbeyrac, Jean 2of., 27f., 47, 63, 146, 168f., 237, 243, 253-257, 259f., 265f., 269, 271, 304-309, 316f., 320

Beccaria, Cesare $\quad 306,313$

Benedict IV, Pope 314

Bernstorff, Johann Hartwig Ernst von 81

Bertolini, Stefano 309

Bodin, Jean 137, 161, 200

Boeckler, Johann Heinrich $\quad$ 46, 255

Böhmer, Justus Henning 196

Bornemann, Mathias Hastrup 67f., 70

Boucher d'Argis, Antoine-Gaspard $312 f$.

Bourguet, Louis 253f., 257

Bousquet, Marc-Michel 256-26o, 273

Braunschweig-Wolfenbüttel, Dukes of 32

Brühl, Heinrich von $\quad 298$

Buckisch und Loewenfels, Gottfried Ferdinand von 198

Budde(us), Johann Franz 18, 27, 31, 265

Buisson, Leonard $\quad 236$

Burlamaqui, Jean-Jacques $\quad 174,236-248,25$ o, 253-256, 269-271, 304-306, 309-314, $316,319 f$.

Bynkershoek, Cornelius van $\quad$ 161, 291, 295
Camillo, Pietro (pseudonym: Mili, Callimaco) $\quad 306$

Carafa, Giuseppe Maria 314

Catharina II, Czar of Russia 83

Chapuis, Antoine 259

Charles II, King of England 232

Charles of Bourbon, King of Naples 314

Charles vi, Emperor of the Holy Roman Empire 43

Charles XII, King of Sweden $\quad$ 12f., 179-181

Chauvin, Etienne 21

Choisy, François-Timoléon de 297

Christian Ernst, Margrave of Brandenburg-Bayreuth $16 f$.

Christian v, King of Denmark-Norway 56

Christian vi, King of DenmarkNorway 48,56

Christian VII, King of Denmark 234

Chrysostom, John $\quad 263$

Cicero, Marcus Tullius $\quad$ 18, 30, 278

Clavel de Brenles, Jacques Abram Daniel 257, 259

Cocceji, Heinrich $\quad$ 198, 214, 255, 26o, 266-269, 271, 273f.

Cocceji, Samuel 92, 254f., 26o, 266-269, 271, 273f.

Conforti, Francesco 313

Conring, Hermann $\quad$ 193, 196

Courtin, Antoine de 21

Crispi, Count Benedetto 31of.

Crousaz, Jean-Pierre de 244, 254, 257 f.

Cumberland, Richard 110

Davenant (D'Avenant), Charles de $149 f$.

Dichmann, Carl Frederik 70

Dickmann, Fritz 192

Diderot, Denis 312

Droysen, Johann Gustav 192

Eggers, Christian Ulrich Detlev von $65 f$. Eschenburg, Johann Joachim $\quad 96-98$

Fabricius, Johann Andreas 96

Felice, Fortunato Bartolomeo de $\quad 304,309 f$.

Fénelon, François $232 f$. 
Francis II, Duke of Lorraine 305

Francke, August Hermann 31

Franzoja, Abbot Matteo 317

Frederick I, King of Prussia 14, 20

Frederick II, King of Prussia $\quad$ 253, 267f., 273,298

Frederick II, Landgrave of HessenKassel 236, 240-242, 244-248

Frederick IV, King of DenmarkNorway $\quad 41-43,45^{-49}, 56$

Frederick Wilhem I, King of Prussia 136, 267

Gaius $\quad 269$

Galiani, Ferdinando $317 \mathrm{f}$.

Galissà y Costa, Luciano 311

Gatti, Giovanni 31of., 319

Genghis-Khan 180

Gentili, Alberico $\quad$ 173, 20o, 258f., 288, $318 f$.

Gentz, Friedrich 77

Gerstlacher, Carl Friedrich $\quad$ 193, 198

Glafey, Adam Friedrich 93f., 96, 101

Gottorp, Charles Frederick of 42f., $45^{-48,54 f .}$

Gottsched, Johann Christoph 18

Gozzi, Gasparo 311

Grandi, Michele $308 f$.

Grégoire, Henri Jean-Baptiste 74

Griebner, Michael Heinrich 5of.

Grimm, Friedrich Melchior $\quad 246$

Gronovius, Johann Friedrich 254f., 26o

Gross von Trockau, Christoph Adam 17-21, $29,32 f$.

Grotius, Hugo 11, 21, 27f., 3of., 41, 45f., 5of., 53f., 63-65, 68, 70, 79, 81, 85, 92f., 109, 128, 132, 135f., 145f., 16of., 165-172, 174, 200, 254-256, 258-274, 279, 288, 293, 307f., 310, 312, 319

Gundling, Nicolaus Hieronymus 95f., 133f., 139-141, 147, 151, 194, 197, 205, 216f., 259, 265

Günther, Karl Gottlob $\quad 66,74,97$

Gustav III, King of Sweden $\quad 244-247,250$

Häberlin, Franz Dominicus 210

Häberlin, Karl Friedrich 195

Heineccius, Johann Gottlieb $132-136,138 f$., 141-149, 151-153, 265, 317

Helvétius, Claude-Adrien 246

Hermogenian $\quad 269$
Hertenstein, Johann Heinrich 32

Hertius, Johann Nicolaus $\quad 267,273$

Heumann, Christoph August $\quad 89,91,95$

Hobbes, Thomas 55, 107-110, 118-129, 134f., $137,145,149,152,16 \circ, 164,176 f$., 20o, 232f., 259, 263f., 282, 310

Hojer, Andreas $\quad 39-44,48-57,65 f$.

Holberg, Ludvig $39,41,57,62$

Holstein-Gottorp, Dukes of / House of $\quad 40-49,56$

Horn, Johann Friedrich 55

Huber, Ulrik 51

Hübner, Martin 81

Hurtigkarl, Frederik Theodor 67

James II, King of England $\quad 167$

Jenisch, Daniel 77

Justinian I, Roman Emperor $\quad$ 267, 269

Kahle, Louis Martin 147

Kant, Immanuel $\quad 61,66 f$.

Kemmerich, Dietrich Hermann 14-19, 24-29, 33

Köhler, Johann David 210

Krause, Johann Christian 211

Krohg, Christian 6of., 66-68,70-86

Krug, Wilhelm Traugott 71

Kulpis, Johann Georg 27

Lampredi, Giovanni Maria 317-319

Lamy, Bernard 29

Leibniz, Gottfried Wilhelm 143, 164, 188f., 198f., 205-2o8, 254, 267, 273

Leopold I, Emperor of the Holy Roman Empire 205

Locke, John 29-31, 245

Loschi, Antonio Lodovico 311-313

Louis XIV, King of France 21, 143f., 175, 18of., 202f., 205-2o8, 211

Louis XV, King of France 299

Loys de Bochat, Charles-Guillaume $\quad 256-26$, 269, 273

Ludewig, Johann Peter von 265, 267, 273

Mably, Gabriel Bonnot de $\quad 73,97,198$, 211, $310 f$.

Machiavelli, Niccolò $\quad$ 142f., 265

Magalotti, Pietro Antonio $319 f$.

Marcus Aurelius, Roman Emperor 177 
Marmontel, Jean-François 246

Martens, Georg Friedrich von $\quad 66,73 f$., 85, 92, 94, 97

Matveyev, Andrey Artamonovich $\quad$ 11-14, 16

Mei, Cosimo 311

Meusel, Johann Georg 97

Mezeray, François-Eudes 297

Mili, Callimaco, (see Camillo, Pietro) 306

Mirabeau, Honoré-Gabriel Riqueti de 246

Montesquieu, Charles de Secondat, Baron de 29, 304

Moser, Friedrich Karl von 196

Moser, Johann Jacob $\quad 15,42,66,92,94,189$, $193,195,197,211-213,215^{-218}$

Mussard, Bénigne $\quad 256$

Napoleon Bonaparte $\quad 85,311$

Nerva, Roman Emperor 177

Noël de Saint Clair, Jean Baptiste $\quad 316$

Nørregaard, Lauritz $62 \mathrm{f}$.

Ockley, Simon 297

Ompteda, Dietrich Heinrich Ludwig von 96f., 100-102

Orontes (see Vetter, Johann Christoph) 22-24, 26 f.

Ostervald, Frédéric Samuel 311

Peter I, Czar of Russia $\quad 11-13,15,163,174-183$

Pitteri, Francesco 309

Porpora, Antonio 308

Pufendorf, Samuel 2of., 27f., 3of., 41, 47,

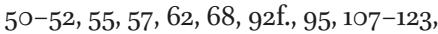
125-129, 135-138, 143-149, 16o, 162-164, 168-170, 174, 176, 189, 194, 196, 198-200, 202f., 205f., 2o8-21o, 218, 237, 254-256, 258f., 263-266, 269, 273f., 279, 282f., 288, 304, 3o6-310, 312, 319f.

Pütter, Johann Stephan $\quad$ 96, 99-101, 189, 195 , 197, 211

Quesnay, François $\quad 246$

Rachel, Samuel $\quad 50,5^{6}$

Ranke, Leopold von 192

Reitzer, Christian 41

Reventlow, Christian Ditlev Frederick, Count of 234

Reverdil, Élie Salomon Francois 234
Richelieu, Armand-Jean du Plessis, Duc de 204

Risi, Paolo 314

Römer, Carl Heinrich von 97

Rousseau, Jean-Jacques $\quad 29,163,176 f$., 198, 229-237, 240, 242-250, 304

Saint- Pierre, Charles Irénée Castel de 149, 199

Scheffer, Carl Fredrik $\quad 245^{-248,250}$

Schiller, Friedrich 102

Schlegel, Johann Friedrich Wilhelm 61,63 , 65-67, 69f., 81, 84f.

Schmauss, Johann Jacob 132f., 135f., 138-144, 146f., 150-153, 196f., $209 f$.

Schmeitzel, Martin 96

Schmerfeld, Johann Daniel 240

Schmid, Christian Heinrich 96

Schmitt, Carl 172

Schowart, Anton Wilhelm 31

Schröter, Christian 31

Schwarz, Christian Gottlieb 50,55

Seckendorff, Ernst Friedrich von 22

Seckendorff, Johann Wilhelm

Gottfried von 22

Seigneux de Correvon, Gabriel 257

Senkenberg, Renatus Karl von $194 \mathrm{f}$.

Simoni, Alberto de 314

Simon-August, Count of LippeDetmold 258

Sinold, Philipp Balthasar (von Schütz) $\quad 28$

Smith, Adam $\quad 267,274$

Stanislaus I Leszcynski, King of Poland $12 f$.

Steck, Johann Christoph 213-216

Stenbock, Magnus Gustafsson 4 43-45, 54

Stolle, Gottlieb 95

Suárez, Francisco $\quad$ 92, 261

Sulzer, Johann Georg $96 f$.

Tacitus 180

Tamburini, Abbot Pietro 316

Tamerlane 180

Teissier, Antoine 21

Textor, Johann Wolfgang 95

Thomasius, Christian $\quad 16,27-29,33,39,41$, 5of., 57, 93-95, 132f., 135f., 138, 189, 194, 265,304

Titius, Gottlieb Gerhard $\quad 27,50,55$

Trajan, Roman Emperor 177 
Treitschke, Heinrich von 192

Tribonianus, Flavius $\quad 266,269$

Valvasense, Pietro 306

Vattel, Emer de $\quad 63-66,68,71,73-75,77$, 79, 85, 97f., 101, 145, 152f., 159-168, 170-183, 188, 193, 201-204, 218, 253-255, 269-274, 278-300, 304-309, $311-320$

Verri, Alessandro $\quad 313 f$.

Vetter, Johann Christoph (pseudonym: Orontes) 18, 22, 29

Vetter, Johann Friedrich 195

Vitoria, Francisco de 128, 200
Vitriarius, Philipp Reinhard $\quad$ 27, 255f.

Voltaire $163,180-182,244,246,304$

Weghorst, Henrik $\quad 41,50,56 f$.

Whitworth, Charles 13, 15

William of Orange, King of England $\quad 167$

William VIII, Landgrave of Hessen-Kassel 236

Wolff, Christian $\quad 62,68,94,96,98,101,159$, 164, 168-171, 174-176, 181, 201-203, 214, 245, 253f., 271f., 279-284, 287, 289, 304, $310,317,319$

Ziegler, Caspar $\quad$ 27,53

Zschackwitz, Johann Ehrenfried $197 f$. 


\section{Places Index}

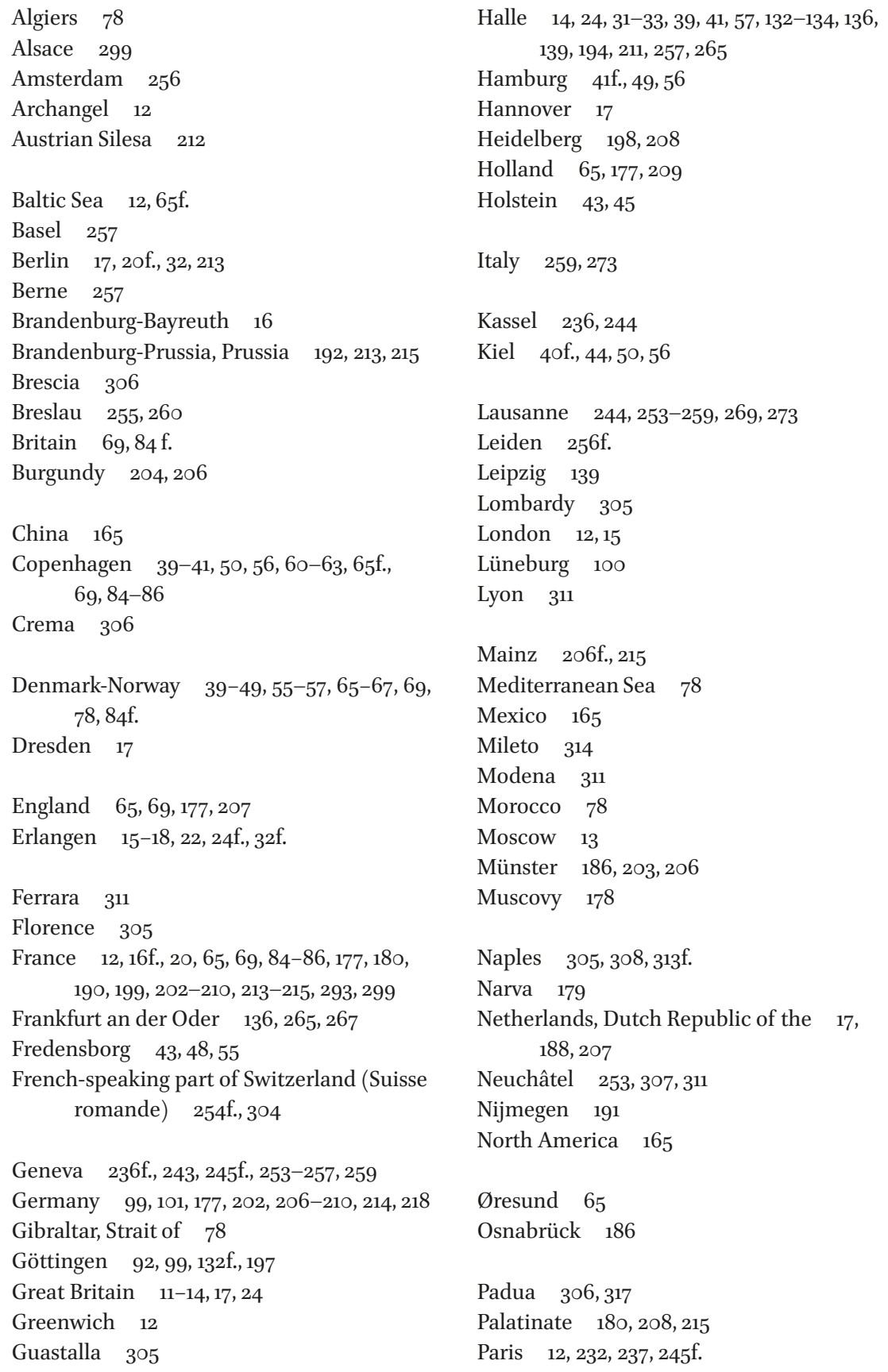




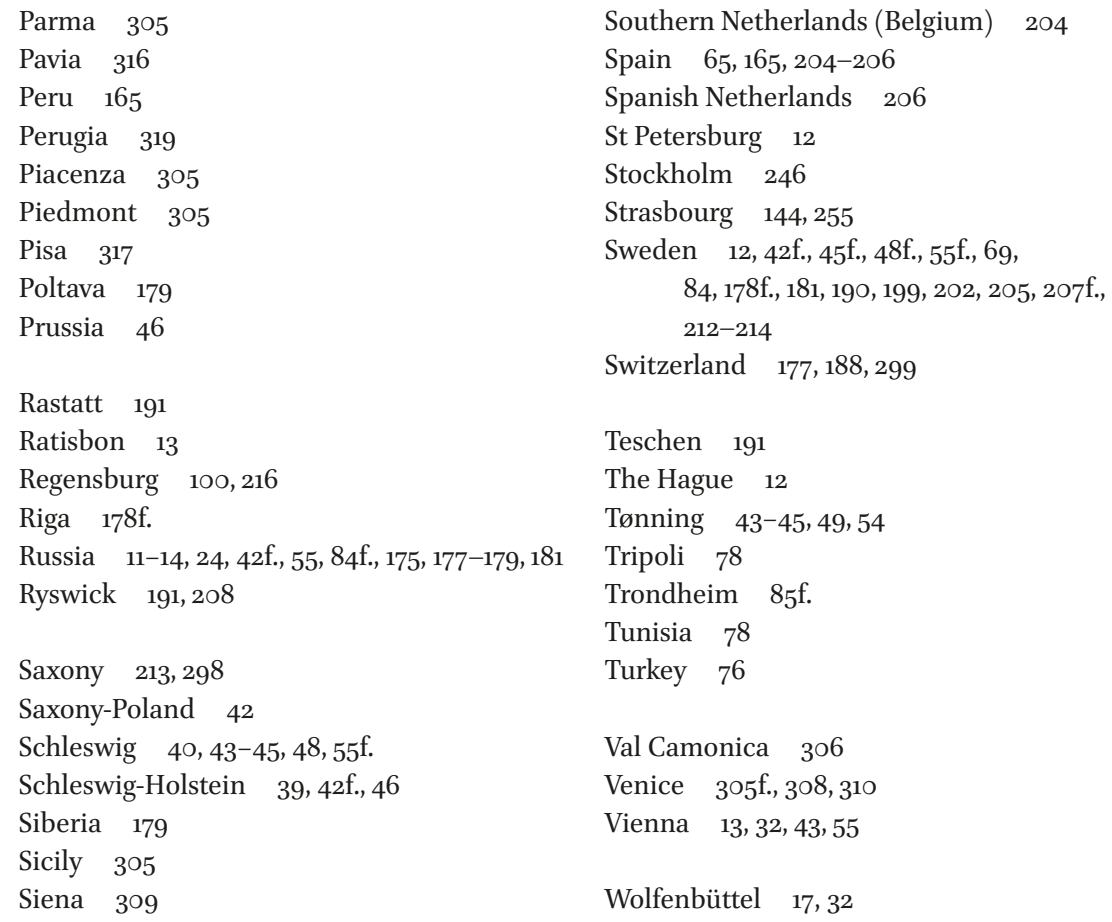




\section{Subjects Index}

\author{
Absolutism 243f., 247 \\ Academy / Academia \\ Academia Equestris 17 \\ Academia Practica 17, 33 \\ of Geneva 236f., 253, 256 \\ of Lausanne 244, 253-255, 257 \\ Royal Danish Naval Academy $6 \circ, 66$, \\ 68-70, 78, 85f. \\ Adaptation $305,315,321$ \\ Agreement 94, 261, 264, 266, 27of. \\ Agriculture 164 \\ Alliance 97 \\ Ambassador 11, 14f., 24, 259, 264, 297 \\ Army 233, 235, 242 \\ Arts and sciences $176 f$. \\ Atheism 23 \\ Balance of power $132,147,149-153$, \\ 259,267 \\ Barbarians, barbarism $\quad 76 \mathrm{f}$., 163, 176, 180, 183 \\ Belligerents $\quad 81-83$ \\ Bellum justum $\quad 21$ \\ Benevolence 24gf. \\ Bibliography 101 \\ Bildung 102 \\ British Parliament 14 \\ British Royal Navy $\quad 69,84$
}

Catholics / Catholicism 194, 197, 205, 215 f., 307

Cavalier 23

Church 165

Civil

Civil order 22gf.

Civil servant 34

Civil society $\quad 97,109,119-121,126,129$

Civilization, civilized $\quad 99,161,163,167$, 178,18 o

civilized nations $\quad 163,175$ f., 178

civilized people $\quad 167$

Civitas maxima (great republic) 271f., 28of., 283

Clementia 299

Colonization $\quad 161,165$

Commentary $260,265,268,273$
Commerce 291-293, 299

Conscience $\quad 161,173$

Consent $\quad 63-65,71,82 f$., 262f., 265, 268, 271f., $279,287,289,291$

Constitution $305,313,315$

Contraband $\quad 82-84$

Contract (see also Covenant) $\quad 81,98 f$., 264, 270

Corruption 233

Cosmopolitanism 294

Counselling (political) 33

Country 96,100

Court 15, 17, 23, 26f., 29, 33f., 233, 235f., 242

european 11,14

princely 14, 16

Courtier 34

Covenant (see also Contract) 264, 266, 27of.

Custom 72f., 76, 94, 98f., 263, 265f., 27of. activation of $287,292 \mathrm{f}$.

fictional character of 293

formation of $279,287,289 f$., 296

general rules of $289,295^{-297}$

identification of $\quad 287,289 f$., 296

indifferent 290, 295-297

non-indifferent $\quad 295^{-297}$

publicity of $286 f$.

regional 29of., 294, 299

universal 290, 294f., 297, 299

violation of $\quad 291,294 f ., 297$

Declaration of war (see War, declaration of)

Diplomacy $\quad 66,210 f ., 216,305,307,313$

Diplomat 93, 100

Diplomatic immunity $\quad 11,14 f$.

Diplomatic Priviliges Act 14

Diplomatic theory $15 f$.

Discipline gof.

Duty $23,93,96,238$

École romande du droit naturel (see Swiss school of natural law)

Edict of Nantes 21

Education, royal $229-237,239-244,247-250$

Encyclopaedia, encyclopaedic 91f., 96, 99-101 
Enlightenment / enlightened $132,134,162$, 182, 244-248, 305f., 309, 316, 320 enlightened absolutism $\quad 181$ enlightened despotism $\quad 177,181$ enlightened prince $\quad 229,231-250$

Envois 62, 67, 73

Erudition 17f., 22f., 33, 91, 257, 259, 319

Ethics 16, 23, 25, 229-231, 233, 235, 245

Europe / European / Europeans 1-7, 11. 14.26. 29f., 43, 46, 48, 51, 66, 69, 72-74, $76-78,999,108,128,136,138,140-144$, 146-153, 159-162, 164f., 167, 174f., 178-18o, 182f., 19o-192, 194, 198-200, 202, 205, 209-211, 214, 218, 232, 243, 247, 259, 267, 273f., 279, 285, 290, 293-295, 297f., 310, 317 f.

Examples, historical 297

Exams 18,26

Exercitia $\quad 16,26$

Exercitium disputatorium 18

Expediency 282,300

Feeling $249 f$.

Foreign languages $\quad 16,18$

Franckesche Stiftungen (Francke Foundations) $\quad 31$

Freedom 235f., 245, 247

French (language) 159

French Colony 17, 21

Gallant, gallantry $\quad 20,33$

German (language) 18f., 26-28, 89, 91

German Empire (see Holy Roman Empire)

German liberties (teutsche Freiheit) 197, 218

Germans 166

Glory $\quad 168,180-182$

Göttingen school of Law 99

Governance, political 90

Government, good $\quad 231,237,243,245^{-248}$

Grammar school 19

Grand Alliance / League of Augsburg 12

Grand Tour 17

Guarantee, guarantor $\quad$ 189-192, 195, 198-200, 202-218

Helvetic Confederation $\quad 254$

Higher education 18,29

Historia literaria 89, 91, 95f., 99-102

Historians of scholarship $\quad 102$
Historiographers, national $\quad 288$

History 14, 16, 23, 132f., 135, 138, 140-143, 147-151, 16o, 174

civil 90

classical $\quad 288$

ecclesiastical 90

philosophical histories $\quad 162,180,182$

of disciplines 91

of international law $\quad 1-3$

of learning $89,92,96$, $101 f$.

of natural law 95

of scholarship $\quad 91$

Holy Roman Emperor $\quad$ 190, 201, 204f., 207, 212-216

Holy Roman Empire / German Empire 13, 17, 26, 31f., 99f., 137, 139-141, 143, 186-192, 195-199, 201-204, 206-210, 212-215, 217f.

Huguenots 16, 21

Imperial constitution $\quad$ 186, 189-191, 193, 197-199, 204, 211f., 214f., 217

Imperial Diet 13

Imperial estates (including Imperial princes) 186-188, 190, 194-197, 199-205, 207-210, 212-217

Indians 166

Indignation 230,250

Interest $132,137,147-153,232 f$., 239

International order $162,169 f ., 175,198$, 209, 290

International relations $11,14,27 f$., 63,66 , 161f., 170, 174, 272, 279

Intervention $186,200-203,208,210,212 f$., 216-218, 298

Jus foederum $\quad 208-210,218$

Jus publicum universale $\quad 196$

Jurisprudence 3 o, 5o, 54, 95, 97f., 159, 168, 313,317

Jurist 89,231

Jus gentium (see: Law of nations) $\quad$ 92, 95-97

Justice $\quad 170-173,229-231,233,238,242,249$

Latin (language) 159

Law 14, 160, 162, 164, 174, 177, 182, 229-231, 233, 235, 238f., 245, 247

case 100

civil 16, 19, 27, 3of., 47, 5of., 236, 264, 274

constitutional 14,100 
contract 28

cosmopolitan (Weltbürgerrecht) $\quad 61,74$

customary 64

diplomatic 15f., 24

fecial (jus feciale) 68

feudal 19

fundamental 245 f.

human 270

international (see Law of nations)

municipal 262

natural, law of nature (see Law of nature)

obligatory 94

politic law 254

positive 47,5 of., 98-100

private 28,31

public (jus publicum; Staatsrecht) 16, 18, 20, 25, 28, 31, 61, 65f., 19o, 192f., 197, 204, 211, 213, 216, 218f., 246, 258, 273

Roman 256, 261, 274

universal 238,246

of humanity $169,236,239$

of justice 236,239

of the people 246

of war $125^{-127}$

Law of nations (jus gentium) 1-4, 14-18, 2of., $23-25,27-34,47,5$ o, 6o-69, 73-79, 82f., 85, 91-101, 107, 159, 161f., 182, 189-191, 198f., 202-204, 211f., 218f., 236-239, 242, 245f., 253-265, 269-271, 273f., 304-3o6, 308 , 311f., 315-321

conventional $64,66,286 f$.

customary $\quad 64,66-68,269,271,287,289$

definition of $\quad 262 f$., 269

dualist account of $\quad 255,261,271,273 f$.

general 94, $99 f$.

natural $61,68,70-73,75,77,80,82-85$,

270, 272, 286, 28 gf.

naturalist account of $\quad 255,265,269,273 f$.

necessary $64,71,178,270,272$

positive $61,64-67,71-76,78,80,82-86$, 98-10o, 261, 264f., 27of., 287

Roman-law notion of $\quad 261,263 f$., 269 treaty 269,271

voluntary (voluntarium) 64, 71, 79, 92f., 99, 161, 164, 170-173, 178, 261-273, 286f., 28gf.

Law of nature (jus naturae/ natural law/ jus universale) 14-18, 2of., 23-25, 27-34, 46f., 5o-52, 55, 57, 6o-65, 67f., 7of., 79f., 92f., 95-99, 101, 107-129, 132f., 135-142,
144, 146f., 149, 151-153, 161, 17of., 173, 187-19o, 192-196, 198-205, 214-219, 236-246, 248f., 253-267, 269-273, 281, 284, 286, 289f., 293, 304, 306, 309-313, 315 f., 320

Law of nature and nations $169,253^{-256}$, 26o, 266, 26gf., 273

Lawyer 97f., 10of.

League of Armed Neutrality first (1780-1783) 84 second (1800-1801) $\quad 67,84$

Lecture announcement $\quad 17,25$

Legal

doctrine $305,313,315,318$

education 100

studies 102

theory 99

transformation 315

Literary establishment $\quad 231,234,236,243$

Literary production 304

Logic $25 f$.

Love

of men / of the people $\quad 248-250$

of oneself 249

Magistrate $14 \mathrm{f}$.

Maturity 51,54

Matveyev incident $\quad 11-16,24,28$

Memorialists 288

Memorizing 19

Mercenary service $\quad 258,273$

Military 34

Minister $13-15,308$

Minority $45^{-48,} 5^{0}-5^{2}$ according to law of nature $\quad 5^{1-53}$ according to positive law $5^{1}$ in war $\quad 5^{2-54}$

Moderation $298 \mathrm{f}$.

Monarchy 209, 231-233, 243, 246, 310

Monsters 163, 166f., 169, 172, 174f., 179, 183

Moral $\quad 23-25,28,52,101$

Nation $\quad 262-266,268-272$

European $\quad$ 96, $99 f$.

polished $174 f$.

savage $76 f$.

Natural law (see Law of nature)

Natural right $118,122 f$., 129

Natural sense of judgment 230 
Naturalists $\quad 92$

Nature 229f., 235, 237, 240, $25^{\circ}$

Naval articles 70,79

Negotiations of nations $96 \mathrm{f}$.

Neutral, Neutrality $\quad 68 f$., 78, 81-86, $291 f$.

Nobility $\quad 16-18,20-23,25-27,29-31,33$ f.

Obedience 233, 240-242

Obligation 74, 92, 94, 98f., 116-119, 121, 123f., 254, 261f., 264-266, 268, 270, 272

Opinio juris 291

Pact 97

Paedagogium regium $\quad 3^{1}$

Peace / peaceful / peacetime $62,72,74 f$., $79-82,97,18$ o

universal 204

of Altranstädt 12

of the Pyrenees 150

of Westphalia (see also Treaty of Münster and Osnabrück) 1-3, 100, 140, 143f., 147, 150, 186-204, 206-219

Perfectio $\quad 28 \mathrm{o}-285$

Philosopher 97f., 229-231, 233, 236f., 244, 246, 249 f.

Philosophy $\quad 96-98$

practica, moralis, civilis $\quad 17 f$., $23 \mathrm{f}$., 27,31

Pietas 299

Pirates, piracy $\quad 69,80,169,172$

Pity 230, 250

Political statecraft $\quad 63,65$

Politician 10of.

Politics 16, 24, 31, 94, 239, 241, 243

Pope 174, 203, 314

Preceptor/ Professor/ Instructor/

Educator 23of., 233-237, 239f., $242-245,247$ f., 250

Pretexts 167f., 171-173, 179

Prisoners of war 179, 265

Privateering $80,86,169,172$

Prize court 8of., 86

Progress 1-2, 5, 89, 163, 180, 182f.

Propaedeutic 89-91,102

Protestants / Protestantism 192, 197, 199, 202f., 205, 208f., 213, 215-218, 306, 311

Prudence, political 55

Public 91, 229f.

felicity 231f. happiness 239, 241

institutions $\quad 229-231,248$

interest 231-233, 239

lessons 17

Publisher $\quad 307-310$

Punishment 145f., 169, 286, 298 f.

Ratio 291

Rational thinking 19

Reason 98, 233, 239f., 249, 281, 286, 291

Reasoning, fictional $\quad 283,286,296$

Reichshofrat (Aulic Council) 17

Reichskammergericht (Imperial Chamber

$$
\text { Court) } 17
$$

Religion 23, 77, 99, 143, 194-196, 202f., 216f., $305,309,312$

Repository of knowledge gof.

Republic of Letters 30

Rhenish Alliance (Rheinbund)

$$
\text { 1658-68 205-207 }
$$

Rhetoric 18

Right $62,68-70,73,75,77 f$., 8o, 82-85, 94, 96-98, 229, 237, 239, 241, 249

natural 237,249

perfect, imperfect $5^{\circ}$

of sovereignty 239

of war, by law of nature $\quad 5^{0}-55$

Ritterakademie $\quad$ 15-19, 22, 25f., 29f., 32-34

Berlin 20, 32

Brandenburg 32

Erlangen $\quad 15 f$., 18, 22, 25, 32f.

Liegnitz (Legnica) $31 \mathrm{f}$.

Vienna 32

Wolfenbüttel 32

Scholasticism 135

Scientific research 90

Scythians 166

Self-interest $231,233-235,237,279-284$, 289,300

Self-preservation $\quad 135,138,148$

Shipping $69,78,84$

Siècle classique 20

Sociability (socialitas, sociabilité, sociality) 24, 110-121, 267, 270

Société du comte de la Lippe (Simon August von Lippe-Detmold) $258 \mathrm{f}$.

Society $\quad 238,245$

Society of states $\quad 262$ 


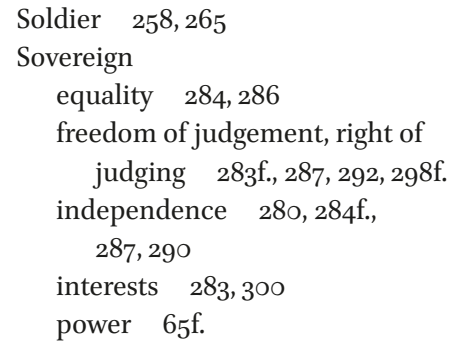

Sovereignty $135,137,149,152$ f., 172f., 186-188, 19o, 196, 199-203, 218, 305, 312

Staatenkunde 100

State

civil $47,5^{2}$

of nature / of liberty $47,5^{2-54,134 f \text {., }}$ $145^{f}$., 152

States 92, 232, 238-240, 261-265, 271f., 305, $310,312,315,317 \mathrm{f}$.

barbarian 166, $172 \mathrm{f}$.

European 99

German territorial states 100

systems of $135,137 \mathrm{f}$.

theory of 100

Students gof., 10of.

Succession, successor 177

Swiss $\quad 253-256,258,272-274$

Swiss school of natural law / École romande du droit naturel 254f., 269, 273, 304-306, 314, 316, 320f.

Tartars $\quad 166$

Teaching $89,306,316-318$

method 16, 18f., 25f., 29, 33

the law of nature and nations $\quad 253-256,269$

Territorial estates $187,195,212$

Textbook 16, 19, 27, 89, 258, 317, 320

Trade $\quad 72,78,81 f$., 286, 292f., 317-319

Transfer 306,315

Translation $\quad 265,269,304-313,315,319 f$.

Treaty $73,162,284,286 f ., 290,292,299 f$.

of Fontainebleau (1807) 86

of Frederiksborg 43, 48, 55

of Nijmegen (1679) 191

of Rastatt and Baden (1714) 191

of Ryswick (1697) 191, 208

of Teschen (1779) 191

of Traventhal 43

of Westphalia 46

Trust 141-143
Tyrant / tyranny / tyrannical rule 167,169 , 18o, 196, $202 f$.

University $17,19,29-31,33$

of Basel 257

of Copenhagen $\quad 39-42,60-63,66$

of Frankfurt (Oder) 31, 267

of Göttingen 197

of Halle 14, 24, 32f., 41, 57, 194, 211, 257

of Heidelberg 198,208

of Jena 15

of Kiel 4of., 44, 56

of Leiden $256 f$.

of Leipzig 14

of Modena 311

of Pavia 316

of Rostock 14

of Strasbourg 30, 255

of Wittenberg 15

Usbecks 166

Usus 291, 300

Virtue $55,236,240,242,245$

War $62,67,69,72,79-84,97,166-173$, 177-181, 229f., 233, 240-242, $244 f$.

American War of Independence

$$
\left(1775^{-1783)} 84\right.
$$

Anglo-French War (1778-1783) 84

Battle of Copenhagen $\quad 69,84-85 f$.

Franco-Spanish war (1635-59) 204, 206

Great Northern War (1710-1721) 13, 42-48, 69,80

Napoleonic Wars (1803-1815) 85

of the Polish Succession $\quad 43 \mathrm{f}$.

of the Second Coalition (1798-1802) 84

Seven Years' War $\quad 213,292,315$

of the Spanish Succession 13

Thirty Years' War (1618-48) 30, 33, 197, 202, 204, 208, 210, 217

declaration of $172 \mathrm{f}$., $287,290-293$

in due form 291

of extinction 53

just $171-173,179,259,265,268$

punitive 170

right of (see Right of war)

Warfare $79 f$., 167f., 172f., 178

Wartime $\quad 68,79 f ., 84$

Westphalian myth $\quad$ 186-188, 191, 196, 199, 217 